\title{
Ethanol Annual Report FY 1990
}

\author{
Edited by \\ R.H. Texeira and \\ B.J. Goodman \\ January 1991
}

Prepared under task no. BF921010 Solar Energy Research Institute A division of Midwest Research Institute 1617 Cole Boulevard Golden, Colorado 80401-3393

Prepared for the U.S. Department of Energy Contract No. DE-AC02-83CH10033

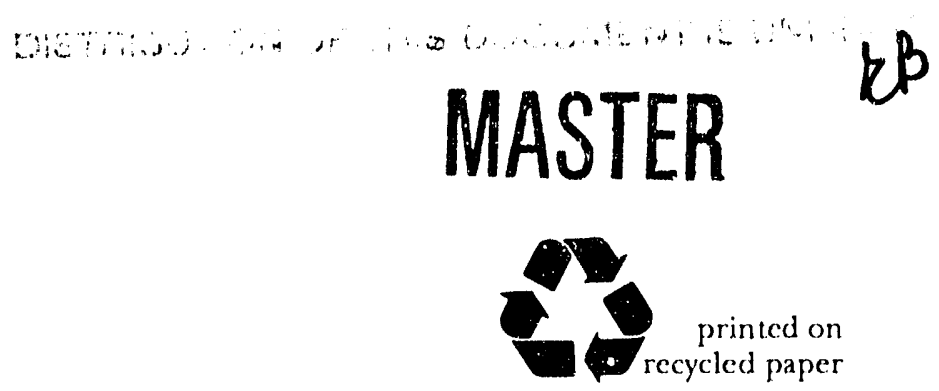


NOTICE: This report was prepared as an account of work sponsored by an agency of the United States government. Neither the United States government nor any agency thereof, nor any of their employees, makes any warranty, express or implied, or assumes any legal liability or responsibility for the accuracy, completeness, or usefulness of any information, apparatus, product, or process disclosed, or represents that its use would not infringe privateiy owned rights. Reference herein to any specific commercial product, process, or service by trade name, trademark, manufacturer, or otherwise does not necessarily constitute or imply its endorsement, recommendation, or favring by the Lirited States governmitht or any agency thereof. The views and opinions of authors expressed herein do noi necessarily state or reflucit tise of the United States governmont or any agency thereof

Printed in the United States of America

Available from:

National Technical Information Service

U.S. Department of Commerce

5285 Port Royal Road

Springfield, VA 22161

Price: Microfiche A01, Printed Copy A16

Codes are used for pricing all publications. The code is determined by the number of pages in the publication. Information pertaining to the pricing codes can be found in the current issue of the following publication; which are generally available in most libraries. Energy Research Abstracts (ERA); Government Reports Announcements and Index (GRA and I); Scientific and Techrical Abstract Reports (STAR); and publication NTIS-PR-360 available from NTIS at the above address. 


\section{Profaco}

This report summarizes the research progress and accomplishments of the U.S. Department of Energy (DOE) Ethanol from Biomass Program, field managed by the Solar Energy Research Institute, during FY 1990. The report includes an overview of the entire program and summaries of individual research projects. For further details, contact Norman Hinman at the SERI Program Office, (303) 231-1281. 


\section{TABLE OF CONTENTS}

$\underline{\text { Page }}$

Overview $\ldots \ldots \ldots \ldots \ldots \ldots \ldots \ldots \ldots \ldots \ldots \ldots \ldots \ldots \ldots \ldots \ldots \ldots \ldots \ldots$

The DOE/SERI Ethanol from Biomass Program $\ldots \ldots \ldots \ldots \ldots \ldots$

Technoeconomic Analysis $\ldots \ldots \ldots \ldots \ldots \ldots \ldots \ldots \ldots \ldots \ldots \ldots \ldots \ldots \ldots \ldots$

Preliminary Estimate of the Cost of Ethanol Production for

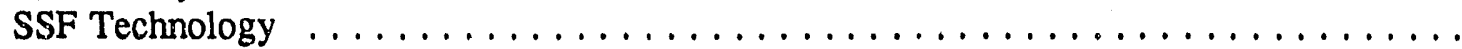

Pretreatment Research $\ldots \ldots \ldots \ldots \ldots \ldots \ldots \ldots \ldots \ldots \ldots \ldots \ldots \ldots \ldots$

Pretreatment Research Overview ........................ 39

Biomass Characterization - Progress Report . . . . . . . . . . . . . . . . . 43

Analysis of Dilute Acid Pretreatment Versus Acid-Catalyzed Steam Explosion . . . . . . . 60

Dilute Acid Pretreatment of Com Cobs, Com Stover, and Short-Rotation Crops . . . . . . 71

Ammonia Fiber Explosion (AFEX) Pretreatment $\ldots \ldots \ldots \ldots \ldots \ldots \ldots \ldots$

Pretreatment of Aspen Wood Aimed at High Hemicellulose Retention . . . . . . . . . 92

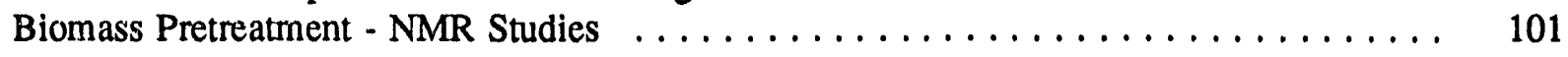

Cellulose Conversion Research $\ldots \ldots \ldots \ldots \ldots \ldots \ldots \ldots \ldots \ldots \ldots \ldots \ldots \ldots$

Overview of the Simultaneous Saccharification and Fermentation Process

foi Etisanol Production from Cellulosic Biomass $\ldots \ldots \ldots \ldots \ldots \ldots \ldots \ldots$

Ethanol Production by Simultaneous Saccharification and Fermentation (SSF)

of Pretreated Herbaceous Crops, Corn Cob, and Corn Stover . . . . . . . . . . . .

Development of a Preliminary Mathematical Model for the Conversion

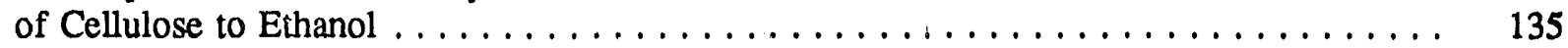

Liquid Fluidization of Aspen Wood Chip Beds $\ldots \ldots \ldots \ldots \ldots \ldots \ldots \ldots \ldots \ldots$

Cloning Enzymes for Use in Converting Biomass to Ethanol $\ldots \ldots \ldots \ldots \ldots \ldots$

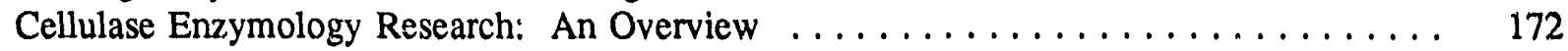

Enhanced Utilization of Fungal $\beta$-D-Glucosidase $\ldots \ldots \ldots \ldots \ldots \ldots \ldots \ldots$

Use of MAb-Colloidal Gold Conjugates to Visualize Trichoderma reesei

CBH I and EG I on Aspen Cellulose . . . . . . . . . . . . . . . . . . . . . 189

The Effect of Denaturation and Reduction on Cellobiohydrolase I

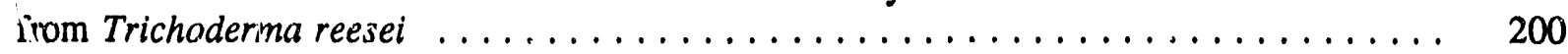

The Thermal Unfolding of Trichoderma reesei CBH I $\ldots \ldots \ldots \ldots \ldots \ldots \ldots \ldots$

Bacterial Cellulases: Regulation of Synthesis . . . . . . . . . . . . . . . 227

Xylose Fermentation Research $\ldots \ldots \ldots \ldots \ldots \ldots \ldots \ldots \ldots \ldots \ldots \ldots \ldots \ldots$

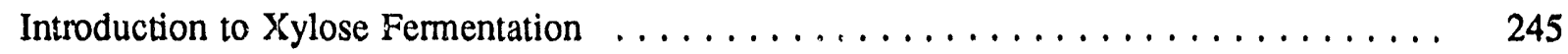

Simultaneous Fermentation and Isomerization of Xylose to Ethanol . . . . . . . . . 248

Xylose Isomerase Production and Plasmid in Recombinant $E$. coli . . . . . . . . . . 265

Cloning of Xylulokinase Gene for Improved Xylose and Xylulose Fermentation . . . . . . 273

Studies in Ethanol Production from Xylose Using Recombinant

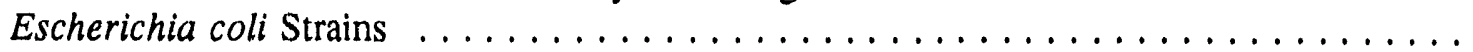


TP-3996

TABLE OF CONTENTS (Continued)

Page

Lignin Conversion Research . . . . . . . . . . . . . . . . . . . . . . . . . . . . . . . . 299

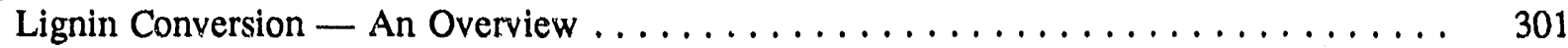

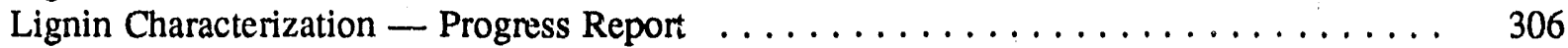

Liquid Fuels From Lignins . . . . . . . . . . . . . . . . . . . . . . . . . . 322

The Conversion of Lignin Model Compounds into Phenolic Products Using $\mathrm{MoS}_{2}$ and Pt on Acidic Supports 


\section{Overview}

1 


\title{
Tho DOE/SERI Ethanol from BIomass Program
}

\author{
C. E. Wyman \\ Biotechnology Research Branch \\ Fuels and Chemicals \\ Research and Engineering Division \\ Solar Energy Research Institute \\ Golden, Colorado 80401
}

\begin{abstract}
Cellulosic biomass includes agricultural and forestry wastes, municipal solid waste, and energy crops. Enough ethanol could be made from cellulosic biomass within the United States to replace all gasoline, reducing our strategic vulnerability and lowering our trade deficit for imports. Ethanol blends and neat fuel also decrease emissions of carbon monoxide and smog, respectively. In addition, producing ethanol from biomass does not contribute to the accumulation of carbon dioxide in the atmosphere and the potential for global climate change. The simultaneous saccharification and fermentation (SSF) process is favored for producing ethanol from the major fraction of biomass, cellulose, because of its low cost potential. Technology has also been developed for converting the second largest fraction, hemicellulose, into ethanol. The remaining fraction, lignin, can be burned as boiler fuel to power the conversion process and possibly generate extra electricity to export. Developments in conversion technology have reduced the selling price of thanol from about $\$ 3.60 /$ gal 10 years ago to only about $\$ 1.35 /$ gal now. Additional technical targets have been identified to bring the selling price down to about $\$ 0.60 / \mathrm{gal}$, a level that is competitive with oil at $\$ 25 / \mathrm{bbl}$. The Ethanol from Biomass Program, which is managed by the Solar Energy Research Institute for the Department of Energy, is structured to support research and development that will advance the technology to achieve this goal. This review presents an update on the status of the program.
\end{abstract}

\section{Introduction}

Transportation fuels are almost totally derived from petroleum and account for more than one-quarter of the total energy used in the United States in 1989, more than 81 quads (U.S. Department of Energy 1990). Currently, about $50 \%$ of all petroleum used in the United States is imported from other countries, and imports have risen markedly over the last few years (U.S. Department of Energy 1990). Because OPEC controls about $75 \%$ of the world's oil reserves, while the United States has only about $5 \%$ of that total, it is likely that petroleum imports will continue to rise. Few substitutes currently exist for petroleum-basted transportation fuels, and the United States is extremely vulnerable both strategically and economically to 
disruptions in thcir supply, as shown by our recent experience with Iraq's invasion of Kuwait. Shortages of transportation fuels previously triggered the "energy crisis" of 1973 and subsequent events. In addition, imported petroleum contributed about $40 \%$ of the balance-of-payments deficit for the United States in 1989 (Wald 1990).

Many cities, such as Los Angeles, suffer from poor air quality because of smog caused primarily by evaporative losses during fueling of automobiles, losses from the fuel system. and nitrogen oxides and unburncd" hydrocarbons from automotive exhaust (U.S. Environmental Protection Agency 1989). Other high-altitude cities, such as Denver, experience excessive levels of carbon monoxide because of incomplete combustion of carbon-containing fuels. Petroleum-derived transportation fuels are the source for up to two-thirds of carbon monoxide and one-third to one-half of smog-causing emissions (U.S. Environmental Protection Agency 1987; Browning et al. 1981; Risch 1988; U.S. Department of Energy 1978; Wilson 1987).

Scientists predict that the accumulation of carbon dioxide in the atmosphere as we burn fossil fuels could trap heat and cause global climate change. Possible consequences of this "greenhouse effect" include transformation of huge areas of our country from heavily forested woodlands (the Southeast) into deserts and movement of the corn belt from the Midwest to Canada over the next 40 to 50 years. The United States is responsible for about one-quarter of the carbon dioxide released into the atmosphere from fossil fuel use, and transportation fuels produced from petroleum add about $27 \%$ of that total (Edmonds et al. 1989).

Ethanol is a clean-burning liquid fuel that can be readily substituted for gasoline in our transportation sector. When ethanol is produced from renewable sources of cellulosic biomass, ethanol use can improve energy security, reduce the balance-of-payments deficit, decrease urban air pollution, and reduce accumulation of carbon dioxide (Wyman and Hinman 1990; Lynd 1989; Lynd 1990). The Ethanol from Biomass Program, managed by the Solar Energy Research Institute (SERI) for the Department of Energy (DOE), is directed at lowering the cost of ethanol production to the point where ethanol can compete with gasoline without tax incentives, so that the benefits of this unique fuel can be realized. In this overview, the benefits of ethanol use will be briefly summarized, the technology for ethanol production from cellulosic biomass will be described, and the Ethanol from Biomass Program will be outlined. The results of the research supported by the program follow in this volume.

\section{Fuel Properties of Ethanol}

More than 800 million gallons of fuel ethanol was produced from com in the United States, the equivalent of 0.06 quad (U.S. Department of Agriculture 1987). The corn ethanol produced was blended at $10 \%$ with about $7 \%$ of the gasoline consumed. Because com is grown domestically, ethanol use reduces the balanceof-payments deficits for imports of fuels while providing a secure source of transportation fuel.

Ethanol blends cause engines set for gasoline to run lean, and blends reduce carbon monoxide emissions by $10 \%$ to $30 \%$ (U.S. Department of Agriculture 1987; Livo et al. 1989; Johnson 1989; Watson 1988). in addition to $10 \%$ blends, ethanol can be reacted with isobutylene to form ethyl tert-butyl ether (ETBE) for blending with gasoline (Pahl 1988; Anderson 1988). If ETBE is blended at 22\% with gasoline, the amount of ethanol used is equivalent to that for $10 \%$ blends, and ETBE in gasoline also reduces carbon monoxide emissions. As an added benefit, ETBE lowers the Reid vapor pressure of gasoline, thereby decreasing the release of smog-forming compounds as well. Alternatively, ethanol can be employed directly as a neat (close to $100 \%$ ) fuel. Use of neat ethanol reduces smog formation because the lower volatility of neat ethanol reduces emissions, the photochemical reactivity of ethanol and its combustion products is low, and the amount of nitrogen oxides can be less because of reduced flame temperatures 
(U.S. Environmental Protection Agency 1987; Browning et al. 1981; Risch 1988; U.S. Department of Energy 1978; Wilson 1987).

As shown in Table 1, ethanol has many fuel properties that are desirable. Blends of ethanol or ETBE with gasoline increase the octane of the mixture and can improve the performance. Neat ethanol provides superior efficiency and performance to gasoline because it requires lower stoichiometric air/fuel ratios, has a higher latent heat of vaporization, provides higher octane values, and has a lower flame temperature. Thus, ethanol and methanol are often preferred to gasoline for high performance in automobile races such as the Indianapolis 500. The fact that the majority of new cars in Brazil have been run on pure ethanol clearly shows that it is a suitable fuel.

When blenced with gasoline at the $10 \%$ ethanol level as a direct blend or at equivalent levels through use of ETBE, the current potential market for ethanol is about 11 billion gallons or 1.3 quads. For use as a neat fuel, about 140 billion gallons of ethanol would displace the existing gasoline consumption of 112 billion gallons (13 quads), because ethanol can provide approximately $80 \%$ of the mileage of gasoline on a volumetric basis (Browning et al. 1981; Risch 1988; U.S. Department of Energy 1978; Wilson 1987; Bernhardt 1978; Kampen 1988). An additional market of 8 billion gallons of ethanol is potentially available for use as a solvent and as a feedstock for production of ethylene and other chemicals (Busche 1985).

\section{Blomass Feedstock Options}

Ethanol can be produced from several carbohydrate-containing feedstocks including sugar, corn starch, and cellulosic biomass. Processes for utilizing these substrates are in various stages of technical maturity. Processes for sugar and corn conversion are practiced commercially; processes for cellulosic biomass utilization are still under development in this country. Although ethanol is also made from ethylene, that technology does not address some of the critical issues that warrant fuel ethanol production in the first place and has been displaced by fermentation ethanol for fuel use (Chemical Marketing Reporter 1985). Thus, the focus of this discussion will be on fermentation ethanol.

\section{Sugar Cane}

About 3.0 billion gallons of ethanol are produced annually in Brazil from sugar cane (J.E. Sinor Consultants 1990). For a time, the majority of new cars in that country ran on neat ethanol while the remainder operated on $20 \%$ ethanol - $80 \%$ gasoline blends (New Fuels Report 1990a). However, the price of ethanol in Brazil is higher than for gasoline; ethanol is subsidized by taxes on gasoline to promote its use as a fuel. Furthermore, because sugar is primarily used as food, rising world sugar prices have recently resulted in shortages of sugar for ethanol production. Extensive news coverage has resulted from these and the related problems that Brazil has experienced with substitution of ethanol derived from sugar cane for gasoline (New Fuels Report 1990a; New Fuels Report 1990b; Kandell 1989; Anderson 1990). In the United States, sugar prices are controlled at $\$ 360 /$ ton, and ethanol would have to sell at a price of more than $\$ 2.30 / \mathrm{gal}$ at the plant gate just to recover the cost of sugar. Because this is well above current wholesale gasoline prices of about $\$ 0.55$ to $\$ 0.75 /$ gal, fermentation of sugar to ethanol is not a competitive technology in this country. 


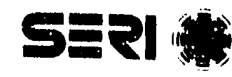

TP-3996

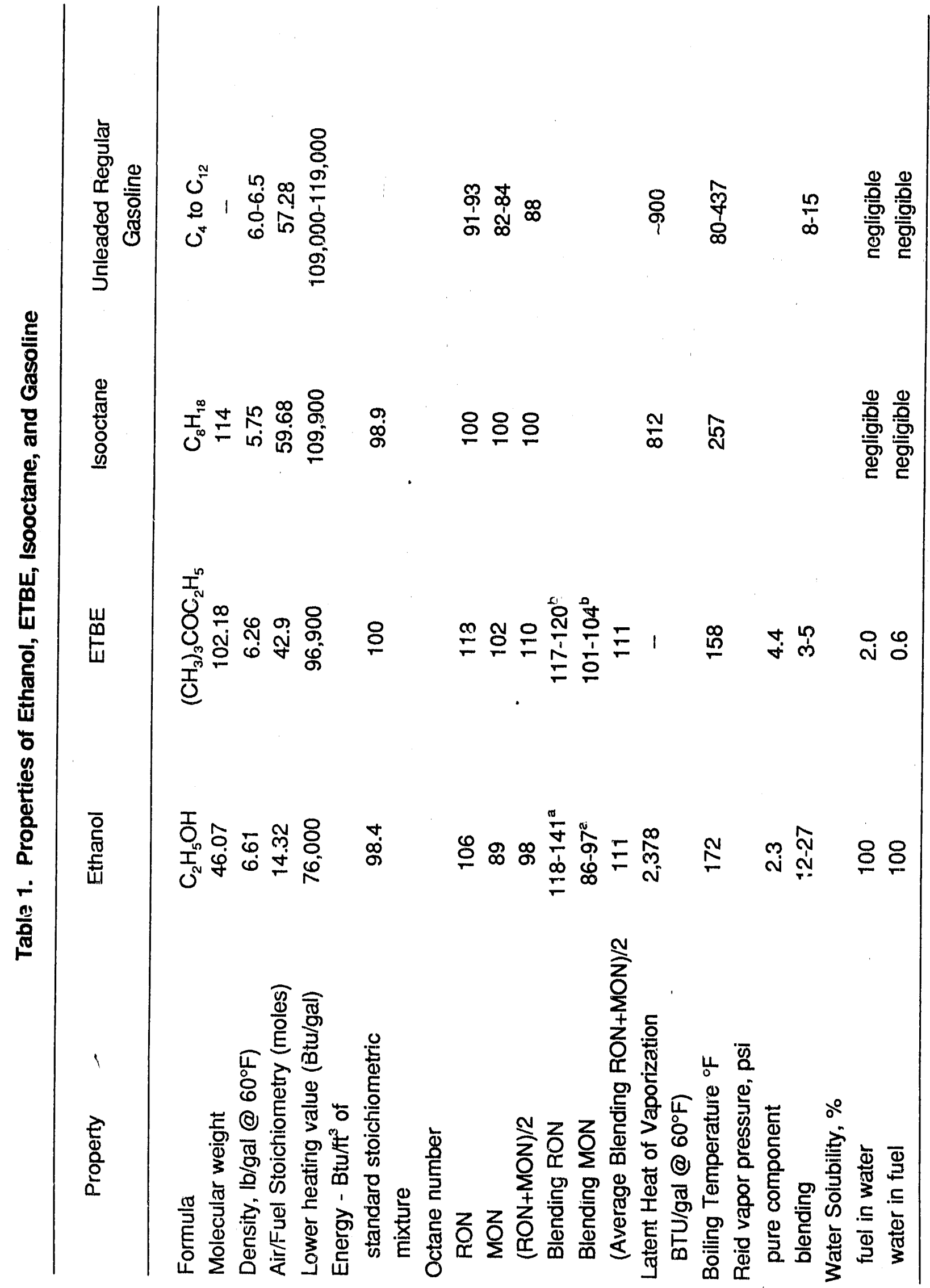

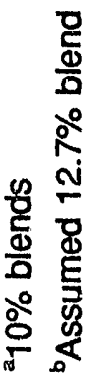




\section{Corn and Other Starch Crops}

In the United States, about 320 million bushels of corn are used each year to produce more than 800 million gallons of anhydrous ethanol for 10\% blends with gasoline (U.S. Department of Agriculture 1987). However, ethanol from com sells for between $\$ 1.10$ and $\$ 1.55 / \mathrm{gal}$ and the price of corn at about $\$ 100 /$ ton is too high to produce ethanol at prices competitive with gasoline at today's wholesale prices of $\$ 0.55$ to 0.75/gal, even with substantial co-product credits (Wyman and Hinman 1990). Thus, relaxation of gasoline taxes is employed to encourage use of ethanol blends in the Unites States. The U.S. Department of Agriculture has estimated that approximately 4 to 5 billion additional gallons of ethanol could be produced from 1.6 billion bushels of corn in the United States before agricultural resources would be taxed and strong upward pressure exerted on grain prices (U.S. Department of Agriculture 1989). Thus, although corn could prove a valuable source of ethanol in the short run, the increase in grain prices and the decrease in co-product prices with increased production could hinder substantial growth in ethanol production from corn.

\section{Cellulosic Blomass}

Cellulosic biomass is a complex mixture of carbohydrate polymers from plant cell walls known as cellulose and hemicellulose, plus lignin and a small amount of other compounds known as extractives, as shown in Figure 1. Examples include agricultural and forestry residues, municipal solid waste (MSW), herbaceous and woody plants, and underutilized standing forests. Cellulosic biomass is much less expensive than corn or sugar because it has no food value. The cellulose fraction is composed of glucose sugar molecules bonded together in long chains that are held together in a crystalline structure. The hemicellulose portion of biomass is made of long chains of a number of different sugars and does not have a crystalline structure. For hardwoods, the predominant component of hemicellulose is xylose, a fivecarbon sugar that has historically been more difficult to convert into useful products than glucose.

For the United States, it is estimated that the total amount of underutilized wood, agricultural residues, short-rotation energy crops, and MSW could provide about 2700 million dry tons of cellulosic biomass per year at prices from $\$ 20$ to $\$ 70$ per dry ton (Lynd 1989). This quantity of feedstock can generate about 300 billion gallons of ethanol, more than enough to meet the total current gasoline market in the United States of 140 billion gallons of ethanol equivalent twice over. The price of these raw materials is also low enough to provide a reasonable margin for conversion into ethanol. Even though these values are subject to significant uncertainty, they indicate that the resource base of renewable feedstocks is substantial while the cost is reasonable. Thus, cellulosic biomass is a favorable feedstock for fuel ethanol production.

The cost of the feedstock is an important factor in deternining the selling price of ethanol. Therefore, use of an inexpensive feedstock will make the process cost competitive sooner. Several possible low-value or waste streams could prove attractive, including the carbohydrate fractions of corn gluten feed from corn wet milling; distillers dried grains and solubles from whole grain processing; agricultural waste streams such as corn cobs, com stover, or wheat straw; commercial processing waste streams such as white water in paper manufacture; and domestic wastes such as waste paper ind MSW. Although such feedstocks are of limited availability, they provide an opportunity to establish the technology early.

Ultimately, abundant feedstocks are required to achieve large-scale ethanol production. Thus, the Oak Ridge National I aboratory (ORNL) manages a Biomass Prociuction Program for the U.S. Department of Energy to develop technology for producing fast-growing herbac sous and woody crops that will provide an abundant and low-cost substrate for ethanol production. Although low-cost feedstocks can provide 


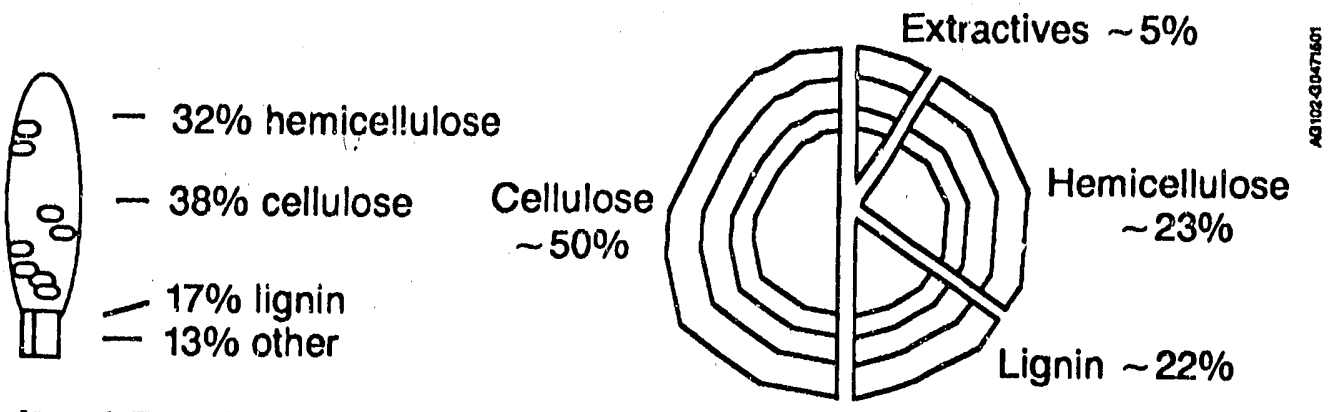

Agricultural Residues

Underutilized and Short Rotation Hardwoods
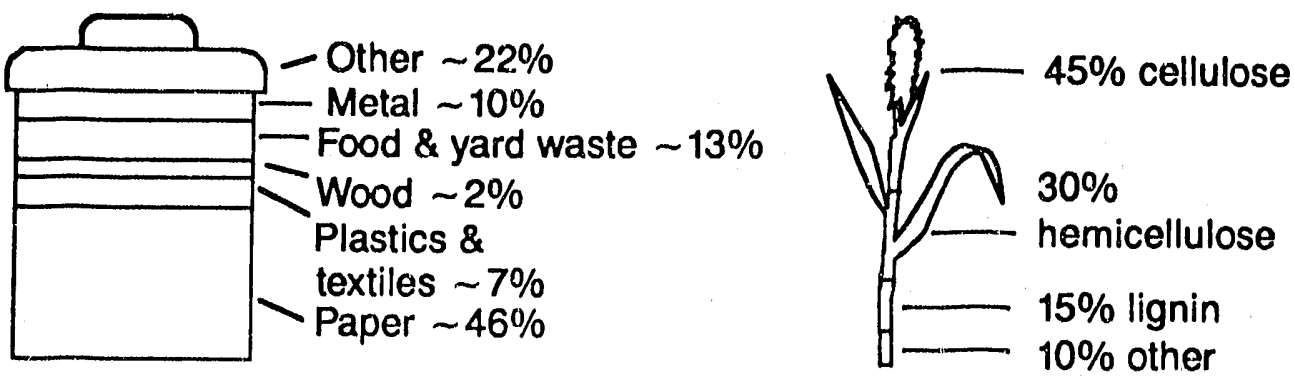

Municipal Solid Waste

Herbaceous Energy Crops

Figure 1. Cellulosic biomass consists of cellulose, hemicellulose, llgnin, and some extractlves as shown here for representative examples of agricultural residues (corn cobs), hardwood, municipal solid waste, and herbaceous plants.

near-term opportunities to apply ethanol production technology, encrgy crops developed by ORNL will be essential to widespread ethanol use.

\section{Conversion of Cellulosic Blomass into Ethanol}

Production of ethanol from sugar and starch has been practiced commercially for a number of years, but because sugar and starch are valuable as food, their cost alone is greater than the value of the fuel ethanol that can be made from them (Wyman and Hinman 1990). On the other hand, cellulosic biomass is an inexpensive feedstock, and acids or enzymes will catalyze the breakdown of the cellulose and hemicellulose chains into their component sugar molecules, which can be fermented into ethanol. Lignin is a complex phenolic polymer that cannot be fermented into ethanol. The challenge is to develop lowcost methods to convert the naturally resistant cellulose and hemicellulose into ethanol.

Over the years, a number of processes have been studiec for conversion of cellulose-containing biomass into ethanol catalyzed by dilute acid, concentrated acid, or enzymes known as cellulases. In each of these options, the feedstock is pretreated to reduce its size and open up the structure, as shown in Figure 2 . The cellulose fraction is hydrolyzed by acids or enzymes to produce glucose sugar, which is subsequently fermented to ethanol. The soluble xylose sugars derived from hemicellulose are also fermented to ethanol and the lignin fraction can be burned as fucl to power the rest of the process, converted into octane boosters, or used as a fecdstock for the production of chemicals. 


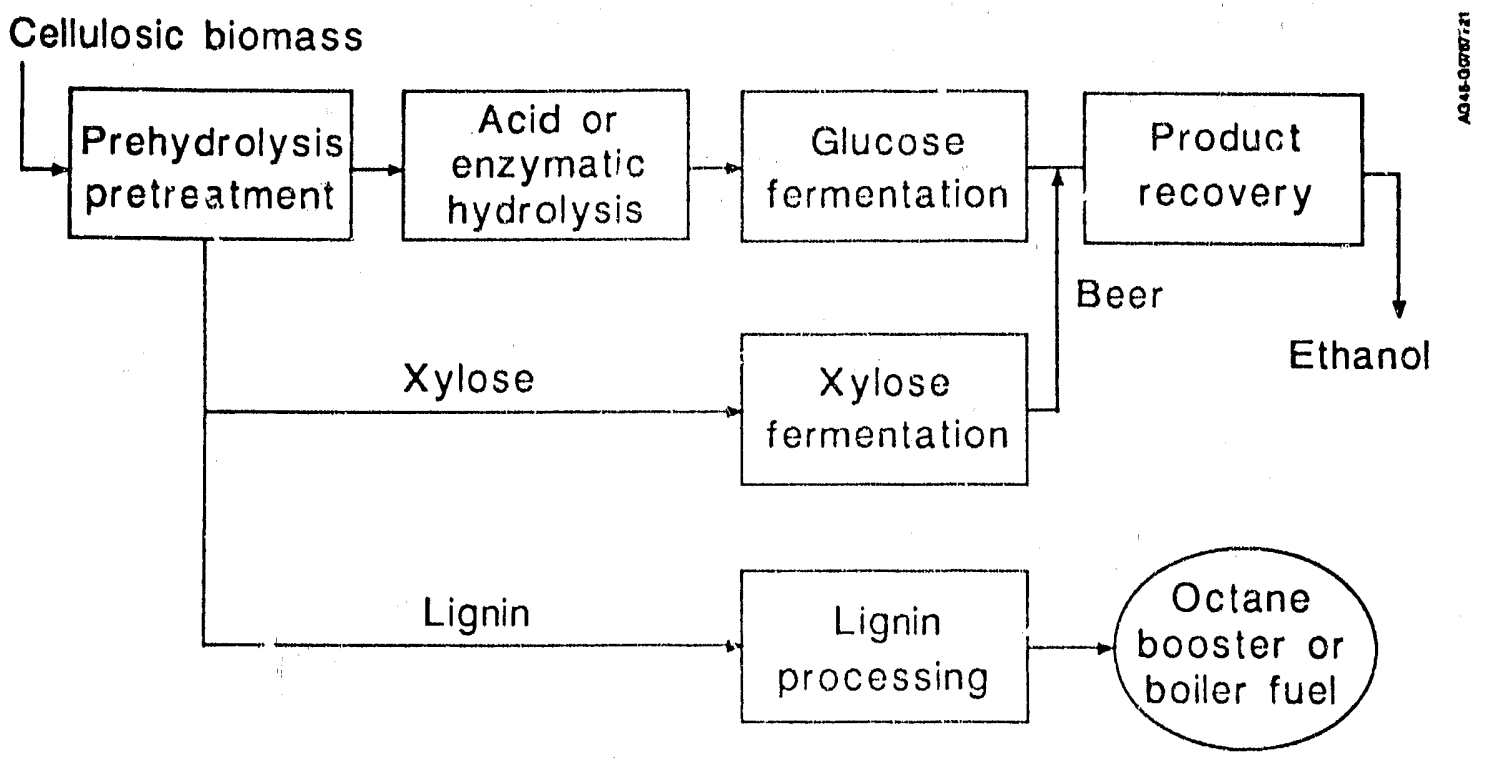

Figure 2. The process flow dlagram for acid- or enzyme-catalyzed conversion of cellulosic blomass to ethanol

\section{Acld-Catalyzed Processes}

Several dilute acid hydrolysis pilot plants were constructed in the United States during war time as part of an effort to produce ethanol for fuel use (Wenzl 1970), but the economics were too unfavorable to allow continued operation in a free market economy. Dilute acid-catalyzed processes are currently operated in the Soviet Union for converting cellulosic biomass into ethanol and single cell protein. Thus, acid-catalyzed processes provide a near-term technology for production of fuel-grade ethanol from cellulosic biomass, but the low yields of $50 \%$ to $70 \%$ typical of dilute acid systems make them unable to compete with existing fuel options (Wright 1983; Wright 1988a). Concentrated sulfuric or halogen acid options achieve the high yielús icquired. However, because low-cost acids (e.g., sulfuric) must be used in large amounts while more potent halogen acius are relatively expensive, recycle of acid by efficient, low-cost recovery ope ations is essential to achieve economic operation (Wright and Power 1985a; Wright et al. 1985b). Unfortunately, the acids must also be recovered at a cost substantially lower than that of producing these inexpensive materials in the first place--a difficult requirement.

\section{Erzyme-Catalyzed Processes}

Enzyme-catalyzed processes achieve high yields under mild conditions with relatively low amounts of catalyst. Enzymes are also biodegradable and environmentally benign. Over the years, several enzymebased processes have been studied at the laboratory scale, but only a few investigations have been taken to a larger scale. The processes considered are discussed below.

\section{Separate Hydrolysis and Fermentation}

In the separate hydrolysis and fermentation (SHF) process, the cellulosic biomass is first processed in a pretreatment device to open the biomass structure and facilitate subsequent processing. A portion of the 
pretreated biomass is used in an enzyme production vessel to support growth of a fungus that produces cellulase enzyme, and the cellulase enzyme is added to the bulk of the pretreated sulustrate in a hydrolysis reactor. At this stage, the enzymes catalyze the breakdown of the cellulose by the so-called hydrolysis reaction to form glucose sugar. The stream from the hydrolysis process passes on to a fermenter to which yeast are added to convert the glucose into ethanol. Finally, the ethanol is separated from the rest of the fermentation broth in a purification step (Mandels et al. 1974; Wilke et al. 1976).

\section{SImultaneous Saccharification and Fermentation}

The seruence of steps for the simultaneous saccharification and fermentation (SSF) process is virtually the same as for separate hydrolysis and fermentation except that hydrolysis and fermentation are combined in one vessel (Gauss et al. 1976; Takagi et al. 1977). The presence of yeast along with the enzymes minimizes accumulation of sugar in the vessel and because the sugar produced during breakdown of the cellulose slows down the action of the cellulase enzymes, higher rates and yields are possible for SSF than SHF. Additional benefits are that one of the expensive fermentation vessels is eliminated, and that the prestnce of ethanol makes the fermentation mixtre less vulnerable to invasion by unwanted microorganisms.

\section{Direct Microblal Converslon}

The direct microbial conversion (DMC) process combines the enzyme production, cellulose hydrolysis, and sugar fermentation steps in one vessel (Veldhuis et al. 1936; $\mathrm{Ng}$ et al. 1977; Cooney et al. 1978). In the most extensively te.ted configuration, two bacteria are employed that produce cellulase enzymes and ferment the sugars formed by breakdown of cellulose and hemicellulose into ethanol. Unfortunately, the bacteria also produce a number of prod:ucts in addition to ethanol and yields are lower than for the SHF or SSF processes.

Although the cost of cellulosic biomass is low enough to provide a reasonable margin for profitable conversion into ethanol, evaluations of acid-catalyzed options for converting cellulosic biomass into ethanol have shown that the ethanol yields from these processes are too low while concentrated acid options require acid recovery at lower costs than are now feasible. On the other hand, the enzymecatalyzed options provide high yields of ethanol with low concentrations of enzyme. In addition, although the pricc of ethanol produced from some enzyme- and acid-catalyzed processes may be close now, enzyme-catalyzed processes have tremendous potential for technology improvements that could bring the selling price of ethanol down to levels competitive with existing fuels (Wright 1988a; Wright 1988b). In particular, SERI has focused on the SSF process as a promising route to achieve low-cost fuel ethanol profuction within a reasonable time frame (Wright et al. 1988c). As shown in Figure 3, the SSF process combines the enzymatic hydrolysis of cellulose and fermentation of the glucose sugars produced in one vessel to speed rates while reducing equipment costs.

Progress on the enzyme-catalyzed processes to convert cellulosic biomass into fuel ethanol has been substantial over the last 10 years, with projected selling prices dropping from about $\$ 3.60 / \mathrm{gal}$ in 1980 to only about $\$ 1.35 /$ gal (Wright 1988a; Wright 1988b; Hinman et al. 1989). This reduction in selling price is due to improved rates and yields by use of the SSF process, improvements in enzymes to achieve high yiclds with lower loadings, proper selection of fermentative microbes, and advances in xylose fermentations through genetic engineering. 


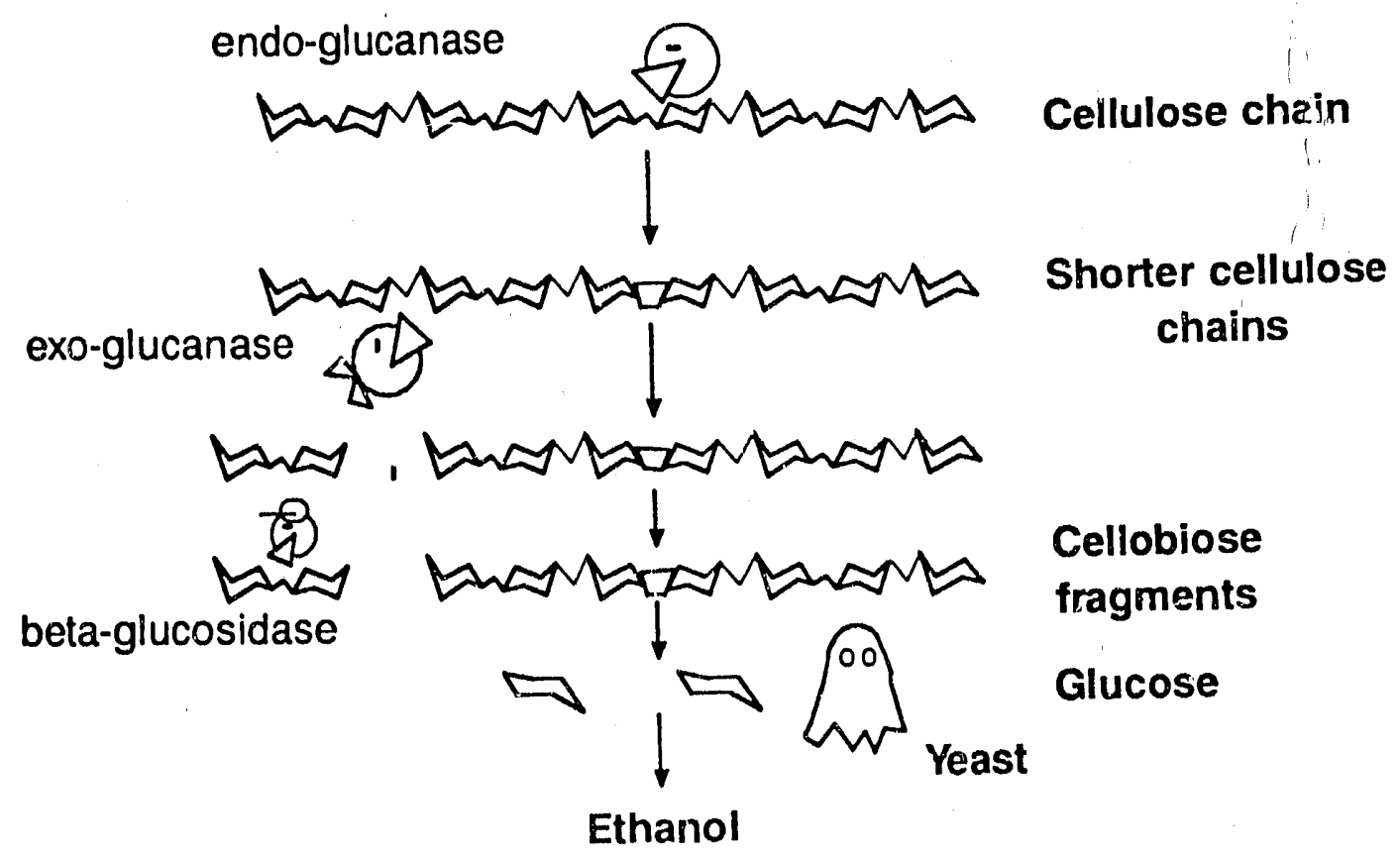

Figure 3. The simultaneous sacchariflcation and fermentation (SSF) process comblnes cellulose breakdown Into glucose by cellulase enzymes (endo- and exo-glucanase pius beta-glucosidase) with fermentation of glucose into ethanol to speed rates and lower costs.

\section{Pretreatment of Cellulosic Biomass}

Cellulosic biomass is naturally resistant to cnzymatic attack, and a pretreatment step is required to overcome this resistance if the enzyme-catalyzed hydrolysis process is to proceed at a reasonable rate with the high yields vital to economic viability. Several options have been considered for biomass pretreatment including steam explosion, acid-catalyzed steam explosion, organosolv, and dilute acid. At this time, the dilute acid option appears to have the best near-term economic potential (Wright 1988b). In this process, about $0.5 \%$ sulfuric acid is added to the feedstock, and the mixture is heated to around $140^{\circ}$ to $160^{\circ} \mathrm{C}$ for 5 to $20 \mathrm{~min}$. Under these conditions, most of the hemicellulose is broken down to form xylose sugars, leaving a porous material of primarily cellulose and lignin that is more accessible for enzymatic attack. Evaluation of the dilute acid process with various agricultural residues, short-rotation hardwoods, and herbaceous energy crops has consistently shown that the conversion yields correlate well with the degree of hemicellulose removal (Torget et al. 1990). Although this process has good near-term potential, significant benefit would result if a low-cost scheme could be devised that would also remove lignin, because the solid lignin associated with the cellulose creates some processing difficulties in the fermentation step.

\section{Hemicellulose Utilization}

The hemicellulose polymers in cellulosic biomass such as hardwood, agricultural residues, and herbaceous plants can be readily broken down to form the five-carbon sugar xylose during the pretreatment step. However, until iecently, the xylose stream could not be utilized, and it was necessary to send this material to waste disposal. From an economic perspective, this costs the process twice: first, because we paid for 
the xylose, it is costly to throw it away; and second, the cost of waste disposal inflicts a large penalty on the process.

Several options, outlined below, have been examined for xylose utilization.

\section{Conversion of Xylose Into Furfural}

For dilute acid-catalyzed breakdown of cellulose to fermentation sugars, a significant fraction of the xylose will degrade into furfural (Wright 1983). Similarly, the xylose released by pretreatment can also be reacted to furfural. This product is currently manufactured for use in foundry and other applications, so it could be sold as a by-product, generating additional revenues. However, the furfural market would be quickly saturated by the volume of furfural that would accompany large-scale application of ethanol as a fuel (Gaines and Karpuk 1986). Thus, although furfural sales could provide a valuable role in initial introduction of a few ethanol plants, it would not support the commercialization of a large-scale ethano! production capability.

\section{Yeast for Ethanol Production}

Another avenue is to use certain strains of yeast that are known to ferment xylose into ethanol, such as Candida shehatae, Pichia stipitis, and Pachysolen tannophilus (Jeffries et al. 1985; Gong et al. 1981; Beck et . 1. 1990; Jeffries 1989). However, these strains require small amounts of oxygen in the fermentation broth to ferment xylose. Unfortunately, large-scale production of ethanol fuels will probably require the use of huge fermenters with volumes approaching a million gallons each, and proper control of oxygen in such large vessels could be virtually impossible. Furthermore, these yeast strains typically cannot yet achieve very high ethanol yields or rates or tolerate high ethanol concentrations (Hinman et al. 1989).

\section{Other Mlcroorganlsms for Ethanol Production}

Other microorganisms, such as thermophilic bacteria and fungi, can anaerobically ferment xylose into ethanol (Lynd 1989; Buchert et al. 1989; Antonopoulos and Wene 1987; Asther and Khan 1984; Alexander et al. 1981; Slapack et al. 1987). However, ethanol tolerance has not been satisfactorily demonstrated for bacteria, although some new evidence suggests previous conclusions may have been premature (Lynd 1991). Similarly, historic data suggest that ethanol yields are low. However, new information indicales that the yields could be improved in continuous culture (Lynd 1991). The fungi evaluated currently suffer from similar limitations in both ethanol tolerance and yield.

\section{SImultaneous Fermentation and Isomerizatlon of Xylose to Ethanol}

Several groups have studied the use of xylose isomerase enzyme to convert xylose into an isomer called xylulose that many yeast can ferment into ethanol under anaerobic conditions (Jeffries 1981; Chaing et al. 1981). Recently, researchers at SERI have genetically engineered the common bacteria Escherichia coll to produce large quantities of xylose isomerase for such a process, and ethanol yields of $70 \%$ of theoretical have been achieved in the simultaneous fermentation and isomerization of xylose (SFIX) process (Lastick et al. 1990). In this configuration, the enzyme and yeast are employed togethe $r$ to drive the equilibrium limited fermentation to completion, with the primary yield loss resulting from xylitol formation (Lastick et al. 1990; Tewari et al. 1985). The SFIX process has the advantage of employing anaerobic yeast that 
are easier to use at a large scale, but the need to provide xylose isomerase enzyme and adjust for differences in $\mathrm{pH}$ optima between the yeast and enzyme complicate the technology.

\section{Genetically Altered E. coll}

Researchers at the University of Florida have successfully introduced the genes from Zymomonas mobilis into the common bacteria $E$. coli so that the latter can now ferment xylose directly into ethanol (Ingram and Conway 1988; Ingram et al. 1987). This approach has the advantage that a single organism can carry out the fermentation of xylose, and initial data suggest high yields are possible. However, E. coli requires operation at near neutral $\mathrm{pH}$ while production of by-product acids tends to drive the $\mathrm{pH}$ down, thus requiring high addition of bases to control the $\mathrm{pH}$. Furthermore, a rich (expensive) media is apparently required, and some of the media may be converted into ethanol, accounting for some of the yield. More evaluation and development are needed to be sure that this organism will be economical for the conversion of xylose into ethanol.

At this time, the most promising option for xylose conversion is the use of genetically engineered $E$. coli followed by the SFIX system. However, full integration of these technologies into the overall conversion process is required to tvaluate and improve their performance. Advantages would also result if the limitations of these ontions could be overcome by further genetic modifications or other approaches.

\section{Lignin Conversion}

As shown in Figure 1, lignin generally represents the third largest fraction of cellulosic biomass and is not significantly different in quantity than hemicellulose. Thus, it is important to derive value from the lignin fraction if the economic goals of the Ethanol from Biomass Program are to be achieved. Three options, discussed below, lead the possibilities for lignin use.

\section{Use as a Boller Fuel}

Lignin has a high energy content and can be used as a boiler fuel (Wright 1988a; Hinman et al. 1989; Domalski et al. 1987). The amount of lignin in most feedstocks is nore than enough to supply all the heat required for the pretreatment, enzyme production, ccllulose conversion, and xylose fermentation step, plus to generate enough electricity to meet the electrical demands of these processes. In fact, excess electricity beyond all of these needs is generated, and additional revenue can be generated from electricity exports from the plant. The electricity sold for current plant designs is equivalent to about $10 \%$ of the Btu value of the echanol product, and greater revenues are likely as the technology is improved to require less process heat and electricity.

\section{Productlon of Octane Boosters}

Lignin is a complex phenolic polymer that can be broken down to form a mixture of monomeric phenolic compounds and hydrocarbons. The phenolic fraction can be reacted with alcohols to form methyl or ethyl aryl ethers, which are good oxygenated octane boosters (Johnson et al, 1990). Because octane boosters are more valuable than boiler lucl, this option for lignin use would generate more revenue. However, the technology must be improved to provide high product yields, and the conversion costs must be very low to provide a net income gain for the ethanol plant. 


\section{Production of Chemicals from Lignin}

A number of chemicals could be produced from lignin including phenolic compounds, aromatics, dibasic acids, and olefins (Busche 1985). Such materials could have a high value that would augment the total revenue for the ethanol plant. However, just as for the conversion of lignin into octane boosters, the cost of the conversion process mist be low enough to ensure a net gain in reverue. In addition, high yields of target products will likely be necessary to achieve economic viability.

\section{Global Climate Change}

The carbon dioxide released during ethanol fermentation and combustion is recycled back to grow new biomass, which replenishes that harvested for ethanol manufacture. In addition, the lignin in the feedstock can be burned to provide all of the process heat and electricity needed to drive the conversion process, and some electricity is left to sell for added revenue. Thus, as illustrated in Figure 4, carbon dioxide actually rrovides the key link between the fuel and the biomass resource; it does not accumulate in the atmosphere as a result of either conversion or utilization (Wyman and Hinman 1990; Lynd 1990). Of course, new trees or othrr biomass must be planted to replace those that are harvested for energy, just as is done in the agricultural, paper, and forest products industries. As an added benefit, growth and harvesting of cellulosic feedstocks requires far less fertilizer and cultivation than food crops, thereby reducing the fossil fuel requirements for biomass production. Although some argue that the use of coal, natural gas, and petroleum in ethanol production from corn negates some of the benefits with respert to global climate change (Ho 1989; Segal 1989), these conclusions are heavily swayed by the high use of coal to provide process heat and electricity for ethanol production from corn; the use of lignin as a boiler fuel negates this major carton dioxide contribution. Furthermore, biomass, methane from biomass, and neat ethanol could be substituted directly for fossil fuels in the cultivation and harvesting of cellulosic biomass, maintaining the carbon dioxide balance.

\section{Potentia! for Improvement}

Although research progress has been substantial, significant opportunities still exist to lower the selling price of ethanol from cellulosic biomass to $\$ 0.60 /$ gal at the plant gate. Key target areas include further improvements in glucose and xylose yields from pretreatment, increased ethanol yields to $90 \%$ or greater from cellulose and xylose fermentations, decreased stirring and pretreatment power requirements, better productivities through continuous processing and biocatalyst immobilization, low-cost production of octane enhancers or chemicals from lignin, increased ethanol ccncentration, and reduction of fermentation times. Because feedstock costs are a significant fraction of the final product selling price, improvements in feedstock production, collection, and genetics could provide additional cost reductions through economies of scale for larger ethanol plants, decreased feedstock costs, and less nonfermentable feedstock. Many of these goals have been met individually; the evidence that the rest can be achieved is great. The primary need is to meet them simultaneously. It is also encouraging that enough options exist to lower the selling price of ethanol that not all the technical goals must be achieved to reach the target selling price.

\section{Report Organization}

In this annual report, the research to be presented is grouped into four primary areas. First, the results of a recently completed and comprehensive process evaluation of the overall technology for ethanol production from cellulosic biomass will be reported. This study, which has been verified independently 


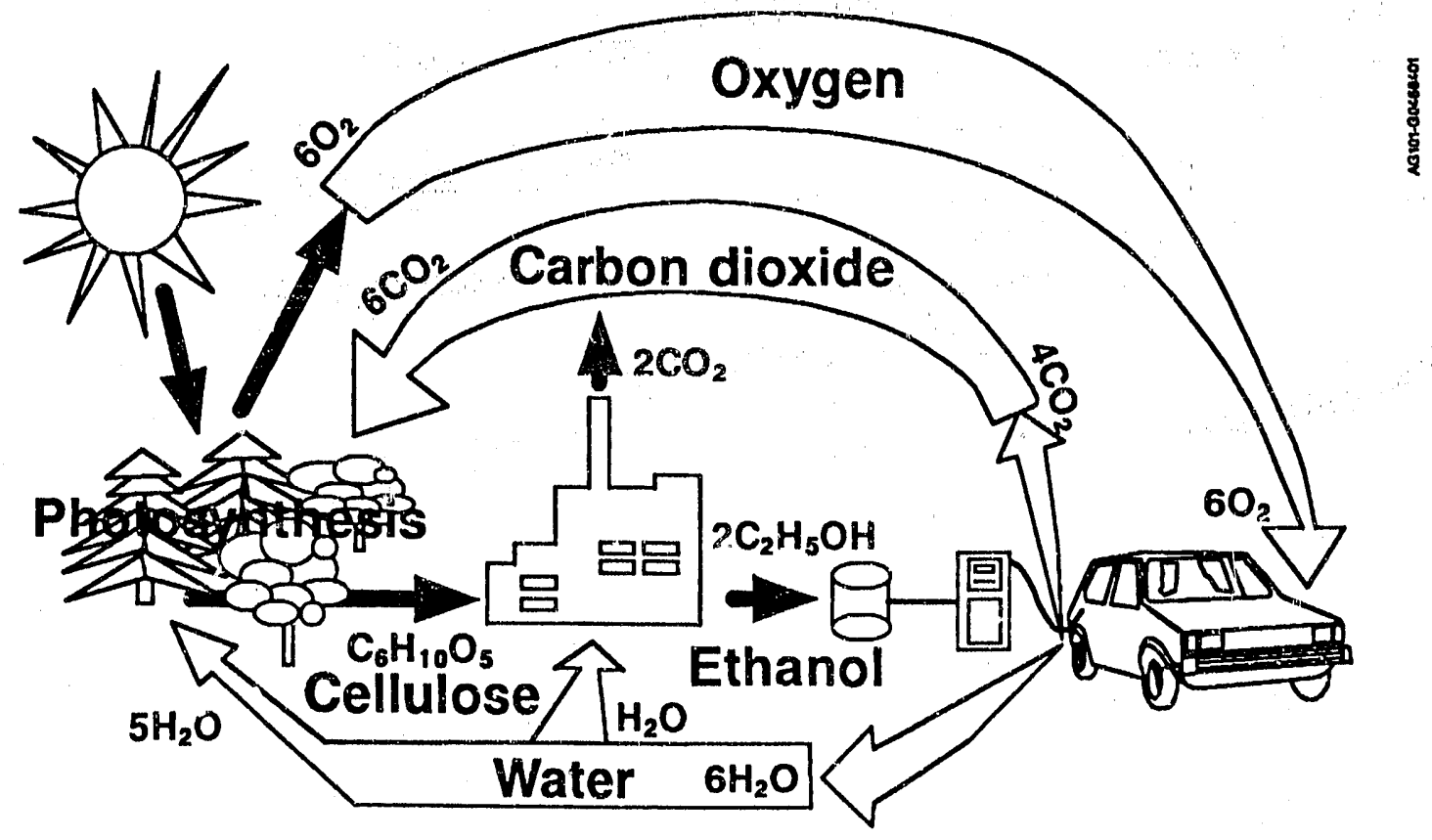

Figure 4. For production of ethanol from cellulosic blomass, the carbon dloxide released in the fermentation step and during ethanol combustion is recycled to grow now plants to replenish those harvested as feedstock. Because the lignin in the biomass can be burned as boiler fuel to provide all the energy needed to run the overall process, no fossil fuel is required in the process, and ethanol production and use contributes no net accumulation of carbon dioxide to the atmosphere.

by Chem Systems, identifies the current state of the technology and defines areas for process improvements. Next, a section on pretreatment research provides the results of several investigations directed at reducing costs and improving yields for the pretreatment step. Following that, the cellulose conversion research section includes reviews of several projects concerned with improving the cellulase enzymes and the SSF process for converting the main biomass component, cellulose, into ethanol. The xylose fermentation research portion of the document follows with results of the research on the SFIX process and comparisons of performance with yeast and genetically engineered $E$. coli. Finally, the report concludes with reviews of some projects on converting lignin into octane boosters such as methyl aryl ethers. An overview of each topical area is presented before the individual papers for each section of the document.

\section{Conclusions}

Ethanol is a clean-burning, high-octane fuel that can be used in today's transportation sector. Enough ethanol could be made from cellulosic biomass within the United States to replace gasoline consumption twice over. 'This means that using ethanol derived from biomass such as agricultural and forestry wastes would reduce the strategic vulnerability of the United States, prevent sudden changes in price, and lower our trade deficit for imports. When blended with gasoline, ethanol or the oxygenate ETBE derived from ethanol reduces emissions of carbon monoxide and unburned hydrocarbons. "Pure" ethanol reduces release of smog-forming compounds. The carbon dioside released during ethanol production and use can be 
recaptured by plants to replenish the biomass supply, so ethanol does not contribute to the accumulation of carbon dioxide in the atmosphere and th? potential for global climate change because of the greenhouse effect. Both acid- and enzyme-catalyzed reactions have been evaluated for conversion of cellulosic biomass into ethanol, and research has been focused on enzymatic hydrolysis technology because of its potential to achieve high yields of ethanol under mild conditions. In particular, the SSF process is favored for ethanol production from the major cellulose fraction of the feedstock because of its low cost potential. Technology has also been developed for converting the second largest fraction, hemicellulose, into ethanol, and the remaining lignin can be burned as boiler fuel to power the conversion process and generate enough extra electricity to export. Together, developments in conversion technology have reduced the selling price of ethanol from about $\$ 3.60 /$ gal 10 years ago to only $\$ 1.35 / \mathrm{gal}$ now. Additional technical targets have been identified to bring the selling price down to about $\$ 0.60 /$ gal with an aggressive research and development program.

\section{References}

Alexander, J. K., Connors, R., and Yamamato, N. 1981. "Production of Liquid Fuels from Cellulose by Combined Saccharification--Fermentation for Cocultivation of Clostridia." In Allvances in Biote hnology, Vol. II, ed. M. Moo-Young. New York: Pergamon Press.

Anderson, E. 1988. Chem. Eng. News 65(43):11.

Anderson, E. 1990. Chem. Eng. News 68(3):6.

Antonopoulos, A. A., and Wene, E. G. 1987. FY 1987 Biochemical Conversion Program Annual Review, C-51. Golden, CO: Solar Energy Research Institute.

Asther, M., and Khan, A. W. 1984. Biotechnol. Lett. 6(12):809.

Beck, M. J., Johnson, R. D., and Baker, C. S. 1990. Appl. Biochem. Biotechnol. 24/25:415.

Bernhardt, W. 1978. Proceedings: International Symposium on Alcohol Fuel Technology--Methanol and Ethanol, 1-5. Washington, DC: English translation published by U.S. Department of Energy, Assistant Secretary for Conservation and Solar Applications.

"Brazil Alcohol Vehicle Production Plummets, As Once Huge Demand Ebbs." 1990a. New Fuels Report. June 4, 11.

"Brazil Sees 1-Billion Liter Ethanol Shortage as Sugar Prices Remain High." 1990b. New Fuels Report. June 4,11

Browning, L. H., Pefley, R. K., and Suga, T. P. 1981. In Proceedings of the 16th Intersociety Energy Conversion Engineering Conference, Atlanta, Georgia, August 9-14.

Buchert, J., Pols, J., and Poutanen, K. 1989. Appl. Biochem. Biotechnol. 20/21:309.

Busche, R. M. 1985. Biotech. Prog. 1(3):165.

Chaing, L-C., Hsiao, H-Y., Ueng, P. P., Chen, L-F., and Tsao, G. T. 1981. Biotechnol. Bioeng. Symp. 11:263. 
"Chemical Profile: Ethanol." 1985. Chemical Marketing Reporter. January 25.

Cooney, C. L., Wang, D.I.C., Wang, S. D., Gordon, J., and Jiminez, M. 1978. Biotechnol. Bioeng. Symp. Ser. 8:103.

Domalsk:, E. S., Jobe, Jr., T. L., and Milne, T. A. 1987. Thermodynamic Data for Biomass Materials and Waste Components. New York: American Society of Mechanical Engineers.

Edmonds, J. A., Ashton, W. B., Cheng, H. C., and Steinberg, M. February 1989. A Preliminary Analysis of U.S. $\mathrm{CO}_{2}$ Emissions Reduction Potential from Energy Conservation and Substitution of Natural Gas for Coal in the Period to 2010. DOE/NBB-0085, Washington, DC: U.S. Department of Energy, Office of Energy Research.

Gaines, L. L., and Karpuk, M. 1987. "Fermentation of Lignocellulosic Feedstocks: Product Markets and Values." In Proceedings of the Energy from Biomass and Wastes X. Conference, ed. D. L. Klass, 13951416. Chicago, IL: Institute of Gas Technology.

Gauss, W. F., Suzuki, S., and Takagi, M. 1976. "Manufacture of Alcohol from Cellulosic Materials Using Plural Ferments." U.S. Patent 3,990,944, November 9.

Gong, C.S., McCracken, L. D., and Tsao, G. T. 1981. Biotechnol. Lett. 3(5):245-250.

Hinman, N. D., Wright, J. D., Hoagland, W., and Wyman, C. E. 1989. Appl. Biochem. Biotechnol. 20/21:391.

Ho, S.P. 1989. "Global Impact of Ethanol Versus Gasoline." 1989 National Conference on Clean Air Issues and America's Motor Fuel Business, Washington DC, October 3-5.

Ingram, L. O., Conway, T., Clark, D. P., Sewell, G. W., and Preston, J. F. 1987. Appl. Environ. Microbiol. 53(10):2420.

Ingram, L. O., and Conway, T. 1988. App!. Environ. Microbiol. 54(2):397.

J.E. Sinor Consultants, Inc. February 1990. Clean Fuels Report. 1(2):82-101.

Jeffries, T. W. 1989. "Comparison of Alternatives for the Fermentation of Pentoses to Ethanol by Yeasts." In Energy Applications of Biomass, ed. M.Z. Lowenstein, 231. New York: Elsevier Applied Science.

Jeffries, T. W., Fardy, J. H., and Lightfoot, E. N. 1985. Biotechnol. Bioeng. 27(2):171-176.

Jeffries, T. W. 1981. Biotechnol. Bioeng. Symp. 11:315.

Johnson, D. K., Chum, H. L., Anzick, P., and Baldwin, R. M. 1990. Appl. Biochem. Biotechnol. $24 / 25: 31$

Johnson, L. 1989. "Vehicle Performance and Mir Quality Issues of 10\% Ethanol and 90\% Gasoline Blends." 24th Intersociety Energy Conversion Engineering Conference, Washington, DC, August 8.

Kampen, W. H. 1988. Hydrocarb Proc. 59(2):72. 
Kandell, J. 1989. "Brazil's Costly Mix: Autos and Alcohol; Alternative-Energy Plan Falters as Oil Prices Fall." Wall Street Journal, September 28.

Lastick, S. M., Mohagheghi, A., Tucker, M. P., and Grohmann, K. 1990. Appl. Biochem. Biotechnol. 24/25:431.

Livo, K. B., and Gallagher, J. 1989. "Environmental Influence of Oxygenates." AIChE National Meeting, San Francisco, California, November 9.

Lynd, L. R., Ahn, H-J., Anderson, G., Hill, P., Kersey, D. S., and Klapatch, T. 1991. Appl. Biochem. Biotechnol. Accepted for publication.

Lynd, L. R. 1990. Appl. Biochem. Biotechnol. 24/25: 695.

Lynd, L. R. 1989. Adv. in Biochem. Eng./Biotechnol. 38:1.

Mandels, M. L., Hontz, L., and Nystrom, J. 1974. Biotechnol. Bioeng. 16:1471.

Ng, T. K., Weimer, s J., and Zeikus, J. G. 1977. Arch. Microbiol. 114:1.

Pahl, R. H. 1988. "Motor Fuel and Automotive Technology Development Providing Cleaner Air for All Americans." Testimony before Joint Congressional Briefing, June 14.

Risch, C. 1988. Presentation to the California Air Resources Board Public Meeting on Clean Fuels. Sacramento, California.

Segal, M. 1989. CRS Report for Congress, The Library of Congress, Washington, DC, March 6.

Slapack, G. E., Russell, I., and Stcwart, G. G. 1989. Thermophilic Microbes in Ethanol Production. Boca Raton, FL: CRC Press.

Takagi, M., Abe, S., Suzuki, S., Evert, G. H., and Yata, N. 1977. In Proc. Bioconv. Symp., 551. Delhi: IIT.

Tewari, Y. B., Steckler, D. K., and Goldberg, R. N. 1985. Biophys. Chem. 22:181-185.

Torget, R., Werdene, P., Himmel, M., and Grohmann, K. 1990. Appl. Biochem. Biotechnol. 24/25:115.

U.S. Department of Agriculture. November 1987. Fuel Ethanol Cost-Effectiveness Study. Washington, DC: National Advisory Panel on Cost-Effectiveness of Fuel Ethanol Production.

U.S. Department of Agriculture. A.ugust 1989. Ethanol's Role in Clean Air, USDA Backgrounder Series. Washington, DC.

U.S. Department of Energy. May 1990. Annual Energy Review 1989. Energy Information Administration. Washington, DC: Government Printing Office.

U.S. Department of Energy. 1978. Comparative Automotive Engine Operation When Fueled with Ethanol and Methanol. HCP/W1737-01 UC-96, Washington, DC. 
U.S. Environmental Protection Agency. Ju:y 1989. EPA Lists Places Failing to Meet Ozone or Carbon Monoxide Standards. Washington, DC: Office of Public Affairs.

U.S. Environmental Protection Agency. 1987. Air Quality Benefits of Alternative Fuels. Washington, DC: Office of Mobile Sources.

Veldhuis, M. K., Christensen, L. M., and Fulmer, E. I. 1936. Ind. Eng. Chem. 28:430.

Wald, M. L. 1990. "Greater Reliance on Foreign Oil Feared as U.S. Output Tumbles." New York Times, New York, January 18.

Watson, E. B. June 1988. Alternative Fuels for Cars and Light Trucks: An Introduction to Oxygenated Fuels. State Government Technical Brief, Washington, DC: American Society of Mechanical Engineers.

Wenzl, H. F. 1970. The Chemical Technology of Wood. New York: Academic Press.

Wilke, C. R., Yang, R. D., and Stockar, U. V. 1976. Biotechnol. Bioeng. Symp. Ser. 6:155.

Wilson, R. D. 1987. Statement Before the Consumer Subcommittee on Commerce, Science, and Transportation, U.S. Senate, November 12.

Wright, J. D., and Power, A. J. 1985a. Biotechnol. Bioeng. Symp. 15:511.

Wright, J. D., Power, A. J., and Bergeron, P. W. June 1985b. Evaluation of Concentrated Halogen Acid Hydrolysis Processes for Alcohol Fuel Production. SERI/TR-232-2386, Golden, CO: Solar Energy Fesearch Institute.

Wright, J. D. 1988a, Energy Progress 8(2):71.

Wright, J. D. August 1988b. Chem. Eng. Prog. 84(8):62-74.

Wright, J. D., Wyman, C. E., and Grohmann, K. 1988c. Appl. Biochem. Biotechnol. 18:75.

Wright, J. D. April 1983. High Temperature Acid Hydrolysis of Cellulose for Alcohol Fuel Production. SERI/TR-231-1714, Golden, CO: Solar Energy Research Institute.

Wyman, C. E., and Hinman, N. D. 1990. Appl. Biochem. Biotechnol. 24/25:735. 
Technoeconomic Analysis

$=$ 


\title{
Preliminary Estimate of the Cost of Ethanol Production for SSF Technology
}

\author{
N. D. Hinman, D. J. Schell, C. J. Riley, \\ P. W. Bergeron, and P. J. Walter \\ Biotechnology Research Branch \\ Fuels and Chemicals \\ Research and Engineering Division \\ Solar Energy Research Institute \\ Golden, Colorado 80401
}

\begin{abstract}
SERI recently ( ompleted a detailed engineering and economic analysis of the simultaneous saccharification and fermentation (SSF)-based wood-to-ethanol process. The base case design was based on a plant capacity of 1,920 dry tons/day and a wood cost of $\$ 42 /$ dry ton. For this case, the preliminary estimate of the production cost of the ethanol product is about $\$ 1.27 / \mathrm{gal}$. The combined effects of optimization, increasing plant capacity to 10,000 dry tons/day, and reducing wood cost to $\$ 34 /$ dry ton are to reduce the preliminary estimate of the production cost to about $\$ 0.83 / \mathrm{gal}$. Other technology improvements further reduce the production cost to about $\$ 0.60 /$ gal or less. Certain technical assumptions, inherent in the analysis, are being investigated further.
\end{abstract}

\section{Introduction}

Ethanol has received considerable attention over the years as an octane booster, fuel extender, or neat liquid fuel. Today, there is heightened interest in ethanol as a transportation fuel. This stems from the facts that half of all Americans live in areas that fail to meet federal clean air standards and that the combustion of conventional hydrocarbon transportation fuels contributes more to our nation's ground level air pollution than any other human activity. In addition, essentially all conventional transportation fuels are derived from petroleum, a finite resource in the United States. We currently import about $50 \%$ of the petroleum we consume as a nation. Moreover, approximately $40 \%$ of the U.S. balance-of-payments deficit results from dollars paid for imported oil. Finally, combustion of conventional transportation fuels contributes about $27 \%$ of the $\mathrm{CO}_{2}$ released to the atmosphere in the United States each year; many believe that the accumulation of $\mathrm{CO}_{2}$ will lead to the warming of the earth and severe climatic, environmental, and socioeconomic consequences. Ethanol produced from lignocellulosic biomass can make a significant contribution to solving these problems. 
Several carbohydrate-containing feedstocks, including sugar crops, starch crops, and lignocellulosic materials, can be used as substrates for biological production of ethanol. In the United States, about 6.9 million tons of sugar are produced annually, but with prices controlled at about $\$ 360$ per ton, sugar is too expensive to use for ethanol production. Almost all of the 800 to 850 million gallons of fuel ethanol currently produced in the United States is derived from corn kernels, a starch crop. Because corn typically sells for about $\$ 90$ per dry ton (about $\$ 2.10$ /bushel), the price of the ethanol produced from this substrate is currently higher than the price of gasoline. Noreover, the potential annual ethanol production from corn kernels is estimated to be 4 billion gal/yr, which is only about $4 \%$ of the current automobile fuels market.

Lignoccllulosic materials have promise as a substrate for ethanol production in the United States because of their low cost and their huge potential availability. This potential has been estimated at 2.7 billion tons per year or the equivalent of about 300 billion gallons of ethanol, which is significantly more fuel than the current U.S. automobile fleet consumes annually.

Lignocellulosic materials are composed of carbohydrate polymers known as cellulose and hemicellulose plus lignin and smaller amounts of other materials. Agricultural residues municipal solid waste, underutilized standing forests and residues from logging operations, energy crops such as short-rotation woody crops and herbaceous crops, and waste streams from industrial operations are examples of this largely untapped source of renewable material.

The use of domestic lignocellulosic substrates for fuel cthanol production would increase fuel flexibility and reduce the related strategic vulnerability of our petroleum-based transportation fuel system. Also, because the carbon dioxide released during production and use of ethanol is recycled during the growth of biomass, there would be much less net accumulation of $\mathrm{CO}_{2}$ to the atmosphere. In fact, if ethanol is used to run lignocellulose procuction operations, the net contribution of $\mathrm{CO}_{2}$ to the atmosphere would be essentially zero. Thus, ethanol from lignocellulosic materials holds great promise as a new industry in the United States and has the potential for making a significant contribution to the solution of major problems facing our country.

The purpose of this study was to carry out an engineering and economic analysis of the current wood-toethanol process. A detailed analysis was performed on a base case prevess having a plant capacity of 1,920 dry tons/day and a hardwood feedstock cost of $\$ 42 /$ dry ton. Using the design and economic information from the base case, a spreadsheet model of the wood-to-ethanol process was developed. This model was used to optimize the base case process and to examine the effect on ethanol production cost of (1) increased plant capacity, (2) decreased wood cost, and (3) technological improvemerts.

\section{Methodology}

\section{Process Design}

\section{Introduction}

The current process of wood to ethanol is a simplified, straightforward process that contains significant improvements over processes developed in the early 1980s. As shown in Figure 1, the basic units of this process consist of feed handling, pretreatment, cellulase production, xylose and cellulose fermentations, 
and ethanol purification. In this study, several alternative technologies were considered for pretreatment, cellulase production, and xylose and cellulose fermentations. The technologies selected for each of these basic units were as follows:

\section{Unit.}

Pretreatment

Cellulase production

Xylose fermentation

Cellulose fermentation

\section{Technology}

Dilute sulfuric acid

Batch culture with Trichoderma reesei

Genetically engineered $E$. coli

SSF

The performance data on which the base case design was based come from SERI and other laboratories. The reported yields are not the best ever achieved, but rather conservative and reproducible values that form a reasonable basis for a design, reflecting the current state of process development. For dilute sulfuric acid pretreatment, yields and process conditions were taken from the work of $\mathrm{K}$. Grohmann et al. (1985); performance data obtained by D. Spindler (1989) for a genetically engineered $E$. coli developed by $L$. Ingram of the University of Florida was used for xylose fermentation; cellulase production was carried out using data from several laboratories including Tangnu et al. (1981) and Hendy et al. (1982); and data for SSF were obtained from Spindler et al. (1988; 1989a; 1989b).

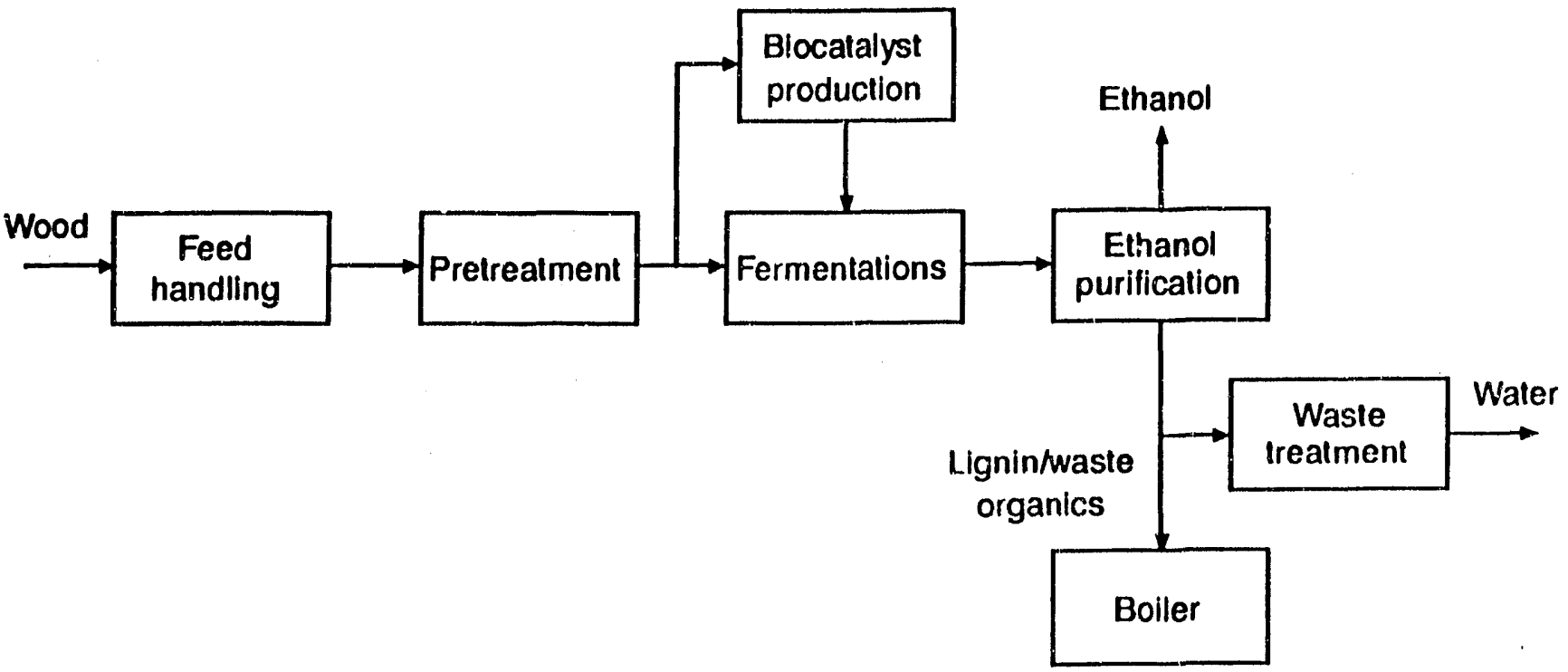

Figure 1. Blomass-to-ethanol process 


\section{Design Basls}

The design basis of the base case process follows.

- Plant type

- Plant location

- On-stream time

- Feed

- Nominal capacity

- Feed composition (dry basis)
Grass roots, $\mathrm{N}^{\text {th }}$ plant

Unspecified

$8,000 \mathrm{~h} / \mathrm{yr}$

1.0-in. wood chips

$160,000 \mathrm{lb}$ dry wood/h (1,920 dry tons/day)

46.2 wi\% ccllulose

$24.0 \mathrm{wt} \%$ xylan

$24.0 \mathrm{wt} \%$ lignin

$5.6 \mathrm{wt} \%$ solubles

$0.2 \mathrm{wt} \%$ ash

$50.0 \mathrm{wt} \%$

Bo:ler fuel

Cooling tower blowdown sent to evaporation pond Gypsum and boiler ash sent to off-site disposal Fermentative $\mathrm{CO}_{2}$ vented to atmosphere Flume pond drained to evaporation pond

On-site generation from lignin and other waste organics

On-site generation from excess steam

Excess sold over the fence

\section{Design Procedure}

For the base case, 19 detailed process flowsheets were prepared for the entire plant, including inside battery limits as well as off-sites. Detailed material balances were calculated for all areas of the plant and a complete utility summary was prepared. A complete list was compiled with sizes and specifications for more than 230 pieces of equipment, including sparcs. 


\section{Economics}

\section{Introduction}

SERI developed investment and cost of production estimates for a base case plant producing 57.9 million gal/yr of denatured cthanol product based on a wood feedstock. The plant is based on the process design described above.

\section{Capltal Investment}

The investment cost for the base case was developed by determining bare equipment costs for each piece of equipment. Costs on major pieces of equipment were obtained from recent vendor quotes (Chem Systems, Inc. 1990) as well as from other data sources, which include the ICARUS (1987) cost estimating systeri and enginecring studies carried out under subcontract to SERI (Badger Engineers 1984; A.D. Little, Inc. 1984; Chem Systems, Inc. 1985, 1990; Stone and Webster 1985a, 1985b). From the bare equipment costs, the fixed capital investment was estimated using installation factors. These factors are based on vendor information, data for fermentation-type plants, and information from ICARUS (1987). Fixed capital investment includes direct field costs (labor and materials for purchased equipment, equipment sclting, piping, civil, steel, instrumentation, electrical, insulation, painting, and buildings) and indirect costs (enginecring, construction overhead, contractor's fec, contingency, and special charges).

The total capital investment includes fixed capital investment, miscellaneous fees, start-up costs, and working capital. Start-up cosis are 5\% of fixed capital cost and working capital is based on a formula that takes into account warchouse/spare inventory, accounts reccivable/payable, and cash on hand.

\section{Annual Cash Costs}

Cash costs include expendilures for wood, raw materials, utilities, labor, maintenance, plant overhead, property taxes, and insurance. For the base case, the cost of wood was assumed to be $\$ 42 /$ dry ton, and materials costs were at the current market value. Labor rites were assumed to be $\$ 29,400 / y r$ to $\$ 40,000 / y r$, and direct overhead was at $45 \%$ of labor. Maintenance costs were at $3 \%$ of fixed capital investment and plant overhead was at $65 \%$ of labor plus maintenance. Taxes and insurance were $1.5 \%$ of fixed capital investment.

\section{Annual Capital Charge}

The annual capital charge was at $20 \%$ of the total capital investment. This includes depreciation, income taxes at 37\%, 10\% rate of return after tax, 15-year plant life, and 3-year construction period.

\section{Results of Base Case Analysis}

\section{Capital Investment}

A breakdown of the total capital investment for the base case is shown in Table 1. The fixed capital investment is estimated at $\$ 120$ million and the total capital investment is estimated at $\$ 147.2$ million. Utilities account for $40.3 \%$ of the fixed capital. In fact, the boiler and turbo generator alone account for $29 \%$ of the fixed capital. The prehydrolysis area accounts for $17.7 \%$ of the fixed capital and the SSF area 
Table 1. EstImated Base Case Capital Investment

\begin{tabular}{lr}
\hline Plant & MM\$ \\
\hline 100 Wood Handling & 2.28 \\
200 Prehydrolysis & 7.42 \\
300 Xylose Fermentation & 1.98 \\
400 Cellulase Production & 0.86 \\
500 SSF & 7.10 \\
600 Ethanol Recovery & 1.24 \\
700 Off-site Tankage & 1.00 \\
800 Environmental Systems & 1.31 \\
900 Utilities (except boiler) & 10.60 \\
Miscellaneous & 2.03 \\
& \\
Total Equipment Cost (except boiler) & 35.82 \\
Times 2.85 Installation Factor & 102.06 \\
Boiler Package & 18.02 \\
& \\
Fixed Capital Investment & 120.07 \\
& \\
Miscellaneous & 12.00 \\
Start-up Costs & 6.00 \\
Woiking Capital & 9.10 \\
& \\
Total Capltal Investment & 147.20 \\
\hline
\end{tabular}

accounts for $16.8 \%$. The remaining $25.2 \%$ is divided fairly evenly between the other six plant areas and miscellancous items.

\section{Steam Consumption/Production}

All steam requirements for the plant are provided by the combustion of lignin and waste organics. Total steam produced for the base case is 444 thousand $\mathrm{lb} / \mathrm{h}$ of 1,100 psia steam. From this, 41.4 thousand $\mathrm{lb} / \mathrm{h}$ of 150 psig and 222.9 thousand $\mathrm{lb} / \mathrm{h}$ or 50 psig steam are extracted in a turbo generator and electricity is generated. The steam requirements of the plant are shown in Table 2. Stcam is used prinarily by the ethanol recovery and pretreatment units. The total steam energy consumed per gallon of ethanol product is $33,000 \mathrm{Btu} / \mathrm{gal}$.

\section{Electriclty Production/Consumption}

All power requirements for the plant are provided by cogenerated power from lignin and other waste organics. Total electricity produced for the base case is $36.1 \mathrm{MW}$, whereas $22.7 \mathrm{MW}$ is consumed by the plant. The remaining $13.4 \mathrm{MW}$ is sold at $\$ 0.03 / \mathrm{kWh}$. A breakdown of electricity usage is shown in 
Table 2. Plant Steam Requirements

\begin{tabular}{lcc}
\hline & \multicolumn{2}{c}{ Thousand $\mathrm{lb} / \mathrm{h}$} \\
& $50 \mathrm{psig}$ & $150 \mathrm{psig}$ \\
\hline 100 Wood Handling & - & - \\
200 Pretreatment & 30.6 & 41.4 \\
300 Xylose Fermentation & - & - \\
400 Cellulase Production & 0.12 & - \\
500 SSF & - & - \\
600 Ethanol Purification & 171.1 & - \\
700 Off-site Tanks & - & - \\
800 Waste Treatrnent & - & - \\
900 Utillities & 1.1 & - \\
Miscellaneous & 20.0 & - \\
Total & $\mathbf{2 2 2 . 9 2}$ & $\mathbf{4 1 . 4}$ \\
\hline
\end{tabular}

Table 3. Here it is seen that the utilities area consumes $44.5 \%$ of the electricity, mainly by the chilled water system and air comn ssors. The next largest users are the mills in the wood handling area. This area consumes $33.8 \%$ of $": e$ electricity. Total electricity consumed per gallon of ethanol product is $3.14 \mathrm{kwh} / \mathrm{gal}$.

\section{Production Costs}

A summary of the costs of production for the base case plant is shown in Table 4. For this case, the preliminary estimate of the cost of ethanol production is about $\$ 1.27 /$ gal, which includes a $\$ 0.06 /$ gal credit for electricity sales. The annual capital charge is the largest component of this cost, representing $38.3 \%$ of the cost. The wood cost at $\$ 42 /$ dry ton is the second largest cost at $35 \%$ of the total cost. Materials are $10.1 \%$ of the cost and the remaining $16.6 \%$ is divided between maintenance, labor/direct overhead, general overhead, taxes/insurance, and miscellaneous. The estimated production cost minus the wood is $\$ 0.81 / \mathrm{gal}$.

\section{Potentlal Improvements to Base Case Economics}

\section{Optimlzation of the Base Case}

A spreadsheet model of the SSF-based biomass-to-ethanol plant was developed from the design and equipment cost information from the base case. This model was used to optimize certain base case operations.

One operation examined was the use of recycled water to mect process water requirements. For the base case, process water requirements are met partially by recycled water and partially by fiesh well water. However, analysis shows that maximum use of recycled water is preferable, lowering the cost of ethanol production by $\$ 0 \mathrm{~J} / \mathrm{g}$ ill. This results from a smaller waste treatment plant and improved overall yicld of ethanol from rec, iled xylose. 
Table 3. Plant Electricity Requirements

\begin{tabular}{llc}
\hline $\begin{array}{l}\text { Area } \\
\text { No. }\end{array}$ & Section & $\begin{array}{c}\text { Electricity } \\
\text { Consumed (kW) }\end{array}$ \\
\hline 100 & Wood Handling & 7,690 \\
200 & Pretreatment & 410 \\
300 & Xylose Fermentation & 597 \\
400 & Cellulase Production & 746 \\
500 & SSF & 2,237 \\
600 & Ethanol Purification & 485 \\
700 & Off-site Tanks & 89 \\
800 & Waste Treatment & 373 \\
900 & Utilities & 10,126 \\
& & 22,753 \\
Total electrlsity consumed & 36,100 \\
& & \\
Electricity produced, kW & 13,347 \\
Surplus power produced &
\end{tabular}

Table 4. Estimated Base Case Cost of Production

Capacity: $1,920 \mathrm{dry}$ tons/day

Throughput: $57.91 \mathrm{milli}$ ion gal/yr

Total Capital Investment: $\$ 147.2$ million

\begin{tabular}{lcc}
\hline & $M M \$ / Y r$ & $\phi / g a l$ \\
\hline Wood & 26.88 & 46.4 \\
Materials & 7.74 & 13.4 \\
Gypsum Disposal & 0.40 & 0.7 \\
Electricity & $(3.22)$ & $(5.6)$ \\
Water & 0.12 & 0.2 \\
Labor/Supervision & 1.57 & 2.7 \\
Maintenance & 4.14 & 7.2 \\
Direct Overhead & 0.71 & 1.2 \\
General Overhead & 3.71 & 6.4 \\
Insurance, Property Tax & 2.07 & -3.6 \\
Total Cash Cost & & 76.2 \\
& 44.11 & 50.8 \\
Annual Capital Charge & 29.44 & \\
& & \\
Total Cost of Production & $\mathbf{7 3 . 5 5}$ & $\mathbf{1 2 7 . 0}$ \\
\hline
\end{tabular}


The optimum amount of cellulase to employ with SSF was also examined. In the base case, 7 international units (IU) of cellulase per gram of cellulose was used in SSF, whereas a more optimal use is about 13 IUs. At this level, the base case production cost drops by about $\$ 0.07 /$ gal. Although the cost associated with the cellulase production unit increases, the SSF yield improves.

The combined effect of the two optimizations described above is to lower the base case production cost by $\$ 0.11 / \mathrm{gal}$.

\section{Effect of Increased Plant Capacity}

The effect of increased plant capacity on production cost is shown in Table 5. Here it can be seen that increasing plant capacity from 1,920 dry tons/day to 10,000 dry tons/day decreases the production cost by $\$ 0.25 / \mathrm{gal}$. A r.ming a biomass yield of 10 tons/acre, the radius of feedstock collection for this larger plant is only a littli over 10 miles.

\section{Effect of Wood Cost}

The effect of wood cost on the production cost relative to the base case is shown in Table 6. This table shows that at $\$ 34 /$ dry ton (the goal of the Biomass Production Program), the production cost is lowered $\$ 0.09 / \mathrm{gal}$, whereas at zero feedstock cost, the production cost is lowered $\$ 0.46 / \mathrm{gal}$.

\section{Combined Effect of Optimization, Increased Plant Capacity, and Lower Feedstock Cost}

The combined effects of optimization and increasing plant capacity to 10,000 dry tons/day as a function of feedstock cost are shown in Figure 2. Here it is seen that for an optimized plant at 10,000 dry tons per day capacity and a feedstock cost of $\$ 34 /$ dry ton, the production cost of ethanol is lowered $\$ 0.44 / \mathrm{gal}$.

Table 5. Effect of Plant Capacity on EstImated Production Cost

\begin{tabular}{lc}
\hline $\begin{array}{l}\text { Plant Capacity } \\
\text { (dry tons/day) }\end{array}$ & $\begin{array}{c}\text { Production Cost } \\
\text { (\$/gal) }\end{array}$ \\
\hline 1,920 (base case) & 1.27 \\
5,000 & 1.11 \\
10,000 & 1.02 \\
20,000 & 0.94 \\
\hline
\end{tabular}


Table 6. Effect of Wood Cost on Estlmated Production Cost

\begin{tabular}{cc}
\hline $\begin{array}{c}\text { Wood Cost } \\
(\$ / \text { dry ton })\end{array}$ & $\begin{array}{c}\text { Production Cost } \\
(\$ / \text { gal })\end{array}$ \\
\hline 42 & 1.27 \\
40 & 1.25 \\
35 & 1.19 \\
34 & 1.18 \\
30 & 1.13 \\
25 & 1.08 \\
20 & 1.02 \\
15 & 0.97 \\
10 & 0.91 \\
0 & 0.81 \\
\hline
\end{tabular}

\section{Improvements to Technology}

Improvements to the base case biomass-to-ethanol technology can reduce the cost of production by (1) increasing the yield of available carbohydrate to ethanol, (2) increasing the revenue from electricity, (3) decreasing capital-related costs, or (4) decreasing noncapital-related cash costs. The effect of improving yield and decreasing capital- and noncapital-related cash costs is shown in Figure 3. Clearly, improving yield over the $68 \%$ yield for the base case has the biggest impact on production cost. Decreasing capital-related costs is next in importance, with decreasing noncapital-related cash cost of least importance.

Using the spreadsheet model, the effects of several specific performance improvements in the base case were investigated, as shown in Table 7. As expected, improvements of yields, particularly SSF yields, have significant impact on the production cost. Reduction of SSF fermentation time also has a significant effect. The combined effect of the individual improvements is shown in Table 8 for the case with wood at $\$ 42 /$ dry ton and plant capacity of 1,920 dry tons/day as well as for wood at $\$ 34 /$ dry ton and a plant capacity of 10,000 dry tons/day. For the latter case, the production cost is $\$ 0.61 / \mathrm{gal}$.

Other technology improvements besides those shown in Table 7 are possible. They include (1) use of fcedstocks with higher carbohydrate content, (2) further reduction of power for milling, (3) reduced power and capital for air compression, (4) increased efficiency of the boiler/turbo generator, (5) improved heat integration, (6) reduced nutrient costs, and (7) advanced bioreactor designs.

\section{Conclusions}

Progress in the development of an SSF-based biomass-to-ethanol process has been steady and significant since 1980. In 1980 , the production cost of ethanol was estimated at $\$ 3.60 /$ gal; today the preliminary estimate of the cost for a base case design is $\$ 1.27 /$ gal. This current base case cost assumes a feedstock cost of $\$ 42 /$ dry ton and a plant capacity of 1,920 dry tons/day. Moreover, this cost is for an unoptimized 


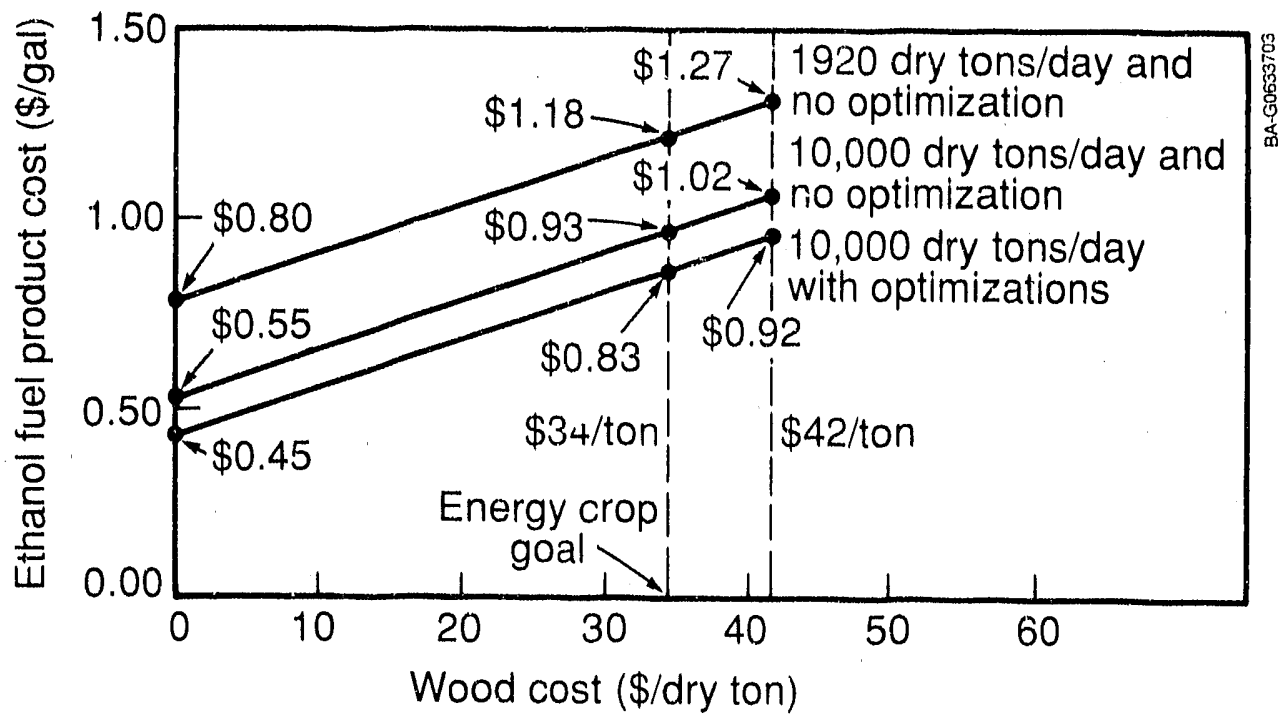

Figure 2. Combined effects of plant size and optimizatlon versus wood cost

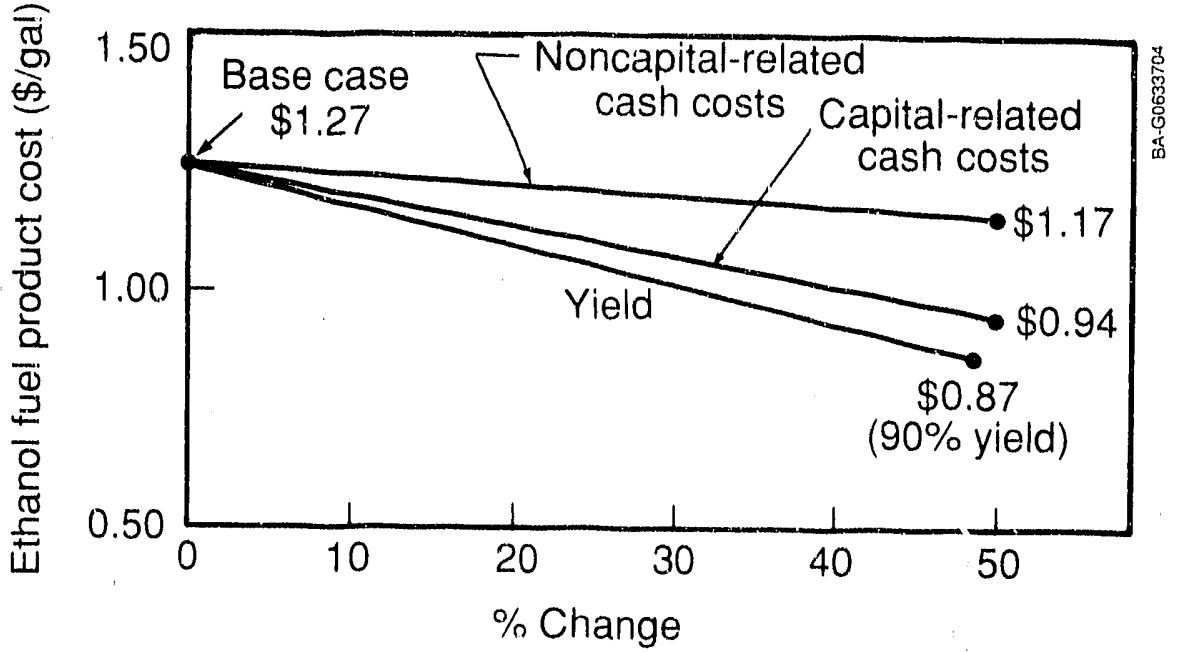

Figure 3. Effect of Increased yleld, decreased capital cost, and decreased cash costs 
Table 7. Effect of Speclflc Improvements on EstImated Production Cost of Fuel Ethanol

Improvement

Decrease From Base

Case of $\$ 1.27 / \mathrm{gal}$

(ф/gal)

Yield-Related

- Improve SSF yleld to $90 \%$

- Improve xylose to ethanol yield to $90 \%$

7

- Minimize need to regrow T. reesei to

produce each batch of cellulase

6

- Improve xylan to xylose yield to $90 \%$

2

Capital-Related

- Decrease SSF fermentation time to 2 days

- Decrease xylose fermentation time to 1 day

- Decrease cellulose fermentation time to 4 days

Noncapltal-Related

- Decrease milling HP by $35 \%$

2

Table 8. Comblned Effect of Indivldual Technical Improvements on Estimated Productlon Cost of Ethanol

\begin{tabular}{lc}
\hline \multicolumn{1}{c}{ Case } & $\begin{array}{r}\text { Production Cost } \\
(\$ / \text { gal })\end{array}$ \\
\hline $\begin{array}{l}\text { Base case of wood at } \$ 42 / \text { dry ton and } \\
\text { capacity at } 1,920 \text { dry tons/day }\end{array}$ & 1.27 \\
$\begin{array}{l}\text { Technical improvements shown in Table 7, } \\
\text { wood at } \$ 42 / \text { dry ton and capacity at } \\
1,920 \text { dry tons/day }\end{array}$ & 0.83 \\
$\begin{array}{l}\text { Technical improvements shown in Table } 7, \\
\text { wood at } \$ 34 / \text { dry ton and capacity at } \\
10,000 \text { dry tons/day }\end{array}$ & 0.61 \\
\hline
\end{tabular}


plant. However, certain technical assumptions inherent in the analysis must be investigated before the analysis can be finalized.

For an optimized plant using wood at $\$ 34 /$ dry ton and having a capacity of 10,000 dry tons/day, the production cost of fuel is estimated to be $34 \%$ below the base case cost. The base case yleld of ethanol from available carbohydrate is $68 \%$, and improvements in yicld will have a significant impact on the production cost. Substantial improvements in yicld are possible and are being achieved in the laboratory. Technology improvements that result in lower capital-related costs will also have a significant impact on production cost, but not to the same extent as yield improvements. Lowering noncapital-related cash costs will have less impact on production costs.

Use of a spreadshect model of the SSF-based biomass-to-cthanol process indicates that, with certain specific improvements in yields and reaction rates together with $\$ 34 /$ dry ton feedstock and a capacity of 10,000 dry tons/day, the cost of ethanol production can be reduced to $\$ 0.61 /$ gal. Other improvements, which could reduce the cost even further, are also possible.

\section{Acknowledgment}

This work was supported by the Ethanol from Biomass Program of the U.S. Department of Energy's Biofuels Systems Division.

\section{References}

Arthur D. Little, Inc. 1984. SERI Subcontract No. 625-RIER-BEA-84.

Badgers Enginecrs, Inc. 1984. SERI Subcontract No, ZX-3-030-96-2.

Chem Systems, Inc. 1985. SERI Subcontract No. XX-3-03097-2.

Chem Systems, Inc. 1990. Subcontract No. HD-0-10116-1.

Grohmann, K., Torget, R., and Himmel, M. 1985. Biotechnol. Bioeng. Symp. 15:59-80.

Hendy, N., Wilkc, C., and Blanch, H. 1982. Biotechnol. Lett. 4(12):785-788.

ICARUS Corporation. 1987. Cost Systems User's Manual.

Spindler, D.C., Wyman, C. E., Mohagheghi, A., and Grohmann, K. 1988. Appl. Biochem. Biotechnol. 17:279-283.

Spindler, D.D., Wyman, C. E., and Grohmann, K. 1989a. Biotechnol. Bioeng. 34:189-195.

Spindler, D.D., Wyman, C. E., Grohmann, K., and Mohagheghi, A. 1989b. Appl. Biochem. Biotechnol. 20/21:529-540.

Spindler, D. D. 1989. Personal communication, Solar Energy Research Iastitute.

Stone and Webster Enginecring Corp. 1985a. SERI Subcontract No. ZX-3-03097-1. 
Pretreatment Research 


\title{
Pretreatment Research Overvlow
}

\author{
K. Grohmann, R. Torget, and M. Himmel \\ Biotechnology Research Branch \\ Fuels and Chemicals \\ Research and Engineering Division \\ Solar Energy Research Institute \\ Golden, Colorado 80401
}

Cellulose and hemicelluloses in native lignocellulosic biomass are only slightly digestible by cellulase and hemicellulase enzymes. The recalcitrance of polysaccharides in cell walls of plants to enzymatic hydrolysis is caused by lignin-hemicellulose matrices, which encase cellulose fibers and prevent access of cellulase enzymes to these fibers. Therefore, most if not all biomass substrates have to be pretreated before high yields of sugars by enzymatic hydrolysis can be achieved. All pretreatments involve one or more mechanical comminution steps to decrease the particle size and increase the surface area. Mechanical treatments at high shear (e.g., ball milling) can also tear up the cell walls and increase the enzymatic digestibility of polysaccharides. However, purely mechanical pretreatments require high energy inputs and are rather costly. Similar arguments apply to more exotic physical pretreatment methods, such as irradiation with $x$-rays or $\gamma$-rays. Currently, the most promising approaches to pretreatments are different versions of chemomechanical treatments, where physical forces decrease the particle size and chemical agents break down and dissolve the lignin-hemicellulose matrices. Depending on the pretreatment method and substrate used, hemicelluloses alone or both lignin and hemicelluloses are depolymerized and removed from cellulose fibers.

The Ethanol from Biomass Program supported six pretreatment projects in FY 1990. These projects are summarized in this introduction with more details provided in the papers that follow.

\section{In-House Research}

\section{Biomass Characterization}

SERI researchers were active in preparing biomass reference materials for the voluntary standards activity of the International Energy Agency. Four research samples of various biomass materials are being prepared in collaboration with the National Institute of Standards and Technology. SERI researchers and their university collaborators have also been developing rapid instrumental methods for analyses of biomass feedstocks. The methodology will be useful to both production and conversion efforts, because 
they may allow rapid screening of plant species, clones, and mutants for incorporation into desired conversion processes. In FY 1990, the emphasis was placed on developing a fast pyrolysis/molecular beam mass spectrometry technique. Multivariate techniques were used to analyze the pyrolysis data and predict the relative concentrations of major and minor components of 19 herbaceous biomass species. The absolute calibration of the technique by other instrumental and chemical methods is in progress.

\section{DIlute Acld Pretreatment of Short-Rotation Crops and Corn Crop ResIdues}

SERI researchers have been pursuing dilute acid prehydrolysis at elevated temperatures as a pretreatment method for the last several years. The original experimental work with wheat straw and aspen wood established kinetic paramelers for hemicellulose hydrolysis and led to a correlation between xylan removal and increased cnzymatic digestibility of cellulose. Over the last 2 to 3 years, the method has been extended to short-rotation woody and herbaceous crops being developed by the DOE Biomass Production Program managed by Oak Ridge National Laboratory.

Two corn crop residues, corn stover and corn cobs, were also evaluated under funding of the Western Regional Biomass Program, which is managed by the Western Area Power Administration. The evaluation of the first series of short-rotation crops was completed in the summer of 1990. In summary, researchers evaluated the susceptibility of six hardwoods to dilute acid pretreatment; specifically, two poplar hybrids, sweetgum, sycamore, silver maple, and black locust. The conditions chosen from previous work with aspen wood and wheat straw were: sulfuric acid catalyst in water at $0.45 \%-0.50 \%(\mathrm{v} / \mathrm{v})$ concentration; temperature $140^{\circ}$ and $160^{\circ} \mathrm{C}$; and reaction times of 0 to $60 \mathrm{~min}$ at $140^{\circ} \mathrm{C}$, and 0 to $20 \mathrm{~min}$ at $160^{\circ} \mathrm{C}$. All hardwoods were susceptible to dilute acid pretreatment at $160^{\circ} \mathrm{C}$ for 10 to $20 \mathrm{~min}$, but significantly lower enzymatic digestibilities were observed for black locust and silver maple pretreated at $140^{\circ} \mathrm{C}$. These results indicate that additional temperature effects, such as condensation of lignin, can be important pretreatment mechanisms in some hardwoods. The corn cobs were unusually susceptible to dilute acid pretreatment: all xylan dissolved and a highly digestible residue was obtained after only 5 min at $140^{\circ} \mathrm{C}$. The short-rotation herbaceous crops were three grasses and two ligumes. The grasses behaved as wheat straw, but the legumes appear to be more resistant to dilute acid pretreatment than all other substrates investigated so far. Low digestibilities of cellulose (50\%-60\%) were observed for both legumes pretreated at $140^{\circ}$ and $160^{\circ} \mathrm{C}$. The observed results indicate that higher temperatures may be necessary for efficient acid-catalyzed pretreatment of legumes.

\section{Economic Comparison o. Dilute Acld Pretreatment and Steam Explosion}

SERI researchers completed preliminary engineering ana explosion pretreatments for wheat straw and aspen wood. Uncatalyzed steam explosion was not considered because xylose yields are significantly lower than from the other two methods. Detailed process flowsheets, material and energy balances, and equipment costs were prepared and used for technical and economic analyses. For the same pretreatment process, the sugars produced from aspen wood were slightly cheaper than those from wheat straw because of the higher carbohydrate content of aspen. The dilute acid pretreatment had more favorable economics than $\mathrm{SO}_{2}$-catalyzed steam explosion, because extensive equipment for $\mathrm{SO}_{2}$ recovery was not required in dilute acid pretreatment. 


\section{Subcontracted Research}

\section{Ammonia Fiber Explosion (AFEX) Pretreatment}

The Ammonia Fiber Explosion (AFEX) process treats lignocellulose with high-pressure liquid ammonia ant then explosively releases the pressure. The combined chemical effect (cellulose decrystallization) and physical effect (increased accessible surface area) dramatically increase lignocellulose susceptibility to enzymatic attack. There are many adjustable parameters in the AFEX process: ammonia loading, water loading, temperature, time, blowdown pressure, and number of treatments. Scientists explored the effect of these parameters on the enzymatic susceptibility of bagasse. The treatment effectiveness was not very sensitive to ammonia or water loading. However, the treatment was very sensitive to temperature; higher temperatures $\left(93^{\circ} \mathrm{C}\right)$ were significantly better than lower temperatures $\left(13^{\circ} \mathrm{C}\right)$. Multiple treatments benefited reactivity; however, there were diminishing retums with each subsequent treatment. Importantly, a 3-atm blowdown produced bagasse that was nearly as reactive as a 1.5 -atm blowdown, thus offering tremendous savings in reccmpression costs. High sugar yields were demonstrated for enzymatic hydrolysis of cellulose in optimally pretreated bagasse.

\section{Pretreatment of Aspen Wood Almed at HIgh Hemlcellulose Retention}

Monoethanolamine (MEA) and supercritical $\mathrm{CO}_{2}-\mathrm{SO}_{2}$ were used as pretreatment reagents for aspen wood to enhance the susceptibility in enzymatic hydrolysis by cellulase enzyme. These pretreatment methods were investigated for their effectiveness in enhancing enzymatic hydrolysis as well as retaining the hemicellulose fraction. After pretreatment with MEA, 76\%-93\% of original xylan in aspen was retained. In supercritical $\mathrm{CO}_{2}-\mathrm{SO}_{2}$ pretreatment, xylan retention varied widely between $32 \%$ and $91 \%$, depending on time and temperature of the reaction. Glucomannan and arabinogalactan were solubilized in water, thus lowering the yield of carbohydrates in the insoluble residue. For both pretreatments conducted at optimum conditions, an overall carbohydrate yield of $83 \%$ could be achieved after enzymatic hydrolysis. Treatment with $50 \%$ MEA removed $91 \%$ of the original lignin, while supercritical $\mathrm{CO}_{2}-\mathrm{SO}_{2}$ applied at $130^{\circ} \mathrm{C}$ for $4 \mathrm{~h}$ removed only $61 \%$.

The effect of enzyme loading on the hydrolysis rates of $\alpha$-cellulose and MEA-pretreated substrate was studied. For $\alpha$-cellulose, the rate of hydrolysis increased only up to enzyme loading of 113 international filter paper units (IFPU) cellulase/g cellulose. With MEA-pretreated substrate, however, the hydrolysis rates increased with enzyme loading up to $226 \mathrm{IFPU} / \mathrm{g}$ substrate. The hydrolysis rates were higher for the pretreated aspen than those for $\alpha$-cellulose at similar enzyme loadings. The pretreated aspen was found to be suitable for further conversion into acetone and butanol by using $C$. acetobutylicum and cellulase in a simultaneous saccharification and fermentation process.

\section{Biomass Pretreatment - NMR Studles}

Peracetic acid is a selective delignifying agent which, when used in small amounts under very mild conditions, results in increased accessibility of biomass toward cellulases and other hydrolytic enzymes. There is also some evidence that peracetic acid may mimic brown rot fungi by modifying lignin through its selective oxidative reactions. However, when the three biomass materials-ponderosa pine, quaking aspen, and wheat straw--were treated with peracetic acid, lignin modifications did not correlate very well with the subsequent enzymatic hydrolysis. Ponderosa pine lignin seemed the most modified and wheat straw lignin the least, with aspen occupying an intermediate position. However, when comparing enzymatic hydrolysis, aspen had the most improved accessibility, with wheat straw also improving significantly, and ponderosa showing only slightly increased accessibility for the enzymes. Wood has also 
been decayed using the fungus Poria monticola, and modifications of the lignin resulting from the peracetic pretreatment are being compared with the lignin resulting from brown rot decay. This work is still in progress.

As can be seen from the factor score plot and the variance diagram, the samples fall into five groups in the factor space. These groups were related to the differences in chemical composition between groups and similarity within grcups. These differences can be correlated with conversion technologies in predicting the performance of various species in specific conversion processes. Table 2 shows the relative concentration of the major chemical components in the biomass species estimated from the factor analysis of the pyrolysis data. The MBMS factor scores obtained from the factor analysis are proportional to the concentration of the classes of compounds present in the herbaceous biomass species. However, because factor scores in any class of compounds (e.g., hexosans) were assigned an arbitrary value of 100 and the scores of the other samples were scaled to this value. The scores therefore reflect the relative concentration of these chemical compounds in the biomass species. It is clear from Table 2 that there is a wide variation in converting these species to fuels. These data can serve as a guide for selection of species that will undergo conversion into R\&D alcohols. Also, the data can guide selection of species that will undergo conversion into R\&D alcohols. Also, the data can guide selection of further herbaceous species for conversion. These experiments are very fast. In one day, one can screen dozens of samples and provide ranking order for important species composition.

Table 2. Relative MBMS Factor Score on Varlous Compound Classes in the Herbaceous Blomass Specles ( \pm )

\begin{tabular}{lccc}
\hline \multicolumn{1}{c}{ Species } & Pentosans $^{\mathrm{a}}$ & Hexosans $^{\mathrm{a}}$ & Lignin $^{\mathrm{a}}$ \\
\hline Alfalfa & 17 & 30 & 59 \\
Eastern gama grass & 37 & 41 & 32 \\
Energy cane & 88 & 45 & 40 \\
Forage brassica & 26 & 31 & 100 \\
Kale & 14 & 100 & 32 \\
Orchard grass & 40 & 29 & 39 \\
Perennial ryegrass & 100 & 29 & 63 \\
Reed canary grass & 24 & 78 & 20 \\
Smooth bromegrass & 40 & 40 & 41 \\
Sudan grass & 42 & 44 & 42 \\
Sweet sorghum & 92 & 46 & 48 \\
Switchgrass & 85 & 35 & 38 \\
Tall fescue & 48 & 32 & 36 \\
Timothy grass & 36 & 32 & 39 \\
\hline
\end{tabular}

"The sample with the highest MBMS factor score in each compound class is assigned an arbitrary value of 100 and other sample scores are scaled to this value. 


\title{
Blomass Characterization - Progress Report
}

\author{
F. A. Agblevor and H. L. Chum \\ Chemical Conversion Branch \\ Fuels and Chemicals \\ Research and Engineering Division \\ Solar Energy Research Institute \\ Golden, Colorado 80401
}

\begin{abstract}
The goal of this task is to develop rapid chemical and spectroscopic characterization methods for biomass feedstocks to predict composition and relate composition to conversion performance in a variety of biomass-to-fuels conversion processes. Thus, this task bridges biomass production and conversion programs, provides some guidance to biomass production researchers as to desired traits in biomass feedstocks for conversion processes, and may provide conversion researchers and industry with reliable, fast analytical techniyues for process control. This report summarizes research in progress on various aspects of the task. The main areas addressed include (1) preparation of International Energy Agency (IEA) biomass reference materials for the IEA Voluntary Standards Activity (Task 7); (2) feedstock quality for energy products, in cooperation with the IEA/Bioenergy Agreement (BA) (Task 5 Activity); (3) illustration of the effect of feedstock composition on the biomass to fuels for selected conversion routes; (4) preliminary investigation of the lignification process in grasses using fast characterization methods, work done in collaboration with $\mathrm{R}$. Babcock, a science school teacher from Seoul American High School, Seoul, S. Korea; and (5) rapid chemical characterization of biomass by integrated multivariate analysis of multisource spectrometric data in collaboration with Colorado State University, Regional Nuclear Magnetic Resonance facility.
\end{abstract}

Three presentations were made as a result of this work. Papers relating to Area 2 were presented at the IEA/BA Task 5 meetings in Toronto, Canada, June 1989 and July 1990, and at the Terrestrial Energy Crops Program, 1988 Conference and Workshop, Washington, DC, July 1989. Publications of these areas are listed.

\section{Preparation of Internatlonal Energy Agency (IEA) Blomass Reference Materlals for the IEA Voluntary Standards Actlvity}

Since 1986, the IEA has sponsored the "Voluntary Standards Activity," through Biomass Conversion Annexes, with SERI as the lead organization. Many countries are participating in this effort-Canada, Finland, The Netherlands, New Zealand, Norway, Sweden, and the United States. Among many activities, the IEA is conducting a series of analytical round robin tests. These activities are co-sponsored by the 
Biomass Characterization Subtask, which is directly sponsored by the U.S. Department of Energy (DOE) Biofuels Program, and have been partly sponsored by the Bioenergy Development Program of the Renewable Energy Branch of Energy, Mines, and Resources (EMR) of Canada. In particular, for the Voluntary Standards Activity, a round robin is being conducted on comparative analyses of wood and herbaceous samples, employing the protocol of $\mathrm{O}$. Theander (University of Agricultural Science in Uppsala, Sweden) hoping to unify the fields of wood and herbaccous analyses. The need for this unification is clear because protocols for analyzing herbaceous species include fractionation of the herbaccous biomass (see Goering and Van Soest 1970) and therefore do not provide total composition information, cssential for conversion processes. Wood analysis protocols cannot be followed without substantial modifications of the methods for herbaceous species. Theander has now incorporated these modifications; their applicability will be tested.

The need for suitable standards in the worldwide biomass research community has been well established. The first step toward the establishment of standards is the institution of suitable research matcrials that are analyzed by a variety of well-defined methods. Based on these methods, certified standard materials may emerge in the future. (A parallel effort in the lignin field is described in the lignin characterization report in this document). To this end, in July 1990, H. Chum issued a call for participation in the analytical round robin on whole feedstock analysis to about 700 researchers in various laboratories throughout the world. Participation in the round robins is confidential, as to which results belong to which laboratory. To preserve confidentiality, statistical analysis of the data will be performed by rapporteurs, who do not have the knowledge or access to the files at SERI that contain the identity of the coded laboratorics. Results of this test will be discussed at the Pre-Symposium on Modern Methods of Analysis of Wood and Annual Plants in New Orleans, La., in 1991, organized by H. Chum and G. Gellerstedt. This symposium precedes the international conference Cellulose 91, which combines three 1991 international conferences in New Orleans, Lil., December 2-6, 1991. As of September 1, 1990, ten laboratories worldwide joined the round robin as defined. Several others volunteered to perform their own analytical methods, instead of following Theander's protocol, thus providing additional value to the round robin in terms of comparisons with the currently available methods of analyses.

\section{IEA Reference Blomass Materials}

Under an agreement with the National Institute of Standards and Technology (NIST, formerly National Bureau of Standards), NIST is preparing and packaging 5()-g samples of various biomass materials for the initial testing: Populus deltoides from the Oak Ridge National Laboratory (ORNL) production program (J. Cushman); Pinus radiata from Ministry of Forestry, Forest Research Institute, Rotorua, New Zealand; wheat straw (Colorado); and sugarcane bagasse from the Hawaiian Sugar Planters Association. These materials will be available to laboratories participating in the IEA Voluntary Standard Methods of Analysis Activities. These materials are designated Rescarch Materials only, and not Standard Reference Materials because of the much higher level of analysis and certification required to achieve "standard" status; the current stage is necessary to achicve the reference standard level. To date, about $50 \mathrm{~kg}$ each of air-dried samples of the above biomass materials have been shipped to NIST for Wiley milling, packaging, and distribution to the round robin test participants. The wood samples have been hammer/Wiley milled to $-20 /+80$ mesh size and are ready for packaging and shipment. Most of the sugarcane bagasse and wheat straw samples have also been Wiley milled. Becaluse of the length of these preparations, the current set of round robin samples does not include a truly herbaceous species. Such matcrials are planned to be incorporated as part of later round robins, when the method and its application have been more widely tested worldwide.

In parallel, the rescarchers under J. MCKinley at BC Research Corporation are testing 'Theander's protocol under direct sponsorship of the electromagnetic resonance (EMR) program. This testing will provide a 
step-by-step analytical protocol that will be followed by the international researchers. BC Research's protocol will first be tested by SERI researchers and then distributed with the samples worldwide.

\section{Feedstock Quallty for Energy Products, In Cooperation with the IEA/BA Task 5 Actlvity}

The activities of Task 5 are supported by Austria, Belgium, Canada, Denmark, Finland, Italy, Norway, Sweden, United Kingdom, and the United States. These activities deal with biomass production systems and are heavily focused on the growth and production of the most appropriate feedstocks for conversion into fuels. To that effect, a dialogue between production and conversion researchers has been established, with a variety of analytical data exchange and information on desired traits and characteristics of various feedstocks. SERI researchers have been participating in the activities of the IEA biomass production systems for the past 2 years. Agblevor et al. (1989) reported on the multivariate approach to the rapid screening of biomass feedstocks for thermochemical conversion processes at the 1989 IEA/BA Task 5 meeting. At the 1990 meeting on Feedstock Quality, Tree Ideotype, and Ecophysiology carried out in Toronto, July 31-August 4, 1990, representatives of Belgium, Canada, Finland, Sweden, United Kingdom, and the United States, along with invited countries (Hungary), discussed wood feedstock quality as it relates to conversion processes. $H$. Chum presented a talk on feedstock quality parameters for energy products, co-products, and byproducts at the invitation of L. Zsuffa (University of Toronto), the Operating Agent for Task 5. A review of desirable characteristics of feedstocks for conversion through biochemical or thermochemical processes was presented.

Conversion needs are process specific. High cellulosic- and hemicellulosic-content feedstocks are desired with low acetyl, uronic acid, ash, and lignin content for selective conversion of biomass to ethanol. For thermochemical conversion of biomass into synthesis gas/methanol (or other alcohols), the highest heat content is desired; therefore, feedstocks with a high lignin content are appropriate. In both cases, high density and productivity, and low moisture and ash content are desired traits.

In addition, a revicw of lignin biogenesis (see, for instance, Lewis and Yamamoto, 1990) was made to indicate that not only general compositional characteristics could be varied but also specific oualities of the polymeric components of biomass, which may lead to better feedstocks for conversion provesses. For instance, if hardwoods containing more syringyl are developed (through screening and characterization of cxisting clones, or modification through breeding, or other approaches), these feedstocks would be very casy to delignify, because of the increased proportion of alkyl aryl ether bonding in the polymer. These are the bonds that are easiest to cleave in a variety of pretreatment processes, and thus are the most suited for biomass-to-ethanol conversion processes. In all cases, stable, uniform, reproducible, and low-cost feedstocks are desirable. Analogies were drawn with feedstock qualities for conventional processing of biomass (sec, for instance, Cowling and Kirk 1976).

These activities will continue with a more detailed assessment of the literature data on the biomass quality question by L. Zsuffa, H. Chum, and L. Sennerby-Fosse (Sweden). Exchanges of analytical data bases will be carried out in 1990-1991, and a close relationship will be maintained between the various tasks of the IEA activities related to biomass production, storage, conversion, and standards activities. 


\section{Illustration of the Effect of Feedstock Composition on Blomass to Fueis for Selected Conversion Routes}

The efficient conversion of biomass feedstocks to fuels and chemicals requires a thorough understanding of the chemical and physical properties of the biomass feedstocks. Furthermore, the diversity of biomass feedstocks suggests that a fasi method be developed to rapidly screen suitable feedstocks for the various conversion processes. During the past year, a rapid screening method for herbaceous biomass feedstocks was developed. These studies are being expanded to include additional techniques, and to incorporate a larger data base of samples to validate and expand the analytical areas.

\section{Multivarlate Approach to the Rapld Screening of Blomass Feedstocks for Conversion Processes}

A rapid screening method for selecting biomass species to suit specific conversion processes is being developed. In this approach, herbaceous biomass samples were pyrolyzed at atmospheric pressure and $600^{\circ} \mathrm{C}$, with analysis of the primary products in real time by molecular beam mass spectrometry (MBMS). Multivariate techniques were used to analyze the pyrolysis data and to classify the biomass species as well as to predict the relative concentration of some pyrolysis products that are indicators of the ability of these feedstocks to undergo conversion under biochemical and thermochemical conditions. The potential of the multivariate approach to determine biomass feedstock composition is discussed; additional characterization methods are presented in the rapid characterization section that follows. The ultimate objective of this study is to provide a rapid screening tool for feedstocks and a method for predicting the composition and conversion properties of a wide variety of biomass resources. Our initial report is on the ability of these techniques to predict composition in a very fast way for a wide variety of herbaceous feedstocks of interest to the program.

A wide varicty of biomass resources exists for conversion to fuels and chemicals, (e.g., forest, shortrotation, and herbaceous biomass; micro- and macro-algae; waste wood from the forest products industry; and agricultural waste). Similarly, a variety of conversion routes (biological, gasification, and pyrolysis) exist to transform these biomass resources into useful products. The chemical and physical properties of these biomass feedstocks play a major role on the chosen conversion route and product yield. The conventional wet chemical methods for analyzing these materials are time-consuming and have been developed for a variety of purposes, including assessment of their protein value, a different characteristic than that sought in biomass-for-fuels processes. The development of a more rapid method for assessing biomass composition and suitability for a variety of conversion processes could be very helpful not only to conversion but also to production researchers in this area. Pyrolysis-mass spectrometry (PY-MS) as a qualitative technique for fingerprinting complex substances is a well-established method (e.g., Irwin 1979; Meuzelaar et al. 1974; Windig et al. 1987). The multivariate analytical technique for determini.g the partial or absolute chemical composition of complex biopolymers from pyrolysis-mass spectral data is a relatively recent development that is still evolving (e.g., Windig et al. 1983, 1981). In employing this technique for semi-quantitative analysis of complex materials, it is assumed that the pyrolysis-mass spectra are additive and well-behaved with respect to the principal constituents of the starting materials. However, pyrolysis products from plant cell wall constituents can be influenced by the presence of alkali metals, which can complicate data interpretation (see Evans and Milne 1987). Consequently, there is the need for the development of new methods to deal with the diversity of actual samples. The objective of this paper is to show preliminary data on how PY-MS combined with factor analysis can be used to rapidly screen biomass feedstocks for desirable conversion characteristics.

Nineteen herbaceous biomass species were air-dried at room temperature and ground to 1-mm mesh size for the pyrolysis experiments (sce Table 1). Each herbaceous sample was homogenized in a V-blender and $25-$ to $30-\mathrm{mg}$ lots were pyrolyzed in a single-stage pyrolysis reactor in a helium atmosphere. The 
primary pyrolysis products were analyzed on an Extrel quadrupole molecular beam mass spectrometer (see Evans et al. 1986 and Evans and Milne 1987 for details of instrumentation). The mass spectra were recorded on a Teknivent data acquisition system for the total and individual ion current in real time. The spectra were averaged over the pyrolysis product wave and the background noise was subtracted. Each sample was run in triplicate to assess reproducibility of the results.

The data analysis was accomplished with the Interactive Self-modeling Multivariate Analysis (ISMA) package, courtesy of W. Windig of the Chemometrics Laboratory, Analytical Technologies Division of Eastman Kodak Co., Rochester, New York. The data were normalized to the total ion current (TIC) to account for sample size variation; data reduction and analyses were performed on the correlation aroundthe-origin matrix. The factor analysis resu'ts were presented as factor scores, which showed the major differences between the mass intensities from different samples. Similar samples formed clusters in the factor space. The relationship between the MBMS pyrolysis data and the chemical composition of the feedstock was obtained trom the variance diagram. This diagram presents factor-analyzed data graphically,

Table 1. Herbaceous Specles Investlgated by Pyrolysls Mass Spectrometry

\section{Common Name}

Sweet sorghum (SS)

Switchgrass (SWG)

Weeping love grass (LG)

Sericea lespedeza (SL)

Johnson grass (JG)

Bermuda grass (BG)

Alfalfa (AL)

Energy cane (EC)

Tall fescue (TF)

Timothy grass (TG)

Perennial ryegrass (PRG)

Orchard grass (ORG)

Smooth bromegrass (SBG)

- Eastern gama grass (EGG)

Forage brassica (FBR)

Kale (KL)

Reed canary grass (RCG)

Sudan grass (SUG)

Bird's-foot trefoil (BFT)

\section{Taxonomy}

(Sorghum bicolor var. "M81E")

(Panicum virgatum L.)

(Erogrostis curvula)

(Lespedeza cuneata)

(Sorghum halapense)

(Cynodon dactylon)

(Medicago sativa)

Unknown

(Festuca arundinacea Schreb)

(Phleum pratense L. var. Climax)

(Lolium perenne L. var. Linn)

(Dactylis glomerata L. var. Pennlate)

(Bromus inermis Leyss var. Saratoga)

(Tripsacum dactyloides L. var. Liberty)

(Brassica napus var. M. Mixed)

(Brassica oleracea var. Maris Kestral)

(Phalaris arundinacea L. var. Common)

(Sorghum sudanense var. Piper)

(I.otus corniculatus L.) 
showing the correlation of mas: variables in the two-dimensional factor space. Local maxima in this factor space indicate well-corrclated mass variables and imply common chemical behavior. The relative concentration of various components from the pyrolysis mass spectra were estimated by the pure mass method (sce Windig et al. 1981; 1983; 1987).

Typical pyrolysis mass spectra of five representative herbaceous species are shown in Figure 1. Five major compound classes were identified: cellulose and other hexosans showed typical ion series such as $\mathrm{m} / \mathrm{z} 54,68,96,102,126$, and 144. The C-5 hemicelluloses and other pentosans (such as those in extractives) showed prominent peaks at $\mathrm{m} / \mathrm{z} 57,85,96$, and 114 . Lignin peaks were represented by the guaiacyl series $\mathrm{m} / \mathrm{z} 124,138,164$, and 180 and syringyl series $\mathrm{m} / \mathrm{z} 154,167,168,180,194$, and 210. Coumaryl series were also prominent as indicated by $\mathrm{m} / \mathrm{z} 94,120$, and 150 . Another series at $\mathrm{m} / \mathrm{z} 67,79$, $80,82,93$, and 117 is probably due to proteins present in the leguminous samples. The spectra have a high degree of visual similarity and require data analysis techniques to clearly bring out differences.

Factor analysis on the correlation around the origin matrix was performed on the 100 masses that exhibited high variance in the data set. The plot of the factor scores (sce Figure 2) clearly shows five distinct biomass groups. Kale and reed canary grass, which are rich in cellulose and other hexosan sugars, have similar spectra and form a distinct subset. Sweet sorghum, eastern gama grass, switchgrass, and sudan grass form another subset in the factor space. The component spectrum of this subsel (derived mathematically) has prominent pentosan peaks as well as peaks deriving from coumaryl-containing compounds. Energy cane, a sugar cane hybrid, can be considered as a subset of this pentosan-rich group. The legume, alfalfa, had a unique spectra and is well separated from the grasses. This is not surprising because of its high protein content (Cherney ct al. 1988; 1989). Forage brassica, which has a relatively high lignin content, is shown as another subset in the factor space. However, about a third of the samples form a cluster at the center of the factor space (Figure 2). These samples (tall fescue, orchard grass, perennial ryegrass, timothy grass, and smooth bromegrass) appear to have similar chemical composition.

The variance diagram (VARDIA), which graphically displays the location of the linear combination of masses derived from distinct chemical components in the samples, clearly shows five major maxima (Figure 3). The location of each maxima is measured in degrees from Factor 2. A maximum is observed at $20^{\circ}$. Comparing this plot to the factor score plot (Figure 2), we can deduce that this axis is important in kale and reed canary grass. The factor spectrum of this maximum (Figure 4a) reveals typical cellulose and hexosan peaks. This is in agreement with the fact that kale and reed canary grass contain storage carbohydrates as well as cellulose (sce Cherney ot al. 1989). This component axis at $20^{\circ}$ was used to estimate the relative concentration of hexosans in the samples.

The variance diagram also shows four other maxima at $110^{\circ}, 190^{\circ}, 280^{\circ}$, and $310^{\circ}$ rotation. The four maxima correspond respectively to proteins (or other nitrogenous compounds), lignin, phenolic acids and pentosans. The factor spectrum for the maxima at $110^{\circ}$ (Figure $4 \mathrm{~b}$ ) shows masses $\mathrm{m} / \mathrm{z} 67,79,80,82,93$, and 117, which have been shown to originate from proteins. Moreover, because alfalla, a protein-rich legume, falls on this maxima, it is logical to conclude that the peaks corresponding to this maxima could derive from proteins or other nitrogenous compounds (see Chen and Anderson 1981).

The maximum at $190^{\circ}$ was assigned to lignin on the basis of the work of Evans and Milne (1987). The scries $\mathrm{m} / \mathrm{z} 124,138,164$, and 180 and $\mathrm{m} / \mathrm{z} 154,167,168,194$, and 210 derives from guaiacyl and syringyl components of lignin, respectivcly (Figure 4c). It is also interesting to note the two maxima at $280^{\circ}$ and $310^{\circ}$ rotation. Although these two maxima are not well resolved, the factor spectrum (Figure 4d) shows that pentosans and phenolic acids are dominant. The maximum ai $280^{\circ}$ rotation is due to phenolic acid groups (c.g., $\mathrm{m} / \mathrm{z} 94,120,150)$ and is strong in energy cane (prominent $\mathrm{m} / \mathrm{z} 120$ and 150 ). 

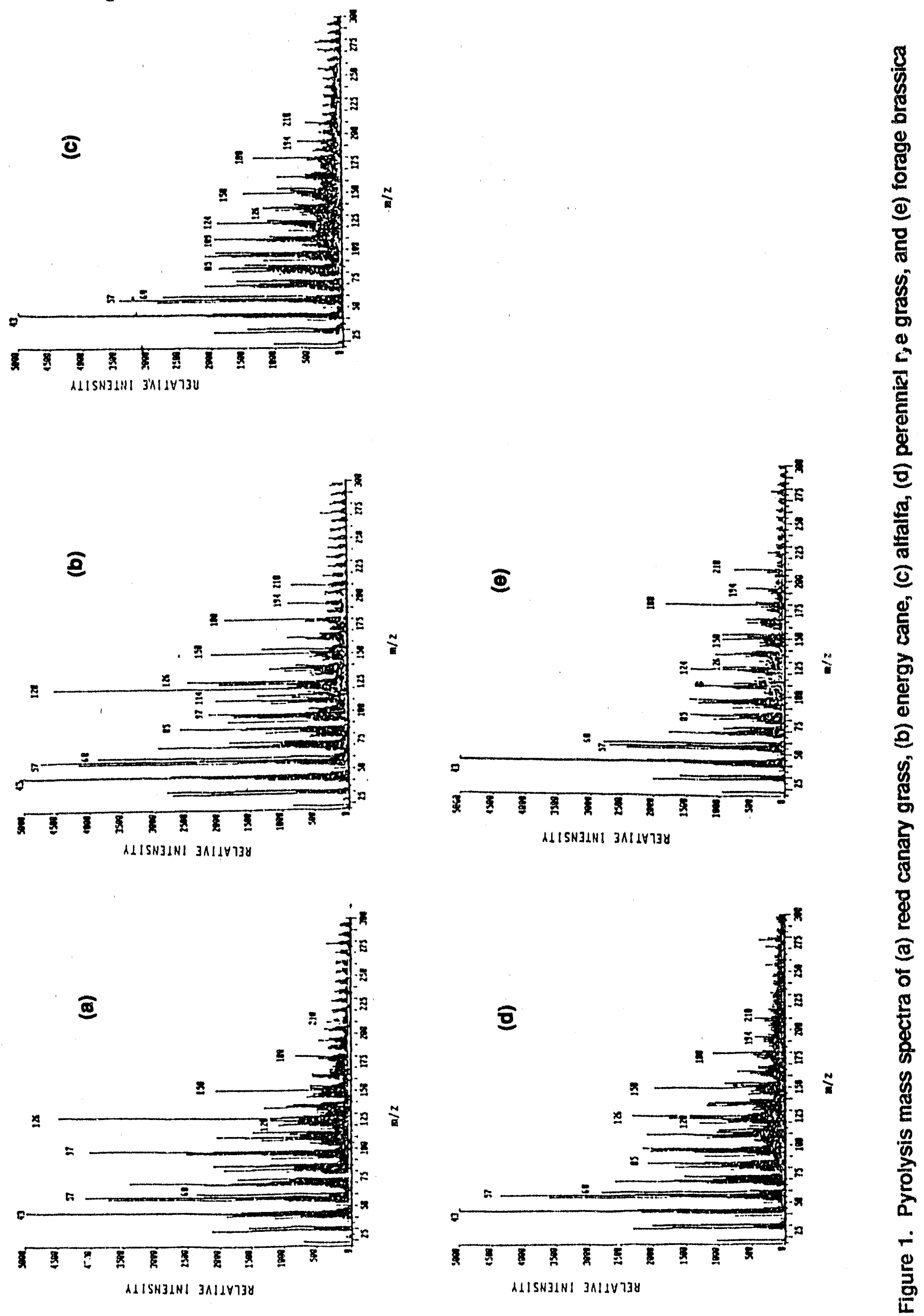


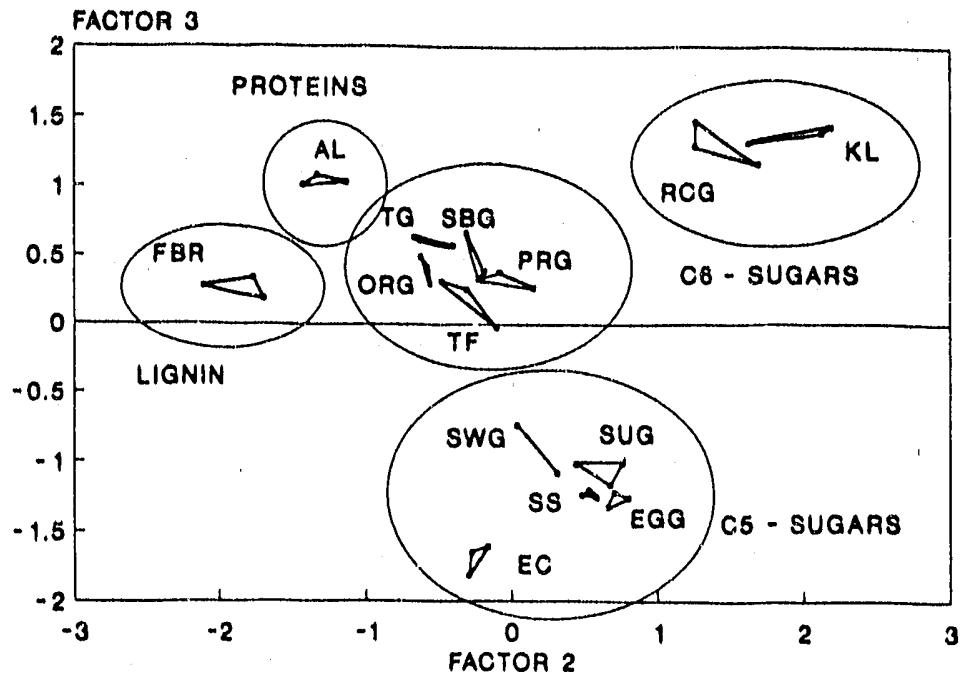

Figure 2. Factor score plot of Factor 2 versus Factor 3 showing clusters of herbaceous specles with similar pyrolysis products

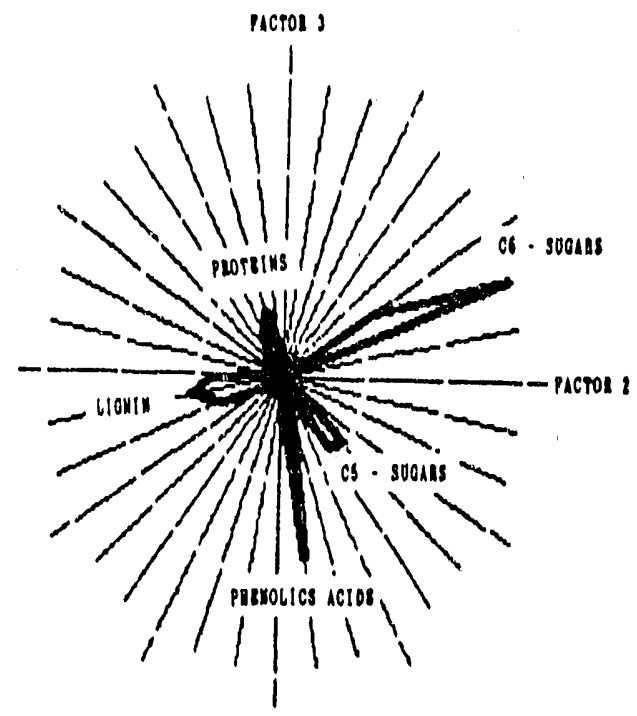

Figure 3. Varlance dlagram of Factor 2 versus Factor 3 showing the flve major groups of compounds In the pyrolysis products 

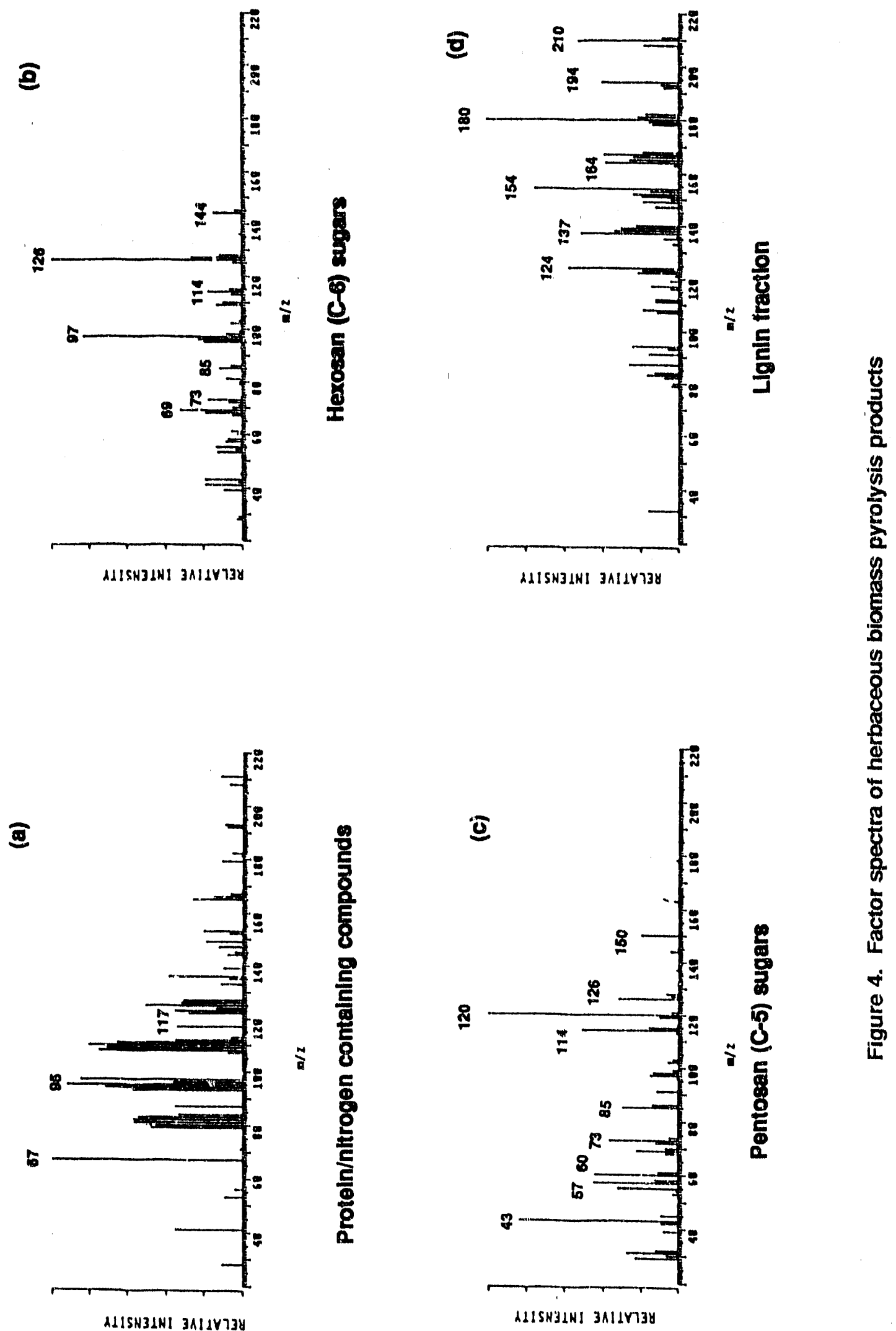
The maximum at $310^{\circ}$ rotation has strong peaks at $\mathrm{m} / \mathrm{z} 57,85,96$, and 114 , which are typical of pentosans. However, because these maxima are not resolved (orthorgonal), relative simultaneous semiquantitative estimates of these components were difficult to carry out. In the samples analyzed, these two components were correlated among the samples analyzed. With a broader data base, which contains samples with different ratios of these components, it would be possible to quantitate for these two components.

As can be seen from the factor score plot and the variance diagram, the samples fall into five groups in the factor space. These groups were related to the differences in chemical composition between groups and similarity within groups. These differences can be correlated with conversion technologies in predicting the performance of various species in specific conversion processes. Table 2 shows the relative concentration of the major chemical components in the biomass species estimated from the factor analysis of the pyrolysis data. The MBMS factor scores obtained from the factor analysis are proportional to the concentration of the classes of compounds present in the herbaceous biomass species. However, because suitable calibration mixtures were not avallable at the time of these studies, the samples with the highest factor scores in any class of compounds (e.g., hexosans) were assigned an arbitrary value of 100 and the scores of the other samples were scaled to this value. The scores therefore reflect the relative concentration

Table 2. Relatlve MEMS Factor Score on Varlous Compound Classes In the Herbaceous Blomass Specles $( \pm 2)$

\begin{tabular}{lrrr}
\hline Species & Pentosans $^{\mathrm{a}}$ & Hexosans $^{\mathrm{a}}$ & Lignin $^{\mathrm{a}}$ \\
\hline Alfalfa & 17 & 30 & 59 \\
Eastern gama grass & 97 & 41 & 32 \\
Energy cane & 88 & 45 & 40 \\
Forage brassica & 26 & 31 & 100 \\
Kale & 14 & 100 & 32 \\
Orchard grass & 40 & 29 & 39 \\
Perennlal ryegrass & 100 & 29 & 63 \\
Reed canary grass & 24 & 78 & 20 \\
Smooth bromegrass & 40 & 40 & 41 \\
Sudan grass & 42 & 44 & 42 \\
Sweet sorghum & 92 & 46 & 48 \\
Swltchgrass & 85 & 35 & 38 \\
Tall fescue & 48 & 32 & 36 \\
Timothy grass & 36 & 32 & 39 \\
\hline
\end{tabular}

${ }^{a}$ The sample with the highest MBMS factor score in each compound class is assigned an artitrary value of 100 and other sample scores are scaled to this value. 
of these chemical compounds in the biomass species. Il is clear from Table 2 that there is a wide variation in the chemical compositton of these herbaceous species, which is to be expected. This diversity can be exploited in converting these species to fucls. These data can serve as a guide for selection of spectes that will undergo conversion into R\&D alcohols. Also, the data cim guide selection of further herbaceous species for conversion. These experiments are very fast. In one day, one can screen dozens of samples and provide ranking order for tmportant species composition.

To illustrate that these observed varialions correspond to real concentrations once appropriate callbration factors are derived, the relative estimates of $\mathrm{m} / \mathrm{z} 120$, which have been shown to originate from $\mathrm{p}$-coumaric acid, were compared with p-coumaric acid contents of these herbaccous species determined by the conventional wet-chemical method (see Cherney et al. 1988 and 1989; Chen and Anderson 1981). Figure 5 shows a good agreement between estimates from the factor analysis method and the conventional wet chemical method $\left(r^{2}=0.92\right)$. Similarly, factor analytical estimates of the relative lignin contents of switchgrass, weeping love grass, sweet sorghum and sericea lespedeza show the same trend as lignin content determined by the wet chemical analysis (Van Soest method) of similar samples (see Table 3). The good agreement in the trends of the data of the two methods is a positive demonstration of the effectiveness of this approach as a semi-quantitative method for analyzing biomass samples. The multivariate analysis method will have some advantages over the Goering and Van Soest (1970) method in determining lignin content of herbaceous species in that it ls very fast and requires very small sample sizes $(25-30 \mathrm{mg})$. Furthermore, unlike the Goering and Van Soest method, which uses several fractionation steps, it is a one-step procedure that uses wl sle biomass samples. The method has the potential for accuratcly estimating the lignin contents of herbiceous biomass species if a routine calibration procedure is developed and the precision is improved. However, similar conclusions cannot be drawn for the structural carbohydrate fractions of these herbaceous biomass species because the nonstructural carbohydrate pyrolysis products interfere with their mass spectra. Also, the alkali metal effect on carbohydrate pyrolysis can cause ambiguities. Improvement of the data handling procedure may solve this problem. For biomass conversion technologies, however, the estimates of the relative hexosan and pentosan contents of the herbaceous species can serve as a preliminary screening procedure for selecting feedstocks for production lor specific conversion processes.

\section{Prellminary Investlgation of the Lignification Process In Grasses Using Fast Characteriza- tion Methods of Analyses}

During a 6-weck summer assignment to SERI, R. Babcock (a science teacher from the Scoul American High School in Korca with a masters degree in biology) and SERI rescarchers investigated the suitability of the MBMS and Fourler transform infrared (FTIR) methods on determining compositional changes in the chemical composition of grasses grown in a hydroponic medium. Fast-germinating seeds of oats, barley, and wheat were oblatned from the regional seed repository in Fort Collins, Colo. The rate of growth of plant roots and leaves were monitored and the plants were harvested after 7 and 14 days. The air-dried roots and leaves were analyzed by FTIR spectrometry and PY/MS, after the plant materials were submitted to cryogenic grinding. In this way, a fine powder plant material results, which can be used for the preparation of $\mathrm{KBr}$ pellets for transmission FrTR spectroscopy. 'This technique is more precise for quantitation, and more operator-independent than the diffuse-reflectance methods.

The germination plots of barley and wheal were identical within the experimental error, whereas the germination of oats was delayed for a few days. Figure 6 shows the FTIR for selected fractions analyzed for these plant materials. Very good guality spectral data can be oblained using this technique. The slow growth period in the germination of the oats seeds parallels the presence of a relatively high absorption 
Table 3. Comparlson of Raw MBMS Factor Scores on Llgnin to $\mathrm{KMnO}_{4}$ Llgnin Determined by the Van Soest Method

\begin{tabular}{lcc}
\hline \multicolumn{1}{c}{ Species $^{\mathrm{a}}$} & $\begin{array}{c}\text { Raw MBMS Factor } \\
\text { Score on Lignin }\end{array}$ & $\mathrm{KMO}_{4}$ Lignin (\%) \\
\hline Weoping love grass (VPI) & $0.75(0.09)^{\circ}$ & 7.1 \\
Sweet sorghum (VPI) & $0.78(0.11)$ & 7.4 \\
Switchgrass (VPI) & $0.89(0.09)$ & 9.5 \\
Sericea lespedeza (VPI) & $1.80(0.16)$ & 19.0 \\
\hline
\end{tabular}

aSamples from Virginia Polytechnic Institute

bData provided by A. Turhollow, Oak Ridge National Laboratory

'Standard deviations on triplicate runs in parenthesis

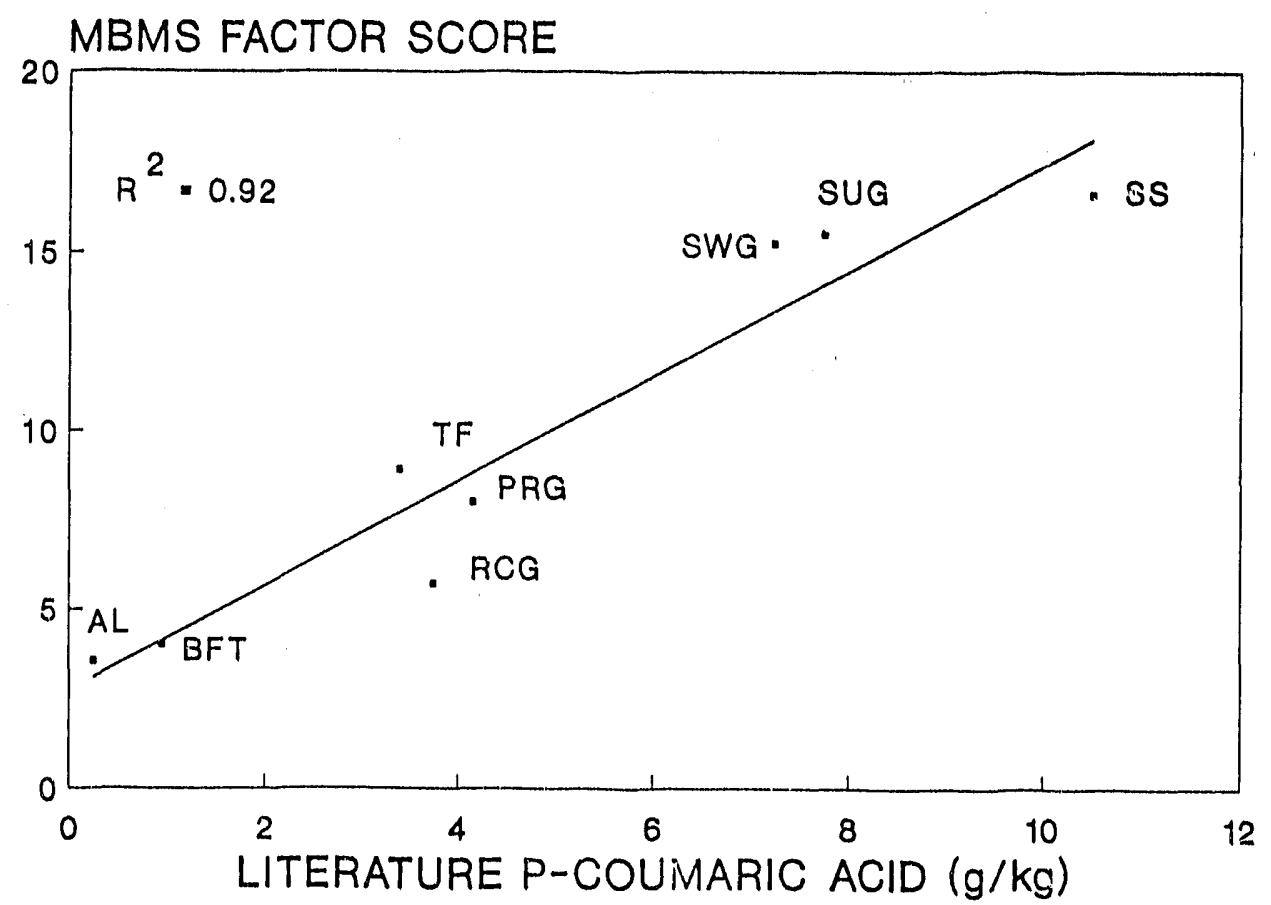

Figure 5. Comparison of the relative p-coumaric acid content of herbaceous blomass specles determined from factor analysis data to those determined from conventional wetchemical analysis 


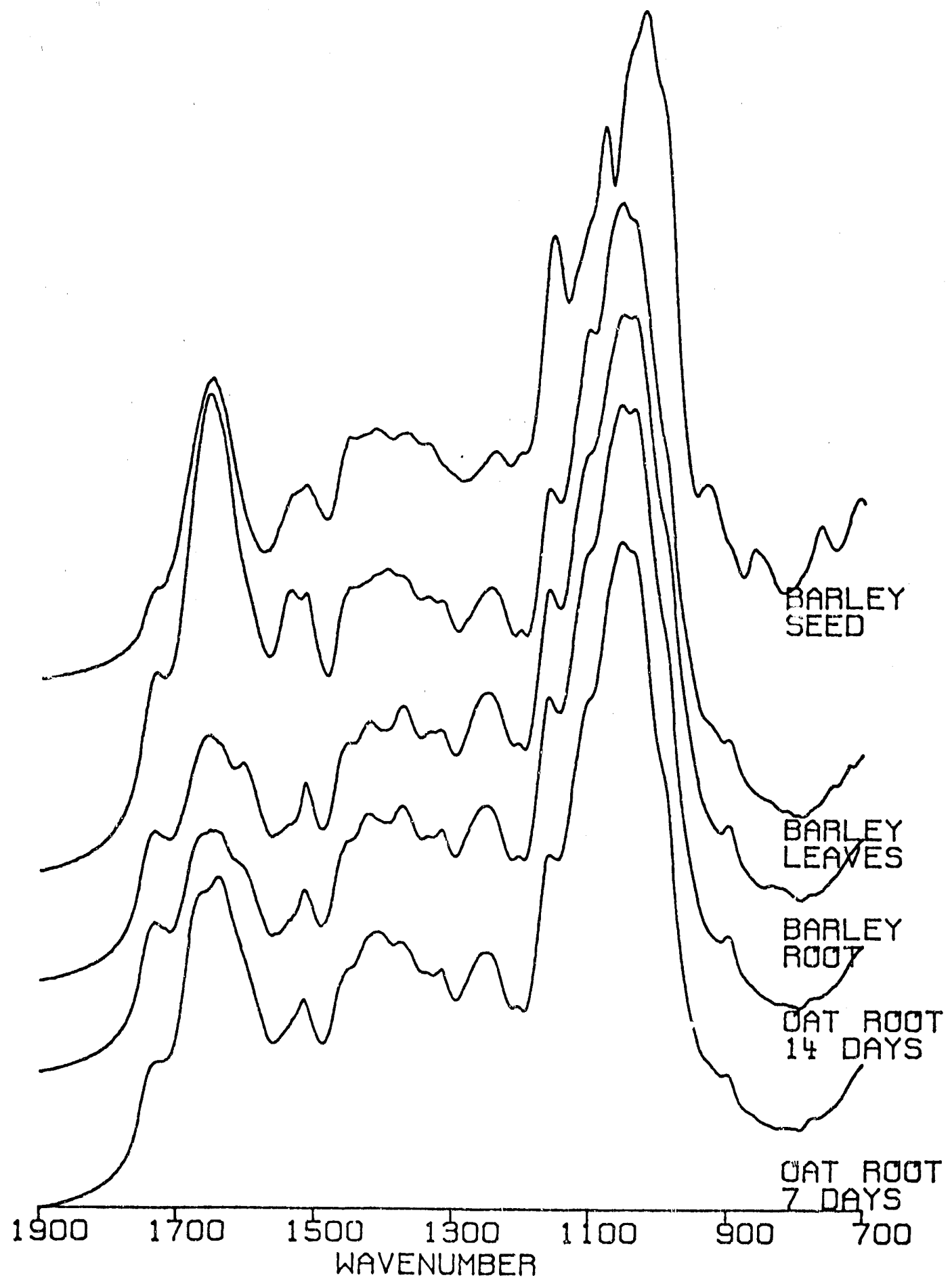

Figure 6. FTIR of seed, leaves, and root systems for oats and barley grown hydroponically for 7 or 14 days 
at 1640 wave number, characteristic of phenolic compounds. Seven days after germination, the roots of he oats seedlings contained relatively higher amounts of phenolic compounds than the seedling root at 14 days. The levels of the phenolic compounds after 14 days were comparable to those found in the wheat and barley seedlings. It is also interesting to note that lignin/phenolic compounds formation starts earlier in the roots than in the leaves (see Figure 7). This is evidenced by the lignin (lignan) peak at $\mathrm{m} / \mathrm{z}$ 180 (due to coniferyl alcohol) in the pyrolysis mass spectra of barley roots, which is conspicuously absent in the leaves of the same age. There is also a rapid change in the content of the coumaryl types of phenolic compounds in the leaves and roots as shown by the changes in the relative intensity of $\mathrm{m} / \mathrm{L} 150$ (due to coumaryl alcohol) in the pyrolysis mass spectra (see Figure 7). The disappearance of starch and formation of cellulose and other glucosides is also apparent from the FTIR results. Factor analysis is being applied to the data set to provide additional interpretation information.

These methods are suitable for following the compositional changes using small amounts of plant materials, and they could be very suitable to follow plant growth in the presence of labeled compounds. It is hoped that the project will be reactivated and completed when Babcock takes a 1-yr sabbatical leave from his teaching job next year.

\section{Rapld Characterlzation of Blomass by Integrated Multivarlate Analysls of Multi-Source Spectrometrlc Data}

PY/MS is a rapid analytical tool for analyzing very complex biopolymers; however, the results are sometimes ambiguous because of the destructive nature of the pyrolysis step and the ambiguity of the electron ionization mass spectra for certain classes of compounds. Other complementary techniques such as FTIK spectrometry and Cross-Polarization Magic-Angle Spinning (CP/MAS) solid state NMR can provide specific information about the chemical nature of solids and thus complement the PY/MS data set. These types of data can likewise be analyzed by the multivariate technique and the results of all the analyses correlated to provide maximum information about the samples. The timely development of this integrated spectroscopic technique to the point of demonstrated potential will allow its systematic application to the full range of feedstocks under development for both biochemical and thermochemical conversion processes. Rapid screening of the composition and correlation with performance in potential applications could lead to very efficient plant breeding and genetic engineering programs.

Fifteen biomass matcrials (herbaceous and woody) were selected for preliminary testing of the proposed technique. Transmission FTIR data have been recorded for these samples and quantitative solid state CP/MAS NMR spectra have also been recorded for most of these biomass samples. Multivariate analysis and correlation of the NMR and FTIR results with PY/MS data is still in progress.

\section{Publications and Presentations}

Milne, T. A., Brennan, A. H., and Glenn, B. H. 1989. Sourcebook of Methods of Analysis for Biomass and Biomass-derived Fuels and Chemicals. New York and London: Elsevier Science Publishers.

Milne, T. A. 1989. "Voluntary Standards for Biomass for Fuels and Chemicals." Final report to the IEA for 1986-1988; to be published in Biomass, logether with other IEA lask activity reports.

Walsh, T. L., Jr. and Milne, T. A. 1989. "Development of Standards for Biomass." Prepared for publication in the American Society for Testing and Materials (ASTM) Standardization News. 

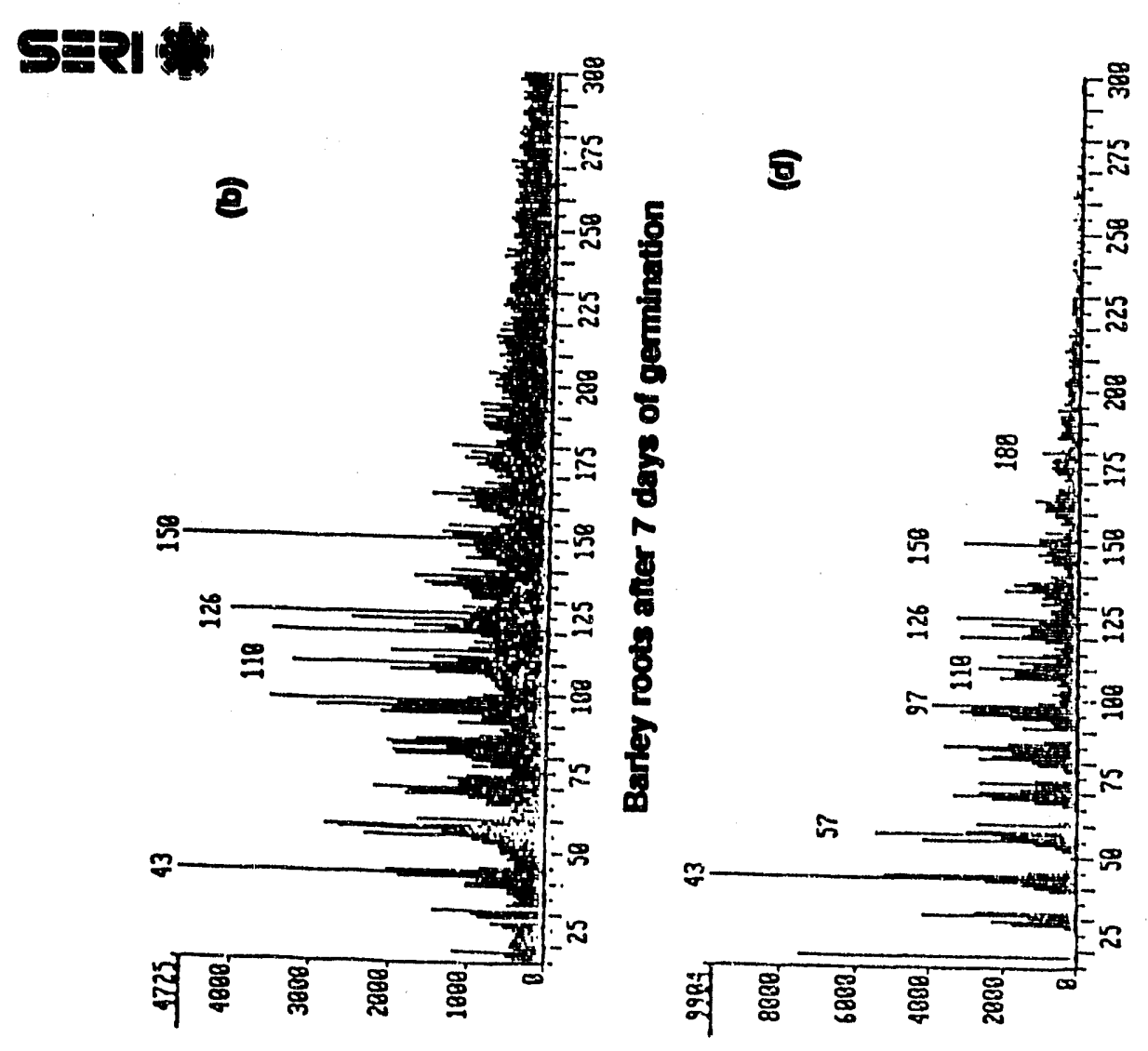

TP-3996

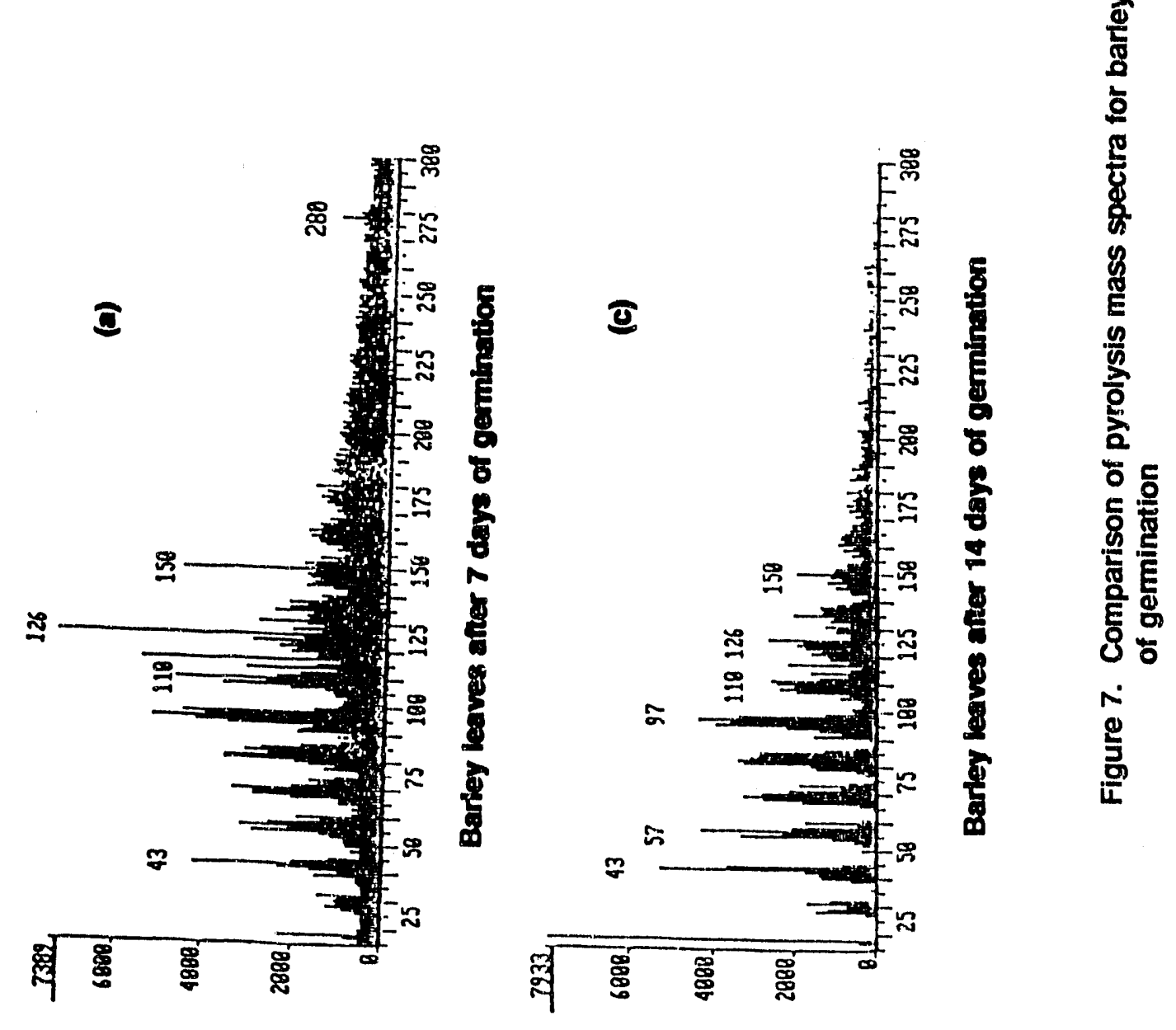


Milne, T. A. and Chum, H. L. 1989. "Methods of Analysis of Biomass for Fuels and Chemicals." Paper presented at the 7th Canadian Bioenergy R\&D Seminar, Ottawa, Canada.

Agblevor, F. A., Evans, R. J. and Milne, T. A. 1989. "Multivariate Approach to the Rapid Screening of Biomass Feedstocks for Thermochemical and Biochemical Conversion Processes." In Improvement of Feedstock Quality, IEA Information Report 89:2, Compiled by W. A. Kenney, R. L. Gambles, and L. Zsuffa, published by the IEA/BA-Task 5 Wood Feedstock Quality, Canada.

\section{Acknowledgments}

The authors wish to acknowledge J. Cushman of ORNL and the subcontractors of the U.S. Department of Energy Biofuels and Municipal Waste Technology Division, Biomass Production Plogram for supplying research samples. This work was funded by the Biofuels and Municipal Waste Technology Divisisn of the U.S. Department of Energy. Some of the work was co-sponsored by the IEA Voluntary Stardards Activity, T. Milne, Activity Leader, and D. Stevens, Operating Agent. The cooperation of the varicus participating countries in the preparation of feedstock samples and of the NIST are grateílly acknowledged.

\section{References}

Chen, Wen-Ju Lin, and Anderson, J. W. 1981. The American Journal of Chemical Nutrition. 34:1077-1082.

Cherney, J. H., Johnson, K. D., Volenec, J. J., and Anliker, K. S. 1988. Biomass 17:215-238.

Chemcy, J. H., Lowenberb-DeBoer, J., Johnson, K. D., and Volenec, J. J. 1989. Energy from Biomass and Wastes XII, ed. D. L. Klass, 289-300. Chicago, IL: Institute of Gas Technology.

Cowling, E. G., and Kirk, T. K. 1976. Biotechnol. Bioeng. Sym. 6:95-123.

Evans, R. J., Milne, T. A., and Soltys, M. N. 1986. J. Anal. Appl. Pyrol. 9:207-236.

Evans, R. J., and Milne, T. A. 1987. Energy and Fuels 1 2:123-137.

Goering, H. K., and Van Soest, P. J. Forage Fiber Analysis 1970. Agriculture Handbook 379. Washington, DC: U.S. Department of Agriculture.

Irwin, W. J. 1979. J. Anal. Appl. Pyrol. 1:3-25, 89-122.

Lewis, N. G., Yamamoto, E. 1990. Annu. Rev. Plant Physiol. Plant Mol. Biol. 41:455-496.

Meuzelaar, H. L. C., Kistemaker, P. G., and Posthummus, M. A. 1974. Biomed. Mass Spectrom. 1:312320.

Windig, W., Haverkamp, J., and Kistemaker, P. G. 1983. Anal. Chem. 55:81-88.

Windig, W., Kistemaker, P. G., and Haverkamp, J. 1981/1982. J. Anal. Appl. Pyrol. 3:199-212. 
Windig, W., McClennen, W. J., and Meuzelaar, H. L. C. 1987. Chemometrics and Intelligent Laboratory Systems 1:151-165.

Windig, W., Meuzelaar, H. L. C., Hames, B. A., Campbell, W. F., and Asay, K. H. 1983. J. Anal. Appl. Pyrol. 5:183-198. 


\title{
Analysis of Dilute Acld Pretreatment Versus Acid-Catalyzed Steam Explosion
}

\author{
D.J. Schell, R. Torget, A. Power*, P.J. Walter, K. Grohmann, and \\ N.D. Hinman \\ Biotechnology Research Branch \\ Fuels and Chemicals \\ Research and Engincering Division \\ Solar Energy Research Institute \\ Golden, Colorado 80401 \\ *Arthur J. Power and Associates, Inc. \\ Boulder, Colorado 80304
}

\begin{abstract}
Lignocellulosic biomass is one of the most plentiful and potentially least expensive feedstocks for ethanol production. The cellulose component can be broken down into glucose by enzymes and then converted to ethanol by yeast. However, hyirolysis of ccllulose to glucose is difficult and some form of pretreatment is necessary to increase the susceptibility of cellulose to enzymatic attack. An analysis has been completed of two pretreatment options: dilute sulfuric acid hydrolysis and sulfur dioxide impregnated steam explosion for two feedstocks, wheat straw and aspen wood chips. Detailed process flowsheets and material and energy balances were used to generate equipment cost information. A technical and economic analysis compared the two feedstocks for each of the two pretreatments. For the same pretreatment, sugars produced from aspen wood hydrolysis were cheaper because of the higher carbohydrate content of aspen, while dilute acid pretreatment is favored over acid-catalyzed steam explosion.
\end{abstract}

\section{Introduction}

Of the many biomass feedstocks available for ethanol production, one of the most abundant and cheapest is cellulosic biomass. Cellulose, a polymer of glucose, can be broken down into glucose by enzymes and then converied to ethanol by yeast. However, hydrolysis of cellulose in raw cellulosic biomass is difficult. This has been attributed to the crystallinity of cellulose and the lignin-hemicellulose sheath that surrounds the cellulose. Thus, some form of pretreatment is necessary to disrupt the lignin-hemicellulose sheath and increase the susceptibility of the cellulose to cnzymatic attack. Pretreatment can also hydrolyze 
hemicellulose to its individual sugar components. In the case of hardwoods and wheat straw, the hemicellulose is composed primarily of the five-carbon sugar xylose, a sugar that can also be converted to ethanol. The conversion of xylose to ethanol improves the overall economics of the cellulosic biomassto-cthanol process (Hinman et al. 1989).

Several processes can be used for pretreatment of biomass, including autohydrolysis steam explosion, steam explosion with an acid catalyst, dilute sulfuric acid hydrolysis, and the organosolv process. The dilute acid process uses low concentrations of sulfuric acid at relatively low temperatures $\left(160^{\circ} \mathrm{C}\right.$ for 10 $\mathrm{min}$ ) to achieve near-complete conversion of the hemicellulose xylans to xylose (Grohmann et al, 1986: Torget et al. 1988). However, prior to this step, particle size is reduced to near $1.0 \mathrm{~mm}$, requiring significant amounts of energy. Both steam explosion processes use high-pressure steam and rapid depressurization to both reduce the size of the biomass particle and partially hydrolyze the hemicellulose fraction. Both require operationally complex steam explosion guns. With autohydrolysis steam explosion, the yield of xylose is low (30\%-50\%) (Wright 1988). However, the yield can be improved by using a catalyst, such as $\mathrm{SO}_{2}$ (Schwald et al. 1989), which is the basis for the acid-catalyzed steam explosion process. The organosolv process uses an organic solvent to dissolve the lignin and hemicellulose fractions from the cellulose. The lignin is then precipitated from solution, leaving the xylose in the liquid stream. This process is complicated and expensive, but produces a high-quality lignin stream that could be converted to high-value products.

Because of the low xylose yields and their negative impact on ethanol production economics, a detailed analysis of autohydrolysis steam explosion was not carried out in this study. Furthermore, because of the expense and complexily of the organosolv process and because there are no current large markets for highquality lignin, this process also was not considered further. The economics of the two remaining pretreatment options, steam explosion with an acid catalyst and dilute sulfuric acid pretreatment, were evaluated with two different feedstocks: wheat straw and aspen wood chips. These materials are representative of the performance expected for two of the most abundant categories of cellulosic biomass, herbaccous and wood energy crops.

\section{Methodology}

Each of the four feedstock/pretreatment combinations is analyzed on the basis of total sugar (glucose as unconverted cellulose and xylose) produced, which could then be converted to ethanol. The cconomic information is summarized on the basis of total sugars, assuming $90 \%$ of the cellulose leaving the pretreatment process could be converted to glucose. However, the analysis does not consider conversion of cellulose to glucose or subsequent cunversion of sugars to ethanol, but only considers the pretreatment processes. Assuming a different yicld of glucose from cellulose will change the absolute cost of the processes, but not the relative comparison between processes.

\section{Process Descriptlon}

\section{Acid-Catalyzed Steam Explosion With Aspen Wood}

A flowsheet of the acid-catalyzed steam explosion process for aspen wood chips is shown in Figure 1. The design for the steam explosion system is adopted from a design by Stone and Webster Enginecring Corp. (Stone and Webster Engineering Corp. 1985), and the design of the $\mathrm{SO}_{2}$ recovery section is based on the work of several groups (Schwald 1989; Mackie et al. 1985; Wayman and Parekh 1988; Brownell 
and Saddler 1984). Finally, the design of the lime slurry preparation system section is adopted from a study by Badger Engincers, Inc. (1984).

Aspen wood chips are stored in an open pile and delivered by front-end loaders to a screen that removes oversized material, which is sent to a rechipper. The screened material is loaded into a stainless-steel steam explosion gun. Each stainless stecl gun is a $3.5 \mathrm{ft}(1.07 \mathrm{~m})$ diamcter pipe, $14.5 \mathrm{ft}(4.45 \mathrm{~m})$ long, designed for $650 \mathrm{psig}(4480 \mathrm{kPa}$ ), and sealed on each end by quick-opening, full-port plug or ball valves. Once the chips are sealed inside the gun, steam and vaporized sulfur dioxide are added and the chips are cooked for $2 \mathrm{~min}$. Sulfur dioxide added to the gun is taken as a liquid from a carbon steel storage vessel, pumped to $600 \mathrm{psig}$ (4236 kPa), vaporized, and mixed with steam. After cooking, the material is blown down into a 316 stainless steel flash vessel operating at $60 \mathrm{psig}(515 \mathrm{Kpa})$. The steam-exploded wood then flows to a second 316 stainless steel atmospheric flash tank where final cooling takes place.

Flash vapor from each of the flash tanks, containing water vapor and $\mathrm{SO}_{2}$, is sent to partial condensers (304 stainless stecl tubes/carbon steel shell). The condensate, still containing a small amount of $\mathrm{SO}_{2}$, is collected in a condensate receiver, then pumped to a 316 stainless steel open-steam stripping column. The $\mathrm{SO}_{2}$ removed from the top of the column is combined with the uncondensed $\mathrm{SO}_{2}$ from the partial condensers, compressed to a liquid, and recycled back to the liquid $\mathrm{SO}_{2}$ storage tank. The water from the bottom of the column is sent to waste treatment. This extensive $\mathrm{SO}_{2}$ recovery system is employed to significantly reduce any discharge to the environment.

Exploded wood in the bottom of the atmospheric flash tank is combined with a fraction of the liquid steam from the downstream washing filter belt to obtain a pumpable slurry. The slurry is pumped to the washing filter belt to remove the $\mathrm{SO}_{2}$, xylose, and other soluble material from the solid cellulose/lignin slurry. The cellulose lignin material can then be sent to an ethanol production unit. The liquid stream from the filter belt is sent to a stripping column, heated by a steam reboiler. The $\mathrm{SO}_{2}$ removed by this column is compressed and condensed, and recycled back to the liquid $\mathrm{SO}_{2}$ storage tank.

The acidified liquid (from conversion of $\mathrm{SO}_{2}$ to $\mathrm{H}_{2} \mathrm{SO}_{4}$ ) from the bottom of the stripping column is sent to a 304 stainless steel vessel for neutralization by a lime slurry, producing a neutral xylose-containing stream, which can be sent to an ethanol production unit. A small amount of this stream is taken and mixed with lime in a carbon steel vessel to produce the lime slurry.

\section{Acid-Catalyzed Steam Explosion With Wheat Straw}

The wheat straw plant accepts bales that are managed by a crane system and stored in a pile. After the bales are broken apart in a bale shredder, the material is screened and sent to a separator bin that removes dirt, dust, and grains from the fibers. The fibers are then sent to the steam explosion guns. The remainder of the process is shown in Figure 1.

\section{Dilute Sulfuric Acld Pretreatment With Aspen Wood}

A flowsheet for the dilute sulfuric acid process with aspen wood chips is shown in Figure 2. The pretreatment part of this process is based on the design of Torget et al. (1988). Wood chips are screened to remove the oversize material, which is sent to a rechipper. The acceptable material is sent to a disk refiner. Here the chips are milled to reduce the particle size to approximately $1.0 \mathrm{~mm}$. Following this, the milled wood enters the steam-heated impregnator where water and acid are added. This reactor ensures that acid thoroughly diffuses into the wood particles. The acidified slurry is then fed to the 


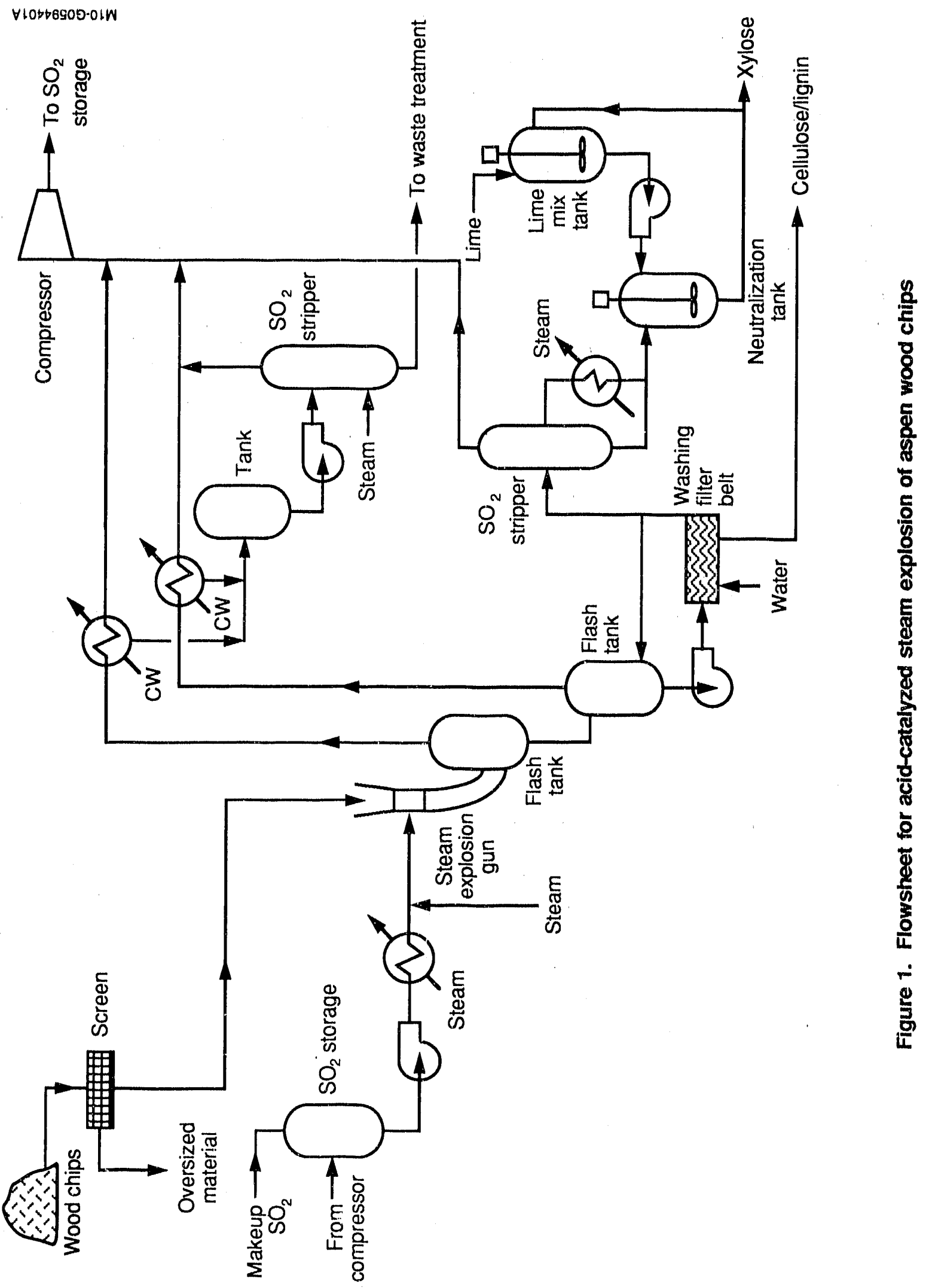




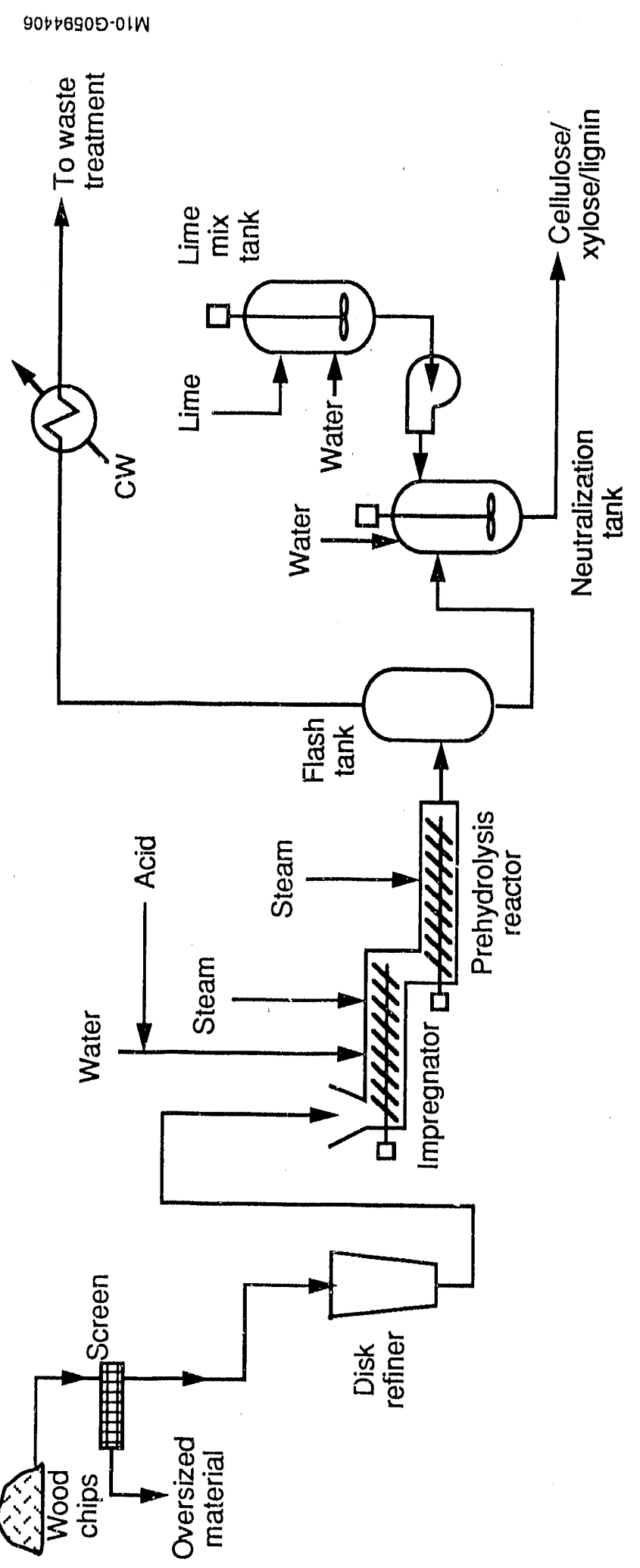

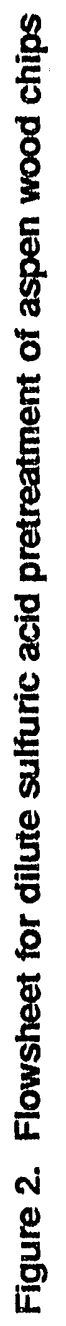


prehydrolysis reactor, which is steam-heated to $160^{\circ} \mathrm{C}$. Both the impregnation and prehydrolysis reactors are constructed of Carpenter-20 alloy for corrosion resistance. After prehydrolysis, the wood slurry is cooled by flashing to atmospheric pressure and subsequently conveyed to the neutralization tank. The vapors from the flash tank are condensed and sent to waste treatment. The sulfuric acid in the wood slurry is neutralized in the neutralization tank by a lime slurry and additional water is added to make a pumpable wood slurry.

\section{Dllute Sulfurlc Acld Protreatment With Wheat Straw}

The design of the feed handling/storage and preparation areas is the same as that described for acidcatalyzed steam explosion with wheat straw. After screening, the straw is sent to a disk refiner and the remainder of the process is as described above for dilute sulfuric acid pretreatment with aspen wood.

\section{Plant Capaclty and Feed Composition}

Process flow diagrams for each feedstock were developed based on a delivered flow rate of $160,000 \mathrm{lb} / \mathrm{h}$ $(72,700 \mathrm{~kg} / \mathrm{h})$ of dry feedstock to the pretreatment section of the plant. Aspen wood enters the plant at $50 \%$ moisture and wheat straw enters the plant at 12\% moisture (Strehler 1987). The chemical composition of each feedstock is given in Table 1.

\section{Design Basls}

\section{Acld-Catalyzed Steam Explosion}

The chips are held in the steam explosion guns for $2.0 \mathrm{~min}$ at $240^{\circ} \mathrm{C}$ (Schwald et al. 1989). An additional $0.5 \mathrm{~min}$ is needed for loading and preheating and another $0.5 \mathrm{~min}$ for blowdown and cleaning. The total cycle time per gun is $3 \mathrm{~min}$, although this has not been demonstrated at the large scale assumed for this plant.

The $\mathrm{SO}_{2}$ used for steam explosion is $1.6 \mathrm{~kg} / 100 \mathrm{~kg}$ of dry wood and the high-pressure steam use is $0.85 \mathrm{~kg} / \mathrm{kg}$ dry wood (Schwald et al. 1989). For wheat straw, the $\mathrm{SO}_{2}$ use is the same and the highpressure steam use is calculated to be approximately $0.45 \mathrm{~kg} / \mathrm{kg}$ dry straw because of the lower water content. The xylan conversion from a $\mathrm{SO}_{2}$-catalyzed steam explosion is $75 \%$ conversion to xylose, $15 \%$ conversion to furfural, $5 \%$ unchanged, and $5 \%$ degraded to solid products (Mackie et al. 1985). Cellulose is assumed unchanged. The $\mathrm{SO}_{2}$ is converted as follows: $9.2 \%$ to sulfuric acid, $9.7 \%$ to lignin sulfonic acids, $74.2 \%$ unconverted and available for recycle, and $6.5 \%$ retained with the lignin (Schwald et al.1989). The washing filter belt system is a five-stage washing operation, similar to a paper pulp stock washer, in which $99 \%$ of the solubles is recovered (Stone and Webster Engineering Corp. 1985).

\section{Dllute Sulfuric Acld Pretreatment}

The milling step requires $125 \mathrm{hp} / \mathrm{ton} / \mathrm{h}$ (94 kW/ton) of electrical power for wood and $12.5 \mathrm{hp} / \mathrm{ton} / \mathrm{h}$ $\left(6.4 \mathrm{~kW} /\right.$ ton) for wheat straw (Rodarmel 1990). The impregnator operates at $100^{\circ} \mathrm{C}$ with a 10 -min residence time (Torget et al. 1989). The prehydrolysis reactor operates at $160^{\circ} \mathrm{C}$ for a 10 -min residence time and with an acid concentration of 1 wt\% after steam and water addition (Torget et al 1989). Xylan 
Table 1. Chemlcal Composition of Aspen Wood and Wheat Straw

\begin{tabular}{lcc}
\hline & $\begin{array}{c}\text { Aspen Wood } \\
(\%)\end{array}$ & $\begin{array}{c}\text { Wheat Straw } \\
(\%)\end{array}$ \\
\hline Cellulose & 46.2 & 40.8 \\
Xylan & 24.0 & 27.0 \\
Lignin & 24.0 & 18.4 \\
Ash & 0.2 & 11.2 \\
Other & 5.6 & 2.6 \\
\hline
\end{tabular}

is assumed converted as follows: $80 \%$ to xylose, $13 \%$ to furfural, and $7 \%$ unconverted (Grohmann et al. 1986). Also, during prehydrolysis $4 \%$ of the cellulose is converted to glucose (Seaman 1945); the rest is assumed unchanged.

\section{Capltal Cost EstImate and Economlc Analysls}

Heat and material balances were developed and used to specify equipment sizes. Purchased equipment cost is estimated using information from COADE (1983); Icarus Corp. (1987); Guthrie (1974); Stone and Webster Engineering Corp. (1985); and Badger Engineers, Inc. (1984). Total fixed investment is estimated as 2.85 times the purchased equipment cost (Chem Systems, Inc. 1990) plus an additional $2.0 \%$ for miscellaneous equipment. Working capital is $4.8 \%$ and start-up cost is $5.0 \%$ of total fixed investment (Chem Systems, Inc, 1990). The annual capital charge (depreciation, taxes, insurance, and rate of return) is total capital invested (fixed plus working plus start-up cost) times a fixed charge rate (FCR) of 0.20 , typical for these types of plants (Chem Systems, Inc. 1990; Chem Systems, Inc. 1989). Chemical costs are taken from the Chemical Marketing Reporter (1990). Utility cost for process water, cooling water, and steam are estimated from Peters and Timmerhaus (1980) and electricity is assumed to cost $\$ 0.04 / \mathrm{kWh}$. Manpower required is estimated from a previous study (Chem Systems, Inc. 1990) as 14 laborers at $\$ 29,800 / \mathrm{yr}$ and 3 foreman at $\$ 34,000 / \mathrm{yr}$. Maintenance is $3.0 \%$ of total capital invested and overhead is $65 \%$ of labor plus maintenance. Insurance and taxes is $1.5 \%$ of total fixed investment. Byproduct credit is taken for lignin sent to the boiler and is estimated as the heating value of lignin divided by the total heating value of the feedstock times the feedstock cost.

\section{Results}

An economic summary of acid-catalyzed steam explosion for both aspen wood and wheat straw is given in Table 2 for a feedstock cost of $\$ 42 /$ dry ton (Wright et al. 1988) and a FCR of 0.2 . The sugar selling price (glucose and xylose) as a function of feedstock cost is shown in Figure 3 for both feedstocks. It is somewhat cheaper to produce sugars from aspen wood $f(r$ the same feedstock cost. This is due to the greater amount of sugars contained in aspen wood (70\% cellulose and xylans) when compared to wheat straw (68\% cellulose and xylans). Also, aspen wood has a larger byproduct credit because of its larger lignin content. 
An economic summary of dilute sulfuric acid pretreatment for both aspen wood and wheat straw is given in Table 3 for a feedstock cost of $\$ 42 /$ dry ton. The sugar selling price as a function of feedstock cost is also shown in Figure 3. In this case, aspen wood also results in a lower sugar selling price for the same feedstock cost, except below $\$ 35 /$ dry ton where the cost is approximately the same. In this case, the advantages of the higher carbohydrate content of the aspen wood are offset by the greater electrical cost required to mill the aspen.

\section{Discussion}

The choice of feedstocks for sugar production will probably be governed by plant location. Plants situated in heavy food crop agricultural areas will probably use agricultural residues such as wheat straw. In other areas, it will probably be more advantageous to use wood energy crops as represented by aspen where agricultural residues are not readily available. There is not an overwhelming advantage to either feedstock, particularly for dilute sulfuric acid, if they are obtained at the same price. However, feedstock cost does have a significant effect on sugar selling price. A decrease in feedstock cost from $\$ 60$ to $\$ 20 /$ dry ton decreases the selling price by approximately $2.0 \% / \mathrm{lb}$ sugar, which is a $35 \%$ reduction for steam explosion and a $42 \%$ reduction for dilute sulfuric acid.

The data in Tables 2 and 3 show that dilute sulfuric acid is approximately 20\% cheaper than steam explosion using the process configuration and yields assumed in this study. The higher cost for steam explosion is primarily due to the higher capital cost associated with $\mathrm{SO}_{2}$ recovery. These results are based on our current understanding of each of these processes. Future improvements and changes to the process configuration could alter these results.

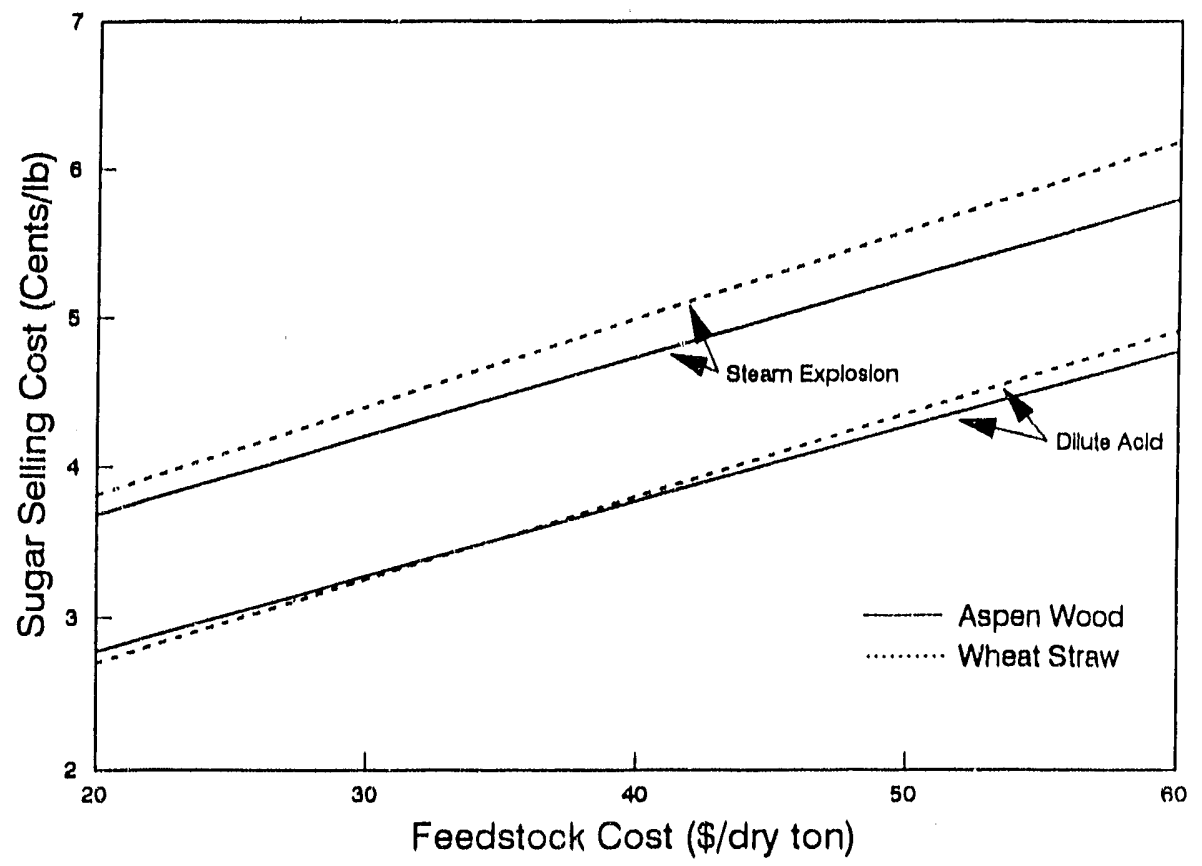

Figure 3. Sugar selling cost as a function of feedstock type and cost for both aspen wood and wheat straw 
Table 2. Economic Summary of the Steam Explosion Process

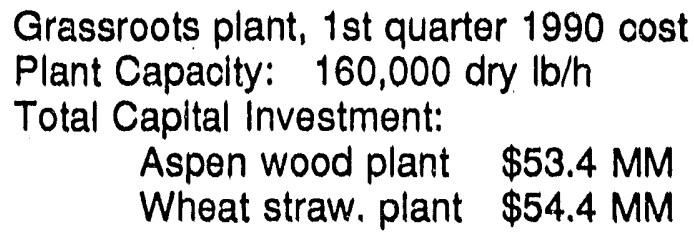

Aspen $\quad \frac{\text { Wheat Straw }}{\text { c/lb sugars }}$

Raw Materlals

$\begin{array}{lll}\text { Feed } & 3.28 & 3.44 \\ \mathrm{SO}_{2} & 0.07 & 0.08 \\ \mathrm{Lime} & 0.01 & 0.01\end{array}$

Utilitles

Process Water

0.07

0.08

Cooling Water

0.09

0.10

Steam-60 psig

0.28

0.26

Steam-600 psig

0.30

0.16

Electricity

0.03

0.05

Labor

0.06

0.06

Maintenance

0.18

0.19

Overhead

0.16

0.16

Insurance and Taxes

0.08

0.09

Byproduct Credits

Lignin

1.06

0.96

Capltal Charges

1.30

1.39

Totals

4.85

5.11

Feedstock Cost: $\$ 42 /$ dry ton

FCR:

0.20 
Table 3. Economic Summary of the Dilute Acld Process

Grassroots plant, 1st quarter 1990 cost

Plant Capacity: $\quad 160,000$ dry lb/h

Total Capital Investment:

Aspen wood plant $\$ 32.5 \mathrm{MM}$

Wheat straw plant $\$ 34.3 \mathrm{MM}$

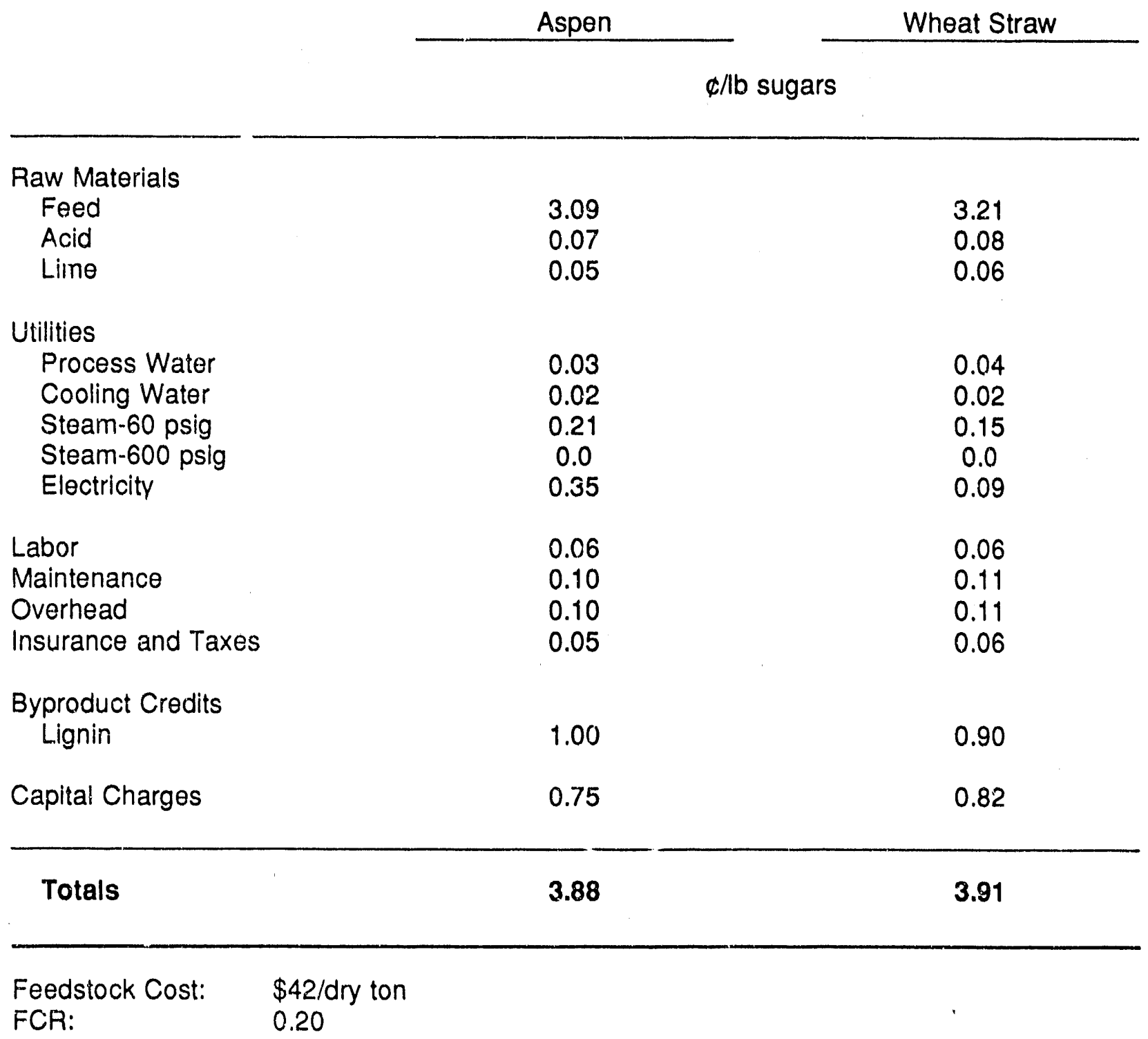




\section{References}

Badger Engineers, Inc. 1984. Economic Feasibility Study of an Acid Hydrolysis Based Ethanol Plant. SERI Subcontract No. ZX-3-03096-2.

Brownell, H.H., and Saddler, J.N. 1984. Biotechnol. Bioeng. Symp. 14:55-68.

Chem Systems, Inc. 1989. Assessment of Cost of Methanol From Biomass, SERI Subcontract Report.

Chem Systems, Inc. 1990. Technical and Economic Evaluation: Wood to Ethanol Process, Subcontract Report submitted to the Solar Energy Research Institute.

Chemical Marketing Reporter. 1990. March 12, 237.

COADE. 1983. CHEMCOST Capital Cost and Profitability Analysis (Program for Microcomputers), Houston, TX.

Grohmann, K., Torget, R., and Himmel, M. 1986. Biotechnol. Bioeng. Symp. 15:59.

Guthrie, K.M. 1974. Process Plant Estimating and Control. Solana Beach, CA: Craftsman Book Company of America.

Hinman, N.D., Wright, J.D., Hoagland, W., and Wyman, C.E. 1989. Appl. Biochem. Biotechnol. 20/21:391.

Icarus Corp. 1987. Icarus Cost System Report.

Mackie, K.L., et al. 1985. Journal of Wood Chemistry and Technology 5:405-425.

Peters, M.S., and Timmerhaus, K.D. 1980. Plant Design and Economics for Engineers. New York: McGraw-Hill.

Rodarme: R. 1990. Personal communication, ABB Sprout Bauer, Inc.

Saeman, J.F. 1945. Ind. Eng. Chem. 37:43.

Schwald, W., Breuil, C., Brownell, H., Chan, M., and Saddler, J. 1989. Appl. Biochem. Biotechnol. 20/21:29-44.

Stone and Webster Engineering Corp. 1985. Economic Feasibility Study of an Enzyme-Based Ethanol Plant, SERI Subcontract No. ZX-3-03097-1.

Strehler, A. 1987. In Biomass Energy: From Harvesing to Storage, 191-199. New York: Elsevier.

Torget, R., Himmel, M., Wright, J.D., and Grohmann, K. 1988. Appl. Biochem. Biotechnol. 17:1989.

Wayman, M., and Parekh, S.R. 1988. Appl. Biochem. Biotechnol. 17:33-44.

Wright, J.D. 1988. Chem. Eng. Prog. 84:62.

Wright, J.D., Wyman, C.E. and Grohmann, K. 1988. Appl. Biochem. Biotechnol. 18:75-90. 


\title{
Dilute Acid Pretreatment of Corn Cobs, Corn Stover, and Short-Rotation Crops
}

\author{
R. Torget, P. Walter, M. Himmel, and K. Grohmann \\ Biotechnology Research Branch \\ Fuels and Chemicals \\ Research and Engineering Division \\ Solar Energy Research Institute \\ Golden, Colorado 80401
}

\begin{abstract}
As a prerequisite for the enzymatic saccharification or simultaneous saccharification and fermentation process for ethanol synthesis, a dilute acid pretreatment of the biomass has been shown to be very effective. Three hardwoods (silver maple, sycamore, and black locust) and two corn resiuues (cobs and stover) were subjected to prehydrolysis with dilute sulfuric acid at $140^{\circ}$ and $160^{\circ} \mathrm{C}$ for reaction times ranging from 5 to $60 \mathrm{~min}$. Although the hemicelluloses from all five samples could be completely hydrolyzed at both $140^{\circ}$ and $160^{\circ} \mathrm{C}$, hydrolysis at $160^{\circ} \mathrm{C}$ for the woods and stover produced a superior substrate for the cellulase enzyme from Trichoderma reesei in which more than $90 \%$ of the cellulose was hydrolyzed by the enzyme. Corn cobs produced an excellent substrate after only $5 \mathrm{~min}$ at $140^{\circ} \mathrm{C}$. Small amounts of lignin and glucan were also solubilized by the acid in all samples.
\end{abstract}

\section{Introduction}

It has been estimated that the ethanol made from underutilized lignocellulosic biomass, if used as a neat fucl and properly managed, could meet all annual transportation needs in the United States. The concept of substituting ethanol or ethanol blends with gasoline in the United States stems from the estimate that, by the turn of the century, the United States will import up to $60 \%$ of its oil, thus opening the door to further dominance by OPEC in world energy markets (Wright 1988).

The economics of ethanol production from lignocellulosics are yield-sensitive (Wright 1988) and are thus directly related to feed costs, which are, ir turn, a function of transportation. Thus, a proposed ethanolfrom-biomass process, which could be used at a variety of locations, must be versatile enough to accept a variety of feedstocks such as hardwoods or agricultural residues, depending on the supply and demand in each locality.

All lignocellulosic biomass resists cellulytic breakdown of its major chemical component, cellulose, which

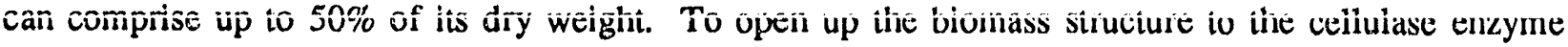


complex, we have chosen dilute sulfuric acid prehydrolysis (Grohmann et al. 1984, 1985, 1986; Himmcl et al. 1985; Torget 1985; Torget et al. 1988, 1990; Grethlein 1980, 1985; Grethlein et al. 1984; Knappert ct al. 1980, 1981; Allen et al. 1983; Sudo et al. 1986) that breaks the lignin-hemicellulose barrier and liberntes free pentose and some hexose sugars. The solid portion that remains after prehydrolysis is amenable to enzymatic breakdown of cellulose to glucose.

The past experimental work performed at SERI led to the following observations:

- The increase in cnzymatic digestibility of cellulose in pretreated wheat straw and aspen wood correlates strongly with hydrolysis of hemicelluloses in both substrates during acid-catalyzed pretreatment (Grohmann et al. 1985).

- The power consumption for dry milling of wheat straw and aspen wood to relatively coarse meals $(+100$ mesh to $-1 / 2$ in.) is not prohibitively high and costly. A less complete set of data was also obtained for corn cobs and com stover, two major agricultural residues (Himmel et al. 1985).

- Agricultural residues are much more friable than aspen wood; therefore, their milling consumes much less energy (Himmel et al. 1985).

- Knife mills are more efficient equipment for milling of wheat straw, corn stover, and aspen wood than hammer mills, but knife mills are also very sensitive to mechanically tough fractions in some biomass (corn cobs) and contaminants (e.g., metals and stones) introduced with biomass feedstocks.

- Dilute acid pretreatment can be readily extended to operation at high concentrations of solids (i.e., up to $40 \mathrm{wt} \%$ ) (Grohmann et al. 1986). The operation at a high concentration of solids will lead to sizable savings in the consumption of steam and in the case of aspen wood, an additional savings in the amount of acid catalyst would be realized. The savings in the consumption of acid catalyst are much smaller for wheat straw because the relatively high ash content neutralizes some of the catalyst.

- Investigation of the effects of particle size of pretreated aspen wood on enzymatic saccharification of cellulose indicates that efficient hydrolysis proceeds for particle sizes of 20 mesh and smaller (Torget et al. 1988).

- Dilute acid pretreatment of aspen is less sensitive to particle size effects than enzymatic hydrolysis and large (1-in.) chips can be pretreated. However, increasing particle sizes imposes heat and mass transfer limitations, which increase the reaction time. More detailed particle size studies are needed before optimal sizes for pretreatment and enzymatic hydrolysis can be determined (Torget et al. 1988).

- A preliminary process design and economic evaluation of the dilute acid pretreatment was prepared for aspen wood (Torget et al. 1988). The results indicate that dilute acid pretreatment can provide feedstocks for enzymatic saccharification at competitive costs when compared to other pretreatment options under development.

We have confirmed sporadic previous observations that the hydrolysis of hemicellulose (xylans) is biphasic in hardwoods. We have also obtained evidence that i is biphasic in wheat straw (Torget 1985; Grohmann et al. 1985). The rate of hydrolysis of xylan backbones can be best described as two concurrent reactions, one fast and one slow. Approximately $70 \%$ of the xylan backbone in aspen wood hydrolyzes via a fast reaction and $30 \%$ via a slow reaction regardless of temperature in the range of $95^{\circ}-140^{\circ} \mathrm{C}$. The behavior of the cyilans in the wheat stilaw secms io be diî́erent from that in aspen wood because the traction of 
xylan that hydrolyzes slowly decreases as the temperature of the pretreatment is increased from $95^{\circ}$ to $140^{\circ} \mathrm{C}$. The biphasic rate of xylan removal has significant implications for the pretreatment and xylose yields. The effective pretreatment requires nearly complete removal of xylan, which proceeds rapidly only at $120^{\circ} \mathrm{C}$ or above with the low (ca $0.5 \%$ ) concentrations of sulfuric acid we have been investigating. The presence of a slow fraction also decreases the xylose yield in some process configurations because more xylose is converted to furfural while the slow fraction is being hydrolyzed. Nevertheless, xylose is produced in approximately $80 \%$ yield during dilute acid pretreatment of both substrates.

Independent investigations by H. Grethlein and coworkers (Grethlein 1980, 1985; Grethlein et al. 1984; Knappert et al. 1980, 1981; Allen et al. 1983), which were performed at higher temperatures $\left(180^{\circ}-230^{\circ} \mathrm{C}\right)$, provide additional information that the dilute acid pretreatment is effective for mixed southern hardwoods but not for softwoods (pine). They also made a very important observation (Grethlein 1985) that dilute acid pretreatment creates pores in the wood that are large enough for enzyme molecules to penetrate and access cellulose fibers. The large pores are probably produced by removal of hemicelluloses and concurrent condensation of lignin.

The investigations in FY 1989 and 1990 have been focused on evaluations of woody and herbaceous energy crops being developed by the Biomass Production Program managed by Oak Ridge National Laboratory (ORNL) and two corn samples for the Western Regional Biomass Program managed by the Western Area Power Administration. Samples of three short-rotation woody crops (silver maple, sycamore, and black locust) and two herbaceous crops (canary reed grass and flat sweetpea) were obtained from ORNL program subcontractors. Two com samples (com cobs and corn stover) were obtained locally. The wood samples were debarked prior to evaluation. Complete results are presented for the wood and corn samples. However, the susceptibility of the two herbaceous samples to dilute acid pretreatment and enzymatic hydrolysis is being evaluated at the present time, and the results will not be reported in this summary because experimental work has not been completed.

\section{Materlals and Methods}

Hardwood stems 2 to 4 in. in diameter were cut into sections 2 to $4 \mathrm{ft}$ long, air dried, and stored in a dry room at ambient temperature. Whole aerial parts of mature corn stalks and cobs were also harvested, dried, and stored as above.

The following species were used for pretreatment investigations:

- Hardwoods

- silver maple (Acer saccharinum)

- sycamore (Platanus occidentalis)

- black locust (Robinia pseudoacacia)

- Corn residues

- corn cobs

- corn stover.

The bark was loosened by brief steaming ( $30 \mathrm{~min}$, dry cycle) in the autoclave. The bark sections were then stripped from steamed wood by hand or loosened with a knife. The wood sections were air dried, chipped, and knife-milled to pass through a 2-mm rejection screen. Dry corn samples were also 
knife-milled (Thomas-Wiley laboratory mill, Arthur H. Thomas, Co., Philadelphia, Penn.) to pass through a $2-\mathrm{mm}$ rejection screen. Milled material was not separated into additional fractions.

A ccllulase preparation (Celluclast $1.5 \mathrm{~L}$ ) produced by Trichoderma reesel was a gift from NOVO Industries, Lid. (Copenhagen, Denmark). The cellulase preparation was in liquid form, stabilized by the addition of glycerol. The specific activity of the enzyme preparation was approximately 72 international filter paper units (IFPU)/mL (Knappert et al, 1981). Fungal $\beta$-glucosidase (Novozyme 188, NOVO, Ltd., specific activity [Ghose 1987] $250 \mathrm{IU} / \mathrm{mL}$ ) was used to supplement the $\beta$-glucosidase activity in the cellulase preparation. The remaining chemicals were purchased from national laboratory supply houses. Cellulose powder ( $\alpha$-cellulose) was used as a control substrate and was obtained from Sigma Chemical Co. (St. Louis, Mo.).

\section{Chemical Pretreatments}

The wood and herbaccous particles were pretreated with dilute $(0.45 \%-0.50 \% \mathrm{v} / \mathrm{v})$ sulfuric acid solutions in a 1-L stainless steel reactor (Carpenter $20 \mathrm{Cb}-3$, Parr Co., Moline, Ill.) equipped with an impeller mixer and a pressurized injection device (Himmel 1986). Because of mixing limitations of impeller mixers with biomass particles, only low-solid slurries (10\%) were investigated. Dilute acid pretreatrnent experiments were performed at $140^{\circ}$ and $160^{\circ} \mathrm{C}$. Reaction began when the slurries of biomass in deionized water reached the desired reaction temperature; acid was then injected. Zero time denotes biomass slurries heated in water to the reaction temperature. The acid concentrations were calculated to yield hydrolysis $\mathrm{pH}$ of 1.35 to 1.45 after $140^{\circ} \mathrm{C}$ for $30 \mathrm{~min}$. All pretreated biomass particles were exhaustively washed in deionized water to remove water-soluble components.

A portion of the solid wet residues was stored frozen at $-20^{\circ} \mathrm{C}$ for subsequent enzymatic hydrolysis. The remaining material was air dried at $45^{\circ} \mathrm{C}$ for subsequent chemical analyses. Volumes of combined filtrate and washes were measured and recorded. The combined liquids were neutralized with calcium carbonate, filtered, and stored at $4^{\circ} \mathrm{C}$ for analyses.

\section{Enzymatic Hydrolysls}

Enzymatic hydrolysis was performed in batch mode at $50^{\circ} \mathrm{C}, \mathrm{pH} 4.8$, in gently rotated glass vials (Grohmann et al. 1985, 1986). Cellulase enzyme loading was approximately 42 IFPU/g of cellulose ( $\beta$-glucosidase activity was approximately $4.9 \mathrm{IU} / \mathrm{g}$ of cellulose), and initial cellulose concentrations were adjusted to $1 \%$. The reaction time for digestibility determination was usually four days and was defined by negligible additional relcase of glucose from the $\alpha$-cellulose control and pretreated substrates. Glucose released by the enzymatic hydrolysis was determined with a YSI Glucose analyzer (Yellow Springs Instruments, Yellow Springs, Ohio) and by ion moderated partition (IMP) chromatography when information about other sugars was required. Enzymatic digestibility was calculated as the percentage of the total glucose (corrected for hydration) released from the total anhydroglucose in the biomass sample at the end of hydrolysis. Release of the other sugars was not considered in this study because they are solubilized by the pretreatment.

\section{Analytlcal Methods}

Dry weights and ash content of all solids were determined by standard methods (Moore et al. 1967). Lignin and other acid-insoluble components were determined as Klason lignin (Moore et al. 1967). Carbohydrate composition of biomanss soliưs was deiennined by a iwo-stage suifuric acid hydrolysis 
(Moore et al. 1967) followed by determination of monomeric sugars by IMP chromatography. Monosaccharides in all neutralized hydrolyzates were determined by IMP chromatography using Aminex HPX 87-P column (Bio-Rad, Richmond, Calif.), deionized water as eluant, and refractive index detection. Acetic acid and furfural in aqueous solutions were determined by gas chromatography (Grohmann et $\mathrm{al}$. 1985, 1986).

\section{Results and Discussion}

This study is a continuation of our efforts to determine the universal applicability of dilute sulfuric acid pretreatrnent to complete enzymatic breakdown of cellulose found in short-rotation woody and herbaceous crops (Grohmann et al. 1984, 1985, 1986; Himmel et al. 1985; Torget 1985; Torget et al. 1988, 1990). We have previously shown that a direct relationship exists between dilute acid mediated xylan removal and concomitant increased enzymatic breakdown of cellulose (Grohmann et al. 1985). It has also been reported that the economics of ethanol production using lignocellulosic biomass as a feedstock depends on yield and the cost of the feedstock (Wright 1988). It is, therefore, advantageous to have one dilute acid pretreatment facility using a variety of lignocellulosic feedstocks depending on supply, demand, and price of the feed. Our research, in collaboration with the DOE Biomass Production Program managed by ORNL, expects to discover suitable lignocellulosic biomass feedstocks for the pretreatment and bioconversion to fuel grade ethanol.

\section{Hardwoods}

The approximate chemical compositions of the wood samples from three short-rotation trees are shown in Table 1. The composition of all three samples is typical for woods from hardwood trees. Major component is cellulose (glucan) followed by lignin, xylan, and a variety of minor components. Very low ash content of all wood samples is also notable. The milled woods were subjected to dilute acid prehydrolysis and its effects on enzymatic hydrolysis were investigated. The conditions (i.e., pH, acid concentration, and reaction temperature) of pretreatment were chosen to be the same investigated previously with aspen wood and wheat straw (Grohmann et al. 1984; Grohmann et al. 1985; Grohmann et al. 1986; Torget 1985). By keeping the key parameters constant, we can compare the results obtained with short-rotation hardwoods to those obtained previously with aspen wood. The pretreatment experiments were performed in a stirred Parr reactor as described in the Materials and Methods section. The digestibility of carbohydrates was determined by prolonged incubations with an excess of cellulase/ $\beta$-glucosidase enzyme mixtures until sugar release became negligible. Control experiments with $\alpha$-cellulose and pretreated samples required approximately 4 days. The pretreated solids were exhaustively washed with water to remove potential water-soluble compounds that could interfere with enzymatic digestion and analysis.

Dilute sulfuric acid prehydrolysis of lignocellulosics for the biosynthesis of ethanol is used to cleave scveral classes of covalent bonds both in the lignin and hemicellulose fractions producing greater pore volume and greater accessibility for ccllulase enzymes (Grethlein 1985). The hemicellulose fraction is nearly completely hydrolyzed to monomeric sugars, whereas the lignin primarily recondenses forming an altered lignin polymer. The key results are shown in Figures 1 through 4 and Tables 1 and 2. Because 


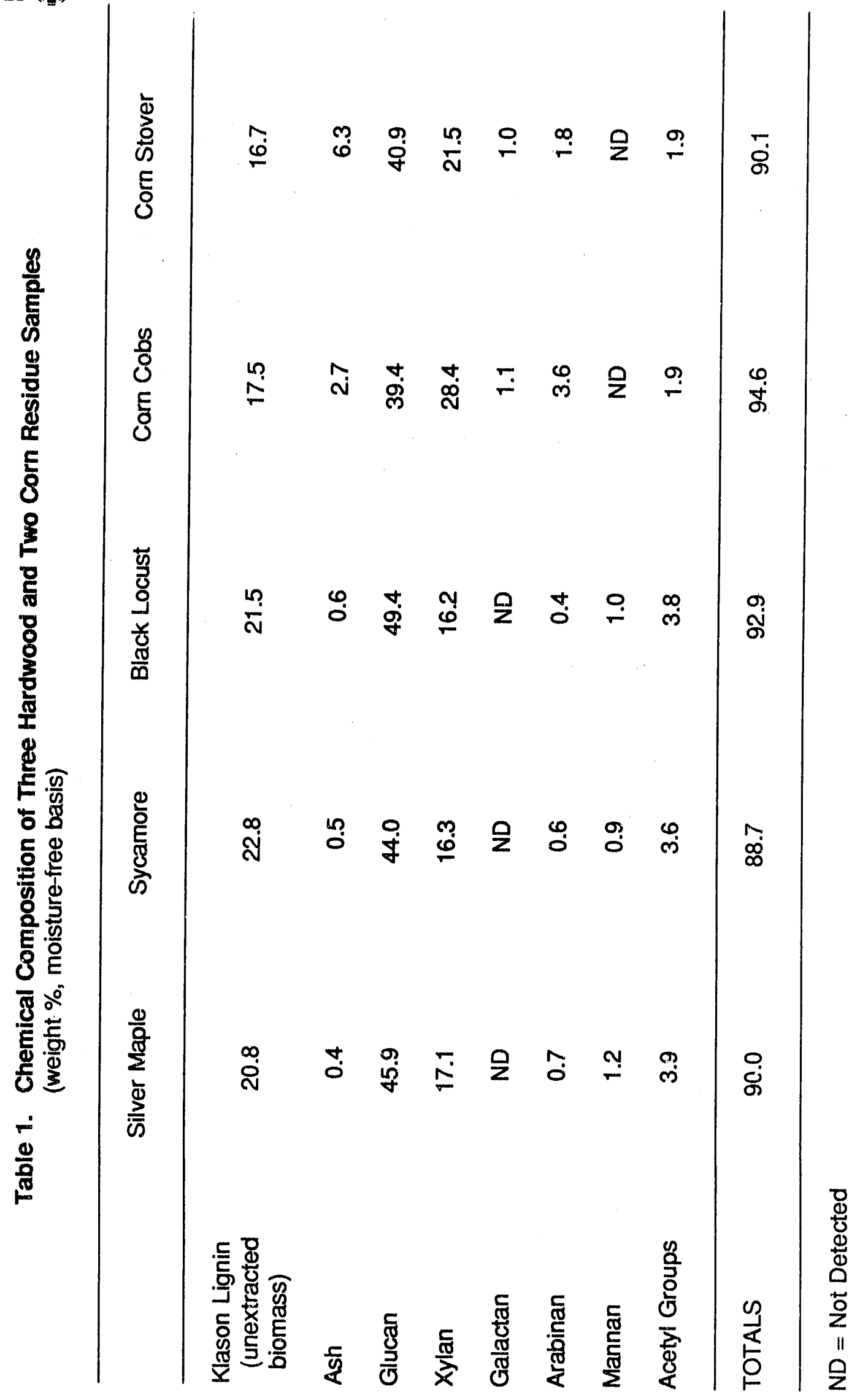


TP-3996

Percent dry weight lose

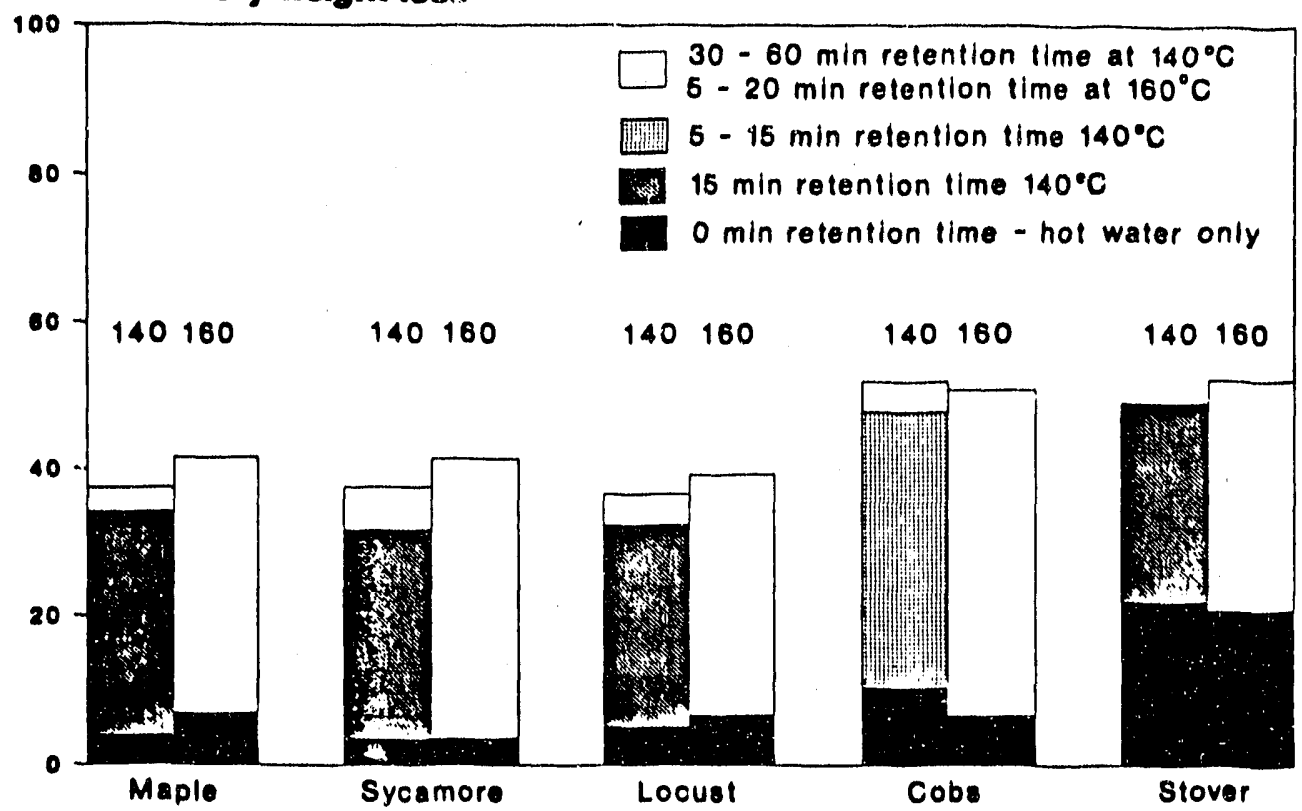

Figure 1. Pattern of dry welght loss during acld pretreatment of hardwood and corn samples

Hardwood residues

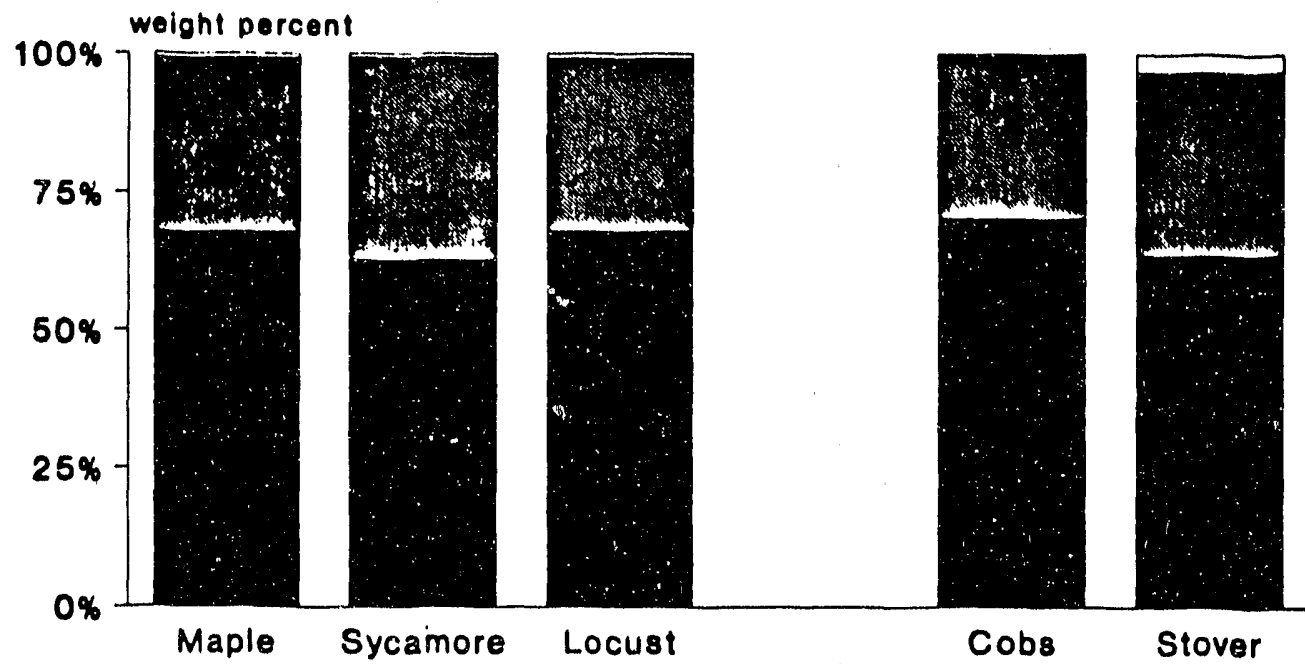

Figure 2. Average residue compositions of hardwood and corn samples after pretreatment at $160^{\circ} \mathrm{C}$ for $10 \mathrm{mln}$ 


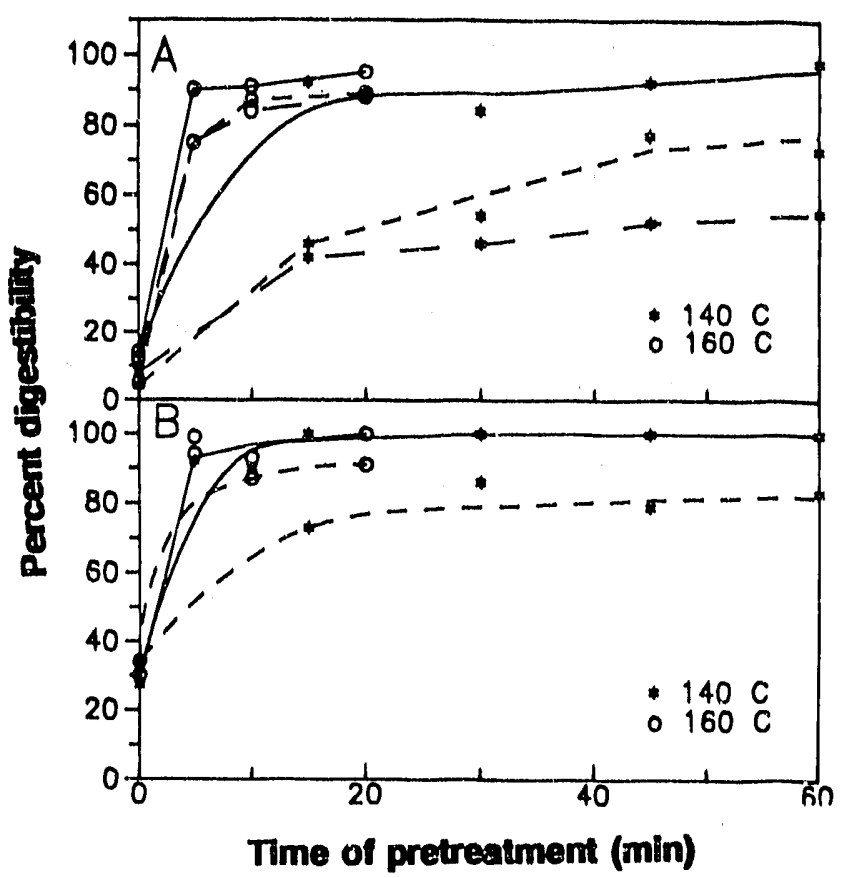

TP-3996

Flgure 3. Panel A: Changes In enzymatlc dlgestiblilty of cellulose In maple ( - ), black locuet $(-\ldots)$, and sycamore $\left({ }_{-}-\right)$wood samples as a function of reactlon time in dilute acld protreatment

Panel B: Changes In enzymatlc digestlbility of cellulose in corn cobs ( - ), and otover $\left(---_{-}\right)$as a function of reaction time in dilute acld pretreatment

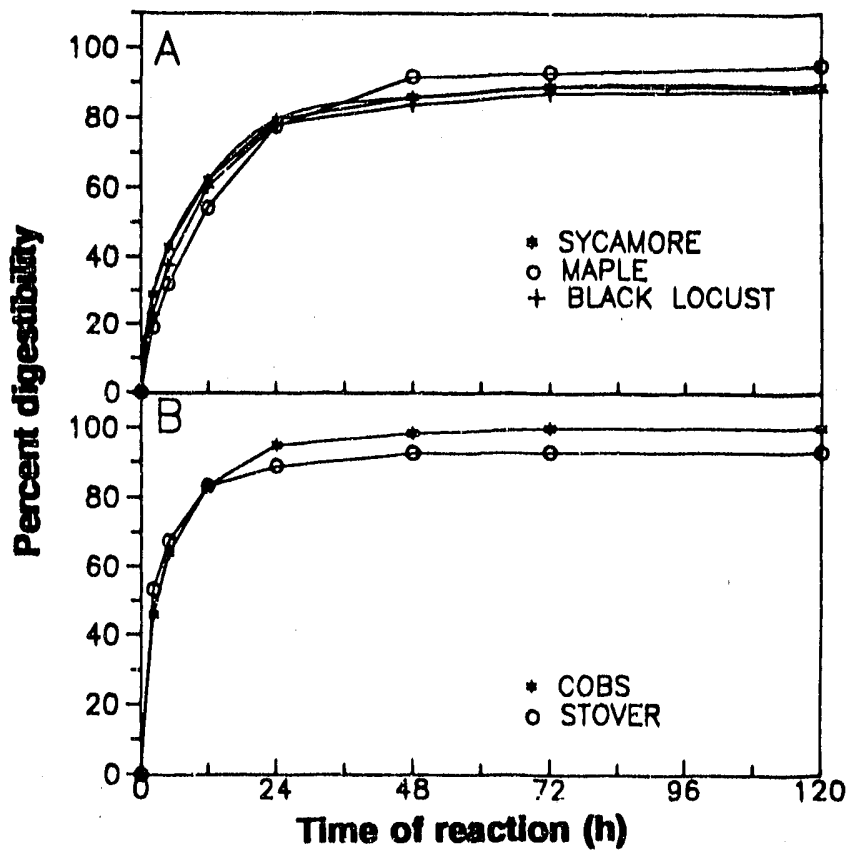

Figure 4. KInetlcs of enzymatlc release of glucose from wood and corn samples pretreated at $160^{\circ} \mathrm{C}$ for $10 \mathrm{~min}$ In dilute acld

Panel A: Hardwood samples

Panel B: Corn samples 
TP.3996

\section{Tabie 2. Solubillzation of Hardwood and Corn Components Durlng Pretreatment at $160^{\circ} \mathrm{C}$ for 5 to $10 \mathrm{~min}$ (\% of original)}

\begin{tabular}{lccccc}
\hline & $\begin{array}{c}\text { Silver } \\
\text { Maple }\end{array}$ & Sycamore & Black Locust & Corn Cobs & Corn Stover \\
\hline Klason Lignin & 13 & 6 & 16 & 26 & 9 \\
Glucan & 13 & 15 & 17 & 14 & 25 \\
Xylan & 97 & 98 & 97 & 100 & 93 \\
Galactan & -- & -- & -- & 100 & 100 \\
Arabinan & 100 & 100 & 100 & 100 & 100 \\
Mannan & 100 & 100 & 100 & -- & -- \\
Acetyl Groups & 100 & 100 & 100 & 100 & 100 \\
\hline
\end{tabular}

the hemicellulose and other minor components of wood can be completely hydrolyzed by the acid, the change in dry weight loss as a function of hydrolysis time is a useful parameter to determine completion of hydrolysis at a given temperature. The loss of dry weight of maple, black locust, and sycamore wood meals as a function of pretreatment time at $140^{\circ}$ or $160^{\circ} \mathrm{C}$ is shown in Figure 1; results are very similar for all three woods. Small amounts of wood (3\% to $8 \%$ ) became solubilized with hot water and much larger ( $34 \%$ to $42 \%$ ) amounts were solubilized during dilute acid pretreatment. The hydrolyses of substrates pretreated at $140^{\circ} \mathrm{C}$ were practically complete in a $15-$ to 30 -min interval, and in 5 min when pretreatment was at $160^{\circ} \mathrm{C}$. This is very similar to the results previously obtained with other short-rotation woody and herbaceous crops (Grohmann et al. 1984, 1986; Torget 1985; and Torget et al. 1990).

It was mentioned earlier that the economics of ethanol production from biomass are yield-sensitive. Therefore, because the dilute acid pretreatment is a hydrolytic ciction releasing free hemicellulosic sugars as well as some glucose from cellulose or glucans, and because the degradation of these sugars is also acid catalyzed, hydrolytic conditions must be chosen that assure that the solid cellulosic product is enzymatically degradable while maximizing the yield of free sugars in the supernatant. Solubilization of the major components of the three hardwoods for averaged reaction times of 5 to $10 \mathrm{~min}$ at $160^{\circ} \mathrm{C}$ is shown in Table 2. Results for pretreatments at $140^{\circ} \mathrm{C}$ with reaction times of 30 to $60 \mathrm{~min}$ were very similar (data not shown). The lignin was solubilized only slightly (6\% to $16 \%$ loss) during the pretreatments at both temperatures and a large part of solubilization (40\% to $100 \%$ ) occurred during the initial heating period in water (data not shown). Glucan (cellulose) hydrolysis was also low with only $13 \%$ to $17 \%$ solubilized from all three woods. It should be emphasized at this point, however, that solubilization of sugars during dilute acid pretreatment does not represent any large actual loss for subsequent fermentations. All sugars can be recovered in aqueous solutions after pretreatment and eventually fermented to ethanol or other products. Actual recoveries of hemicellulosic sugars in liquids from pretreatments at $140^{\circ} \mathrm{C}$ (15 to $30 \mathrm{~min}$ retention time) and $160^{\circ} \mathrm{C} \mathrm{(5} \mathrm{to} 10 \mathrm{~min}$ retention time) were approximately $80 \%$ to $90 \%$ for xylose and $90 \%$ to $100 \%$ for galactose and arabinose. Pretreatments at $160^{\circ} \mathrm{C}$ for $20 \mathrm{~min}$ were too severe and higher destruction of sugars was observed. Small amounts of 
furfural $(0.04$ to $0.08 \mathrm{wt} \%)$ and acetic acid $(0.3 \mathrm{wt} \%)$ also accumulated in liquids from these pretreatments. Overall, material balances for glucan and xylan were similar for short reaction times with recoveries calculated at $94 \%$ to $103 \%$ from the starting blomass.

The composition of all three pretreated wood solids were very similar after removal of hemicelluloses. Average compositions for samples pretreated at $160^{\circ} \mathrm{C}$ for $10 \mathrm{~min}$ are shown in Figure 2. Tha main component $(64 \%$ to $70 \%)$ is cellulose, followed by lignin. Traces of xylan (2\%) also remained in many pretreated samples.

The dllute acid pretreatment increased the enzymatic digestibility of all three hardwoods dramatically when performed at $160^{\circ} \mathrm{C}$ (Figure 3). Cellulose digestibility in all three woods reached $88 \%$ to $94 \%$ after 10 min with maple achieving the highest level. The development of high digestibilities of cellulose in all three woods pretreated at $160^{\circ} \mathrm{C}$ coincided with hydrolysis and solubilization of xylan. When $140^{\circ} \mathrm{C}$ was used as a prehydrolysis temperature, only maple yielded a highly digestible substrate, with the degree of digestibility again being directly correlated with xylan removal (data not shown). When either the sycamore or black locust was pretreated at $140^{\circ} \mathrm{C}$, lower digestibilities (Figure 3) were observed (75\% for sycamore and only $52 \%$ for black locust) even though near-complete removal of xylan was achieved (data not shown). This indicates that additional reactions, such as lignin condensation, may contribute to development of porosity and enhanced cellulose accessibility during dilute acid pretreatment (Grethlein 1985).

The rates of enzymatic release of glucose from all three woods pretreated at $160^{\circ} \mathrm{C}$ for $10 \mathrm{~min}$ were nearly identical (Figure 4). The enzymatic reaction was complete after $48 \mathrm{~h}$. This observation is different from previous work using other hardwoods, in which it took from 3 to 5 days to completely digest the cellulose (Torget et al. 1990).

\section{Corn Resldues}

The approximate chemical compositions of the corn samples are shown in Table 1. The composition of the stover is very similar to wheat straw with a slightly lower ash content. The cobs, however, have a very high xylan content and significantly lower ash level than that found in stover or wheat straw. Due to the lower ash content found in cobs, less sulfuric acid $(0.45 \% \mathrm{v} / \mathrm{v}$ as compared to $0.5 \% \mathrm{v} / \mathrm{v}$ required for stover) is necessary to achieve the hydrolysis pH of 1.35 for the cob slurries when compared to stover.

The patterns of dry weight loss (Figure 1) versus time at $140^{\circ}$ and $160^{\circ} \mathrm{C}$ were very similar for the two substrates with the exception of the initial time. The cobs behaved more like wood with less than 10 wt $\%$ being solubilized by hot water, while hot water solubilized slightly more than $20 \mathrm{wt} \%$ of the stover, similar to wheat straw. More than $50 \%$ of both substrates were solubilized during dilute acid pretreatment. The hydrolyses were practically complete in a $5-\mathrm{min}$ interval at $140^{\circ} \mathrm{C}$ for the cobs and in 15 to $30 \mathrm{~min}$ for the stover; at $160^{\circ} \mathrm{C}$ both pretreatments were complete in $5 \mathrm{~min}$. These results are very similar to the results obtained previously (Torget et al. 1990).

Although the hemicellulosic sugars from both substrates were almost completely solubilized during the pretreatment, lignin and glucan solubilization was substrate specific (Table 2). At either temperature, the lignin from the stover was solubilized only slightly (13\% to $17 \%$ ) while the glucan solubilization was higher ( $9 \%$ to $28 \%$ ). Using cobs as the substrate at either temperature, as much as $33 \%$ of the lignin was 
solubilized and only $6 \%$ to $14 \%$ of the glucan was released. The solubilized sugars were again recovered from liquid fractions in high yields, together with minor amounts of furfural $(0.3 \%$ for cobs and $0.1 \%$ for stover) and acetic acld ( $0.4 \%$ for both) (data not shown). The composition of the pretreated solids changes very little after removal of hemicelluloses (Figure 2). The main component (70\%) is cellulose, followed by lignin. Traces of xylan (3\%) also renained in the pretreated stover while all xylan was removed from the cob residues.

Cellulose digestibility in both substrates reached $90 \%$ to $100 \%$ after 5 to $10 \mathrm{~min}$ of pretreatment at $160^{\circ} \mathrm{C}$ (Figure 3). Slightly lower (79\% to $86 \%$ ) digestibilities were observed after 30 to $60 \mathrm{~min}$ at $140^{\circ} \mathrm{C}$ for the stover, but after only $5 \mathrm{~min}$ at $140^{\circ} \mathrm{C}$ the cellulose in cobs was $90 \%$ digestible. The development of high enzymatic digestibilities of cellulose in both substrates pretreated at $160^{\circ} \mathrm{C}$ coincided with hydrolysis and solubilization of xylan, as we previously observed for dilute acid pretreatment of aspen and wheat straw.

The rates of enzymatically released glucose from the corn residues pretreated at $160^{\circ} \mathrm{C}$ for 10 min are seen in Figure 4. The rates are identical for both substrates and the reaction is essentially complete after only $24 \mathrm{~h}$. These results are very similar to grasses and wheat straw, and 2 to 3 times faster than hardwoods (Grohmann et al. 1985; Torget et al. 1990). Additional studies using narrower particle size ranges are needed to establish if cellulose fibers in pretreated corn residues are inherently more digestible than those in pretreated hardwoods, or if the differences are caused by other factors, such as particle dimensions and enzyme penetration into the interior of pretreated particles.

\section{Acknowledgments}

The authors wish to thank the Biomass Production Program at ORNL for providing samples of hardwoods and herbaceous crops for our research. This work was funded by the Ethanol from Biomass Program of the Blofuels Systems Division of the U.S. Department of Energy, and the Western Regional Biomass Program, which is managed by the Western Area Power Administration.

\section{References}

Allen, C.D., Grethlein, H.E., and Converse, A.O. 1983. Biotechnol. Bioeng. Symp. 13:99-111.

Ghose, T.K. 1987. Pure and Appl. Chem. 59:257-268.

Grethlein, H.E. 1980. U.S. Patent No. 4,237,226, December 2, 1980.

Grethlein, H.E., 1985. BioTechnol. 3:155-160.

Grethlein, H.E., Allen, D.C., and Converse, A.O. 1984. Biotechnol. Bioeng. 26:1498-1505.

Grohmann, K., Himmel, M., Rivard, C., Tucker, M., Baker, J., Torget, R., and Graboski, M. 1984. Biotechnol. Bioeng. Symp. 14:139-157.

Grohmann, K., Torget, R., and Himmel, M. 1985. Biotechnol. Bioeng. Symp. 15:59-80. 
Grohmann, K., Torget, R., and Himmel, M. 1986. Biotechnol. Bioeng. Symp. 17:135-151.

Himmel, M. 1986. Biotechnol. Bioeng. 28:126-128.

Himmel, M., Tucker, M., Baker, J., Rivard, C., Oh, K., and Grohmann, K, 1985. Biotechnol. Bioeng. Symp. 15:39-58.

Knappert, D., Grethlein, H., and Converse, A. 1980. Biotechnol. Bioeng. Symp. 17:1449-1463.

Knappert, D., Grethlein, H., and Converse, A. 1981. Blotechnol. Bioeng, Symp. 11:67-77.

Moore, W.E., and Johnson, D.B., 1967. Procedures for the Chemical Analysis of Wood and Wood Products. Madison, WI: U.S.D.A. Forest Products Laboratory.

Sudo, K., Shimizu, K., Ishil, T., Fujil, T., and Nagasawa, S. 1986. Holzforschung 40:339-345.

Torget, R. 1985. "Kinetics of Dilute Sulfuric Acid Pretreatment of Wheat Straw." M.S. Thesis, Colorado School of Mines, Golden, Colorado.

Torget, R., Himmel, M., Wright, J., and Grohmann, K. 1988. Appl. Blochem. Biotechnol. 17:89-104.

Torget, R., Werdene, P., Himmel, H., and Grohmann, K. 1990. Appl. Biochem. Biotechnol., 24:115-126.

Wright, J.D. August 1988. Chem. Eng, Prog. 62-74. 


\title{
Anımonla Fiber Explos!on (AFEX) Pretreatment
}

\author{
M. T. Holtzapple \\ Department of Chemical Engineering \\ Texas A\&M University \\ College Station, Texas 77843
}

\begin{abstract}
The Axnmonia Fiber Explosion (AFEX) process treats lignocellulose with high-pressure liquid ammonia and then $x$ pisively releases the pressure. The combined chemical effect (cellulose decrystallization) and physical etfect (increased accessible surface area) dramatically increase lignocellulose susceptibility to enzymatic attack. There are many adjustable parameters in the AFEX process: ammonia loading, water loading, temperature, time, blowdown pressure, and number of treatments. The effect of these parameters on the enzymatic susceptibility of bagasse was explored. The treatment effectiveness was not very sensitive to ammonia or water loading. However, the treatment was very sensitive to temperature; higher temperatures $\left(93^{\circ} \mathrm{C}\right)$ were significantly better than lower temperatures $\left(13^{\circ} \mathrm{C}\right)$. Multiple treaiments benefited reactivity; however, there were diminishing returns with each subsequent treatment. Importantly, a 3-atm blowdown produced bagasse that was nearly as reactive as a 1.5-atm blowdown, thus offering tremendous savings in recompression costs. Nearly quantitative sugar yields were demonstrated using a very low enzyme loading (5 IU/o).
\end{abstract}

\section{Introduction}

The use of lignocellulose has the potential to solve or mitigate problems such as global warming, balance of trade. Third Worid debt, air pollution, trash disposal, soil erosion, herbicide/pesticide accumulation, and deforestation. However, because native lignc cllulose is chemically recalcitrant, the key to using lignocellulose is to identify an effective pretreatmert that enables rapid and complete enzymatic conversion to fermentable sugars. Pretreatments may be categorized as chemical, physi zal, or physicochemical (Dale, 1985). Table 1 summarizes these pretreatments and shows that all of them--except Ammonia Fib. Explosion (AFEX) - have one or more severe weaknesses. The AFEX process uses a volatile reagent (ammonia) that is easily recovered. The processing conditions are mild, which minimizes biomass degradation. Capital and energy requirements are modest. It is estimated that the entire cost of the process, including ammonia, utilities, labor, fixed charges, and interest on capital (at 15\%) is \$25-\$29/torne (Holtzapple et al. 1990a). 
Table 1. Weaknesses of Varlous Llgnocellulose Pretreatments

\begin{tabular}{|c|c|c|c|c|c|}
\hline CHEMICAL & REACTIVITY & ENERGY & CAPITAL & $\begin{array}{l}\text { CHEMICAL, } \\
\text { RECOVERY }\end{array}$ & DEGRADATION \\
\hline ORGANOSOLV & $x$ & & & & $x$ \\
\hline $\mathrm{NaOH}$ & & & & $x$ & \\
\hline $\mathrm{NH}_{3}$ & $x$ & & & & \\
\hline CONC ACID & & & & $x$ & $x$ \\
\hline DIL ACID & & & & $x$ & $x$ \\
\hline SOLVENTS & & & & $x$ & \\
\hline AUTOHYDROLYSIS & & & & & $x$ \\
\hline \multicolumn{6}{|l|}{ PHYSICAL } \\
\hline BALL MILL & & $x$ & $x$ & & \\
\hline TWO-ROLL MILL & & $x$ & $x$ & & \\
\hline \multicolumn{6}{|l|}{ PHYSICOCHEMICAL } \\
\hline STEAM EXPLOSION & & & & & $x$ \\
\hline AFEX & & & & & \\
\hline
\end{tabular}

$X=$ WEAKNESS

In the AFEX process (Dale an' Moreira 1982; Dale et al. 1985), lignocellulose is soaked with high-pressure (ca. $15 \mathrm{~atm}$ ) liquid ammonia at moderate temperatures $\left(\mathrm{ca} .50^{\circ} \mathrm{C}\right.$ ) for about $15 \mathrm{~min}$ causing cellulose to decrystallize. Then the pressure is instantaneousiy released, causing the ammonia to flash violently and disrupt the fibrous structure. The chemical effects (cellulose decrystallization, henicellulose prehydrolysis, and lignin alterations) combi. $d$ with the physical effect (increase in accessible surface area) markedly increase the susceptibility of lignocellulose to enzymatic hydrolysis. Figure 1 shows a schematic diagram of an industrial-scale AFEX process. All the ammonia, except that chemically bound as ammonium ions, will be recovered for reuse. Typically, about $0.5 \%$ to $1.0 \%$ ammonia remains in the lignocellulose (Dale and Moreira 1982), which serves as a nitrogen source for the microbes that use the sugars enzymatically hydrolyzed from the lignocellulose.

The explosive pressure release of AFEX invites comparisons with the steam explosion process (Brownell et al. 1986). The processes are very different, however. Steam explosion operates at substantially higher temperatures (ca. $235^{\circ} \mathrm{C}$ ) and pressures (ca. $32 \mathrm{~atm}$ ), which degrade about $10 \%$ to $20 \%$ of the biomass. The mechanical disruption of lignocellulose fibers by steam explosion does not contribute to the efficacy of the piocess (Biowinell êt à. 19806), Kaihuer, ine increased reactivity frum steam explosion results from 


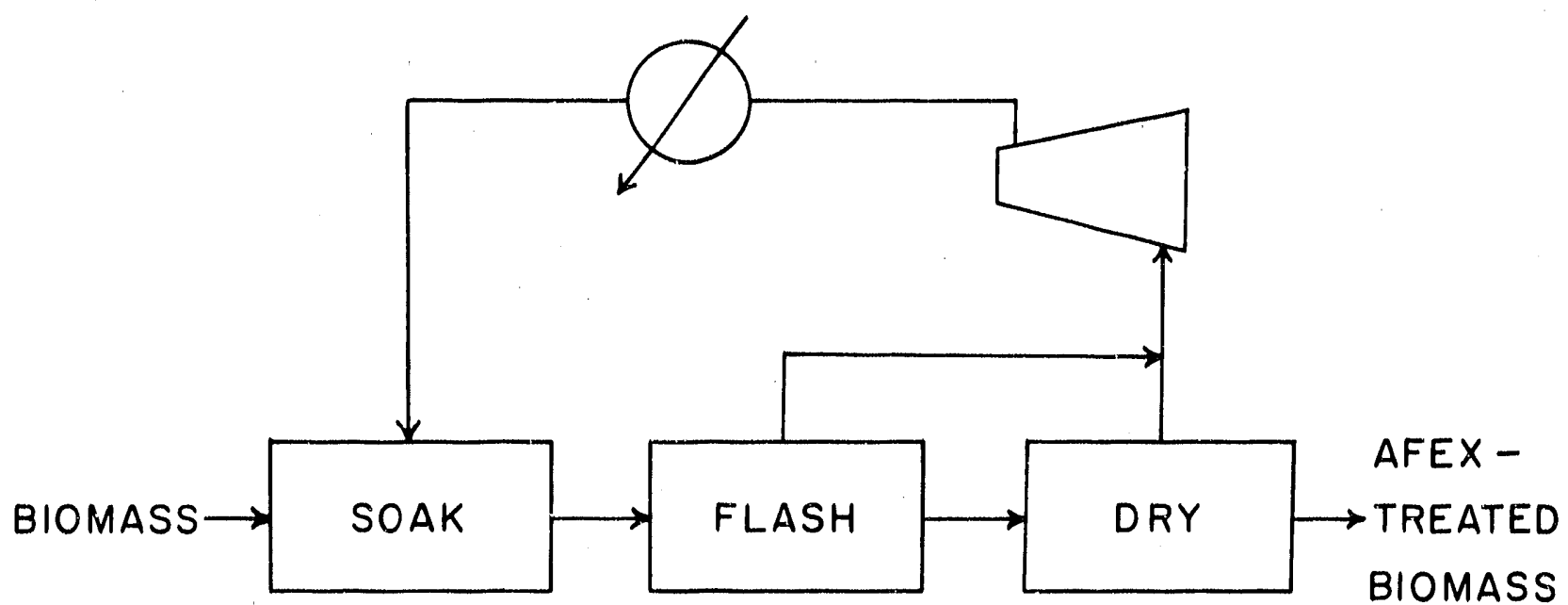

Flgure 1. Schematic dlagram of an Industrial AFEX process

autohydrolysis of the lignocellulose by organic acids released by the high temperatures. $A$ recent comparison of AFEX with steam explosion (Mes-Hartree et al. 1988) shows that AFEX-treated biomass can have up to $236 \%$ greater enzymatic reactivity than steam-exploded biomass. It should be emphasized that the AFEX treatment was not optimized in this comparison.

It is the purpose of this paper to explore optimal conditions for the AFEX treatment of bagasse, the residue remaining after sucrose is extracted from sugarcane. Only about one-third of sugarcane dry matter is sucrose, so the remaining two-thirds is frequently wasted. Because sugarcane is the world's most abundant agricultural product-outproducing milk, wheat, corn, and rice-significant quantities of bagasse are available for use (Ziborsky et al. 1981). The AFEX process has many degrees of freedom: ammonia loading, water loading, temperature, time, blowdown pressure, and multiple AFEX treatments. As will be shown, multiple AFEX treatments significantly improve the enzymatic reactivity compared to a single treatment. Multiple stesam explosions are not a viable option because too much of the biomass would be degraded.

\section{Materials and Methods}

Bagasse was supplied from both Louisiana and South Texas. The samples were air dried and ground in a blender to a particle size of approximately $1 \mathrm{~mm} \times 15 \mathrm{~mm}$.

The reactor consisted of a 4-L Autoclave Engineers pressure vessel. The vessel was charged with prewetted bagasse and a known amount of liquid ammonia was added. The contents were brought to temperature and held for the desired residence time. Then, a $2.85-\mathrm{cm}$ ball valve was quickly opened, releasing the pressure to a blowdown tank. The final blowdown pressure was regulated by charging the blowdown tank with a desired pressure of nitrogen gas.

After air drying the ammonia from the AFEX-treated samples, $7.5 \mathrm{~g}$ of biomass were added to $150 \mathrm{~mL}$ of $0.05 \mathrm{M} \mathrm{pH} 4.8$ citrate buffer, which was prewarmed to the reaction temperature of $50^{\circ} \mathrm{C}$ in a $100-\mathrm{rpm}$ shaking water bath. Genencor 300P cellulase with a filter paper activity (Mandels et al. 1976) of $132 \mathrm{IU} / \mathrm{g}$ dry powder was added so the cellulase loading was $5 \mathrm{IU} / \mathrm{g}$ dry biomass. Trichoderma reesei cellulase has a specific activity of about $0.7 \mathrm{IU} / \mathrm{mg}$ protein, so this enzyme loading corresponds to $7 \mathrm{~kg}$ cellulase 
protein/tonne dry biomass. The cellulase activity was supplemented with Novo 188 cellobiase to reduce cellobiose inhibition. One-milliliter liquid samples were boiled in a sealed test tube for 30 min to denature the enzyme. The boiled samples were filtered through $0.22 \mu \mu \mathrm{m}$ nylon membrane filters. The reducing sugar concentration was measured using the DNS assay (Miller 1959). (Note: All reducing sugar yiclds are expressed as $\mathrm{mg}$ equivalent glucose/g dry substrate because glucose was used as the calibration standard.)

\section{Results and Discussion}

Including controls, a total of 31 bagasse samples was hydrolyzed. In all cases, the curves that describe sugar production versus time had a similar shape; only the scale was different. Figure 2 shows sugar yiclds versus time with the data normalized to the 3-day yicld. The 3-day sugar yield is a convenient measure of the enzymatic susceptibility of the AFEX-treated bagasse. The normalized curve allows determination of sugar yields at times other than 3 days. For example, about $50 \%$ of the sugars were relcased in $2 \mathrm{~h}$ and $85 \%$ were released in $24 \mathrm{~h}$.

The bagasse samples were treated according to the conditions described in Table 2. Figure 3 shows the results from multiple AFEX treatments. There was nearly a linear increase in reactivity with each treatment for the first three treatments. Although the latter three treatments also were beneficial, there were diminishing returns because the improvement was not as great. The results were nearly identical for the two blowdown pressures, although the lower pressure $(1.5 \mathrm{~atm})$ caused the material to be slightly more reactive than the higher blowdown pressure $(3.0 \mathrm{~atm})$. Higher blowdown pressures result in significant compressor energy savings. For example, a 3-atm blowdown uses only about $40 \%$ to $60 \%$ of the compression energy required by a 1-atm blowdown (Holtzapple et al. 1990a).

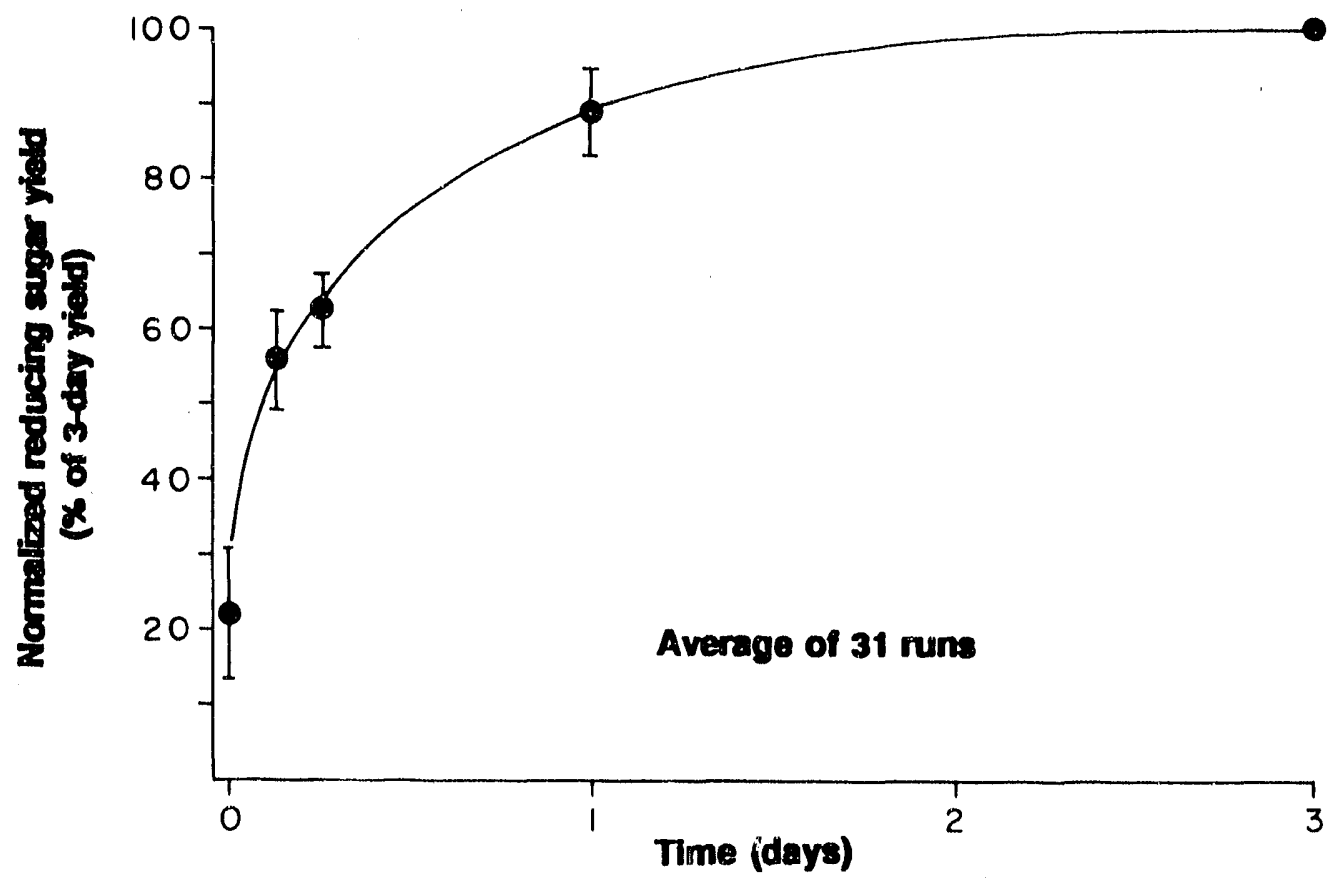

Figuire 2. riormaiized nyaroiysis proiiie for bagasse (3-day yleld $=100$, error bars are +1 standard deviation) 
Figure 4 shows the effect of ammonia loading on biomass reactivity. Above $1 \mathrm{~kg}$ ammonia/kg dry bagasse, the reactivity is fairly constant, although $1.5 \mathrm{~kg}$ ammonia $/ \mathrm{kg}$ dry bagasse is best. This loading was used in subsequent bagasse experiments.

Figure 5 shows the effect of water loading on biomass reactivity. The maximum reactivity was achieved with $0.25 \mathrm{~kg}$ water $/ \mathrm{kg}$ dry bagasse, so this was used in subsequent experiments. This optimum is similar to the optimum determined for alfalfa (0.3 $\mathrm{kg}$ water $/ \mathrm{kg}$ dry alfalfa) (Dale and Moreira 1982).

The role of water in the AFEX process is uncertain, but it probably promotes hydrolysis of the hemicellulose. At $52^{\circ} \mathrm{C}$, the importance of this effect seems to be minor since the bone-dry bagasse (prepared by drying in an oven at $135^{\circ} \mathrm{C}$ ) had $90 \%$ of the reactivity of the optimal water loading.

It is known that steam autoclaving biomass after AFEX treatment has a beneficial effect because sugar yields from wheat straw were increased about 15\% compared to AFEX treatment alone (Holtzapple et al. 1990b). To test the effect of steaming before AFEX treatment, one of the samples was wetted with $20 \%$ moisture and steam autoclaved for $15 \mathrm{~min}$. at $128^{\circ} \mathrm{C}$. It was subsequently dried at $135^{\circ} \mathrm{C}$ in the drying oven and then treated by the AFEX process. As shown in Figure 5, this treatment affected biomass reactivity detrimentally. Although more steaming conditions must be tried before definitive conclusions can be made, it appears that treatment with steam prior to AFEX is not beneficial.

Table 2. Summary of AFEX Treatment Conditions

\begin{tabular}{|c|c|c|c|c|c|c|c|}
\hline Exp & $\begin{array}{c}\mathrm{NH}_{3} \\
\text { Loading } \\
\text { (kg/kg) }\end{array}$ & $\begin{array}{c}\mathrm{H}_{2} \mathrm{O} \\
\text { Loading }^{*} \\
(\mathrm{~kg} / \mathrm{kg})\end{array}$ & $\begin{array}{c}\text { Reactor } \\
\text { Temp. } \\
\left({ }^{\circ} \mathrm{C}\right)\end{array}$ & $\begin{array}{l}\text { Reactor } \\
\text { Press. } \\
\text { (atm abs) }\end{array}$ & $\begin{array}{l}\text { Blowdown } \\
\text { Press. } \\
\text { (atm abs) }\end{array}$ & $\begin{array}{c}\text { Reactor } \\
\text { Time } \\
\text { (min) }\end{array}$ & $\begin{array}{c}\text { Number } \\
\text { of } \\
\text { Treat. }\end{array}$ \\
\hline 1 & $\begin{array}{l}1.0 \\
1.0\end{array}$ & $\begin{array}{l}0.25 \\
0.25\end{array}$ & $\begin{array}{l}52 \\
52\end{array}$ & $\begin{array}{l}14.0 \\
14.0\end{array}$ & $\begin{array}{l}1.5 \\
3.0\end{array}$ & $\begin{array}{l}15 \\
15\end{array}$ & $\begin{array}{l}1 \text { to } 6 \\
1 \text { to } 6\end{array}$ \\
\hline 2 & $\begin{array}{l}1.0 \\
1.5 \\
2.0 \\
2.5\end{array}$ & $\begin{array}{l}0.25 \\
0.25 \\
0.25 \\
0.25\end{array}$ & $\begin{array}{l}52 \\
52 \\
52 \\
52\end{array}$ & $\begin{array}{l}10.3 \\
16.6 \\
19.5 \\
18.6\end{array}$ & $\begin{array}{l}1.6 \\
1.6 \\
1.6 \\
1.6\end{array}$ & $\begin{array}{l}15 \\
15 \\
15 \\
15\end{array}$ & $\begin{array}{l}1 \\
1 \\
1 \\
1\end{array}$ \\
\hline 3 & $\begin{array}{l}1.5 \\
1.5 \\
1.5 \\
1.5\end{array}$ & $\begin{array}{l}0.00 \\
0.10 \\
0.25 \\
0.50\end{array}$ & $\begin{array}{l}52 \\
52 \\
52 \\
52\end{array}$ & $\begin{array}{l}21.5 \\
18.8 \\
16.0 \\
12.3\end{array}$ & $\begin{array}{l}1.6 \\
1.6 \\
1.6 \\
1.6\end{array}$ & $\begin{array}{l}15 \\
15 \\
15 \\
15\end{array}$ & $\begin{array}{l}1 \\
1 \\
1 \\
1\end{array}$ \\
\hline 4 & $\begin{array}{l}1.5 \\
1.5 \\
1.5 \\
1.5\end{array}$ & $\begin{array}{l}0.25 \\
0.25 \\
0.25 \\
0.25\end{array}$ & $\begin{array}{l}13 \\
38 \\
66 \\
93\end{array}$ & $\begin{array}{c}7.1 \\
13.7 \\
20.3 \\
32.2\end{array}$ & $\begin{array}{l}1.3 \\
1.5 \\
1.6 \\
1.7\end{array}$ & $\begin{array}{l}10 \\
10 \\
30 \\
50\end{array}$ & $\begin{array}{l}1 \\
1 \\
1 \\
1\end{array}$ \\
\hline 5 & 1.5 & 0.25 & 93 & 32.2 & 1.7 & 50 & 1 to 3 \\
\hline
\end{tabular}

"Note: Loadings are expressed on a dry weight basis. 


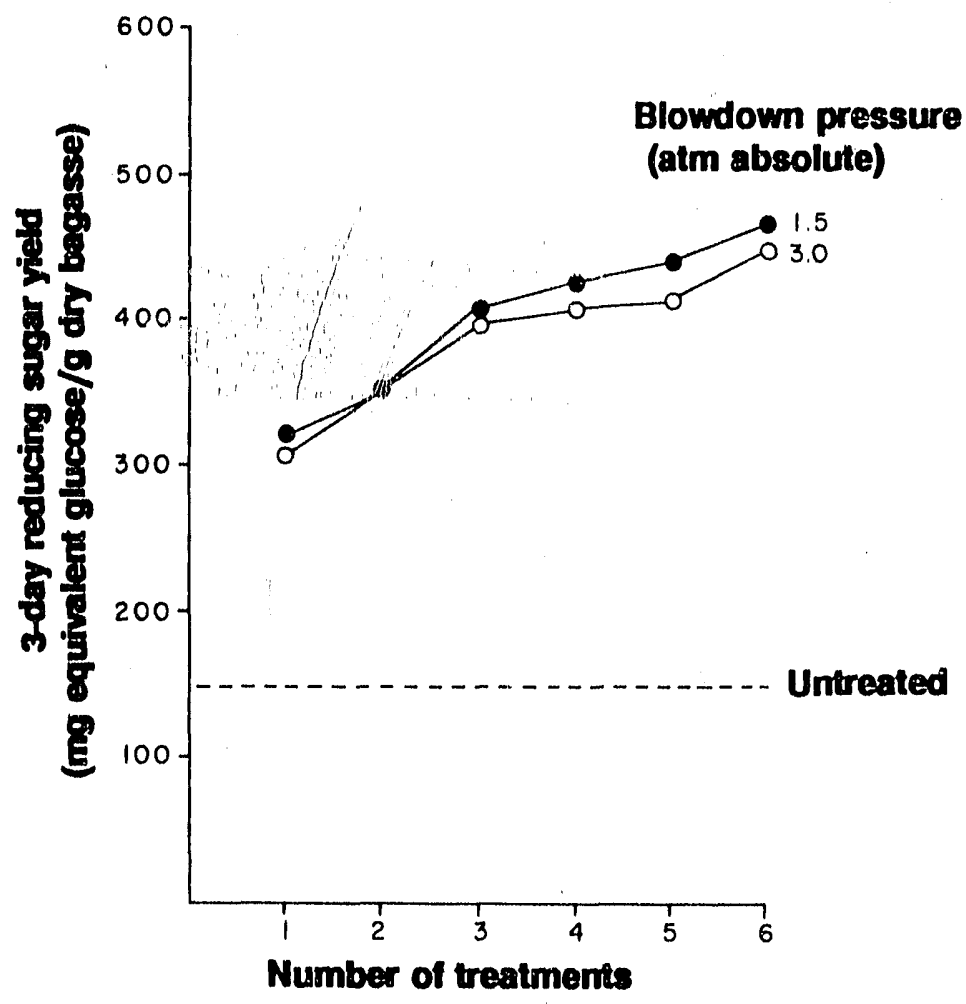

Figure 3. Bagasse Experiment 1: Sugar ylelds from multiple AFEX treatments using two different blowdown pressures (Louisiana bagasse)

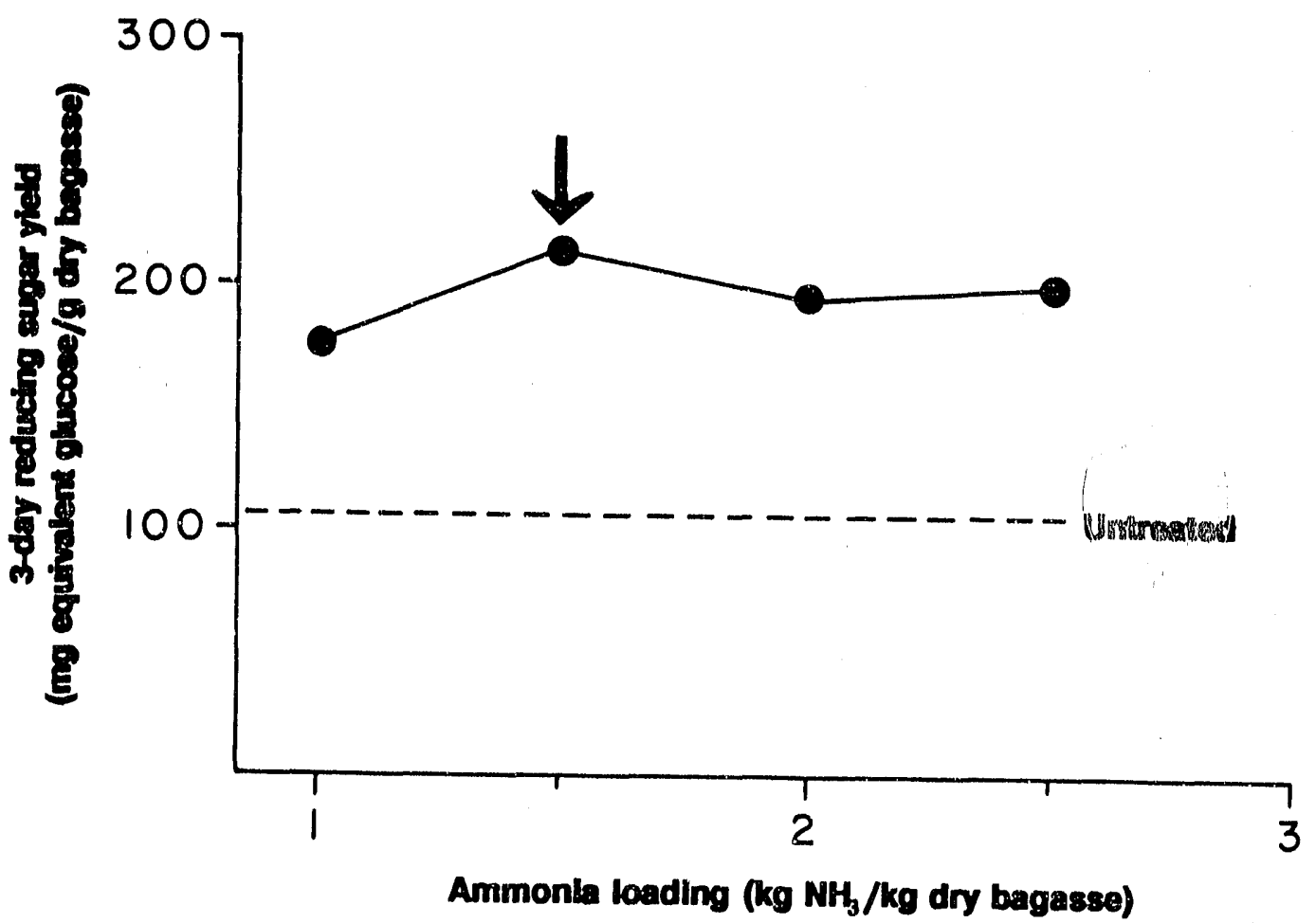

Flgure 4. Bagasse Experlment 2: Effest of ammenla loading on eugar ylolds (South Toxas Lacasso) 


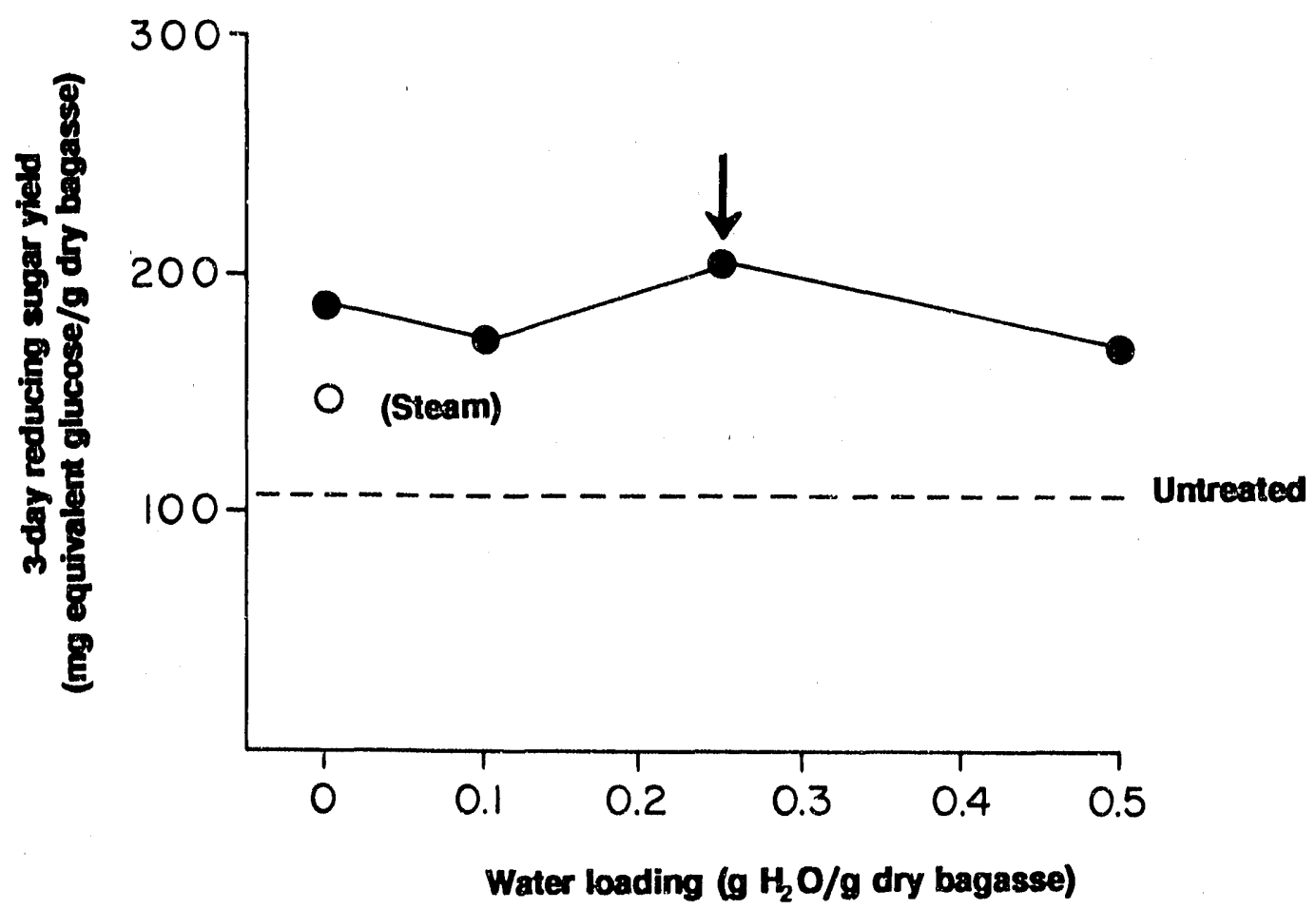

Figure 5. Bagasse Experiment 3: Effect of water loading on sugar ylelds (South Texas bagasse)

Reactor temperature is an important variable. At higher reactor temperatures, more ammonia vapors flash, causing greater disruption of the fibrous structure. Also, chemical reactions such as alkaline hydrolysis of hemicellulose will be accelerated at higher temperatures. Figure 6 shows the dramatic effect of increasing temperature. The sugar yields from a $93^{\circ} \mathrm{C}$ treatment were 3.5 times greater than those from a $13^{\circ} \mathrm{C}$ treatment. Therefore, a $93^{\circ} \mathrm{C}$ treatment temperature was used in subsequent experiments. Further temperature increases above $93^{\circ} \mathrm{C}$ may be beneficial, although this must be demonstrated.

Multiple AFEX treatments markedly increase enzymatic reactivity. Figure 7 shows the effect of using up to three treatments of bagasse. The first treatment increased the sugar yields by about 4.5 times compared to the control, the second treatment increased yields about 6 times, and the third treatment increased yields by almost 7 times. With three treatments, the sugar yield was $680 \mathrm{mg}$ sugar/g dry bagasse, which represents over $90 \%$ conversion of the cellulose and hemicellulose.

\section{Conclusions}

Nearly quantitative sugar yields have been produced from bagasse. Although this level of conversion has been demonstrated in previous AFEX studies (Dale and Moreira 1982; Dale et al. 1985), the cellulase loadings employed here were substantially less (5 IU/g versus $80 \mathrm{IU} / \mathrm{g}$ ). We believe that the cellulase loadings employed in this study are economically viable even if cellulase is not recycled.

Bagasse was difficult to treat because it has a fairly high lignin contcnt (about 20\%). Howeverer, miultiple treatments using high temperatures allowed nearly theoretical yields of sugars to be produced. Ammonia 


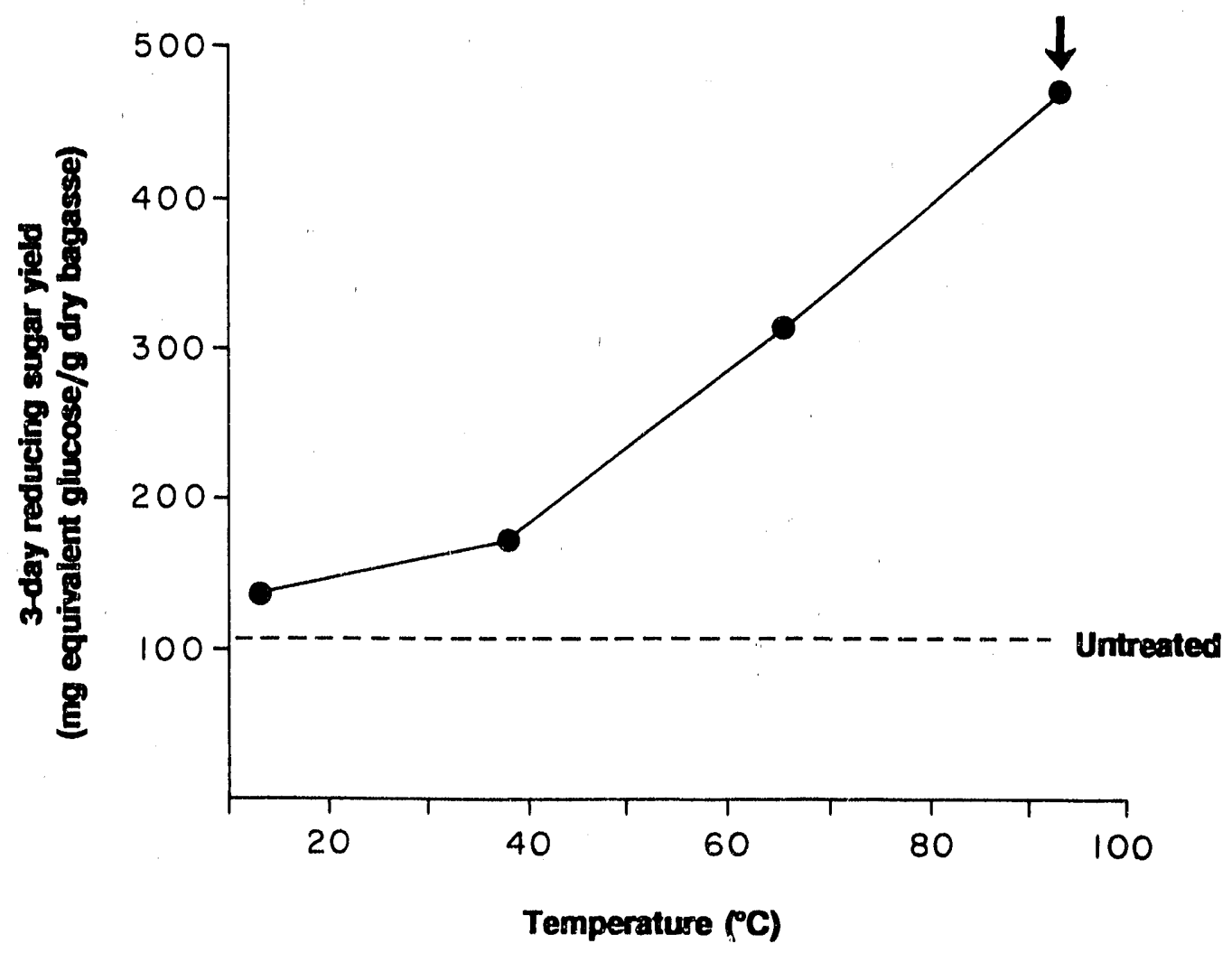

Figure 6. Bagasse Experiment 4: Effect of temperature on sugar yields (South Texas bagasse)

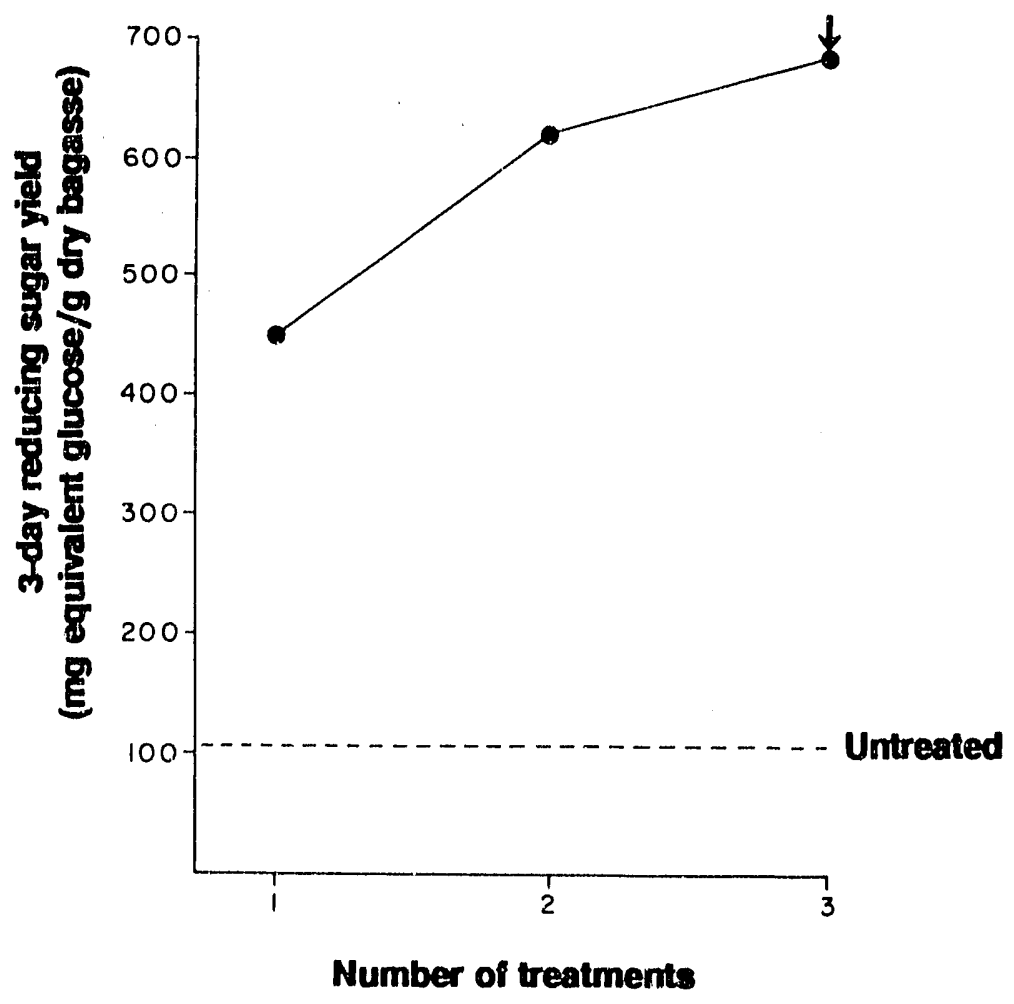

Figure 7. Bagasse Experiment 5: Effect of multiple treatments on sugar ylelds (South Texas bagasse) 
and water loading had relatively minor effects on the reactivity of biomass while temperature and number of treatments had the greatest effect. Previous studies with AFEX always used a 1-atm blowdown pressure (Dale and Moreira 1982; Dale et al. 1985). Here, we showed that excellent treatment results from blowdown pressures up to $3 \mathrm{~atm}$. The ability to use a higher blowdown pressure results in a tremendous energy saving compared to 1-atm blowdowns.

\section{Acknowledgment}

Support for this work was provided by the Solar Energy Research Institute and the Center for Energy and Mineral Resources, Texas A\&M University.

\section{References}

Brownell, H.H., Yu, E.K.C., and Saddler, J.N. 1986. Biotechnol. Bioeng. 28:792-801.

Dale, B.E. and Moreira, M.J. 1982. Biotechnol. Bioeng. Symp. No. 12, 31-43.

Dale, B.E., Henk, L.L., and Shiang M. 1985. Devel. Indust. Micro, 26:223-233.

Dale, B.E. 1985. Annual Reports on Fermentation Processes, Vol. 8, 299-323. New York: Academic Press.

Mandels, M., Andreotti, R., and Roche, C. 1976. Biotechnol. Bioeng. Symp. No. 6, 21-33.

Mes-Hartree, M., Dale B.E., and Craig, W.K. 1988. Appl. Microbiol. Biotechnol. 29:462-468.

Miller, G.L. 1959. Anal. Chem. 31:426-428.

Holtzapple, M.T., Jun, J.-H., Ashok, G., Patibandla, S.L., and Dale, B.E. 1990a. Accepted in Appl. Biochem. Biotechnol.

Holtzapple, M.T., Ripley, E.P., Figueroa, J.G., and Dale, B.E. 1990b. Submitted to Biotechnol. Bioeng. Zaborsky, O.R., McClure, T.A., and Lipinsky, E.S. 1981. CRC Handbook of Blosolar Resources Vol. II, 31. Boca Raton, FL: CRC Press. 


\title{
Pretreatment of Aspen Wood Almed at High Hemicellulose Retention
}

\author{
M. M. Shah and Y. Y. Lee \\ Department of Chemical Engineering \\ Auburn University, Alabama 36849 \\ and \\ R. Torget \\ Biotechnology Research Branch \\ Fuels and Chemicals \\ Research and Engineering Division \\ Solar Energy Research Institute \\ Golden, Colorado 80401
}

\begin{abstract}
Moncethanolamine (MEA) and supercritical $\mathrm{CO}_{2}-\mathrm{SO}_{2}$ were used as pretreatment reagents for aspen wood to enhance the susceptibility in enzymatic hydrolysis by cellulase enzyme. These pretreatment methods were investigated for their effectiveness in enhancing enzymatic hydrolysis as well as retaining the hemicellulose fraction. After pretreatment with MEA, 76\%-93\% of original xylan in aspen was retained. In supercritical $\mathrm{CO}_{2}-\mathrm{SO}_{2}$ pretreatment, xylan retention varied widely between $32 \%$ to $91 \%$, depending on time and temperature of the rear on. Glucomannan and arabinogalactan were solubilized in water, lowering the yield of carbohydrat , in the insoluble residue. For both pretrzatments conducted at optimum conditions, an overall carbohydrate yield of $83 \%$ could be achieved after enzymatic hydrolysis. Treatment with $50 \%$ MEA removed $91 \%$ of the original lignin, while supercritical $\mathrm{CO}_{2}-\mathrm{SO}_{2}$ applied at $130^{\circ} \mathrm{C}$ for $4 \mathrm{~h}$ removed only $61 \%$.

The effect of enzyme loading on the hydrolysis rates of $\alpha$-cellulose and MEA-pretreated substrate was studied. For $\alpha$-cellulose, the rate of hydrolysis increased only up to enzyme loading of 113 international filter paper units (IFPU) cellulase/g cellulose. With MEA-pretreated substrate, however, the hydrolysis rate: increased with enzyme loading up to $226 \mathrm{IFPU} / \mathrm{g}$ substrate. The hydrolysis rates were higher for the pretreated aspen than those for $\alpha$-cellulose at similar enzyme loadings. The pretreated aspen was found to be suitable for further conversion into acetone and butanol under the SSF scheme by using Clostridium acetobutylicum and cellulase.
\end{abstract}




\section{Introduction}

Pretreatment is a necessary operation in the biological conversion of cellulosic substrates. Hemicellulose accounts for about $35 \%$ of the total carbohydrates in hardwood. Its recovery as a suitable fermentation substrate is essential in an overall bioconversion scheme. Because hemicellulose is associated with lignin, pretreatment intended to remove lignin usually induces separation of a hemicellulose fraction into a watersoluble form. The liquid residue coming off the pretreatment process also contains extraneous materials, so hemicellulose may lose its value as fermentation substrate.

Most chemical pretreatments are carried out to make the cellulosic portion accessible to the cellulase enzyme. These pretreatments remove lignin and/or hemicellulose from the wood and open up the rigid structure of the wood. Organosolv pretreatment, for example, removes lignin as well as hemicellulose (Holtzapple and Humphrey 1984), whereas steam explosion with sulfur dioxide addition (Clark and Mackie 1987) and dilute acid pretreatment (Grohmann' et al. 1985) hydrolyze primarily the hemicellulose content. Low-temperature alkali extraction was proven to effectively separate most of the hemicellulose from wheat straw (Cunningham et al. 1986).

Unconventional pretreatment methods were also investigated by various researchers. Treatment of various hardwoods with supercritical ammonia rendered $70 \%-80 \%$ conversion of hemicellulose to monomeric sugars by cellulase enzyme (Chou 1986). Supercritical carbon dioxide removed extractives from the wood (McDonald et al. 1983). A supercritical carbon dioxide-sulfur dioxide mixture was used to delignify softwood (Tillman and Lee 1990). Explosive decompression of lignocellulosic residues with high-pressure carbon dioxide removed and solubilized most of the hemicellulose (Puri and Mamers 1983). Monoethanolamine (MEA) is well known as a delignification reagent (Wise et al. 1939; Nelson and Lening 1957).

In this study, pretreatments of aspen wood with a supercritical carbon dioxide-sulfur dioxide mixture and MEA were investigated for their efficiencies in retaining a hemicellulose fraction in solid residue and in increasing the susceptibility of cellulosics to enzyme action. The pretreated substrates were further tested for their fermentability by converting them into acetone and butanol under a simultaneous saccharification and fermentation (SSF) scheme using Clostridium acetobutylicum and cellulase enzyme.

\section{Materials and Methods}

\section{Substrates and Enzyme}

Aspen chips were obtained from the Solar Energy Research Institute, Golden, Colo. Chips with nominal size of 0.066-0.25 in. were used. Cellulase enzyme (Genencor, $85 \mathrm{IFPU} / \mathrm{mL}$ ) was also provided by SERI. $\alpha$-celiulose was obtained from Sigma Chemical Company.

\section{MEA Pretreatment}

Aspen chips were soaked in aqueous solution of MEA for $24 \mathrm{~h}$. The concentration of MEA ranged from $5 \%-50 \%(\mathrm{v} / \mathrm{v})$. MEA solution was filtered and wet chips (liquid/solid ratio of 2.5 ) were charged into an autoclave (Parr Instruments). Pretreatment reaction was carried out at $186^{\circ} \mathrm{C}$ for $3 \mathrm{~h}$ under 200 psig nitrogen. Chips removed from the reactor were soaked in $2 \% \mathrm{NaOH}$ solution for $24 \mathrm{~h}$ to extract lignin. Several water washes were given until the filtrate was colorless. 


\section{Supercritlcal $\mathrm{CO}_{2}-\mathrm{SO}_{2}$ Pretreatment}

Aspen chips were presoaked in $2 \% \mathrm{NaOH}$ solution for $24 \mathrm{~h}$. Solution was filtered and chips were charged to Parr autoclave. The reactor was charged with $\mathrm{CO}_{2} / \mathrm{SO}_{2}$ (with molar composition of $98 \% / 2 \%$ ) mixture. Temperature was varied from $120^{\circ}$ to $150^{\circ} \mathrm{C}$, and pressure was kept at or near $2000 \mathrm{psig}$. Reaction time was varied from 2 to $4 \mathrm{~h}$. Treated chips were washed with water until the filtrate became colorless.

\section{Enzymatic Hydrolysis}

Cellulosic substrates were added to serum bottles containing $35 \mathrm{~mL}, 0.01 \mathrm{M}$ of citrate buffer $(4.5 \mathrm{pH})$ to the level of $1.5 \%$ to $2 \%(\mathrm{w} / \mathrm{v})$. Bottles were sealed and autoclaved at $121^{\circ} \mathrm{C}$ for $15 \mathrm{~min}$. Cellulase was added to start hydrolysis, which was carried out in a constant temperature shaker bath $\left(120 \mathrm{rpm}, 50^{\circ} \mathrm{C}\right)$.

\section{Sulfurlc Acld Hydrolysis}

Sulfuric acid was added to a sample of liquid residue to the level of $5 \%(\mathrm{v} / \mathrm{v})$. The hydrolysis was carried out at $120^{\circ} \mathrm{C}$ for $1 \mathrm{~h}$. The samples were neutralized and then analyzed on high-performance liquid chromatography (HPLC).

\section{Analytical Methods}

Sugars were analyzed by HPLC using a column packed with Bio-Rad, Aminex Q15S resin. Fermentation products were analyzed by a gas chromatograph (Varian Model 3700) equipped with chromosorb 101 column. Lignin content of pretreated chips was estimated by the TAPPI standard method T236 os-76.

\section{Results and Discussion}

Carbohydrate yields were calculated on the basis of reported aspen composition (Chum et al. 1988). Glucose and xylose yields are expressed as a percentage of glucose and xylose, respectively, in original aspen unless noted otherwise.

\section{Effect of Pretreatments on Hemlcellulose Retention}

The carbohydrate yields and lignin removal data for MEA pretreatment are summarized in Table 1. Similar data for supercritical $\mathrm{CO}_{2}-\mathrm{SO}_{2}$ are given in Table 2.

\section{MEA Pretreatment}

The loss of xylan was low with MEA pretreatment, with only $6 \%$ to $8 \%$ of xylan being lost in liquid residue (see Table 1). The recovery of the remainder of xylan from solid residue by enzymatic hydrolysis 
Table 1. Carbohydrate Yield and LIgnin Removal for MEA.Pretreated Hardwood

\begin{tabular}{|c|c|c|c|c|c|}
\hline \multirow[b]{2}{*}{$\begin{array}{c}\text { MEA } \\
\text { Concentration } \\
(\% \vee / v)\end{array}$} & \multirow[b]{2}{*}{$\begin{array}{c}\text { Lignin } \\
\text { Removed } \\
(\%)^{\mathrm{a}}\end{array}$} & \multicolumn{3}{|c|}{ Solld Residue } & \multirow{2}{*}{$\begin{array}{c}\begin{array}{c}\text { Liquild } \\
\text { Resldue }\end{array} \\
\begin{array}{c}\text { Xylose } \\
\text { Yleld } \\
(\%)\end{array}\end{array}$} \\
\hline & & $\begin{array}{c}\text { Glucose } \\
\text { Yleld } \\
(\%)\end{array}$ & $\begin{array}{l}\text { Xylose } \\
\text { Yleld } \\
(\%)\end{array}$ & $\begin{array}{c}\text { Total } \\
\text { Carbohydrates } \\
(\%)^{b}\end{array}$ & \\
\hline $\begin{array}{c}5 \\
10 \\
20 \\
30 \\
40 \\
50\end{array}$ & $\begin{array}{l}49.8 \\
61.5 \\
76.5 \\
79.6 \\
87.9 \\
91.2\end{array}$ & $\begin{array}{l}90.7 \\
92.4 \\
88.9 \\
89.9 \\
90.5 \\
86.3\end{array}$ & $\begin{array}{l}76.6 \\
83.7 \\
84.8 \\
84.2 \\
88.0 \\
92.9\end{array}$ & $\begin{array}{l}82.3 \\
85.3 \\
83.2 \\
83.8 \\
85.2 \\
83.6\end{array}$ & $\begin{array}{l}9.8 \\
6.7 \\
6.6 \\
6.7 \\
7.8 \\
7.6\end{array}$ \\
\hline
\end{tabular}

${ }^{a}$ Based on initial lignin content in aspen

based on inltial total carbohydrate content in aspen

Table 2. Carbohydrate Yleld and LIgnIn Removal for Supercritical $\mathrm{CO}_{2}-\mathrm{SO}_{2}-$ Pretreated Hardwood

\begin{tabular}{|c|c|c|c|c|c|c|}
\hline \multirow[b]{2}{*}{$\begin{array}{l}\text { Temp. } \\
\left({ }^{\circ} \mathrm{C}\right)\end{array}$} & \multirow[b]{2}{*}{$\begin{array}{l}\text { Time } \\
\text { (h) }\end{array}$} & \multirow[b]{2}{*}{$\begin{array}{l}\text { Lignin } \\
\text { Removed } \\
(\%)^{\mathrm{a}}\end{array}$} & \multicolumn{3}{|c|}{ Solld Residue } & \multirow{2}{*}{$\begin{array}{l}\begin{array}{l}\text { Liquid } \\
\text { Residue }\end{array} \\
\\
\begin{array}{c}\text { Xylose } \\
\text { Yield } \\
(\%)\end{array}\end{array}$} \\
\hline & & & $\begin{array}{c}\text { Glucose } \\
\text { Yield } \\
(\%)\end{array}$ & $\begin{array}{c}\text { Xylos } \theta \\
\text { Yield } \\
(\%)\end{array}$ & $\begin{array}{c}\text { Total } \\
\text { Carbo- } \\
\text { hydrates } \\
(\%)^{b}\end{array}$ & \\
\hline 120 & 3 & 32.0 & 77.7 & 71.7 & 71.2 & 15.8 \\
\hline 120 & 4 & 44.4 & 80.9 & 79.3 & 75.2 & 20.9 \\
\hline 130 & 2 & 38.6 & 77.1 & 91.3 & 75.8 & 8.5 \\
\hline 130 & 3 & 54.3 & 90.1 & 70.1 & 79.0 & 24.2 \\
\hline 130 & 4 & 60.8 & 93.1 & 77.7 & 83.0 & 20.3 \\
\hline 140 & 2 & 56.9 & 83.1 & 60.9 & 71.8 & 30.2 \\
\hline 140 & 3 & 74.2 & 87.1 & 67.4 & 76.3 & 32.3 \\
\hline 140 & 4 & 84.0 & 91.9 & 63.0 & 78.3 & 29.1 \\
\hline 150 & 2 & 72.1 & 83.9 & 64.7 & 73.4 & 34.0 \\
\hline 150 & 3 & 77.2 & 87.2 & 46.7 & 70.8 & 48.9 \\
\hline 150 & 4 & 54.2 & 91.6 & 32.0 & 70.0 & 53.8 \\
\hline
\end{tabular}

a Based on initial lignin content in aspen

based on initial total carbohydrate content in aspen 
varled considerably depending on the MEA concentration employed in the pretreatment. Using 5\% MEA, $76 \%$ of original xylan was hydrolyzed and recovered. With $50 \%$ MEA treatment, the xylose yleld was increased to $93 \%$. The increase in the MEA concentration also enhanced delignification of aspen (see Table 1). The degree of delignification was a good index for efiectiveness of pretreatment; high delignification gave a high level of xylose yield upon enzymatic hydrolysis. One favorable aspect of this method was that the action of MEA selectively removed lignin, thus keeping the hemicellulose relatively intact. For this reason, a carbohydrate yleld as high as $85 \%$ was attainable. However, arabinose, mannose, and galactose, which are minor constituents in hemicellulose, could not be detected in analysis of the pretreated solid substrates. This indicates that arabinogalactan and glucomannan were solubilized during the pretreatment process. These three sugars account for $6 \%$ to $7 \%$ of total carbohydrates (Chum et al. 1988).

\section{Supercritical $\mathrm{CO}_{2}-\mathrm{SO}_{2}$ Pretreatment}

The xylan retention in solids varied widely from $32 \%$ to $91 \%$ depending on the pretreatment conditions (see Table 2). At $120^{\circ} \mathrm{C}$ for $3 \mathrm{~h}$, the conditions were mild enough to retain most of the xylan. As a pretreatment, however, it was not effective to promote enzymatic hydrolysis as much of the lignin was still retained in the solids. At $130^{\circ} \mathrm{C}$ and $2 \mathrm{~h}, 91 \%$ xylan was hydrolyzed, but cellulose hydrolysis was incomplete. High temperature and reaction time enhanced lignin removal, thereby increasing accessibility of the substrate to the cellulase enzyme. However, these conditions were also severe enough to hydrolyze xylan into monomeric sugars. The optimum condition therefore exists with respect to minimum xylan loss and the effectiveness of pretreatment for enzymatic hydrolysis. The optimum pretreatment condition is believed to be near $130^{\circ} \mathrm{C}$ for $4 \mathrm{~h}$. At this point a xylan yield of $78 \%$ and an overall carbohydrate yield of $83 \%$ were obtained (see Table 2). These results collectively indicate that treatment with supercritical $\mathrm{CO}_{2}-\mathrm{SO}_{2}$ is not as selective to lignin removal as is the MEA treatment. This pretreatment also solubilized arabinogalactan and glucomannan, thus lowering the yleld of carbohydrates by $6 \%$ to $7 \%$.

\section{Effect of Pretreatments on Enzymatlc Hydrolysls}

The rates of enzymatic hydrolysis of the pretreated substrates were experimentally studied to judge the effectiveness of various treatments. The enzyme loading of 226 IFPU/g substrate was employed in all the experiments.

\section{MEA Pretreatment}

Formation of glucose (as hexosan) and xylose (as pentosan) during enzymatic hydrolysis for the substrates pretreated with MEA is shown in Figure 1. The rate of hydrolysis increased with MEA level employed in the pretreatment up to $20 \%$ concentration. The difference between the rates at $20 \%$ and $50 \%$ MEA was rather insignificant. The terminal glucose yield after enzymatic hydrolysis varied between $86 \%$ and $92 \%$ for various levels of MEA pretreatmerit. This indicated that the cellulose fraction is made almost completely accessible to the enzyme by $20 \%$ MEA pretreatment. However, terminal xylose yield increased with MEA concentration. This increase was accompanied by an increase in lignin removal. It seems that a high degree of lignin removal is necessary for complete hydrolysis of xylan. 


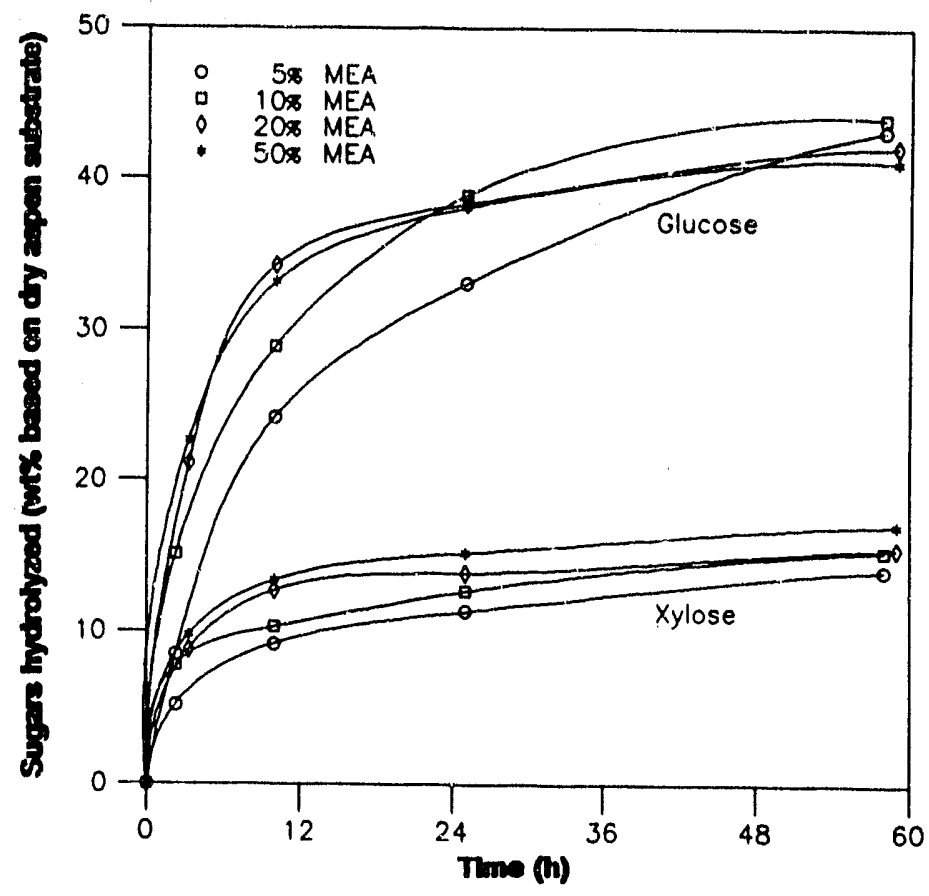

Flgure 1. Enzymatic hydrolysis of MEA-pretreated aspen

\section{Supercritical $\mathrm{CO}_{2}-\mathrm{SO}_{2}$ Protreatment}

The time course for enzymatic hydrolysis of glucan and xylan is presented in Figure 2. High pretreatment temperature enhanced delignification and loss of hemicellulose. The rate of enzymatic hydrolysis was also increased with temperature in pretreatment. For the treatments at $120^{\circ} \mathrm{C}$, the rate of hydrolysis was slow and incomplete. For the treatments at $150^{\circ} \mathrm{C}$, carbohydrates in the substrate were completely hydrolyzed. At this temperature, however, more than $30 \%$ of the xylan was hydrolyzed during the pretreatment itself. Therefore, xylose yield in the subsequent enzymatic hydrolysis of the solid residue was low (see Table 2). Thus in this method, it is important to keep the pretreatment condition near optimum, as discussed earlier, to achieve high carbohydrate yields and reasonable rates of hydrolysis.

\section{Effect of Enzyme Loading on Hydrolysis Rates}

Hydrolysis curves for aspen pretreated with 50\% MEA and $\alpha$-cellulose at various enzyme loadings are shown in Figures 3 and 4, respectively. In the case of aspen substrate, glucose and xylose yields were expressed as the weight percentage of glucose and xylose present in pretreated substrates. The rate of hydrolysis for pretreated substrate was much higher than the rate for $\alpha$-cellulose. The crystalline nature of $\alpha$-cellulose makes it a poor substrate for enzymatic hydrolysis. For $\alpha$-cellulose, the rate of hydrolysis increased with enzyme loading up to $113 \mathrm{IFPU} / \mathrm{g}$ substrate. This indicates that above a certain enzyme loading, the hydrolysis rate is limited only by the available surface area. For pretreated aspen, the rate kept increasing with increases in enzyme concentration up to $226 \mathrm{IFPU} / \mathrm{g}$ substrate. It implies 


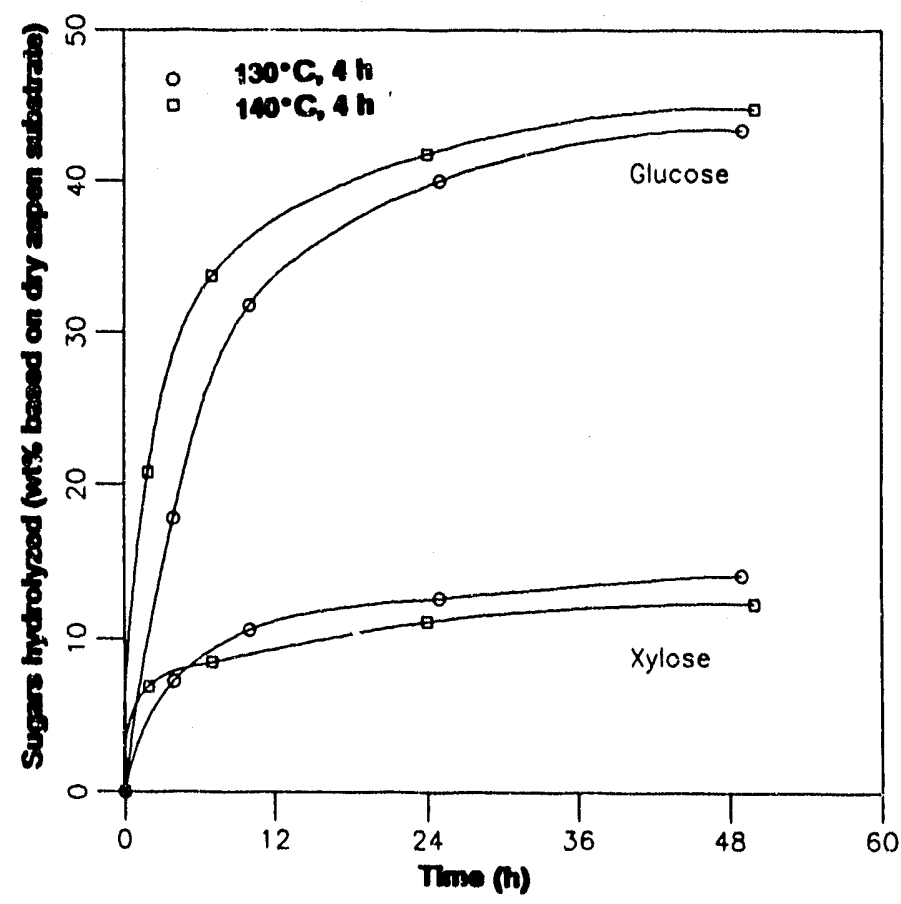

Flguro 2. Enzymatic hydrolysls of supercritlcal $\mathrm{CO}_{2}-\mathrm{SO}_{2}-$ protreated aspen

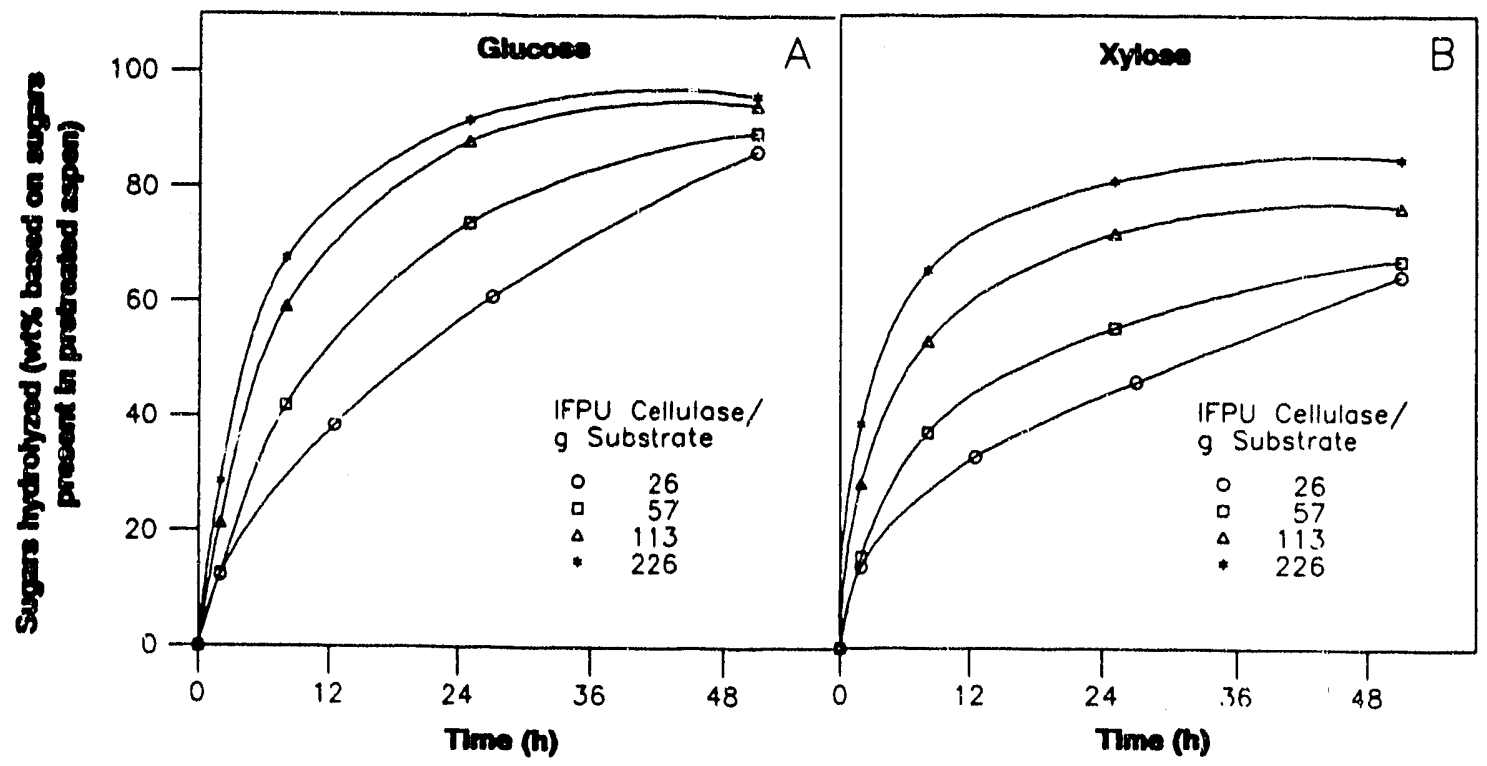

Figure 3. Effect of enzyme loading on hydrolysis rates for MEA-pretreated aspen 


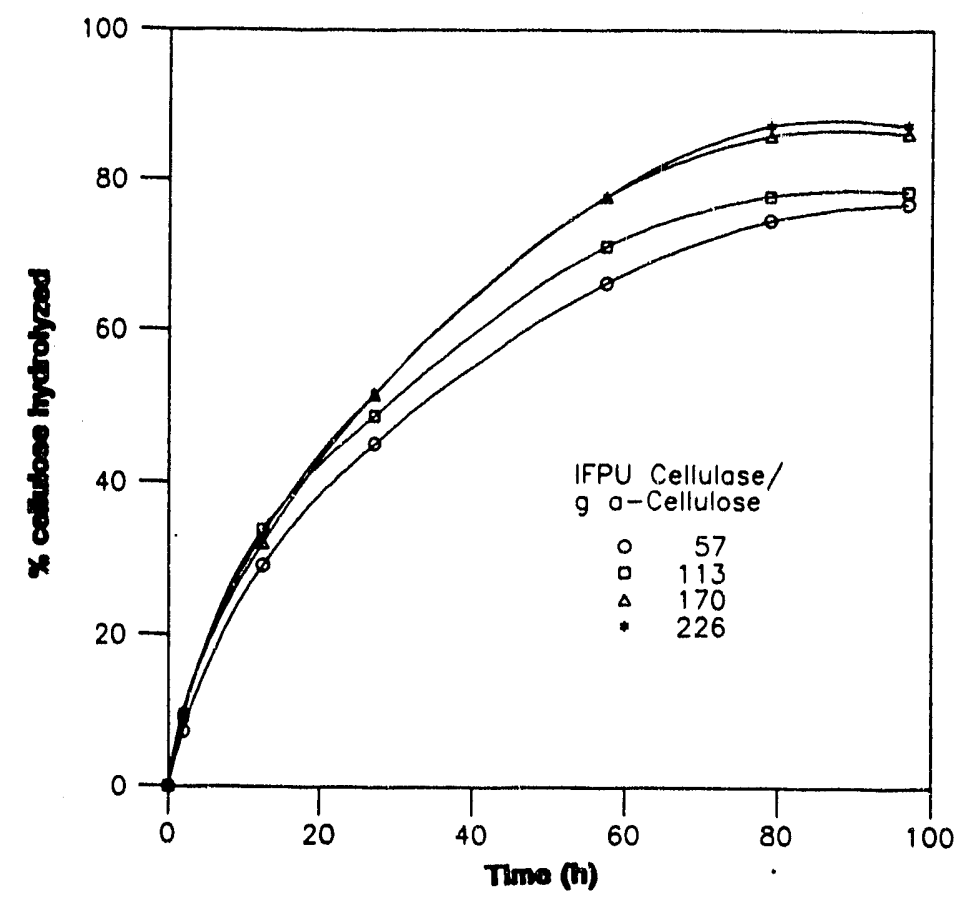

Flgure 4. Effect of enzyme loading on hydrolysls rates for $\alpha$-cellulose

that surface area of pretreated substrate is much higher than that of pure cellulose on weight basis. At an enzyme loading of 226 IFPU/g, a glucose yield of $96 \%$ and a xylose yield of $85 \%$ were obtained from MEA-pretreated substrate in $51 \mathrm{~h}$. At a similar enzyme loading, an $88 \%$ glucose yield was ottained from $\alpha$-cellulose in $97 \mathrm{~h}$.

\section{SSF of Pretreated Aspen}

Pretreated aspen was further examined as a substrate in SSF under a realistic process condition. The substrates produced from both the pretreatments were effectively converted to acetone and butanol by using $C$. acetobutylicum and cellulase enzyme. Solvent yield ranged from $22-24 \mathrm{~g} / 100 \mathrm{~g}$ substrate used (Shah et al. 1990). This result has proven that $\mathrm{MEA}$ and supercritical $\mathrm{CO}_{2}-\mathrm{SO}_{2}$ pretreatment each produced substrate usable as a direct SSF feed.

\section{Conclusions}

MEA and supercritical $\mathrm{CO}_{2}-\mathrm{SO}_{2}$ treatments were effective in retaining a major fraction of hemicellulose intact in the solids. The xylose yield upon enzymatic hydrolysis was affected by the presence of lignin. An increase in the degree of delignification resulte in improved glucose and xylose recovery upon enzymatic hydrolysis. MEA could remove lignin without affecting hemicellulose retention in the solids. In the supercritical $\mathrm{CO}_{2}-\mathrm{S}_{2}$ method, increased delignification was accompanied by an increased loss of xylan. An overall carbohycirate yield of $83 \%$ could be attained in both the pretreatments. However, losses 
of arabinogalactan and glucomannan were inevitable in either method. An increase in the separation of lignin also improved the rate of enzyme hydrolysis; thus, the degree of delignification is a good index for the effectiveness of pretreatment.

\section{References}

Chou, Y. C. T. 1986. Biotechnol. Bioeng. Symp. 17:19-32.

Chum, H. L., Johnson, D. K., Black, S., Baker, J., Grohmann, K., Sarkanen, K. V., Wallace, K., and Schroeder, H. A. 1988. Biotechnol. Bioeng. 31:643-649.

Clark, T. A., and Mackie, K. L. 1987. J. Wood Chem. Technol. 7(3):373-403.

Cunningham, R. L., Carr, M. E., and Bagby, M. O. 1986. Biotechnol. Bioeng. Symp. 17:159-168.

Grohmann, K., Torget, R., and Himmel, M. 1985. Biotechnol. Bioeng. Symp. 15:59-80.

Holtzapple, M. T., and Humphrey, A. E. 1984. Biotechnol. Bioeng, 26:670-676.

McDonald, E. C., Howard, J., and Bennett, B. 1983. Fluid Phase Equili. 10:337-44.

Neison, G. E., and Lening, J. A. 1957. TAPPI 40:846-48.

Puri, V. P., and Mamers, H. 1983. Biotechnol. Bioeng. 25:3149-61.

Shah, M. M., Song, S. K., Lee, Y. Y., and Torget, R. 1990. Appl. Biochem. Biotechnol. in press.

Tillman, L. M., and Lee, Y. Y. 1990. TAPPI in press.

Wise, L. E., Peterson, F. C., and Harlow, W. M. 1939. Ind. Eng. Chem. Anal. Ed. 11:18-19. 


\title{
Blomass Pretreatment - NMR Studies
}

\author{
H. A. Schroeder and R. Rodriquez \\ Department of Forest and Wood Sciences \\ Colorado State University \\ Ft. Collins, Colorado 80523 \\ L. L. Henk and V. G. Murphy \\ Department of Agricultural and Chemical Engineering \\ Colorado State University \\ Ft. Collins, Colorado 80523
}

\begin{abstract}
Peracetic acid is a selective delignifying agent that when used in small amounts under very mild conditions results in increased accessibility of biomass toward cellulases and other hydrolytic enzymes. There is some evidence that peracetic acid may mimic brown rotters by modifying lignin through its selective oxidative reactions. When the three biomass materials, ponderosa pine, quaking aspen, and wheat straw are treated with peracetic acid, the effect does not correlate very well with the subsequent enzymatic hydrolysis. The ponderosa pine lignin seems the most modified and the wheat straw lignin the least, with aspen occupying an intermediate position. However, when comparing enzymatic hydrolysis, the aspen has the most improved accessibility, with wheat straw also improving significantly, and ponderosa showing only slightly increased accessibility for the enzymes. Wood has been decayed using the brown rotter, Poria monticola, and modifications of the lignin resulting from the peracetic pretreatment are being compared with the lignin resulting from brown rot decay. This work is still in progress.
\end{abstract}

\section{Introduction}

Lignccellulosic material varies considerably in its accessibility to enzymes, especially cellulases and related hydrolytic enzymes. The carbohydrate fraction within the cell wall of woody biomass is particularly inaccessible to enzymes. The carbohydrates in softwoods are essentially completely uravailable while those in hardwoods vary from no accessibility to about $15 \%$ accessible, with the exception of the genus Populus where the carbohydrates are more accessible.

Effective enzymatic hydrolysis of the cell wall carbohydrates in woody biomass requires a pretreatment of the material. There are numerous pretreatments that will accomplish the task to varying degrees of effectiveness, depending somewhat on the extent to which the treatment is allowed to proceed. These pretreatments may be divided, depending on their primary mode of action, into either physical or chemical, although in some cases there is apparently considerable overlap. 
There are numerous processes that are oxidative and that increase enzyme accessibility. Because lignin is the easily oxidizable constituent of the cell wall, it is the lignin that is being modified. Conversely, any oxidation of the carbohydrate portion, especially if substantial, could effect enzymatic hydrolysis or subsequent utilization of the hydrolysis product, the sugars. Within reasonable limits, the $\mathrm{pH}$ of the oxidizing medium does not seem to affect enzyme accessibility. Oxidizing agents have varied from alkaline peroxide and ozone to peracetic acid and nitric acid.

Peracetic acid seems especially well suited for studying the pretreatment of biomass for increasing enzymatic accessibility. In sufficient amount, peracetic acid will delignify wood, resulting in a holocellulose preparation. Modification of the residual cell wall carbohydrates is very slight, with oxidation of the reducing end groups of the polysaccharides and some small increase in the carbonyl content (Browning 1967).

Under pretreatment conditions, the biomass is subjected to very dilute solutions of peracetic acid at ambient temperatures for extended time periods. The treatment is such that there is virtually no delignification but the lignin has been modified through oxidation. In prior research, it has been shown that such a peracetic acid pretreatment will increase considerably ruminal fluid digestibility.

In nature, brown rotters degrade woody biomass by hydrolyzing the carbohydrate portion of the material and metabolizing the sugars so obtained. Because cellulases and related enzymes are utilized, the brown rot fungi must have their own built-in pretreatment to provide the needed accessibility. The brown rot fungi must modify the lignin component of the cell wall as is evidenced by the change in color of the lignin from an off-white to a reddish-brown color. The change in color is due to an increase in chromophobic groups resulting from oxidation. There is also a reduction in the methoxy content of the lignin and an increase in the free phenolic hydroxyl content. The increase in free phenolic hydroxyl is greater than that due to the methoxyl loss alone (Jin et al. 1990).

Peracetic acid in its action, at least to some extent, and perhaps to a considerable extent, seems to mimic metabolism of phenolic compounds. Peracetic acid will cause some loss of methoxy groups and an increase in phenolic hydroxyls greater than that due to the loss in methoxyl content. This increase in phenolic hydroxyls is to some extent due to direct substitution of hydroxyl onto the aromatic ring, and also due to some cleavage of the aliphatic side group from the aromatic ring where there is a carbinol or carbonyl functional group at the benzyl position. If there is a sufficient peracetic acid available, there is quinone formation and eventual formation of dicarboxylic acids with destruction of the aromatic ring (Chang and Allan 1971).

The objectives of this research are to treat select types of biomass with a minimal amount of peracetic acid to provide accessibility for cellulases and other related hydrolytic enzymes. Accessibility will be determined by the amount of sugars produced. The same biomass will be subjected to brown rot decay. The modification of lignin caused by thic brown rot will be compared to that resulting from the peracetic acid pretreatment.

\section{Materials and Methods}

Wheat straw, quaking aspen, and ponderosa pine were air dried, milled, and screened with the fraction 6080 mesh used for the pretreatment. Peracetic acid was prepared from acetic anhydride and $35 \%$ hydrogen peroxide and analyzed shortly before using. The biomass materials were treated with $8 \%$ peracetic acid (based on oven-dried material) in a wood-to-liquor ratio of $1: 6$ (actual solution concentration $1 \frac{1}{3} \%$ peracetic acid). Samples were taken from the pretreatment mixture for up to 60 days total elapsed time. The 
samples were washed with water until neutral and dried to an approximate moisture content of $40 \%$ at room temperature.

The biomass materials were analyzed using the Tappi Standard Methods (1989) before treatment with peracetic acid. Both Klason lignin and acid-soluble lignin was determined before and after treatment with peracetic acid. Weight loss as a result of the peracetic acid treatment was determined and compared with controls using only water for a similar length of time.

For the enzymatic hydrolysis, a mixture of commercial cellulases was used (Cellulcast and Nozyme) with various loadings in terms of international filter paper units (IFPU). The conditions used were: enzyme ratio of cellulase/cellobiase $(10: 1)$; solids-to-enzyme-mixture ratio $(1: 50)$; temperature of $50^{\circ} \mathrm{C}, \mathrm{pH}$ of solution 4.8 , shaker at $125 \mathrm{rpm}$ for 5 days.

Weight loss was determined after enzymatic hydrolysis, as was sugar liberated. Reducing sugars were estimated as glucose colorimetrically using dinitrosalicylic acid (DNSA) reagent (Miller 1959). A second procedure for analyzing sugars utilized high-performance liquid chromatograph using an Amimex HPX 87-P column (Bio-Rad, Richmond, Calif.).

The wheat straw, quaking aspen, and ponderosa pine were subjected to decay by the brown rot fungus, Poria monticola, for 6 months. After sterilization, feeder strips of wood were placed in shallow agar media in Petri dishes and inoculated with the fungus. After several days of fungal growth, the sterilized biomass materiais were added as thin wafers of wood, or in the case of wheat straw, cut stalks. After 6 months, the decayed material was removed from the Petri dish, the mycellium removed, and loss of weight because of decay determined.

Lignin was isolated from the original biomass materials, the peracetic acid treated materials, and the material subjected to decay by the brown rotter, Poria monticola. Two different procedures have been employed for the lignin isolation. The recently developed method (Funaoka and Abe 1989) was used for isolation of lignin from the original materials. The modified lignins could not be isolated by this method. These lignins were isolated by modifying the procedure used for obtaining lignins from material decayed by white-rot fungi (Kirk and Chang 1974). The modifications in method include Soxhlet extraction using a dioxane/water azeotrope $(81.6 / 18.4)$ containing $1 \%$ concentrated $\mathrm{HCl}$.

\section{Results and Discussion}

Three biomass materials were chosen for this study: ponderosa pine as a typical softwood, quaking aspen for the hardwood, and wheat straw as the agricultural residue. Aspen is not a typical hardwood, because of its ease of delignification, but it has been widely evaluated as a biomass raw material for conversion. Wheat straw is a member of the grass family, and by including it in the study, the three major types of woody biomass are represented.

Table 1 shows the analysis of the biomass material used in this study. The holocellulose values are all too high, but the other values are reasonable. The wheat straw lignin value was determined by methods applicable to wood and not by the usual permanganate oxidation procedure normally employed in analyzing agricultural biomass. Work is in progress determining the ash and nitrogen content of the wheat straw lignin.

Table 2 gives the results of the lignin analysis on the original nuterial, the $8 \%$ peracetic acid treated material, and control material. The controls were water soaked for the same length of time that the peracetic acid treatment lasted. The difference betiveen these two should indicate loss of lignin, or change 
Table 1. Analysis of the Original Blomass Materlals (values given in percent by weight)

\begin{tabular}{lccccc}
\hline \multicolumn{1}{c}{ Material } & $\begin{array}{c}\text { Extractive } \\
\text { Amount }^{\mathrm{a}}\end{array}$ & Holocellulose $^{\mathrm{b}}$ & Cellulose $^{\mathrm{c}}$ & $\begin{array}{c}\text { Total } \\
\text { Lignin }^{\mathrm{d}}\end{array}$ & Ash \\
\hline Ponderosa pine & 2.37 & 79.43 & 53.81 & 26.29 & 0.21 \\
Aspen & 2.97 & 85.85 & 51.51 & 23.05 & 0.29 \\
Wheat straw & 17.48 & 89.60 & 43.58 & $23.58^{\ominus}$ & 8.67 \\
\hline
\end{tabular}

${ }^{a} E$ thyl alcohol/benzene extraction plus hot water wash. Based on original dry weight. All other values on extractive-free weight

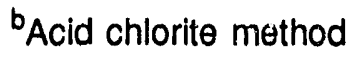

${ }^{c} \alpha$-Cellulose value

${ }^{d}$ Klason lignin plus acid-soluble lignin

${ }^{\theta}$ Wheat straw lignin not corrected for ash or protein content

Table 2. Llgnin Analysis and Changes In Llgnin Amount and Type due to Peracetlc Acld Treatment (values given in percent by weight)

\begin{tabular}{llll}
\hline \multicolumn{1}{c}{ Material } & Klason lignin & Acid soluble lignin & Total lignin \\
\cline { 3 - 4 } $\begin{array}{l}\text { Original (untreated) } \\
\text { ponderosa pine }\end{array}$ & 25.83 & & \\
$\begin{array}{l}\text { aspen } \\
\text { wheat straw }\end{array}$ & 18.17 & 0.46 & 26.29 \\
$\begin{array}{l}\text { Control (water soaked) } \\
\text { ponderosa pine }\end{array}$ & 19.94 & 3.64 & 23.05 \\
$\begin{array}{l}\text { aspen } \\
\text { wheat straw }\end{array}$ & $26.33(+0.50)^{\mathrm{a}}$ & $0.43(-0.03)$ & 23.58 \\
& $17.72(-0.45)$ & $3.96(-0.92)$ & $26.76(+0.47)$ \\
$\begin{array}{l}\text { Peracetic acid treated } \\
\text { ponderosa }\end{array}$ & $19.83(-0.11)$ & $1.25(-2.39)$ & $21.68(-1.37)$ \\
aspen & & & $21.08(-2.50)$ \\
wheat straw & $22.60(-3.73)^{\mathrm{b}}$ & $2.12(+1.69)$ & \\
& $16.09(-1.63)$ & $4.27(+0.31)$ & $24.72(-2.04)$ \\
& $16.46(-3.37)$ & $4.18(+2.93)$ & $20.36(-1.32)$ \\
& & & \\
\hline
\end{tabular}

${ }^{a}$ Values in parenthesis indicate change from untreated material

${ }^{b}$ Values in parenthesis indicate change from control material 
in lignin type (Klason and acid soluble) as a result of the peracetic acid treatment. Accuracy of the analysis is probably $\pm 0.5 \%$ for Klason lignin and $\pm 0.1 \%$ for acid-soluble lignin. The values indicate some small loss of acid-soluble lignin for aspen and wheat straw upon water soaking. This could also be an artifact caused by loss of other phenolic substances in the material. The change in values after peracetic acid treatment are interesting. The greatest change occurred in ponderosa pine with a $14 \%$ reduction in Klason lignin with both a significant increase in acid-soluble lignin and material lost. From ruminal fluid digestibility studies and from cellulose hydrolysis studies, it was assumed that this material was least affected by the pretreatment with peracetic acid. Aspen showed the least change in Klason lignin content resulting from the treatment and wheat straw showed the least total change.

F artially as a result of the lignin analysis, total weight loss for the three biomass materials during pretreatment was also determined using a water soak control. The results are given in Table 3. Ponderosa pine apparently lost appreciable water-soluble material as indicated by the control. It is very surprising that the difference between the control and the peracetic acid treatment loss is exactly the loss in total lignin resulting from the treatment. The aspen material indicates significant loss of nonlignin components during peracetic acid treatment. Comparing values from Tables 2 and 3, this amounts to $3.81 \%$. Although wheat straw had considerable loss of material during water soaking, there was no loss of material, including lignin, during the peracetic acid treatment. Only an increasing amount of lignin became acidsoluble ignin.

The weight loss caused by enzymatic hydrolysis is given in Table 4. Method A is the procedure used at SERI. The values obtained using Method A are low for both ponderosa pine and aspen when compared to ruminal fluid digestibility, with the exception of the ponderosa control. For ruminal fluid digestibility, untreated aspen has values around $25 \%$ weight loss; with $8 \%$ peracetic acid, pretreated aspen and ponderosa pine give weight losses of $67 \%$ and $28 \%$, respectively. The difference in values between cellulase hydrolysis and ruminal fluid digestibility may be due to possible lack of optimization of the cellulase hydrolysis procedure or due to the ruminal fluid having a much more complex enzyme mixture, including many nonhydrolytic enzymes. Method B was employed in order to observ : if greatly increasing the relative amount of enzyme compared to substrate would increase weight loss. Just the opposite occurred without exception in all samples. This may indicate absorption of the enzyme onto the substrate, thereby actually limiting accessibility.

Table 5 gives the effect of peracetic acid concentration during pretreatment in the glucose yield obtained during subsequent enzymatic hydrolysis. The values in Table 5 are all lower for the $8 \%$ peracetic acid pretreatment than the weight loss values given in Table 4, which is to be expected. The yield for 5\% peracetic acid pretreated wheat straw is obviously in error and should be rerun. Kinetic studies have also been performed on the rate of glucose release during enzymatic hy'drolysis, which shows that more than $75 \%$ of the sugar is released in the first $2 \mathrm{~h}$ of hydrolysis. Five days of enzymatic hydrolysis is .... ie than sufficient for total hydrolysis. Cellulose gave a glucose yield of $96 \%$, essentially indicating total hydrolysis.

The weight loss caused by fungal decay by the brown rotter, Poria monticola, is given in Table 6 . The weight loss of individual test samples is given to indicate the rather amazing reproducibility. As expected, ponderosa pine showed less of 2 weight loss than aspen, and wheat straw showed slightly more weight loss. 
Table 3. Welght Loss During Pretreatment (values given in percent by weight)

\begin{tabular}{lc}
\multicolumn{1}{c}{ Material } & Weight Loss \\
\hline Ponderosa pine & \\
control (water-soaked) & 4.70 \\
peracetic acld treated & 6.74 \\
difference & -2.04 \\
Aspen & \\
control (water-soaked) & 0.87 \\
peracetic acid treated & 6.00 \\
difference & -5.13 \\
Wheat straw & \\
control (water-soaked) & 10.79 \\
peracetic acid treated & 10.85 \\
difference & -0.06 \\
\hline
\end{tabular}

Table 4. Welght Loss of Material due to Enzymatlc Hydrolysis (values given in percent by weight)

\begin{tabular}{|c|c|c|c|}
\hline \multirow{2}{*}{\multicolumn{2}{|c|}{ Material }} & \multicolumn{2}{|c|}{ Weight Loss } \\
\hline & & Method A & Mothod B \\
\hline \multicolumn{2}{|c|}{$\begin{array}{l}\text { Ponderosa pine } \\
\text { control (untreated) } \\
8 \% \text { peracetic acid }\end{array}$} & $\begin{array}{l}4.45 \\
6.55\end{array}$ & $\begin{array}{l}1.65 \\
5.38\end{array}$ \\
\hline $\begin{array}{l}\text { Aspen } \\
\text { control (ur } \\
8 \% \text { perac }\end{array}$ & $\begin{array}{l}\text { itreated) } \\
\text { etic acid }\end{array}$ & $\begin{array}{l}10.71 \\
30.75\end{array}$ & $\begin{array}{r}6.64 \\
22.50\end{array}$ \\
\hline $\begin{array}{l}\text { Wheat strai } \\
\text { control (ur } \\
\& \% \text { perac }\end{array}$ & $\begin{array}{l}w \\
\text { ntreated) } \\
\text { etic acid }\end{array}$ & $\begin{array}{l}12.42 \\
22.22\end{array}$ & $\begin{array}{l}10.91 \\
18.00\end{array}$ \\
\hline Mothod A) & \multicolumn{3}{|c|}{$\begin{array}{l}\text { Enzymes: cellulase/cellobiase (10:1), loading } 42 \text { IFPU } \\
\text { Solid/enzyme mlxture ratio } 1: 50 \\
\text { Temperature } 50^{\circ} \mathrm{C}, \mathrm{pH} 4.8,125 \mathrm{rpm}, 5 \text { days } \\
\text { Material pretreated } 30 \text { days, wood/liquid ratio } 1: 6\end{array}$} \\
\hline Method B) & \multicolumn{3}{|c|}{$\begin{array}{l}\text { Enzymes: cellulase/cellobiase }(10: 1) \text { loading } 75 \text { IFPU } \\
\text { Solid/enzyme mixture ratio } 1: 10 \\
\text { Temperature } 50^{\circ} \mathrm{C}, \mathrm{pH} 4.8,125 \mathrm{rpm}, 5 \text { days } \\
\text { Material pretreated } 30 \text { days, wood/liquid ratio } 1: 6\end{array}$} \\
\hline
\end{tabular}


Table 5. Glucose Yleld of Peracetlc Acld Pretreated Materlal after Enzymatlc Hydrolysls (values given in percent by weight)

\begin{tabular}{lcc}
\hline Material & Peracetic acid amount & Glucose yields \\
\hline Ponderosa pine & 0 & 2.33 \\
& 3 & 2.83 \\
& 5 & 3.62 \\
& 8 & 4.39 \\
Aspen & 11 & 4.82 \\
& 0 & 10.27 \\
& 2 & 11.58 \\
& 3 & 14.24 \\
Wheat straw & 5 & 18.22 \\
& 8 & 24.10 \\
& 0 & 11.36 \\
& 2 & 12.77 \\
& 3 & 13.64 \\
Cellulose control & 5 & 9.60 \\
& 8 & 19.24 \\
\hline
\end{tabular}

Enzymatic hydrolysis: cellulase /cellobiase (10:1), loading 42 IFPU, solids/enzyme mixture ratio $1: 50$, temperature $50^{\circ} \mathrm{C}, \mathrm{pH} 4.8,125 \mathrm{rpm}$ shaker, 5 days. Material pretreated 30 days, wood/liquid ratio 1:6.

Work still in progress involves the isolation of lignin from the original biomass, the peracetic acid treated material, and the material subjected to decay by the brown rotter, Poria monticola. Because this aspect of the study is still ongoing, no values for the amount of lignin isolated are currently available.

The procedure of Kirk and Chang (1974) may need to be further modified to obtain adequate material. It is also desirable to obtain all three types of material using the same procedure. Work still to be accomplished once the lignins are isolated and purified includes comparing them using nuclear magnetic resonance both in the solid state and liquid state. Other analytical procedures will be applied to the isolated material including infrared and the deterr.ination of molecular weights.

One other aspect of work still in progress is achieving a mass balance in going from the original biomass materials through the pretreatment step and finally enzymatic hydrolysis.

\section{Conclusions}

There is some evidence that peracetic acid may mimic brown rotters in providing accessibility for cellulases and other hydrolytic enzymes. Lignin is mudified through oxidation in both cases. Lignin loss is very low when biomass is treated with small amounts of peracetic acid under mild conditions in very dilute solutions; however, accessibility for enzymes is significantly increased. When comparing ponderosa pine, quaking aspen, and wheat straw, the effect of peracetic acid pretreatment and subsequent enzymatic 
Table 6. Welght Loss of Materlal Decayed for Six Months by Porla monticola (values given in percent by weight)

\begin{tabular}{lcc}
\hline Material & Weight ioss & Average value \\
\hline Ponderosa pine & 25.2 & 25.2 \\
& 26.4 & \\
& 26.5 & \\
& 25.0 & \\
Aspen & 23.0 & 30.3 \\
& 30.9 & \\
& 31.5 & \\
& 29.2 & \\
Wheat straw & 30.7 & 32.4 \\
& 29.0 & \\
& 32.4 & \\
\hline
\end{tabular}

Wood samples $3.0 \times 3.0 \times 0.3 \mathrm{~cm}$. Oven dried at $60^{\circ} \mathrm{C}$, sterillzed by steaming $15 \mathrm{~min}$. Straw cut to $4-\mathrm{cm}$ lengths and sterilized. Malt agar gel was at $3.36 \%$ solids.

hydrolysis does not seem to correlate very well. The ponderosa pine lignin seems to be most modified and the wheat straw lignin the least, with aspen occupying an intermediate position. However, when comparing enzymatic hydrolysis, the aspen has the most improved accessibility, with wheat straw also improving significantly, and ponderosa pine showing only slightly increased accessibility for the enzymes.

The more significant aspect of the study, determining the actual changes occurring in the lignin during peracetic acid pretreatment, and comparing that change with those changes in lignin caused by brown rot decay, is still in progress. It could be that because softwoods exhibit the most resistance to enzymatic hydrolysis, i.e., are the least accessible, meaning that greater changes to the lignin are necessary for comparable accessibility for cellulase and other hydrolytic enzymes.

\section{Acknowledgment}

Support for this work was provided by the Solar Energy Research Institute under subcontract XK-7-07031-6.

\section{References}

Browning, B.L. 1967. Methods of Wood Chemistry Vol. II, 882 pp. New York: Interscience Publ.

Chang, H.-M., and Allan, G.G. 1971. "Oxidation." In Lignins: Occurrence, Formation, Structure, and Reactions, ed. K. V. Sarkanen, and C. H. Ludwig, 916 pp. New York: Wiley-Interscience.

Funaoka, M., and Abe, I. 1989. TAPPI 72:145-149. 
Jin, L., Nicholas, D.D., and Kirk, T.K. 1990. Wood Sci. Technol. 24:263«276.

Kirk, T.K., and Chang, H.-M. 1974. Holzforchung 18:217-222.

Miller, G... 1959. Anal. Chem. 31:426-428.

Tappi Standard Methods. 1989. Atlanta, GA: Technical Association of the Pulp and Paper Industry. 
Cellulose Conversion Research 


\title{
Overvlew of the Simultaneous Saccharlfication and Fermentation Process for Ethanol Production from Cellulosic Blomass
}

\author{
C. E. Wyman \\ Biotechnology Research Branch \\ Fuels and Chemicals \\ Research and Fngineering Division \\ Solar Energy Research Institute \\ Golden, Colorado 80401
}

\begin{abstract}
Production of ethanol from cellulosic biomass could provide a renewable source of premium transportation fuels that could reduce or eliminate our dependence on mounting imports of petroleum from unstable sources. Because imported petroleum contributes about $40 \%$ of the balance-of-trade deficit of the United States, ethanol produced from cellulosic materials would also improve the international trade posture of the country while decreasing our vulnerability to price disruptions. When blended with gasoline, ethanol reduces emissions of carbon dioxide and unburned hydrocarbons from vehicles; substitution of pure ethanol for gasoline significantly lowers the emission of smog-forming compounds. Because no fossil fuel is required to produce ethanol from cellulosic biomass, no net accumulation of carbon dioxide in the atmosphere results. Thus, use of ethanol derived from cellulosic resources does not contribute to the possibility of global climate change caused by the greenhouse effect.

Enzymatic conversion technology is emphasized because the high selectivity of enzymes for cellulose conversion into glucose sugar supports high ethanol yields, a key to economic viability. Of the various configurations possible for enzymatic conversion processes, the simultaneous saccharification and fermentation (SSF) process offers the most immediate potential to achieve high yields, rates, and concentrations of ethanol. SSF has been selected for emphasis with the limited resources of the Ethanol from Biomass Program. Primarily through advances in SSF technology, the projected selling price of ethanol from cellulosic biomass has been reduced by a factor of three over the last 10 years. However, further advances on cellulose conversion are required if the program is to meet its goal of producing from renewable feedstocks a liquid transportation fuel that can compete with gasoline without subsidies.
\end{abstract}




\section{Introduction}

Imports now account for about 50\% of the petroleum used in the United States. Furthermore, most other sectors have the ability to switch fuel source, but transportation fuels are currently almost totally derived from petroleum. Thus, it is important to develop domestic sources of transportation fuels to reduce or eliminate our susceptibility to disruptions in supply and uncontrollable shifts in price such as we are experiencing as a result of Iiaq's recent takeover of Kuwait. With petroleum imports contributing about $40 \%$ of the U.S. trade deficit, displacement of gasoline and other transportation ivels by domestically produced fuels would improve our position in world markets.

The United States contributes about $25 \%$ of the carbon dioxide released from fossil fuels to the atmosphere, with transportation fuels accounting for about $27 \%$ of that amouni. Carbon dioxide is believed to be the most important greenhouse gas, trapping nearly 50\% of the radiation that could lead to global climate change. Thus, a case is building for development of transportation fuels that do not contribute to the buildup of carbon dioxide in the atmosphere. In addition, significant air pollution problems are attributet to gasoline ana other conventional fuels, and interest in ways to reduce carbon monc xide and smog in our cities is mounting.

Ethanol is a clean-burning liquid fuel quite similar to methanol but less tcxic. Blending ethanol with gasoline reduces carbon monoxide emissions and substituting "pure" ethanol for gasoline reduces smog. Ethanol can be derived from renewable biomass sources, reducing our dependence on imported oil and our balance-of-trade deficit. About 3 billion gallons of ethanol are now prodiced from cane sugar in Brazil each year, and more than 800 millicn gallons of ethanol are made annually from starch from corn and lesser amounts of other crops in the United States. However, with sugar prices controlled at $\$ 0.18 / \mathrm{lb}$ in the United States, sugar is too expensive for ethanol manufacture while the price of corn exceeds its value for ethanol production in this country (Wyman 1990). Thus, reductions in excise taxes are employed to varying degrees throughout the United States to reduce the effective cost of ethanol from an approximate $\$ 1.20-\$ 1.40 / \mathrm{gal}$ selling price to under $80 \mathrm{c} / \mathrm{gal}$. These tax benefits are a useful means to substitute renewable fuels for imported oil and utilize surplus corn. However, a reduction in the selling price of ethanol or other biomass-derived liquid fuels to levels equivalent to their value would facilitate widespread technology application without unpredictable, special tax considerations while providing a new crop for agriculture.

Ethanol can also be derived from cellulosic biomass such as wood, grasses, agricultural and forestry wastes, and waste paper. Because the cost of these materials is considerably less than for food crops, they contribute only about $30 \%-50 \% / \mathrm{gal}$ to the liquid fuel cost, depending on the feedstock cost and utilization that can be achieved. Furthermore, the application of cellulosic biomass to liquid fuel production does not compete with food uses, and fewer raw material price fluctuations are likely. Some raw materials, such as agricultural residues, are already produced in large quantities. If they could be gathered in a costeffective manner, their use for ethanol production could provide a significant new source of revenue for farms. In the United States, the availability of cellulosic biomass such as agricultural and forestry residues, waste paper, underutilized wood from standing forests, and fast-growing energy crops is estimated to be more than adequate to displace the entire U.S. demand for gasoline twice over (Lynd 1990 and 1989; Wyman and Hinman 1990). Because carbon dioxide provides a mechanism to recycle carbon between the cellulosic biomass and fuel ethanol, production of ethanol from renewable feedstocks does not contribute to accumulation of carbon dioxide in the atmosphere and possible global climate change caused by the greenhouse effect, as shown in Figure 1. 


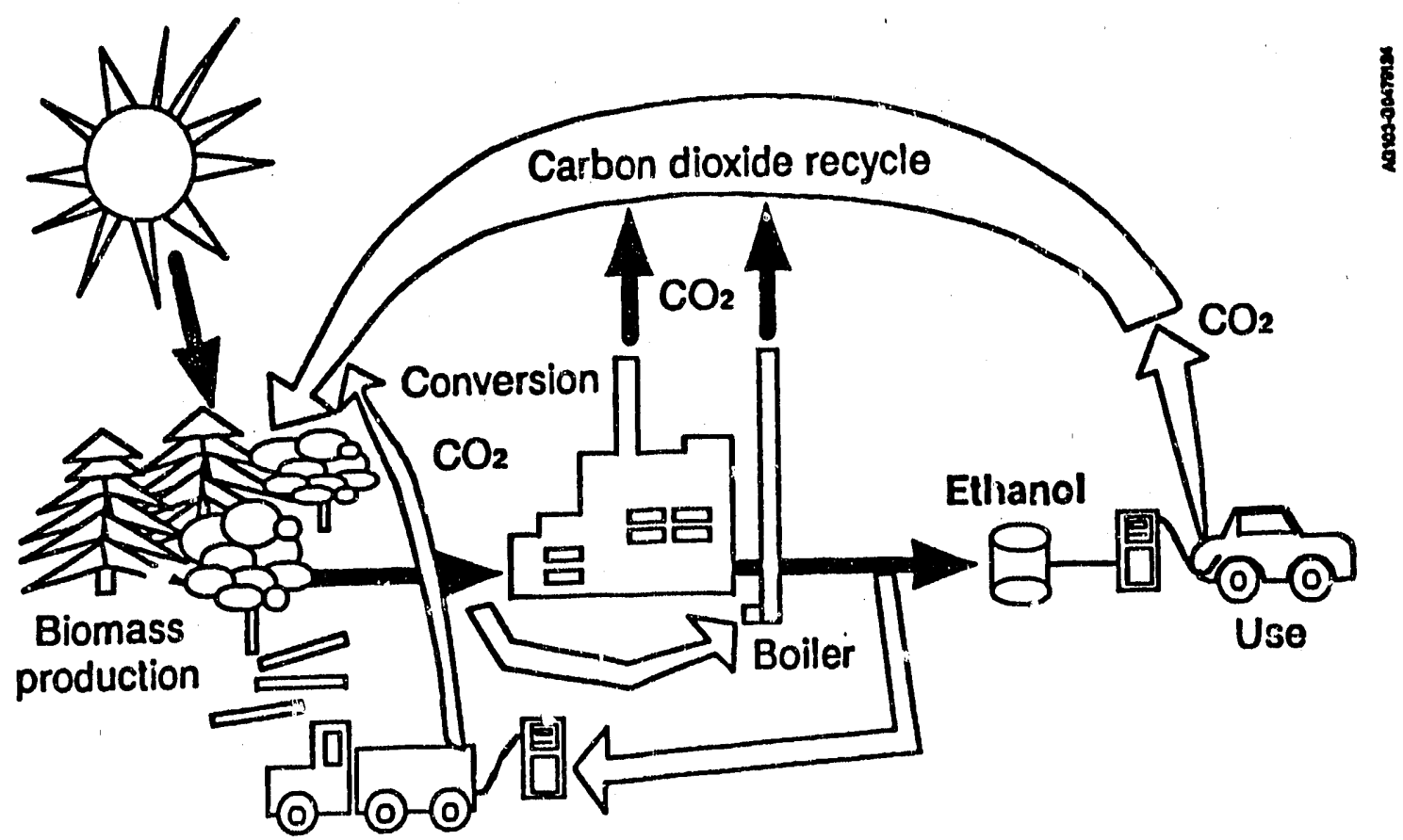

Figure 1. Because ethanol production from cellulosic blomass creates a "carbon cycle" as shown here, it does not contrlbute to the accumulation of carhon dloxide in the atmosphers.

In this section, the technology for converting the celiulose in biomass into ethanol will be discussed. First, the rationale for selecting enzyrnatic hydrolysis for the conversion process will be reviewed, followed by a discussion of the process configurations considered for ethanol production from the cellulose fraction of biomass. Next, the SSF process, the front-running option for ethanol production, will be described in more detail along with an outline of the research needed to make this technology cost competitive. Finally, the projects being supporid through the Ethanol from Biomass Program will be outlined.

\section{Enzymatic Hydrolysis}

The heart of the microbiology-based processes for production of liquid fuels from renewable lignocellulosic substrates is enzymatic hydrolysis. Acid hydrolysis technologies have received attention since the early 1900 s and several large-scale plants have been built throughout the world. However, enzymatic hydrolysis evolved from U.S. Amy studies during World War !' to overcome attack by the fungus Trichoderma reesei on the clothing and tents of soldiers stationed in the tropics. After expending considerable effort in preventing fungal decomposition, in about 1962 Reese and Mandels began to examine the possibility of promoting the decomposition rates of cellulose by this microorganism to generate glucose syrups. The energy crisis of the early 1970s focused interest on the prospect of producing liquid fuels from biomass. Thus, the concept of saccharification of the cellillose in biomass to sugars followed by fermentation to alcohol for a liquid fuel or octane enhancer grew out of the already established cellulose-digesting capability of $T$. reesei (Reese 1976).

Although the enzymatic breakdown of cellulose into its component sugars is conveniently credited to "cellulase," enzymes with three different modes of attack on cellulose are actually involved in the hydrolysis reaction. An endo-glucanase component attaches to the interior of a long cellulose chain, breaking it apart and forming two new ends. Then, exo-glucanases remove cellobiose fragments of two glucose molecules joined together from the ends of the longer cellulose molecules, and these cellobiose 
units exhibit strong inhibitory action on the exo-glucanases. In actuality, the endo- and exo-glucanase components of cellulase activity are thought to occur in two different forms to match the two different orientations of the beta-glucosidase bonds (Eveleigh 1987). The soluble cellobiose is finally broken down into two individual glucose sugar molecules by a $\beta$-glucosidase component that is strongly inhibited by the accumulation of glucose. The severe end-product inhibition of cellulase action by both cellobiose and glucose can greatly limit concentration, yield, and/or reaction rate for enzymatic hydrolysis.

Enzymatic hydrolysis is of interest for fuel production because it avoids many of the problems experienced with acid hydrolysis. Key factors are that the conditions of hydrolysis are mild and inexpensive vessels can contain the reacting mixture. Because the sugars produced by hydrolysis are not subjected to severe environments and cellulase enzymes are highly specific, degradation of sugars to byproducts and waste streams such as hydroxymethylfurfural and tars is avoided. In principle, at least, these low degradation rates alluw essentially complete conversion of the substrate into sugars for fermentation into ethanol. The product stream from enzymatic hydrolysis is also clean, and costly processing is not needed to remove impurities and toxins prior to fermentation. Thus, enzymatic hydrolysis could significantly improve the production cost of liquid fuels from lignocellulosic biomass if high yields, product concentrations, and rates can be realized at low enzyme loadings.

\section{Alternative Processes for Conversion of Cellulose}

Although ihe individual process steps for conversion of lignocellulosic feedstocks into liquid fuels can be conveniently isolated as shown in Figure 2, these steps can be combined in any manner that will minimize the overall conversion costs. Such a grouping of individual steps to form a particular process configuration can be desirable because many of the component steps suffer limitations that can be overcome by synergistic interactions between steps. Furthermore, capital costs are reduced by eliminating process steps. However, the benefits of these combinations are not fully realized with known microorganisms, and considerable research is needed to achieve successful integration. Because of the importance of such interactions, the overall conversion scheme must be considered, and isolated studies of the individual component steps as broken down in Figure 2 would fail to address the issues critical to successful integration of the technology. Therefore, in this portion of the discussion, we will review the front-running integrated microbiology-based process configurations that have been proposed to convert renewable lignocellulosic substrates into liquid fuels.

\section{Separate Hydrolysis and Fermentation (SHF)}

As illustrated in Figure 3, the SHF process utilizes distinct process steps for enzyme production, cellulose hydrolysis, and glucose fermentation. After the feedstock is pretreated to render it susceptible to hydrolysis, a small portion is sent to cellulase production to support growth of a microorganism that will make enzyme, typically the fungus $T$. reesei. The cellulase enzyme is then transferred to another vessel along with the major fraction of the pretreated substrate to hydrolyze the cellulose into glucose sugar. Next, the glucose is sent to one or more reactors to be fermented into ethanol. Finally, the broth from fermentation is passed on to a distillation column or other device to recover the ethanol from the other components. The primary advantage of this configuration is that the enzyme production, cellulose hydrolysis, and sugar fermentation steps can be treated separately, minimizing the research required to deal with interactions between these steps. However, considerable effort is still needed to overcome the end-product inhibition suffered by cellulase enzymes, which impedes attainment of reasonable ethanol concentrations at high rates and with high yields. 
Cellulosic biomass

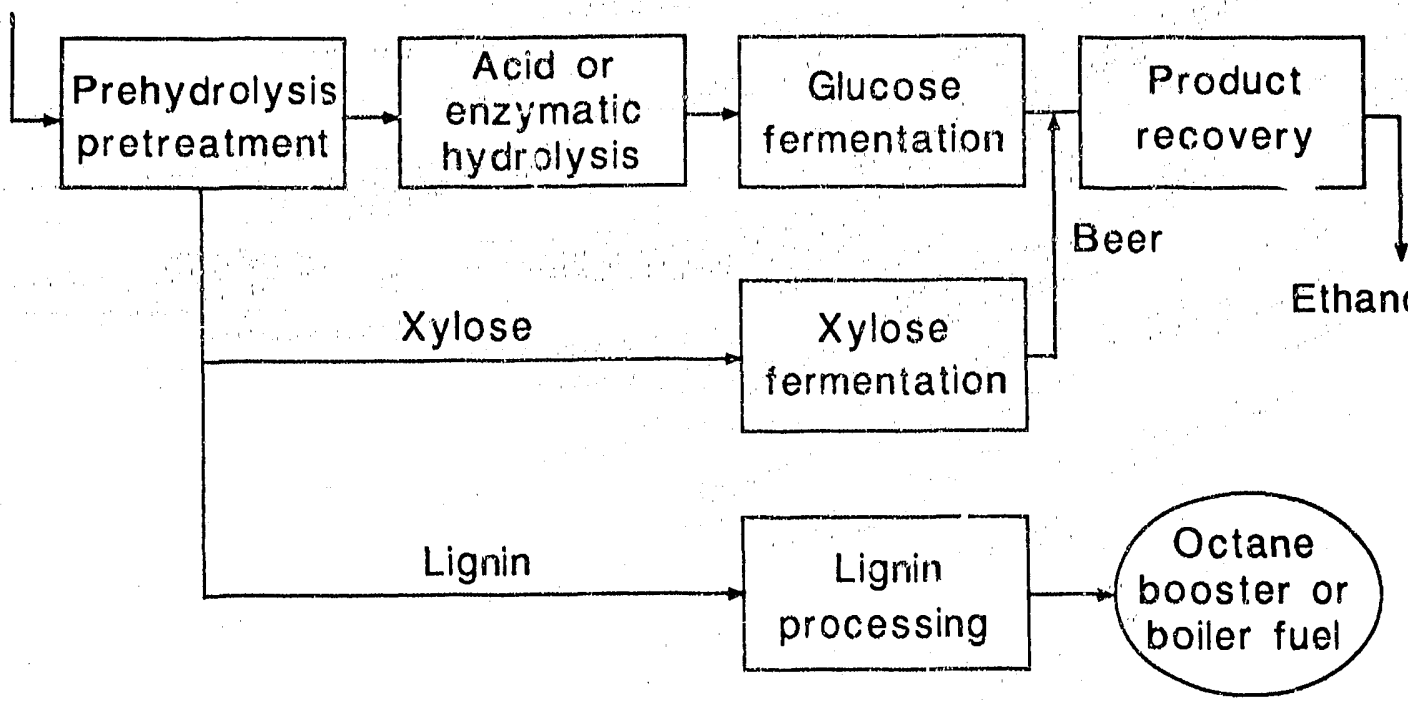

Figure 2. In general, the cellulose fraction of the blomass feedstock is broken down to form glucose sugars by acld or enzymatlc hydrolysis, and the glucose is then fermented Into ethanol.

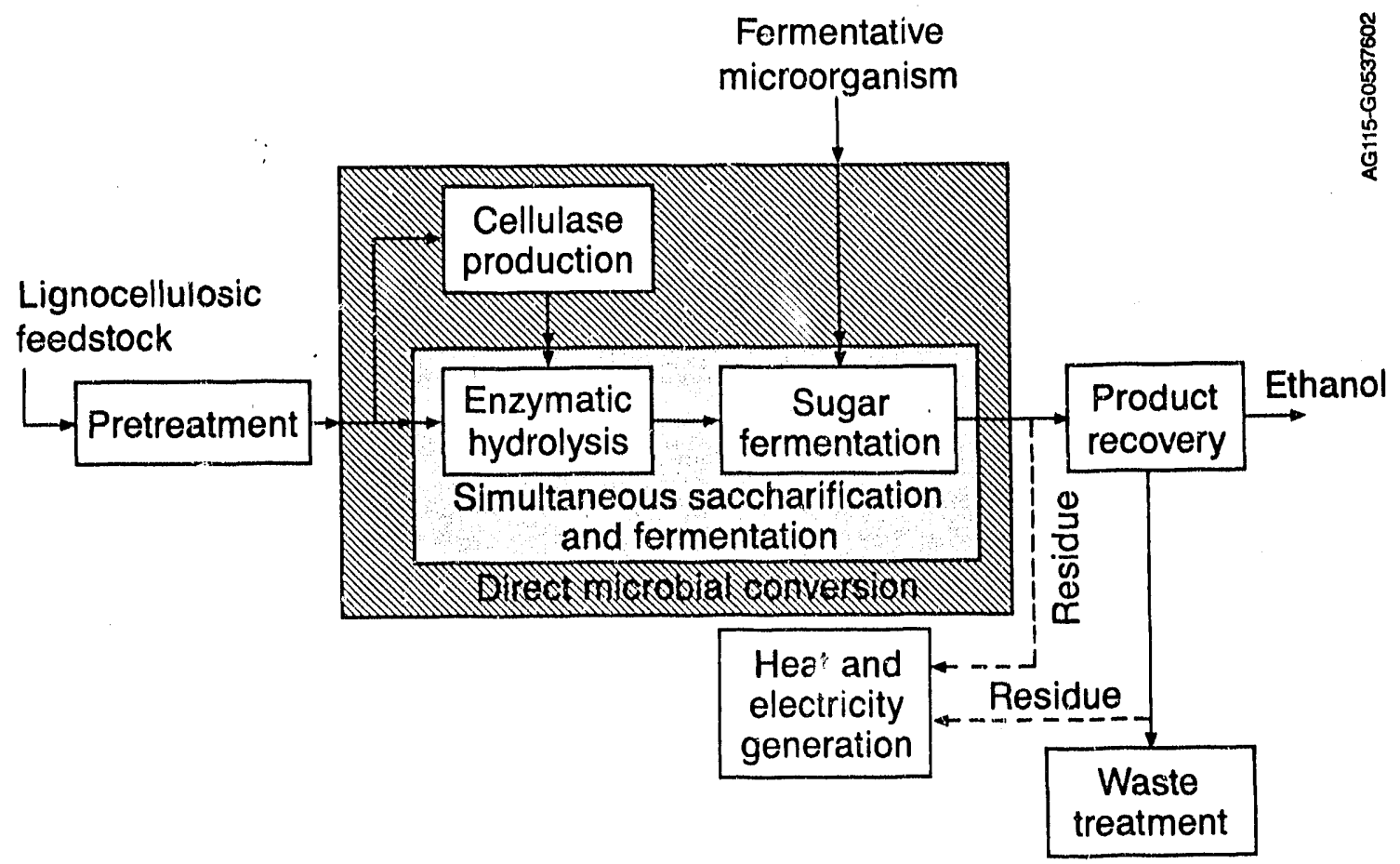

Figure 3. Cellulase enzyme production, cellulose hydrolysls, and glucose fermentatlon are performed in distinct process steps for the separate hydrolysis and fermentation (SHF) process. The simultaneous saccharification and fermentation (SSF) process comb ies the hydrolysis and fermentation steps in one vessel to eliminate equipment, reduce enzyme inhibition by product sugars, and decrease microbial contamination. The direct microbial conversion (DMC) process carries this simplification one step further by utilizing microorganisms that will produce their own cellulase enzymes in addition to fermenting the sugars formed into ethanol. 


\section{SImultaneous Saccharlfication and Fermentation (SSF)}

A second process configuration that has been studied for microbiological production of liquid fuels from cellulosic biomass is the SSF process. It was originally developed at Gulf Oil and the University of Arkansas (Gauss et al. 1976; Takagi et al. 1977) and has since been studied by several others. In SSF, the enzymatic hydrolysis and yeast fermentation steps are combined in one vessel, as shown in Figure 3. Three major potential benefits arise from the combination of steps: end-product inhibition of the enzyme is eliminated or substantially reduced; only one vessel and one set of associated support equipment (e.g., pumps, instrumentation, agitators, etc.) are needed for the conversion of pretreated feedstock to liquid fuels; and the presence of ethanol in the fermentation/hydrolysis broth reduces the probability of microbial contamination. However, despite the significant cost reduction potential of the approach, the combination of enzymes and fermentation microorganisms must operate at identical conditions of temperature and $\mathrm{pH}$, achieve high yields, be used at low enough levels to be economical, and produce reasonable product concentrations for cost-effective recovery. Because of the higher yields and ethanol concentrations demonstrated by SSF, the Ethanol from Biomass Program has focused its limited resources on the SSF process based on $T$. reesei cellulases.

\section{Direct Microblal Conversion (DMC)}

Another option that has received considerable study for production of ethanol from renewable cellulosic iiomass is the DMC process. As illustrated in Figire 3, this process combines enzyme production along with the hydrolysis and fermentation steps in one vessel for direct production of ethanol from renewables. Originally, unpretreated biomass was to be fed to the process, thereby eliminating a costly process step, but it became clear that the extent and rate of degradation needed for an economically viable process can only be achieved with pretreated biomass. Emphasis was initially on the thermophilic bacteria Clostridium thermocellum for hydrolysis of the cellulose and hemicellulose to fermentable sugars as well as conversion of the six-carbon sugars to ethanol. This microorganism is co-cultured with another thermophile, Clostridium thermosaccharolyticum, to ferment the five- and six-carbon sugars to ethanol. These bacterial systems have been studied at the Massachusetts Institute of Technology (Cooney et al. 1987; Wang et al. 1987), Dartmouth (Lynd 1986), the University of Wisconsin, the Institut Pasteur in France, and the New Energy Development Corporation in Japan (New Energy Development Organization 1987). The advantages of the process are somewhat less now that pretreatment must be incorporated into the system, but with the elimination of a separate enzyme production step, DMC nonetheless offers a single-step process for production of ethanol from all of the sugar polymers from cellulosic biomass. In addition, high specific growth rates are observed for bacterial systems, and anaerobic enzyme production is possible, which reduces power requirements and costs for aeration. However, low product selectivity, ethanol tolerance, productivity of ethanol, and cellulose degradation rates must be overcome. Alternatively, other microorganisms may prove more suitable for DMC than bacteria. Lynd has written a fine review on incteria-based processes for ethanol production (Lynd 1989).

\section{Research Needs}

As shown in Figures 2 and 3, five steps are included in all enzymatic hydrolysis processes: pretreatment, enzyme production, hydrolysis, fermentation, and downstream processing. The SSF process measures how well the separate steps of pretreatment, cellulase production, and microorganism selection have taken into account the interaction of the substrate, enzyme, and fermenting microorganism. This is because SSF can perform no better than the pretreatment process, cellulase enzymes, and fermentative microorganisms allow. Furthermore, to a large degree, the costs of downstream product recovery and waste disposal steps are determined by the ability of the SSF process to provide a high product concentration and minimal need 
for waste disposal. Thus, the interplay between these steps must be fully taken into account to arrive at the most cost-cffective overall process for obtaining ethanol from cellulosic feedstocks (Wight 1987).

Although substantial progress has been made on the technology for ethanol production through cellulose conversion, urther improvements are needed to make the technology cost competitive with production of petroleum-terived fuels. First, high yields of ethanol must be achieved with low enzyme costs. Thus, cellulase enzymes must be produed at low cost or used in limited quantities to achitye cverall process viability. The former can be achieved by lowering the cost of cellulase production the by developing faste: growing organisms for cellulase production or hy improving the cellulase production technology. Alternatively, the activity of the cellulase can be enhanced so that less enzyme is required to dchieve a given ethanol yield. Improvements in the pretreatment step can improve ethanol yields as well. Thic requirement can also be met by enhancing the lifetime of the enzymes, provided cost-effective methods can be devised for cellulase recovery. A combination of these approaches is the most probable route to improving yields.

The economics of ethanol production would also benefit from increases in the ethanol concentration. Generally, an ethanol concentration of $6 \%$ to $8 \%$ is beneficial in minim, izing fermentation capacity and lowering the cost of product recovery; although advanced distillation apparently can recorer lower ethanol concentrations at a low cost (Lynd 1984; Lynd 1986).

Faster rates of enzymatic action on the cellulose would improve the economics of the SSF process. Currently, about 5 to 7 days are typically required to complete a fermentation, and a substantial number of very large fermenters is therefore required. Obviously, vessels contribute a large cost to the process, and significant capital cost reductions could be realized if the rates could be speeded to require only about 2 to 3 days to achieve high yiclds. Higher rates could be achieved through improvements in pretreatment or cellulase technology.

The cost of ethanol production is also reduced by continuous operation to maximize vessel productivity. Thus, benefit is gained by devising new continuous ethanol fermentation approaches and establishing approaches to apply the teclinology at a large scale. Large-scale fermentations must also be fully understood to ensure that low-power mixing devices can be employed successfully.

Full process integration is a key step to establishing the performance of the entire SSF process when operated on actual feedstocks. This includes evaluation of front-running feedstocks being developed through the support of the DOE Biomass Production Program under the management of Oak Ridge National Laboratory (ORNL). Low-cost feedstocks that could provide an opportunity for early technology application, such as agricultural residues and waste paper, also merit attention. Selected feedstocks must be processed exactly as specified in process engineering studies, and the flowsheet modified as needed to address any problems. Interaction between experimental verification and process economic studies must be an ongoing effort until a cost-effective design is verified experimentally. Considerable progress has been made in this direction, but testing is still required to finalize process performance and support design of a process development unit (PDU).

For most processes that have been developed to any extent, the sugars produced by hydrolysis of cellulose are fermented to ethanol. Because ethanol has been produced from glucose and other six-carbon sugars for centuries, major innovations are not expected in the basic microorganisms for simple sugar fermentations using a dedicated vessel as depicted in Figure 1. However, improved fermenter designs can still improve process economics (Maiorclla et al. 1984). Furthermore, enzyme action is end-product inhibited, and the SSF process realizes advantages by combining the hydrolysis and fermentation processes, as discussed above. In addition, some of the products from hydrolysis of cellulosic materials such as cellodextrins are not typically fermented in existing commercial facilities that use sugar and starch 
crops. Fuel products are also not constrained by the food grade and taste requirements usually imposed on many existing commercial technologies. Finally, liquid products other than ethanol are potentially useful for fuels but have not received attention in existing markets. Therefore, research is merited on microorganisms that will integrate synergistically with the hydrolysis process as well as ferment hydrolysis products with high yields and at high rates.

\section{Curront Research}

During the last year, SERI researchers have evaluated the performance of threc herbaceous energy crops provided by the DOE Biomass Production Program managed by ORNL, as well as corn cobs and stover for the DOE Western Regional Biomass Program that is managed by the Western Area Power Admiristration. The SSF process achieved superior performance to the SHF option for all feedstocks, and particularly high rates and yields of ethanol were obtained when a cellobiose-fermenting yeast was used in co-culture or the cellulase was augmented with significant amounts of $\beta$-glucosidase or cellulase.

During the last 6 months, a new project has begun at SERI to model the SSF process in enough detail to understand the impact of key conversion steps on performance. To date, a general model has been completed, and the equations have been solved by numerical methods on a personal computer. Some sensitivity analyses have been performed to investigate the impact of key parameters on SSF performance, and the emphasis now is on independent experiments to establish rate constants and other model parameters. Once these values are set, the model predictions can be compared to carefully designed SSF experiments to validate the predictive ability of the model. The end result will be useful in defining research opportunities to improve the SSF technology as well as guiding process trade-offs and optimization in process engineering.

The SSF broth contains solid particulates of lignin, unreacted cellulose, and yeast in a fluid mixture of ethanol, water, enzyme, and other materials. Brown University investigators are studying such particulate suspensions to understand the behavior of these complex mixtures. This study will also provide a basis for design of a continuous SSF process.

Cellulase enzymes are expensive, and significant benefits could result if higher $\beta$-glucosidase and cellulase productivities could be realized. One avenue to this goal is through genetic engineering, in which the genes responsible for enzyme production are isolated from an organism and expressed at higher rates in a host. SERI molecular biologists are taking this approach for the cellulase genes from thermophilic bacteria, and a gene segment has been identified that contains the endoglucanase gene. In addition, research is also in progress to enhance the production of $\beta$-glucosidase or to genetically engineer an ethanol-tolerant yeast strain to allow it to ferment cellobiose.

The addition of $\beta$-glucosidase to the SSF process has repeatedly proven to improve yields of ethanol, but the cost of such heavy supplementation is high. In addition, although the endo- and exo-glucanases can be recovered by absorption on cellulosic materials, the $\beta$-glucosidase fraction is not readily recovered in this fashion because it acts on soluble sugars. Alternatively, $\beta$-glucosidase activity can be enhanced by using cellobiose-fermenting yeast, using cellulase-producing organisms that overproduce $\beta$-glucosidase, and/or by recycling $\beta$-glucosidase. In line with the latter option, SERI scientists are investigating the immobilization of $\beta$-glucosidase on ion exchange resins as a possible means to increase $\beta$-glucosidase loadings while retaining the enzyme to reduce supplementation costs. Several promising solid materials have been identified that retain $\beta$-glucosidase activity, and the immobilized $\beta$-glucosidase has been shown to perform well in the SSF process. 
Although significant progress has been made in the past decade because of our increased knowledge of cellulase action, the mechanism of cellulase hydrolysis is still not clearly understood. Thus, because of the importance of cellulases to the overall program goals, a kcy element of the program is to enhance our knowledge of cellulases and how to improve their activity and lifetime. Colorado State University (CSU) scientists have used monoclonal antibodies to attach colioidal gold to the endo- and exn glucanases to determine if there is a physical association of these two components at the site of hydrolysis. This technique will help us understand the stoichiometry of the cellulase enzyme complex. In addition, scientists at SERI are studying the thermal denaturation of the key cellulase component CBHI to understand how it loses activity and ways to improve lifetime.

Researchers at ORNL have studied the effect of denaturation and reduction on CBHI from $T$. reesei. The rationale is that protein denaturants may be used for cellulase recovery from residual cellulose. The goal is to develop a low-cost approach to cellulase recycle.

A team of researchers at CSU has recently completed a study to optimize the culture conditions for the thermophilic bacteria Acidothermus cellulolyticus. This microorganism was isolated from hot springs in Yellowstone National Park by SERI researchers, and its cellulase enzymes have been shown to be the most thermotolerant of any cellulase yet found. The CSU scientists have examined the influence of various nutrients and established conditions that will augment the productivity of enzyme.

\section{Conclusions}

Cellulosic biomass could be converted into liquid fuel extenders, octane boosters, and neat fuels that would meet our need for premium transportation fuels without relying on unstable foreign sources. Furthermore, fuels derived from cellulosic biomass do not contribute to the accumulation of carbon dioxide in the atmosphere and the possibility of global climate change by the greenhouse effect because carbon dioxide is recycled perpetually between plants, fuels, and carbon dioxide. Ethanol also reduces urban air pollution. The SSF process has been selected for focused development because of its potential for achieving cost-effective ethanol production. Although the price of ethanol from enzymatic hydrolysis of lignocellulosic biomass has dropped substantially over the last ten years because of the advances achieved through the Ethanol from Biomass Program, continued progress is needed to provide technology that can compete in price with conventional petroleum-based fuel routes. Cellulose is the major component of lignocellulosic biomass, and further reductions in cellulose processing costs must be achieved through higher ethanol yields from cellulose, greater ethanol product concentrations, higher conversion rates, continuous processing, and integrated scale testing if the overall enzymatic hydrolysis option is to be cost effective. Thus, the key areas of enzyme production, enzymatic hydrolysis and fermentation, feedstock integration, and enzymology are all significant research elements in the Ethanol from Biomass Program. Success in these research areas has the potential to significantly reduce the cost of ethanol from cellulosic biomass.

\section{References}

Cooney, C.L., Demain, A.L., Sinsky, A.L., and Wang, D.I.C. 1987. Subcontract Progress Reports for September 1981-August 1986 SERI/STR-231-3176 through 3180. Cambridge, MA: Massachusctts Institute of Technology.

Eveleigh, D.E. 1987. Phil. Trans. R. Soc. Lond. A 321:435-447. 
Gauss, W.F., Suzuki, S., and Takagi, M. "Manufacture of Alcohol from Cellulosic Materials Using Plural Ferments," U.S. Patent 3,990,994, November 9, 1976.

Lynd, L.R., and Grethlein, H.E. 1984. Chem. Eng. Prog. 59.

Lynd, L.R., and Grethlein, H.E. 1986. AICHE J. 32(8):1347.

Lynd, L.R., Wolkin, R.H., and Grethlein, H.E. 1986. "Continuous Fermentation of Avicel and Pretreated Mixed Hardwood by Clostridium thermocellum." In Biotechnology and Bioengineering Symposium No. 17, ed. C. Scott. Eighth Symposium on Biotechnology for Fuels and Chemicals.

Lynd, L.R. 1989. Adv. in Biochem. Eng./Blotechnol. 38:1.

Lynd, I.R. 1990. Appl. Biochem. Biotechnol. 24/25:695.

Maiorella, B.L., Blanch, H.W., and Wilke, C.R. 1984. Biotechnol. Bioeng. 26:1003-1025.

Mandels, M. 1981. Ann. Reports Ferm. Proc. 5:35-78.

Montenacourt, B.S. 1983. Trends Biotechnol. 1:156-161.

New Energy Development Organization. 1987. "NEDO" Representative Office: Suite 924, $1800 \mathrm{~K}$. Street, NW, Washington, DC 20006.

Reese, E.T. 1976. Biotechnol. Bioeng. Symp. 6:9-20.

Spindler, D.D., Wyman, C.E., Mohagheghi, A., and Grohmann, K. 1987. Appl. Biochem. Biotechnol. 17:279.

Spindler, D.D., Wyman, C.E., Grohmann, K., and Mohagheghi, A. 1988. Appl. Biochem. Biotechnol. 21.

Spindler, D.D., Wyman, C.E., and Grohmann, K. 1989. Blotechnol. Bioeng. 34(2):189.

Takagi, M., Abe, S., Suzuki, S., Emert, G.H., and Yata, N. 1977. Proc. Bioconv. Symp., 551-571. Delhi: IIT.

Wang, D.I.C., Cooney, C.L., Demain, A.L., Gomez, R.F., and Sinsky, A.J. 1987. Subcontract Progress Reports for March 1979-February 1981. SERI/STR-231-3183 through 3185.

Wright, J.D., Wyman, C.E., and Grohmann, K. 1987. Appl. Blochem. Biotechnol. 18:75.

Wright, J.D. 1987. Annual Biochemical Conversion/Alcohol Fuels Program Review, B-1 to B-12. Golden, CO: Solar Energy Research Institute.

Wyman, C.E., and Hinman, N.D. 1990. Appl. Biochem. Biotechnol. 24/25:735.

Wyman, C.E., Spindler, D.D., Grohmann, K., and Lastick, S.M. 1986. Biotechnol. Bioeng. Symp. 17:221238. 


\section{Blbllography}

Mandels, M. 1981. Ann. Reports Ferm. Proc. 5:35-78.

Montenacourt, B.S. 1983. Trends Biotechnol. 1:156-161.

Spindler, D.D., Wyman, C.E., Mohagheghi, A., and Grohmann, K. 1987. Appl. Blochem. Blotechnol. $17: 279$.

Spindler, D.D., Wyman, C.E., Grohmann, K., and Mohagheghi, A. 1988. Appl. Bioche.n. Biotechnol. 21.

Spindler, D.D., Wyman, C.E., and Grohmann, K. 1989. Biotechnol. Bioeng. 34(2):189.

Wang, D.I.C., Cooney, C.L., Demain, A.L., Gomez, R.F., and Sinsky, A.J. 1987. Degradation of Lignocellulosic Biomass and its Subsequent Utilization for the Production of Chemical Feedstocks, Subcontract Progress Reports for March 1979-February 1981. SERI/STR-231-3183 through 3185.

Wright, J.D., Wyman, C.E., and Grohmann, K. 1987. Appl. Blochem. Blotechnol. 18:75.

Wyman, C.E., and Hinman, N.D. 1990. Appl. Biochem. Biotechnol. 24/25:735.

Wyman, C.E., Spindler, D.D., Gishmann, K., and Lastick, S.M. 1986. Biotechnol. Bioeng. Symp. 17:221238. 


\title{
Ethanol Production by Simultaneous Saccharification and Fermentation (SSF) of Pretreated Herbaceous Crops, Corn Cob, and Corn Stover
}

\author{
D. Spindler, C. Wyman, and K. Grohmann \\ Biotechnology Research Branch \\ Fuels and Chemicals \\ Research and Engineering Division \\ Solar Energy Research Institute \\ Golden, Colorado 80401
}

\begin{abstract}
Three herbaceous crops, (weeping love grass, Eragrotis curvula; Sericea lespedeza, Lespedeza cuneata; and switchgrass, Panicum virgatum), and two agricultural residues (corn cobs and corn stover) were evaluated in the SSF process as dilute acid pretreated substrates for ethanol production. Saccharomyces cerevisiae $\left(D_{5} A\right)$ was used in the fermentations above and in mixed culture with Brettanomyces clausenii $(Y-1414)$. SSFs were performed at $37^{\circ} \mathrm{C}$ for up to 8 days along with sacrinarification without fermentation (SAC) studies at $45^{\circ} \mathrm{C}$ under similar enzyme loadings with cellulise enzyme employed alone or in combination with $\beta$-glucosidase. $S$. cerevisiae performs best with $\$$-glucosidase supplementation to the cellulase enzyme, showing an increased need for supplementation as the cellulase loading is decreased. The mixed culture of $S$. cerevisiae and B. clausenii showed improved results over the single culture of $S$. cerevisiae, especially at the lower enzyme loadings. In all cases, SSFs demonstrate faster and higher conversions than SACs for the same enzyme loadings. Of the three herbaceous crops tested, weeping love grass excels in both rate and final ethanol yield followed closely by switchgrass, while the legume (Sericea lespedeza) trailed behind both grasses in conversion performance. Also, corn cobs appear to be more readily digestible than the stover, although both crop residues prove to be among the best substrates yet evaluated for conversion to ethanol.
\end{abstract}

\section{Introduction}

The process of simultaneous saccharification and fermentation (SSF) for cellulose conversion into ethanol was described more than 10 years ago (Takagi et al. 1977) and has now become a favored process for the conversion of cellulose to ethanol. The SSF process employs fermentative microorganisms in combination with cellulase enzyme to minimize accumulation of sugars in the fermenter. As a result, inhibition of the enzyme by its product sugars is reduced, and higher hydrolysis rates and yields are possible than for saccharification without fermentation (SAC) (Blotkamp et al. 1978). 
Yeast selection for SSF has been described in several publications (Blotkamp et al. 1978; Gonde et al. 1984; Lastick et al. 1983; Lastick et al. 1984; Spindler et al. 1988; Spindler 1987; Szczodrak and Targonski 1988). Some of this work involved the selection of thermotolerant yeasts (Spindler et al. 1988; Spindler 1989; Szczodrak and Targonski 1988), with the goal of using a yeast that can ferment at a temperature close to the optimal hydrolysis temperature for the cellulase enzyme, $45^{\circ} \mathrm{C}$. However, although an increase in temperature can speed the hydrolysis, loss of cell viability results in lower ethanol yields, and $37^{\circ}$ to $40^{\circ} \mathrm{C}$ appears to be the best temperature range for the SSF process.

Cellobiose-iermenting yeasts have been studied because additional $\beta$-glucosidase activity can speed up the SSF reaction (Freer and Detroy 1983; Gonde et al. 1982; Lastick et al. 1984; Wyman et al. 1986). The importance of end-product inhibition of the cellulase enzymes during cellulose hydrolysis has been modeled by Howell (1978). Some publications discuss the advantage of the cellobiose-fermenting yeasts in decreasing end-product inhibition of cellobiose to the cellulase enzyme (Detroy et al. 1981; Gosh et al. 1982). In general, Saccharomyces cerevisiae, a strong ethanol-tolerant glucose fermenter with a fast rate of fermentation, has been found to perform well if the enzyme preparation is high in $\beta$-glucosidase. A mixed culture of Brettanomyces clausenii and $S$. cerevisiae provides better yields, rates, and concentrations if the enzyme is lower in $\beta$-glucosidase (Wyman 1986).

Another important element in the SSF process is the choice of substrate. Several cellulose-containing substrates have been evaluated in the SSF process including sugar cane bagasse, rice straw, wheat straw, woody crops, and paper mill byproducts (Detroy et al. 1981; Katzen et al. 1983; Rivers et al. 1984; Saddler 1982; Saddler et al. 1983; Spindler 1988; Walkinshaw et al. 1984). Although these substrates are all potentially important, fast-growing herbaceous crops and com crop residues may prove economically attractive as substrates for ethanol production in the future, and an important consideration is the acceptability of these crops for biological conversion to ethanol. Therefore, the following evaluations of several promising herbaceous crops and com residue crops as substrates for the SSF process were undertaken. This effort on herbaceous energy crops is in cooperation with the DOE Biomass Production Program managed by Oak Ridge National Laboratory (ORNL) to help guide selection of promising feedstocks for ethanol production while the corn residues were studied for the Western Regional Biomass Program. Because high $\beta$-glucosidase activity has been shown to be important for high yields by Spindler et $\mathfrak{\text { l. }}$. (1989), cellulase enzyme was used alone and with $\beta$-glucosidase supplementation to establish the highest possible cellulose conversioins.

\section{Materials and Methods}

\section{Materials}

Three herbaceous crops employed in this study (weeping love grass, Eragrotis curvula; Sericea lespedeza, Lespedeza cuneata; and switchgrass, Panicum virgatum) were supplied to SERI through the coordination of the Biomass Production Program at ORNL, Oak Ridge, Tenn. The com residues used in this study were harvested from the eastern Colorado slope in the fall of 1984 and selected for absence of rot. The fermentation yeasts used were $S$. cerevisiae $\left(D_{5} A\right)$, a SERI strain derived from Red Star Brewers yeast, and B. clausenii Y-1414 supplied by the Northern Regional Research Laboratory (NRRL), United States Department of Agriculture, Peoria, Ill. Chemicals were purchased from the Sigma Chemical Company, St. Louis, Mo., and yeast extract and peptone growth media were ordered from Difco, Detroit, Mich. Cellulase enzyme (150L) was purchased from Genencor Inc., San Francisco, Calif., and $\beta$-glucosidase (Novozyme - 188) from NOYO Laboratories, Inc., Wilton, Conn. Shaker flask, 250-mL Pyrex graduated vessels were used for most of the fermentations, although larger scale 1-L to 3-L fermentations were performed in Braun Biostat fermenters. 


\section{Methods}

SSFs to screen performance of the substrate were carried out in $250-\mathrm{mL}$ flasks outfitted with stoppers constructed to vent $\mathrm{CO}_{2}$ through a water trap. These flasks contained $10 \mathrm{~J} \mathrm{~mL}$ of fermentation broth and were agitated at $150 \mathrm{rpm}$ in a shaker incubator at $37^{\circ} \mathrm{C}$. A media containing $1 \%$ yeast extract and $2 \%$ peptone $(\mathrm{w} / \mathrm{v})$ was used with a substrate loading of $7.5 \%(\mathrm{w} / \mathrm{v})$ cellulose. The substrate level was limited to $7.5 \%$ cellulose because mixing problems were encountered at higher cellulose levels during preliminary SSF evaluations performed with pretreated wheat straw in previous studies (Spindler et al. 1989). A lipid mixture of ergosterol $(5 \mathrm{mg} / \mathrm{L})$ and oleic acid $(30 \mathrm{mg} / \mathrm{L})$ was added to the media for improved ethanol yield (Janssen et al. 1983). Also, penicillin and streptomycin at $10 \mathrm{mg} / \mathrm{L}$ were used to minimize bacterial contamination. The inocula were grown in a shaker flask with YP media and $2 \%(\mathrm{w} / \mathrm{v})$ glucose at $37^{\circ} \mathrm{C}$, and a $1 / 10(\mathrm{v} / \mathrm{v})$ ratio of yeast culture to total volume of media was added to the fermentation. The substrate was autoclaved in fermentation flasks, and sterile media, lipids, antibiotics and enzyme were added before the inoculum. For SAC, $20-\mathrm{mL}$ vials were used on a rotary shaker incubator set to $45^{\circ} \mathrm{C}$, the approximate optimum temperature for cellulase enzyme. Substrate, sterile water, enzyme, and the, antibiotic tetracycline $(40 \mathrm{ug} / \mathrm{mL})$ were combined to a total volume of $10 \mathrm{~mL}$. Selected fermentations were run in 6-L Braun fermenters to gather more data on the SSFs. The conditions were as above but the analysis included several more parameters as described below.

The SSF ethanol concentrations in the supernatant were measured by gas chromatography using a Porapak Q80/100 column. The internal standard was $4 \%$ isopropanol. For some of the 6-L SSFs, a more detailed analysis was carried out where residual sugars (glucose and cellobiose) were determined as glucose by incubation of the sample with $2 \mathrm{mg} / \mathrm{mL}$ almond extract $\beta$-glucosidase from Sigma for $1 \mathrm{~h}$ at $37^{\circ} \mathrm{C}$, and total sugars were measured on the model 27 glucose analyzer from Yellow Springs Instruments, Yellow Springs, Ohio. For these runs, viable cell densities were measured as colony forming units (CFU) by plating serial dilutions on YPD or YPC plates.

Cellulase enzyme loadings of $7,13,19$, and $26 \mathrm{IU} / \mathrm{g}$ cellulose substrate were used in the shaker flask screening SSFs and for the SACs to span the range of activity previously shown to be important for SSFs. In this work, IU stands for international units of filter paper activity in micromoles of glucose per minute (Ghose 1987). $\beta$-glucosidase enzyme was also employed in these studies at ratios of 1,2 , and 8 parts to 1 part of cellulase as measured by IU of $\beta$-glucosidase per IU of cellulase. The $\beta$-glucosidase activity was determined by $p$-nitrophenyl- $\beta$-glucoside assays at a temperature of $37^{\circ} \mathrm{C}$ because this is the temperature for the SSFs. The IUPAC revisions of measured cellulase activities indicate that the level of $\beta$-glucosidase in an enzyme preparation may affect the results of the cellulase assay in filter paper units (Ghose 1987).

Although in previous work with Sigmacell-50 (Lastick et al. 1983; Lastick et al. 1984; Spindler et al. 1988), we were able to measure the residual cellulose via a wash filtration method, this method was not effective for measuring residual cellulose in real substrates such as pretreated herbaceous crops because of lignin interference. Therefore, for our detailed analysis, an alternate method was developed that could estimate the residual cellulose by poisoning the yeast cells with $\mathrm{NaF}$ and allowing the excess enzyme to complete the saccharification from a given point in time of the SSF. The cellulose concentration is then assumed equal to the total glucose concentration after poisoning minus the concentration before poisoning. Glucose that was associated with the $\beta$-glucosidase enzyme itsclf was subtracted. At lower enzyme levels, additional cellulase and $\beta$-glucosidase were added to ensure complete saccharifications by this method.

The herbaceous crops were knife-milled in 500-g batches through a 2-mm screen (Thomas-Wiley laboratory mill, Arthur H. Thomas, Co., Philadelphia, Penn.) and pretreated with dilute sulfuric acid $(0.5 \% \mathrm{v} / \mathrm{v})$ in a 2-gal Parr reactor. The crops were pretreated at $140^{\circ} \mathrm{C}$ for $1 \mathrm{~h}$ with stirring at $185 \mathrm{rpm}$. After reaction, the slurries were washed several times with hot water in a large Buchner funnel lined with a linen sheet to bring the $\mathrm{pH}$ from $\approx 1.3$ up to $\approx 4.5$. These batches were combined, immediately placed 
in freezer storage bags, and stored at $-20^{\circ} \mathrm{C}$. Approximately $58 \%$ of the pretreated grasses' dry weight was found to be cellulose, $40 \%$ lignin and acid insoluble ash, and $2 \%$ xylan. The pretreated legume gave a lower dry weight of cellulose at $45 \%$, with $51 \%$ lignin and acid insoluble ash, and $2.5 \%$ xylan.

Both corn cobs and corn stover were subjected to primary shredding using an Amerind-Mackissic model 12P hammer mill with 1 -in. round-hole screen openings. The samples were further reduced in size using a laboratory knife mill with a $2-\mathrm{mm}$ rejection screen as for the herbaceous crops. The particles were in dilute sulfuric acid $15 \mathrm{~min}$ for corn cobs at $140^{\circ} \mathrm{C}$ and $10 \mathrm{~min}$ at $160^{\circ} \mathrm{C}$ for corn stover. All pretreated biomass particles were washed to remove water-soluble materials, placed in freez : storage bags, and stored at $-20^{\circ} \mathrm{C}$. Approximately $70 \%$ of the pretreated corn residue dry weight was determined to be cellulose and about 30\% lignin. The xylan content was found to be zero and 3\% for cobs and stover, respectively.

Shaker flask results for the SSF process are reported as percent of maximum theoretical ethanol yields and do not account for substrate used for cell growth. Thus, the maximum expected ethanol yield is about $95 \%$, assuming about $5 \%$ of the substrate is needed for cell growth and maintenance. These calculations are based on the measured ethanol concentrations and a $56.7 \%$ theoretical ethanol yield conversion of cellulose to ethanol only. However, the straight saccharification (SAC) yields are calculated as the amount of glucose produced compared to the potential glucose in the cellulose. Thus, comparison of the SSF and SAC results must consider that subsequent fermentation of the sugars produced in the latter will also result in about a $5 \%$ loss to cell growth.

The $\beta$-glucosiuase activity of the Novo-188 cellobiose enzyme lised in supplementation for both saccharifications and SSFs was determined by performing p-nitrophenyl- $\beta$-glucoside assays at selected temperatures of $37^{\circ}, 40^{\circ}$, and $50^{\circ} \mathrm{C}$. It was found that at $37^{\circ} \mathrm{C}$ the activity is $125 \mathrm{IU} / \mathrm{mL}$, at $40^{\circ} \mathrm{C}$ the activity is $200 \mathrm{IU} / \mathrm{mL}$, and at $50^{\circ} \mathrm{C}$ it is $500 \mathrm{IU} / \mathrm{mL}$. Because the SSFs of herbaceous crops and corn residue crops were performed at $37^{\circ} \mathrm{C}$, the $\beta$-glucosidase activity was based on this temperature while the IUs for the cellulase activity are measured at $50^{\circ} \mathrm{C}$ according to the IUPAC procedures (Ghose 1987). Similarly, the saccharifications run at $45^{\circ} \mathrm{C}$ were supplemented with $\beta$-glucosidase reflective of the $37^{\circ} \mathrm{C}$ assay.

\section{Results}

Figure 1 compares the final SAC sugar yiclds for herbaceous crops with SSF ethanol yields at 13 IU cellulase/g cellulose and various B-glucosidase loadings. SSF yields are consistently higher despite being penalized by their small loss of sugars to support yeast growth and maintenance (see Methods). Although the saccharifications were run at $45^{\circ} \mathrm{C}$, the $\beta$-glucosidase ratios reflect the activity measured at a temperature of $37^{\circ} \mathrm{C}$. Therefore, because the $\beta$-glucosidase activity in saccharification was higher than indicated for supplementation, the greatest difference between SAC and SSF is at the zero $\beta$-glucosidase addition level. Even with this increased $\beta$-glucosidase activity in the SAC, SSF still outperforms SAC at all enzyme loadings and $\beta$-glucosidase supplementation.

Tabie 1 and Figure 2 present the final (8-day) ethanol yiclds for SSF with different substrates and several enzyme loadings and yeast combinations run in $250-\mathrm{mL}$ shaker flasks. Just as for the straight saccharification, the rates and yields are consistently higher for wecping love grass and switchgrass compared to the legume Sericea lespedeza. We also observe higher final ethanol yields for the mixed culture fermentation than for $S$. cerevisiae, particularly at lower enzyme loadings.

Key performance parameters for an SSF fermentation of weeping love grass with $S$. cerevisiae are presented in Figure 3. A cellulase loading of $26 \mathrm{IU} / \mathrm{g}$ ccllulose was used along with an 8:1 ratio of $\beta$ - 
glucosidase supplementation. The ethanol concentration continually increased as the cellulose dropped; glucose initially increased to about $3 \mathrm{~g} / \mathrm{L}$ and then quickly dropped to less than $1 \mathrm{~g} / \mathrm{L}$. Both the ethanol yield and cellulose used correlate closely. The cell viability first increases to a maximum of $5 \times 10^{7}$ and then declines to $2.5 \times 10^{7}$ CFUs. It is worth noting that $S$. cerevisiae shows sustained viability throughout the fermentation.

The ethanol yields for the detailed fermentations correspond closely to the results for the shaker flask SSFs. Once again, $S$. cerevisiae exhibits a high rate of conversion at 26 IU cellulase/g cellulose supplemented with a 8:1 $\beta$-glucosidase to cellulase ratio. The fermentation was nearly complete in 3 to 4 days for weeping love grass, although the other two substrates took 4 to 5 days. Similar results would be expected with the mixed culture.

Figure 4 compares the final ethanol yields in SSFs with $S$. cerevisiae alone and in mixed culture $\left(-7^{\circ} \mathrm{C}\right.$ ) to sugar yields from $45^{\circ} \mathrm{C} \mathrm{SACs}$ for both corn cob and stover at the various enzyme loadings. The left half of the figure presents results without $\beta$-glucosidase supplementation, and a marked improvement in yield for the mixed culture at low cellulase loadings is evident. This difference is attributed to the $\beta$ glucosidase activity of $B$. clausenii, and the results on the right half of the figure for $8: 1 \beta$-glucosidase supplementation support this conclusion. As with the herbaceous crops, the final SSF ethanol yields and rates are consistently higher than for SAC under all conditions, despite loss of sugars to support yeast growth and maintenance in the SSF process, which is not accounted for in the SAC results.

Table 2 presents the final (7-day) ethanol yields for SSFs and percent sugar yields of SACs at the enzyme loadings and yeast combinations run in $250-\mathrm{mL}$ shaker flasks for corn cobs and stover. Again, the mixed culture excels in final yield for most of the fermentations at low cellulase loadings, and the SSF yields are consistently higher than the SAC conversions. Fermentations for corn cobs and stover took 3-5 days to complete depending on the enzyme loadings.

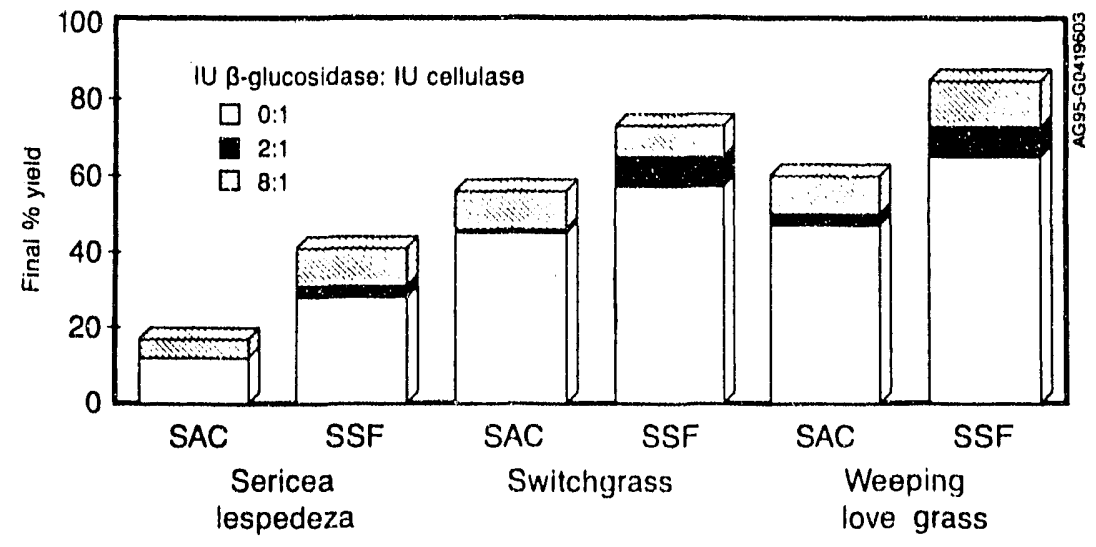

Figure 1. Comparison of sacchariflcation alone (SAC) and simultaneous saccharlification and fermentation (SSF) of herbaceous crops at $13 / U$ cellulase $/ g 7.5 \%$ cellulose and varlous $\beta$-glucosidase loadings. The SSFs were run with the mixed culture of $S$. cerevisiae and B. clausenii at $37^{\circ} \mathrm{C}$, while all of the SACs were performed at $45^{\circ} \mathrm{C}$. The bars indicate percent final saccharification yields for SAC and final percent of theoretical ethanol yields for SSF. 


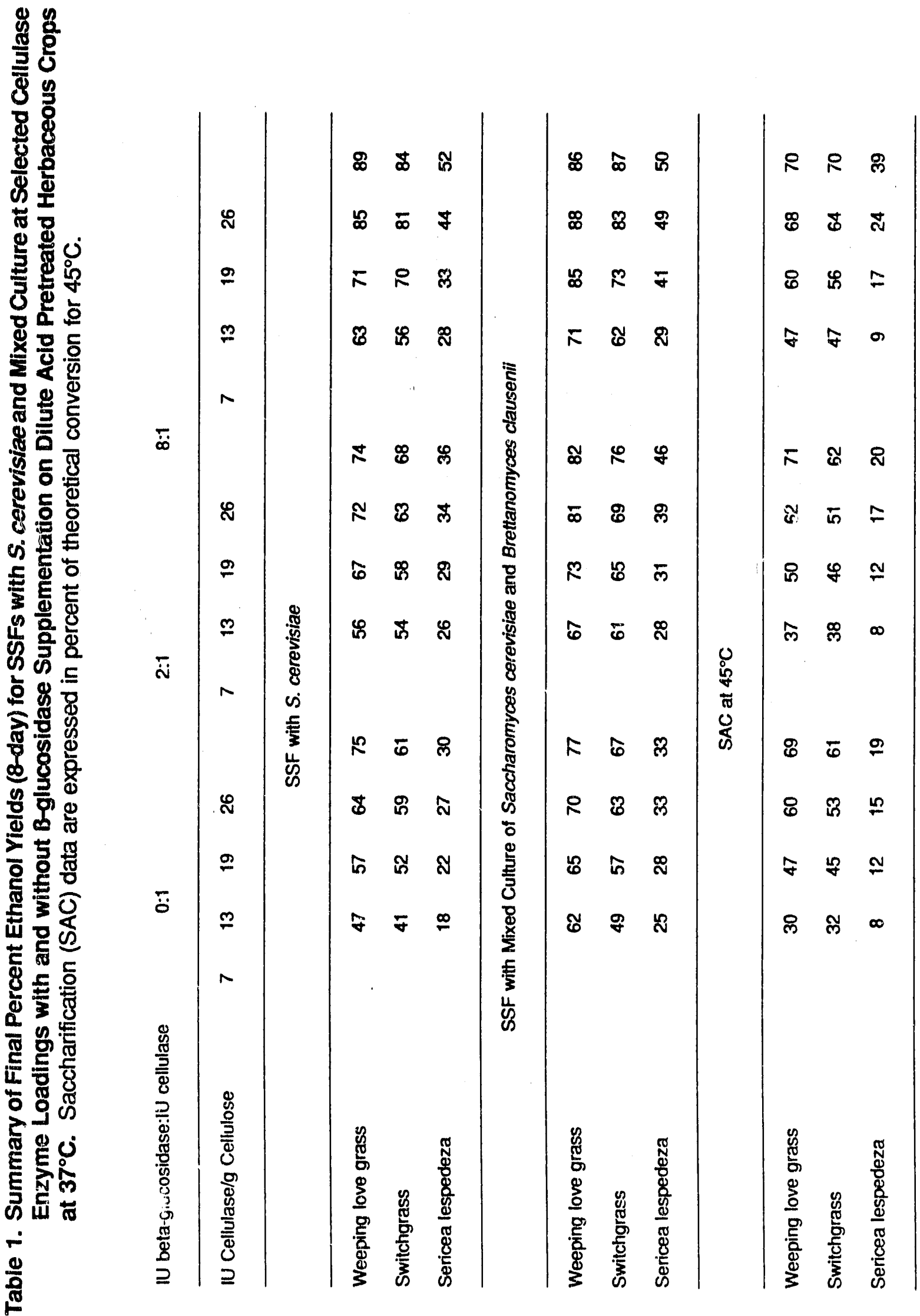




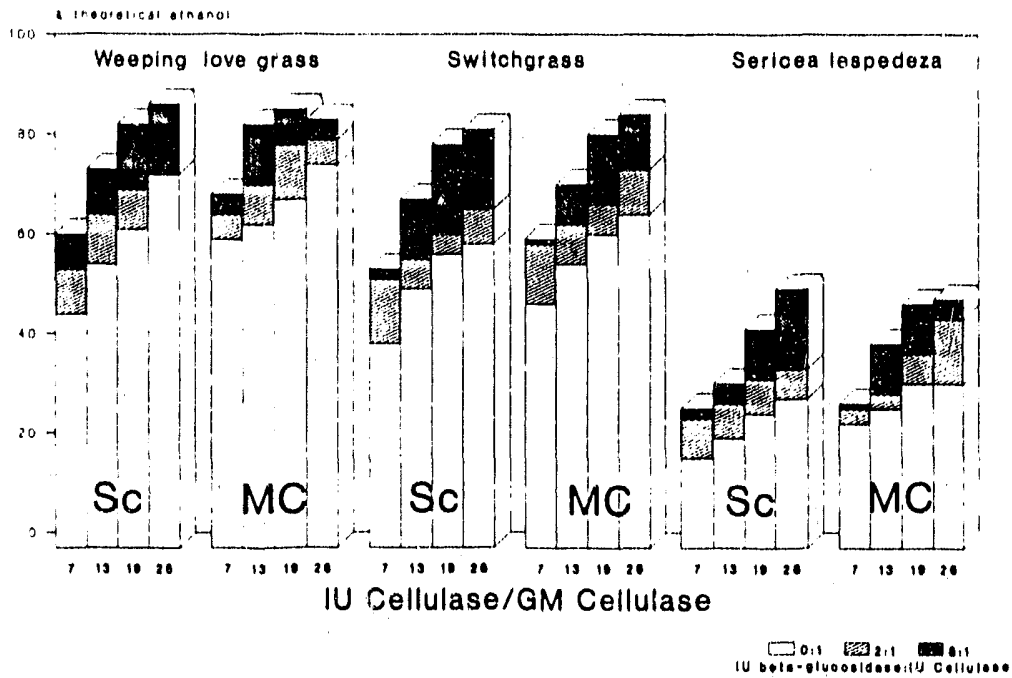

Figure 2. Final theoretical ethenol ylelds for herbaceous crops at varlous cellulase loadings per gram of $7.5 \%$ cellulose with and without $\beta$-glucosidase suppleinentation for both the single culture of $S$. corevislae (SG) and the mixed culture (MC) of S. cerevislae and B. clausenll at $37^{\circ} \mathrm{C}$.

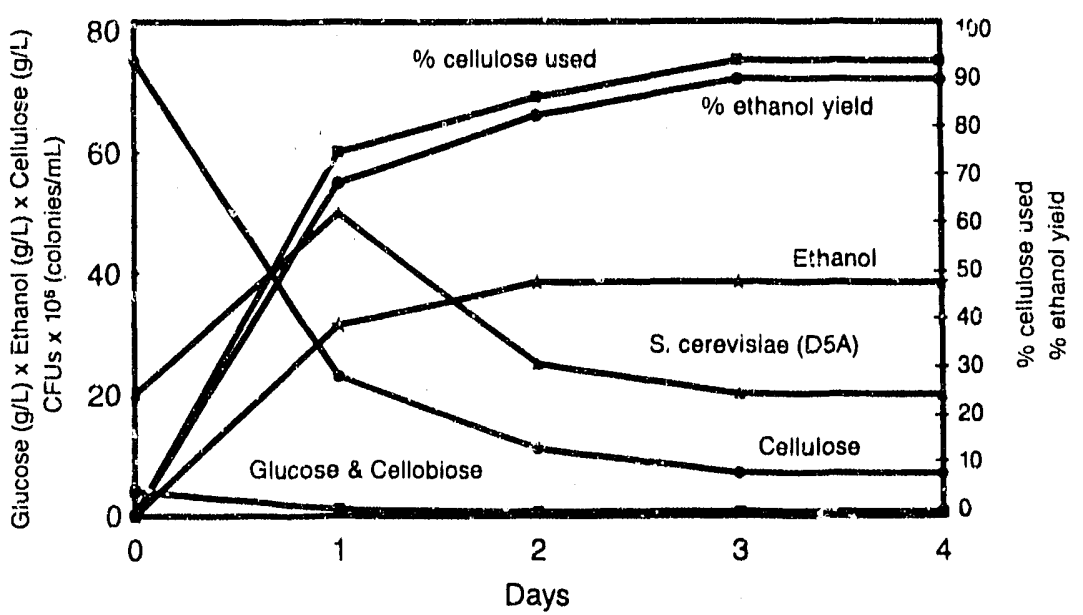

Flgure 3. Detalled fermentation study with weoping love grass at an enzyme loading of 26 IU cellulase/g cellulose and an 8:1 ratlo of $\beta$-glucosidase 'o ceilulase (IU/IU). This SSF was performed at $37^{\circ} \mathrm{C}$ with $S$. cerevisiae and $7.5 \%$ cellulose.

\section{Conclusions}

Without $\beta$-glucosidase supplementation, the overall rates and yields were better for the mixed culture than for $S$. cerevisiae because of the additional $\beta$-glucosidase activity produced by $B$. clausenil. However, $S$. cerevisiae performed about the same with substantial $\beta$-glucosidase addition and high cellulose loadings. These results point out the benefit of providing proper $\beta$-glucosidase levels to prevent accumulation of the powerful inhibitor cellobiose. Thus, the use of a mixed culture of a cellobiose-fernenting organism 


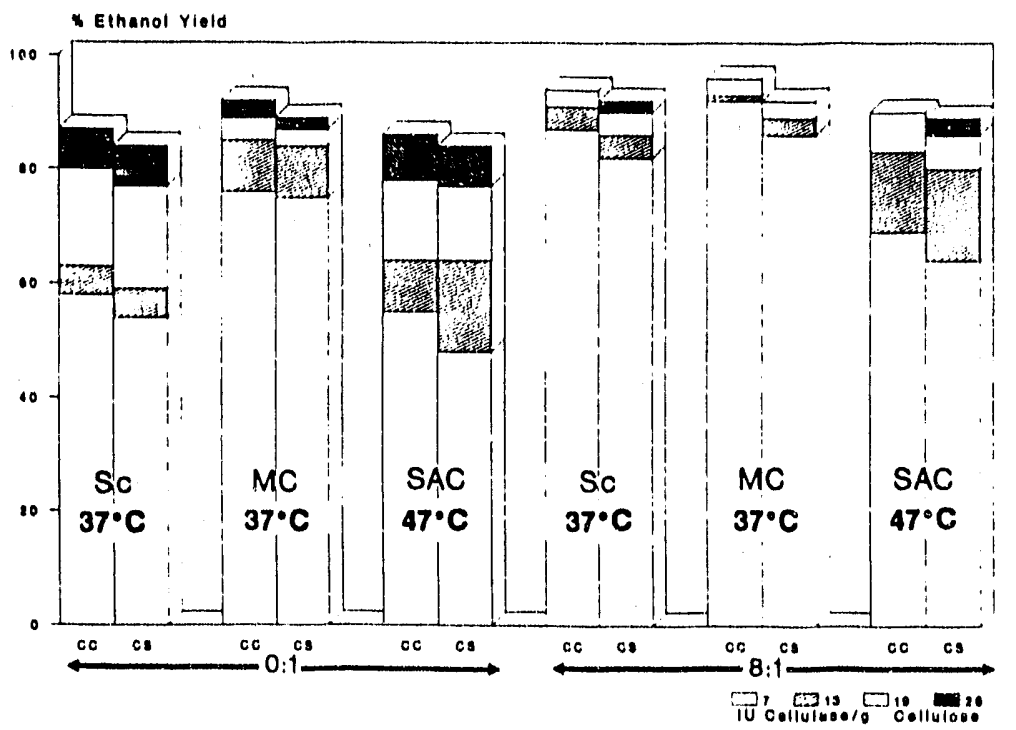

Figure 4. Final percent theoretical ethanol ylelds for SSFs of corn cobs and stover performed with S. cerevislae (SC) and the mixed culture of S. cerevislae and B. clausenil (MC) at $37^{\circ} \mathrm{C}$, and final percent saccharlfications without fermentation (SAC) at $45^{\circ} \mathrm{C}$. The substrate concentration is $7.5 \%$ cellulose from corn cob (cc) and corn stover (cs) with selected cellulase enzyme loadings, and with (8:1) and without (0:1) $\beta$-glucosidase supplementation.

with an ethanol-tolerant strain or supplementation of the enzyme broth with $\beta$-glucosidase will continue to be desirable for obtaining high yields until a cellulase enzyme is developed that has higher $\beta$ glucosidase activity or is less inhibited by cellobiose.

From our data, we can conclude that weeping love gras ${ }^{n}$, switchgrass, corn cobs, and corn stover respond well to dilute acid pretreatment, ac'ieve fast enzymatic hydrolysis rates, and give high ethanol yields by the SSF process. The legume Sericea lespedeza did not respond as well to the dilute acid pretreatment conditions used for the other two grasses, and the conversion of cellulose to sugars or ethanol was much less for this substrate. However, it may be possible to increase the yields by alteration of the pretreatment condition.

\section{Acknowledgments}

We would like to thank ORNL, manager of the DOE Biomass Production Program, and D. Parrish, P. Sullivan and S. Nagle from Virginia Polytechnic Institute and State University for providing the herbaceous crops. Also, R. Torget and P. Walter from SERI should be recognized for dilute acid pretreatment of these crops. This research was supported by the DOE Ethanol from Biomass Program of the MRE. Biofuels Systems Division and the DOE Western Regional Biomass Program, managed by the Western area Power Administration. 

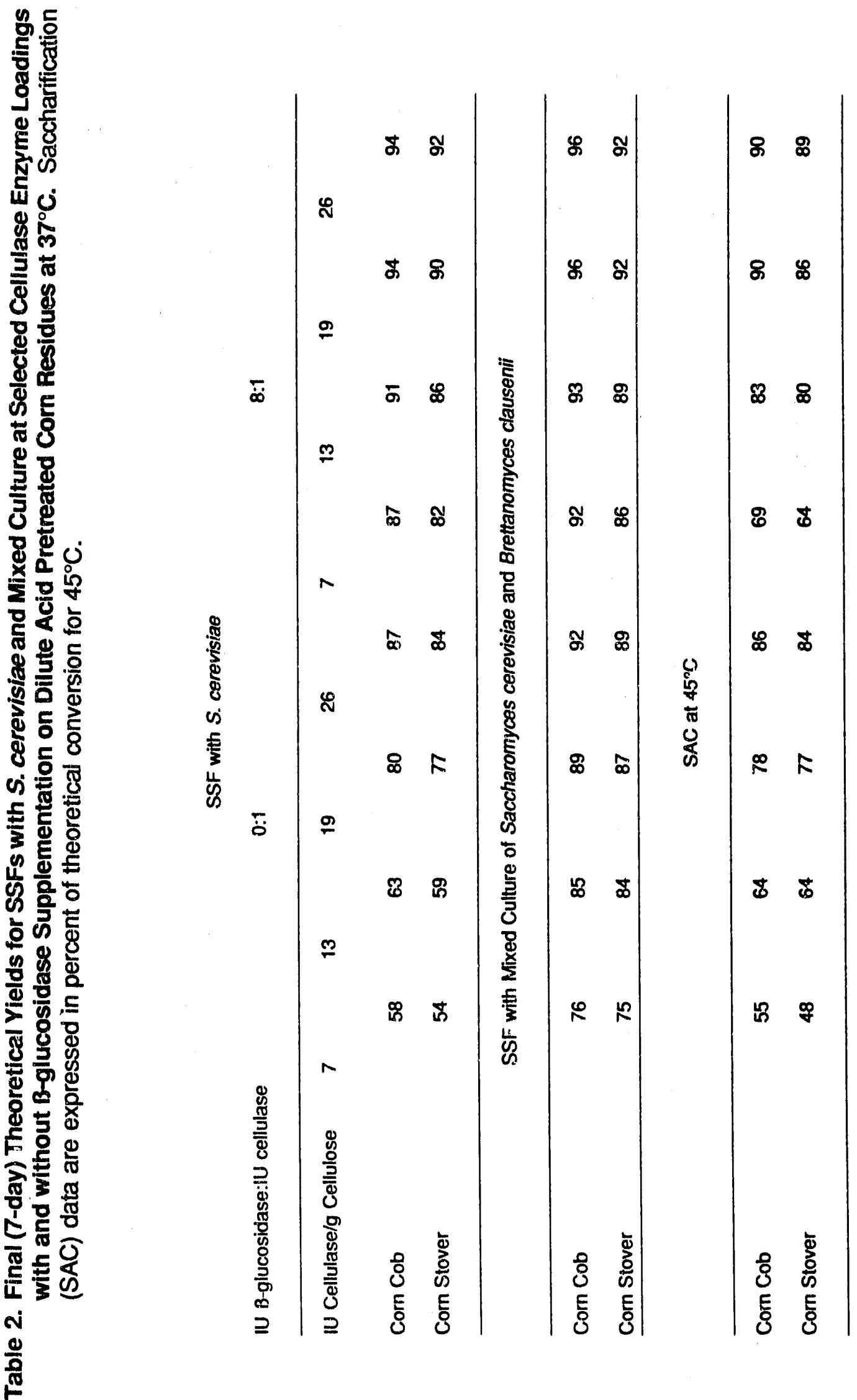


\section{References}

Bagby, M.O., and Widstrom, N.W. 1987. "Biomass Uses and Conversions." In Corn Chemistry and Technology, ed. S. A. Watson. 20:575.

Blotkamp, P.J., Takagi, M., Femberton, M.S., and Emert, G.H. 1978. The American Institute of Chemical Engineers 85-90.

Detroy, R.W., Lindenfelser, L.A., Sommer, S., and Orton, W.L. 1981. Biotechnol. Bioeng, 23:1527-1535.

Freer, S.N., and Detroy, R.W. 1983. Biotechnol. Bioeng. 25:541-557.

Ghose, T.K. 1987. Biochemical Engint ering Centre, Indian Institute of Technology 59:257-268 IUPAC.

Gosh, P., Pamment N.B., and Martin W.R.B. 1982. Enzyme Micro. Tech. 4:425-430.

Gonde, P., Blondin, B., Ratomahenina, R., Amaud, A., and Galzy, P. 1982. J. Ferm. Technol. 60/6:579584.

Gonde, P., Glondin, B., Leclerc, M., Ratomahenina, R., Arnaud, R., and Galzy, P. 1984. Appl. Environ. Microbiol. 265-269.

Howell, J.A. 1978. Biotechnol. Bioeng. 20:847-863.

Janssen, J.H., Burris, N., Woodward, A., and Bailey, R.B. 1983. Appl. Environ. Microbiol. 598-602.

Katzen, R., Fredrickson, R.E., Kaupisch, K.F., and Yeats, C.E. 1983, J. Appl. Poly. Sci.: Appl. Poly. Symp. 37:787-795.

Lastick, S.M., Spindler, D.D, and Grohmann, K. 1983. "Fermentation of Soluble Cello-oligosaccharides by Yeasts," In Wood and Agricultural Residues, 239, ed. E. J. Soltes.

Lastick, S.M., Spindler, D.D., Terrel, S., and Grohmann, K. 1984. Biotechnol. 84: 277-289.

Rivers, D.B., Zanin, G.M., and Emert, G.H. 1984. Proc. Arkansas Acad. Sci. 38:95-96.

Saddler, J.N., Mes-Hartree, M., Yu, E.K.C., and Brownell, H.H. 1983. Biotechnol. and Bioeng. Symp. 13:225-238.

Spindler, D.D., Wyman, C.E., Mohagheghi, A., and Grohmann, K. 1987. Biotechnol. Bioeng. 18:279-294

Spindler, D.D., Wyman, C.E., and Grohmann, K. 1988. Accepted For publication in Biotechnol. Bioeng.

Spindler, D.D., Wyman, C.E., Grohmann, K., and Mohagheghi, A. 1989. Biotechnol. Bioeng. 19:2021.

Spindler, D.D, Wyman, C.E., and Grohmann, K. 1990. Biotechnol. Bioeng. 35.

Szczodrak, J., and Targonski, Z. 1988. Biotechnol. Bioeng. 31:300-303. 
Takagi, M., Abe, S., Suzuki, S., Emert, G.H., and Yata, N. 1977. "A Method for Production of Alcohol Directly from Cellulose Using Cellulase und Yeast." In Proc. Bloconv. Symp., 551-571. Delhi: IIT.

Wyman, C.E., Spindler, D.D., Grohmann, K., and Lastick, S.M. 1986. Biotechnol. Bioeng. 17:221-238. 


\title{
Development of a Preliminary Mathematical Model for the Conversion of Cellulose to Ethanol
}

\author{
G. P. Philippidis \\ Biotechnology Research Branch \\ Fuels and Chemicals \\ Research and Engineering Division \\ Solar Energy Research Institute \\ Golden, Colorado 80401
}

\begin{abstract}
The conversion of cellulose is the heart of the ethanol production pro/ess, because it determines the yield, concentration, and synthesis rate of ethanol. This single step iavolves a complex combination of heterogeneous and homogeneous biocatalytic reactions that carry or i the simultaneous saccharification and fermentation (SSF) of lignocellulosic biomass.

In this activity, SSF was analyzed into its major steps and a preliminary mathematical model was formulated. The quality of the substrate and enzyme and the modes of substrate-enzyme and enzymemicroorganism interaction were identified as the key factors in SSF. Hence, the structure of lignocellulose, the intrinsic kinetic properties of the enzymes, the inhibitory effects of cellobiose, glucose, and ethanol on enzyme activity, and the adsorptive loss of enzyme to lignin, were taken into consideration in the model.

Based on these factors, kinetic expressions were developed for the adsorption of cellulase to cellulose, the cellulose hydrolysis to cellobiose, the hydrolysis of cellobiose to glucose by B-glucosidase, the uptake of glucose by the fermentative organism, and the formation of ethanol. Critical experimentation will lead to determination of the parameter values describing these steps, and SSF kinetic data will allow the validity of the model to be examined. The model will then serve as a tool for rational SSF improvement and commercialization.
\end{abstract}

\section{Introduction}

The oil crises of the 1973-1979 period and the recent turmoil in the Persian Gulf have served as reminders of the vulnerability of the U.S. economy to fluctuations in the oil market, because of its heavy dependence on foreign fuels. Hence, considerable attention has been focused on the strategic importance of domestic renewable resources and the need for development of technology to produce alternative fuels that will replace or supplement gasoline. Lignocellulosic biomass (deciduous and coniferous woods, grasses, and agricultural residues) is the most abundant renewable resource on earth. As a result, the use of 
lignocellulosics as a feedstock for the production of alternative fuels, such as ethanol, is a subject of continuing interest.

Lignocellulosic biomass consists primarily of cellulose, hemicellulose, and lignin, typically at an approximate 50:25:25 weight ratio. Although rich in carbohydrates, lignocellulose is an insoluble substrate with a complex structure, which makes efficient conversion into fermentable sugars and subsequently into ethanol difficult. In a simplified representation, lignocellulose can be depicted as a network of cellulose embedded in a sheath of hemicellulose and lignin (Fan et al. 1980b). Bondings among cellulose chains present additional constraints for the hydrolysis of cellulose to sugars.

After years of research, the biochemical conversion of lignocellulose to ethanol using cellulase enzymes and fermentative organisms has prevailed among relevant technologies. In particular, the integration of cellulose hydrolysis to sugars and sugar fermentation to ethanol into a single step (simultaneous saccharification and fermentation or SSF) has greatly enhanced the kinetics of biomass conversion and turned it into an economically promising process (Wright et al. 1988). This is primarily because of circumvention of enzyme inhibition by hydrolysis products, since they are consumed by the fermenting organism. As a result, yields and rates are improved and ethanol concentration is higher. Also, less capital equipment is required because the conversion takes place in one step instead of two. Furthermore, the presence of ethanol reduces the risks of contamination by undesirable organisms.

Five major steps are employed in lignocellulose bioconversion technology (Figure 1):

(1) Pretreatment of lignocellulose, using chemical or mechanical means to disrupt its structure and rencier it more accessible to enzymatic attack

(2) Enzyme production using cellulase-secreting organisms, such as fungi or bacteria

(3) Fermentation using bacteria or yeasts to convert xylose, derived from hemicellulose during pretreatment, into ethanol

(4) SSF, which is the simultaneous hydrolysis of cellulose to cellobiose by cellulase, breakdown of cellobiose to glucose by B-glucosidase, and fermentation of glucose to ethanol by yeasts or bacteria

(5) Ethanol recovery from the SSF effluent.

SSF is at the center of the conversion process because it determines the rate and yield of cellulose conversion to ethanol, as well as the concentration of ethanol for product recovery. The importance of its performance is underlined by the significant contribution of SSF to the capital cost of the bioconversion process, which exceeds 25\% (SERI 1990) (Figure 2). It becomes, therefore, imperative to understand the kinetics of SSF and express quantitatively the dependence of its rate on variables that can be manipulated. This task can be realized in a comprehensive and rational way by developing a mathematical model that conceptualizes the performance of SSF. Through the model, issues of major importance, such as the conversion rate and yield of ethanol production from cellulose as a function of enzyme loading, ethanol concentration, mode of operation, and composition of different feedstocks, can be systematically addressed.

The kinetics of SSF depend mainly on four factors: (1) quality and quantity of the lignocellulosic substrate, (2) quality and quantity of the cellulase and B-glucosidase enzyme system, (3) mode of interaction between substrate and enzyme, and (4) mode of interaction between enzyme and fermentative organism. The structural characteristics of the substrate determine the accessibility of lignocelluluse to enzymatic degradation. The quality of the enzyme system affects the activity of its components, as they hydrolyze cellulose in a cooperative mode. The interaction of the enzyme with the substrate regulates the extent of enzyme adsorption on the substrate and hence the rate of this heterogeneous reaction. Finally, the interaction of the ethanol-producing organism with the enzyme influences the growth kinetics of the 


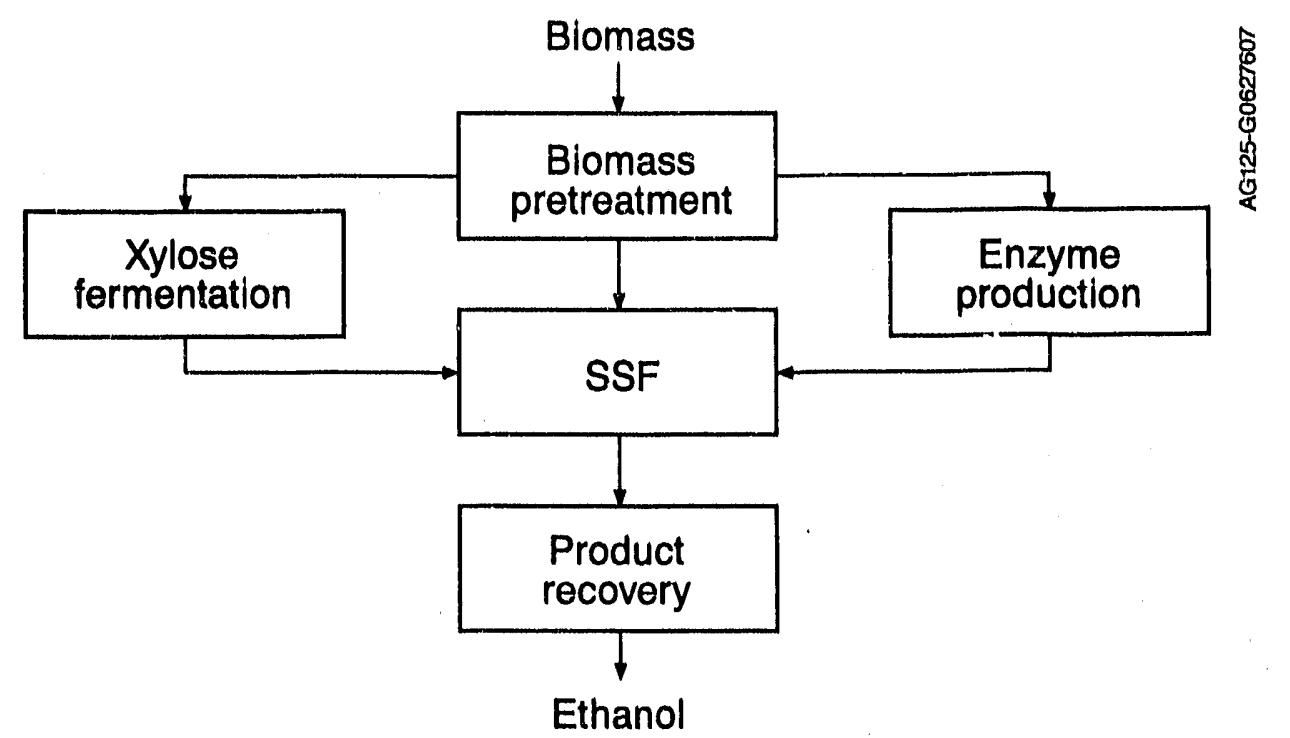

Flgure 1. Schematic overvlew of the blomass-to-ethanol converslon process

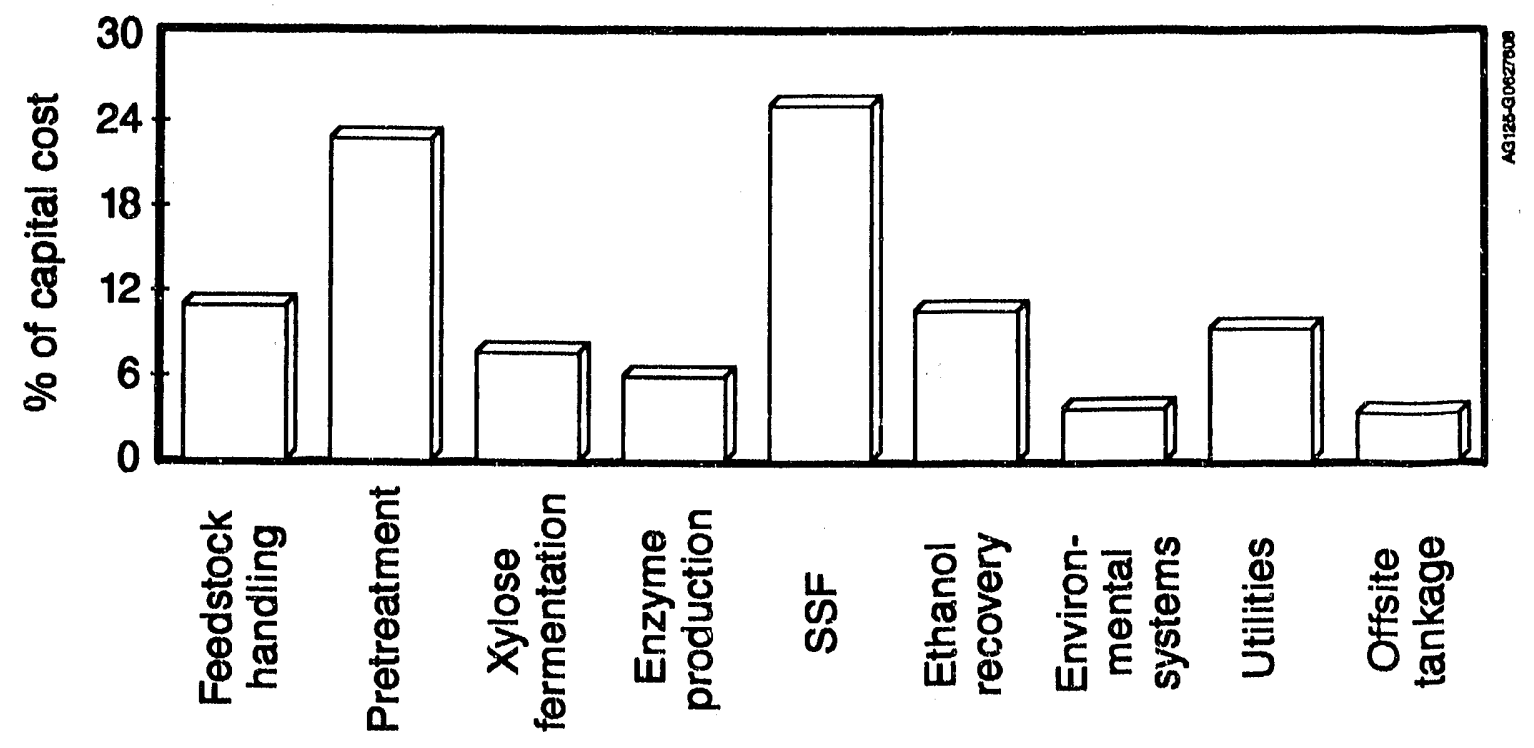

Figure 2. Breakdown of the flxed capltal cost of a blomass-to-ethanol conversion plant 
cells and their ethanol productivity, as well as the potential inhibitory effect of the hydrolysis products (cellobiose, glucose) and ethanol on enzyme activity.

Cellulose hydrolysis kinetics has been the subject of extensive research, and several mathematical models have been proposed to date. Some models have been based on empirical formulations (King 1966; Ghose 1969; Chiang 1979; Holtzapple et al. 1984b), mass transfer considerations (Ross and Updegraff 1971), depolymerization kinetics (Okazaki and Moo-Young 1978; Lee et al. 1978), Michaelis-Menten kinetics with product inhibition (Howell and Stuck 1975; Peitersen and Ross 1979; Beltrame et al. 1984), enzyme adsorption kinetics (Wald et al. 1984; Converse and Grethlein 1987), enzyme deactivation (Howell and Mangat 1978), enzyme adsorption and deactivation (Converse et al. 1988), a combination of MichaelisMenten with product inhibition and enzyme adsorption kinetics (Huang 1975; Holtzapple et al, 1984a; Asenjo et al. 1986), substrate structure considerations (Humphrey 1979; Ryu et al. 1982; Sattler et al. 1989), and a combination of substrate structure and enzyme adsorption considerations (Fan and Lee 1983). However, only a few of these researchers have attempted to model hydrolysis and fermentation of cellulose as an integrated process (Peitersen and Ross 1979; Asenjo et al. 1986). Although several of the proposed models are to some extent successful in describing the kinetics of cellulose hydrolysis, their validity is limited to certain hydrolysis systems and conditions. This is primarily due to the fact that all four factors affecting SSF kinetics, as outlined in the previous paragraph, have not been taken into consideration.

The objective of this work is to identify and analyze the steps of the SSF process and develop a preliminary mathematical representation of its kinetics. Such an analysis will lead to the formulation of a descriptive and predictive model for the conversion of cellulose to ethanol. The model, based on mathematical expressions describing the physical and chemical phenomena of the SSF process, will provide valuable insight into key interactions and rate limitations in SSF. Thus, it will allow simulation of the behavior of the system under variable conditions and serve as a guide for rational improvement and scale-up of the bioconversion process.

\section{Cellulose and Cellulase}

Cellulose is an insoluble, high-molecular-weight, linear polymer of D-glucose residues linked by B-1,4-glucosidic bonds. The degree of polymerization of native celluloses varies between 3,500 and 10,000 (Reese et al. 1972). Cellulose chains, held together by hydrogen bonds among hydroxyl groups of adjacent molecules and van der Waals forces, form elementary fibrils (protofibrils) approximately $4 \mathrm{~nm}$ wide, $3 \mathrm{~nm}$ thick, and $10 \mathrm{~nm}$ long (Fan et al. 1980b). Several protofibrils, in turn, associated together by hemicellulose (a xylose polymer) form microfic ' $1 \mathrm{~s}$, approximately $25 \mathrm{~nm}$ wide (Fan et al. 1980b). Lamellae of microfibrils are surrounded by layers of lignin (a phenylpropane polymer) and hemicellulose that protect cellulose from enzymatic attack. Microfibril regions of dense interchain bonding form crystalline areas, whereas other regions have less ordered structure (smaller degree of crystallinity).

Cellulases are enzymes that have the ability to degrade cellulose and perform a crucial function in the SSF process by catalyzing the hydrolysis of cellulose to soluble carbohydrates. In reality, cellulase is not a single enzyme but a multicomponent enzyme system with variable composition depending on its source. In general, fungal cellulases are often represented as three major components: 1,4-ß-D-glucan glucanohydrolase (endoglucanase), 1,4-B-D-glucan cellobiohydrolase (exoglucanase), and $\beta$-D-glucoside glucohydrolase (ß-glucosidase). The three components are believed to function synergistically. A generally accepted enzymatic mechanism distinguishes the actions of the three components slich that endoglucanase attacks $\beta$-1,4-glucosidic bonds randomly, creating shorter-length cellulose chains; exoglucanase attacks these chains at the nonreducing termini, generating celloblose residues; and B-glucosidase cleaves cellobiose to form glucose units (Eveleigh 1987). 


\section{Model Description}

Based on this mechanism of cellulase action, the following model was developed for the conversion of cellulose into ethanol (Figure 3 ). Cellulase $\left(E_{1}\right)$, assumed to consist of only endoglucanase and exoglucanase, adsorbs onto the solid lignocellulosic substrate. The adsorption is followed by degradation of cellulose $(C)$ to shorter-length polysaccharide chains through the action of endoglucanase $\left(E_{1 \mathrm{a}}\right)$ and hydrolysis of these chains to cellobiose $(B)$ by exoglucanase $\left(E_{1 b}\right)$. However, because the concentration of the insoluble intermediate sugars cannot be determined experimentally, the reaction scheme is further simplified to direct conversion of cellulose to cellobiose. Cellobiose diffuses into the aqueous phase, where B-glucosidase $\left(E_{2}\right)$ catalyzes its hydrolysis to glucose $(G)$. Glucose is taken up by the yeast cells to serve as carbon/energy source and lead to production of ethanol $(E)$, as the major metabolic product, and cell mass $(\mathrm{X})$.

The model is hased on the following assumptions:

(1) Cellulase consists of endoglucanase and exoglucanase, but no distinction is made between the actions of the two components because there are no accurate analytical procedures to determine their mass ratio in cellulase.

(2) Cellulose is hydrolyzed to cellobiose by cellulase with negligible formation of glucose.

(3) Cellulase and B-glucosidase are exogenously added to the SSF fermenter, as is the common practice.

(4) The pH during the SSF does not vary considerably, thus having no effect on enzyme activity and cell growth.

(5) Ethanol and carbon dioxide are the major metabolic products of the organism employed.

(6) The growth medium provides all other nutrients, except for carbon source; the concentration of these nutrients is high enough to allow growth to be limited by the carbon source (glucose) derived from cellulose.

This model is not restricted to any particular SSF system or conditions. The substrate is assumed to be any lignocellulosic or celluiosic material and the enzymes can be any cellulase and B-glucosidase. The microorganism employed for fermentation can be any organism that grows on glucose and produces ethanol.

\section{Model Formulation}

Because cellulose is an insoluble substrate, the enzyme needs to adsorb on its surface to promote hydrolysis. Therefore, the hydrolysis of cellulose to cellobiose is a heterogeneous reaction of a solid reactant in an aqueous phase. Similarly, the production of ethanol by the cells is a heterogeneous reaction that requires the transfer of glucose across the cellular envelope to the metabolic enzymes in the cytoplasm. In contrast, the hydrolysis of cellobiose to glucose by B-glucosidase, is carried out in solution. Thus, the conversion of cellulose to ethanol presents a complex combination of heterogeneous and homogeneous catalyses, with strong interdependence: the product of cellulose hydrolysis is the reactant for the subsequent B-glucosidase action, and the product of this reaction serves as the substrate for cell metabolism. Because it has been well documented that cellobiose and glucose are inhibitors of cellulases (Holtzapple et al. 1990) and B-glucosidases (Beltrame et al. 1983), accumulation of any intermediate as a result of lack of coordination among the three catalysts will have a deleterious effect on the overall process. 


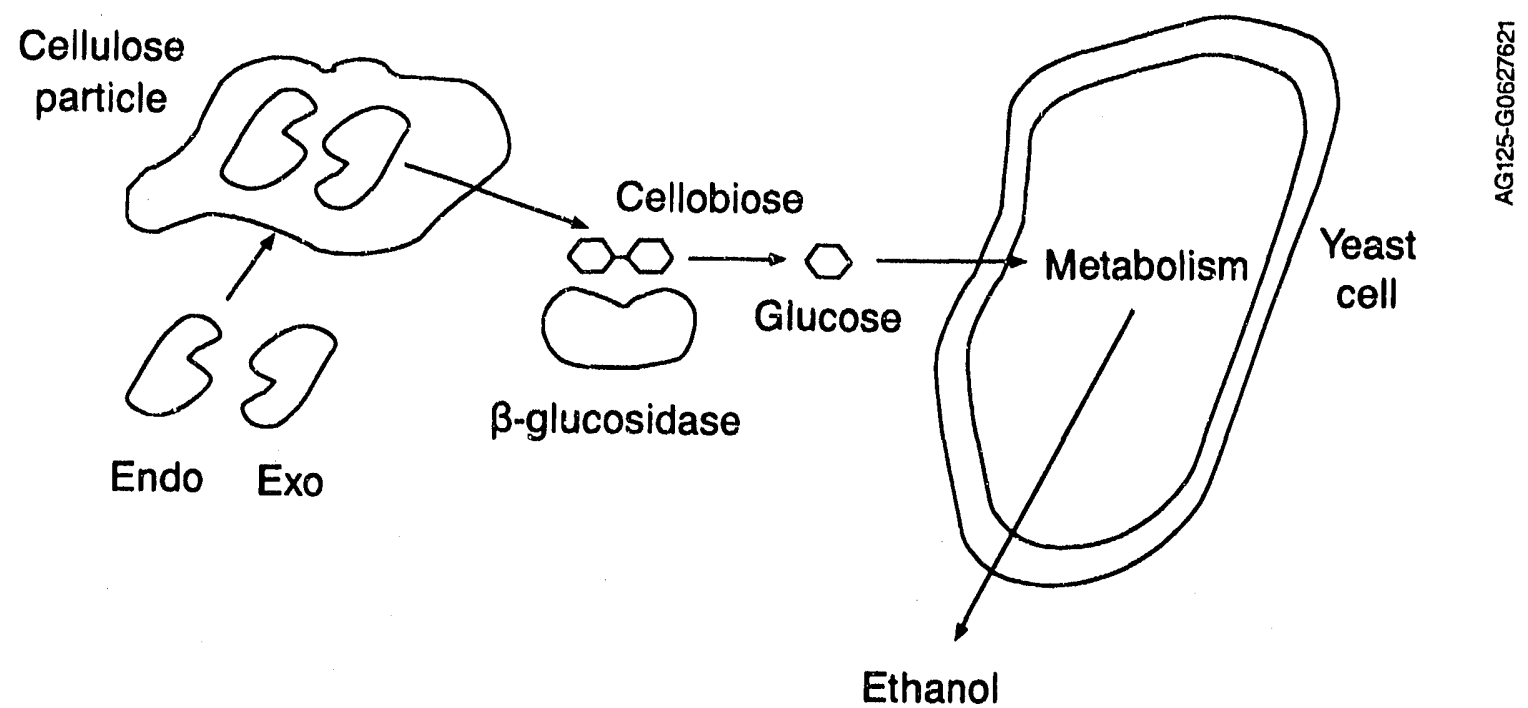

Flgure 3. Sch6matic representation of the SSF conversion steps

The complexity of the SSF reaction sequence makes its mathematical representation a challenging task. To develop a comprehensive model, it is imperative to identify and analyze the steps that compose the cellulose-to-ethanol conversion process (Figure 3):

(1) Cellulase diffusion toward the cellulose particles

(2) Adsorption of cellulase on the surface of cellulose

(3) Hydrolysis of cellulose to cellobiose catalyzed by cellulase

(4) Diffusion of cellobiose into the aqueous phase

(5) Hydrolysis of cellobiose to givcose catalyzed by B-glucosidase

(6) Diffusion of glucose toward the cells

(7) Uptake of glucose by the cells

(8) Glucose catabolism and ethanol synthesis

(9) Ethanol secretion into the aqueous phase.

\section{Enzyme and Product Diffusion}

Cellulases are large enzymes with an average diameter of $4 \mathrm{~nm}$ (Van Dyke 1972). Hence, the diffusivity of cellulase in the aqueous phase could be low and influence the rate of SSF. However, experimental studies in a $50 \mathrm{~g} / \mathrm{L}$ cellulose suspension have indicated that enzyme diffusion is rapid relative to the surface reaction catalyzed by cellulase (Lee and Fan 1982). Moreover, because cellobiose and glucose are much smaller molecules with high diffusivities in aqueous solutions (on the order of $10^{-5} \mathrm{~cm}^{2} / \mathrm{s}$ ), their diffusion should not be controlling the overall cellulose conversion rate. The same is expected for ethanol diffusion outside the cell. Therefore, no mass transfer limitations are considered in the proposed model. It should be mentioned, nevertheless, that high cellulose concentrations (exceeding $75 \mathrm{~g} / \mathrm{L}$ ) reduce significantly the fluidity of the suspension (Lee and Fan 1982) and may potentially create conditions of diffusion limitations. Such conditions need to be investigated. 


\section{Cellulase Adsorption to Cellulose}

Because cellulose hydrolysis is a heterogeneous reaction, its rate will depend on the extent of cellulase adsorption on its surface. It is believed that the cellulase components, endoglucanase and exoglucanase, adsorb to cellulose at the same proportion (Ooshima ct al. 1990), whereas B-glucosidase remains in the aqueous phase (Ooshima et al. 1983). Previous studies have shown that enzyme adsorption to cellulose is fast compared to the cellulose hydrolysis rate, reaching its maximum within 2 min (Lee and Fan 1982). The initial extent of enzyme adsorption $\left[\mathrm{E}_{1}\right]_{0}^{*}$ depended on the initial cellulose concentration $[\mathrm{C}]_{0^{\prime}}$ followed Langmuir adsorption kinctics, and exhibited a linear relationship with the initial free enzyme concentration $\left[\mathrm{E}_{1}\right]_{0}$ (Lee and Fan 1982). In contrast, another study showed a Langmuir-type dependence of $\left[\mathrm{E}_{1}\right]_{0}^{*}$ on $\left[\mathrm{E}_{1}\right]_{0}$, using a broader range of enzyme concentration (Wald et al. 1984; Ooshima et al. 1990). Furthermore, the initial adsorbed enzyme concentration $\left[\mathrm{E}_{1}\right] 0$ also depends on the initial surface area of the substrate $a_{0}$. The concentration $\left[E_{1}\right]_{0}^{*}$ was found to increase linearly with $a_{0}$ in all the above cited references.

Taking all this information into account, the dependence of the initial adsorbed enzyme concentration $\left[E_{1}\right]_{0}^{*}$ on the initial available cellulose surlace area $\left(a_{0}\right)$, initial enzyme concentration $\left(\left[E_{1}\right]_{0}\right)$, and initial substrate concentration $\left([\mathrm{C}]_{0}\right)$ can be depicted by Equation (1):

$$
\left[\mathrm{E}_{1}\right]_{0}^{*}=\frac{\eta \mathrm{a}_{0}\left[\mathrm{E}_{1}\right]_{0}[\mathrm{C}]_{0}}{\mathrm{~K}_{\mathrm{a}}+\left[\mathrm{E}_{1}\right]_{0}+[\mathrm{C}]_{0}}
$$

where $\eta$ and $K_{a}$ are model parameters.

As the hydrolysis reaction continues, however, desorption of the enzyme on a volumetric basis is observed, although the amount of enzyme per mass unit of cellulose (specific adsorption) remains unaffected (Lee and Fan lyc 3$)$. The decrease in $\left[E_{1}\right]^{*}$ over time can be attributed to the consumption (hydrolysis) of cellulose and the concomitant decrease of available surface area a. On the other hand, the specific adsorption does not change, since the affinity of cellulase for cellulose remains constant. The change in $\left[\mathrm{E}_{1}\right]^{*}$ over time is described by Equation (2):

$$
\left[\mathrm{E}_{1}\right]^{*}=\left[\mathrm{E}_{1}\right]_{0}^{*}\left(\frac{\mathrm{a}}{\mathrm{a}_{0}}\right)
$$

The available surface area is calculated from the pore volume accessible to dextran molecules of diameters similar to that of cellulase (Grethlcin 1985), using the solute exclusion technique (Sione and Scallan 1968). This method, however, only measures the surface area of the pores (internal surface area) of the cellulose particles, leaving their external surface area unaccounted for. If the cellulose particles are depicted as spheres, then the external surface area of cellulose is proportional to the two-thirds power of its concentration (Wald et al. 1984). Consequently, a combination of external and internal surface area will represent more accurately the total available surface area, a, of cellulose for enzyme adsorption. Still, the available surface area a is not readily measurable and researchers to date have attempted to develop empirical correlations between a and [C]. Such studies have proposed that a is proportional to [C] (Fan and Lee 1983) or to the square power of [C] (Converse et al. 1988). The dependence of a on [C] may vary among different cellulose substrates and may be affected by the pretreatment conditions to which the substrate has been subjected. 'Therefore, it becomes cvident that an experimental study needs to be carried out for each substrate, if the surface area is to be expressed as a function of residual cellulose concentration during the course of SSF. 
In addition to cellulose, lignocellulosic biomass contains lignin. Cellulase and B-glucosidase tend to adsorb to lignin, with the extent of adsorption being affected by the nature of lignin (Sutcliffe and Saddler 1986). It has been reported that cellulase and B-glucosidase adsorb to lignin at similar proportions and the adsorption is practically irreversible (Ooshima et al. 1990). Because the enzyme molecules that adsorb to lignin become unavailable for hydrolysis, adsorption effectively inactivates a portion of cellulase and B-glucosidase, thus reducing the concentrations of the two enzymes $\left[E_{1}\right]^{*}$ and $\left[E_{2}\right]$. $A$ Langmuir relationship has been proposed between the initial amount of enzyme adsorbed on lignin and the initial enzyme concentration (Ooshima et al. 1990). Furthermore, a linear dependence of adsorbed B-glucosidase on lignin concentration [L] has been demonstraied (Tatsumoto et al. 1988). Taking into consideration these reports of rapid and irreversible adsorption of the enzymes to lignin, $\left[\mathrm{E}_{1}\right]^{*}$ and $\left[\mathrm{E}_{2}\right]$ need to be multiplied by the corrections

$$
\begin{aligned}
& \text { For } \mathrm{E}_{1}: 1-\mathrm{K}_{1 \mathrm{~L}}[\mathrm{~L}] \\
& \text { For } \mathrm{E}_{2}: 1-\mathrm{K}_{2 \mathrm{~L}}[\mathrm{~L}]
\end{aligned}
$$

where $K_{1 L}$ and $K_{2 L}$ are model parameters, in order to calculate the concentrations of active $E_{1}$ and $E_{2}$. If the employed enzyme concentrations $\left[\mathrm{E}_{1}\right]_{0}$ and $\left[\mathrm{E}_{2}\right]_{0}$ do not saturate the adsorption capacity of lignin, then Langmuir adsorption functions also need to be included in Equations (3) and (4).

\section{Hydrolysis of Cellulose to Celloblose}

The initial rate of cellulose hydrolysis is expected to be proportional to the initial concentration of active adsorbed cellulase (Lee and Fan 1982; Converse et al. 1988). This rate has reportedly exhibited a strong linear dependence on the initial crystallinity of cellulose, determined by $x$-ray diffractometry, and a rather weak dependence on the initial surface area of the substrate, when pure cellulose was employed (Fan et al. 1980a; Lee and Fan 1982). In contrast, Grethlein, using acid-pretreated hardwoods and softwoods, has reported a strong linear correlation between initial hydrolysis rate and initial substrate surface area, while substrate crystallinity had no effect (Grethlein 1985).

For extended time periods of cellulose hydrolysis, it has been well documented that the rate of cellulose hydrolysis decreases rapidly with time (Lee and Fan 1983; Wald et al. 1984; Sattler et al. 1989). This rate decrease may be due to several factors. Among those suggested, structural features of cellulose (increasing crystallinity and decreasing available surface area) and enzyme inhibition and inactivation have been considered by several researchers. Experimental data have shown that the digestibility of cellulose decreases rapidly during the course of hydrolysis, and it has been postulated that the decrease was caused by changes in the crystallinity and available surface area of the substrate (Lee and Fan 1983). In their modeling work, these researchers employed a rclative digestibility factor to account for the effect of structural transformations of the substrate on the rate of hydrolysis (Fan and Lee 1983). Other reports have attributed the decrease of the hydrolysis rate to the decreasing available surface area (Grous et al. 1986; Converse et al. 1990) or both the surface area and enzyme inhibition by the products of hydrolysis (Wald et al. 1984), since accumulation of cellobiose and glucose during SSF may inhibit the activity of cellulase. Although both compounds have been found to inhibit the rate of cellulose hydrolysis, with cellobiose being a stronger inhibitor (Lee and Fan 1983; Holtzapple el al. 1990), the mode of inhibition seems to vary among cellulases from different sources (Holtzapple et al. 1990). Moreover, enzyme deactivation (Converse et al. 1988), enzyme desorption from cellulose in the presence of cellobiose or glucose (Lee and Fan 1983), and cellulase inhibition by etianol (Holtzapple et al. 1990) may also result in a decrease of the cellulose hydrolysis rate. Conceivably, increased crystallinity slows down the specific rate of the hydrolysis reaction, decreased surface area decreases the concentration of active adsorbed 
enzyme that can initiate hydrolysis, and product inhibition/deactivation decreases the activity of the enzyme.

From the above information, it becomes evident that the degree of contribution of substrate crystallinity, available surface area, and enzyme inhibition/deactivation to the observed decrease of cellulose hydrolysis rate remains uncertain and may even depend on the identity of the substrate and the pretreatment method employed. In view of this, a substrate reactivity coefficient $\phi$ is introduced in the model to account for the experimentally noticed decrease in substrate digestibility and distinguish it from changes in the available surface area of cellulose, which was taken into account in Equation (2), and enzyme inhibition. The parameter $\phi$ is time-dependent and is defined as the ratio of cellulose hydrolysis rate at the time point of interest during SSF to the initial hydrolysis rate of the same substrate, each normalized to iive respective available surface area. Thus, at the initiation of the SSF the value of substrate reactivity is equal to unity $\left(\phi_{0}=1\right)$. Because $\phi$ may vary among lignocelluloses of different origins, it would be useful to establish a relationship between $\phi$ and the residual cellulose concentration [C].

Taking $\phi$ into account, as well as noncompetitive inhibition of cellulase by cellobiose (B), glucose (G), and ethanol (E) (Holtzapple et al. 1990), the rate of cellulose hydrolysis to cellobiose, $r_{1}$, is expressed by Equation (5):

$$
r_{1}=\frac{k_{1} \phi\left[E_{1}\right]^{*}}{1+\frac{[B]}{K_{1 B}}+\frac{[G]}{K_{1 G}}} \cdot \frac{K_{1 E}}{K_{1 \mathrm{E}}+[E]}
$$

where $k_{1}$ is the specific rate of cellulose hydrolysis and $\mathrm{K}_{1 \mathrm{~B}}, \mathrm{~K}_{1 \mathrm{G}}$, and $\mathrm{K}_{1 \mathrm{E}}$ are the inhibition constants of cellulase for cellobiose, glucose, and ethanol, respectively.

\section{Celloblose Hydrolysis to Glucose}

In contrast to cellulase, B-glucosidase does not seem to adsorb to cellulose (Ooshima et al. 1990). It remains in the aqueous phase, where it catalyzes the hydrolysis of cellobiose to glucose, thus preventing accumulation of cellobiose, which is a strong inhibitor of cellulase as mentioned earlier. It has been reported that the action of Trichoderma reesei B-glucosidase is inhibited by its substrate cellobiose (Hong et al. 1981) and is also competitively inhibited by its product glucose (Hong et al. 1981; Lee and Fan 1983). The same observation was made with crude B-glucosidase from Aspergillus niger; interestingly, product inhibition followed a noncompetitive mode for purified $A$. niger B-glucosidase (Beltrame ct al. 1983).

Adsorption of B-glucosidase to lignin has been reported (Tatsumoto et al. 1988; Ooshima et al. 1990). The adsorption, which seems to be irreversible (Ooshima et al. 1990), decreases the concentration of active B-glucosidase in solution and thus the rate of cellobiose hydrolysis. The extent of adsorption followed Langmuir kinetics with regard to enzyme concentration (Ooshima et al. 1990), whereas it varied linearly with the lignin content of biomass (Tatsumoto et al. 1988).

Taking into consideration the homogeneous nature of the reaction, as well as substrate (B) and product $(G)$ inhibition of $B$-glucosidase $\left(E_{2}\right)$, the following expression is used in the model to describe the kinetics of cellobiose hydrolysis: 


$$
r_{2}=\frac{k_{2}\left[E_{2}\right]_{0}[B]}{K_{m}\left[1+\frac{[G]}{K_{2 G}}\right]+[B]\left[1+\frac{[B]}{K_{2 B}}\right]} \cdot \frac{K_{2 E}}{K_{2 E}+[E]}
$$

where $k_{2}$ is the specific rate of cellobiose hydrolysis; $K_{m}$ is the Michaelis constant of the enzyme for cellobiose; and $\mathrm{K}_{2 \mathrm{~B}}, \mathrm{~K}_{2 \mathrm{G}}$, and $\mathrm{K}_{2 \mathrm{E}}$ are the inhibition constants of B-glucosidase for cellobiose, glucose, and ethanol, respectively. The potential inhibitory effect of ethanol $(E)$ on the enzyme has been also included in Equation (6).

\section{Glucose Uptake and Fermentation to Ethanol}

Glucose, the product of cellulose hydrolysis by cellulase and B-glucosidase, serves as the carbon/energy source for the fermentative organism. It is transported by the active mechanism of the phosphotransferase system across the cellular envelope into the cytoplasm, where it enters the glycolytic pathway to be catabolized into metabolic intermediates and eventually cell mass $(\mathrm{X})$, with the concomitant synthesis of ethanol (E). Other metabolic products may also be synthesized, but they are considered negligible for ethanol-producing anaerobic organisms.

A Monod kinetic expression, which includes substrate $(G)$ inhibition, is used in the model to account for the dependence of microbial growth on the concentration of glucose present:

$$
\frac{d[X]}{d t}=\mu_{m} \frac{[G]}{K_{3}+[G]+[G]^{2} / K_{i}} \cdot \frac{K_{3 E}}{K_{3 E}+[E]}[X]-k_{d}[X]
$$

where $\mathrm{K}_{3}$ is the Monod constant for glucose (variable among organisms), $\mathrm{K}_{\mathrm{f}}$ is the substrate inhibition constant, and $\mathrm{K}_{\mathrm{SE}}$ is the inhibition constant of cell growth caused by ethanol. The last term of Equation (7) represents potential cell lysis, assumed to be proportional to the cell mass concentration present; $k_{d}$ is the specific rate of cell death. The maximal specific growth rate of an organism, $\mu_{m}$, when grown under glucose limitation, is believed to be determined by the maximal uptake rate of glucose by the cells (Button 1985).

The product (ethanol, E) formation rate is considered in the model to consist of a growth-associated and a nongrowth-associated term (Leudeking and Piret 1959) and also depends on the concentration of giıcose (G) according to Monod kinetics:

$$
\frac{\mathrm{d}[\mathrm{E}]}{\mathrm{dt}}=\left(\alpha \frac{\mathrm{d}[\mathrm{X}]}{\mathrm{dt}}+\beta[\mathrm{X}]\right) \frac{[\mathrm{G}]}{\mathrm{K}_{4}+[\mathrm{G}]}
$$

where $\alpha$ is the growth-associated ethanol formation constant, $\beta$ is the nongrowth-associated specific ethanol production rate, and $\mathrm{K}_{4}$ is the Monod constant for ethanol synthesis.

In addition to cell mass, a portion of the glucose taken up by the cells serves as source for cell maintenance and is considered proportional to the concentration of cell mass present (Pirt 1965). Then, the glucose utilization rate $r_{3}$ by the organism can be described by Equation (9): 


$$
r_{3}=\frac{1}{Y_{x / s}} \cdot \frac{d[X]}{d t}+m[X]
$$

where $\mathrm{Y}_{\mathrm{x} / \mathrm{s}}$ is the yield coefficient for cell mass on substrate (glucose) and $\mathrm{m}$ is the specific rate of substrate consumption for maintenance functions. The use of a constant $Y_{x / s}$ represents an implicit model assumption that cell mass yield from glucose remains essentially constant throughout the SSF course. It should also be emphasized that Equation (9) does not include an additional term of glucose consumption for the formation of ethanol, be:ause ethanol is a product directly associated with energy generation by the organism (Roels 1983).

\section{Model Summary}

A combination of Equations (1-6) and (9) gives rise to the kinetic expressions of the model for cellulose, cellobiose, and glucose utilization, as summarized below:

\section{Cellulose Utilization}

$$
\mathrm{r}_{1}=\frac{\mathrm{k}_{1} \phi \eta \mathrm{a}\left[\mathrm{E}_{1}\right]_{0}[\mathrm{C}]_{0}}{\left(\mathrm{~K}_{\mathrm{a}}+\left[\mathrm{E}_{1}\right]_{0}+[\mathrm{C}]_{0}\right)\left(1+\frac{[\mathrm{B}]}{\mathrm{K}_{1 \mathrm{~B}}}+\frac{[\mathrm{G}]}{\mathrm{K}_{1 \mathrm{G}}}\right)} \cdot \frac{\mathrm{K}_{1} \mathrm{E}}{\mathrm{K}_{1 \mathrm{E}}+[\mathrm{E}]}\left(1-\mathrm{K}_{1 \mathrm{~L}}[\mathrm{~L}]\right)
$$

\section{Celloblose UtIllzation}

$$
r_{2}=\frac{k_{2}\left[E_{2}\right]_{0}[B]}{K_{m}\left[1+\frac{[G]}{K_{2 G}}\right]+[B]\left[1+\frac{[B]}{K_{2 B}}\right]} \cdot \frac{K_{2 E}}{K_{2 E}+[E]}\left(1-K_{2 L}[L]\right)
$$

\section{Glucose Utilization}

$$
r_{3}=\frac{1}{Y_{x / s}} \cdot \frac{d[X]}{d t}+m[X]
$$

Based on these rate expressions, as well as Equations (7) and (8), the profiles of cellulose, cellobiose, glucose, cell mass, and ethanol during the course of SSF are described by the following equations: 
Collulose

$$
\frac{\mathrm{d}[\mathrm{C}]}{\mathrm{dt}}=-\mathrm{r}_{1}
$$

\section{Celloblose}

$$
\frac{\mathrm{d}[\mathrm{B}]}{\mathrm{dt}}=\mathrm{r}_{1}-\mathrm{r}_{2}
$$

\section{Glucose}

$$
\frac{\mathrm{d}[\mathrm{G}]}{\mathrm{dt}}=\mathrm{r}_{2}-\mathrm{r}_{3}
$$

Cell Mass

$$
\frac{d[X]}{d t}=\mu_{m} \frac{[G]}{K_{3}+[G]+[G]^{2} / K_{i}} \cdot \frac{K_{3 E}}{K_{3 E}+[E]}[X]-k_{d}[X]
$$

\section{Ethanol}

$$
\frac{\mathrm{d}[\mathrm{E}]}{\mathrm{dt}}=\left(\alpha \frac{\mathrm{d}[\mathrm{X}]}{\mathrm{dt}}+\beta[\mathrm{X}]\right) \frac{[\mathrm{G}]}{\mathrm{K}_{4}+[\mathrm{G}]}
$$

Thus, the preliminary mathematical model of SSF is composed of five differential equations that describe the relationships among eight variables, namely the concentrations of cellulase, B-glucosidase, cellulose, lignin, cellobiose, glucose, ethanol, and cell mass. In the current model formulation, however, the total concentrations of the two enzymes are considered constant during SSF, because enzyme deactivation is assumed negligible. Similarly, lignin concentration is considered constant because lignin is chemically inert. Therefore, the model consists of a system of five equations with five dependent variables and one independent (time).

The outlined model can be easily modified to account for different SSF condisons and modes of operation. For example, Equation (8) can be applied for multiple metabolic products, if necessary. In this case, it may also be necessary to modify Equation (9) for products not directly associated with energy generation by the organism. For simultaneous SSF and enzyme synthesis, a mass balance equation for the enzyme has to be included in the model, and Equation (9) will require an additional term to account for the consumption of substrate for enzyme synthesis. For organisms that can hydrolyze both cellobiose and glucose, Equations (6) and (9) need to be modified appropriately. The model can also be adopted for aerobic fermentations. Moreover, it can be used in a fed-batch operation by considering the rate of 
exogenous addition of substrate and/or enzyme. For continuous SSF, all time derivatives of the model are set equal to zero and the dilution rate of the process becomes the independent variable.

\section{Model Evaluation and Application}

With the SSF model formulated, the parameters of the model are now being determined. This is being achieved by performing (ritical experiments, each one examining the kinetics of a particular step of the SSF process, isolated to the maximal feasible extent from all other steps. This is the most reliable means to acquire an accurate measure of the model parameters and avoid the vagueness in parameter values that results from simply fitting the whole model to SSF kinetic data. An example of the proposed methodology is the determination of the inhibition constants of B-glucosidase (Equation [6]). In order to estimate $\mathrm{K}_{2 \mathrm{~B}}, \mathrm{~K}_{2 \mathrm{G}}$, and $\mathrm{K}_{2 \mathrm{E}}$, the enzymatic activity of B-glucosidase on celloblose will $\mathrm{h}$. measured in the presence of various concentrations of glucose and ethanol, which will be provided exogenously at the initiation of the reaction. This experiment will be repeated at a variety of substrate (cellobiose) concentrations to evaluate the dependence of $r$ simultaneously on the cellobiose, glucose, and ethanol concentration. The use of nonlinear regression to correlate Equation (6) with the collected kinetic data allows the optimal values of $\mathrm{K}_{2 \mathrm{~B}}, \mathrm{~K}_{2 \mathrm{G}}$, and $\mathrm{K}_{2 \mathrm{E}}$ to be extracted. The regression algorithm consists of a least squares minimization procedure (a modification of the Levenberg-Marquardt technique) that combines the Gauss-Newton and the steepest descent methods.

After determining the parameter values independently, the model will be evaluated using SSF data under varying conditions. The ability of the model to correctly depict the performance of SSF will be measured by the magnitude of the deviation of model predictions from experimental observations. In this phase of model development, final adjustments will be performed to increase the confidence level of the predictive ability of the mathematical model.

Once the model has been evaluated, it can be used to assess the impact that SSF variables and parameters have on ethanol productivity. Such a sensitivity analysis will help determine reaction steps that need to be improved to enhance the rate of the process. Figure 4 demonstraizs the application of sensitivity analysis with arbitrary parameters used in the model. It depicts the effect of B-glucosidase supplementation on ethanol yield. Although an increase of $B$-glucosidase concentration to two units (arbitrary) greatly improves ethanol yield, further increase does not lead to significant improvement and may therefore be uneconomical. From the same graph, it can be deduced that during the initiation of SSF, B-glucosidase concentration has no significant effect on ethanol yield, thus raising the possibility of a different step being rate determining at the onset of the process. These predictions of the model (using hypothetical parameter values) seem to be in qualitative agreement with the experimental results depicted in Figure 5 and underline the valuable information that a mathematical model can offer about a complex process. Once these parameters have been determined experimentally and validated, the model will clarify the critical steps in achieving high rate, yield, and concentration of ethanol via the SSF process. The sensitivity analysis will thus point out the desired properties of the substrate, the enzymes, and the microorganism, whose parameters affect SSF. Based on the recommendations of the model, the biomass pretreatment and enzyme production, as well as the structure of the overall biomass to ethanol system, will be adjusted to improve the performance of the bioconversion process.

Finally, the SSF model will be used as a tool in the evaluation and scale-up of the process. It will be particularly useful in establishing the trade-off between cellulase loading, $\beta$-glucosidase supplementation, yeast choice, and SSF performance. As a result, it should be possible to select the lowest cost process design for commercial use. Moreover, the model will identify critical relationships that must be dealt with in process scale-up. 


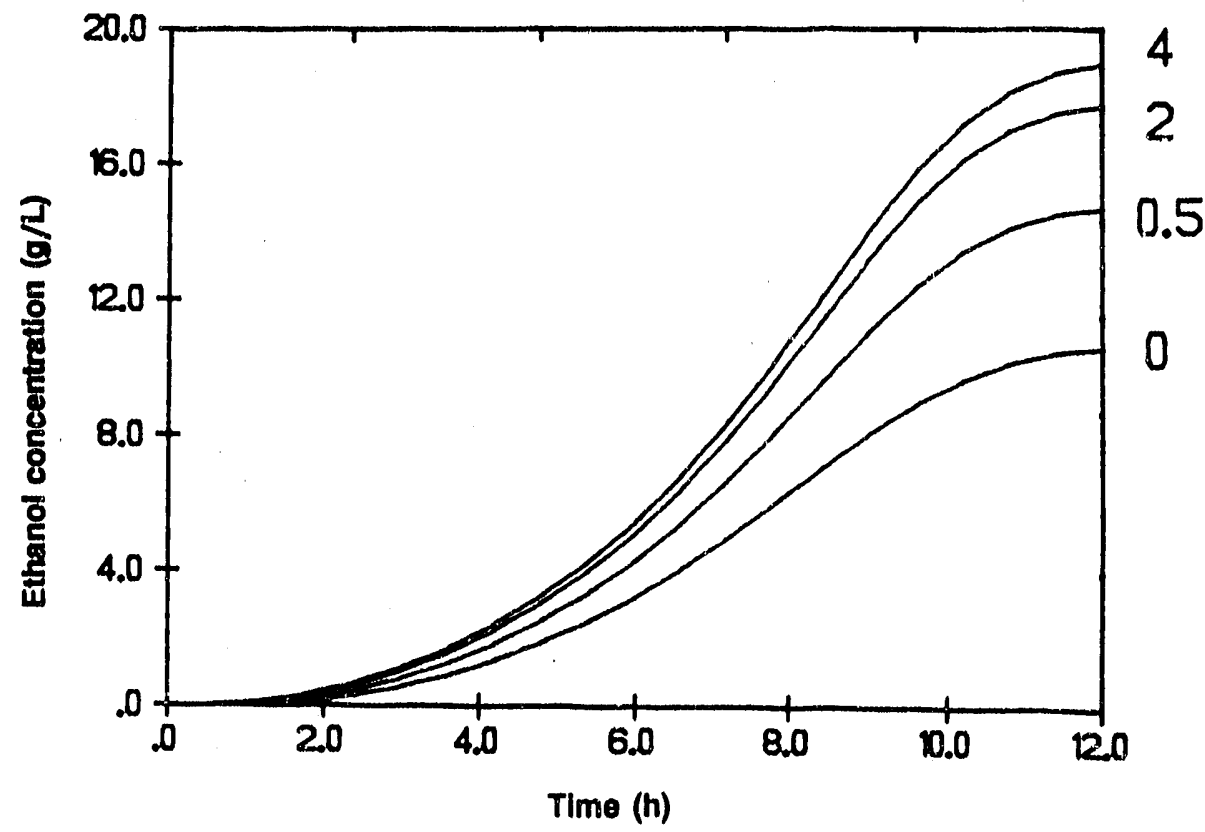

Figure 4. Model sImulation of the effect of B-glucosidase supplementation on ethanol yleld (the parameters on the curves represent arbltrary enzyme activity units)

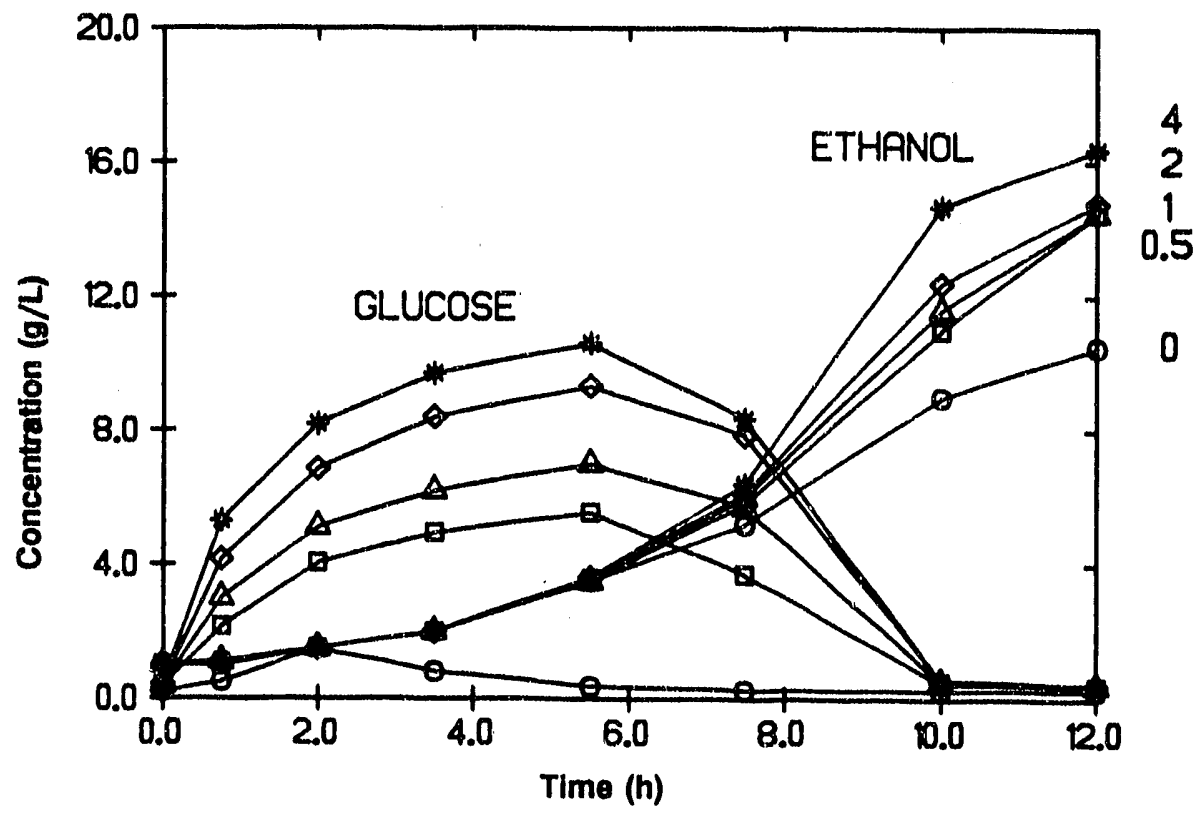

Figure 5. Effect of B-glucosidase supplementation on ethanol ylold (experimental data). SSF was performed in a $80 \mathrm{~g} / \mathrm{L}$ avicel cellulose suspension, at $37^{\circ} \mathrm{C}$ and $\mathrm{pH} 4.8$, using yeast, $T$. reesei cellulase (25 international units/g cellulose) and various B-glucosidase/cellulase activity ratios, which correspond to the enzyme activity units of Figure 4: $0: 0 ; \square: 0.5 ; \Delta: 1 ; 0: 2 ; ": 4$. 


\section{Acknowledgments}

This study was funded by the Biofuels Systems Division of the U.S. Department of Energy. The experimental work was performed by D. D. Spindler.

\section{Nomenclature}

a

$\alpha$

B

[B]

[C]

[E]

$\left[\mathrm{E}_{1}\right]$

$\left[E_{1}\right]^{*}$

$\left[\mathrm{E}_{2}\right]$

[G]

$k_{d}$

$\mathrm{k}_{1}, \mathrm{k}_{2}$

$\mathrm{K}_{\mathbf{a}}$

$K_{i}$

$\mathrm{K}_{\mathrm{m}}$

$K_{1 B}, K_{2 B}$

$K_{1 E}, K_{2 E}, K_{3 E}$

$\mathrm{K}_{10}, \mathrm{~K}_{2 \mathrm{O}}$

$\mathrm{K}_{1 \mathrm{~L}}, \mathrm{~K}_{2 \mathrm{~L}}$

$\mathrm{K}_{3}$

$\mathrm{K}_{4}$

[L]

m

$\mu_{\mathrm{m}}$

$\mathrm{n}$

$\phi$

$r_{1}, r_{2}, r_{3}$

Available surface area of cellulose $\left(\mathrm{m}^{2}\right)$

Growth-associated ethanol formation constant $(\mathrm{g} / \mathrm{g})$

Nongrowth-associated specific ethanol production rate $(\mathrm{g} / \mathrm{g} / \mathrm{h})$

Concentration of cellobiose $(\mathrm{g} / \mathrm{L})$

Concentration of cellulose $(\mathrm{g} / \mathrm{L})[\mathrm{E}]$

Concentration of cellulose $(\mathrm{g} / \mathrm{L})$

Concentration of ethanol $(\mathrm{g} / \mathrm{L})$

Concentration of cellulase in solution $(\mathrm{g} / \mathrm{L})$

Concentration of adsorbed cellulase $(\mathrm{g} / \mathrm{L})$

Concentration of $B$-glucosidase $(\mathrm{g} / \mathrm{L})$

Concentration of glucose $(\mathrm{g} / \mathrm{L})$

Specific rate of cell death $\left(\mathrm{h}^{-1}\right)$

Specific rate of cellulose and cellobiose hydrolysis, respectively $\left(\mathrm{h}^{-1}\right)$

Constant in cellulase adsorption Equation (1) $(\mathrm{g} / \mathrm{L})$

Constant of substrate (glucose) inhibition on cell growth $(\mathrm{g} / \mathrm{L})$

Michaelis constant of $B$-glucosidase for cellobiose $(g / L)$

Inhibition constants for cellobiose on cellulase and B-glucosidase, respectively $(g / L)$

Inhibition constants for etnanol on cellulase, B-glucosidase, and cell growth, respectively $(\mathrm{g} / \mathrm{L})$

Inhibition constants for glucose on cellulase and B-glucosidase, respectively $(\mathrm{g} / \mathrm{L})$

Constants for cellulase and B-glucosidase adsorption to lignin, respectively $(\mathrm{L} / \mathrm{g})$

Monod constant of glucose for cell growth $(\mathrm{g} / \mathrm{L})$

Monod constant of glucose for ethanol synthesis $(\mathrm{g} / \mathrm{L})$

Concentration of lignin $(\mathrm{g} / \mathrm{L})$

Specific rate of substrate consumption for maintenance functions $(\mathrm{g} / \mathrm{g} / \mathrm{h})$

Maximal specific growth rate $\left(\mathrm{h}^{-1}\right)$

Constant in cellulase adsorption Equation (1) $\left(\mathrm{m}^{-2}\right)$

Cellulose reactivity coefficient (dimensionless)

Rate of cellulose, cellobiose, and glucose utilization, respectively $(\mathrm{g} / \mathrm{L} / \mathrm{h})$ 
Time (h)

[X] Concentration of cell mass $(\mathrm{g} / \mathrm{L})$

$\mathbf{Y}_{\mathbf{x} / \mathbf{s}}$ Yield coefficient for cell mass on substrate (glucose) (g/g)

Subscripts

0 Initial value

\section{References}

Asenjo, J.A., Spencer, J.L., and Phuvan, V. 1986. Ann. N. Y. Acad. Sci. 404-20.

Beltrame, P.L., Carniti, P., Focher, B., Marzetti, A., and Sarto, V. 1983. Chim. Ind. 65:398-41.

Beltrame, P.L., Carniti, P., Focher, B., Marzetti, A., and Sarto, V. 1984. Biotechnol, Bioeng. 26:1233-38.

Button, D.K. 1985. Microb. Rev. 49:270-97.

Chiang, L.C. 1979. "Evaluation of Digestibility Assays and Kinetic Models for Cellulose Biodegradation." Ph.D. diss., University of Missouri, Columbia.

Converse, A.O., and Grethlein, H.E. 1987. Enzyme Microb. Technol. 9:79-82.

Converse, A.O., Matsuno, R., Tanaka, M., and Taniguchi, M. 1988. Biotechnol. Bioeng. 32:38-45.

Converse, A.O., Ooshima, H., and Burns, D.S. 1990. Appl. Blochem. Blotechnol. 24:67-73.

Eveleigh, D.E. 1987. Phil. Trans. R. Soc. Lond. 321:435-47.

Fan, L.T., Lee, Y.-H., and Beardmore, D.H. 1980a. Biotechnol. Bioeng. 22:177-99.

Fan, L.T., Lee, Y.-H., and Beardmore, D.H. 1980b. "Major Chemical and Physical Features of Cellulosic Materials as Substrates for Enzymatic Hydrolysis." In Advances in Biochemical Engineering 14:101-17, ed. A. Fiechter. Berlin: Springer-Verlag.

Fan, L.T., and Lee, Y.-H. 1983. Biotechnol. Bioeng. 25:2707-33.

Ghose, T.K. 1969. Biotechnol. Bioeng. 11:239-61.

Grethlein, H.E. 1985. Biotechnol. 3:155-60.

Grous, W.R., Converse, A.O., and Grethlein, H.E. 1986. Enzyme Microb. Technol. 8:274-80.

Holtzapple, M.T., Caram, H.S., and Humphrey, A.E. 1984a. Biotechnol. Bioeng. 26:775-80.

Holtzapple, M.T., Caram, H.S., and Humphrey, A.E. 1984b. Biotechnol. Bioeng. 26:936-41.

Holtzapple, M., Cognata, M., Shu, Y., and Hendrickson, C. 1990. Biotechnol. Bioeng. 36:275-87. 
Hong, J., Gong, C.-S., Wankat, P.C., and Tsao, G.T. 1981. Blotechnol. Bloeng. 23:2779-88.

Howell, J.A., and Stuck, J.D. 1975. Blotechnol. Bioeng. 17:873-93.

Howell, J.A., and Mangat, M. 1978. Biotechnol. Bioeng. 20:847-63.

Huang, A.A. 1975. Biotechnol. Bloeng. 17:1421-33.

Humphrey, A.E. 1979. "The Hydrolysis of Cellulosic Materials to Useful Products." In Hydrolysis of Cellulose: Mechanisms of Enzymatic and Acldic Catalysis, eds. R. D. Brown, and L. Jurasek, 25-53. Washington, DC: American Chemical Society.

King, K.W. 1966. Biochem. Blophys. Res. Commun. 24:295-98.

Gong, C.-S., and Tsao, G.T. 1980. Biotechnol. Bloeng. 22:1107-26.

Lee, S.E., Armiger, W.B., Watteeuw, C.M., and Humphrey, A.E. 1978. Blotechnol. Bloeng. 20:141-44.

Lee, Y.-H., and Fan, L.T. 1982. Biotechnol. Bioeng. 24:2383-2406.

Lee, Y.-H., and Fan, L.T. 1983. Blotechnol. Bloeng. 2 i:939-66.

Leudeking, R., and Piret, E.L. 1959. J. Blochem. Microbiol. Technol. Eng. 1:393-412.

Okazaki, M., and Moo-Young, M. 1978. Biotechnol. Bloeng. 20:637-63.

Ooshima, H., Sakata, M., and Harano, Y. 1983. Biotechnol. Bioeng. 25:3103-14.

Ooshima, H., Burns, D.S., and Converse, A.O. 1990. Biotechnol. Bioeng. 36:446-52.

Peitersen, N., and Ross, E.W. 1979. Biotechnol. Bioeng. 21:997-1017.

Pirt, S.J. 1965. Proc, R. Soc. Lond. Ser. B 163:224-31.

Reese, E.T., Mandels, M., and Weiss, A.H. 1972. "Cellulose as a Novel Energy Source." In Advances in Biochemical Engineering, Vol. 2, eds. T. K. Ghose, A. Fiechter, and N. Blakebrough, 181-200. Berlin: Springer-Verlag.

Roels, J.A. 1983. Energetics and Kinetics in Biotechnology. Amsterdam: Elsevier Biomedical.

Ross, L.W., and Updegraff, D.M. 1971. Blotechnol. Bloeng. 13:99-111.

Ryu, D.D.Y., Lee, S.B., Tassinari, T., and Macy, C. 1982. Biotechnol. Bioeng. 24:1047-67.

Sattler, W., Esterbauer, H., Glatter, O., and Steiner, W. 1989. Biotechnol. Bioeng. 33:1221-34.

Solar Energy Research Institute. August 1990. Economic Analysis of Biomass to Ethanol Conversion (draft).

Stone, J.F., and Scallan, A.M. 1968. Cellulose Chem. Tech. 3:343-58. 
Sutcliffe, R., and Saddler, J.N. 1986. Biotechnol. Bloeng. Symp. 17:749-62.

Tatsumoto, K., Baker, J.O., Tucker, M.P., Oh, K.K., Mohagheghi, A., Grohmann, K., and Himmel, M.E. 1988. Appl. Blochem. Biotechnol. 18:159-74.

Van Dyke, B.H. Jr. 1972. "Enzymatic Hydrolysis of Cellulose-A Kinetic Study." Ph.D. diss., Massachusetts Institute of Technology.

Wald, S., Wilke, C.R., and Blanch, H.W. 1984. Biotechnol. Bioeng. 26:221-30.

Wright, J.D., Wyman, C.E., and Grohmann, K. 1988. Appl. Biochem. Biotechnol. 18:75-90. 


\title{
Liquid Fluidization of Aspen Wood Chip Beds
}

\author{
G. Hradil and J. M. Calo \\ Chemical Engineering Program \\ Division of Engineering \\ Brown University \\ Providence, Rhode Island 02912
}

\begin{abstract}
Liquid-fluidized and derivative reactor types are being examined as potential reactor systems for the SERI simultaneous saccharification and fermentation (SSF) process. This assessment requires the investigation and characterization of the fluidization behavior of biomass (i.e., aspen wood chip) beds. A laboratoryscale, liquid-fluidized column, which was designed and constructed specifically for such experimental studies, is described. This paper summarizes the results obtained with this apparatus.

The incipient fluidization bchavior of unreacted aspen wood chip beds was found to be dominated by flow maldistribution causej by "channcling" or "jetting." This behavior is most marked for smaller particles with narrow size distributions. A broader range of particle sizes tends to reduce this effect. Enzymatically hydrolyzed wood chip beds also exhibited better performance.

Particle segregation with axial location (i.e., larger particles concentrating at the bottom of the bed, and smaller particles at the top) was found to be prominent for the aspen wood chips. This effect is reduced by column tilt, which causes secondary solid phase recirculation. This latter behavior appears to introduce liquid phase dispersion via interphase mass transport from porous particles, and also additional mixing. However, a mass transfer analysis indicates that intraparticle diffusion should be the rate-limiting process at typical fluidization velocities, in which case fluidization in vertically aligned columns may provide sufficient interphase mass transfer.
\end{abstract}

Generally, this project has demonstrated that liquid-fluidized beds are practical candidates for reactor systems for the SSF process.

\section{Introduction}

The primary objective of this project is to investigate and characterize the behavior of liquid-fluidized and derivative reactor types for enzymatic hydrolysis and simultaneous saccharification of aspen wood chips, i.e., the SERI SSF process. Liquid-fluidized beds and three phase reactors have previously been used for biomass (i.e., flocculent yeast and filamentous fungi) applications (Smith et al. 1978; Couderc 1985). In 
particular, a liquid-fluidized bed reactor type scems to offer some significant advantages over other reactor types for the SSF process now under development at SERI.

Liquid-solid contacting has been shown to have a strong influence on the rate of enzymatic hydrolysis (Elander 1988). In a typical slurry reactor, mechanical agitation is most commonly used to provide the mixing. This type of agitation creates large liquid shear rates, which may cause enzyme deactivation (Elander 1988). A liquid-fluidized bed reactor could provide good liquid-solid contacting without such large shear rates, thereby minimizing enzyme deactivation. In addition, the economics of the SSF process have been shown to be sensitive to agitation energy costs (Wright 1988); mild liquid fluidization may prove to be a less energy-intensive alternative.

Although there has been a considerable amount of work on liquid-fluidized beds, only recently has it become more than just a scientific curiosity, with many projected applications in the area of biotechnology. However, much of the fundamental published work concerning fluidization characteristics has been conducted with beds of monodisperse, spherical, nonporous particles; less is known about the behavior of nonspherical, irregularly shaped, porous particles, with very wide particle size distributions, as is the expected case for aspen wood chip biornass in the SSF process. The relatively smaller amount of work that has been done with polydisperse particles is typically limited to two sizes of glass beads with a size ratio of no greater than 10, while the expected situation for the current application is irregular, porous particles with sizes ranging from $1 \mathrm{~mm}$ to $25 \mu \mathrm{m}$ (Schell 1988). Add to this other potential complications, such as the variation of particle characteristics with extent of reaction, and the possibility of particle agglomeration, and it becomes clear that the correlations developed for simpler systems are insufficient to describe the situation under enzymatic hydrolysis conditions, and that specific experimental work on this system is necessary.

\section{The Llquid-Fluidized Bed Laboratory Apparatus}

A schematic of the laboratory-scale fluidized bed reactor, which was developed to conduct the experimental studies, is presented in Figure 1. The column was fabricated from 2.25-in. I.D. Lucite pipe with polyvinyl chloride (PVC) fittings and flanges. The column is $1.5 \mathrm{~m}$ high with a $5-\mathrm{cm}$ inner diameter. The diameter was selected based on experimental data showing that the void fraction-velocity relationship for a liquid-fluidized bed becomes independent of the total particle loading and the column diameter when the column-to-particle diameter aspect ratio is 10 to 20 (Couderc 1985). For a 5-cm I.D. column, this criterion is observed for particle sizes of $2.5 \mathrm{~mm}$ and less. Also, the expected void fractions under operating conditions indicate that a length of $1 \mathrm{~m}$ is adequate for the fluidized section. The lower $50 \mathrm{~cm}$ of the column serves as a homogenizing section to provide uniform flow at the entrance of fluidized section. If the flow velocity is nonuniform, secondary flows will develop, resulting in mixing. The homogenizing section is composed of a bed of $6-\mathrm{mm}$ diameter polymer spheres, $30 \mathrm{~cm}$ in length, capped with a porous plastic disk that serves as the liquid distributor for the fluidized section.

A positive displacement pump (2-gpm capacity) powered by a variable speed motor is used for liquid recirculation and fluidization. However, for some of the experiments, feedwater taken directly from the building supply was used as the fluidization medium. A pressure-regulating valve is used to stabilize the water pressure, and two needle valves and flow meters are used to provide a flow rate range of $10.4000 \mathrm{~mL} / \mathrm{min}$. 


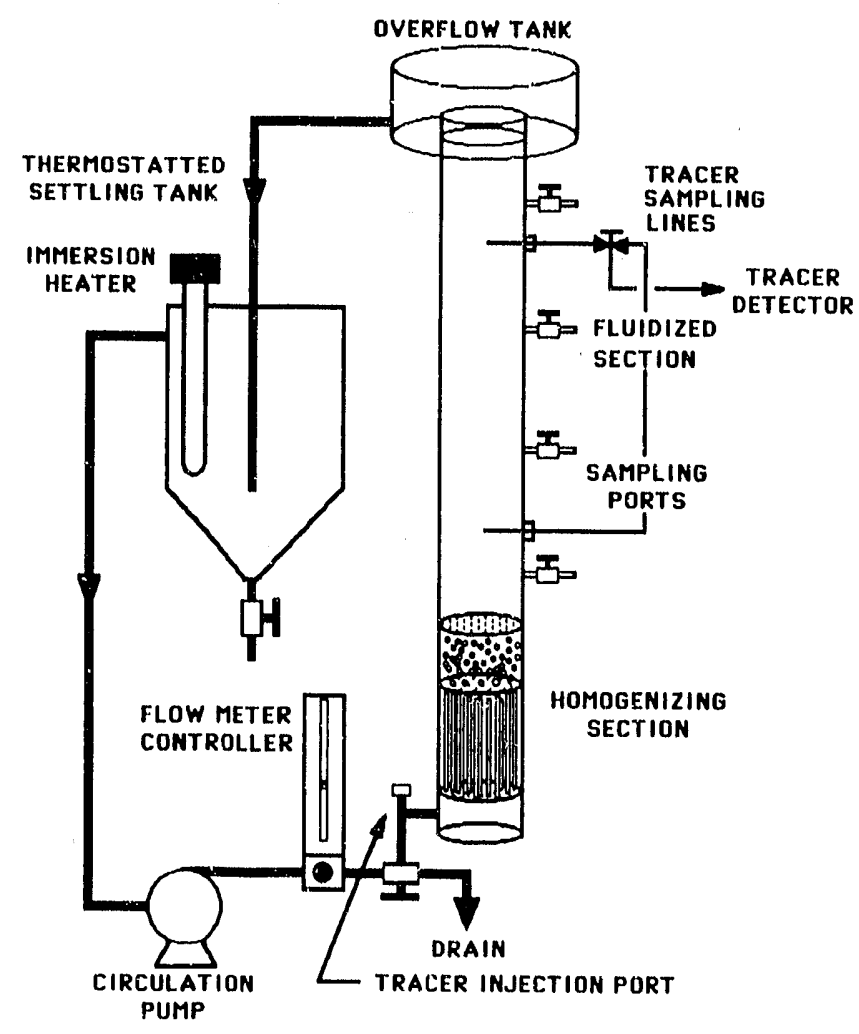

TP-3996

Figure 1. Schematic of the laboratory fluldized bed reactor system

The experimental apparatus includes provision for fine control of the "angle of tilt" of the fluidized column. With this arrangement, the column can be tilted from $0^{\circ}$ to $5^{\circ}$ from the vertical with an accuracy of $+0.1^{\circ}$. In addition to allowing precise vertical alignment, this modification also enables studies of mixing resulting from the secondary flow introduced by vertical misalignment. This was found to have an important effect on liquid phase dispersion in bubble columns by Rice and co-workers (1988), and our own work has shown that the angle of inclination has a strong effect on solid phase dispersion in liquidfluidized beds.

For the solid phase axial dispersion and particle segregation experiments it is necessary to determine the particle size distribution as a function of axial position. The column is equipped with four $3 / 8$-in. ball valves through which the fluidized bed may be sampled.

The column has also been fitted for two-station, stimulus-response tracer experiments to determine the mass transfer characteristics of the beds. The sample ports are connected via $1 / 16$-in. stainless steel tubing to a three-way valve, so that either port may be selected for sampling. A Micromeritics continuous flow refractometer is being used in conjunction with the MacADIOS $411 \mathrm{I} / \mathrm{O}$ interface and a Macintosh Plus microcomputer for data acquisition. 


\title{
Physical Fluidization Characteristics of Aspen Wood Chips
}

\author{
Fluld Bed Expansion and MInImum Fluidization Velocity
}

\section{Background}

Fluidization by a liquid occurs when a bed of particles is subjected to an upward flow of fluid of the proper velocity. At a critical liquid flow rate, the normal forces between particles will be balanced by the buoyancy induced by the liquid upflow; this condition represents the onset of fluidization, and is known as the minimum fluidization velocity, $u_{m \cdot}$. At higher velocities, the bed will expand, and fluidization will continue until the flow becomes so rapid that the particles are entrained and transported out of the bed; this regime is known as hydraulic transport. A momentum balance on the column shows tha' the preswure drop through the fluidized section is equal to the buoyant weight of the particles divided by the crosssectional area of the column. Because the buoyant weight of the particles is constant, the pressure drop will be constant in a fluidized column, regardless of the fluid velocity. However, the ber height, and therefore the bed voidage, will be a function of fluid velocity.

The minimum fluidization velocity depends on particle properties such as density, size, and shape. Therefore, a distinct minimum fluidization velocity is only possible if the bed is homogeneous with respect to particle size and density. For a distribution of sizes, fluidization will occur over a range of velocities. In this situation it is customary to calculate the minimum fluidization velocity for the smallest and the largest particles in the system in order to define the range of velocities over which fluidization takes place.

Another important parameter characterizing liquid-fluidized beds is the bed void fraction, $\varepsilon$ (i.e., the volume fraction of the fluid phase). Once again, much of the work has been done for systems consisting of glass spheres fluidized with water. The first important work on this problem was done by Richardson and Zaki (1954). These workers correlated the bed void fraction, $\varepsilon$, to the superficial fluid velocity, $u$, and the terminal free-fall velocity of a single sphere, $u_{i}$, as:

$$
u / u_{i}=\varepsilon^{n}
$$

where $\mathrm{n}$ is dependent on the Reynolds number and the ratio of the particle-to-column diameter.

\section{Experimental Results}

Experiments were performed using three different sieve cuts of the $1 / 8$-in. nominal aspen wood chips supplied by SERI, as wcll as the complete "as received" size distribution. The three different size classes of wood chips are characterized by the smallest dimension of: (A) $>1 \mathrm{~mm}$, (B) between $0.6 \mathrm{~mm}$ and $1 \mathrm{~mm}$, and $(\mathrm{C})$ between $0.2 \mathrm{~mm}$ and $0.6 \mathrm{~mm}$.

One of the first experimental observations was the formation of jets or channels in the fluidized bed as the fluid velocity was increased. This was an unexpected phenomenon that occurred for all the wood chip beds tested except one. At certain liquid velocities, the bed would collapse as channels formed through which the entire liquid flow would pass. The formation and destruction of these channels is reversible and exhibits hysteresis. Al low flow rates the bed expands, but the void fraction is still too low to allow particle mobility. As the flow rate is increased, the void fraction increases and particle motion is observed in the bed. At this point channels form and the bed begins to collapse. The liquid flow rate must then be increased significantly to refluidize the bed. This effect is more pronounced for the smaller sized wood 
chips and is caused by the "nesting" behavior of the predominantly prolate shape of these wood chips. It is significant to note that the mixed wood chip bed is less prone to channeling than the largest (A: $>1 \mathrm{~mm}$ ) sieve cut. The only bed that exhibited no significant jetting was one that consisted of partially enzymatically hydrolyzed ( $30 \%)$, > 1-mm wood chips. This result is not yet completely understood, but changes in density and/or external physical properties are known to affect fluidization characteristics of bed materials.

The jetting behavior coupled with the particle size distribution make it impossible to define a single minimum fluidization velocity. However, bed expansion was observed at velocities of about $0.3 \mathrm{~cm} / \mathrm{s}$ for most of the beds tested. After this initial expansion, the bed would immediately collapse as jetting started. Perhaps more relevant for a bed that exhibits jetting is the minimum velocity for steady nonjetting fluidization. This velocity is typically about $1.2 \mathrm{~cm} / \mathrm{s}$, but varies with the particle size distribution of the bed.

The results of the wood chip bed expansion experiments are summarized in Figure 2. The step evident in the $>1-\mathrm{mm}$ monodisperse data is due to the onset of channeling or jetting. All the other data were obtained in the fluidized regime. As can be scen, the mixed bed of wood chips exhibits the greatest expansion, while the enzymatically hydrolyzed bed is the most resistant to channeling. The smaller sized, monodisperse bed $(0.6 \mathrm{~mm}<1 \mathrm{~mm})$ also expands rapidly but is very prone to channeling. Monodisperse beds $<0.6 \mathrm{~mm}$ are so prone to channeling that it is very difficult to maintain a fluidized state because when there is sufficient fluid velocity to overcome channeling, there is also significant loss of wood chips because of hydraulic transport. For this reason, no data are reported here for sieved wood chip beds $<0.6 \mathrm{~mm}$.

The bed expansion results were fit to the Richardson-Zaki equation to obtain the two parameters, ui and $n$. The fit to this equation was good. The values of $n$ ranged from 6.5 for the $B$-size bed, to 9 for the A-size bed. The single particle, free-fall velocity obtained from the parameter fit ranged from $2.1 \mathrm{~cm} / \mathrm{s}$ for the A-size bed to $3.0 \mathrm{~cm} / \mathrm{s}$ for the B-size bed. The terminal velocities obtained from the parameter fit are in good agreement with directly measured velocities.

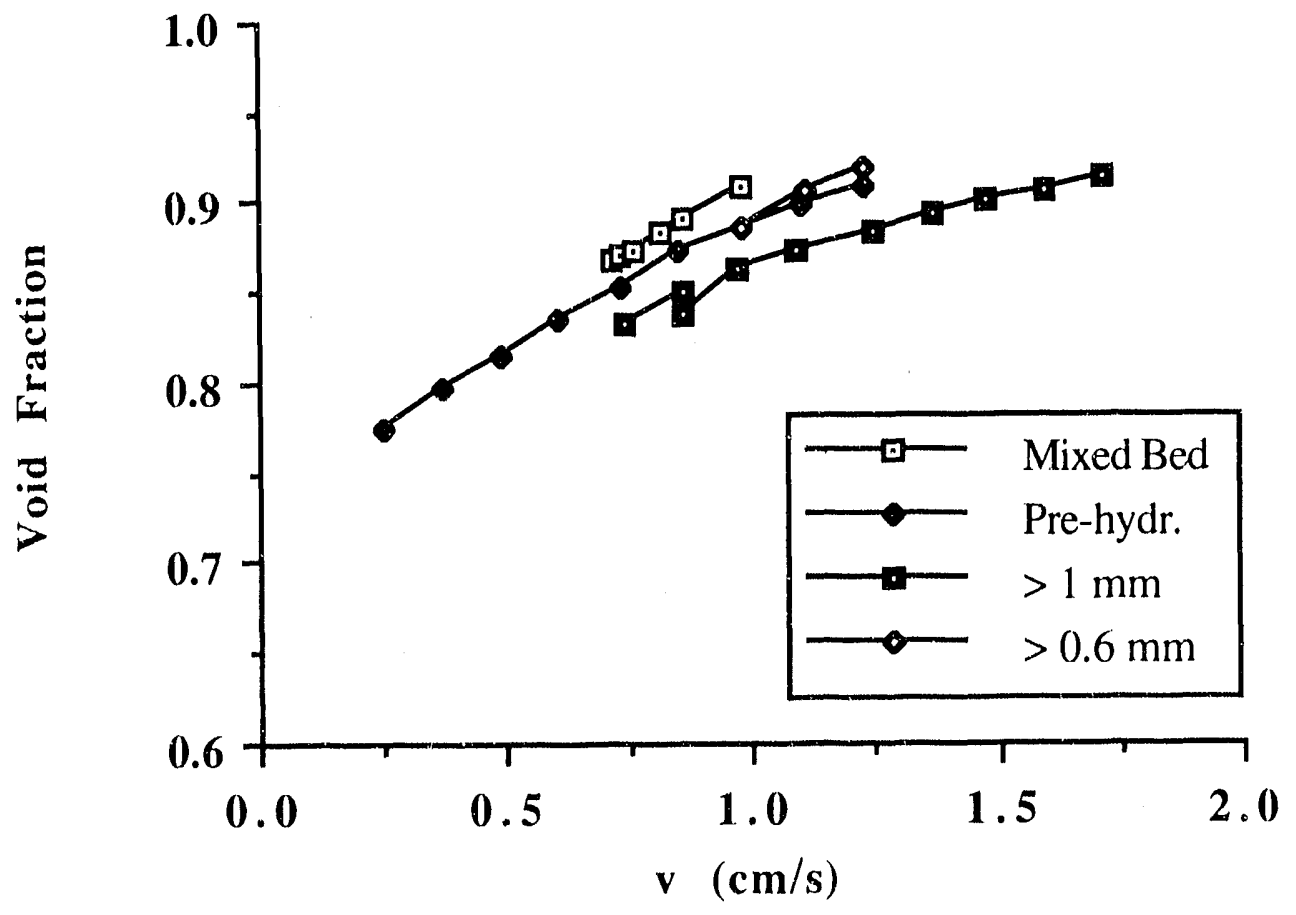

Figure 2. Fluldized bed expansion as a function of llauld flow rate 


\section{Particle Segregation and Solld Phase Dispersion}

It is well known that particles in liquid-fluidized beds segregate according to their size and density. The smaller or less dense particles accumulate at the top of the bed, while the bottom of the bed is populated by the larger or denser particles. This effect has been investigated primarily in water-glass bead systems, with mixed packings of two particle sizes (Al-Dibouni and Garside 1979). We have now also investigated this effect with aspen wood chip beds.

Experiments were conducted using a bed that $50 \%$ by weight of two adjacent sieve cuts of the $1 / 8$-in. nominal aspen wood chips provided by SERI, i.e., A- and B-size particles. This packing was fluidized for $10 \mathrm{~min}$ to allow particle segregation to take place before samples were taken. The samples were taken starting from the top sample port and proceeding downward in the column to minimize the disturbance to the unsampled portion of the bed. The samples were then dried and sieved to determine the particle size distribution. The results of this experiment are presented in Figure 3, which shows a strong segregation effect, as expected.

\section{The Solld Phase Disperslon Coefficlent}

A solid phase dispersion coefficient can be determined from particle size distribution data obtained from fluidized beds made up of bimodally sized particles, using the technique described by Van der Meer ct al. (1984), from the following expression:

$$
\mathrm{W} z / \mathrm{E}=-\ln [\mathrm{x} /(1-\mathrm{x})] \text {, }
$$

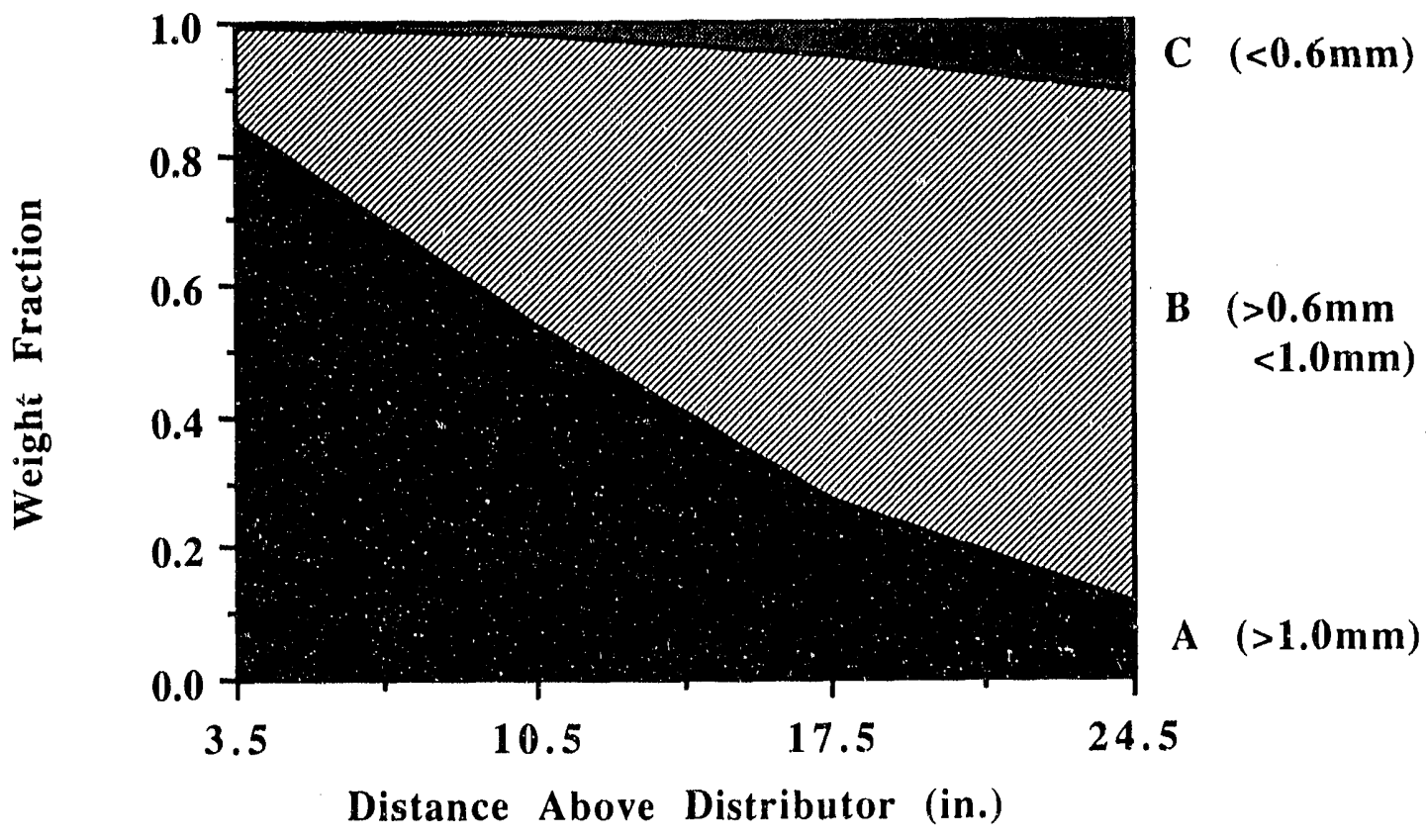

Figure 3. Particle size varlation with helght in a llquid-fluidized bed of aspen wood chips at a velocity of $1.38 \mathrm{~cm} / \mathrm{s}$, for a vertically allgned column 
where $w$ is the classification velocity, $z$ is the axial location, and $x=c / c^{\infty}$, in which $c$ is the concentration of the one size of particle at location $\mathrm{z}$, and $\mathrm{c}^{\infty}$ is the concentration of the same particle at a distance well away from the mixing zonc. If the right hand side of Equation (2) is plotted versus $z$, the slope of the resulting line should be equal to $w / E$. Martin et al. (1981) have proposed the following expression for the classification velocity:

$$
\mathrm{W}=2.5\left(\mathrm{u}-\mathrm{u}_{\mathrm{m} f}\right)\left(\mathrm{v}_{1}-\mathrm{v}_{\mathrm{g}}\right) / \mathrm{v}_{\mathrm{s}} \text {, }
$$

where $u, u_{m f}$ are the fluid velocity and fluid velocity at minimum fluidization, and $v_{1}, v_{1}$ are the free-fall velocities of the large and small particles, respectively.

Experiments were conducted in a vertically aligned (i.e., $0^{\circ}$ angle of inclination), fluidized bed with a bimodal particle size distribution (i.e., $A$ and B) for liquid velocities of 1.38 and $1.60 \mathrm{~cm} / \mathrm{s}$. The terminal velocitics of the large and small particles were determined from a series of measurements as 2.8 and $1.9 \mathrm{~cm} / \mathrm{s}$, respectively. The minimum fluidization velocity for this bed was $0.44 \mathrm{~cm} / \mathrm{s}$. Using these values in Equation (2), $w=1.08$ and $1.38 \mathrm{~cm} / \mathrm{s}$ for the two liquid velocities, respectively. These, in turn, yielded values of $\mathrm{E}=17.5$ and $23.4 \mathrm{~cm}^{2} / \mathrm{s}$, which are in good agreement with those reported by Al-Dibouni and Garside (1979).

\section{Solld Phase Dispersion In Incllned Beds}

The effect of angle of inclination on fluidization behavior has also been investigated for aspen wood chip beds. Visual observations of fluidized bed operation under these conditions reveal increased solid phase mobility resulting from secondary recirculation of the solid phase and, consequently, decreasing particle segregation with increasing inclination. This latter behavior is reflected in the particle size distribution data presented in Figure 4, which clearly show that although particle segregation has been significantly decreased, it is still cvident.

Solid phase dispersion coefficients for inclined beds were determined in the same manner as described above. However, some of the data from the nonvertical experiments were observed to be nonlinear at small values of $z$. The large-scale recirculation of the solid phase that occurs in the tilted fluidized beds is the most likely cause of this behavior. The formulation described by Equation (2) assumes Fickian-like dispersion, which may not describe the large-scale secondary flow very well. Despite this acknowledged drawback, the model was applied to the linear portion of the data to obtain some measure of solid phase dispersion in inclined columns. These results are summarized in Figure 5, which shows that solid phase dispersion is significantly increased by inclination, although the effect secms to saturate above a tilt of $1^{\circ}$. This latter value is most probably related to the bed aspect ratio.

\section{Stimulus-Response Tracer Studies}

\section{Background and Approach}

As has already been noted, the mass transport characteristics of any candidate reactor system for the SSF are critical process parameters. In our work, we have been applying stimulus-response tracer techniques to assess these parameters. The methodology was originally developed on a small-scale packed bed, and subsequently applied to the liquid-fluidized laboratory column. The stimulus-response method basically involves the measurement of the response of the reactor system to an input of inert tracer (glucose, in the current application) in terms of all the transport mechanisms responsible for dispersion, i.e., bulk liquid phase dispersion, interphase mass transport, and intraphase diffusion. 


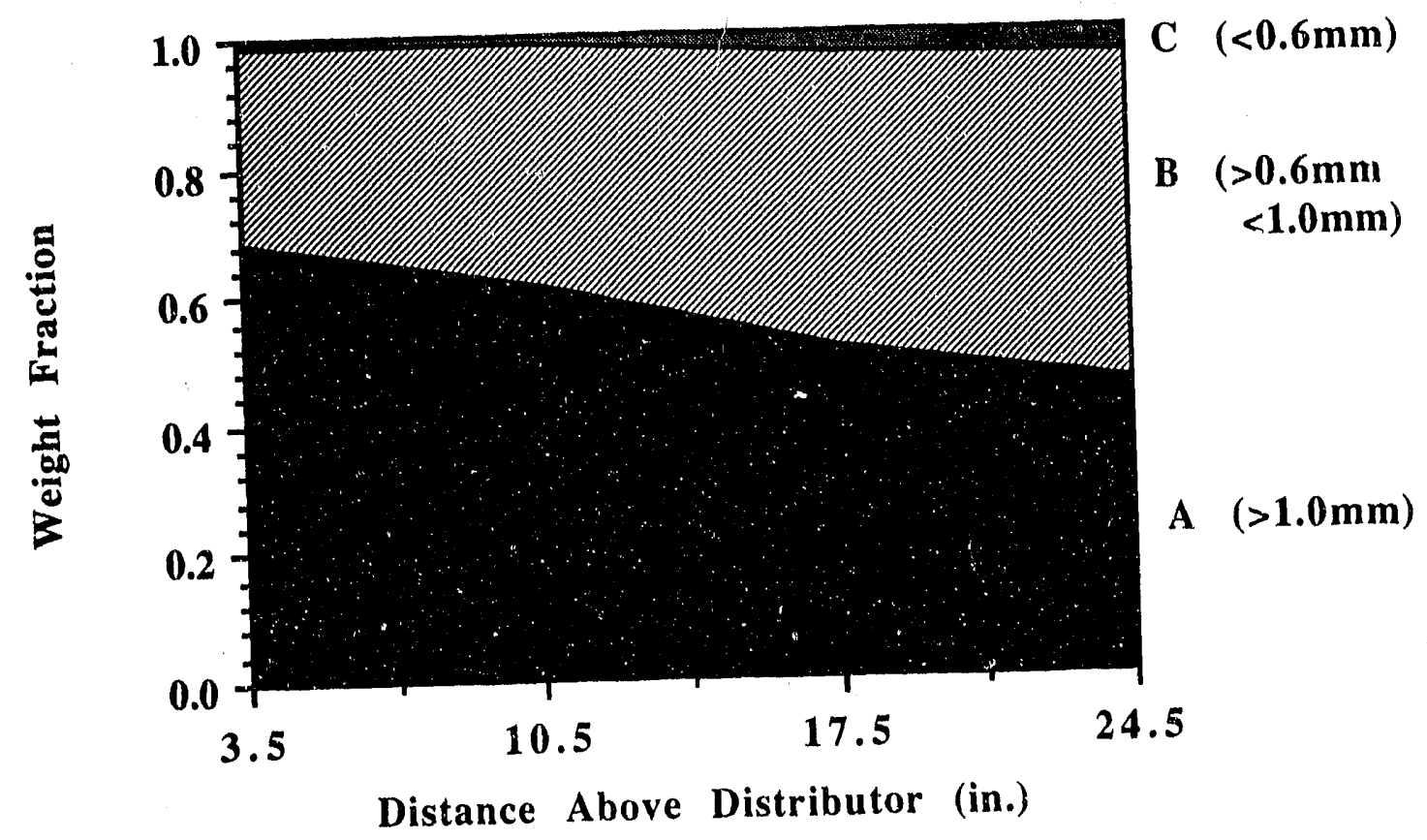

Figure 4. Partlcle size varlation with helght in a liquld-fluldlzed bed of aspen wood chips for the same condition as In Flgure 3 , but with the column Inclined $2^{\circ}$ from the vertical

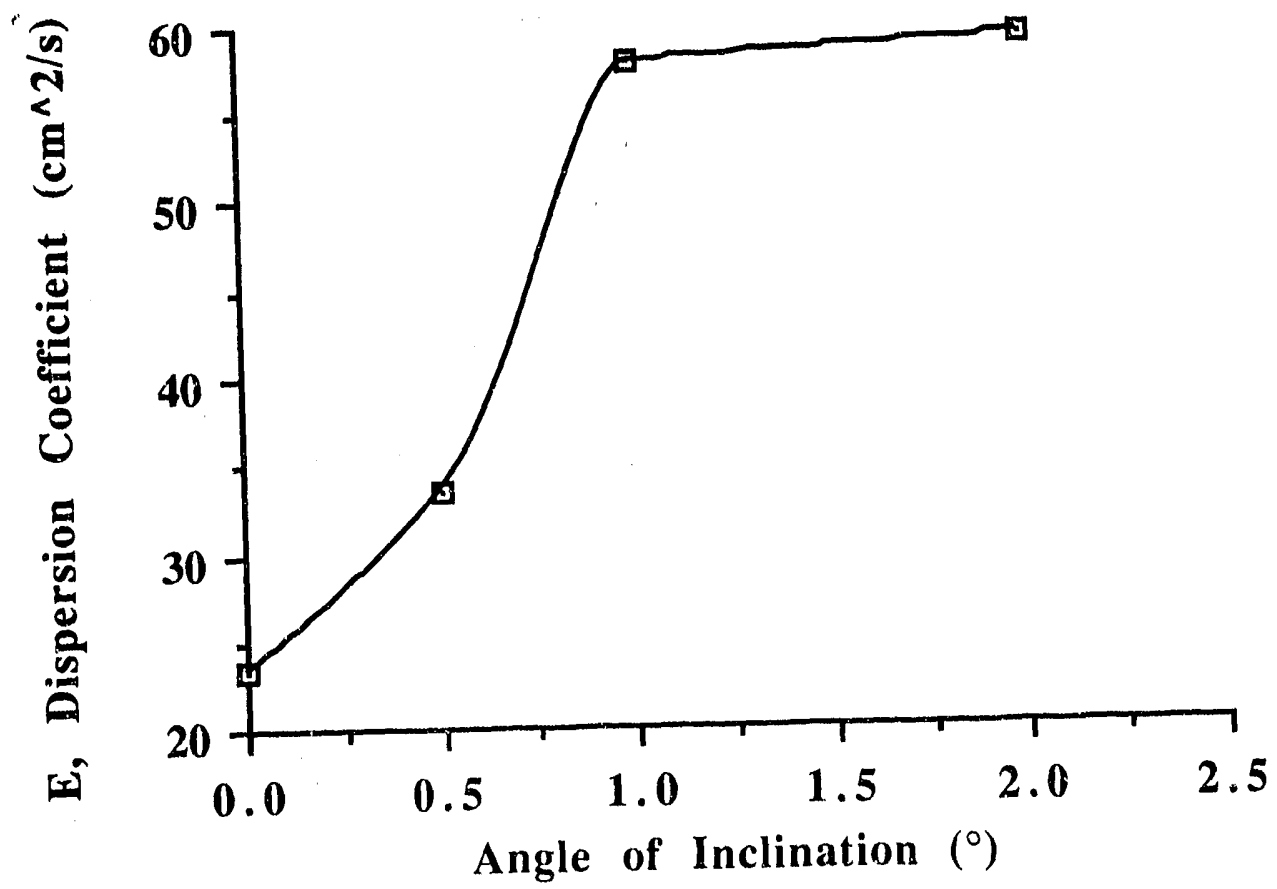

Figure 5. Solld phase dispersion coefficlent as a function of angle of Inclination for a llquldfluldization velocity of $1.38 \mathrm{~cm} / \mathrm{s}$ 
In the current case, we are using a "two-station" technique, which employs the difference in moments obtained at two axial sampling locations to eliminate the effect of stimulus pulse shape on subsequent data analysis. The mass transport parameters are determined from the difference moments using known analytical expressions (c.g., sec Kucera 1965).

\section{Summary of Results}

Stimulus-response results from the vertically aligned, liquid-fluidized column for fully segregated operation where the particle phase does not migrate can be analyzed as an "expanded" packed bed. Tracer experiments in the vertically aligned, fluidized bed with nonporous packing (i.e., 4.4-mm plastic spheres) revealed negligible liquid phase axial dispersion. In addition, this result was insensitive to liquid velocity. In the licquid-fluidized bed, the bulk phase velocity is an order of magnitude larger than those examined in our small-scale packed bed experiments. This reduces the interphase mass transfer resistance sufficiently to make the overall mass transfer process in the liquid-fluidized bed intraparticle diffusioncontrolled. Second station tracer responses as a function of angle of inclination for a liquid-fluidized bed of nonporous particles (i.e., 4.4-mm plastic spheres) are shown in Figure 6. These data clearly show no influence of column tilt on pulse dispersion. Analysis of these data also indicates that bulk liquid phase mixing in the axial direction is negligible in this case.

In contrast to the preceding, second station tracer responses for a liquid-fluidized bed of porous aspen wood chip particles (size distribution A), presented in Figure 7, clearly show a marked effect of angle of inclination on pulse dispersion. This behavior is attributed to interphase transport of tracer from mobile porous particles as a result of the secondary recirculatory flow induced by bed inclination. The analysis of tracer dispersion is more complex for this latter case, but it can potentially yield a direct measure of solid plase dispersion in such beds. A method of analysis is currently being developed for this purpose.

\section{Summary and Conclusions}

This project has demonstrated that liquid-fluidized beds are practical candidates for reactor systems for the SSF process. However, attention should be paid to the possibility of flow maldistribution (i.e., "channeling" or "jetting") at low liquid velocities for incompletely fluidized beds, which may tend to lower process performance under such conditions.

Particle segregation with axial location (i.e., larger particles concentrating at the bottom of the bed, and smaller particles at the top) was found to be prominent for the aspen wood chips. This effect is reduced by column tilt, which causes solid phase recirculation. This latter behavior appears to introduce liquid phase dispersion via interphase mass transport from porous particles, and also additional mixing. However, a mass transfer analysis indicates that intraparticle diffusion should be the rate-limiting process at typical fluddization velocities, in which case fluidization in vertically aligned columns may provide sufficient interphase mass transfer.

\section{Future Work}

The final phase of our project will te the enzymatic hydrolysis of aspen wood chip beds in the laboratoryscale, liquid-fluidized column. The apparatus has been equipped for these studies and preliminary hydrolysis experiments have been conducted. The rate of hydrolysis will be studied as a function of liquid velocity and enzyme loading. The particle size evolution and character of the wood chips will also be determined as a function of extent of conversion. 


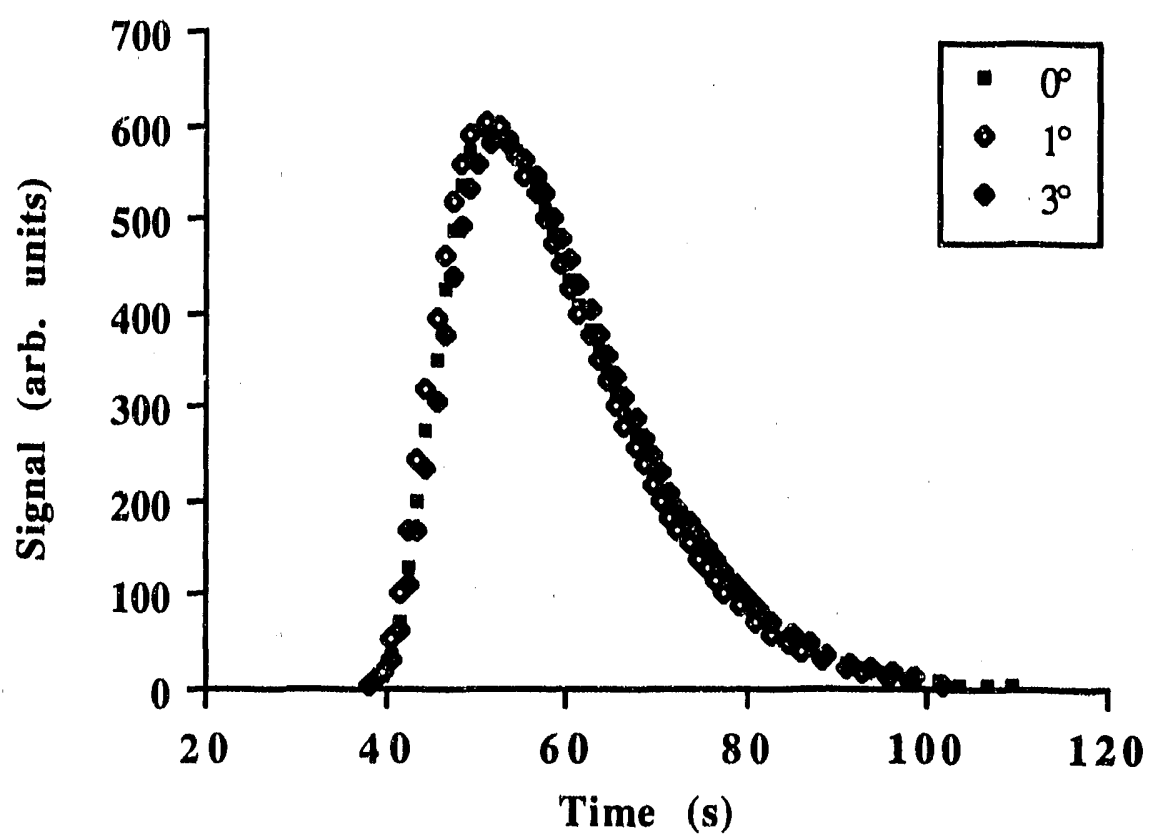

Figure 6. Second station tracer response as a function of angle of Inclination for llquid-fluldized beds of nonporous $4.4-\mathrm{mm}$ plastic spheres at a fluldization veloclty of $1.96 \mathrm{~cm} / \mathrm{s}$

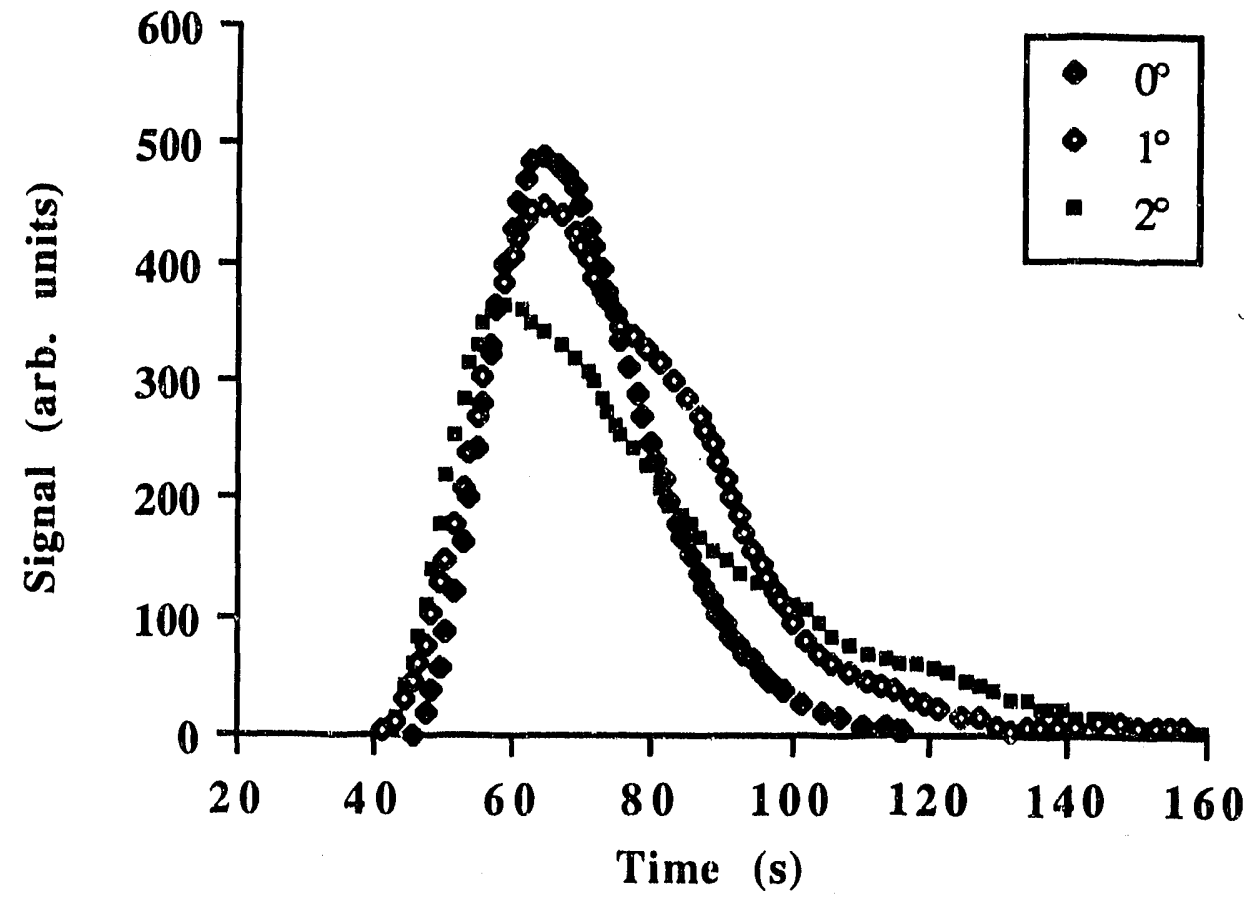

Figure 7. Second station tracer response as a function of angle of inclination for llquid-fluidized bods of aspen wood chlps (size distribution A) at a fluldization veloclty of $1.48 \mathrm{~cm} / \mathrm{s}$ 


\section{References}

Al Dibouni, M. R., and Garside, J. 1979. Trans. Instn. Chem. Eng. 57:94.

Couderc, J.-P. 1985. In Fluidization, 2nd ed., eds. J, F. Davidson, R. Clift, and D. Harrison. London: Academic Press.

Elander, R. T. 1988, "Mixing Requirements for Enzymatic Hydrolysis of Cellulose." Master's Thesis, Department of Agricultural and Chemical Engineering, Colorado State University, Fort Collins, Colorado.

Kucera, J. 1965. J. Chromatogr. 19:237.

Martin, B. L. A., Kolar, A., and Wesselingh, J. A. 1981. Trans. Instn. Chem. Eng. 59:100.

Rice, R. G., Geary, N. W., and Barbe, D. T. 1988. Paper No. 72i, AIChE 1988 Summer National Meeting, Denver, Colorado.

Richardson, J. F., and Zaki, W. N. 1954. Trans. Instn. Chem. Eng. 32:35.

Schell, D., 1988. Personal communication, Solar Energy Research Institute.

Smith, E. L., James, A., and Fidgett, M. 1978. In Fluidization, 196. Cambridge, England: Cambridge University Press.

Van der Meer, A. P., Blanchard, C.M.R.J.P., and Wesselingh, J. A. 1984. Chem. Eng. Res. Des. 62:214.

Wright, J. 1988. Economics of Enzymatic Hydrolysis Processes, SERI/TP-231-3310. Goldun, Colorado: Solar Energy Research Institute. 


\title{
Cloning Enzymes for Use In Converting Blomass to Ethanol
}

\author{
S.M. Lastick, A. Mohagheghi, M.P. Tucker, and K. Grohmann \\ Blotechnology Research Branch \\ Fucls and Chemicals \\ Research and Engineering Division \\ Solar Energy Research Institute \\ Golden, Colorado 80401
}

\begin{abstract}
Bacterial cellulase enzymes that can hydrolyze carboxymethyl-cellulose (CMC) have been identified after transfection of Escherichia coll with lambda vectors containing DNA fragments isolated from a thermophilic bacterium. The enzyme(s) were identified by screening plates that contained CMC stained with Congo Red. Lysates of cells transformed with these clones produce thermotolerant cellulase activity, confirming that the enzyme(s) were derived from gene(s) that originated in the thermophilic bacterium. Because the DNA fragments cloned with the lambda vector were restricted to from 9 to 23 kilobases (KB), they could contain more than one cellulase gene.
\end{abstract}

\section{Introduction}

Fermentation of lignoccllulosic biomass to ethanol can be performed by simultaneous saccharification and fermentation (SSF), utilizing fungal cellulase enzymes to convert insoluble cellulose to soluble fermentable sugars (Lastick et al. 1984; Wyman et al. 1986; Spindler et al. 1987). The enzyme $\beta$-glucosidase is also necessary for the conversion of the initial product of cellulase hydrolysis, the soluble sugar cellobiose, to glucose. This is because cellobiose inhibits cellulase enzymes. Cellobiose concentrations can be kept at non-inhibitory levels by combining the enzymatic saccharification of cellulose with fermentation of the final end product, glucose, to ethanol (i.e., SSF).

Cellulase enzymes have been isolated from a number of different strains of fungi and bacteria, but the only significant commercial source for the cellulase enzymes are those obtained from mutants of the fungal strain Trichoderma reesei, and for $\beta$-glucosidase, from strains of Aspergillus niger. (For current information on cellulase enzymes and their applications, see the symposia edited by Aubert et al. 1988; 
Coughlan 1989; and Kublcek et al. 1990.) Producing these fungal enzymes represents a signiffeant cost In the SSF process. Compared with the production of enzymes from bacterla, the cost of producing enzymes from fungl is very high. Bacteria grow much faster than fungl, and there are methods avaliable to overproduce enzymes in bacteria by the use of recombinant DNA techniques.

Genetic engineering can reduce the cost of ethanol production from biomass in two important ways. One is by overproducing needed enzymes. The second is to change the metabolism of organisms that perform the fermentation(s) by the introduction of forcign genes. Because $T$. reesel produces an insufficient amount of $\beta$-glucosidase, additional enzyme is added to maintain low levels of cellobiose in the SSF process. Many yeast strains are able to ferment cellobiose because they produce $\beta$ uglucosidases, but industrial yeasts that are highly tolerant to ethanol do not produce this enzyme. Thus the introduction of a $\beta$-glucosidase gene into these ethanol-tolerant yeasts could reduce the cost of producing this enzyme.

In order to economically convert blomass feedstocks to ethanol, the cost of the enzymes used in the process must be minimized. The goal of this project is to use recombinant DNA technology to reduce these costs. When a gene is transferred by recombinant DNA techniques from one organism to another, producing an active enzyme that is encoded by the gene is most successful if the organisms are somewhat related. Thus, our goals are to transfer bacterial cellulase genes into the strains of the bacterlum Escherichia coli for their overproduction; yeast $\beta$-glucosidases are being transferred into strains of the ethanol-tolerant yeast, Saccharomyces cerevisiae, in an attempt to allow the strain to ferment cellobiose. Techniques for the introduction and manipulation of genes are available for these host strains.

\section{Methods}

DNA was isolated from the cellobiose-fermenting yeast strains Brettanomyces clausenii, Candida lusitaniae, and Torulopsis wickerhamii (Lastick et al. 1984), and from the cellulase-producing thermophilic bacterium. Fragments of the DNA preparations of appropriate size were obtained by partial digestion using the restriction endonuclease SaulIIA. This procedure produces a semi-random mix of DNA fragments because this enzyme cuts DNA at sites that are expected to occur at very many locations on the DNA. Preparative agarose gel electrophoresis was then used to select fragments of 4 to $9 \mathrm{~KB}$ in size for ligation to plasmid vectors (i.e., cloning yeast $\beta$-glucosidases) or 9 to $23 \mathrm{~KB}$ in size for ligation to lambda $(\lambda)$ vectors (i.e., cloning bacterial cellulases).

Yeast plasmid YRp17, which can be used to transform both E. coli and S. cerevisiae, was used for transformation of yeast DNA fragments. Transformation into E. coli utilizes antibiotic resistance genes for identification of cells containing cloned vectors. Using traditional methods for yeast transformantion results in 100 to 1000 fewer transformed yeast cells for a given amount of DNA than for bacterial transformations. Thus, to provide for a large amount of randomly cut fragments that represent the entire genome of the donor yeast, a genebank of DNA is being developed by initially transforming $E$. coli. The plasmid DNA is then isolated from large cultures for yeast transformation and plate screening, using a chromogenic indicator for $\beta$-glucosidase (X-giu).

A lambda bacteriophage vector was used to transfect DNA isolated from a thermophilic bacterial strain into $E$. coli strains. Bacteriophage vectors containing the forcign DNA were screened for cellulases by plating with $E$. coli on modified tryptone/magnesium sulfate plates with top agar that contained $0.5 \%$ low viscosity $\mathrm{CMC}$; in some cases, $0.1 \%$ cellobiose was added to the top agar overlay. After overnight incubation at $37^{\circ} \mathrm{C}$, the plates were stained with phosphate buffered Congo Red (1 $\left.\mathrm{mM}\right)$, and destained with $1 \mathrm{M}$ of $\mathrm{NaCl}$. Plaques that produced clearing of the stained $\mathrm{CMC}$ were excised and the phage particles were allowed to diffuse into buffer overnight at $4^{\circ} \mathrm{C}$. These isolates were then titered, and diluted samples of each isolate were tested by spotting $5 \mu \mathrm{L}$ onto a plate overlatd with $E$, coli cells as before. 
Positive isolates were then purified by replating at a dilution that produced 20 to 30 plaques per plate, without staining. Seven plaques from each isolate were then re-tested by spot tests and one positive isolate of each of the seven was used to prepare large-scale lysates. The lysates were then tested by plating at low titer; pure isolates produced clearing of stained CMC around all phage plaques.

Cellulase activity was assayed using p-nitrophenyl- $\beta$-cellobioside (pnp-cellobioside) in $\mathfrak{j} 0 \mathrm{mM}$ acetate buffer ( $\mathrm{pH} 5.0)$ at $65^{\circ} \mathrm{C}$ (or as specifled) for $1 \mathrm{~h}$.

\section{Results and Discussion}

\section{Yeast Transformation for $\beta$-glucosidase Activity}

S. cerevisiae transformants have been obtained using traditional methods, which involve the enzymatic conversion of cells to protoplasts and transformation with ligated yeast plasmid vectors that contain the foreign gene fragments, followed by regeneration of the transformed cells. Using this procedure, no positive transformants have been obtained. This result is probably due to the low transformation efficiency obtained using the traditional methods. A new transformation procedure, which involves the electrophoretic introduction of genes into yeast, is currently being used. With this procedure, transformation efficiencies close to those obtained with bacterial transformation are obtained.

\section{Isolation of Cellulase Genes}

Genes irom a thermophilic bacterial strain that produce cellulase enzymes were isolated as described (see methods). The rate at which these cellulase are genes found by plate screening is approximately one for 2000 phage plaques. Because the average bacterium contains about 3000 genes, and the size (an average of $16 \mathrm{~KB}$ ) of the cloned DNA could potentially contain 5 or more average size genes, it is not unreasonable to find this rate of occurrence. Spot tests on CMC-cellulose containing plates using the initial isolates of the phage vectors clearly show the hydrolysis of the stained CMC (Figure 1). These isolates are initially contaminated by phage that do not produce cellulase activity due to diffusion of phage between neighboring plaques, and during the staining procedure. After the isolates are purified, as described, all phage in the lysate hydrolyze the CMC. The omission of cellobiose $(0.1 \%)$ from the overlay on these plates did not affect CMC hydrolysis with any of the isolates that have been obtained to date (Figure 2).

Cellulase enzymes that have been isolated from this acidophilic, thermophilic organism are characterized by extremely high temperature optima and activity at much lower $\mathrm{pH}$ values than enzymes produced by the $E$. coli host. Assays of the phage lysates on two of the initial isolates clearly indicate that the genes are from the thermophile; for both phage lysates, the optimum temperature for hydrolysis of pnp-cellobioside was approximately $75^{\circ} \mathrm{C}$ (Figure 3). In addition, the activity of both samples remain constant over a period of $3 \mathrm{~h}$ at $75^{\circ} \mathrm{C}$ (Figure 4).

When the phage lysates were pretreated for periods from $1 \mathrm{~h}$ to $3 \mathrm{~h}$ in acetatc buffer at $65^{\circ} \mathrm{C}$, an initial decrease in activity was observed (Figure 5). This could be duc to lack of substrate in the preincubation or other extraneous factors, but it is also possible that a mixture of cellulases is present in the lysates, some being more stable under the preincubation conditions. 


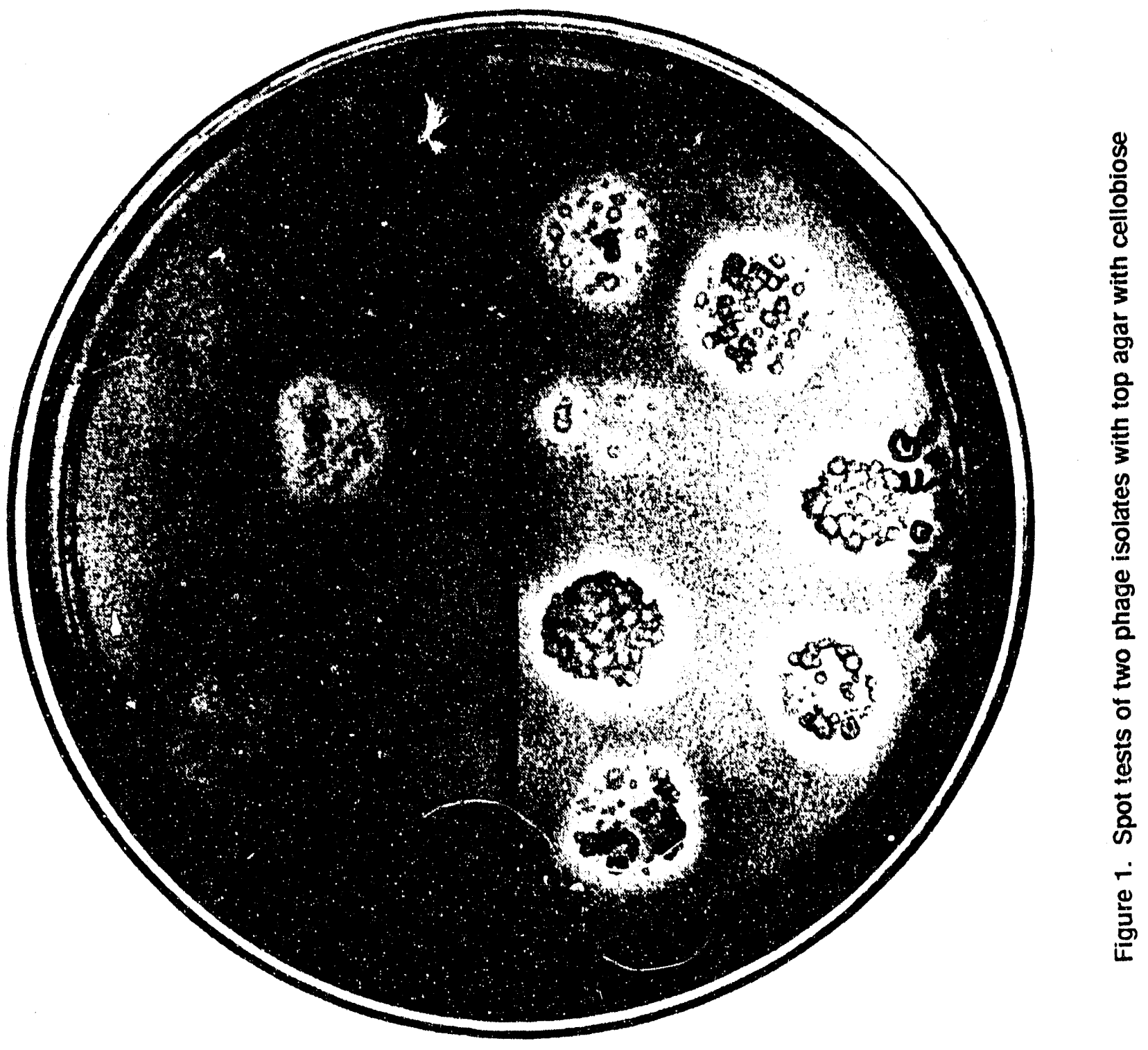




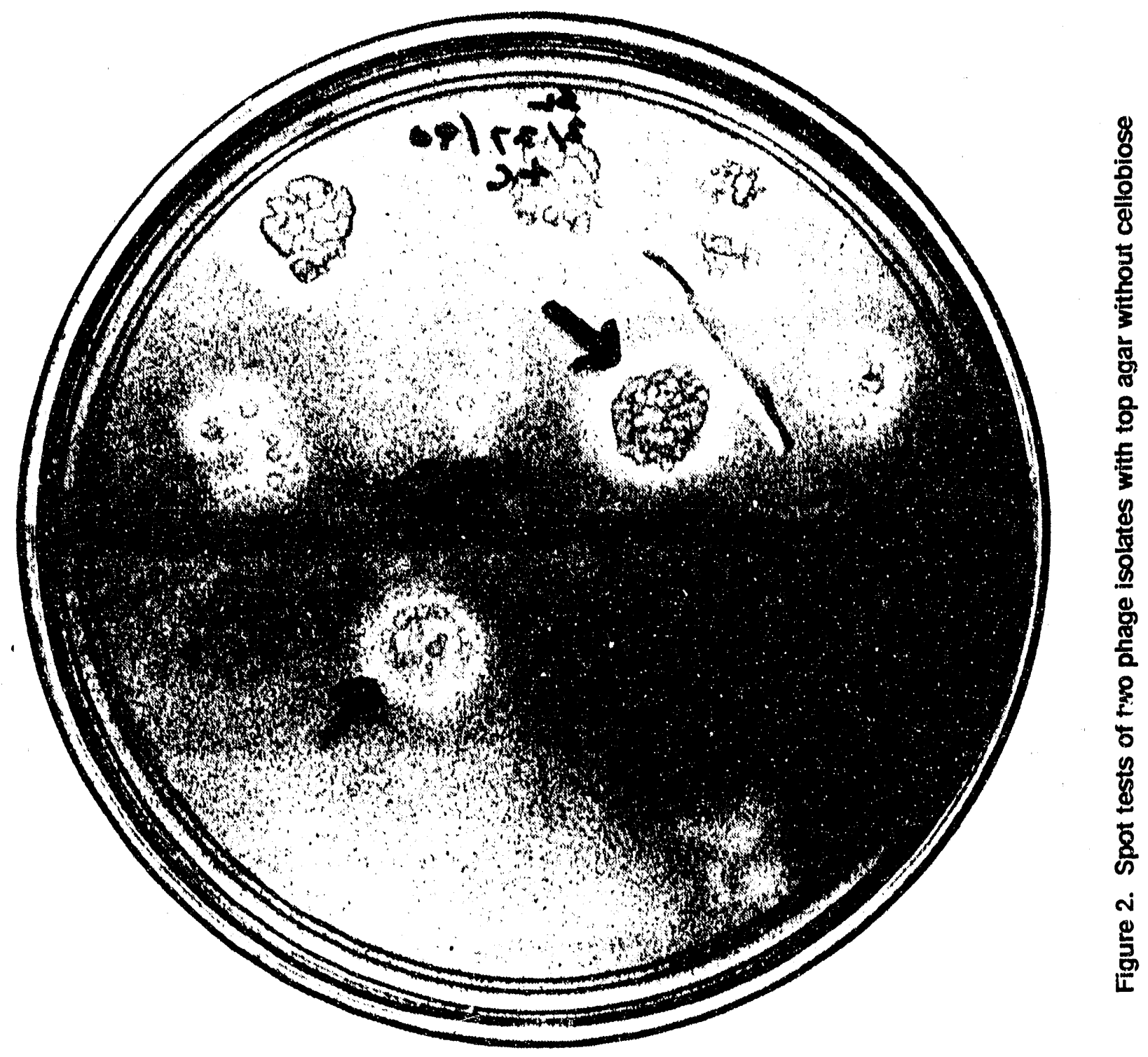


Temperature optimum

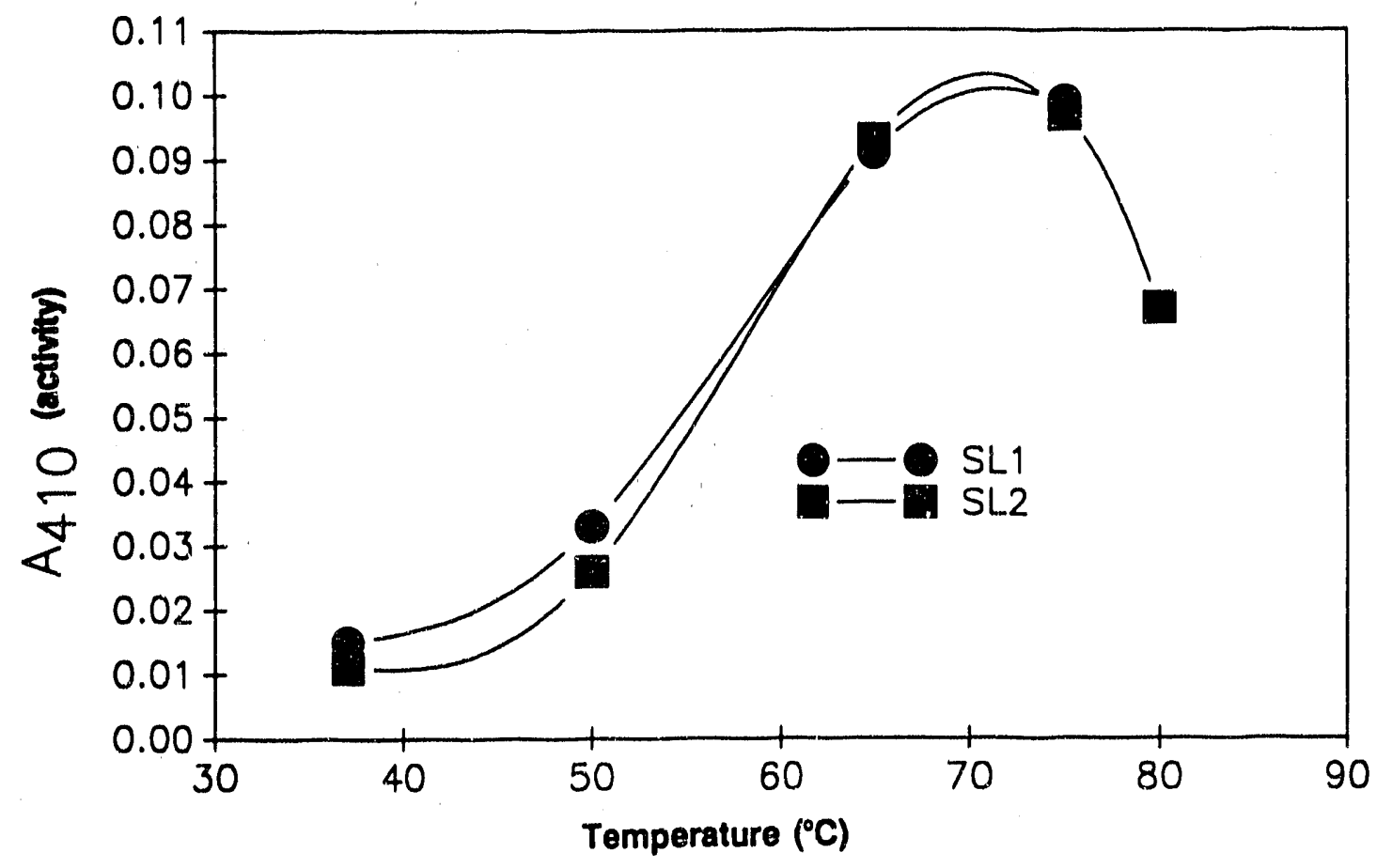

Figure 3. Temperature optimum of cellulase actlvity in phage lysates

Hydrolysis of pnp-cellobioside

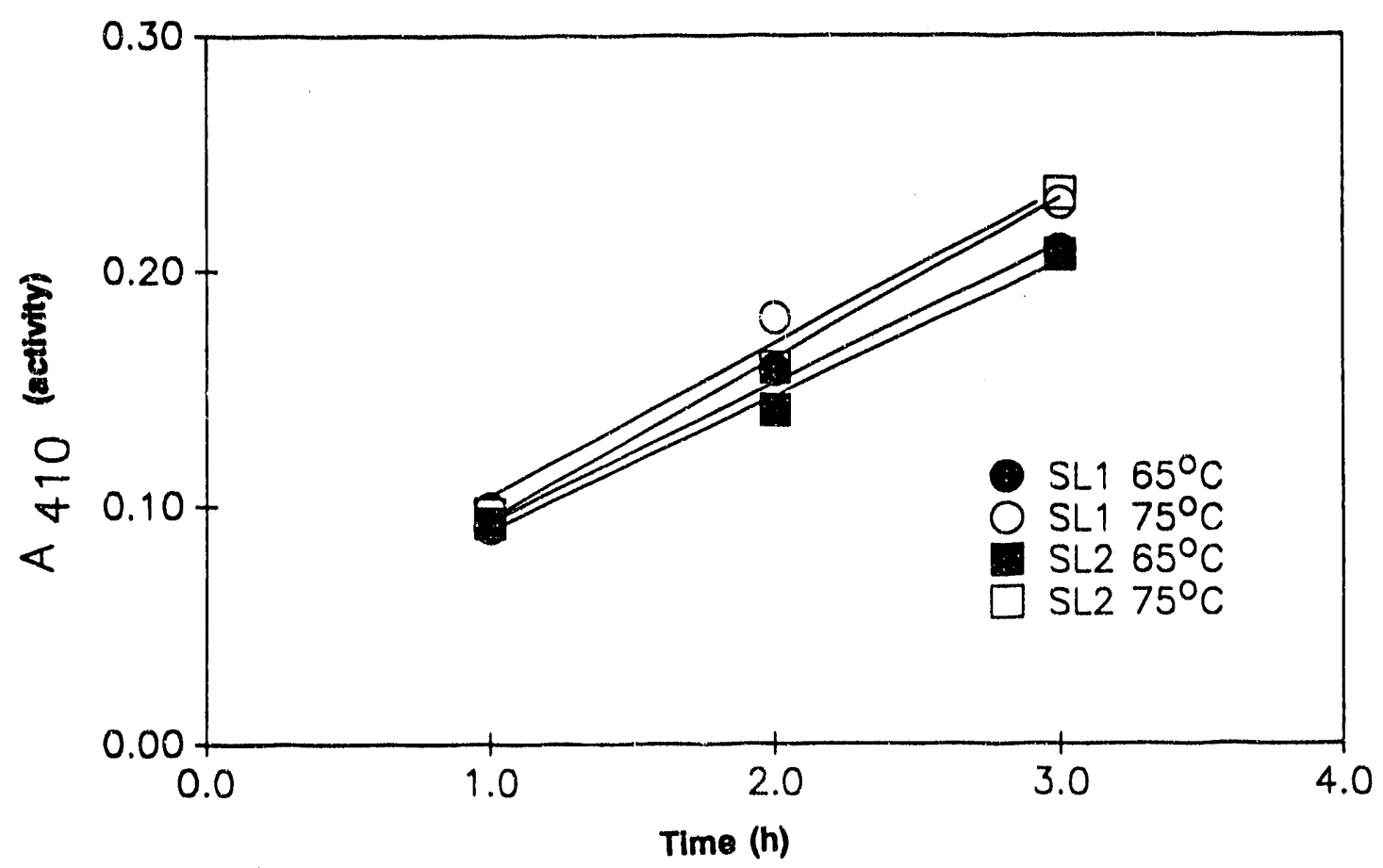

Figure 4. Tlme course of pnp-cellobloside hydrolysis by cellulase actlvity in phage lysates 
It is known that bacteria contain different genes that produce cellulase activity. For example, the thermophilic bactcrium, Clostridium thermocellum, produces a combination of 14 to 18 different proteins, referred to as a "cellulosome," for the hydrolysis of cellulose. In this strain, as well as other bacteria, several different cellulase genes have been isolated (Beguin et al. 1987). Because cellulases work synergistically, it is quite possible that the control of their production may be coordinated by the transcription of a group of nearby genes, as is common in other related bacterial pathways such as the well-studied genes that metabolize lactose. Thus, the large fragments that are cloned into the $\lambda$ vector might well contain more than one cellulase gene. Currently, the DNA fragments that are being isolated from the thermophilic bacterium are being characterized in terms of the cellulolytic genes they contain.

\section{Acknowledgments}

This work was funded by the Biochemical Conversion Program of the DOE Biofuels and Municipal Waste Technology Division.

\section{References}

Aubert, J.-P., Beguin, P. and Millet, J., eds. 1988. Biochemistry and Genetics of Cellulose Degradation, 428 pp. San Dicgo, CA: Academic Press.

Be'guin, P., Gilkes, N.R., Kilbum, D.G., Miller, R.C., O'Neill, G.P., Warren, A.R.J. 1987. CRC Critical Reviews in Biotechnology 6:129-162.

Coughlan, M.P., ed. 1989. Enzyme Systems for Lignocellulose Degradation, 408 pp. Essex, UK: Elsevier Science Publishers, LTD.

Kubicek, C.P., Eveleigh, D.E., Esterbauer, H., Steiner, W., and Kubicek-Pranz, E.M. 1990. Trichoderma Reesei Cellulases: Biochemistry, Genetics, Physiology and Applications, $221 \mathrm{pp}$. Cambridge, UK: Royal Society of Chemistry.

Lastick, S.M., Spindler, D., Terrell, S., and Grohmann, K. 1984. Biotech. Report 1984. 2:277-289.

Spindler, D.D., Wyman, C.E., Mohagheghi, A. and Grohman, K. 1987. Biotechnol. Bioeng. 18:279-294.

Wyman, C.E., Spindler, D.D., Grohmann, K., and Lastick, S.M. 1986. Biotechnol. Bioeng. 17:221-238. 


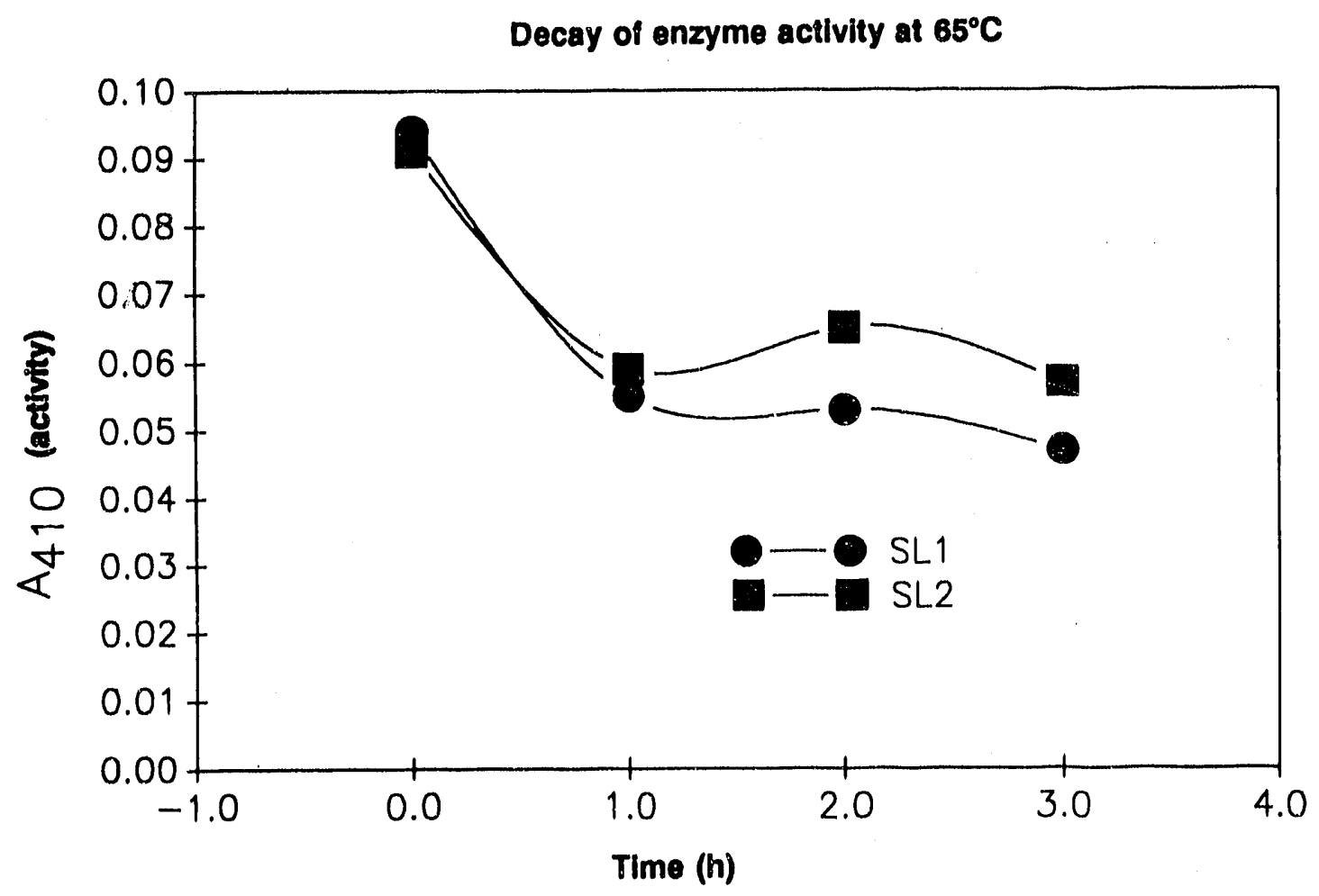

Flgure 5. Pre-Incubation of phage lysates at $65^{\circ} \mathrm{C}$. Assay was for $1 \mathrm{~h}, 65^{\circ} \mathrm{C}$ 


\title{
Cellulase Enzymology Research: An Overview
}

\author{
M. E. Himmel and K. Grohmann \\ Biotechnology Research Branch \\ Fuels and Chemicals \\ Research and Engineering Division \\ Solar Energy Research Institute \\ Golden, Colorado 80401
}

\begin{abstract}
The bioconversion process for converting cellulosic biomass to alcohol fuels must become more economical before industry can cornmercialize this technology on a large scale. Cellulase enzymology research funded by the Ethanol from Biomass Program investigates key aspects of the problem of either reducing the quantity of cellulase enzymes used in industrial processes or recycling the enzymes from the spent process stream. The first goal may be achieved by advancing the understanding of the optimum conditions for action of cellulase enzymes, including synergism between enzymes (either by direct visualization as in electron microscopy, or through more indirect methods such as kinetic analysis), elucidation of enzyme active site geometry, and general structure-function relationships for the key cellulase component enzymes. The challenge of enzyme recycle can be relieved through studies designed to investigate the recovery of selected cellulase enzymes, using chemical denaturants such as guanidinium hydrochloride to remove cellulases tightly bound to cellulose, or by immobilization on ion-exchange resins. New, thermal stable cellulase enzymes produced by Acidothermus cellulolyticus were also evaluated for potential adaptation to the ethanol from biomass process.
\end{abstract}

\section{Introduction}

\section{Research In the Ethanol from Biomass Program}

Although an abundant biopolymer, cellulose is unique in that it is highly crystalline, insoluble in water, and highly resistant to depolymerization. The enzymatic degradation of cellulose to small reducing sugars is generally considered to be accomplished by the synergistic action of three clạsses of enzymes: first, the

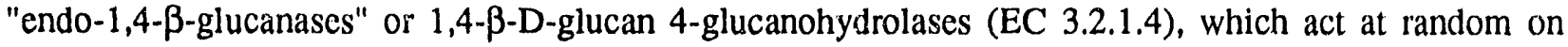


soluble and insoluble 1,4- $\beta$-glucan substrates and are commonly measured by the detection of reducing groups released from carboxymethylcellulose (CMC); second, the "exo-1,4- $\beta$-glucosidases," including both 1,4- $\beta$-D-glucan glucohydrolases (EC 3.2.1.74), which liberate $D$-glucose from 1,4- $\beta$-D-glucans and hydrolyze $D$-cellobiose slowly, and 1,4- $\beta$-D-glucan cellobiohydrolase (EC 3.2.1.91), which liberates $D$ cellobiose from 1,4- $\beta$-glucans; and third, the " $\beta$-D-glucosidases" or $\beta$-D-glucoside glucohydrolases (EC 3.2.1.21), which act to release D-glucose units form soluble cellodextrins and an array of glycosides.

Because the cost of producing the enzymatic "catalysts" proposed in the simultaneous saccharification and fermentation (SSF) process has been identified as a sensitive issue, the effective incorporation of cellulases into these process schemes requires the maximization of the available enzymatic activity to the process. This requirement can be met by ensuring that the enzymes used are obtainable at minimal cost, are of the highest stability possible, and are potentially recoverable from the process and reusable.

Enzymology research performed at SERI and by SERI subcontractors funded by the DOE Ethanol from Biomass Program in FY 1989-90 has focused on the problem of enhancing the utility of the individual components of the fungal cellulase system, specifically $\beta$-D-glucosidase and cellobiohydrolase (CBH) $\mathrm{I}$. These two enzymes have been chosen for special attention because of the key role they play in the hydrolysis of lignocellulose and the well-known observation that CBH I is the most abundant component of the Trichoderma reesei cellulase system.

\section{Cellulase and $\beta-D$-glucosldase Recycle}

In the following report, we describe advances made at SERI during FY 1989-90 in the recycle of Aspergillus niger $\beta$-D-glucosidase by immobilization of the enzyme on a series of commercial ionexchange supports. The characteristics of the immobilized enzymes studied included activity loading, activity retention, and increased thermal half-life. The use of these supports in SSF experiments using pretreated aspen wood as substrate is also described. (See paper entitled "Immobilization of Fungal B-Dglucosidase".)

Scientists at Oak Ridge National Laboratory (ORNL) also pursued enzyme recovery research by conducting a task entitled "Recovery and Reuse of Cellulase." This work, funded by the Ethanol from Biomass Program, describes the use of Macrosorb particles to recover cellulase from solution and its subsequent reuse. The recent development of maintenance-free propylene alginate-bone gelatine spheres at ORNL has allowed them to be used for the entrapment of $\beta$-D-glucosidase. A second project conducted at ORNL investigated the use of protein denaturants for the recovery of cellulose-bound cellulase enzymes. This work showed that CBH I was only partially unfolded by treatment with this denaturant, but the properties of the renatured enzyme appeared identical to those of the native enzyme. During this study it was discovered that guanidine hydrochloride competitively inhibited CBH I, and it was suggested that inhibition was caused by an interaction between the positively charged guanidinium group and an essential carboxylate group present in the active site of this enzyme. Because guanidine only partially unfolded the enzyme, it was assumed that the disulfide bonds in this enzyme would have to be reduced in order for complete unfolding to occur. Preliminary experiments suggested that the reduction of CBH I with dithiotreitol (DTT) results in the reduction of only 2 to 3 out of a possible 12 disulfide bonds even under denaturing conditions. It appears, therefore, that this enzyme is extremely difficult to reduce and unfold, and may suggest that it possesses a tightly folded conformation. 


\section{Enzyme Structural Studles}

This report also describes the work at SERI in FY 1989-90 in characterizing the structural organization of $\mathrm{CBH}$ I from $T$. reesei through studies of its thermal denaturation behavior. Purified CBH I was subjected to thermal denaturation analysis using differential scanning calorimetry (DSC). As many as three endothermic structural transitions were detected during heating of the native enzyme from $20^{\circ}$ to $75^{\circ} \mathrm{C}$ at a range of $\mathrm{pH}$ values from 4.80 to 8.34. DSC analyses of the separated proteolytic fragments representing the catalytic "core" and cellulose-binding "tail" regions of the CBH I molecule revealed that all three of the transitions were associated with the core region. Studies of this type are important because the loss of cellulase activities from solution (i.e., under process conditions) is a key economic concern. The mechanisms by which cellulase enzymes lose structural integrity and unfold at high temperature can be used to model the important processes of activity loss under industrial process conditions, such as high shear, foaming, and protease action. (See paper entitled "Thermal Unfolding of $T$. reesei $\mathrm{CBH} \mathrm{I}^{\prime}$.)

We have also conducted studies at SERI designed to define the nature of the glycosylation of one important enzyme in the cellulase system, $\beta$-D-glucosidase isolated from A. niger. Apart from traditional fermentation optimization work designed to reduce the cost of secreted cellulases from the original fungal source, recombinant technology efforts have also become increasingly important for cost-effective enzyme production. Workers both in the United States and abroad have diligently pursued the prospect of cloning the key cellulase genes in both bacterial, yeast, and nonsource fungal hosts. The exciting potential benefit of developing overproduction systems for fungal cellulases in $E$. coli is, however, predicated on the assumption that the cloned enzyme(s) will be active and stable as produced by the bacterial host - a questionable assumption, considering that bacterial hosts do not glycosylate cloned proteins. This condition is important when considering fungal polysaccharidases, which are usually glycosylated to various degrees when produced by the original fungi. Although the role played by the carbohydrate portion of proteins (glycoprotein) is not fully understood, the properties of solution stability (primarily thermal stability), substrate recognition and binding, and perhaps peptide chain flexibility can be attributed to glycosylation.

\section{Studles of Cellulase Appllcations}

Studies investigating the way cellulase enzymes work together, or synergism, are important to the economic application of cellulase activity, especially on recalcitrant substrates. A study funded by the DOE Ethanol from Biomass Program at Colorado State University (CSU) entitled "Visualization of Active Enzyme Complex by SEM" addressed this problem. R. Ellis and co-workers were competitively selected to develop mono-specific antibodies to all four Trichoderma cellulases and apply these "probes" to the direct visualization of the labeled enzymes on a cellulosic substances using scanning electron microscopy (SEM). The benefit of this research lies in the establishment of a monoclonal antibody cell line collection for CBH I \& II and endoglucanase (EG) I \& II, the development of affinity purification techniques for these enzymes for research purposes, and an increased understanding of the ratios of CBH and EG enzymes necessary for optimal saccharification. The visualization of $T$. reesei $\mathrm{CBH}$ I and EG I on pretreated aspen cellulose using monoclonal antibody-colloidal gold conjugates was recently accomplished by these scientists. The work showed that both enzymes tended to segregate onto zones of substrate that undoubtedly differed in cellulose structure. Thus, groupings of CBH I and of EG I were found extensively. Where proximity was observed, the endoglucanases were always associated with one or more cellobiohydrolases. From these observations, it is possible to imagine, consistent with the accepted theory, that initial attack is by an endoglucanase. Neighboring cellobiohydrolase enzymes would then bind to the hydrolyzed glucosidic bonds, causing desorption of the endoglucanase. Other sites of mixed enzyme binding support the picture that the endoglucanase could continue to hydrolyze glucosidic bonds downstram fiom the initial binding site, subsequently being followed by more cellobiohydrolase enzymes. 
Stereo micrographs also showed that individual $\mathrm{CBH}$ I probes could be found binding the terminus of single cellulose fibrils extending off the plane of the cellulose sheet. These observations indicate that the MAb-colloidal gold label is a valuable tool for visualizing cellulase enzymes in situ.

A further applications study was conducted at ORNL, entitled "Comparison of the Properties of Cellulase Enzyme Components Before and After Their Use to Catalyze the Hydrolysis of Cellulose." In performing this study, J. Woodward and co-workers determined the kinetics of adsorption of all four cellulase components from $T$. reesei on pure cellulose. Although the kinetics of the adsorption of $\mathrm{CBH} I$ and the other cellulase components to lignocellulosic materials such as steam-exploded wood have not been measured, this group of researchers will purify an endoglucanase component from $T$. reesei by chromatofocusing, which together with the CBH 1 component already purified, will be used in these studies and in determining synergistic effects between them on "real" cellulosic biomass.

Workers at CSU were also competitively selected by SERI to conduct a research subcontract entitled "Optimization of the Cellulase Productivity by Acidothermus cellulolyticus." J. Linden and co-workers studied the regulation of cellulase synthesis in A. cellulolyticus, a promising producer of thermal stable cellulase enzymes. Various compounds, such as L-sorbose, cyclic AMP (cAMP), L-glucose, 2-deoxyglucose, glucose-1-phosphate (G-1-P), sophorose, salicin, sugar alcohols, and isopropylthioglucoside (IPTglu), were added along with Solka Floc (SF) to fermentations to maximize cellulase production. During the course of the subcontract, the cellulase titer in fermentation broths was increased from the initial levels of $0.05 \mathrm{U} / \mathrm{mL}$ found for simple sugars only, to $0.105 \mathrm{U} / \mathrm{mL}$ with optimal mixtures of SF and cellobiose. The highest level of enzyme activity, i.e., $0.200 \mathrm{U} / \mathrm{mL}$, was achieved with both salicin + SF or G-1-P + SF substrates. These investigators also found that when cAMP was added exogenously to $A$. cellulolyticus cultures in the concentration range of 0.01 to $0.2 \mathrm{~g} / \mathrm{L}$, cAMP did not affect cell growth. However, cellulase yields were increased with the increasing levels of cAMP. The enzyme production rates, between 35 and $50 \mathrm{~h}$ in cAMP with SF, were identical with the different levels of cAMP addition during fermentations. L-sorbose, L-glucose, 2-DG, G-1-P, sophorose, IPTglu, and sugar alcohols enhanced cellulase activity produced in the medium, but the starting time and the time required to reach the maximum enzyme activity were different in each condition. All these substances functioned as moderators in a proposed cellulase synthesis model. From the experimental results, only cellobiose, xylose, sophorose, and unknown soluble derivatives from cellulose were considered as inducers. In the proposed regulatory mechanism of cellulase synthesis for A. cellulolyticus, the repressor, inducer, cAMP, and moderator were all involved in controlling the rate and the yield of enzyme production. 


\title{
Enhanced UtIlization of Fungal $\beta$-D-Glucosidase
}

\author{
M.E. Himmel, D.J. Mitchell, J.O. Baker, and K. Grohmann \\ Biotechnology Research Branch \\ Fuels and Chemicals \\ Research and Engineering Division \\ Solar Energy Research Institute \\ Golden, Colorado 80401
}

\begin{abstract}
Process engineering studies have shown that the successful commercialization of biocatalyst-based processes (such as the conversion of cellulose to fermentable sugars) is sensitive to the cost of enzyme prodiction. The recycle of enzyme activity in such processes would substantially decrease the enzyme loading for the process and thus conserve this key component. We have therefore investigated immobilization on ion-exchange resins for activity recovery from cellulose hydrolysis reactors. Immobilization of $\beta$-D-glucosidase by adsorption on anionic exchange resins is discussed as an economically viable method of enzyme recovery. Attachment of the enzyme to several resins is presented. However, the focus of the work was on the adsorption of the enzyme to Macrosorb KAX DEAE and its application in simultaneous saccharification and fermentation (SSF), because of the outstanding characteristics possessed by this immobilized enzyme (IME) system. These characteristics included activity loading, activity retention, and increased thermal half-life. It must be noted that this IME system is not acceptable for process applications because of the prohibitively high cost of the Macrosorb resin; it is, however, a benchmark for the technical evaluation of other anion exchange resins.
\end{abstract}

\section{Introduction}

\section{Overview}

The immobilization of biocatalysts by either direct binding or physical retention has been reviewed extensively (Hartmeier 1986; Woodward 1985; Rosevear et al. 1987; Swaisgood et al. 1989). Methods for immobilization by binding can be further divided into (1) binding to carriers (i.e., either by ionic, adsorptive, or covalent mechanisms); and (2) binding to each other or to other proteins (i.e., homo- and heteroconjugates). Methods of physical retention include: (1) matrix entrapment in beads, fibers, or sheets; and (2) membrane enclosure in either microcapsules or membrane reactors. The primary reasons for using immobilization technology in industry, apart from special research applications, include enitianiced 
separation of enzymes from process streams, increased practical concentrations of catalytic activity, potential advantages in the kinetics of enzymes used in multi-enzyme process when held in close spatial proximity, and an enhancement in stability. Immobilized enzymes are used widely in the pharmaceutical, food, fine chemicals, and medical industries. Experiences reported in the literature have shown that the properties of an enzyme after immobilization or crosslinking cannot always be inferred from those of the free enzyme.

\section{Polysaccharldases}

Polysaccharide degrading or transforming enzymes represent a major component of the U.S. market volume of commercial enzymes (e.g., $\$ 1.30$ million in a total market of $\$ 340$ in 1986) (Hartmeier 1986). Industrial polysaccharidase enzymes have been successfully immobilized on many supports, a few examples of which include glucoamylase on aluminum oxide (Krakowiak et al, 1984), dextransucrase on DEAE-Sephadex (Ogino 1970), $\beta$-lactamase on Sepharose (Pastorino et al. 1985), and $\beta$-galactosidase on nylon-acrylate copolymer (Beddows et al. 1981). Cellulases represent another class of polysaccharidedegrading enzymes subjected to immobilization. Successful attempts to yield active, soluble immobilized cellulase systems include carbodilmide crosslinking to high-molecular-weight polyvinylalcohol (Rao and Mishra 1984) and hexamethylene diisocyanate crosslinking to polyethyleneglycols (Kumakura and Kaetsu 1985a). Cellulases nave been entrapped within hydroxyethyl methylacrylate (Kumakura and Kaetsu 1985b) and acrylamide gels (Roy et al. 1984). In other applications, cellulases have been immobilized on insoluble carriers. These systems include CNBr-activated Sepharose and Affi-Gel 15 (Chim-anage et al. 1986), glutaraldehyde-activated nylon (Jain and Wilkins 1987), and ion exchange resins such as Macrosorb (Woodward and Bales 1989), among others. Woodward concludes in a recent review (1985), however, that immobilization of cellulases to insoluble supports-or most types of entrapment-lead to a severely limited hydrolysis system because of the greatly reduced access of enzyme to substrate. This concern extends to application of immobilized forms of other true polymer or insoluble substrate degrading enzymes as well.

\section{$\beta$-D-glucosidase}

$\beta$-D-glucosidase catalyzes the hydrolysis of cellobiose and some aryl-glucopyranosides, including the two most commonly used analytical substrates: $p$-nitrophenyl- $\beta$-D-glucopyranoside and 4-methylumbelliferyl- $\beta$ D-glucopyranoside. $\beta$-D-glucosidase has long been recognized as the limiting enzyme in the efficient degradation of cellulosic materials to glucose (Wood and McCrae 1979; Sternberg et al. 1977). This is due to two factors: (1) the hydrolysis intermediate, cellobiose, is a strong inhibitor of the cellulolytic cnzymes; and (2) the commonly utilized cellulolytic enzyme systems are deficient in $\beta$-D-glucosidase. Although good evidence exists that cellulase enzymes may be recycled by virtue of their strong affinity for cellulosic substrates (i.e., via cellulose residue recovery from final process hydrolysis stages), the costeffective recovery of the expensive $\beta$-D-glucosidase from process streams may only be accomplished using insoluble, enzyme-laden supports. There have been innumerable studies describing immobilized enzyme (IME) systems over the past two decades, with more than 100 describing immobilization of $\beta$-Dglucosidases alone. A review of the most relevant works through 1988 was recently included in a mini review of immobilized cellulases (Woodward 1989). These studies have involved the entire spectrum of immobilization techniques, from co-entrapment of $\beta$-D-glucosidase with yeast cells in calcium alginate beads (Hahn-Hagerdal 1984), to adsorption through the polysaccharide moiety of the protein to Concanavalin A sepharose (Woodward et al. 1986), and glutaraldehyde attachment to chitosan (Desai et al. 1986). However, these researchers have either not utilized or have not completely characterized systems that could be applied at the process scale. In other words, these studies have dealt entirely with IME systems that do not fit all the required criteria for an economically viable process. These process-relevant 
criteria included cost of support, cost of immobilization, activity loading, activity retention, mechanical stability, and IME recoverability. The previous work appears to fall short on one or more of these criteria; thus, the issue of an economically viable IME system for $\beta$-D-glucosidase recovery remains open and in need of resolution.

During the past year, several new studies have been published on $\beta$-D-glucosidase IME systems that attempt to fulfill these process-relevant criteria. Immobilization of $\beta$-D-glucosidase by attachment to polyurethane foam (Chakrabarti and Storey 1989) has shown some promise as an economical IME system because of the support's resistance to enzymatic and microbial degradation, advantageous physical properties, and improved kinetics. However, the potential for fouling by particulate matter exhibited by foams renders these supports suspect for use in a reactor with real lignocellulosic materials. An attempt to immobilize $\beta$-D-glucosidase onto magnetic particles has recently been reported (Dekker 1989). The enzyme was immobilized onto polyethyleneimine/glutaraldehyde-activated magnetite (PAM) and titanium (IV) oxide $\left(\mathrm{TiO}_{2}\right)$-coated magnetite (TAM) to use their magnetic properties in recovery. Both IMEs suffered from low activity yield upon immobilization and had less than optimal physical recovery even though they were magnetic, rendering them impractical for process utilization. An in situ immobilized, cell associated $\beta$-D-glucosidase from Aspergillus phoenicis grown as beads in shake flasks would have a potential use in a cellobiose hydrolysis reactor (Reczey et al. 1989); however, application to real lignocellulosic reactors may be limited because of the mechanical shear sensitivity. One study showing promise for process-scale application is the adsorption of $\beta$-D-glucosidase from Trichoderma reesei onto sandy alumina (Fadda et al. 1989). The combination of low support cost, realistic activity loading and retention, and excellent mechanical characteristics is promising. Sandy alumina bound nearly 70 pNPG units/g support while improving the enzyme's kinetics and displaying adequate operational stability. These studies are the most promising investigations reported within the past year, but none of these studies fully ch f $_{\text {; }}$ acterizes the process-scale potential of the IME system. Unfortunately, an IME system that fulfills all the relevant criteria for process utilization will most probably not be reported in a traditional journal, but in the claims of a patent application.

In the work presented, we will discuss an anion exchange resin immobilized $\beta$-D-glucosidase system. Anion exchange resins possess very favorable physical and chemical characteristics. Some commercially available resins are inexpensive ( $\$ 6$ to $\$ 8 / \mathrm{lb}$ ), and have excellent mechanical stabilities, high recovery potentials (because of their macroreticulate size and high densities), and adequate loading potentials at their cost. The focus of this study is the use of the resin Macrosorb KAX DEAE for binding $\beta$-Dglucosidase and the preliminary use of these loaded resins in SSF experiments. Macrosorb is not a candidate for industrial use because of the high support costs. However, the exceptional physicochemical characteristics of this support provide a case study against which other anionic exchange resin IMEs can be technically evaluated in the search for an economically viable IME system for use in a large-scale ethanol fermentation.

\section{Materlials and Methods}

\section{Chemlcals and Reagents}

All common reagents and buffer components used in this study were of reagent grade and were obtained from Fisher or VWR Scientific. p-Nitrophenyl- $\beta$-D-glucopyranoside, Amberlyst A-26, IRA-900, and IRA93 anion exchange resins were obtained from Sigma Chemical Co. Macrosorb KAX DEAE resin was obtained from Sterling Organics. Water used to prepare solutions was deionized using a Nanopure water system. The commercial cellulase preparation used in this study was Genencor GC 123 (1ot \# D7246), which demonstrates $90 \mathrm{IFPU} / \mathrm{mL}$ at $45^{\circ} \mathrm{C}$. 


\section{Instrumentation}

A Pharmacia BioPllot Column Chromatography system was used to perform large-scale size exclusion chromatography $(\mathrm{SEC})$ with an $11.3 \times 90 \mathrm{~cm}$ BioProcess column packed with Sephacryl S-200 HR gel. High-performance size exclusion (HPSEC) and ion exchange chromatography (HPIEC) were conducted with Pharmacia Superose 6 and 12 (HR 10/30) and Mono-Q (HR 5/5) columns respectively, equipped with Beckman model 520 system controller and Beckman model 110B high-performance liquid chromatography (HPLC) pumps. $\beta$-D-glucosidase preparations were concentrated and dialyzed with an Amicon model DC2 Hollow Fiber Ultraconcentrator equipped with H1P10-20 or H1P100-20 cartridges. Resin-bound enzyme was packed in Pharmacia C 10/20 jacketed columns for kinetic analysis. Glucose concentrations in hydrolyzates were determined with a YSI Model 27 glucose analyzer from Yellow Springs Instruments.

\section{Enzyme Purlfication}

$\beta$-D-glucosidase preparations were used in three grades, based on state of enzyme purity, during the course of this study. All grades of $\beta$-D-glucosidase were derived from the Aspergillus niger commercial enzyme, Novozym SP188 (Novo Lid., batch DCN-01).

\section{Dlaflitered $\beta-D-g l u c o s / d a s e$}

This enzyme grade was prepared by the exhaustive ultradialysis of Novozym SP188 with $10 \mathrm{mM}$ phosphate buffer, pH 6.5. Amicon H1P10-20 hollow fiber cartridges were used for this purpose.

\section{SEC purlfled $\beta-D \cdot g /$ cosidase}

This enzyme grade was prepared by applying diafiltered SP188 to the Sephacryl S-200 column. The column was operated at a flow rate of $15 \mathrm{~mL} / \mathrm{min}$ in $10 \mathrm{mM}$ phosphate buffer, pH 6.5 , with $100 \mathrm{mM}$ $\mathrm{NaCl}$. $\beta$-D-glucosidase activity was found in an early eluting peak, which proved to be approximately 92\% $\beta$-D-glucosidase by SDS-polyacrylamide gel electrophoresis (PAGE)(data not shown).

\section{High purity $\beta-D \cdot g l u c o s i d a s e$}

The high purity enzyme grade for kinetic and DSC studies was prepared by a sequential HPSEC and HPIEC procedure, previously reported by Baker et al. (1988), using the Sephacryl S-200 and Mono-Q columns, respectively. This approach yields a $\beta$-D-glucosidase preparation of approximately $99 \%$ purity by SDS-PAGE.

\section{Enzyme Actlvlty Measurements}

$\beta$-D-glucosidase activity was determined according to the method of Wood (1971) as aryl- $\beta$-D-glucosidase by the hydrolysis of $p$-nitrophenyl- $\beta$-D-glucopyranoside (pNPG). In general, the concentration of p-nitrophenolate anion was determined from the extinction at $410 \mathrm{~nm}$ under alkaline conditions induced by the addition of $2 \mathrm{M} \mathrm{Na}_{2} \mathrm{CO}_{3}$ following a 30-min incubation period of enzyme and pNPG. Cellulase assays followed the method described by Chose et al. (1987). 


\section{Activity and Proteln Binding Studles}

All four anion exchange resins tested were exhaustively water washed and de-fined. Amberlite IRA-900, Macrosorb KAX DEAE, and Amberlyst A-26 resins were titrated to pH 5.0 with $50 \mathrm{mM}$ sodium acetate buffer, $\mathrm{pH} 5.0$, and then exchanged with $10 \mathrm{mM}$ sodium acetate buffer, $\mathrm{pH} 5.0$, through several washes. Titration with $0.01 \mathrm{~N} \mathrm{HCl}$ was required for the Amberlite IRA-93 because it was purchased in a free-base form. Once the resin was titrated to $\mathrm{pH} \mathrm{2,} \mathrm{the} \mathrm{same} \mathrm{sodium} \mathrm{acetate} \mathrm{buffer} \mathrm{exchange} \mathrm{procedure} \mathrm{given}$ above was used. Once all resins were in $10 \mathrm{mM}$ sodium acetate, 0.5 -g samples were placed into tubes containing varying amounts of H1P10-20-ultrafiltered Novozym SP188 enzyme (also in $10 \mathrm{mM}$ sodium acetate buffer, $\mathrm{pH} 5.0$ ). These samples were incubated for $18 \mathrm{~h}$ at $22^{\circ} \mathrm{C}$ (this period of time was determined to be twice the minimum incubation time required for complete adsorption). The amounts of protein and activity adsorbed were then determined by the difference from the initial solution concentrations. To determine enzyme inactivation during immobilization, the protein was eluted with $10 \mathrm{mM}$ sodium acetate buffer, pH 5.0, with $1.0 \mathrm{M} \mathrm{NaCl}$. Protein concentrations were obtained with the BCA protein assay kit from Pierce. Activity was measured by the PNPG assay described above.

Because protein adsorption to an anion exchange resin is reversible and does not constitute a classical immobilization, the ability of the resins to retain activity under SSF conditions must be determined. Macrosorb KAX DEAE and the Rohm and Haas resins loared with $\beta$-D-glucosidase were tested with solutions of potentially competitive ionic species. Several batch washes of a $1 \% \mathrm{w} / \mathrm{v}$ slurry were required to ensure complete equilibrium elution for a given concentration, as determined from the absence of pNPG units in subsequent washes. Several salt solutions of typical fermentation media components were tested. These included 3-mM to 50-mM solutions of $\mathrm{MgSO}_{4}, \mathrm{KH}_{2} \mathrm{PO}_{4}, \mathrm{NaCl}$, and sodium acetate. Loaded resin was also exposed to Genencor GC 123 cellulase enzyme (1500 IFPU/L) and yeast nitrogen base (YNB) media. Both of these displacement studies were carried out at $22^{\circ}$ and $40^{\circ} \mathrm{C}$.

\section{Stabllity and Performance of Bound Enzyme}

The stability of the IME was determined by two methods. One measurement of bound activity was obtained using traditional cellulose hydrolysis experiments (described below). In the other method, direct kinetic parameter measurements were obtained using a recirculating differential (RDR) reactor system following the method of Ford et al. (1972).

The operational stability of the IME was determined by the performance of the IME in a real cellulose hydrolysis reactor. Fifty-milliliter tubes were charged with $2.5 \mathrm{~g}$ of $\alpha$-cellulose $(50 \mathrm{~g} / \mathrm{L})$ in $10 \mathrm{mM}$ sodium acetate buffer, pH 4.8. Tetracycline and cycloheximide were added to a final concentration of $40 \mu \mathrm{g} / \mathrm{mL}$ and $30 \mu \mathrm{g} / \mathrm{mL}$, respectively, to prevent microbial contamination. Genencor GC 123 cellulase was used at a concentration of 20 IFPU/g cellulose with various quantities of IME ( $300 \mathrm{pNPG}$ U/g wet resin beads at $45^{\circ} \mathrm{C}$ ) to produce ratios of $0,0.25,0.50,1.0,2.0$, and $4.0 \mathrm{pNPG}$ U/IFPU at $45^{\circ} \mathrm{C}$. These solutions were incubated with mixing by gentle inversion at $45^{\circ} \mathrm{C}$ for $120 \mathrm{~h}$. Both glucose and cellobiose were measured over time by direct glucose analysis (YSI model 27 glucose analyzer, Yellow Springs Instruments) and HPLC, respectivcly. The $\beta$-D-glucosidase activity released from the resin was assayed by pNPG activity in the free solution.

The temperature and $\mathrm{pH}$ stability of the Macrosorb KAX DEAE bound enzyme was determined in a recirculating differential reactor system that consisted of a water-jacketed Pharmacia C 10/20 chromatography column packed with $0.2 \mathrm{~g}$ of IME. Substrate solution was delivered îrom a waterjacketed beaker with a MasterFlex pump that provided flow rates up to $50 \mathrm{~mL} / \mathrm{min}$. The cellobiose concentration did not exceed $3 \mathrm{~g} / \mathrm{L}(9 \mathrm{mM})$ to minimize substrate inhibition. The flow rate necessary to minimize the external mass transfer limitation was determined by the achievement of a constant initial 
hydrolysis rate with respect to superficial linear velocity of the substrate solution (Ford et al. 1972). This flow was then utilized for all subsequent studies. The substrate solution $\mathrm{pH}$ remained at 4.75 during the temperature stability study, while the temperature of the water jackets ranged from $25^{\circ}$ to $75^{\circ} \mathrm{C}$. The activation energy was determined from data obtained during the temperature optima study. Rate constants for assays at $20^{\circ}$ to $60^{\circ} \mathrm{C}$ were used in Arrhenius analysis. Temperature half-life studies were conducted at $60^{\circ} \mathrm{C}, \mathrm{pH} 5$. Assays at $55^{\circ} \mathrm{C}$ were run at 1.5 -h intervals. The elapsed time that the resin was exposed to $60^{\circ} \mathrm{C}$ was used to determine the activity half-life. Operating then at $55^{\circ} \mathrm{C}$, the pH of the substrate solutions was varied from 4.65 to 5.70. The lower limit was set at $\mathrm{pH} 4.65$ because of losses of $\beta$-D-glucosidase from the support as the enzyme approached its isoelectric pH (i.e., pH 4.50). The YSI glucose analyzer was used for substrate conversion assay.

\section{KInetles of Bound and Free Enzyme}

The kinetics of the IME were obtained with the recirculating differential reactor system as described above. The appropriate flow rate, temperature optimum, and $\mathrm{pH}$ optimum as described above were used to most accurately establish the kinetic parameters for this IME enzyme. Substrate solutions from 3 to $150 \mathrm{mM}$ cellobiose in $10 \mathrm{mM}$ sodium acetate were appropriate for this portion of the study. Results were analyzed with the ENZFIT software package (Elsevier Publishers) that permits precise Lineweaver-Burk regressions.

\section{Use of Macrosorb-Loaded Resin In SSF}

Resins loaded with $\beta$-D-glucosidase activity were applied to simultaneous saccharification fermentations using dilute acid (DA)-treated aspen as substrate. For these fermentations, 1.5-L Applicon fermenters equipped with both marine and flat-blade type impellers were used. Temperature and $\mathrm{pH}$ were controlled at $37^{\circ} \mathrm{C}$ and 5.0, respectively. Fermenters were inoculated with $S$. cerevisiae grown to mid-log phase in YNB. SSFs were performed in YNB diluted to $30 \%$ with water, with $50 \mathrm{~g} / \mathrm{L} \mathrm{DA}$ aspen meal, and with Genencor GC 123 at a concentration of $30 \mathrm{IFPU} / \mathrm{g}$ substrate cellulose content. $\beta$-D-glucosidase activity was provided to the fermentation both from a soluble source (Novo Sp 188) and from IME (Macrosorb $\mathrm{KAX}$ ). In both cares, the supplementation ratio (SR), cellulase units/ $\beta$ - $D$-glucosidase units, was maintained at 0.5 . Ethanol production was measured by analyzing culture supernatant by gas-liquid chromatography with a Hewlett-Packard model 5880A GC equipped with a Poropak Q column from Supelco, Inc.

\section{Results and Discussion}

\section{Actlvity and Proteln Binding Studles}

Figure 1 shows the protein and activity loading isotherms for Novozym SP188 on the three anionic exchange resins. Obviously the Macrosorb $\mathrm{KAX}$ DEAE possesses the highest loading capacities, retaining 2.5- and 6-fold more protein and activity than IRA-93. These aspects, combined with Macrosorb's superior physicochemical properties, excellent recovery potentiai (Woodward 1989), and low internal diffusion resistance make it an excellent case study for the evaluation of other IME systems. In other words, this IME system will become a : ol against which other attempts to immobilize $\beta$-D-glucosidase on anionic exchange resins can be measured. To succescfully use this IME system in this manner, a 

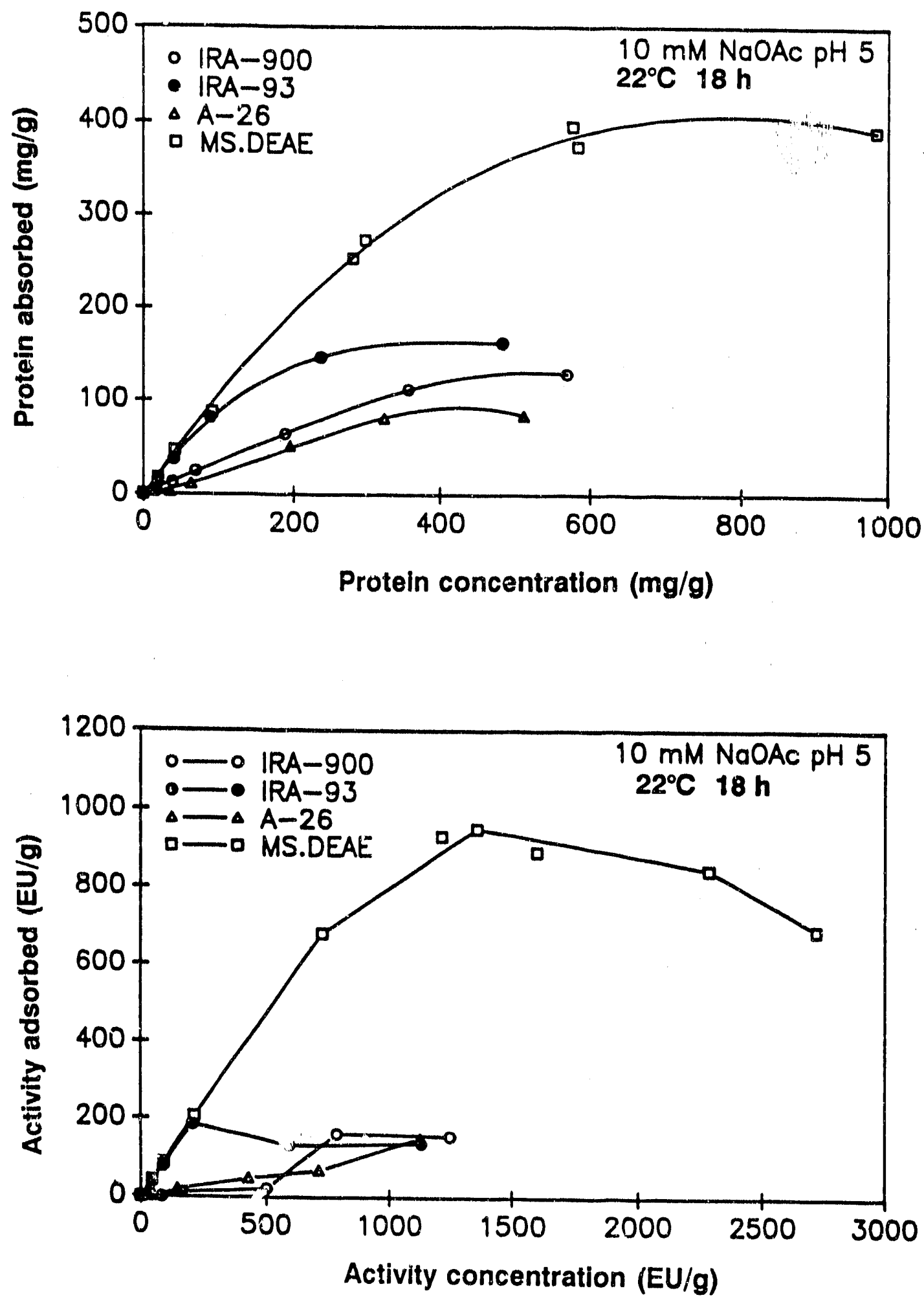

Figure 1. Protein (upper) and activity (lower) loading of four anion exchange resins with Novozym SP188 $\beta$-D-glucosidase in $10 \mathrm{mM}$ sodium acetate pH 5.0. Samples were incubated for $18 \mathrm{~h}$ at $22^{\circ} \mathrm{C}$. 
compicte data base is required. Therefore, the complete evaluation of Macrosorb KAX DEAE bound $\beta$-D-glucosidase is our first step toward selecting an economically viable IME system for use in large-scale ethanol production.

\section{Stabillty and Performance of Macrosorb-Bound Enzyme}

The hydrolysis of $\alpha$-cellulose into glucose by Genencor GC 123 cellulase alone and cellulase supplemented with two ratios each of free and immobilized $\beta$-D-glucosidase is presented in Figure 2 . The increase in conversion upon supplementation is notable (approximately $20 \%$ higher for the $1: 1$ ratio), and the similarity in performance by free and immobilized enzyme is striking. The absence of cellobiose in the media as determined by HPLC indicated that if the hydrolysis was limited, it was not due to $\beta-D$ glucosidase inaccessibility. The ratio at which the supplementation effect begins to diminish is approximately $0.5 \mathrm{pNPG}$ U/IFPU at $45^{\circ} \mathrm{C}$ (data not shown). It is important to note that no pNPG units were eluted from the IME during the hydrolysis, and there is no loss of activity caused by thermal denaturation during the $120 \mathrm{-h}$ incubation at $45^{\circ} \mathrm{C}$ in the controls. Apparently no attrition of the IME occurred (admittedly caused in part by the gentle mixing). The IME was recovered (95\%-100\% by weight) by simple decantation of the media. These are exceptional operational characteristics for an IME in a mixed reactor.

The temperature and $\mathrm{pH}$ stabilities of the free and immobilized enzyme appear in Table 1, along with the kinetic parameters. A flow rate of $\geq 30 \mathrm{~mL} / \mathrm{min}$ was found to be adequate to minimize the external mass transfer effects (data tot shown). The temperature optimum of the IME was higher than that of the free enzyme, because of the increase in thermal stability of the enzyme as determined by the increase in the

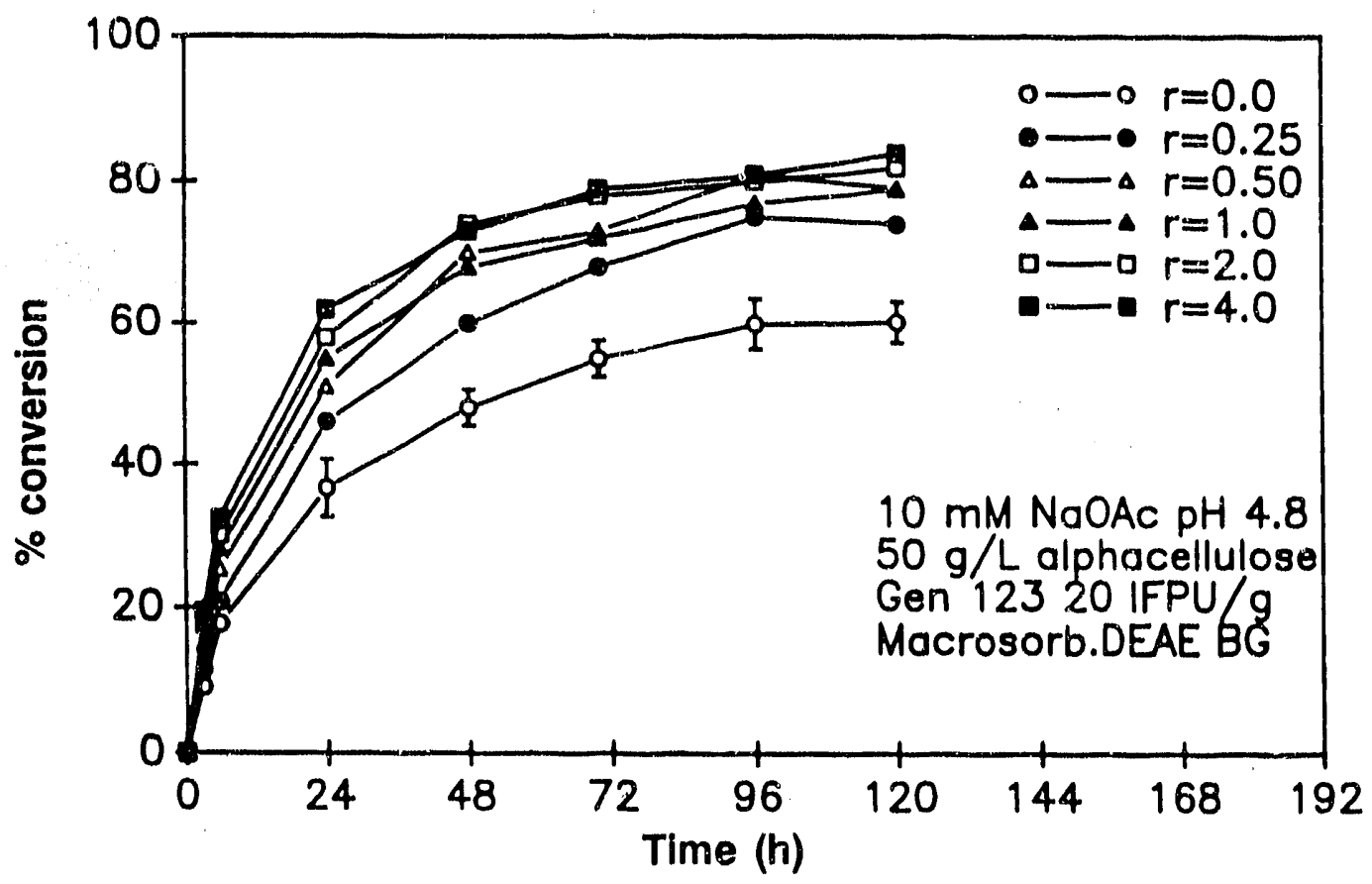

Figure 2. Conversion of $50 \mathrm{~g} / \mathrm{L} \alpha$-cellulose to glucose by Genencor GC 123 cellulase supplemented to varlous ratios ( $r=$ pNPG $U$ at $45^{\circ} \mathrm{C} / \mathrm{IFPU}$ at $45^{\circ} \mathrm{C}$ ) of free and immobilized $\beta-D$-glucosidase. Non-supplemented cellulase is included as a control. Reactions were carried out in mixed tube with $10 \mathrm{mM}$ sodium acetate $\mathrm{pH} 4.8$ at $45^{\circ} \mathrm{C}$. 
activity half-life. This increase in thermal stability was most likely caused by the rich hydrogen-bonding environment influencing the immobilized enzyme. We may also conclude that the pH optimum was

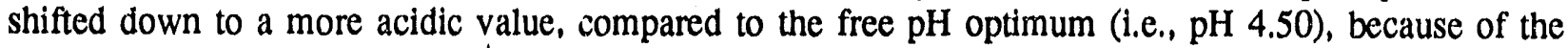
electrostatic partitioning of $\mathrm{H}_{3} \mathrm{O}^{+}$by the positively charged microenvironment inside the IME. The actual value cannot be determined, however, because of the limitation imposed by the elution of activity at $\mathrm{pH}$ 4.55. The decrease in activation energy upon immobilization indicates that the immobilized activity was not as sensitive to temperature changes as the free enzyme.

Figure 3 shows the relative insensitivity of the loaded Macrosob resin to a variety of anionic species likely to be found in SSF broth. With the exception of sulfate, the anions tested do not elute, or compete with, the $\beta$-D-glucosidase bound to Macrosorb at concentrations expected in the SSF system. The anionic displacement of $\beta$-D-glucosidase from all the resins tested was very sensitive to $\mathrm{SO}_{4}{ }^{2-}$ at concentrations of $3 \mathrm{mM}$ and above, with $50 \%$ to $60 \%$ activity loss to solution in $10 \mathrm{mM} \mathrm{MgSO}_{4}$. This is not surprising, because $\mathrm{SO}_{4}{ }^{2-}$ is divalent, nor is it a serious problem because of the observation that only a $1-\mathrm{mM}$ $\mathrm{SO}_{4}{ }^{2-}$ concentration is required in ethanol-producing fermentations. All the resins tested were much less sensitive to the other metal anions evaluated. No losses were observed from Macrosorb at 20-mM anion concentrations; however, $5 \%$ to $10 \%$ activity losses were shown for the Rohm and Haas resins in $20-\mathrm{mM}$ anion solutions. There was little (5\% to $8 \%$ ) displacement of the $\beta$-D-glucosidase by the cellulase proteins (Genencor GC 123) even at unrealistically high protein concentrations (1500 IFPU/L free cel-lulase, i.e., no substrate for binding). The bound enzyme was also very stable to elution by YNB media.

Table 1. Comparlson of the Physicochemlcal Propertles of Free (Novozym SP188) and Macrosorb KAX Immoblilzed $\beta$-D-glucosidase

\begin{tabular}{|c|c|c|}
\hline Property & $\begin{array}{c}\text { Fre } \theta \\
\beta-D \text {-glucosidas }{ }^{a}\end{array}$ & $\begin{array}{l}\text { Macrosorb KAX } \\
\text { Immobilized }\end{array}$ \\
\hline Temperature Optimum & $60^{\circ}-70^{\circ} \mathrm{C}$ & $65^{\circ}-75^{\circ} \mathrm{C}$ \\
\hline pH optimum & 4.5 & $\begin{array}{c}\text { between } \\
4.55 \text { and } 4.70\end{array}$ \\
\hline $\begin{array}{l}\text { Stability (half-life at } \\
\mathrm{pH} 5.0 \text { and } 60^{\circ} \mathrm{C} \text { ) }\end{array}$ & $1.4 h^{c}$ & $9.0 \mathrm{~h}$ \\
\hline Activation energy $(\mathrm{kJ} / \mathrm{mol} / \mathrm{K})$ & 52.5 & 30.0 \\
\hline Apparent $K_{m}$ ( $m M$ celloblose) & 5.6 & 10.1 \\
\hline$V_{\text {max }}$ & $33.7^{d}$ & $117^{\ominus}$ \\
\hline $\mathrm{V}_{\max }$ /apparent $\mathrm{K}_{\mathrm{m}}$ & 6.0 & 11.7 \\
\hline
\end{tabular}

aDekker 1986

bGiven as range from $\mathrm{pH} 4.55$ because enzyme elutes from resin at $\mathrm{pH}$ values less than this

"Baker et al. 1988

d $(\mu \mathrm{mol} / \mathrm{min} / \mathrm{mg}$ protein $)$

( $(\mu \mathrm{mol} / \mathrm{min} / \mathrm{mg}$ bound protein) 


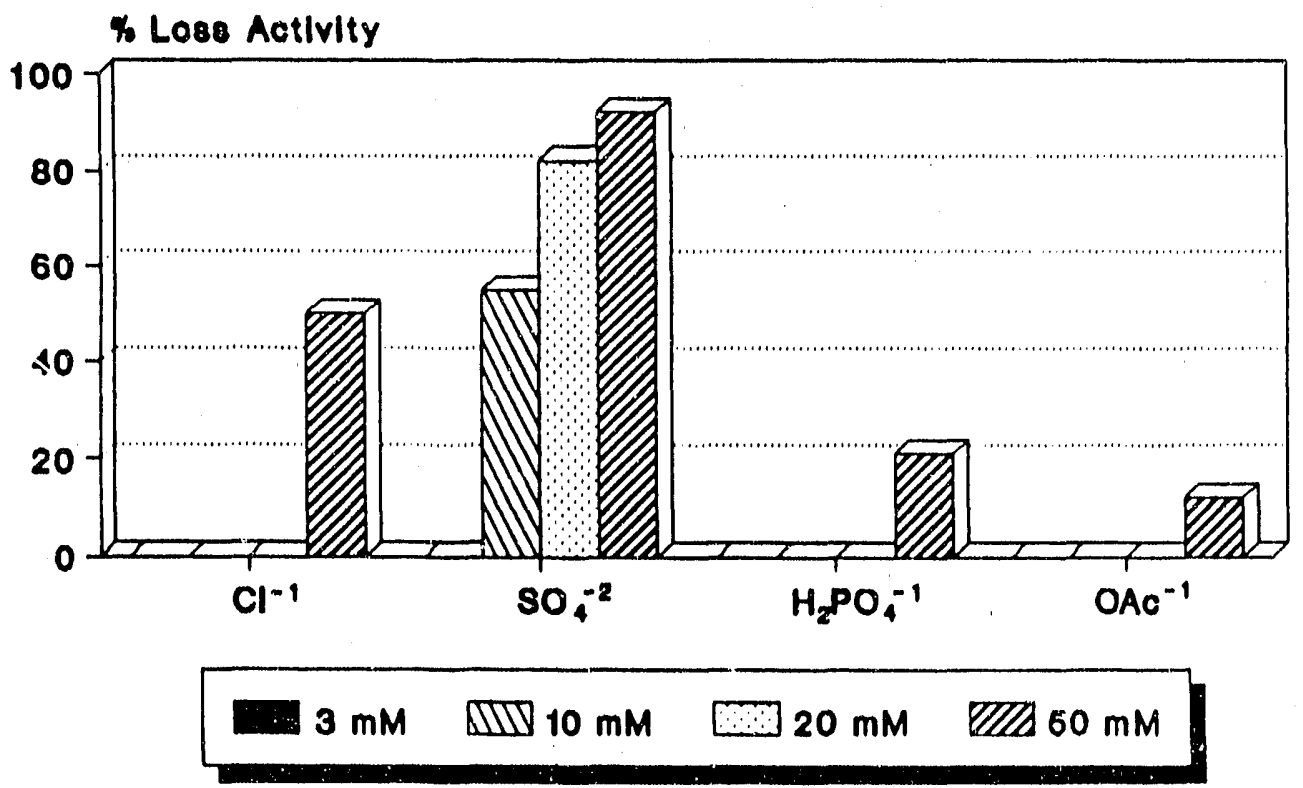

Figure 3. Ion dlsplacement of $\beta-D$-glucosidese activity from Macrosorb KAX DEAE

\section{KInetlcs of Free and Macrosorb-Bound Enzyme}

The results of the Lineweaver-Burk analysis of the initial rates for free and immobilized enzyme appear in Table 1. The small increase in the substrate affinity parameter, $K_{m}$, is probably due to minimal internal mass transfer limitations in the IME, as no substrate-matrix interactions were present. The apparent increase in $V_{\max }$ may be due only to the preferential binding of the resin to $\beta$-D-glucosidase in the presence of other proteins, thus increasing the concentration of $\beta$-D-glucosidase in the resin relative to the solution system.

Macrosorb KAX DEAE binds $\beta$-D-glucosidase more specifically than other proteins; therefore, the activity-to-protein ratio is higher in the resin than in stock solution. The first order rate constant for Michaelis-Menten kinetics, $V_{\max } / \mathrm{K}_{\mathrm{m}}$, describes the kinetics of cellobiose hydrolysis at low $\left([\mathrm{S}]<<\mathrm{K}_{\mathrm{m}}\right)$ substrate concentrations. This low substrate concentration region is of primary interest for IME use in cellulose hydrolysis because of the sensitivity of cellulases to cellobiose inhibition. Supplcmentation of $\beta$-D-glucosidase is necessary for the maintenance of low cellobiose levels for most enzymatic cellulose hydrolysis reactions (Sternberg et al. 1977). Therefore, the effect of immobilization on this ratio is a more appropriate measure of the process-relevant kinetic performance of the IME than either parameter alone. The incrinse in the ratio upon immobilization would indicate an expected increase in performance of the IME in a real cellulose hydrolysis. However, the cellulose hydrolysis ratios (see Figure 4) are based on activities, and not on total protein. Therefore, the similarity in performance of free and immobilized enzyme was not unexpected. 


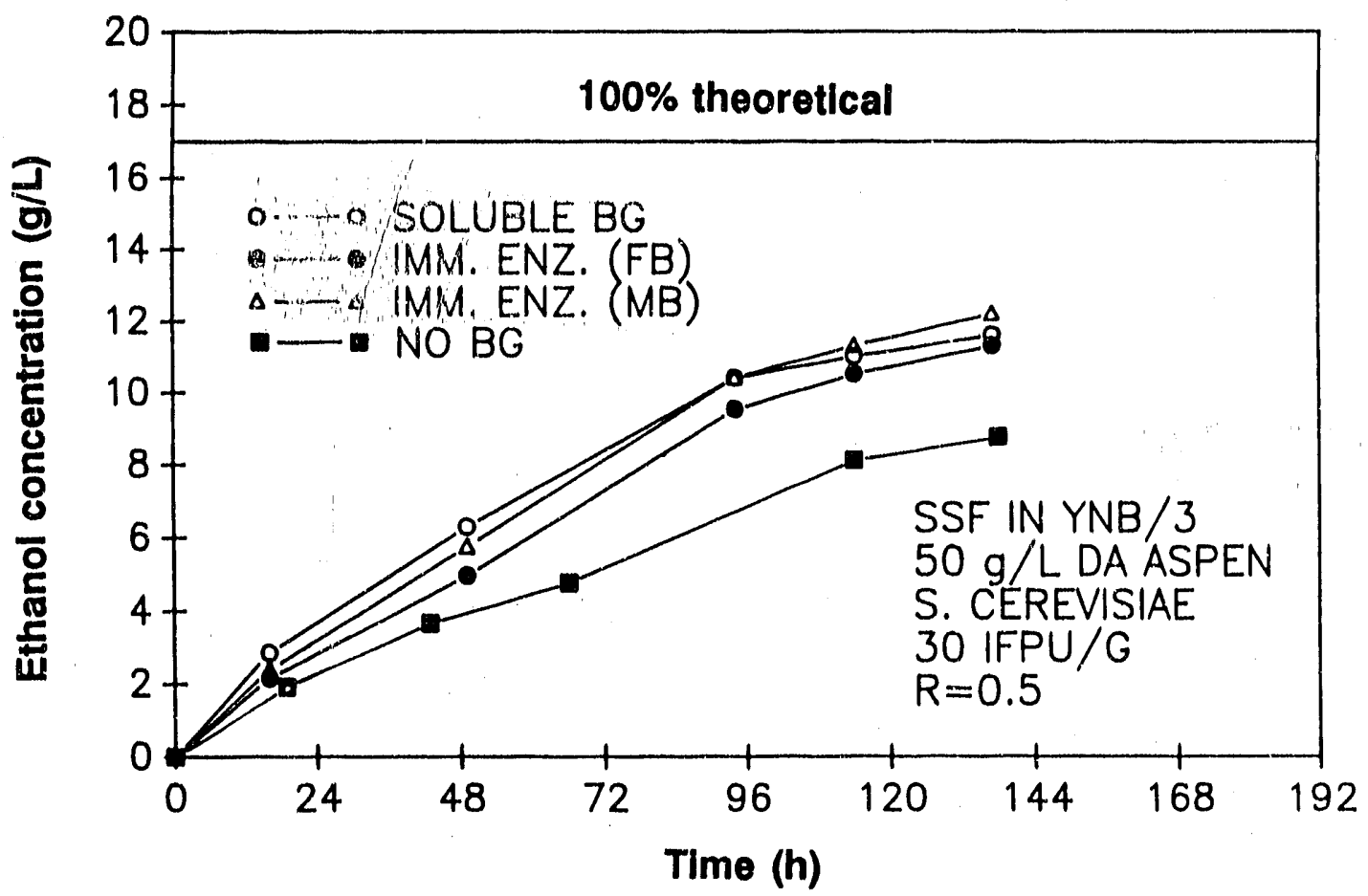

Figure 4. Simultaneous sacchariflcation and fermentation (SSF) with dilute acld treated aspen, S. cerevisiae, Genencor GC 123 cellulase, and two forms of $\beta$-D-glucosidase. Both marine blade (MB) and flat blade (FB) impellers were used. In all cases, a supplementation ratio (R), cellulase units/ $\beta$-D-glucosidase units, was maintained at 0.5 .

\section{SSF UsIng Immobillzed and Soluble $\beta$-D-glucosidase}

SSF experiments conducted with different sources of $\beta$-D-glucosidase are shown in Figure 4. The profile of ethanol production from DA aspen was nearly identical in fermenters charged with soluble $\beta$-D-glucosidase (Novozym Sp 188) and with IME. The control fermentation (solid squares in Figure 4) shows the poorer perforraance typical of an unsupplemented system (i.e., the only source of $\beta$-Dglucosidase was from the Genencor GC 123 preparation). The overall performance of these SSF experiments was quite consistent with those recently reported with similar substrates (Spindler et al. 1990), where the final ethanol concentration demonstrates that a conversion of $70 \%-72 \%$ of theoretical was achieved. Results from the two different impeller blade types showed a possible sensitivity in favor of the marine blade; however, this difference may lie within experimental error.

\section{Conclusions}

We have reported the successful development of an immobilized $\beta$-D-glucosidase system using Macrosorb KAX resin and its use in SSF experiments. Aspergillus niger $\beta$-D-glucosidase was used as the test enzyme for these studies. The economic use of this enzyme may be enhanced through immobilization for recycle and recovery from process streams. Immobilization of this enzyme was also shown to significantly increase the activity half-life of the enzyme at elevated temperature (i.e., $60^{\circ} \mathrm{C}$ ). Application of the immobilized enzyme in authentic SSF experiments shows that this type of immobilization was stable and effective as a source of $\beta$-D-glucosidase activity throughout the fermentation profile. A final ethanol conversion of $70 \%$ of theoretical was achieved. 
Each methodology has its own shortcomings, however, including initial costs and losses of activity. Ultimately, the benefits of each technology must be weighed against the costs, both in terms of economics and enzyme activity recovery. As mentioned previously, an a priori estimate of the benefits of these technologies based on a new enzyme system is difficult, but the potential for these technologies are significant.

\section{Future Direction}

As mentioned earlier in this paper, the cost of the test immobilization support used in this study, Macrosorb KAX DEAE, is prohibitively high for actual process application. It serves, therefore, as a "benchmark" for following work. Future work should be aimed at the identification of cost-effective supports for ion exchange immobilization of fungal $\beta$-D-glucosidase.

\section{Acknowledgment}

This work was funded by the Ethanol from Biomass Program of the DOE Biofuels Systems Division.

\section{References}

Baker, J.O., Oh, K.K., Grohmann, K., and Himmel, M.E. 1988. Biotechnol. Lett. 10:325-330.

Beddows, C.G., Guthrie, J.T., and Abdel-Hay, F.I. 1981. Biotechnol. Bioeng. 23:2885-2889.

Chakrabarti, A.C., and Storey, K.B. 1989. Appl. Biochem. Biotechnol. 22:263-278.

Chim-anage, P., Kashiwagi, Y., Magae, Y., Ohta, T., and Sasaki, T. 1986. Biotechnol. Bioeng. 28:18761978.

Dekker, R.F.H. 1989. Appl. Biochem. Biotechnol. 23:25-39.

Dekker, R.F.H. 1986. Biotechnol. Bioeng. 28:1438-1442.

Desai, J.D., Ray, R., and Desai, A.J. 1986. Ferment. Technol. 64:255-258.

Fadda, M.B., Dessi, M.R., Rinaldi, A., and Satta, G. 1989. Biotechnol. Bioeng. 33:777-779.

Ford, J.R., Lambert, A.H., Cohen, W., and Chambers, R.P. 1972. Biotechnol. Bioeng. Symp. 3:267-284.

Ghose, T.K. 1987. Pure and Appl. Chem. 59:257-268.

Hahn-Hagerdal, B. 1984. Biotechnol. Bioeng. 26:771-774.

Hartmeier, W. 1986. Immobilized Biocatalysts. Springer-Verlag: Berlin.

Jain, P., and Wilkins, E.S. 1987. Biotechnol. Bioeng. 30:1057-1062.

Ǩrakowiak, W., Jach, M., Korona, J., and Sugier, H. 1984. Starch/Starke 36:396-398. 
Kumakura, M., and Kaetsu, I. 1985a. Biotechnol. Lett. 7:773-778.

Kumakura, M., and Kaetsu, I. 1985b. Studia Biophysica 107:103-107.

Ogino, S. 1970. Agric. Biol. Chem. 34:1268-1271.

Pastorino, A.M., Dalzoppo, D., and Fontana, A.J. 1985. Appl. Biochem. 7:93-97.

Rao, M., and Mishra, C. 1984. Biotechnol. Lett. 6:319-322.

Reczey, K., Persson, I., Tjerneld, F., and Hahn-Hagerdal, B. 1989. Biotechnol. Techniques 3:205-210.

Rosevear, A., Kennedy, J.F., and Cabral, J.M.S. 1987. Immobilised Enzymes and Cells. Bristol, UK: Adam Hilger.

Roy, P.K., Roy, U., and Duke, D.K.J. 1984. Chem. Tech. Biotechnol. 34B:165-170.

Spindler, D., Wyman, C., and Grohmann, K. 1990. Appl. Biochem. Biotechnol. 24/25:275-286.

Sternberg, D., Vijayakumar, P., and Reese, E.T. 1977. Can. J. Microbiol. 23:139-147.

Swaisgood, H.E. and Horton, H.R. 1989. In Biocatalysts in Agricultural Biotechnology, eds. J.R. Whitaker and P.E. Sonnet, 242-261. Washington, DC: American Chemical Society.

Wood, T.M. 1971. Biochem. J. 121:353-362.

Wood, T.M. and McCrae, S.I. 1979. In Hydrolysis of Cellulose: Mechanisms of Enzymatic and Acid Catalysis, 181-209. Washington, DC: American Chemical Society.

Woodward, J. 1985. Immobilized Cells and Enzymes, A Practical Approach. Oxford, UK: IRL-Press.

Woodward, J.J. 1989. Biotechnol. 11:299-312.

Woodward, J. and Bales, J.C. 1989. In Bioproducts and Bioprocesses, eds. A. Fiechter, H. Okada, and R. Tanner, 87-101. Berlin: Springer.

Woodward, J., Marquess, H.J., and Picker, C.S. 1986. Prep. Biochem. 16:337-352. 


\title{
Use of MAb-Colloldal Gold Conjugates to "/suallze Trlchoderma reesel CBH I and EG I on Aspen Cellulose
}

\author{
R. P. Ellis, R. A. Nieves, and R. J. Todd \\ Department of Microbiology \\ Colorado State University \\ Fort Collins, Colorado 80523 \\ T. J. A. Johnson \\ Department of Anatomy and Neurobiology \\ Colorado State University \\ Fort Collins, Colorado 80523
}

\begin{abstract}
Monoclonal antibodies (MAbs) specific for cellobiohydrolase I (CBH I) and endoglucanase I (EG I) were conjugated to $10-\mathrm{nm}$ and $15-\mathrm{nm}$ colloidal gold particles, respectively. The binding of CBH I and EG I was visualized by utilizing the MAb-colloidal gold probes. The visualization procedure involved immobilization of cellulose microfibrils on copper EM grids, incubation of the cellulose-coated grids with cellulase(s), binding of MAb-colloidal gold conjugates to cellulase(s), and visualization via transmission clectron microscopy (TEM). CBH I was seen bound to apparent crystalline cellulose as well as apparent amorphous cellulose. EG I was seen bound extensively to apparent amorphous cellulose with minimal binding to crystalline cellulose.
\end{abstract}

\section{Introduction}

Previously, we generated a series of hybridomas, each of which produced MAbs specific for an antigenic epitope of a particular cellulase or cellulases produced by Trichoderma reesei. At least one MAb specific for each of the cellulases CBH I and II and EG I and II was produced. In addition to these uniquely specific MAbs, several MAbs were produced that recognized epitopes shared by two, three, or all four of the above cellulases (Nieves et al. 1990a). We have utilized these MAbs for several purposes, including MAb affinity purification of EG I (Nieves et al. 1990b). We now report the use of MAbs specific for CBH I and EG I, conjugation of the MAbs to 10-nm and 15-nm colloidal gold particles, respectively, and then TEM visualization of the enzyme-MAb gold complexes on cellulose. The research reported herein will enhance efforts at defining the action and stoichiometry of cellulases on cellulose microfibrils. 


\section{Materlals and Methods}

\section{Preparation of Immunoprobes}

The MAbs were exchanged into 5-mM glycylglycine buffer pH 8.2 using disposable, desalting columns (BioRad, Richmond, Calif.). All fractions were pooled and concentrated using Amicon PM 30 membranes (Danvers, Mass.) to a final concentration of $2 \mathrm{mg} / \mathrm{mL}$.

Concentration variable isotherms (CVAI) for both MAbs were constructed as described by DeMey (1986). CVAI are used to calculate the minimum amount of antibody necessary to stabilize the gold sols against salt-induced aggregation, which is increased at $580 \mathrm{~nm}$. Approximately 24 ug of anti-CBH I MAb per milliliter of $10 \mathrm{~nm}$ gold was added to stabilize the gold. This is twice the minimum amount determined by CVAI.

The next day, the suspension was transferred to 5-mL ultra-clear centrifuge tubes (Beckman, Fullerton, Conn.), and centrifuged for $1 \mathrm{~h}$ at $4^{\circ} \mathrm{C}$ using a Beckman SW 50.1 rotor operated at $30,000 \times \mathrm{g}_{\max }$. The supernatant was aspirated, discarded, and the gold was resuspended in $5 \mathrm{mM}$ of Tris buffer $\mathrm{pH} 7.5$. This was repeated thrce times. After the last wash the gold in each tube was suspended and placed in two tubes, and $2.5 \mathrm{~mL}$ of Tris buffer was added to each tube. The gold was centrifuged at $1,920 \times \mathrm{g}_{\max }$ for 10 min to pellet aggregates of colloidal gold. The supernatant was aspirated and stored at $-20^{\circ} \mathrm{C}$ after diluting 1:2 with glycerol.

For labeling anti-EG I MAb, $35 \mathrm{~mL}$ of $15-\mathrm{nm}$ gold was adjusted to $\mathrm{pH} 8.5$ with $0.2 \mathrm{M} \mathrm{K} \mathrm{CO}_{3}$. Anti-EG I $(12 \mathrm{mg}$ ) was added to each milliliter of gold suspension. This is twice the minimum amount determined by CVAI. The immunogold was prepared as described above.

\section{Preparation of Microflbrlllar Aspen Cellulose}

Initial observation of the negatively stained cellulose following dilute sulfuric acid treatment and alkali extraction (Tatsumoto et al. 1988) did not reveal defined microfibrillar structure, and further dispersion of the wood was neccesar" Treated wood $(230 \mathrm{ug})$ was suspended in $300 \mathrm{~mL}$ of deionized water and homogenized at a power : el of 6 for $1 \mathrm{~h}$ using an Ultra-Turrax homogenizer (Tekmar Co., Cincinnati, Ohio). The sample was maintained at $4^{\circ} \mathrm{C}$ during dispersion treatuent. One-milliliter aliquots of cellulose suspension were allowed to sediment for $3 \mathrm{~min}$, drops of the supernatant of sedimented cellulose were placed on parafilm, and carbon-coated electron microscopy (EM) grids were floated on the drops for 10 min. EM grids were prepared by placing 200 mesh copper grids on floating films of $0.5 \%$ formvar in ethylene dichloride. Grids were then air dried and carbon coated. The grids were submerged in drops of distilled water, blot dried, and stored until used.

\section{Electron Microscopy}

Copper grids containing adsorbed aspen cellulose were incubated with enzymes and immunogold at room temperature as follows. EM grids were initially blocked by floating them on drops of $1.3 \%$ nonfat milk powder in 50-mM phosphate buffer $\mathrm{pH} 6.5$ for $30 \mathrm{~min}$. The grids were stream washed with distilled water, blot dried, and floated cn dmps of a Genencor cellulase preparation that contained CBH I and EG I. The cellulase had been diluted with 50-mM acetate buffer ( $\mathrm{pH} 5.0)$ to a protein concentration of $1 \mathrm{mg} / \mathrm{mL}$.

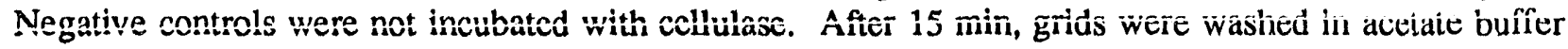
and blot dried. The grids were floated immediately on drops of immunogold that contained 9 parts 
immunogold to 10 parts blocking buffer. Grids were placed in anti-CBH I immunogold, anti-EG I immunogold, or a 1:1 mixture of both, for $30 \mathrm{~min}$. The grids were subsequently stream washed with water, blot dried, and stained with $1 \%$ aqueous uranyl actate for $5 \mathrm{~min}$. The grids were then blot dried and examined on a Philips 400T transmission electron microscope operating at an accelerating voltage of $80 \mathrm{kV}$.

\section{Aggregation of Immunogold Label}

To confirm that observed aggregation of immunogold on cellulose was not an artifact and that indeed it was due to enzyme association, the following experiments were conducted Anti-CBH İ and anti-EG I immunogold labels were introduced separately on EM grids without enzyme. After adsorption these grids were washed in water and then analyzed to determine the state of aggregation of gold colloid in each preparation. The colloids were then counted. A single gold colloid would be counted as a singlet representing $1 \%$ of the total count. Two aggregated colloids would be counted, as one doublet (1\%), three colloids together would be counted as a triplet, etc., up to aggregates of six or more. Once a total of 100 aggregate particles (singlet, doublet, etc.) were counted, a percentile of these was established. The same was done with a grid onto which diluted cellulases $(1 \mathrm{mg} / \mathrm{mL})$ were placed, followed by incubation with anti-CBH I or anti-EG I immunogold.

\section{Results}

\section{Aggregation of Irinunogold Label}

An abundance of singlets, doublets, and higher order aggregates was observed on grids to which anti-CBH I immunogold was bound. Addition of cellulase to the carbon-coated grids increased the number of higher order aggregates while singlets decreased for anti-CBH I gold. This indicates that some CBH I enzyme in the commercial cellulase preparation may be present in aggregated form. The profile for anti-EG I gold was similar to anti-CBH I gold on clean carbon-cciated grids. 'The anti-EG I gold profile did not change when cellulase was preadsorbed to the carbon-coated grids (data not shown).

\section{Visualization of CBH I Bound to Aspen Cellulose}

No apparent gold colloid staining was observed in any of the negative controls (Figure 1). An electron micrograph of $\mathrm{CBH} I$ bound to aspen cellulose shows binding of CBH I to all sections of the cellulose (Figure 2). $\mathrm{CBH}$ I was visualized in aggregated forms on cellulose quite readily. It is evident that the aggregation of gold observed attached to cellulose is not due to intrinsic gold aggregation because more than $70 \%$ of the colloidal gold is found as singlets.

CBH I has affinity to apparent crystalline cellulose as well as to apparent amorphous cellulose. Binding of $\mathrm{CBH}$ I to the terminal ends of aspen cellulose was commonly seen. Figure 3 demonstrates the binding of $\mathrm{CBH} I$ to possible nonreducing ends of aspen fibers produced as a result of pretreatment. 


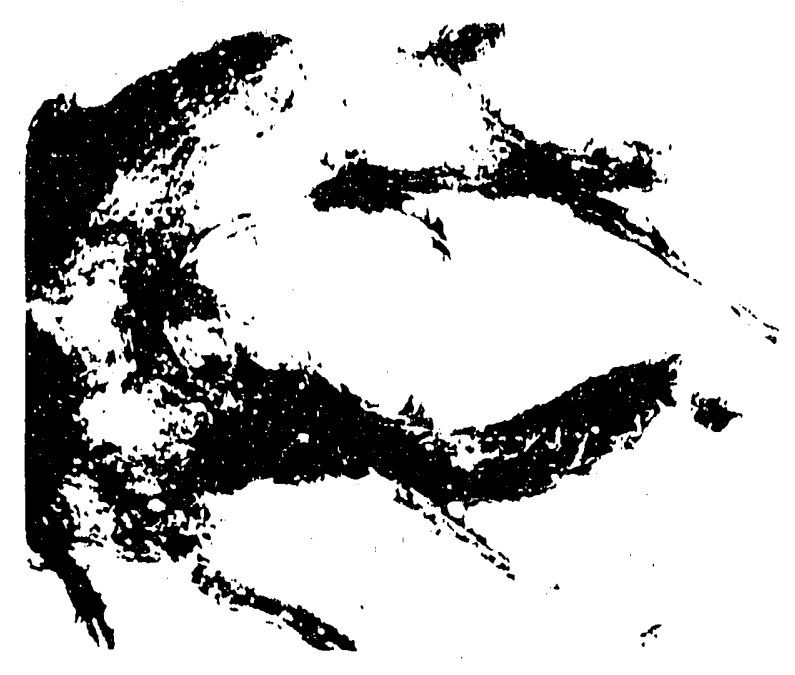

Figure 1. An electron micrograph of a negative controi when antl-CBH I was Incubated with aspen cellulose. Note the absence of gold bincing. (Mag. 17,000x)

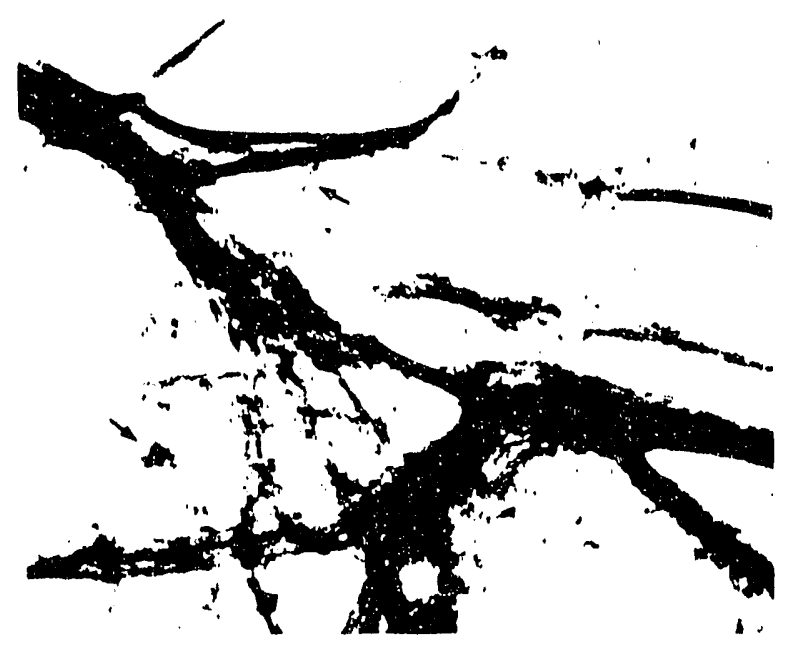

Figure 2. Abundant binding of $\mathrm{CBH} I$ to aspen cellulose as observed with the Immunoprobe. Aggregated binding of $\mathrm{CBHI}$ is observed on apparent amorphous and crystalline regions (arrows). (Mag. 22,000x) 


\section{VIsuallzation of EG I Bound to Aspen Cellulose}

Minimal binding of EG I to aspen cellulose can be observed on the crystalline forms of cellulose but extensive binding can be seen in the amorphous region observed in the middle of the image (Figure 4). It has been stated that the binding capacity of EG I is less than that of CBH I. The micrographs shown here support that data (Reese 1982; Ryu et al. 1984.)

\section{Dual Labellng}

When both immunogold probes were used, different association patterns were observed. Binding of CBH I and EG I to different sites could be observed by the difference in gold diameter. An electron micrograph shows differential binding of CBH I and EG I to apparently intact aspen cellulose (Figure 5). Binding of EG I to apparent amorphous cellulose was also observed. Distinct separation of CBH I and EG I was generally observed.

Infrequently, sites on the cellulose revealed distinct association between both enzymes. Figure 6 demonstrates two bound endoglucanases located near several cellobiohydrolases. Close observation of the micrograph reveals a microfiber(s) adjacent to the visualized enyzmes. Figure 7 reveals two endoglucanase molecules bound to adjacent ends of cellulose microfibers again flanked by cellobiohydrolase molecules.

Some micrographs, when observed in three dimensions, demonstrated the enzymes to be on the same plane (data not shown). However, other micrographs revealed an interesting observation regarding sites of high numbers of aggregated label when viewed in stereo. In some fields, several CBH I molecules were seen bound terminally to cellulose at a low plane, while other cellobiohydrolases and an occasional endoglucanase molecule appeared suspended above the plane of the microfiber. Close observation of such stereo images revealed very fine microfibers that extended from a low plane up to a higher plane where a CBH molecule was attached. Apparently, these enzymes, which initally appeared to be suspended, are actually bound to split microfibers that were different planes than the majority of the cellulose fibers. This observation is an example of the sensitivity that can be obtained from a labeling system and stereo EM.

\section{Discussion}

The use of interdisciplinary biotechniques has increased our ability to visualize macromolecular interactions. We have produced specific probes for the individual cellulases, CBH I and EG I (Nieves et al. 1990a and 1990b). The probes are enzyme specific MAbs adsorbed to colloidal gold. With these probes it is possible to visualize sites on cellulose where cellulases are bound. Stereo TEM imaging of CBH I and EG I permits a high resolution map of enzyme-binding sites.

The dilute acid pretreatment may have produced many chain ends on the long axis of the microfibers. Therefore, the observed abundant binding of $\mathrm{CBH}$ I to the cellulose fibers was expected. In contrast, we observed minimal binding of EG I to the aspen substrate. Earlier reports indicating that EG I binding and activity on crystalline substrates is weaker than that of CBH I (Reese 1982; Henrissat et al. 1985; Woodward et al. 1988) were corroborated by our observations. 


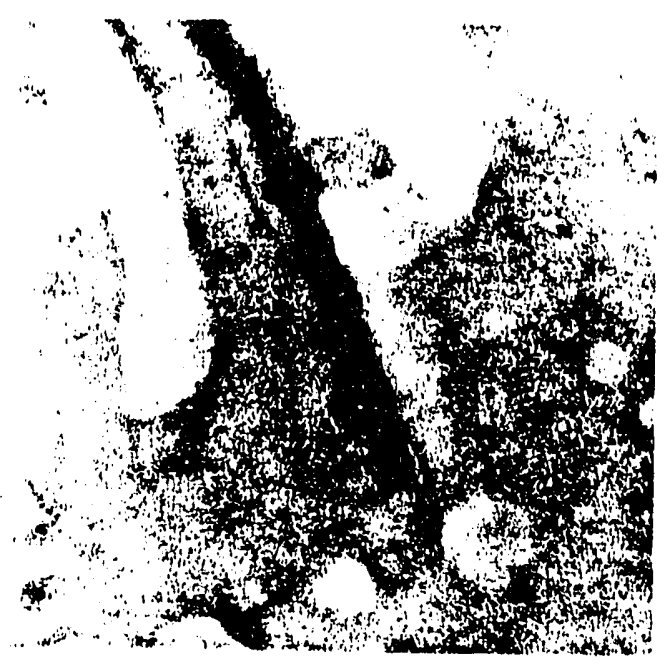

Figure 3. CBH I bound to the terminal end of homogenized aspen cellulose. Terminal binding of $\mathrm{CBH}$ I was occasionally observed. Gold is $10 \mathrm{~nm}$ in diameter. (Mag. 100,000x)

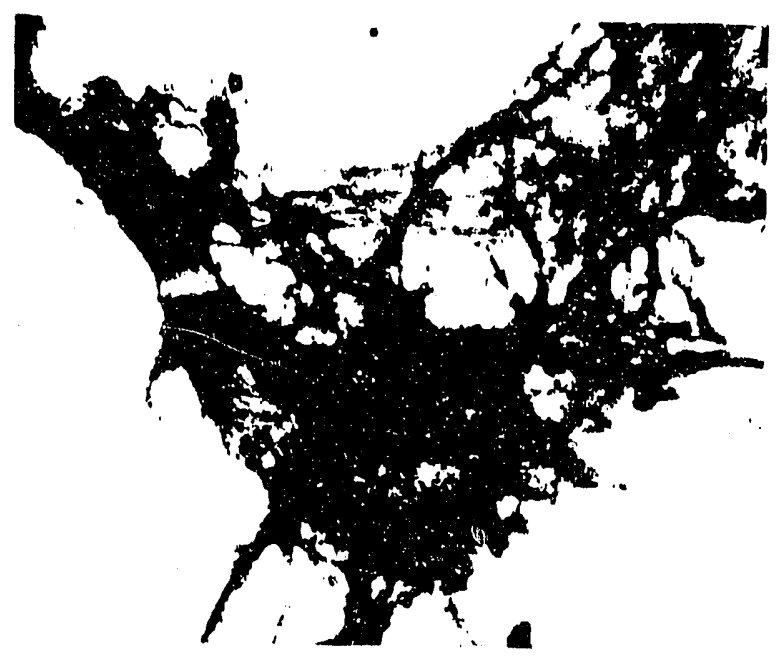

Figure 4. Limited binding of EG I to ordered aspen cellulose as detected by an Immunogoldconjugated MAb to EG I. Note the aggregated binding of EG I to an apparent amorphous region in the center (arrow). (Mag. 13,000x) 


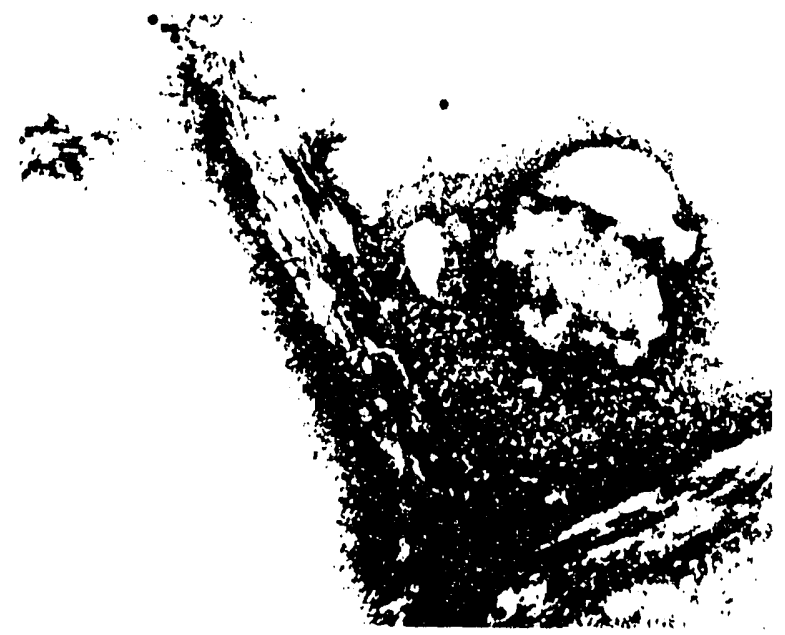

Figure 5. This electron migrograph shows EG I and CBH I bound to intact aspen cellulose. Note the size discrepancy of the gold colloid. Terminal binding of $\mathrm{CBH} I$ is indirectly demonstrated by the 10-nm gold colloid (arrow). (Mag. 80,000x)

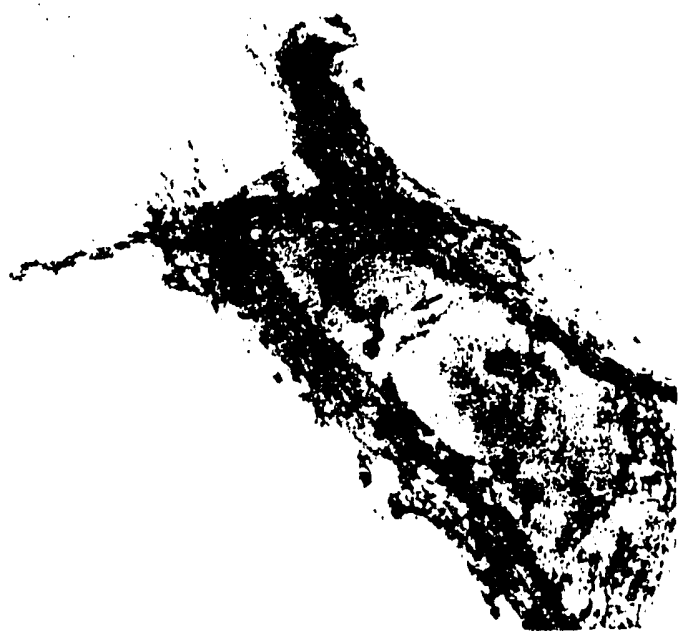

Figure 6. Apparent assoclation of CBH I and EG I is shown In this electron mlcrograph. Several microfibers are seen adjacent to the direction of :mmunogold alignment (arrow). The EG I is located by the large immunogold $(15 \mathrm{~nm})$ ano $\mathrm{CBH}$ I by the smaller immunogold $(10 \mathrm{~nm})$. (Mag. 80,000x) 

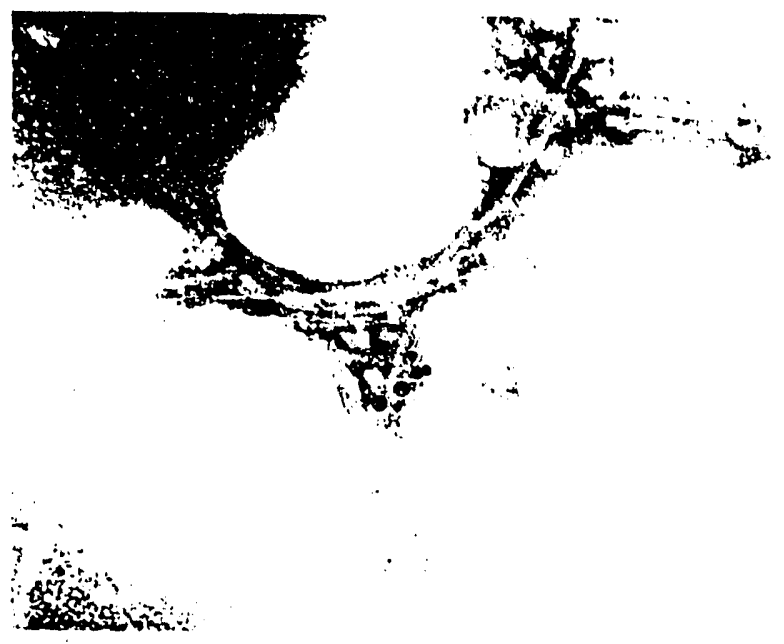

Figure 7. Close approximation of two endoglucanase molecules are seen on elther side of the cellulose fibers. Cellobiohydrolases can be observed flanking one of the endoglucanases. This electron micrograph represents possible association of CBH I ( $10 \mathrm{~nm}$ gold colloid) and EG I ( $15 \mathrm{~nm}$ gold colloid). The large clear rings are thought to be caused by uneven staining of uranyl acetate. (Mag. 80,000x).

EG I was abundantly bound only on areas that contained amorphous aspen cellulose. Hydrolysis studies have shown that endoglucanases do not have the capacity to degrade crystalline cellulose to any extent. Endoglucanases do have the capacity to hydrolyze amorphous or substituted cellulose (Wood and McRae 1979; Coughlan 1985; Wood 1985; Henrissat et al. 1985). Our observations agree with these findings because EG I binds well to the amorphous region of aspen and infrequently to ordered cellulose.

The simultaneous presence of both cellulases was observed by double labeling. Both enzymes were bound well to amorphous cellulose. Obviously, this cellulose contains many binding sites available to both enzymes. It is known that if native ceilulose is pretreated and subsequently exposed to cellulases, increased hydrolysis is observed. Pretreatment can diminish crystallinity and expose the more amorphous regions of cellulose to enzymatic attack (Bisaria and Ghose 1981; Mullings 1985; Klyosov 1986). Our results substantiate that $\mathrm{CBH}$ I and EG I bind well to amorphous cellulose as might be expected from increased hydrolysis rates of the amorphous substrates.

The infrequency of close interaction between CBH I and EG I was not expected. An explanation for the apparent separation may be that a specific molar ratio of EG I and CBH I may be necessary in order to obtain frequent, close interactions. Studies using purified enzymes from $T$. reesei have indicated that the created synergistic effect on cellulose was attained when nonsaturating levels of EG I and CBH I were used (Woodward et al. 1988). By utilizing crude cellulase at a concentration of $1 \mathrm{mg} / \mathrm{mL}$, we may have saturated the substrate and decreased enzyme association. An altemative explanation may be that the two enzymes have clear differences in their preferred binding sites.

The phenomenon of enzyme adsorption and desorption has also been considered in the synergistic interaction of cellulas.es (Ryu et al. 1984; Tanaka et al. 1986; Kim et al. 1988; Kyriacou et al. 1988). It is theorized that after the endoglucanases bind to cellulose, they are displaced by cellobiohydrolase 
molecules, which subsequently attack the newly exposed nonreducing ends. In this situation, observation of both enzymes together in one specific area would not be expected.

Where proximity was observed, the endoglucanases were always associated with one or more cellobiohydrolases. These observations are consistent with the accepted theory that initial attack is by an endoglucanase. Neighboring cellobiohydrolase molecules would then bind to the hydrolyzed glucosidic bonds, causing desorption of the endoglucariase. The endoglucanase could conceivably continue to hydrolyze gludosidic bonds downstream from the initial binding site, subsequently being followed by more cellobiohydrolase enzymes.

Although these results may lead to much speculation, we have demonstrated a useful system for future investigations of cellulases at the molecular level. Using this methodology it will be interesting to examine the interaction between CBH I and CBH II (Fagerstam and Pettersson 1980). It is equally important to investigate whether different molar ratios of purified enzymes will increase visualization of the association between cellobiohydrolases and endoglucanases.

The adsorption of the MAbs to colloidal gold proved to be a reliable technique for the observation of adsorbed enzymes. Aithough these experiments were successful, they raise more questions on the molecular interaction between these two enzymes. Higher levels of binding of CBH I than EG I was observed on ordered aspen cellulose. If the endoglucanases are responsible for initial random binding, one would conceivably observe more EG I bound to the substrate surface. This was not generally observed. Our findings, similar to those of Chanzy et al. (1984), were that CBH I binds readily to cellulose. The exposure of nonreducing ends because of pretreatment could account for the binding observed because $\mathrm{CBH}$ I presumably binds to these termini. Another explanation may be that cellobiohydrolases have a higher binding affinity to native cellulose than endoglucanases (Reese 1982; Henrissat et al. 1985; Woodward et al. 1988). This property has been used in the past to purify the different cellulase components (Reese 1982).

The concentration of CBH I is $70 \%$ in the cellulase mixture, so one would expect the presence of $\mathrm{CBH} \mathrm{I}$ to be greater. Qualitatively, this is what we observe. It has also been stated that CBH I is capable of partial hydrolysis of crystalline cellulose while endoglucanase is not (Coughlan 1985). Our results substantiate this by demonstrating that CBH I binds preferentially to ordered cellulose.

Reese originally theorized that the enzyme that initiates the hydrolysis was cellobiohydrolase (Reese et al. 1950). It is now generally accepted that the endoglucanase actually initiates cellulase degradation (Eveleigh 1987). It is consistent with our results and other observations that CBH I may actually be one of the enzymes that initiates atiack (Enari and Niku-Paavala 1987; Okada et al. 1988). The abundant binding to cellulose, the ability to bind to defined, amorphous cellulose, and the abundance of cellobiohydrolase in culture all indicate the importance of this enzyme. The minimai association observed may also be the result of concentration-dependent adsorption-desorption phenomena. Once the cndoglucanase has bound and hydrolyzes the beta-1,4-linkage, it desorbs, being replaced by the cellobiohydrolase attacking the nonreducing end. As can be seen, studies such as these can raise more questions about the system being investigated.

When observing the micrographs obtained in our experiments in three dimensions, the immunogold is largely on the same plane. From this we may theorize that when these enzymes are associated, the cndoglucanase cleaves at one site and immedis ly a cellobiohydrolase binds to the site before it can reanneal to the surrounding cellulose surface. Consequently, the endoglucanase keeps working its way down the fiber with other cellobiohydrolases following behind. 
These immunoprobes could eventually be used to determine the effect of pretreatment on susceptible cellulose substrates. After pretreatment the cellulose would be incubated with cellulase and labeled with the immunogold. Visualization of increased binding after pretreatment could serve as a quick assay as opposed to the tedious enzyme activity assays normally performed. For this methodology to be optimized, defined resolution of the cellulose would be necessary.

\section{Acknowledgments}

The authors wish to thank S. Shoemaker for providing purified cellulases and M. Himmel for providing the aspen cellulose meal. This research was funded by the Biochemical Conversion Program at the DOE Biofuels and Municipal Waste Technology Division through SERI Subcontract No. XK-7-C7031-1.

\section{References}

Bisaria, V. S., and Ghose, T. K. 1981. Enzyme Microb. Technol. 3:90-104.

Chanzy, H., Henrissat, B., and Vuong, R. 1984. FEBS Lett. 172:193-197.

Coughlan, M. P. 1985. Biotechnol. Genet. Eng. Rev. 31:39-109.

DeMey, J. 1980. "The preparation and use of gold probes." In Immunocytochemistry, 2nd Ed., eds. J. Polak and S. VanNoorden, 115-145. England: John Wright and Sons.

Enari, T. M., and Niku-Paavala, M. L. 1987. CRC Crit. Rev. Biotechnol. 5:67-87.

Eveleigh, D. E. 1987. Phil. Trans. R. Soc. Lond. 321:435-447.

Fagerstam, L. G., and Pettersson, L. G. 1980. FEBS Lett. 119:97-100.

Henrissat, B., Driguez, H., Viet, C., and Schulein, M. 1985. Bio/Technol. 3:722-726.

Krim, D. W., Yang, J. H., and Jeong, Y., K. 1988. Appl. Microbiol. Biotechnol. 28:148-154.

K.lyosov, A. A. 1986. Appl. Biochem. Biotechnol. 12:249-300.

Kyriacou, A., Neufeld, R. J., and Mackenzie, C. R. 1988. Biotechnol. Bioeng. 33:631-637.

Mullings, R. 1985. Enzyme Microb. Technol. 7:586-591.

Nieves, R. A., Himmel, M. E., Todd, R. J., and Ellis, R. P. 1990a. Appl. Environ. Microbiol. 56:11031108.

Nieves, R.A., Ellis, R.P., and Himmel, M.E. 1990b. Appl. Biochem. Biotechnol. 24/25:397-406.

Okada, G., and Tanaka, Y. 1988. Agric. Biol. Chem. 52:2981-2984.

Reese, E.T. 1982. Proc, Biochem. 17:2-6. 
Reese, E.T., Siu, R.G.H., and Levinson, H.S. 1950. J. Bacteriol. 59:485-497.

Ryu, D. D. Y., Kim. C., and Mandels, M. 1984. Biotechnol. Bioeng. 26:488-496.

Tanaka, M., Nakamura, H., Taniguchi, M., Morita, T., Matsuno, R., and Karnikubo, T. 1986. Appl. Microbiol. Biotechnol. 23:263-268.

Tatsumoto, K., Baker, J. O., Tucker, M. P., Oh, K. K., Mohagheghi, A., Grohmann, K., and Himmel, M. E. 1988. Appl. Biochem. Biotechnol. 18:159-174.

Wood, T. M., and McRae, S. I. 1979. Adv. Chem. Ser. 181:181-209.

Wood, T. M. 1985. Biochem. Soc. Trans. 13:407-410.

Woodward, J., Hayes, M. K, and Lee, N. E. 1988. Bio/Technol.6:301-304. 


\title{
The Effect of Denaturation and Reduction on Cellobiohydrolase I from Trichoderma reesel
}

\author{
J. Woodward and P. C. Herrmann \\ Chemical Technology Division \\ Oak Ridge National Laboratory** \\ Oak Ridge, Tennessee 37831-6194
}

\begin{abstract}
These studies stem from our interest in the use of protein denaturants to elute cellulase enzyme components from residual cellulosic substrates. A high concentration $(>\mathrm{f} \underline{\mathrm{M}})$ of the denaturant guanidine hydrochloride, required for elution, was found to only partially unfold the major component of Trichoderma reesei cellulase, cellobiohydrolase I (CBH I). The reason for the loss in catalytic activity was the competitive inhibition of this enzyme and not, as expected, its unfolding or denaturation.

Partial unfolding of CBN I may be attributed to the presence of 12 disulfide bonds/molecules that need to be reduced prior to its complete unfolding. Reduction of CBH I by dithiothreitol at $\mathrm{pH} 8.75$ generated 28 or 0.8 free thiols, depending on the assay used for thiol determination. Isoelectric focusing of reduced $\mathrm{CBH}$ I showed that several protein bands were generated with higher isoelectric points than the native enzyme. Although possessing greatly lowered catalytic activity, reduced CBH I bound as, if not more, efficiently to microcrystalline cellulose.

Papain digestion of CBH I generated "core" enzyme, which apparently completely broke up upon reduction. These data are discussed in relation to structure/function relationships of this key cellulase enzyme component.
\end{abstract}

\section{Introduction}

Fungal cellulases that catalyze the hydrolysis of insoluble cellulose to glucose are composed of cellobiohydrolases (1,4-ß-glucan cellobiohydrolase, EC3.2.1.91), endoglucanases (1,4-(1,3;1,4)-B-D-glucan4-glucanohydrolase, EC3.2.1.4), and B-glucosidases (B-D-glucosideglucohydrolase, EC 3.2.1.21) (Wood 1985).

**Operated by Martin Marictta Energy Systems, Inc., for the U.S. Department of Energy under contract DE-AC05-OR21400. 
Cellobiohydrolase I from Trichoderma reesei is the major component of the cellulase enzyme complex, comprising more than half the protein secreted into the culture medium (Woodward 1987). It consists of 497 amino acid residues (Fägerstam et al. 1988). Small-angle x-ray scattering has shown the enzyme to be shaped like a tadpole (Schmuck et al. 1986). The major domain, or core protein, is ellipsoidal in shape and comprises 420 amino acids. It contains the catalytic center and possesses 10 disulfide bridges (Bhikhabhai and Pettersson 1984). Thirty-six amino acids comprise the minor or C-terminal domain, which reportedly contains the cellulose-binding moiety, two disulfide bridges, and can be cleaved from the holoenzyme by the protease papain (Kraulis et al. 1989; Van Tilbeurgh et al. 1986). The latter protrudes from the core enzyme as a flexible tail; the integrity of its three-dimensional structure is apparently essential for binding (Johansson et al. 1989). The native enzyme reportedly contains no free thiol groups. It is also interesting to note that this structural organization may be general for enzymes that degrade insoluble polysaccharides.

In this paper, studies on the effect of denaturation and reduction of $\mathrm{CBH} I$ are described. The rationale for these studies is to further our understanding of the structure and function relationships of this key cellulase enzyme and to determine the methodology for its successful unfolding and refolding, which may be necessary for its recovery.

\section{Experimental}

\section{Purlfication and Assay of CBH I}

A commercial T. reesei cellulase (Celluclast 1.5L) was obtained from Novo Labs, from which CBH I was purified using isoelectric focusing as described by Offord et al. (1991). Its catalytic activity was assayed using $p$-nitrophenyl-cellobioside (PNPC) as the substrate (Woodward et al, 1990a).

\section{Effect of Gulanldine Hydrochlorlde (gdn) on CBH I}

The effect of gdn on the activity of CBH I was determined by assaying the enzyme in the presence of different concentrations of gdn. Denaturation, or unfolding of the CBH molecules, was monitored by measuring the decrease in fluorescence of a solution of $\mathrm{CBH}(5 \mu \mathrm{L})$ in $1.0 \mathrm{nmL}$ of $\mathrm{Gdn} \mathrm{HCl}(0-6 \underline{\mathrm{M}}$, in $5 \mathrm{mM}$ sodium acetate buffer $\left[\mathrm{pH} \mathrm{5.0]}\right.$ at $23^{\circ} \mathrm{C}$ ) at $350 \mathrm{~nm}$ over a given time interval.

\section{Reduction of CBH I}

Enzyme reduction was carried out by $5 \mathrm{mM}$ dithiothreitol (DTT) and $1 \mathrm{mM}$ ethylenediaminetetraacetic acid (EDTA) in .2 $\mathrm{M}$ Tris/HCl buffer, $\mathrm{pH} 8.75$. The D'T solution was mixed $50 / 50$ (vol/vol) with the enzyme solution $(-1.0 \mathrm{mg} / \mathrm{mL})$ to be reduced. The mixture was allowed to incubate for $3 \mathrm{~h}$ at room temperature. The reaction was quenched by chromatofocusing the mixture through a fast protein liquid chromatography (FPLC) Mono P column and collecting the fractions containing the reduced enzyme. Two reductions were performed: one in which the enzyme was dissolved in $50 \mathrm{mM}$ sodium acetate pH 5 buffer and the other in which the enzyme was dissolved in $0.1 \mathrm{M}$ phosphate buffer, $\mathrm{pH} 8.75$. The $\mathrm{pH}$ of the reduction mixtures were 7.7 and 8.75 . It should be noted that reduction was carried out in the absence of protein denaturants such as gdn or urea. 


\section{DetermInation of Free Thlol Groups}

The determination of free thiols in native and reduced CBH I was made using Ellman's reagent (Ellman 1959) or $\mathrm{N}$-(1-pyrene)maleimide, which is nonfluorescent in aqueous solution but forms strongly fluorescent adducts with sulphydryl groups of proteins (Wu et al. 1976).

\section{Preparation of "Core" CBH I}

Papain solution $\left(32.8 \mu \mathrm{L}, 246 \mathrm{mg} / \mathrm{mL}, 2 \mathrm{mM}\right.$ EDTA, $0.2 \underline{\mathrm{M} \mathrm{NaH}} \mathrm{PO}_{4}, 5 \mathrm{mM}$ L-cysteine, $\left.\mathrm{pH} 7.0\right)$ was incubated with $1 \mathrm{~mL} \mathrm{CBH} \mathrm{I}(2.46 \mathrm{mg} / \mathrm{mL})$, at $37^{\circ} \mathrm{C}$ for 30 min according to the method of Abuja et al. (1988). The "core" CBH I was purified by chromatofocusing using the FPLC as described by Offord et al. (1991). After 30 min of papain treatment, conversion was complete.

\section{Binding of CBH I to Microcrystalline Cellulose}

The binding of native, reduced, and "core" CBH I to Avicel was performed as described in detail previously (Woodward et al. 1988).

\section{Analytical Procedures}

Protein was measured using the Coomassie Blue reagent (Bio-Rad Laboratories, Richmond, Calif.) according to the method of Bradford (1976). Glucose was determined using the hexokinase assay reagent (Woodward and Arnold 1981). Absorbance measurements were made with a Perkin-Elmer Lambda Array Spectrophotometer interfaced with an IBM personal computer.

\section{Results and Discussion}

\section{The Effect of gdn on CBH I}

The fluorescence spectrum of CBH I obtained by excitation at $280 \mathrm{~nm}$ indicated a peak of maximum emission at $350 \mathrm{~nm}$, typical of tryptophan fluorescence domination. It was found that gdn, at concentrations generally regarded to denature or unfold proteins, only partially reduced the tryptophan fluorescence of CBH I (Figure 1). This suggested that only a partial unfolding of the enzyme occurred even at high gdn concentrations and, because CBH I possesses 12 disulfide bonds, it seemed reasonable to assume that reduction of these bonds would be necessary to completely unfold the enzyme molecules.

However, this does not appear to be the case, as will be described below. Removal of gdn from CBH I by dialysis restored the original fluorescence of the enzyme.

During this study it was discovered that gdn competitively inhibited CBH I at concentrations too low to affect its fluorescence (Woodward et al. 1990b). Therefore, it can be concluded that the loss of activity of CBH I by gdn is not primarily caused by unfolding or denaturation. Evidence has been obtained to suggest that there may be a specific interaction between the positively charged guanidinium group of gdn 
ORNL DWG 89A-190

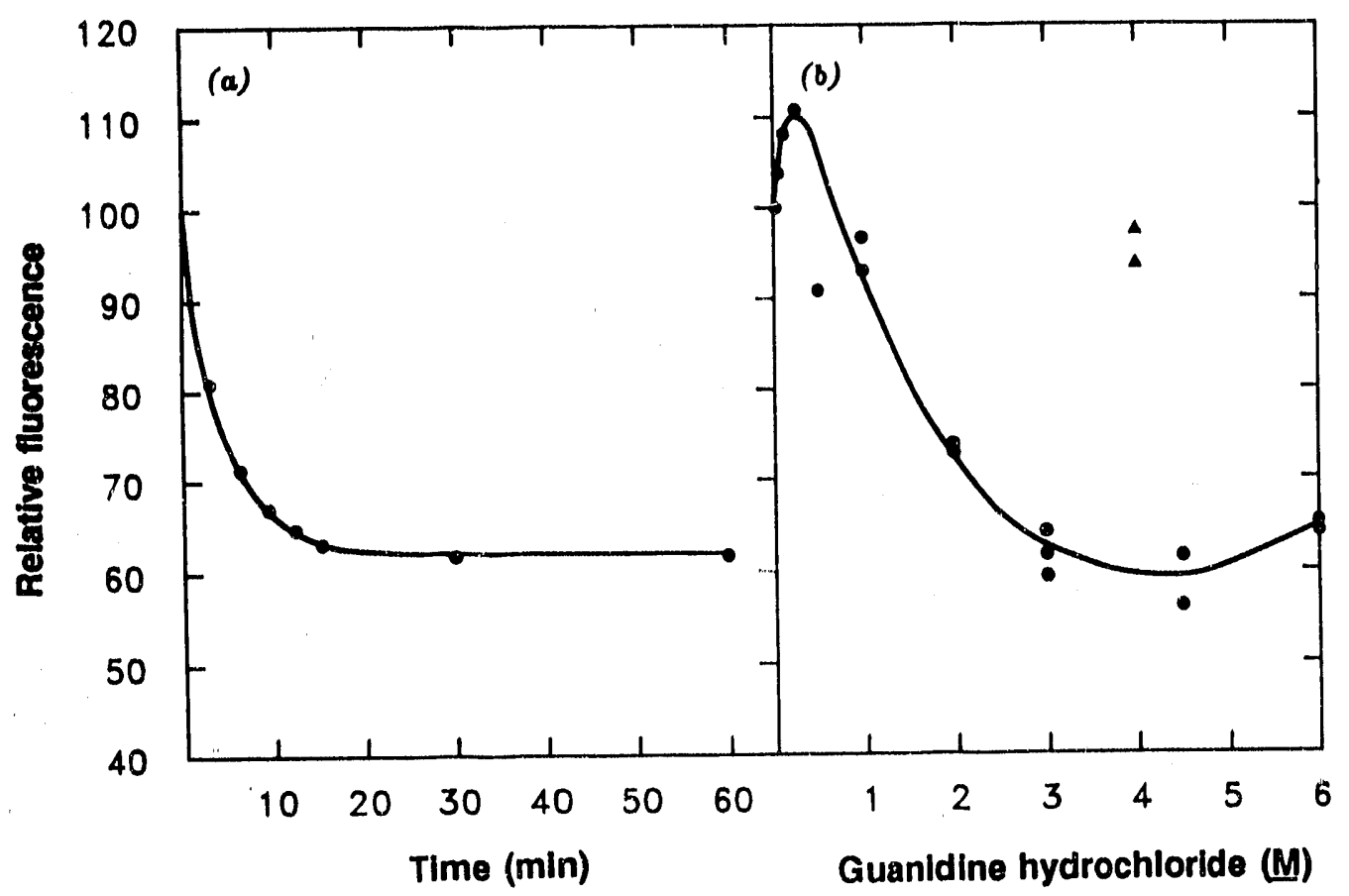

Flgure 1. The effect of Gan HCl on the fluorescence of CBH I. Time course of the decrease in tryptophan fluorescence at $350 \mathrm{~nm}$ of $\mathrm{CBH}$ I by $4.5 \mathrm{M}$ Gdn $\mathrm{HCl}$ : (a) effect of $\mathrm{Gdn} \mathrm{HCl}$ concentration; (b) fluorescence measured $1 \mathrm{~h}$ after incubation with $\mathrm{CBH}$ l. The closed triangles represent the fluorescence of $4 \mathrm{M}$ Gdn HCl-treated $\mathrm{CBH} I$ after its renaturation by gel filtration.

and an essential carboxylic acid residue present in the catalytic site of $\mathrm{CBH}$ I: (1) the PNPC-hydrolyzing activity of CBH I was decreased $90 \%$ or $10 \%$ by $0.5 \mathrm{M}$ gdn or urea, respectively (Figure 2); (2) the chaotropic salt lithium chloride was not inhibitory to $\mathrm{CBH}$ I at $0.14 \underline{\mathrm{M}}$, the concentration of gdn required to inhibit CBH I by 50\%; (3) "core" CBH I was inhibited $50 \%$ by 0.14 M gdn; and (4) several hydrolases and glucosidases with essential carboxylate residues were also inhibited by gdn.

Renaturation and reactivation of $\mathrm{CBH}$ I treated with $4 \underline{\mathrm{M}}$ gdn were achieved by dialysis, and there appeared to be no difference between native and renatured CBH I with respect to their catalytic activity when acting on PNPC or Avicel and their ability to be absorbed on Avicel. It can be concluded, therefore, that if gd: was used as an eluent of cellulase (CBH I) from cellulosic residues, full recovery of activity would be possible.

\section{The Reduction of CBH I by Dithiothreltol}

After the reduction of $\mathrm{CBH} \mathrm{I}$, the number of free thiols generated was determined using the maleimide and Ellman's reagents. There was a major discrepancy in the results obtained by these reagents (Table 1). According to the primary structure of CBH I (Fägerstom et al. 1984), the fully reduced enzyme should possess 24 thiols which, in the native enzyme, have been reported to exist in disulfide bridges (Bhikhabhai and Pettersson 1984). Using the maleimide reagent, which reacts with free thiols to give a 


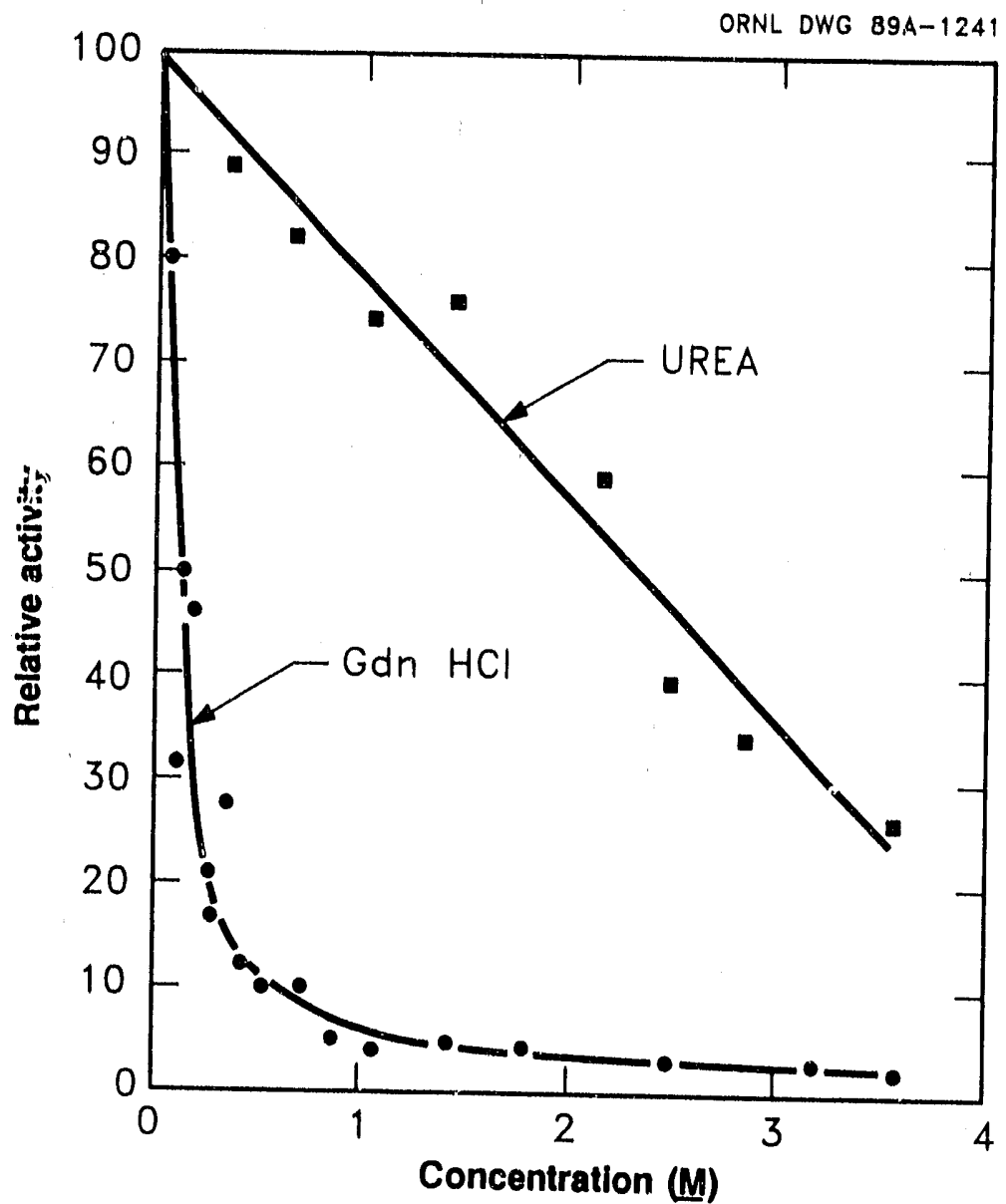

TP-3996

Figure 2. The effect of $\mathrm{Gdn} \mathrm{HCl}$ or urea on $\mathrm{CBH} \mathrm{I}$. CBH I ( $50 \mu \mathrm{L}=35 \mu \mathrm{g}$ protein) was incubated with $500 \mu \mathrm{L}$ PNPC in $50 \mathrm{mM}$ sodium acetate buffer (pH 5.0) at $23^{\circ} \mathrm{C}$ in the presence of $\mathrm{Gdn} \mathrm{HCl}(\cdot)$ or urea ( - ) at the concentrations indicated. After $45 \mathrm{~min}$, aliquot $(0.1 \mathrm{~mL})$ of the reaction mixture was assayed for its PNP concentration. Control activity $(100 \%)=2 \mathrm{nmol}$ PNP $\mathrm{min}^{-1}$.

fluorescent derivative (Figure 3A), it was determined that 0.6 to 2 free thiols were present in the native enzyme. The erizyme reduced at pH 7.7 and 8.75 possessed 8 to 13 and 26 to 28 free thiols, respectively, indicating that the reduction of $\mathrm{CBH}$ I was pH dependent and that the enzyme was fully reduced at $\mathrm{pH}$ 8.75. On the contrary, using Ellman's reagent, which reacts with free thiols as indicated in Figure $3 \mathrm{~B}$, there was, apparently, little reduction of CBH I.

Table 1. The Determination of the Number of Free Thlols Generated by Reduction of CBH I with Dithlothreltol

\begin{tabular}{lccc}
\hline & $\begin{array}{c}\text { Reduced } \\
\mathrm{pH} \mathrm{8.75}\end{array}$ & $\begin{array}{c}\text { Reduced } \\
\mathrm{pH} 7.7\end{array}$ & Native \\
\hline $\begin{array}{l}\text { Thiols/Molecule } \\
\text { Meleimide assay }\end{array}$ & $26-28$ & $8-13$ & $0.6-2$ \\
\hline $\begin{array}{l}\text { Thiols/Molecule } \\
\text { Ellman's assay }\end{array}$ & 0.8 & 0.0 & 0.0 \\
\hline
\end{tabular}


The reason for the discrepancy between the Ellman's and maleimide reagents is unknown. Also, it should be pointed out that the results obtained with the maleimide reagent are preliminary and by no means conclusive. One possible reason for the discrepancy might be that Ellman's reagent is prevented from interacting with free thiols in reduced CBH I because of electrostatic repulsion between the carboxyl groups of the reagent and those in the vicinity of the thiol groups in the reduced CBH I molecules. Decause it appears that $\mathrm{pH}$ has a major effect on the reduction of $\mathrm{CBH}$ I, selective reduction of disulfide bonds in the molecule may be able to be achieved. In some experiments, reduced CBH I was determined to possess 5.3 thiols, indicating that 2 disulfide bonds were reduced.

\section{Propertles of Reduced CBH I}

Reduction of CBH I causes a loss in its catalytic activity (PNPC hydrolysis), which appears to be dependent on the level of reduction (Table 2). Interestingly, the tryptophan fluorescence spectrum of $\mathrm{CBH}$ I reduced at $\mathrm{pH} 8.75$ indicated that the fully reduced enzyme was not completely unfolded, although this may be achieved if the reduced enzyme is treated with a protein denaturant such as gdn or urea (Figure 4).
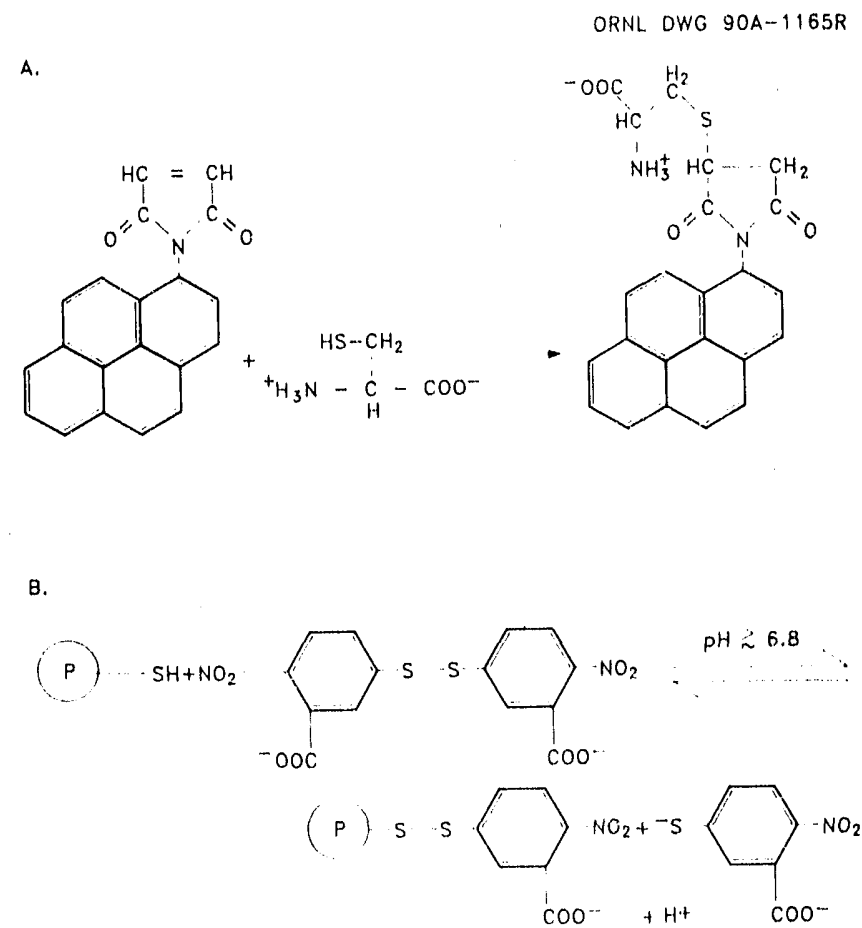

Figure 3. Mechanlsm of reacilon of $\underline{N}$-(1-pyrene) malelmide and Ellman's Reagent with free thlols. A. $\underline{\mathrm{N}}$-(pyrene)maleimide with L-cysteine. B. Ellman's Reagent with protein thiols. 
Isoelectric focusing of $\mathrm{CBH}$ I reduced at $\mathrm{pH} 8.75$ indicated the appearance of several cther bands of protein, all of whose pI were greater than native CBH I (Figure 5). The cause of this is unknown, but possible reasons include: (1) upon reduction of CBH I, several polypeptides are generated, indicating that the native enzyme is composed of sub-units linked together by disulfide bridges; and (2) reduction of CBH I and its sub-forms results in the alteration of their isoelectric points (Offord et al. 1991). SDS-gel electrophoresis of the reduced enzyme may give the answer. It is interesting to note that "core CBH I" completely breaks up upon reduction. This is presumed to occur because the action of papai: not only removes the C-terminal or cellulose binding moiety of CBH I but also nicks the polypeptide in several other places. Until reduction occurs, the conformation of "core" $\mathrm{CBH}$ I remains intact.

Finally, the binding of native, reduced, and "core" CBH I to Avicel was measured. As expected, the "core" enzyme lost its auility to absorb to any great extent on cellulose. The fully reduced enzyme apparently bound with greater efficiency than did the native enzyme or that reduced at ph 7.7 (data not included). Because reduced $\mathrm{CBH} \mathrm{I}$ ( $\mathrm{pH} \mathrm{8.75)} \mathrm{possesses} \mathrm{little} \mathrm{catalytic} \mathrm{activity,} \mathrm{it} \mathrm{is} \mathrm{unlikely} \mathrm{that} \mathrm{the}$ enhanced binding would result in a greater activity towards insoluble cellulosic substrates. The protein species derived from CBH I reduced at $\mathrm{pH} 8.75$ may be more hydrophobic than the native enzyme, resulting in increased binding to cellulose. The cellulose-binding moiety of CBH I is clearly more hydrophobic than the "core" enzyme, possessing 2 and 69 acidic/basic amirio acid residues, respectively.

\section{Conclusions}

It has been shown that the purified $\mathrm{CBH}$ I component of $T$. reese $i$ cellulase is partially unfolded at high concentrations $(\geq \underline{M})$ of gdn. However, lower concentrations ( $0.25 \underline{\mathrm{M}})$ are only required to abolish activity. This loss in CBHI I activity by treatment with gdn cannot be correlated with a decrease in its intrinsic tryptophan fluorescence; therefore, inhibition of $\mathrm{CBH}$ I does not appear to be related to a gross conformational change in this enzyme. The fact that $\mathrm{CBH}$ I can be renatured with full recovery of activity and conformation suggests that gdn can be used to elute cellulase from undigested cellulosic residues. The eluted enzyme can be subsequently reactivated by removal of the denaturant and, hence, reused.

Reduction of native $\mathrm{CBH} \mathrm{I}$ is $\mathrm{pH}$ dependent and results in $>95 \%$ loss in catalytic activity but appears to result in enhanced binding to cellulose. It also results in the appearance of different species of protein, as judged by isoelectric focusing, which may be altered forms of CBH I or actually indicate that the disulfide bridges play an important role in holding together sub-units in the native conformation. "Core" CBH I is completely broken up by reduction, suggesting that papain cleaves CBH I in several places along the polypeptide chain, as well as removing the C-terminal moiety from the native enzyme.

Table 2. Comparlson of the Speciflc Actlvity of Natlve and Reduced CBH I

\begin{tabular}{lccc}
\hline Native & $\begin{array}{c}\text { Reduced } \\
\mathrm{pH} \mathrm{7.7}\end{array}$ & $\begin{array}{c}\text { Reduced } \\
\mathrm{pH} \mathrm{8.75}\end{array}$ \\
\hline $\begin{array}{l}\text { Specific activity } \\
\text { nmo! PNP/min/mg }\end{array}$ & 16.4 & 10.1 & 1.05 \\
\hline
\end{tabular}




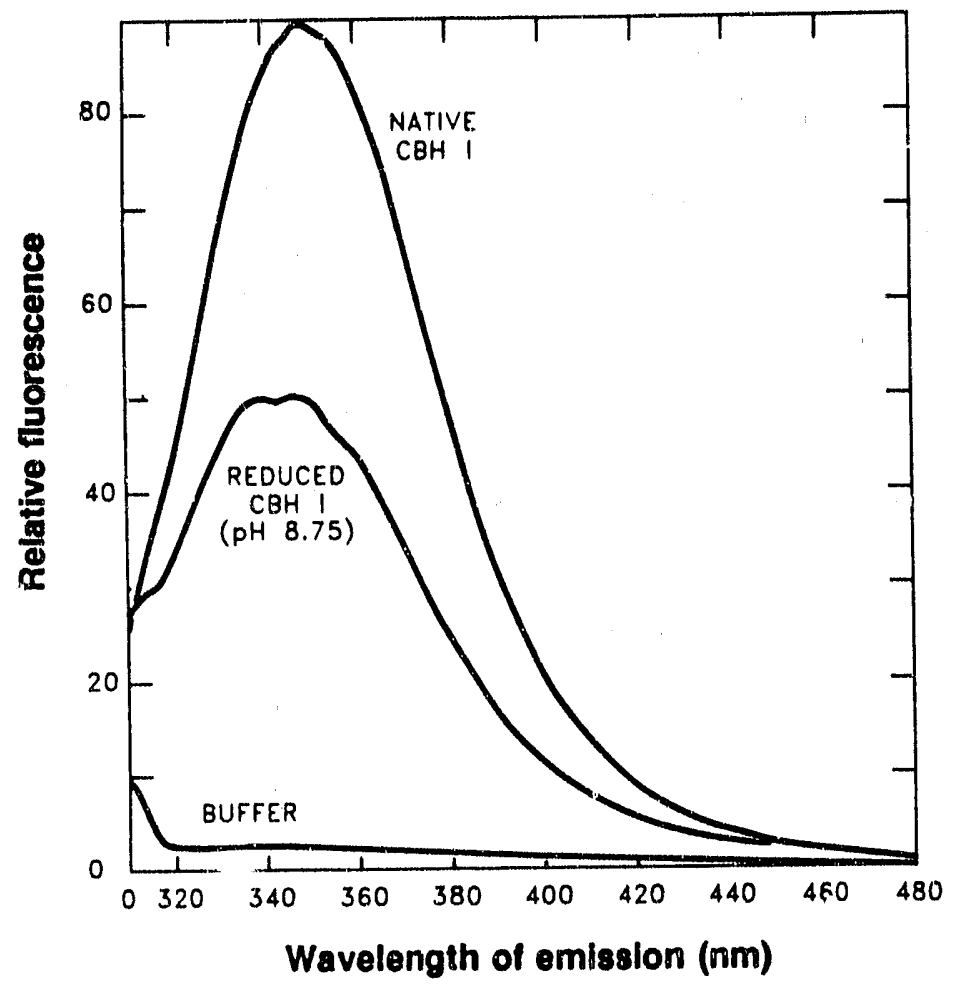

Figure 4. Fluorescence spectra of natlve and reduced CBH I. The enzyme solutions $3.5 \mu \mathrm{g} / \mathrm{mL} 50 \mathrm{mM}$ sodium acetate buffer ( $\mathrm{pH} \mathrm{5.0)}$ were excited at $280 \mathrm{~nm}$.

\section{Acknowledgments}

The secretarial assistance of $D$. Weaver is gratefully acknowledged. This work was supported by the Division of Chemical Sciences, Office of Basic Energy Sciences, U.S. Department of Energy, under contract DE-AC05-840R21400 with Martin Marietta Energy Systems, Inc., and by the Solar Energy Research Institute.

\section{References}

Abuja, P., Schmuck, M., Pitz, I., Tomme, P., Claeyssens, M., and Esterbauer, H. 1988. Eur. Biophys. J. 15:339-342.

Bhikhabhai, R., and Pettersson, G. 1984. Biochem. J. 222:729-736.

Bradford, M. M. 1976. Anal. Biochem. 72:248-254.

Ellman, G. L. 195?. Arch. Biochem. Biophys. 82:70-77.

Făgerstam, L. G., Pettersson, L. G., and Engfitiơñn, J. A. 1984. FEBS Lett. 167:309-315.

Johansson, G., Stahlberg, J., Lindeberg. G., Engström, А., and Pettersson, G. 1989. FEBS Lett. 243:389393. 
6

19

$+$

8

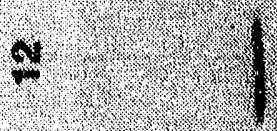

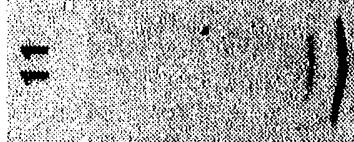

9
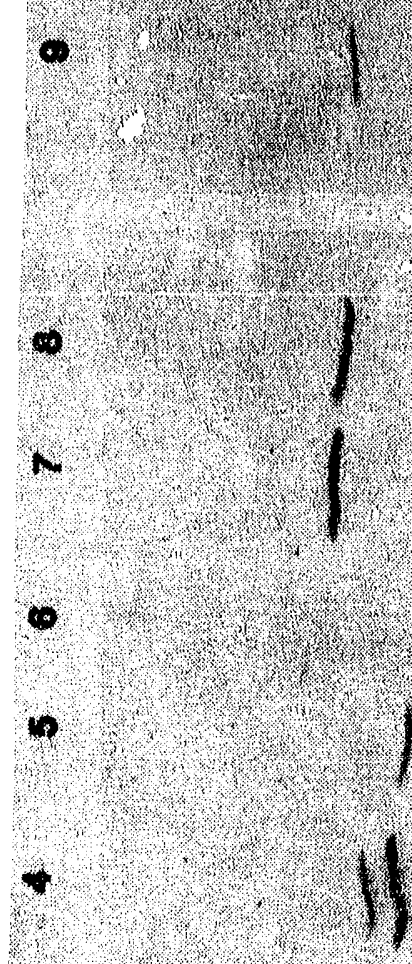

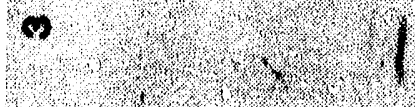
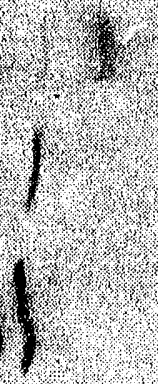

a

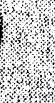

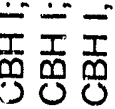

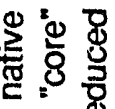
क்

m.

$-\infty$

\& \&

可 空

$-i \frac{0}{0}$

I $\infty \ddot{q}$

息市

8 웜

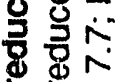

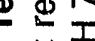

뭉

- $6 \bar{T}$

क्ष

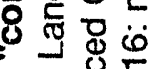

Ф芒焉

尘过焉

폰

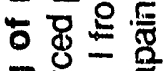

몰옹

क d

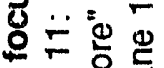

068 两

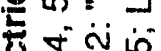

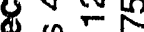

\& $₫ \infty$

辽壱空贡

เi

인 
Kraulis, P. J., Clore, G. M., Nilges, M., Jones, T. A., Pettersson, G., Knowles, J., and Gronenborn, A. M. 1989. Biochem. 28:7241-7257.

Offord, D. A., Lee, N. E., and Woodward, J. 1991. J. Appl. Biochem. Biotechnol. (in press).

Schmuck, M., Pilz, I., Kiayn, M., and Esterbauer, H. 1986. Biotechnol. Lett. 8:397-402.

Tomme, P., Van Tilbeurgh, H., Pettersson, G., Van Domme, J., Vandekerckhove, J., Knowles, J., Terri, T., and Claeyssens, M. 1988. Eur. J. Biochem. 170:575-581.

Van Tilbeurgh, H., Tomme, P. Claeyssens, M., Bhikhabhai, R., and Pettersson, G. 1986. FEBS Lett. 204:223-227.

Wood, T. M. 1985. Biochem. Soc. Trans. 13:407-410.

Woodward, J, and Amold, S. A. 1981. Biotechnol. Bioeng. 23:1553-1562.

Woodward, J. 1987. Carbon Substrates in Biotechnology, Vol. 21, Chapter 4. Oxford: IRL Press.

Woodward, J., Hayes, M. K., and Lee, N. E. 1988. Bio/Technol. 6:301-304.

Woodward, J., Lee, N. E., Carmichael, J. S., McNair, S. L., and Wichert, J. M. 1990a. Biochim. Biophys. Acta 1037:81-85.

Woodward, J., Carmichael, J. S., Capps, K. M., Herrmann, P. C., and Lee, N. E. 1990b. FEBS Lett. in press.

Wu, C-W., Yarbrough, L. R., and Wu, F. Y-H. 1976. Biochem. 15:2863-2868. 


\title{
The Thermal Unfolding of Trichoderma reese! CBH I
}

\author{
J.C. Baker, D.J. Mitchell, K. Grohmann, and M.E. Himmel \\ Biotechnology Research Brarch \\ Fuels and Chemicals \\ Research and E.igineering Division \\ Solar Energy Research Institute \\ Golden, Colorado 80401
}

\begin{abstract}
Purified cellobiohydrolase I ( $\mathrm{CBH}$ I) was subjected to thermal denaturation analysis using differential scanning calorimetry (DSC). As many as three endothermic structural transitions were detected during heating of the native enzyme from $20^{\circ}$ to $75^{\circ} \mathrm{C}$ at a range of $\mathrm{pH}$ values from 4.80 to 8.34. DSC analyses of the separated proteolytic fragments representing the catalytic "core" and cellulose-binding "tail" regions of the $\mathrm{CBH} I$ molecule revealed that all three of the transitions were associated with the core region. Two of these transitions were inferred as the deconvoluted constituent peaks of an asymmetrical peak that appeared at $64^{\circ} \mathrm{C}$ at $\mathrm{pH} 4.8$ but was shifted to $33.4^{\circ} \mathrm{C}$ as the $\mathrm{pH}$ was increased to 8.34 . A much smaller third transition at $55^{\circ} \mathrm{C}$ appeared to be much less pH-dependent but was observed only when the two major transitions were shifted to temperatures suistantially lower than $55^{\circ} \mathrm{C}$ (as at $\mathrm{pH} 7.5$ or above). Cellobiose at $100 \mathrm{mM}$ dramatically stabilized the CBH I molecule, shifting the position of the major, twocomponent peak from $64^{\circ}$ to $72^{\circ} \mathrm{C}$ at $\mathrm{pH} 4.8$, and from $33.4^{\circ}$ to $51.9^{\circ} \mathrm{C}$ at $\mathrm{pH} 8.34$.
\end{abstract}

\section{Introduction}

\section{Beneflis of Structural Studies of Cellulase Enzymes}

Cost-sensitivity studies have shown that the cellulase enzymes used in an ethanol from biomass process must be produced at minimal cost and provide a sustained activity. Determining the activity lifetime of these enzymes in the process ervironment is therefore an import ant issue. Although enzymes lose activity by a variety of mechanisms, most are related to loss of the tertiary structure of the protein, which either directly or indirectly affects the integrity of the active site. Denaturation of proteins by heat is relatively rapid and can be used effectively as a model of other mechanisms of protein peptide unfolding, such as shear or protease action. 
Enzyme structural studies can be used to augment cellulase cloning ef $f^{\prime}$ rtts by understanding differences found between native and recombinant enzymes. An example might be the verification of correct peptide folding in an inactive cloned product. Relative to such a problem, studies of enzyme thermal denaturation can provide information concerning the number and relative stability of protein domains, as well as potential interactions between the domains. In the following study, we have used thermal studies to provide such "baseline" data for the native CBH I, a key component in the fungal cellulase system.

\section{DIfferential Scanning CalorImetry of T. reesel CBH I}

Differential scanning calorimetry (DSC) is a powerful and very general method of studying the structural organization of proteins as it relates to thermal stability (Jackson and Brandts 1970; Privalov and Khechinashvii 1974; Pfell and Privalov 1976; Biltonen et al. 1978; Sturtevant 1987; Privalov and Pote'k'in et al. 1986; Privalov and Gill 1988; Brandts et al. 1989; Bailey et al. 1990). The generality of the method is due to the fact that it detects any temperature-dependent folding/unfolding process that proceeds with a significant uptake or release of heat. Unlike methods denending on changes in intrinsic fluorescence (Lakowicz 1983), DSC does not depend on the convenient location of reporter groups within the molecule. To a much greater extent than circular dichroism methods, it is capable of detecting changes in protein structure that affect primarily the interactions between structural domains, with relatively little effect on the structure of the individual domains themselves and thus relatively little effect on the overall secondarystructure composition of the molecule (Bailey et al. 1990).

Like most other approaches to structural analysis of proteins, however, DSC is most valuable when it is not the only source of structural information conceming a given protein. DSC car, provide evidence concerning the number of domains; or "cooperative unfolding units" into which a protein is divided; the stabilities of the individual domains, and the stabilizing interactions, if any, between the various unfolding units. This "thermodynamic structure" will be much more inieresting and useful if the thermally induced transitions measured by DSC, and the structural units inferred from them, can be assigned to specific regions of a physical structure known from other methods.

Cellobiohydrolase I (CBH I) from Trichoderma reesei is one of four well-characterized enzymes--two endoglucanases (EG I and EG II) and two cellobiohydrolases (CBH I and $\mathrm{CBH}$ II)-that are minimally required for efficient depolymerization of cellulose by the cellulase system of this organism (Fagerstam and Pettersson 1980; Shoemaker et al. 1983a; Wood and McCrae 1986; Henrissat et al. 1985; Knowles et al. 1987; Knowles et al. 1988; Woodward et al. 1988). Because of the importance of CBH I in this system, an unusually large body of information has been collected about the physical structure of this enzyme. The amino-acid sequence has been determined, both directly (Bhikhabhai and Pettersson 1984) and from the DNA sequence (Shoemaker et al. 1983b). The disulfide-bond patterns have been described (Bhikhabhai and Petterson 1984) and significant sequence homologies have been discovered between the $\mathrm{C}$-terminal segment of CBH I and peptide-chain segments found at either the $\mathrm{N}$-terminal or $\mathrm{C}$-terminal of other $T$. reesei enzymes that are known to bind to and hydrolyze crystalline cellulose (Knowles et al. 1987; Knowles et al. 1988).

Small-angle $x$-ray scattering (SAXS) studies have revealed that the CBH I molecule is tadpole-shaped, with an extended tail section connected to an ellipsoidal "head," or core, section thruugh a flexible and heavily glycosylated "hinge" region (Abuja et al. 1988a; Abuja et al. 1988b). Of great importance for the inierpretation of this structural picture is the development of a papain-cleavage precedure capable of splitting the CBH I molecule very specifically into a head or core segment containing the catalytic site for hydrolysis of $\beta$-1,4-glycosidic bonds, and a tail fragment containing most of the glycosylation of the protein along with an extreme C-terminal segment capable of binding tightly to crystalline cellulose (Tomme et al. 1988). 
SAXS studies of the binding of a macromolecular xylan inhibitor to intact $\mathrm{CBH} I$ and to the isolated core fragment have suggested that the catalytic site is located in the core region very near the point of attachment of the tail segment (Abuja et al. 1989). The kinetics of the catalytically active core fragment have been investigated against both crystalline cellulose and small soluble substrates (Tomme et al. 1988), and the binding of the separated tail fragment to crystalline cellulose has been studied, both with the proteolytically derived fragment itself, and with a 36-residue synthetic C-terminal cellulose-birding region ("block A") (Johansson et al. 1989). The solution structure of the synthetic cellulose-binding region has been determined iy means of two-dimensional nuclear magnetic resonance (NMR) (Kraulis et al. 1989) of another $T$. reesei cellobiohydrolase, CBH II (Bergfors et al. 1989), holding out the promise that crystals and an $\mathrm{x}$-ray crystallographic picture of the corresponding portion of CBH I may also he obtained. DSC analysis requires relatively large quantities of purified protein; for this reason it was important to us that (1) CBH I is the most abundantly produced of the enzymes in the T. reesel cellulase mixture (Shoemaker et al. 1983c), and (2) a general purification approach has been outlined (Shoemaker et al. 1983c).

Because of the availability of this remarkably extensive physical picture of the CBH I molecule (as well as the potential availability in adequate quantities of the purified enzyme itself), this enzyme is an outstanding candidate among cellulases for structure/stability analysis by DSC. We present here a comparison of DSC analyses of the intact CBH I molecule with those of the isolated catalytic-region and tail-region proteolytic fragments.

\section{Materlais and Methods}

\section{CBH I Purification}

The purification procedure developed in this study followed the general size exclusion chromatography/ anion exchange chromatography protocol described by Shoemaker for the purification of CBH I (Shoemaker et al. 1983c). The enzyme utilized in this study was purified from a commercial Genencor $150 \mathrm{~L}$ cellulase preparation, reportedly from a high-pzoductivity $T$. reesei mutant strain. Aliquots of Genencor $150 \mathrm{~L}$ were concentrated and dialyzed against $50 \mathrm{mM}$ sodium acetate buffer $\mathrm{pH} 5.0$ with 100 $\mathrm{mM} \mathrm{NaCl}$ (buffer A) using an Amicon (Danvers, Mass.) model DC-2 Hollow Fiber Ultraconcentrator equipped with dual H1P10-20 cartridges. The large capacity of this system permitted the processing of 10-g lots (total protein, BioRad Protein assay, Richmond, Calif.) of the Genencor preparation for subsequent purification. Initial stages of the purification were performed on a BioPilot column chromatography system (Pharmacia LKB Biotechnology, Pleasant Hill, Calif.). All chromatography columns and packing materials were from Pharmacia. Size exclusion chromatography (SEC) of the ultrafiltered cellulase preparation was conducted with a $11.3 \mathrm{~cm} \times 90 \mathrm{~cm}$ BioProcess column packed with Sephacryl S-200 HR gel at a flow rate of buffer A of $10 \mathrm{~mL} / \mathrm{min}$. Approximately $1 \mathrm{~g}$ of total protein was loaded each run. The CBH I positive fractions from each chromatographic step were identified immunologically with an ImmunoBlot assay kit (BioRad) and CBH I-specific monoclonal antibodies (Nieves et al. 1990). The monoclonal antibodies were a gift from R. Ellis at Colorado State University. The CBH I immuno-positive fractions were pooled, concentrated, and dialyzed against $20 \mathrm{mM}$ BisTris pH 5.8 buffer for ion exchange chromatography (IEC). A $6 \mathrm{~mm} \times 20 \mathrm{~cm}$ column packed with Q Sepharose Fast Flow gel was used for this step. This column was subjected to a linear gradient from 0 to $1 \mathrm{M} \mathrm{NaCl}$ in $20 \mathrm{mM}$ BisTris pH 5.8 buffer at a flow rate of $10 \mathrm{~mL} / \mathrm{min}$. CBH I immuno-positive fractions, found to elute at a salt concentration of $0.3 \mathrm{M} \mathrm{NaCl}$, were pooled and concentrated to approximately $1.25 \mathrm{mg} / \mathrm{mL}$. A final high-performance SEC (HPSEC) step was required to obtain a single electrophoretic species by sodium dodecylsulfate gel electrophoresis (SDS-PAGE). SDS-PAGE was performed with the Pharmacia PhastSystem using PhastGel 8\%-25\% crosslinked gradient gel and SDS buffer strips. This step utilized two Pharmacia Superose $6 \& 12$ (HR 10/30) columns connected in series. Buffer A was used at 
a flow rate of $0.5 \mathrm{~mL} / \mathrm{min}$. This column series was calibrated with the Gel Filtration chromatography standards kit from Pharmacia. Approximately $200 \mathrm{mg}$ of CBH I was obtained from $50 \mathrm{~mL}$ of the crude Genencor product.

\section{Papain Cleavage of CBH I}

The CBH I core and tail peptide fractions were produced by proteolytic cleavage with papain (Boehringer Mannheim lot \#11277523-67). The reaction conditions utilized were slightly modified from those given by van Tilbeurgh et al. (1986). Partial proteolysis was carried out in $50 \mathrm{mM}$ ammonium acetate pH 6.2 buffer, with molar ratios of CBH I (MW $67 \mathrm{kDa}$ )/papain (MW $23 \mathrm{kDa}$ ) ranging from $6 / 1$ to $8 / 1$. These reactions were conducted at $22^{\circ} \mathrm{C}$ for 4 to $6 \mathrm{~h}$. The CBH I core and tail fragments of CBH I from these hydrolysates were separated from the unreacted native CBH I by HPSEC with the Pharmacia Superose $6 \& 12$ columns described above.

\section{Instrumentatlon for Differentlal Scanning Microcalorimetry}

Denaturation thermograms were obtained using a Microcal MC-2 Scarining Calorimeter (Microcal, Northampton, Mass.), interfaced though a DT 2801 A/D converter to an IBM PC-XT microcomputer. Instrument control and data acquisition were by means of the DA-2 software package (Microcal). The sample cell capacity is $1.130 \mathrm{~mL}$, and runs were made with an overpressure of $30 \mathrm{psig}\left(\mathrm{N}_{2}\right)$, at scan rates of either 0.5 or $1.0 \mathrm{deg} / \mathrm{min}$.

\section{Sample Preparation}

Piotein samples were concentrated and exchanged into the buffer to be used in each DSC run by extensive diafiltration against the buffer using Amicon stirred cells and ultraconcentration membranes with 45 psig nitrngen pressure. For samples of native $\mathrm{CBH} I$ and of the core fragment of $\mathrm{CBH}$ I, the ultrafiltration membrane used was the polysulfone PM-10 (nominal cut-off, $10 \mathrm{kDa}$ ); the considerably smaller (approx. $10 \mathrm{kDa}$ ) tail fragment of $\mathrm{CBH}$ I was concentrated and diafiltered over a cellulose acetate YC-05 membrane (nominal MW cut-off, $500 \mathrm{Da}$ ).

The protein sample was then degassed under aspirator vacuum for a minimum of $20 \mathrm{~min}$, with stirring, remove excess dissolved gas forced into the solution during the diafiltration step. A sainple of diafiltration buffer, to be used in filling the reference cell of the calorimeter, was given identical treatment. Buffers used were $50 \mathrm{mM}$ acetate ( $\mathrm{pH} 4.80), 43.4 \mathrm{mM}$ 2-[N-morpholino]ethanesulfonic acid (MES) (pH 6.32), 47.6 mM 3-[N-morpholino]propanesulfonic acid (MOPS) (pH 7.50), and $52.3 \mathrm{mM}$ Bicine (pH 8.35). All $\mathrm{pH}$ adjustments were made at $20^{\circ} \mathrm{C}$; the buffer concentrations listed were chosen to yield an ionic strength of $0.0262 \mathrm{M}$ to match that of the $\mathrm{pH} 4.8$ acetatc buficr.

\section{Protein Concentration Determinations}

After the calorimeter celis were filled with protein solution (sample cell) and diafiltration buffer (reference cell), the protein concentration of the sample as loaded was determined spectrophotometrically. For intact CBH I and its core fragment, the extinction coefficient used was $1.42(\mathrm{~g} / \mathrm{L})^{-1}$ at $280 \mathrm{~nm}(\mathrm{G}$ im and Brown 1976). Because the tail fragment of CBH I (approximately residues 430-496) contains four tyrosine residues, but no tryptophan or phenylalanine residues (Shoemaker et al. 1983b; Tomme et al. 1988), the spectrum of this fragment is essentially that of tyrosine, Accordingly, the concentration 0 fragment was determined by measuring the molar concentration of tyrosine residues spectrophotome

lly (molar 
extinction taken as that of the $\mathrm{N}$-acetyl methyl ester in water, equal to $1.420 \times 10^{3} \mathrm{~cm}^{-1}$ at $274.6 \mathrm{~nm}$ and then dividing by a factor of 4 to obtain the molar concentration of the peptide.

\section{Deconvolution Analysis of DSC}

Data analysis was carried out using the DECONV section of the DA-2 software package. This software, which is based on the deconvolution procedure of Freire and Biltonen (1978) allows deconvolution of differential heat-capacity peaks either as the result of simple addition of multiple independent transitions or as the result of more complex mathematical processes representing the combination of transitions that interact in such a way that an obligatory reaction sequence is imposed (sequential transitions).

Each thermogram was normalized on scan rate, the corresponding (scan-rate-normalized) buffer-buffer baseline was subtracted, and the differential heat capacity values were divided by the number of moles of protein or peptide in the sample, to yield ordinate values in terms of calories $\mathrm{mol}^{-1} \mathrm{deg}^{-1}$. The resulting files were then analyzed using the deconvolution software.

\section{DSC Nomenclature}

The term $\mathrm{T}_{\mathrm{m}}$ as used here is not a "melting temperature," but is instead standard DSC usage for the temperature at which the maximum differential heat capacity is observed during the denaturation of a protein sample. (" $T_{\max }$ " would be a more extended expression of this term.) For a two-state (singletransition) process, $T_{m}$ approximates, but is not identical to, the value of $T_{d}$ or $T_{1 / 2}$, the temperature at which the transition is half-complete. $\Delta \mathrm{H}^{\circ}$ is the calorimetrically measured molar enthalpy of denaturation, represented by the area under the endothermic peak, divided by the number of moles of protein in the sample. The van't Hoff, or effective, enthalpy is a measure of the sharpness of the endothermic peak, or an inverse measure of the temperature range over which the transition occurs. For a denaturation that can be represented as a two-state, single-transition process, $\Delta \mathrm{H}_{\mathrm{vH}}=\Delta \mathrm{H}^{\circ}$. Values of $\Delta \mathrm{H}_{\mathrm{vH}} / \Delta \mathrm{H}^{\circ}$ significantly less than unity are generally taken as indicating that a given denaturation process involves more than two significantly populated states and thus more than two transitions. Detailed discussions of these terms can be found in Privalov and Gill 1988, Pfeil and Privalov 1976, Biltonen and Freire 1978, Sturtevant 1987, Privalov and Potekhin 1986, and Privalov and Khechinashvili 1974.

\section{Results}

\section{Purification of $\mathrm{CBH}$ I and $\mathrm{CBH}$ I Fragments}

The purified CBH I preparation eluted at a volume from HPSEC that corresponded to an apparent molecular weight of $70 \mathrm{kDa}$. Interestingly, the core protein prepared by papain cleavage eluted at an earlier volume than did the native enzyme on the HPSEC system (see Figure 1). This fragment was, however, shown to be of a smaller molecular weight (approximately $57 \mathrm{kDa}$ ) by reduced SDS-PAGE on the Pharmacia PhastSystem (see Figure 2). The apparent molecular weight of the native CBH I was 68 $\mathrm{kDa}$ by SDS-PAGE. These values agree well with those found by Tomme et al. (1988). The elution of the $\mathrm{CBH}$ I core at a lesser volume than expected may indicate an altered, if not expanded, structure after papain hydrolysis, thus yielding a larger hydrodynamic radius. The narrow band width of the core fraction (similar to that for native CBH I) indicates that this fragment is monodisperse. Specific activity of the purified enzyme, assayed at $50^{\circ} \mathrm{C}$ against $4.0 \mathrm{mM}$-nitrophenyl- $\beta$-D-cellobioside $(\mathrm{pH} 5.0$ in $10 \mathrm{mM}$ acetate, $0.1 \mathrm{M} \mathrm{NaCl}$ ), was 46.3 nanomoles substrate hydrolyzed per minute per milligram of protein. 


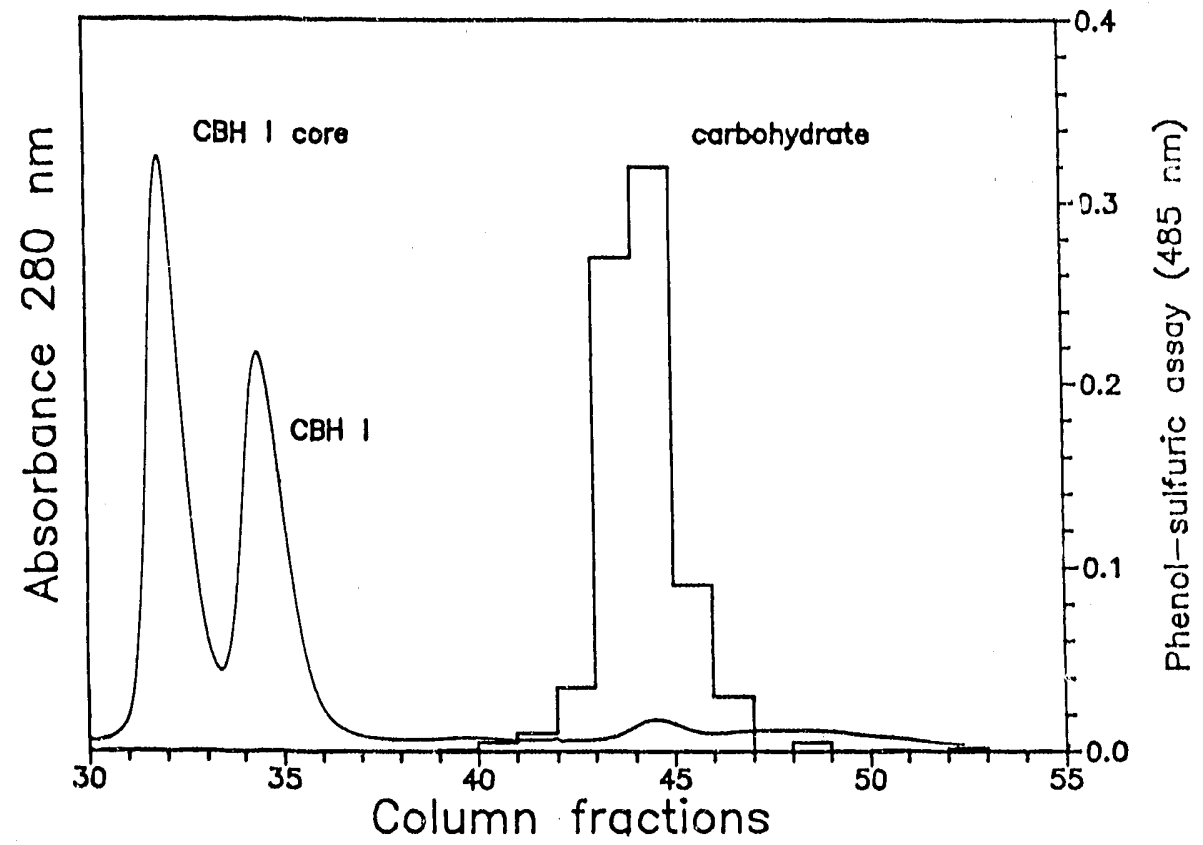

Figure 1. Elution profile of CBH l-papalr, reaction products on two Superose HPSEC columns (HR 6 \& 12) connected in serles. The elution of the tail fragment was confirmed using the phenol-sulfuric acid assay for carbohydrate.

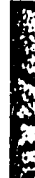

$66-\mathrm{kDa}$

45-kDa

Figure 2. SDS-polyacrylamide gel electrophoresis of the purlifed CBH I and CBH I core fragment using the Pharmacla PhastSystem 


\section{DSC Analysls}

At $\mathrm{pH} 4.80$ in $50 \mathrm{mM}$ acetate, the thermal denaturation of $T$. reesei $\mathrm{CBH}$ I is expressed as a single, asymmetrical endotherm (Figure $3 \mathrm{~A}$, upper curve) with $\mathrm{T}_{\mathrm{m}}$ at $64.05^{\circ} \mathrm{C}_{t}$ calorimetric enthalpy $\left(\Delta \mathrm{H}^{\circ}\right)$ equal to $398 \mathrm{kcal} / \mathrm{mol}$ and effective, or van't Hoff enthalpy $\left(\Delta \mathrm{H}_{\mathrm{vH}}\right)$ of denaturation equal to $173 \mathrm{kcal} / \mathrm{mol}$ (Table 1). The overall process appears to be irreversible, in that no endotherms are observed upon cooling and rescanning of the sample (data not shown). No scan-rate dependence of $\mathrm{T}_{\mathrm{m}}$ is observed, however, upon comparing runs at $60^{\circ} \mathrm{C} / \mathrm{h}$ and $30^{\circ} \mathrm{C} / \mathrm{h}$. Moteover, as shown by Figure 4 , heat uptake for the denaturation can be modeled quite well by a reversible, equilibrium process involving two transitions with $\mathrm{T}_{\mathrm{m}}$ at $61.38^{\circ}$ and $64.36^{\circ} \mathrm{C}$ and enthalpies of approximately $180 \mathrm{kcal} / \mathrm{mol}$ and $235 \mathrm{kcal} / \mathrm{mol}$, respectively. In this model, the two constituent transitions are each assumed to represent a two-state process $\left(\Delta \mathrm{H}_{\mathrm{vH}}=\right.$ $\left.\Delta \mathrm{H}^{\circ}\right)$. It is further assumed that any given protein molecule cannot undergo the second transition until it has undergone the first transition, which in this case is the transition with the lower $T_{m}$ (i.e., these are sequential transitions). The results of similar deconvolutions of samples scanned under other conditions are presented in Table 1.

DSC analyses of the separated proteolytic fragments representing the core and tail regions of the CBH I molecule (Figure 3A) reveal that at $\mathrm{pH} 4.80$ in $50 \mathrm{mM}$ acetate, the thermogram of the core segment essentially reproduces that of the intact molecule under these conditions, whereas the thermogram of the tail fragment has no detectable endotherms in the temperature region between $12^{\circ}$ and $95^{\circ} \mathrm{C}$. (The scan of the tail fragment extended beyond the region shown in the figure.) The virtual identity of the peaks observed near $64^{\circ} \mathrm{C}$ for both CBH I and its core fragment is shown clearly in Figure 5, in which symbols representing the data for CBH I are co-plotted with a line connecting the points (no symbols) for the core fragment.

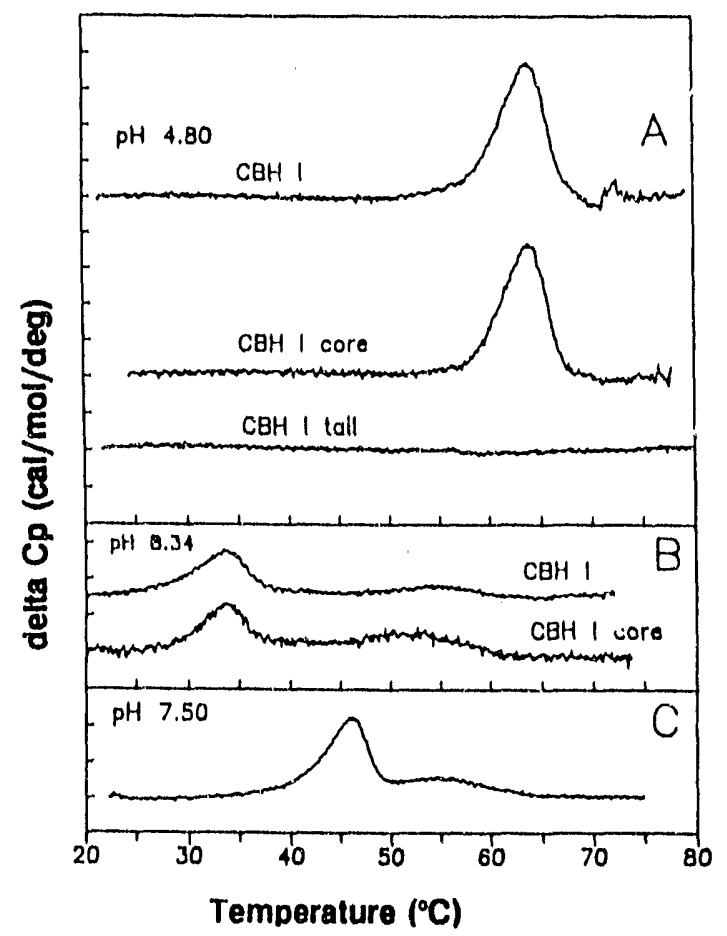

Figure 3. DSC thermograms of native CBH I and of fragments produced by limlted proteolysis. For native $\mathrm{CBH} I$ and the core fragment, protein concentrations were in the range from 0.91 to $1.31 \mathrm{mg} / \mathrm{mL}$. The concentration of the tail fragment was $0.41 \mathrm{mg} / \mathrm{mL}$. Scan rate was $30^{\circ} \mathrm{C} / \mathrm{h}$. Each division on the ordinate represents $20,000 \mathrm{cal} / \mathrm{mol} / \mathrm{deg}$. 


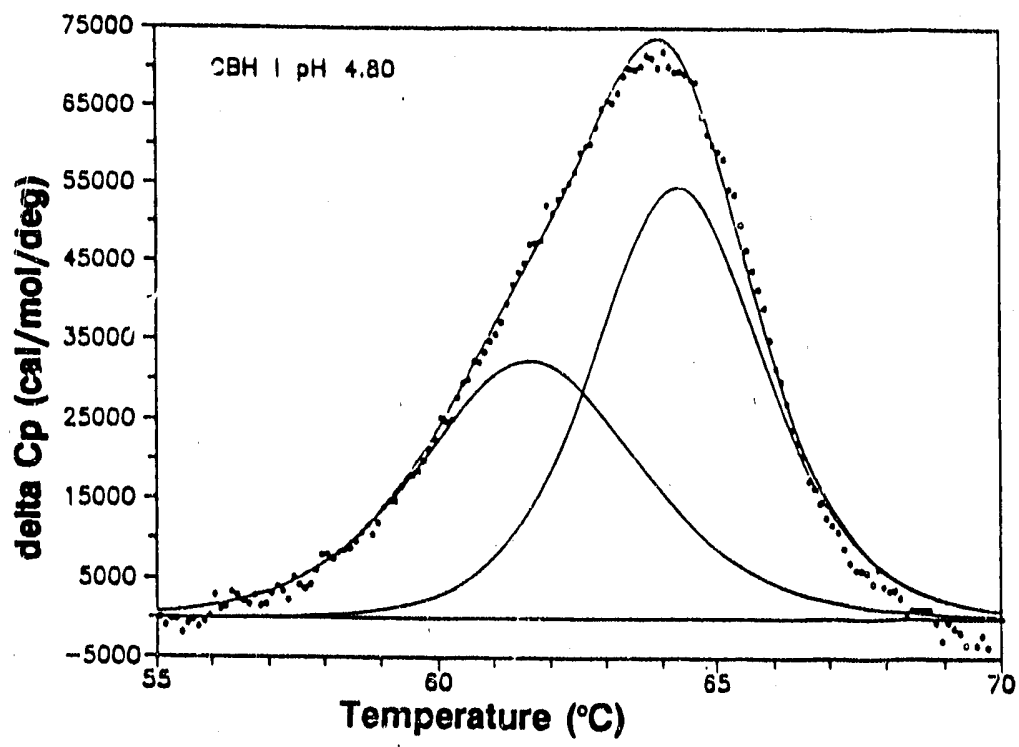

Figure 4. Deconvolution of the denaturational endotherm for native $\mathrm{CBH}$ I at pH 4.80. Circles represent experimental values for differential heat capacity; the solid curves represent the overall best fit model and the two sequential component transitions that contribute to the overall fit ( $S_{e \theta}$ text).

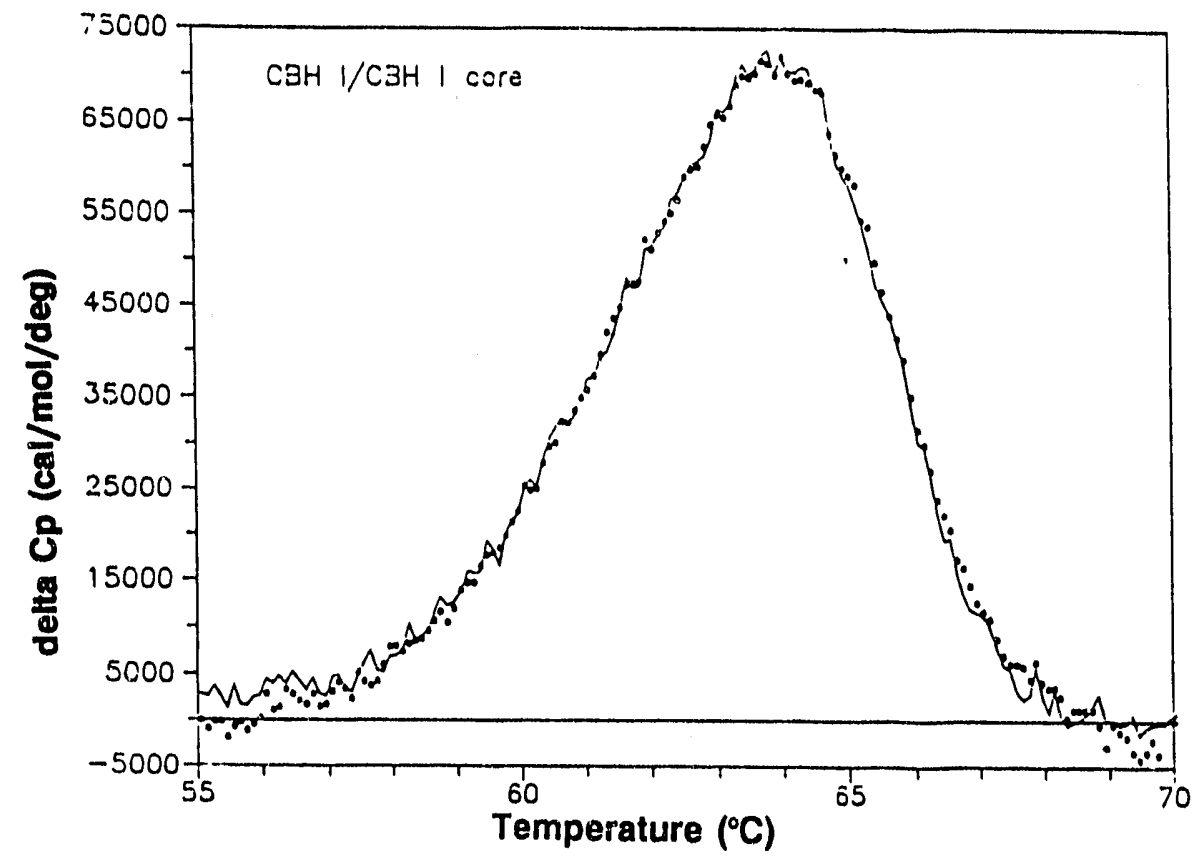

Figure 5. Co-plot of the denaturational endotherms measured at $\mathrm{pH} 4.8$ for natlve CBH I (open clrcles, no connecting lines) and the core fragment (line connecting data points, no symbols). 


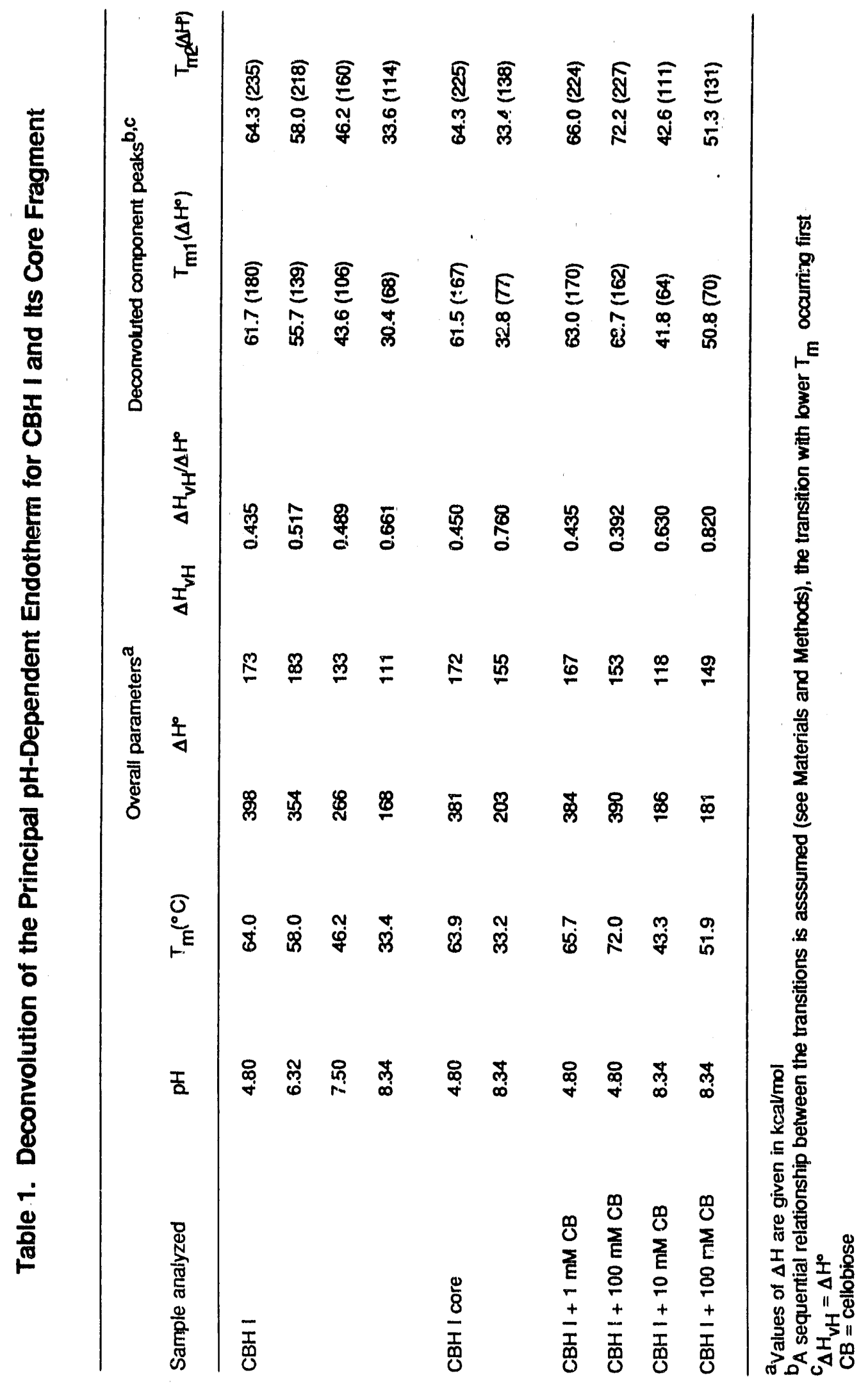


DSC runs carried out on CBH I at an initial pH of 8.34 (Figure 3B) reveal an asymmetrical peak with a shape similar to that observed at $\mathrm{pH} 4.80$, but with a markedly rediced amplitude and with $\mathrm{T}_{\mathrm{m}}$ shifted down by more than $30 \mathrm{deg}$, to approximately $33.4^{\circ} \mathrm{C}$. In addition, at pH 8.34, the thermogram for intact CBH I shows a broad, low peak centered near $55^{\circ} \mathrm{C}$. Thermograms of the core fragment at this high $\mathrm{pH}$ (Figure 3B) show the same shift of the principal peak to lower temperature as is seen for the intact enzymc, and also show the low, broad peak centered near $55^{\circ} \mathrm{C}$. At an intermediate $\mathrm{pH}(7.50$, Figure $3 \mathrm{C}$ ), intact $\mathrm{CBH} I$ again shows two peaks, but the principal peak is not shifted as far down the temperature scale as at $\mathrm{pH} 8.34$, and is not completely resolved from the low peak at $55^{\circ} \mathrm{C}$. This later peak $\left(55^{\circ} \mathrm{C}\right)$ appears, at least over this $\mathrm{pH}$ range, to be much less sensitive to $\mathrm{pH}$ than is the principal, two-component peak. At pH 6.32 (scan not shown) intact $\mathrm{CBH}$ I shows only a single, asymmetrical peak, again similar to that observed at $\mathrm{pH} 4.80$, but with $\mathrm{T}_{\mathrm{in}}$ at $57.95^{\circ} \mathrm{C}$, approximately 6 deg lower than the $\mathrm{T}_{\mathrm{m}}$ measured at $\mathrm{pH}$ 4.8. Because at $\mathrm{pH} 6.32$ the principal peak covers the region on the thermogram in which the "low, broad peak" would appear, were it present at the same position as at pH 7.5 and 8.32 , it is not possible to say with any assurance whether this peak is present at $\mathrm{pH} 6.32$ as well. The $50^{\circ}-58^{\circ} \mathrm{C}$ regions of some scans at pH 4.8, such as the one chosen for illustration in Figure $3 \mathrm{~A}$, may be interpreted as indicating the presence of a broad, low $55^{\circ} \mathrm{C}$ peak overlapping the $64^{\circ} \mathrm{C}$ principal peak; other scans under the same conditions give no such indication. In practice, small nonreproducibilitics in even the most carefully run baselines make it extremely difficult to identify broad, low peaks substantially overlapped by much larger peaks. When the principal, two-component peak is displaced to higher temperatures at $\mathrm{pH} 4.80$ in the presence of high concentrations of the competitive inhibitor cellobiose (see below), the cleared $50^{\circ}-60^{\circ} \mathrm{C}$ region of the bascline shows no indication of a peak at $55^{\circ} \mathrm{C}$.

\section{Calorimetrlc Reverslbillty of the Transitions}

As stated above, the calorimetric events observed at $\mathrm{pH} 4.80$ during heating of $\mathrm{CBH}$ I to $75^{\circ}-80^{\circ} \mathrm{C}$ are irreversible in that when the sample is cooled and subsequently rescanned, no endotherns are observed. When a sample at $\mathrm{pH} 6.32$ is scanned over this same temperature range, again no peaks are observed upon cooling and rescan. For samples scanned to $75^{\circ} \mathrm{C}$ at $\mathrm{pH} 7.5$ and $\mathrm{pH} 8.34$, however, there is partial, but quite significant, reversibility in that rescans of the samples show peaks at the same temperatures, and of the same shapes, but of reduced amplitudes (data not shown). For the pH values tested, and at the ionic strength $(0.026 \mathrm{M})$ employed in these studies, the greatest reversibility was attained at $\mathrm{pH} 7.5$. A sample scanned a total of four times still showed quite recognizable peaks during the fourth scan, with the principal pcak having at each scan approximately $70 \%$ of the area measured during the scan immediately preceding. The percentage of reversibility was smaller at $\mathrm{pH} 8.34$, with the rescanned peak reduced to approximately $30 \%$ the area of the peak observed in the first scan. It is worth noting that when a CBH I sample at $\mathrm{pH} 7.5$ is scanned to $85^{\circ} \mathrm{C}$ rather than to $75^{\circ} \mathrm{C}$, no endotherms at all are observed during a sccond scan.

Simple visual observation of the samples upon removal from the calorimeter cell after the experiments revealed that varying degrees of coagulation had taken place in some of the samples during the experimental cycle. At sample loadings in the neighborhood of $1.0 \mathrm{mg} / \mathrm{mL}$, the samples scanned at $\mathrm{pH}$ 8.34 and $\mathrm{pH} 7.5$ were clear upon removal from the cell. The $\mathrm{pH} 6.32$ samples were somewhat milky in appearance, and the pH 4.8 samples were virtually opaque.

Figure 6 depicts the relationship between the specific enthalpy of denaturation measured for CBH I at each of the $\mathrm{pH}$ values used in this study, and the $\mathrm{T}_{\mathrm{m}}$ of the principal peak at that $\mathrm{pH}$. The straight line represents a least-squares best fit to the four experimental data points and the empirically derived intersection point (Privalov and Khechinashvili 1974, see Discussion) in the upper right corner. All the values determined in the absence of cellobiose, both those at $\mathrm{pH}$ values at which the denaturation exhibits 
a substantial degree of overall reversibility, and those at which the overall process is completely irreversible, are in reasonably good agreement with the linear relationship.

\section{Stabillzation by Celloblose}

Figure 6 also shows that when varying concentrations of the competitive inhibitor cellobiose are present

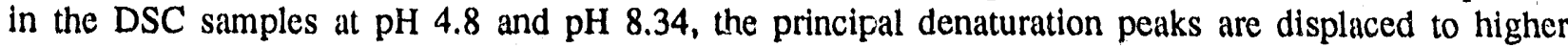
temperatures, as indicated by the higher $T_{m}$ values shown. The $\Delta \mathrm{H}^{\circ}$ values, however, do not follow the trend of increasing enthalpy with increasing $T_{m}$ that is seen for the data in the absence of cellobiose. Instead, the peak areas in the presence of cellobiose are essentially the same as for the peaks appearing at lower temperatures at these $\mathrm{pH}$ values in the absence of cellobiose.

\section{Discussion}

\section{Calorimetrlc Deconvolution Models and the Reversibllity or Irreversibllity of Overall Denaturation Processes}

The deconvolution procedures used to analyze the thermograms presented in this study are based on equilibrium models, even though the overall denaturation process seen over a cycle of heating to a temperature above $T_{m}$ and then cooling to below $T_{m}$ is, depending on the $p H$, either completely or

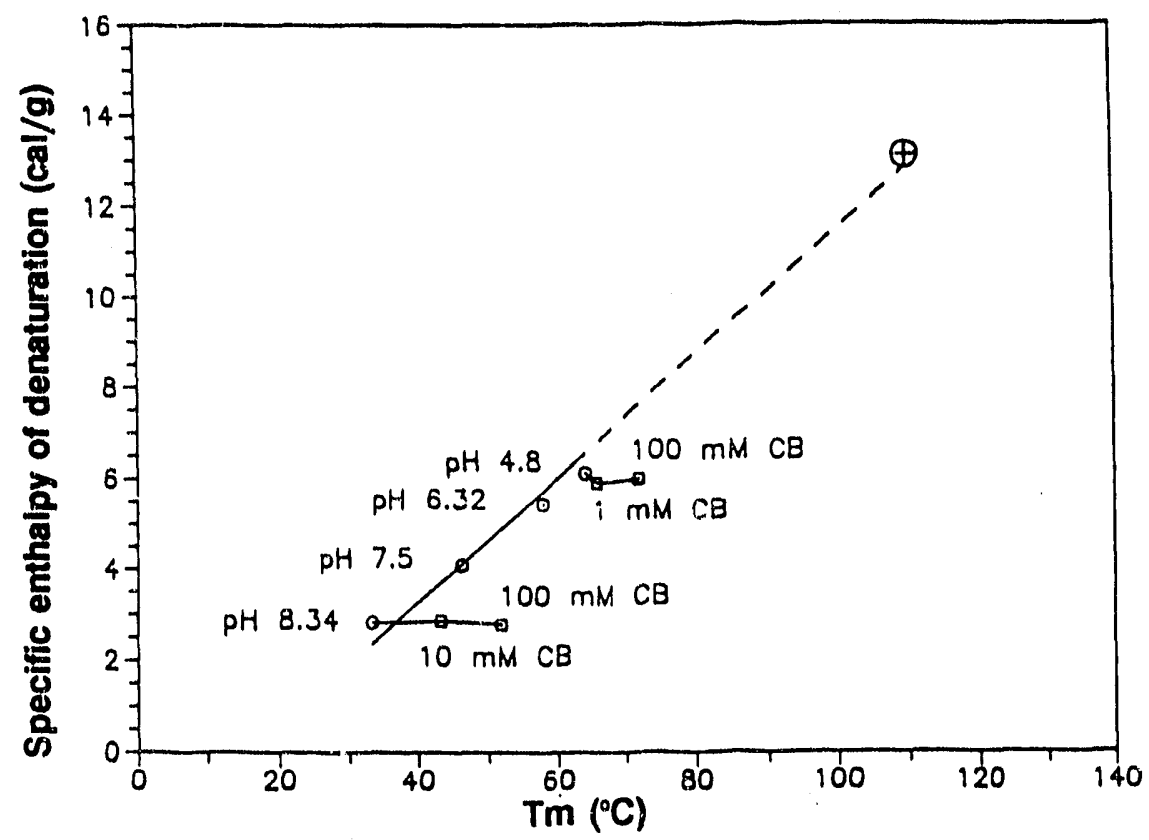

Figure 6. Specific enthalpy of denaturation for native $\mathrm{CBH}$ I, plotted as a function of the overall $T_{m}$ observed as the enzyme molecule is progressively destabilized by increasing the pH. Dot-centered circles represent the specific enthalpy in the absence of cellobiose; the straight line is a linear least-squares best fit to these data points, plus the empirically derived intersection point (Privalov and Khechinashvili 1974, see Discussion) represented by the crossed circle at upper right. The squares represent enthalpies measured at $\mathrm{pH} 4.80$ and $\mathrm{pH} 8.34$ in the presence of the indicated concentrations of cellobiose. 
partially irreversible. There is ample precedent in the literature for the application of equilibrium models in such cases, however. Convincing evidence has been presented that the DSC data for many apparently irreversible protein denaturations can be represented quite weil by equilibrium models (Sturtevant 1987;Edge et al. 1985; Manly et al. 1985; Hu and Sturtevant 1987), as long as the results do not show any dependence of $\mathrm{T}_{\mathfrak{m}}$ on scan rate. In these cases the actual unfolding process may be reversible, and the overall irreversibility may be due to other processes that occur subsequent to the unfolding, as shown in Equation (1),

$$
N \neq U \rightarrow D
$$

in which an unfolded form of the protein $(\mathrm{U})$ is in equilibrium with the native form $(\mathrm{N})$, but can also be converted by an irreversible process to the permanently denatured form, $D$. In the case of our results, one likely candidate for the irreversible post-unfolding step is intramolecular aggregation of the unfolded protein molecules, because the samples at $\mathrm{pH} 4.8$ and $\mathrm{pH} 6.32$ are visibly coagulated after the runs. Frequently, one or more fairly sharp, small exotherms (negative peaks), sometimes followed by or interspersed with endotherms of similar dimensions, are observed in the temperature region immediately above a major unfolding peak. An example of this is seen in the thermogram for CBH I in Figure 3A. These small "baseline disturbances," which are somewhat repeatable from run to run in the sense that they tend to occur in the same temperature range, but are not reproducible in terms of amplitude or exact fine structure, may be the result of coagulation of unfolded protein molecules, followed by disruption of the aggregates upon further heating. The negative sign of some of these fluctuations suggests an exothermic process such as coagulation; the sharpness of the fluctuations may reflect the multimolecular nature of such processes. Another possible explanation for the overall irreversibility is suggested by published observations that proteins can undergo covalent modification when heated to $80^{\circ} \mathrm{C}$ or above (Ahern and Klibanov 1985; Tomazic and Klibanov 1988a; Tomazic and Klibanov 1988b). There may be a connection between such modifications and the fact that the significant reversibility observed for the denaturation of $\mathrm{CBH} \mathrm{I}\left(\mathrm{pH} 7.5\right.$ ) on scanning to $75^{\circ} \mathrm{C}$ is completely destroyed when the sample is scanned to $85^{\circ} \mathrm{C}$ instead.

\section{Locallzation of DSC Transitlons Within the CBH I Molecule}

SAXS studies (Schmuck et al, 1986), partial proteolysis studies (Tomme et al. 1988), and the combination of the two (Abuja et al. 1988) have shown that the CBH I molecule is roughly tadpolc-shaped, with the catalytic site located in the larger (approx. $55 \mathrm{kDa}$ ) core region of the molecule. The site that bind's to crystalline cellulose is located in the considerably smaller (10 kDa) wedge-shaped (Kraulis et al. 1989) tail region, which is connected to the core region by a flexible, heavily glycosylated hinge segment of the peptide chain.

In view of the known bi-lobed structure of $\mathrm{CBH} \mathrm{I}$, our finding that the thermal denaturation of $\mathrm{CBH} I$ at pH 4.8 (Figure $3 \mathrm{~A}$ ) could readily be modeled as the result of two transitions of unequal enthalpy (Figure 4) immediately suggested the possibility that the larger and smaller transitions might represent, respectively, the unfolding of the core and tail regions of the molecule. When the CBH I molecule was subjected to limited proteolysis and the isolated core and tail fragments were analyzed separately by DSC at $\mathrm{pH} 4.8$, however, it was found that the asymmetric endotherm observed for the intact enzyme was almost exactly reproduced by DSC of the core fragment, whereas scanning of the tail fragment produced no detectable endotherms at all. Both of the proposed contributing transitions must therefore be assigned to the core region.

In an attempt to dissect the overall endothermic envelope observed for the intact enzyme and the core fragment, both the core and the intact enzyme were studied by DSC at increasing pH values. In the case of two or more domains of a protein molecule that unfold independently of each other, but nave thermal 
stabilities similar enough that the two independent transitions overlap at a given $\mathrm{pH}$, it may be that the stabilities of the two domains are sufficiently different functions of $\mathrm{pH}$ that a change in $\mathrm{pH}$ will move the two peaks to different positions on the temperature scale. In an alternate possibility, two transitions that actually have substantially different intrinsic $T_{m}$ values may appear as a merged peak under certain solution conditions, because the domain with lower intrinsic $T_{m}$ is significantly stabilized by interactions with the more stable domain (Brandts et al. 1989). In this case, a large change in solution pH might break the interactions at the interface between the domains, thus allowing the two domains to unfold independently, each at its own intrinsic $\mathrm{T}_{\mathrm{m}}$ (Brandts et al. 1989; Bailey et al. 1990).

Varying the $\mathrm{pH}$ from 4.8 to 8.34 does dramatically affect the thermal stability both of the intact enzyme and of the core fragment, decreasing $\mathrm{T}_{\mathrm{m}}$ for the principal peak of both by some $30 \mathrm{deg}$. At $\mathrm{pH} 7.50$ and 8.34 a smaller, relatively $\mathrm{pH}$-independent peak is resolved from the principal peak for both protein native protein and core, but the principal peak retains the same type oi asymmetry it exhibits at pH 4.8 and 6.32 , and is still best deconvoluted with the assumption of two transitions. Thermal denaturation of the core region of $\mathrm{CBH}$ I would appear to involve at least two, and probably three, different transitions. If the large, asymmetrical peak observed for the intact enzyme and for the core is indeed composed of two interacting transitions, a shift in $\mathrm{pH}$ of 3.5 units is apparently not sufficient to uncouple the transitions.

Another reason for varying the $\mathrm{pH}$ in these experiments is that increasing the $\mathrm{pH}$ to values farther removed from the isoelectric point of the protein may reduce the tendency of unfolded molecules to aggregate, thereby permitting demonstration of the reversibility of the usfolding step and facilitating the interpretation of the data. From the results it would appear that this possibility is realized. Privalov and coworkers $1974 ;$ 1988), in analyzing the results of their own investigations and those of other laboratories into the denaturations of a number of small, globular proteins, have delineated an empirical relationship between the magnitude of the enthalpy of denaturation and the $T_{m}$ value of the denaturation. According to their analysis, when the $T_{m}$ and denaturational enthalpy values for a given globular protein are varied (as by changing the $\mathrm{pH}$ ), the enthalpy increases linearly with increases in $T_{m}$. For the same values of $T_{m}$ in the experimentally accessible range, different proteins will have different values of denaturational enthalpy, but the slopes of the linear plots for the different proteins differ in such a way (plots for proteins with smaller enthalpies at low values of $T_{m}$ having larger positive slopes) that all of the plots, if extended linearly to high temperatures, appear to intersect at approximately $110^{\circ} \mathrm{C}$, with a specific enthalpy value of approximately $13.1 \mathrm{cal} / \mathrm{g}$ (Privalov and Khechinashvili 1974). Recent experin exital and theoretical developments indicate that the plots become nonlinear above $80^{\circ} \mathrm{C}$, with intersection at higher temperature and lower enthalpy value than that described above, but the linear approximation-and its apparent intersection near $110^{\circ} \mathrm{C}$-still provide a good fit to the data between $0^{\circ}$ and $80^{\circ} \mathrm{C}$ (Privalov and Potekchin 1986). The $\left(110^{\circ} \mathrm{C}, 13.1 \mathrm{cal} / \mathrm{g}\right)$ point is the "empirically derived intersection point" plotted in Figure 6. The linear relationship between denaturational enthalpy and $T_{m}$ was initially derived using proteins and conditions for which there was substantial reversibility of the overall denaturation process and for which the observed transitions were well explained by two-state (single-transition) models (Privalov and Khechinashvili 1974). The first condition does not apply to some of the data in Figure 6, and all the data are best explained by models involving multiple transitions, but the good fit of the data to the type of linear relationship cbserved for reversible-equilibrium denaturations suggests that interpretation of our data in terms of equilibrium models is justified.

We have interpreted the principal denaturation peaks in our data in terms of multiple sequential transitions, but in fact most of the peaks in the data base can be fitted almost as well by a model involving two independent transitions. For endotherm envelopes of this size and degree of asymmetry, the differences between the fits obtained from sequential and independent models are too small to allow a choice of one or the other based simply on goodness of fit. Our provisional preference for the sequential model is based on other considerations, such as the failure of a 3.5-unit change in $\mathrm{pH}$ to separate the component peaks that are proposed to produce the overall envelope. From the standpoint of effective catalyst design, it 
would be reasonable to expect that two domains of an enzyme would have similar thermal stability limits near the pH of optimal activity. There would not seem to be as great a driving force, however, for the evolutionary selection of domain structures with near-identical thermal stabilities at $\mathrm{pH}$ values far removed from the region at which the enzyme is active. Unless the thermal stabilities of two independent domains happen to vary with $\mathrm{pH}$ in nearly identical manners over a fairly wide $\mathrm{pH}$ range, adjusting the $\mathrm{pH}$ to the extremes would be expected to drive the $T_{m}$ values apart. Another reason for our preference in models is simply the information provided by SAXS studies concerning the geometry of the CBH I molecule. The core region appears to be a fairly compact ellipsoidal mass (Abuja et al. 1988a; Schmuck et al. 1986), with no evidence of domains that are well separated as are the core and tail regions.

\section{Stablizatlon by Celloblose}

The series of DSC scans in the presence of cellobiose was another experiment intended to shed some light on the interaction, or lack thereof, between different parts of the core region. If a potent competitive inhibitor such as cellobiose (Claeyssens et al. 1989) binds to a site that is completely contained within one domain that unfolds independently of any other domain, the binding of the inhibitor would be expected to stabilize only that domain. Conversely, if the binding site is located in a domain that interacts strongly with another, or if the binding site is located in a cleft between two domains, with each domain contributing some groups that interact directly with the inhibitor, then binding of the inhibitor would be expected to stabilize boih of the domains.

At $b$ th at the pH value (4.80) chosen to be near the activity optimum for the enzyme and at the value (8.34) chosen to produce substantial $\mathrm{pH}$ stress, we observe that the enzyme has markedly higher $\mathrm{T}_{\mathrm{m}}$ values in the presence of cellobiose, but the overall shape of the denaturation envelope is very similar to that observed in the absence of the inhibitor. In addition, the overall $\Delta \mathrm{H}^{\circ}$ values in the presence of even quite high concentrations of inhibitor are very close to those observed at lower temperatures in the abscnce of inhibitor, rather than resembling the values that the linear regression of Figure 6 would seem to imply for denaturation processes at these elevated temperatures.

Perhaps the simplest approach to explaining these results is based on the assumption that in the equilibrium depicted in Equation (2),

$$
E I * E+I * U+I
$$

the enzyme-inhibitor complex EI is not significantly unfolded even at temperatures somewhat higher than the high-temperature edge of the apparent unfolding envelope observed in the presence of the inhibitor. Lising this assumption, and the integrated form of the van't Hoff equation for the temperature dependence of an equilibrium constant (Equation [3]) (Moore 1962),

$$
\ln \left(\mathrm{K}_{\mathrm{T} 1} / \mathrm{K}_{\mathrm{T} 2}\right)=(\Delta \mathrm{H} / \mathrm{R})\left(1 / \mathrm{T}_{2}-1 / \mathrm{T}_{1}\right)
$$

it can be shown by setting $T_{1}$ equal to $T_{d}$ (the temperature for half-completion of the unfolding, which for a single-transition process is fairly closely approximated by $T_{m}$ ) and imposing the requirement that half of the total enzyme present must be unfolded (i.e., $[\mathrm{EI}]+[\mathrm{E}]=[\mathrm{U}]$ ), that the apparent $\mathrm{T}_{\mathrm{d}}$ will be displaced to the higher temperature $T_{2}$, as given by Equation (4).

$$
\mathrm{T}_{2}=\mathrm{T}_{1} \Delta \mathrm{H}^{\circ} /\left[\Delta \mathrm{H}^{\circ}-\mathrm{RT}_{1} \ln \left(1+\mathrm{I} / \mathrm{K}_{\mathrm{i}}\right)\right]
$$

In Equations (3) and (4), the temperatures are expressed in degrees Kelvin; I is the concentration of the competitive inhibitor, and $\mathrm{K}_{\mathrm{i}}$ the dissociation constant for the EI complex at the temperature $\mathrm{T}_{2}$. 
In this formulation, the strong resemblance, both in peak shape and peak area, of the denaturation profiles in the presence of inhibitor to those in the absence of inhibitor (Figure 6, Table 1) is explained in terms of the conclusion that the denaturation peaks represent in both cases the same thermodynamic event, i.e., the unfolding of the free enzyme, uncomplexed by inhibitor. The endothermic peaks observed in the presence of inhibitor are thus considered to be simply images of the peaks seen in absence of inhibitor, displaced along the temperature axis according to the general principle described by Equation (4). The $T_{m}$ values observed in the presence of cellobiose therefore serve as approximations only of apparent $T_{d}$ values derived from the values for free enzyme. The $T_{m}$ values for the EI complex have not, according to this analysis, been observed in the results presented here. The $T_{m}$ values observed at the highest cellobiose concentration $(0.1 \mathrm{M})$ used here do, however, indicate lower limits for the actual values for the $\mathrm{CBH}$ //cellobiose complex.

The analysis presented above for the effect of cellobiose on CBH I thermal stability must bu considered preliminary, in that Equation (3), and therefore also Equation (4), which is derived from Equation (3), apply strictly only to single-transition processes. Equation (4) does, however, serve well to illustrate the general type of peak-displacement being proposed here. Exact numerical application of such an equation would require accurate estimates, not currently available, for such quantities as the $K_{i}$ values for native CBH I and cellobiose at $\mathrm{pH}$ values far removed from the activity optimum, and/or at temperatures at which the native enzyme, in the absence of the inhibitor, does not exist in measurable proportions. Qualitatively, however, we believe that the analysis presented above does an excellent job of explaining the results obtained thus far.

\section{Conclusions}

We have adopted as our working hypothesis a model in which thermal denaturation of the core region of CBH I in the pH range $4.80-8.34$ and at ionic strength $0.026 \mathrm{M}$ involves three distinguishabie endothermic transitions. One is relatively independent of $\mathrm{pH}$ and appears to be uncoupled from the other two at $\mathrm{pH} 7.50$ and $\mathrm{pH} 8.34$. The other two (the proposed constituent transitions of the $\mathrm{pH}$-dependent asymmetric "principal peak" of the CBH I thermograms) appear to be tightly coupled over the entire $\mathrm{pH}$ range studied. Results presented for the stabilization of the core region by cellobiose indicate that this potent competitive inhibitor may serve as a powerful probe in DSC studies of the relationship between the stability of the core region as a whole and the maintenance of the structure of the cellobiose-binding region of the catalytic site, and by extension, of the catalytic site as a whole. The fact that the cellulosebinding tail region of the CBH I molecule, which has been shown by NMR studies to have a well-defined structure in solution, does not show any measurable endothermic transitions in the temperature range from $12^{\circ} \mathrm{C}$ to $95^{\circ} \mathrm{C}$ is thought-provoking. Studies utilizing other instrumental techniques are planned to address the question of the temperature-dependence of the conformation of the tail fragment over this range.

\section{Future Direction}

Along with the important kinetic criteria, enzyme stabilities determined by DSC will be used to select the most promising celiulase enzymes for application in the ethanol from biomass process. This technique can be applied in a screening mode for such analyses, where in-depth structural studies are not undertaken.

\section{Acknowledgments}

This work was funded by the Ethanol from Biomass Program of the DOE Biofucìs Systems Division. 


\section{References}

Abuja, P.M., Pilz, I., Tomme, P., and Claeyssens, M. 1989. Biochem. Blophys. Res. Commun. 169:615623.

Abuja, P.M., Pilz, I., Tomme, P., and Claeyssens, M. 1988a. Biochem. Biophys, Res. Commun. 156:180185.

Abuja, P.M., Schmuck, M., Pilz, I., Claeyssens, M., and Esterbauer, H. 1988b. Eur. Biophys. J. 15:339. 342.

Ahern, T.J., and Klibanov, A.M. 1985. Science 228:1280-1284.

Bailey, J.E., Ph.D. Thesis, London University, 1968. In Handbook of Biochemistry-Selected Data for Molecular Biology, ed. H.A. Sober, B-74. Cleveland, OH: Chemical Rubber Co.

Bailey, J.M., Lin, L.-N., Brandts, J.F., and Mas, M.T. 1990. J. Protein Chem. 9:59-67.

Bergfors, T., Rouvinen, J., Lehtovaara, P., Caldenty, X., Tomme, P., Claeyssens, M., Pettersson, G., Teeri, T., Knowles, J., and Jones, T.A. 1989. J. Mol. Biol. 209:167-169.

Bhikhat hai, R., and Pettersson, G. 1984. Biochem. J. 222:729-736.

Biltoner: R.L., and Freire, E. 1978. CRC Crit. Rev. Biochem. 5:85-124.

Brandts, J.F., Hu, C.Q., Lin, L.N., and Mas, M.T. 1989. Blochem. 28:8588-8596.

Claeyssens, M., van Tilbeurgh, H., Tomme, P., Wood, T.M., and McCrae, S.I. 1989. Biochem. J. 261:819. 825.

Edge, V., Allewell, N.M., and Sturtevant, J.M. 1985. Biochem. 24:5899-5906.

Fagerstam, L.G., and Pettersson, L.G. 1980. FEBS Lett. 119:97-100.

Gum, E.K.., and Brown, R.D. 1976. Biochim. Biophys. Acta 446:371-386.

Heririssat, B., Driguez, H., Viet, C., and Schulein, M. 1985. Bio/Technol. 3:722-726.

Hu, C.Q., and Sturtevant, J.M. 1987. Biochem. 26:178-182.

Jackson, W.M., and Brandts, J.F. 1970. Biochem. 9:2294-2301.

Johansson, G., Stahlberg, J., Lindeberg, G., Engstrom, A., and Pettersson, G. 1989. FEBS Lett. 243:389393.

Knowlei, J., Lehtovara, P., and Teeri, T. 1987. Trends Biotechnol. 5:255-261.

Knowles, J., Teeri, T.T., Lehtovaara, P., Penntila, M., and Saloheimo, M. 1988. In Biochemistry and Geratics of Cellulose Degradation, eds. J.-P. Aubert, P. Beguin, and J. Millet, 153-169. London: Academic Press. 
Kraulis, P.J., Clore, M., Nilges, M., Jones, T.A., Pettersson, G., Knowles, J., and Gronenborn, A.M 1989. Biochem. 28:7241-7257.

Lakowicz, J.R. 1983. Principles of Fluorescence Spectroscopy. New York, NY: Plenum Press.

Manly, S.P., Matthews, K.S., and Sturtevant, J.M. 1985. Biochem. 24:3842-3846.

Moore, W.J. 1962. Physical Chemistry, 3rd Edition, 181. London: Prentice-Hall.

Nieves, R.A., Himmel, M.E., Todd, R.J., and Ellis, R.P. 1990. Appl. Environ. Microbiol. 56:1103-1108.

Pfeil, W., and Privalov, P.L. 1976. Biophys. Chem. 4:23-32.

Privalov, P.L., and Gill, S.J. 1988. Advan. Protein Chem. 39:191-234.

Privalov, P.L., and Khechinashvili, N.N. 1974. J. Mol. Biol. 86:665-684.

Privalov, P.L., and Potekhin, S.A. 1986. Methods Enzymol. 131:4-51.

Schmuck, M., Pilz, I., Hayn, M., and Esterbauer, H. 1986. Biotechnol. Lett. 8:397-402.

Shoemaker, S., Schweickart, V., Ladner, M., Gelfand, D., Kwok, S., Myambo, K., and Innis, M. 1983 a. Bio/Technology 1:691-696.

Shoemaker, S., Watt, K., Tsitovsky, G., and Cox, R. 1983b. Bio/Technol. 1:691-696.

Shoemaker, S., Watt, K., Tsitovsky, G., and Cox, R. 1983c. Bio/Technol. 1:687-690.

Sturtevant, J.M. 1987. Ann. Rev. Phys. Chem. 38: 463-88.

Tomazic, S.J., and Klibanov, A.M. 1988a. J. Biol. Chem. 263:3092-3096.

Tomazic, S.J., and Klibanov, A.M. 1988b. J. Biol. Chem. 263:3086-3091.

Tomme, P., van Tilbeurgh, H., Pettersson, G., van Damme, J., Vándekerckhove, J., Knowles, J., Teeri, T., and Claeyssens, M. 1988. Eur. J. Biochem. 170:575-581.

van Tilbeurgh, H., Tomme, P., Claeyssens, M., Blikhabhai, R., and Pettersson, G. 1986. FEBS Lett. 04:223-227.

Wood, T.M., and McCrae, S.I. 1986. Biochem. J. 234:93-99.

Woodward, J., Hayes, M.K., and Lee, N.E. 1988. Bio/Technol. 6:301-304. 


\title{
Bacterlal Cellulases: Regulation of Synthesls
}

\author{
J. C. Linden and M. Shiang \\ Departments of Agricultural and Chemical Engineering \\ and of Microbiology \\ Colorado State University \\ Fort Collins, Colorado 80523
}

\begin{abstract}
Bacteria represent a promising source for the production of industrial enzymes. Bacterial cellulases are an esnecially interesting case in point. Many thermophilic bacterial species produce cellulases that are stable and active at high temperature, resistant to proteolytic attack, and stable to mechanical and chemical denaturation. However, cellulase productivities in bacteria are notoriously low compared to other microbial sources. In this paper, bacterial enzyme production systems will le discussed with a focus on comparisons of the productivities of known bacterial cellulase producers. Experimental results for cellulase production by Acidothermus cellulolyticus are presented and the literature is reviewed in an attempt to develop a model for the regulation of cellulase synthesis in bacterial systems.
\end{abstract}

\section{Introduction}

Successful utilization of cellulose materials, an abundant renewable resource, depends on the economically feasible process for cellulase production, good pretreatment methods for cellulosics, efficient microbial and enzymatic hydrolysis of cellulose to low-molecular-weight products, and appropriate chemical and/or biological conversion of the hydrolysis products to other useful products that can be applied as liquid fuels, chemical feedstocks, and food materials. A major hindrance to the industrial enzymatic hydrolysis is the high cost of cellulase, which has been estimated to be up to $60 \%$ of the total operating costs. Improvement of cellulase production has focused on selection of hypercellulolytic strains, optimization of fermentation conditions, and development of the most effective mode of operation (batch, continuous, fed-batch, etc.). The selection criteria for suitable cellulase sources are fast-growing microorganisms, the strain with high cellulase yields and high specific activity, and enzyme systems with high thermostability.

The degradation of cellulase by bacterial systems occurs both aerobically and anaerobically. The aerobic busteria include Acidothermus cellulolyticus, Cellulomonas sp., Bacillus sp., Pseudomonas sp., Cellvibrio sp., Cytophaga sp., Microbispora sp., and Thermomonospora sp. The anaerobic bacteria are Acetivibrio cellulolyti is, Bacteroides sp., Clostridium sp., Ruminococcus sp., and Micromonospora sp. This review will cover some mesophilic and thermophilic cellulolytic bacteria, some of which have been reviewed by Ljungdahl and Eriksson (1985), Coughlan and Ljungdahl (1988), and Robson and Chambliss (1989). 
According to studies on fungal cellulolytic enzymes, the model of crystalline cellulose hydrolysis requires synergistic action of at least three cellulase components: endo-1,4- $\beta$-glucanase (carboxymethyl cellulase), exo-1,4- $\beta$-glucanase (often a cellobiohydrolase), and $\beta$-glucosidase (cellobiase) (Eriksson 1969; Wood 1985). All cellulolytic bacteria synthesize endoglucanase and either $\beta$-glucosidase (Gong and Tsao 1979; Ohmiya et al. 1985) or cellobiose phosphorylase (Ayers 1958) or a combination of the two (Park and Ryu 1983). Both aerobic and anaerobic bacteria synthesize cellobiose phosphorylase that catalyzes cellobiose to glucose and glucose-1-phosphate (G-1-P). As some of these organisms do not produce a $\beta$-glucosidase, it seems reasonable to assume that the phosphorylases provide a means of metabolizing cellulose degradation products and of diminishing the inhibitory effect of cellobiose on cellulase activity (Coughlan 1985).

The cellulase systems that have been investigated in greatest detail have been derived from mesophilic fungi; the most prominent strains are Trichoderma reesei and its mutants. Major limitations of cellulases from mesophilic fungi are their low temperature stability and low rate of enzyme production. Thermophilic bacteria grow rapidly and produce thermostable cellulase, but have not yielded high productivities because of their inherently lower cellulase yields. Comparisons of cellulase activities and productivities of some mesophilic and thermophilic fungi and bacteria are shown in Table 1.

Extracellular cellulases in bacteria have been purified from a number of bacterial species, including Micromonospora bispora (Bartley et al. 1984), Cytophaga sp. (Chang and Thayer 1977), Streptomyces flavogriseus (MacKenzie et al. 1984), Cellulomonas uda (Nakamura and Kitamura 1983), Clostridium stercorarium (Creuzet et al. 1983), Acetivibrio cellulolyticus (Saddler and Khan 1980), and Ruminococcus albus (Ohmiya et al. 1982). Cellulolytic enzymes of $C$. thermocellum are organized into a distinct multiunit complex named a "cellulosome" by Lamed et al. (1983). Scanning electron microscopic evidence by Lamed et al. $(1987,1988)$ demonstrated a clear correlation between cellulolytic activity and the appearance of protuberance-like structures on the bacterial cell surface. This correlation extended over a wide range of physiological and evolutionary boundaries including Acetivibrio cellulolyticus, Bacteroides cellulosolvens, Cellulomonas sp., Clostridium sp., and Ruminococcus albus.

Cellulolytic bacteria can be found that produce only cell-bound cellulase, such as Cytophaga (Chang and Thayer 1977); only cell-free cellulase, such as Cellvibrio vulgaris (Oberkotter and Rosenberg 1978), Bacillus sp. (Priest 1977), Clostridium sp. (Lee and Blackbum 1975), Acetivibrio cellulolyticus (Saddler and Khan 1980), and Thermoactinomyces (Hagerdal et al. 1978, 1979); and both cell-bound and cell-free cellulase such as Pseudomonas (Yamane et al. 1971), Bacteroides succinogenes (Groleau and Forsberg 1981), and Cellvibrio fulvus (Berg 1975). However, the location of cellulase in bacteria also depends on the environments in which the bacteria are grown and the age of the culture (Berg 1975; Yamane et al. 1971).

The synthesis of cellulases is regulated by induction and catabolite repression mechanisms. Cellulases are induced by soluble derivatives from cellulose or several other low-molecular-weight carbohydrates, but enzyme synthesis is repressed by the presence of glucose or other readily metabolized sugars. Evidence supporting this conclusion has been obtained for bacteria, e.g., Acetivibrio cellulolyticus (Saddler et al. 1980), Acidothermus cellulolyticus (Shiang et al. 1990), Cellulomonas uda (Stoppok et al. 1982), and Thermomonospora (Fennington 1984; Lin and Wilson 1987; Moreira et al. 1981). The known inducers for cellulase synthesis are cellulose, cellulose derivatives, cellobiose, sophorose, and lactose. The effects of cellobiose, lactose, and sophorose on cellulase synthesis of bacterial systems are significantly different from fungal systems. 
Table 1. Cellulase Production by Some Mesophillc and Thermophillic Mlcroorganlsms

\begin{tabular}{|c|c|c|c|c|c|}
\hline $\begin{array}{l}\text { Incuk } \\
\text { temp } \\
{ }^{\circ} \mathrm{C}\end{array}$ & $\begin{array}{l}\text { ation } \\
\text { orature }\end{array}$ & $\begin{array}{l}\text { Cellulosic } \\
\text { substrate }\end{array}$ & $\begin{array}{l}\text { Cellulase } \\
\text { activity } \\
\text { (FPU/mL) }\end{array}$ & $\begin{array}{l}\text { Cellulase } \\
\text { productivity } \\
\text { (FPU/L.h) }\end{array}$ & Ref. \\
\hline 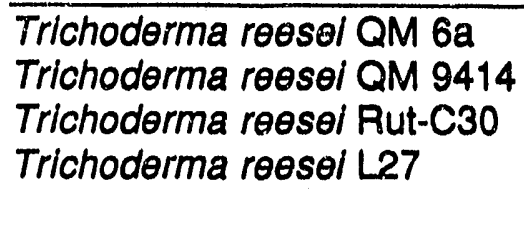 & $\begin{array}{l}28 \\
28 \\
28 \\
28\end{array}$ & $\begin{array}{l}6 \% \text { cotton } \\
6 \% \text { cotton } \\
6 \% \text { cotton } \\
8 \% \text { Avicel }\end{array}$ & $\begin{array}{l}5 \\
10 \\
14 \\
18\end{array}$ & $\begin{array}{l}15 \\
30 \\
42 \\
94\end{array}$ & $\begin{array}{l}\text { Ryu and } \\
\text { Mandels } \\
1980 \\
\text { Shoemaker } \\
\text { et al. } 1981\end{array}$ \\
\hline $\begin{array}{l}\text { Sporotrichum thermophile } \\
\text { Thielavia terrestrls }\end{array}$ & 45 & $1 \%$ Wheat straw & 0.07 & 1.46 & Creese 1983 \\
\hline ATCC 26917 & 52 & $1 \%$ Solka Floc & 0.11 & 3.43 & $\begin{array}{l}\text { Skinner and } \\
\text { Tokuyama } \\
1978\end{array}$ \\
\hline Clostrldium thermocellum & 60 & $1 \%$ Solka Floc & 0.14 & 1.94 & $\begin{array}{l}\text { Sadder and } \\
\text { Chan } 1982\end{array}$ \\
\hline $\begin{array}{l}\text { Thermomonospora fusca } \\
\text { Thermomonospora fusca }\end{array}$ & 55 & $1 \%$ Avicel & 0.15 & 5.10 & $\begin{array}{l}\text { Morelra et } \\
\text { al. } 1981\end{array}$ \\
\hline mutant $\mathrm{N}-35$ & 55 & $1 \%$ Avicel & 0.33 & 27.50 & $\begin{array}{l}\text { Meyer and } \\
\text { Humphrey } \\
1982\end{array}$ \\
\hline $\begin{array}{l}\text { Thermomonospora curvata } \\
\text { Thermomonospora curvata } F\end{array}$ & $\begin{array}{l}53 \\
53\end{array}$ & $\begin{array}{l}\text { Cellulose } \\
\text { Cellulose }\end{array}$ & $\begin{array}{l}0.10 \\
0.18\end{array}$ & $\begin{array}{l}1.39 \\
2.50\end{array}$ & $\begin{array}{l}\text { Fennington } \\
\text { et al. } \\
1983\end{array}$ \\
\hline Thermomonospora curvata & 53 & $8 \%$ cotton & 0.26 & 3.61 & $\begin{array}{l}\text { Fennington } \\
\text { et al. } \\
1984\end{array}$ \\
\hline $\begin{array}{l}\text { Thermomonospora curvata } \\
\text { mutant G-11 }\end{array}$ & 53 & $8 \%$ cotton & 0.29 & 4.03 & $\begin{array}{l}\text { Fennington } \\
\text { et al. } \\
1984\end{array}$ \\
\hline Acidothermus cellulolyticus & 55 & $\begin{array}{l}1.5 \% \text { Solka Floc } \\
\text { and } 0.5 \% \text { sucrose }\end{array}$ & 0.16 & 3.31 & $\begin{array}{l}\text { Shiang et al. } \\
1990\end{array}$ \\
\hline Acetivibrio cellulolyticus & 37 & $0.5 \%$ Avicel & 3.36 & 46.67 & $\begin{array}{l}\text { Saddler and } \\
\text { Khan } 1980\end{array}$ \\
\hline Cellulomonas (NRCC 2406) & 30 & $1 \%$ Solka Floc & 7.00 & 72.92 & $\begin{array}{l}\text { Vladut-Taylor } \\
\text { et al.1986 }\end{array}$ \\
\hline
\end{tabular}




\section{Results}

Acidothermus cellulolyticus was isolated from the acidic hot springs of northern Yellowstone National Park, Wyo. (Mohagheghi et al. 1986). This thermophilic, acidophilic, aerobic, cellulolytic bacterium can grow on several carbohydrates, incli ding glucose, cellobiose, sucrose, xylose, and cellulose (Mohagheghi et al. 1986; Shiang ct al. 1990). It grew at $37^{\circ}$ to $65^{\circ} \mathrm{C}$, with the optimum growth temperature of $55^{\circ} \mathrm{C}$. The $\mathrm{pH}$ range for growth was 3.5 to 7 , with an optimum $\mathrm{pH}$ of 5 . Cellulolytic enzymes were produced when grown on cellobiose and/or cellulose. The cellulolytic activity was secreted mainly during the late $\log$ and early stationary phases of growth. The cellulase enzyme complexes can completely degrade microcrystalline cellulose; this indicates that the full component of celluljlytic enzymes is being secreted (Mohagheghi et al. 1986). The products of cellulose hydrolysis are D.glucose and D-cellobiose. No higher oligosaccharides were detected by high-performance size exclusion chromatography.

The cellulase production, cell growth, and cellobiose degradation rates of batch culture in 2.5, 5.0, 7.5, and $10.0 \mathrm{~g} / \mathrm{L}$ of cellobiose as a substrate were studied by Shiang et al. (1990). The maximum cellulase activities $(0.021$ to $0.069 \mathrm{U} / \mathrm{mL}$ ) and volumetric productivities (between 0.92 and $2.49 \mathrm{U} / \mathrm{L} \cdot \mathrm{h}$ ) were proportional to the concentration of celloblose. Preliminary work showed that the better cellulase yields in batch culture were achieved by use of secondary cellulosic substrates. Cellulase concentration was $0.105 \mathrm{U} / \mathrm{mL}$ achieved in $70 \mathrm{~h}$ using a mixed substrate system containing cellobiose and Solka Floc. This was three times higher than that using $5 \mathrm{~g} / \mathrm{L}$ celloblose alone and $35 \%$ higher than that from the mixture of cellobiose and Avicel (Shiang et al. 1990). The substrate ystem using sucrose and Solka Floc produced the high cellulase activity in the short fermentation time (i.e., $0.110 \mathrm{U} / \mathrm{mL}$ in $50 \mathrm{~h}$ ). Of the sugars added to Solka Floc cellulose fermentations, D-cellobiose, D-glucose, D-fructose, D-xylose, and sucrose stimulated cellulolytic enzyme production, but only D-cellobiose and D-xylose were effective cellulase inducers.

\section{Regulation of Cellulase Synthesis}

The biosynthesis and activity of cellulase are stringently regulated by a variety of factors in wild strains; both types of regulation make cellulase production and utilization costly on a commercial scale. Bacteria exhibit both positive and negative control of protein synthesis. An example of negative control in prokaryotes is the lactose operon, and of positive control, the arabinose operon, both found in $E$. coli. Regulation of catabolite repressible enzymes in bacteria is through an additional control involving the levels of cAMP in the cell. Meanwhile, there is some disagreement as to whether cAMP is involved in controlling cellulase synthesis. The experimental results presented by Suzuki (1975) suggested that it was not involved in the case of $P$. fluorescens var. cellulosa. Goksoyr and Eriksen suggested the possibility that ATP rather than CAMP may be the small molecular regulator in some instances (1980). On the contrary, Wood et al. showed that the addition of cAMP exogenously increased cellulase synthesis in toluene-treated $T$. curvata (1984). Moreover, $T$. curvata catabolite repression-resistant mutants, which expressed cellulase at elevated rates, had two to three times the intracellular cAMP content of the parent strain (Wood et al. 1984). In $T$. fusca, the repression effect was partially relieved when $5 \mathrm{mM}$ cAMP was added concomitantly with the repressing carbon source; however, cAMP never completely abolished repression (Lin and Wilson 1987). Therefore, Stutzenberger suggested that cAMP is involved with regulation of cellulase synthesis by Thermomonospora (Goksoyr and Eriksen 1980).

The CRP, cyclic AMP receptor protein, to which cAMP must be connplexed for release from catabolite repression, has two distinct domains: the $\mathrm{N}$-terminal portion binds $10 \mathrm{CAMP}$, and the carboxyl terminal end binds to DNA. Exactly how glucose affects the intracellular levels of cAMP is still being investigated. One important theory suggests that the repression mechanism is strongly linked with the phosphoenolpyruvate: sugar phosphotransferase transport system (PTS). In the absence of glucose or any 
other repressive sugar, the phosphorylated HPr protein transfers its phosphate moiety to a regulatory protein (RPr). The RPr P then, either by allosteric interaction or by phosphorylation, transforms an inactive adenylate cyclase into an active form. This enzyme catalyzes the conversion of ATP into cAMP. In the presence of glucose, the HPr-P phosphorysates enzyme III of the PTS system which, in turn, phosphorylates the sugar upon transport through the cell membrane. Therefore, in the case of repression, adenylate cyclase remains in the inactive form and the cAMP concentration remains low (Meyer and Humphrey 1982).

Regulation of cellulase synthesis by induction and catabolite repression in $A$. celluislyticus was also studied (Shiang et al. 1991). Various compounds such as L-sorbose, cyclic AMP (cAMP), L-glucose, 2-deoxyglucose (2-DG), G-1-P, sophorose, salicin, sugar alcohols, and is'propylthioglucoside (IPTGlu) were added along with Solka Floc to improve extracellular cellulase formation by the culture. When cAMP was added exogenously to an $A$. cellulolyticus culture in the concentration range of 10 to $200 \mathrm{mg} / \mathrm{L}$, it did not affect cell growth but cellulase yields were increased with the increasing levels of cAMP. The enzyme production rates, between 35 and $50 \mathrm{~h}$, in cAMP with Solka Floc were identified with the different levels of cAMP addition during fermentations. L-Sorbose, L-glucose, 2-DG, G-1-P, sophorose, IPTGlu, and sugar alcohols enhanced cellulase activity produced in the medium, but the starting time and the time requirement to reach the maximum enzyme activity were different in each condition. All these substances functioned as a moderator in a proposed cellulase synthesis model. From the experimental results, only cellobiose, xylose, sophorose, and unknown soluble derivatives from cellulose were considered as inducers. The possible regulatory mechanism of cellulase synthesis was proposed (Shiang et al. 1991). The repressor, inducer, cAMP, and moderator were all involved in controlling the rate and the yleld of enzyme production.

A summary of the key information has been compiled on the anacrobic and aerobic bacteria discussed above. The comparison of the substrates for growth of these organisms in Table 2 shows that all utilize cellobiose and various forms of cellulose. The two species belonging to Bactercides have different specificity for substrates, while those for Ruminococcus, Cellulomonas and Thermomonospora were the same. The data also allow comparison of the behavior of the 13 species of cellulolytic bacteria toward cellobiose. More variability is noted in this regard and no correlation between induction/repression can be made with the mechanism of cellobiose degradation.

\section{Regulation Models of Cellulase Synthesls}

Gong arıd Tsao proposed a unified model for the regulation of cellulase synthesis (1979). This postulated mechanism of regulation took into account the importance of glucosidase in the regulation of glucose and also of cellobiose levels within the cells. In this postulated regulation model, cellobiose and glucose represent the limiting cellulolytic products of the basal cellulase. Cellobiose serves as a carbon source and a potential inducer. Active transport of cellobiose across the cell membrane is achieved by an adaptive transport enzyme system. Both constitutive and adaptive glucosidases are present as a membrane-bound enzyme, which would hydrolyze part of cellobiose to glucose. After cellobiose enters the cells, the intracellular cellobiose could become the active inducer and react with repressor protein, causing induction to occur. Or the potential inducer could be hydrolyzed by intracellular glucosidase resulting in the accumulation of glucose and the repression of cellulase synthesis. The affinity of the active inducer for the repressor protein determines the efficiency of induction. Induction of cellulase synthesis occurs when the repressor protein has been inactivated by the active inducer and transcription and translation follow. The newly synthesized cellulase could remain membrane bound. The release of cellulases across the cell membrane is regulated by a specific releasing mechanism. Newly released extracellular cellulase hydrolyzes cellulose to glucose and cellobiose. Glucose and cellobiose, in turn, support cell growth and 
Table 2. Substrates for Growth of Cellulose Bacterla (a) and Means by which Celloblose is Utllized by Cellulolytlc Bacterla (b)

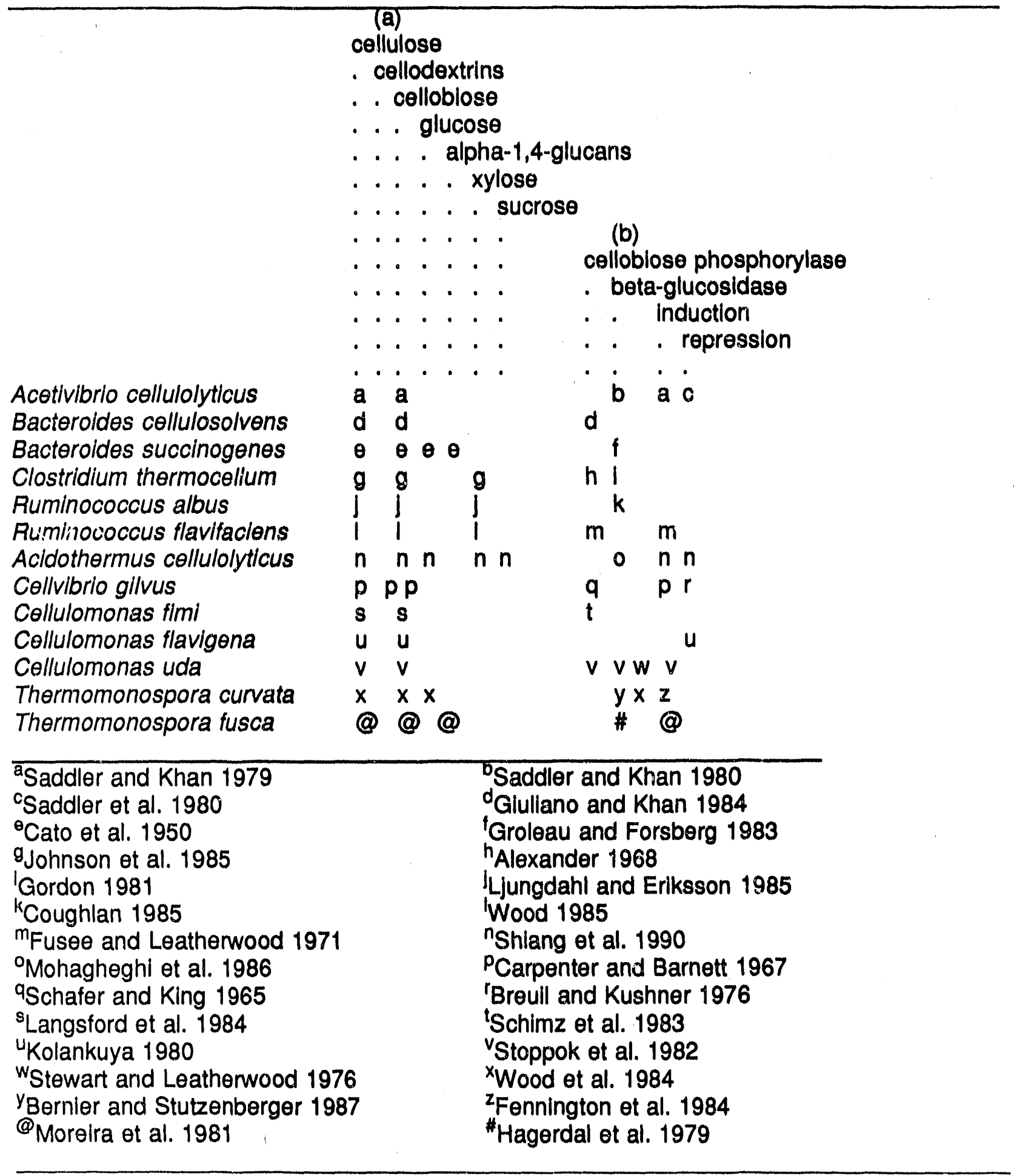


are also involved in the induction and repression. Although intracellular glucosidase hydrolyzes part of intracellular cellobiose to glucose, high levels of intracellular glucose inhibit intracellular glucosidase activity.

Stutzenberger described the regulation of microbial cellulolytic activity at the biosynthetic, secretory, and catalytic levels in detail (1985). One possible model for the regulation of cellulase biosynthesis was characterized. It shared many features in common with the well-studied ara operon in E. coli. In the ara operon, the regulator protein functions as a repressor in the absence of inducer (arabinose) and as an activator in its presence. In addition, it is not synthesized constiutively. However, in the cellulase operon, it is now generally accepted that a low level of constitutive enzymes degrades their exogenous substrates, and the resultant low-molecular-weight products enter the cell and induce further synthesis of extracellular enzymes (Priest 1977). Therefore, the action of a repressor appears undesirable. In Stutzenberger's regulation model of cellulase synthesis, control of $\beta$-glucosidase biosynthesis is not included. It was assumed that the operon is an activator-controlled inducible system requiring the cooperative binding of two regulatory protein to the control region for maximal transcription. One regulatory protein, called CAM for cellulase activator molecule, requires complexation with an inducer in order to bind the specific control region on the DNA. The other regulatory protein is CAP (referred to CRP above), which requires CAMP for binding to DNA. When neither CAM nor CAP are in their complexed states, cellulase operon expression occurs at a very low rate (basal level) because of the inability of RNA polymerase to initiate transcription in their absence. Under conditions of carbon limitation in the absence of an inducer, cAMP levels increase sufficiently to create complexes with CAP. The complexes then bind weakly to the control region and cause a detectable but less than maximal increase in expression. Under conditions in which an inducer is provided at growth-limiting rates, CAM and CAP bind in a cooperative manner to the control region; their simultaneous presence allows maximal transcription by RNA polymerase to provide coordinate expression of the extracellular cellulolytic complex.

\section{Model Development for A. cellulolyticus}

The effect of various compounds, when added along with Solka Floc on cellulase production in A. cellulolyticus, was studied by Shiang et al. (1991). The enzyme production rates at different concentrations of CAMP, which were nearly identical during the 35. to 50-h fermentation period, may be due to limiting rates of permeability of the cAMP into the cell regardless of extracellular concentration (Figure 1). However, increasing amounts of cAMP addition increased final cellulase yields proportionally. This cAMP-specific stimulation of cellulase production in A. cellulolyticus indicates that the synthesis of cellulase, like other inducible catabolic enzymes, may be regulated to some extent by intracellular cAMP levels.

Addition of G-1-P increased cellulase yields and shortened the time required to reach maximum FPA (Figure 2). Enzyme yields and productivities using $0.5 \mathrm{~g} / \mathrm{L} \mathrm{G}-1-\mathrm{P}$ and Solka Floc were almost three times as great as using Solka Floc alone. The maximum enzyme concentration produced after $71 \mathrm{~h}$ of inoculation was $0.201 \mathrm{U} / \mathrm{mL}$ and the volumetric and specific cellulase productivities were $2.83 \mathrm{U} / \mathrm{L} \cdot \mathrm{h}$ and $0.57 \mathrm{U} / \mathrm{g}$ dry $\mathrm{wt} \cdot \mathrm{h}$, respectively. The significantly enharced cellulase production by G-1-P may be as a result of transport system phenomena or enzyme induction. One might postulate the following two processes. First, in the presence of G-1-P, the phosphorylated protein HPr in PTS transfers its phosphate moiety to an RPr. The RPr-P then transforms an inactive adenylate cyclase into an active form. Thus, ATP is converted to CAMP, which complexes a cAMP receptor protein (termed as CRP or CAP) to form CRP.cAMP complex. This complex binds to the promoter and enhances RNA polymerase binding to the operon promoter and initiation of transcription. Secondly, if G-1-P were a phosphorolysis product of 


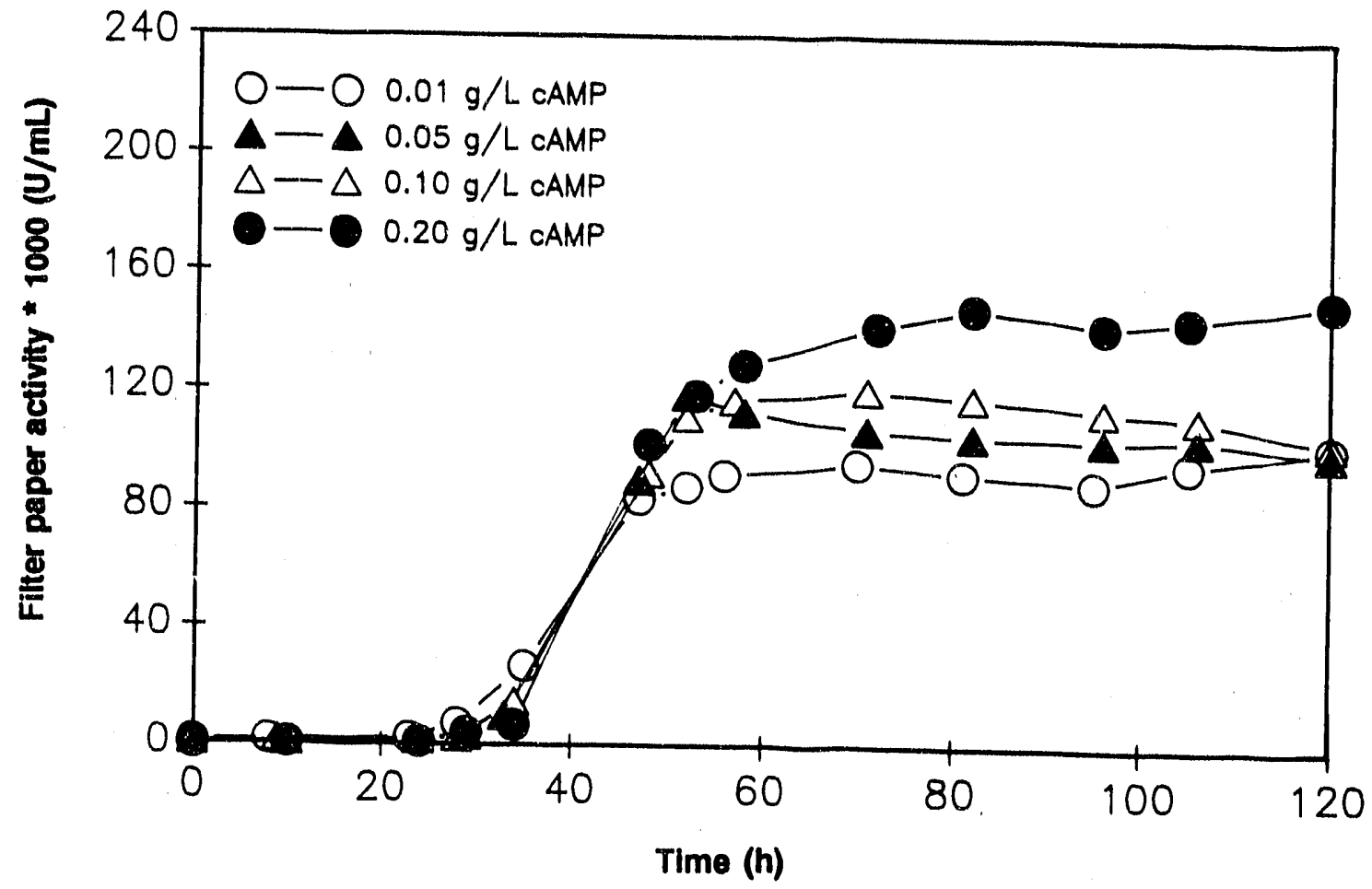

Figure 1. Time course of cellulase activity accumulation In A. cellulolytlcus cultures containing $15 \mathrm{~g} / \mathrm{L}$ Solka Floc and varlous concentrations of CAMP

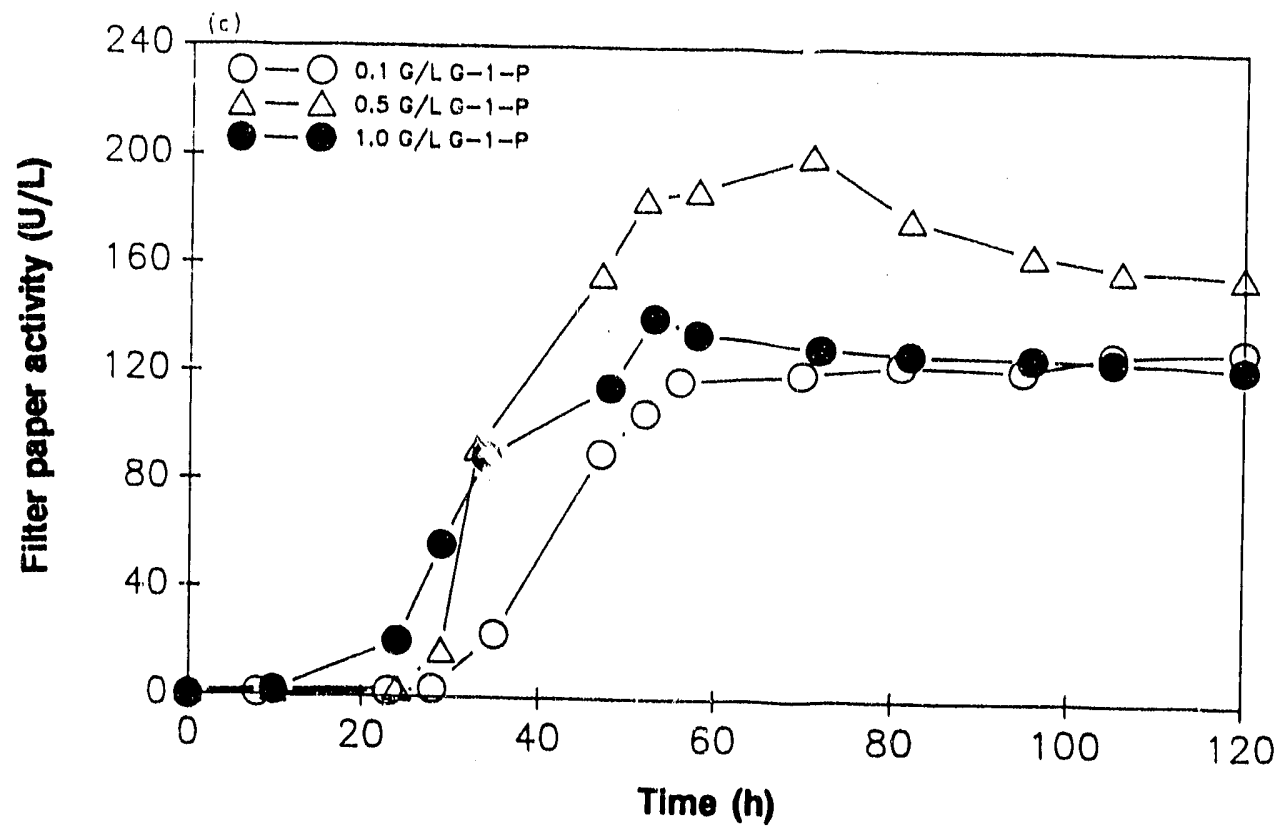

Figure 2. Time course of cellulase activity accumulation In A. cellulo/yticus cultures contalning $15 \mathrm{~g} / \mathrm{L}$ Solka Floc and varlous concentrations of glucose-1-phosphate 
cellobiose by the cellobiose phosphorylase reaction, G-1-P may be acting as a basic inducer molecule to turn on cellulase enzyme synthesis in this culture.

In the $A$. cellulolyticus system, comparisons of maximum cellulase activity, time to maximum FPA, enzyme productivities, and growth parameters with various substances added to Solka Floc are summarized in Table 3. The values can be compared to data from using $15 \mathrm{~g} / \mathrm{L}$ Solka Floc as a sole substrate. Most of the addition components to Solka Floc fermentation enhanced cellulase yields; exceptions are mannose, L-arabinose, and IPTGal. The highest relative enzyme activities (309\% and 308\%) were achieved by applying G-1-P and salicin to Solka Floc, respectively. Only supplementation of cellobiose, sucrose, Lglucose, cAMP, sophorose, xylose, and IPTGlu significantly reduced the time required to reach maximum FPA. The greatest volumetric enzyme productivity improved approximately 4.5 fold (446\%) when using $0.2 \mathrm{~g} / \mathrm{L} \mathrm{L}$-glucose in Solka Floc fermentation. Moreover, adding $0.25 \mathrm{~g} / \mathrm{L}$ IPTGlu increased relative specific enzyme productivity by $400 \%$.

Four categories can be classified by comparing relative maximum enzyme concentration, relative time required to reach the maximum FPA, and chemical structure of these supplementing compounds. The first group is that of compounds that potentially could be degraded to form G-1-P by phosphorylation. They include exogenous G-1-P, IPTGlu, cellobiose, sophorose, salicin, and sucrose. Addition of these compounds to Solka Floc fermentations improved maximum cellulase yields from $171 \%$ to $309 \%$, and the time period for enzyme synthesis reduced from 95\% to 59\% compared with using Solka Floc only. The second group is that of compounds that potentially could be transported by mechanisms other than the PTS presumably used for D-glucose transport. Therefore, the supplementation of these compounds increased cellulase production (178\% to $258 \%$ ) and reduced fermentation time (95\% to $58 \%)$. They are D-xylose, L-sorbose, L-glucose, and 2-deoxyglucose. Both groups may be associated with high concentrations of cAMP. The level of cAMP in the cells is determined by the activities of the enzyme adenylate cyclase. Adenylate cyclase is membrane bound, and its activity is high only if components of the sugar transport system are phosphorylated. This is the case in the absence of its sugars transported. The third group is that of compounds that may potentially be transported either PTS or other mechanisms that inhibit cAMP production. However, cellulase synthesis resumed after these compounds were consumed for sell growth. This group included D-glucose, D-fructose, maltose, mannitol, glycerol, sorbitol, and $\beta$-methyl glucoside. The presence of these compounds in Solka Floc fermentations, enhanced enzyme yields (132\% to 254\%) but the time required to complete cellulase synthesis took longer (106\% to 148\%) than the control. The fourth group is that of compounds that inhibited cellulase production and/or cell growtin. They were L-arabinose, D-mannose, lactose, and IPTGal.

Based both on models from Gong and Tsao (1979), and Stutzenberger (1985), and the results derived from A. cellulolyticus, a possible mechanism for the regulation of cellulase synthesis derived by Shiang et al. (1991) is shown in Figure 3. The new mechanism presumes that the operon consists of R, M, P, $\mathrm{O}$, and $\mathrm{S}$ regions. The product of the gene $\mathrm{R}$ is an inactive repressor protein, and the $\mathrm{M}$ gene codes CAM protein. $\mathrm{P}, \mathrm{O}$, and $\mathrm{S}$ represent promoter, operator, and cellulase structure genes, respectively. Both inactive repressor protein and CAM requires complexation with a repressor and an inducer to form active repressor molecule and active inducer molecule, respectively. Therefore, an active repressor molecule will bind the operator that blocks the transcription process, and the active inducer is able to bind the promoter to initiate transcription by RNA polymerase.

The induction of this operon responds to the intracellular concentration of cAMP, which is determined by the carbon source available to the cell. When cells are grown on cellobiose or cellulose that do not inhibit adenylate cyclase, cAMP is made in sufficient quantities for induction of ce!lulase. On the contrary, when cells are grown on glucose or other readily metabolized carbohydrates that do inhibit adenylate cyclase, very little cAMP is available to permit induction of cellulase. However, once the inhibitory carbon source is exhausted, that is, the cell is maximally derepressed for adenylate cyclase, the cell is capable of 


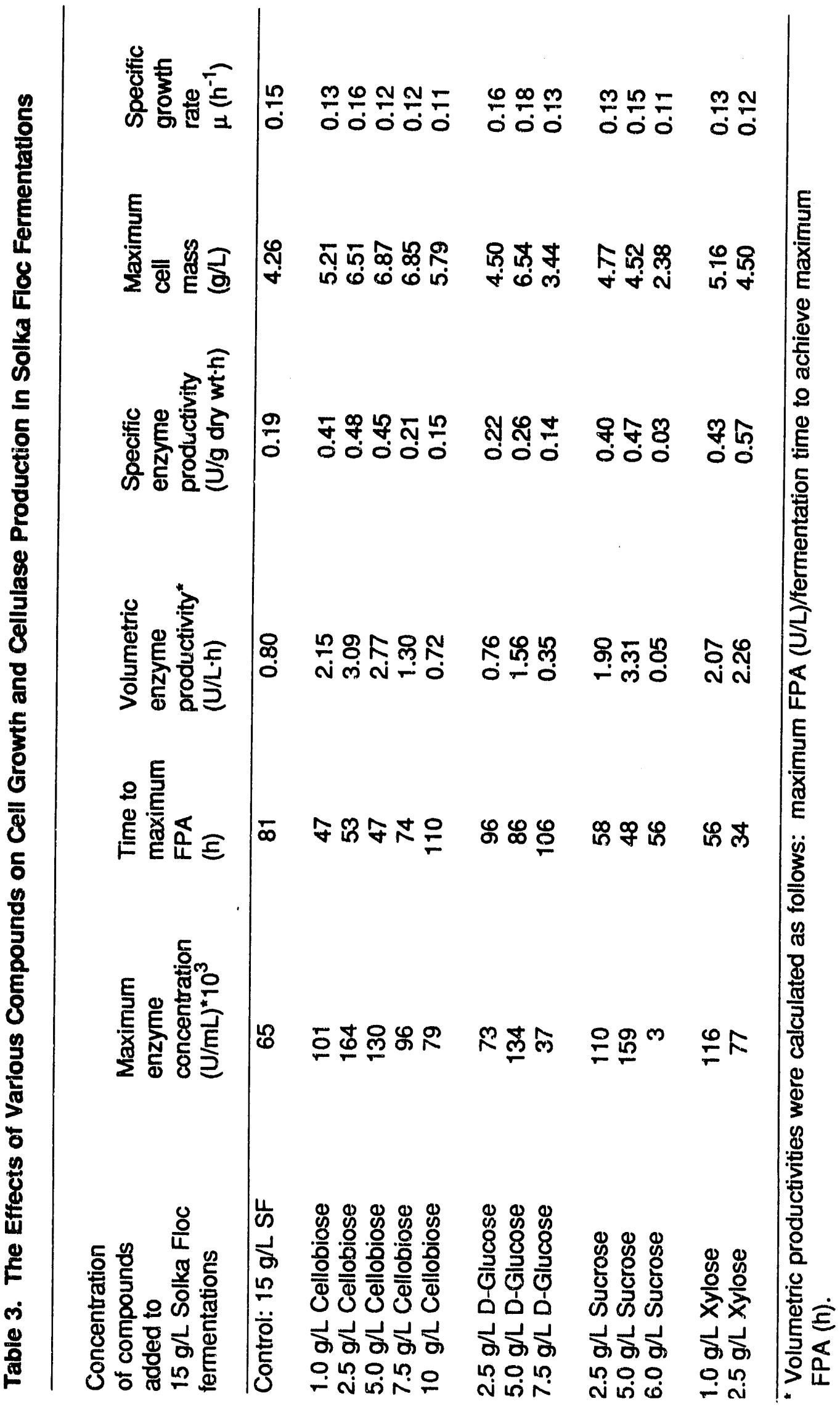




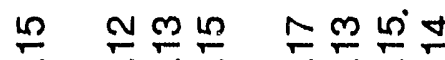

N \pm 10

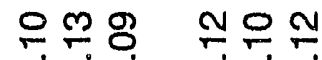

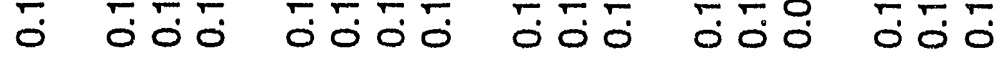

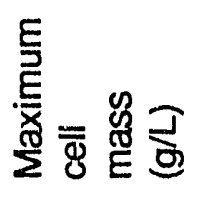

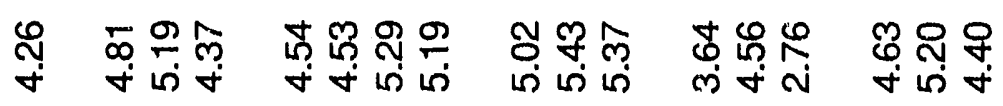

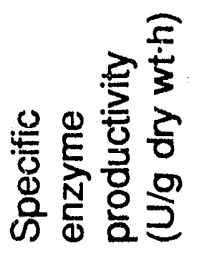

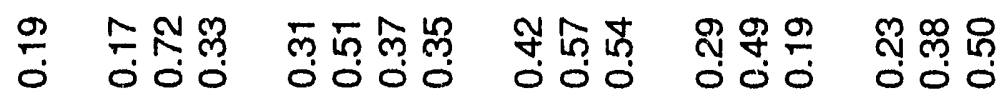

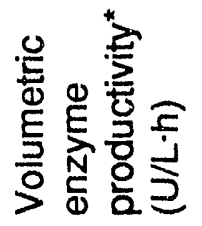

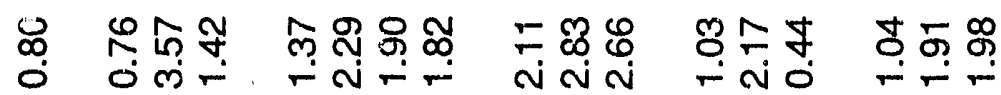

$\stackrel{\frac{E}{5}}{\mathrm{E}}$

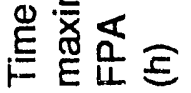

- 윙

ㅇㅠㄸำก

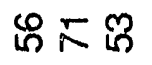

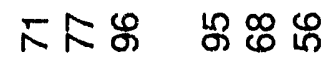

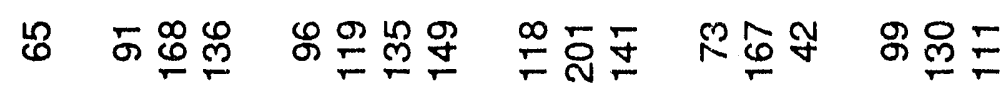

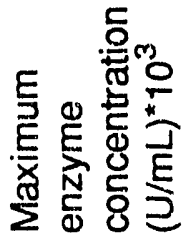

us

ڤิ

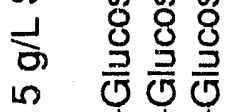

$\sum_{\delta}^{n} \sum_{\delta}^{0} \sum_{\delta}^{n} \frac{n}{\delta}$

- 11

$\mathcal{H}+\mu$

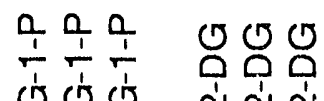

\&

迥 它完

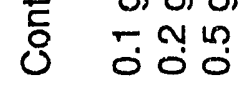

万人

7
7

등동

ஸे

ठิ ธิ ठิ काँ 


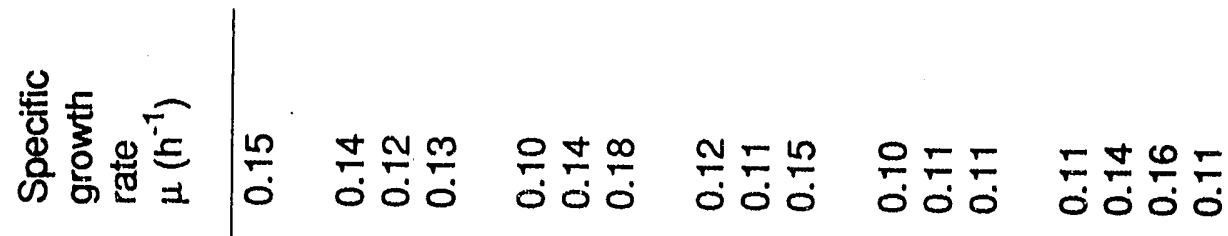

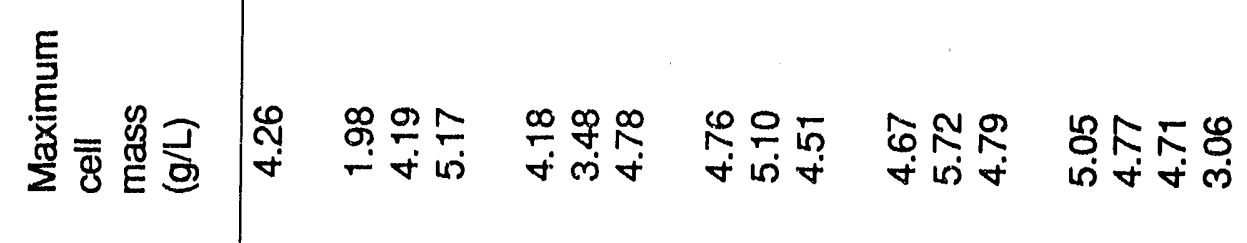

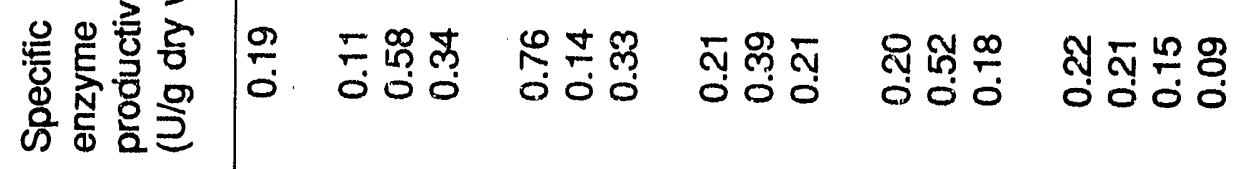

产

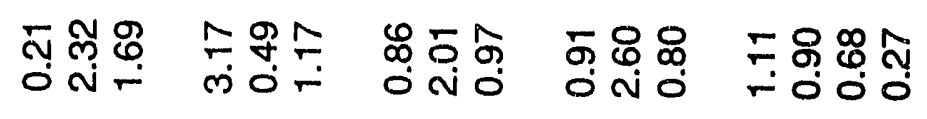

$\stackrel{E}{\stackrel{E}{E}}$

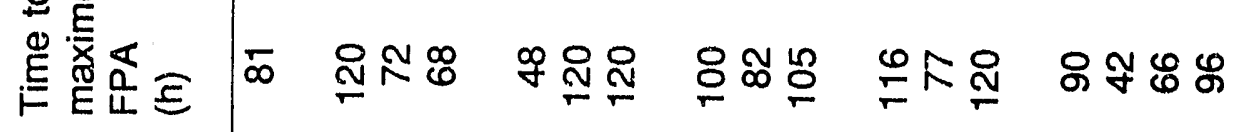

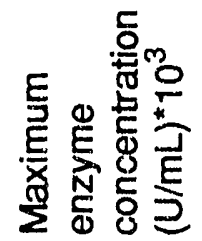

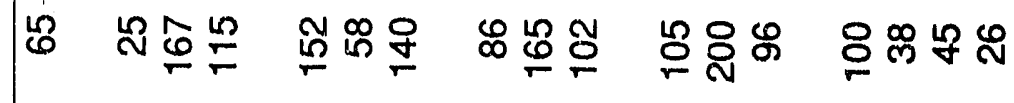
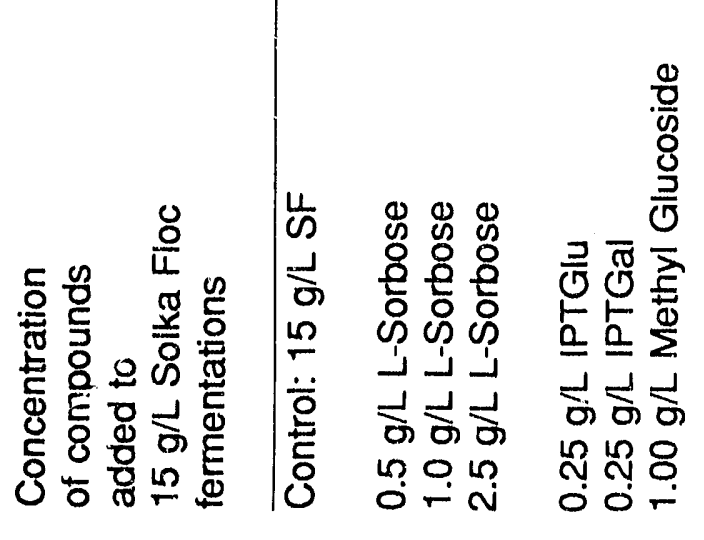

옹 $\overline{0}$

ज交

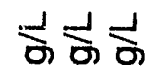

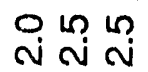

幽

\&

论

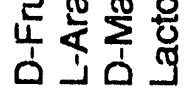

ठेठठ

它灾它

ํㅜ웅

ํํำ 
(a)

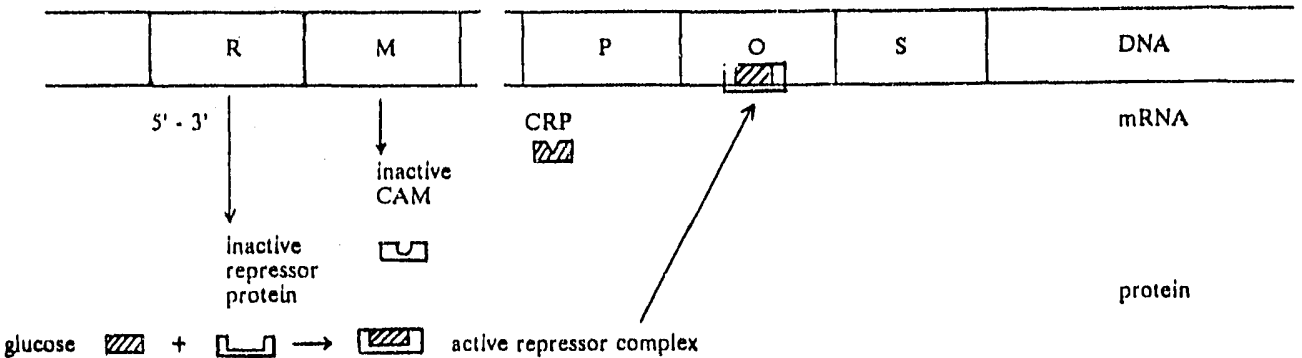

(b)

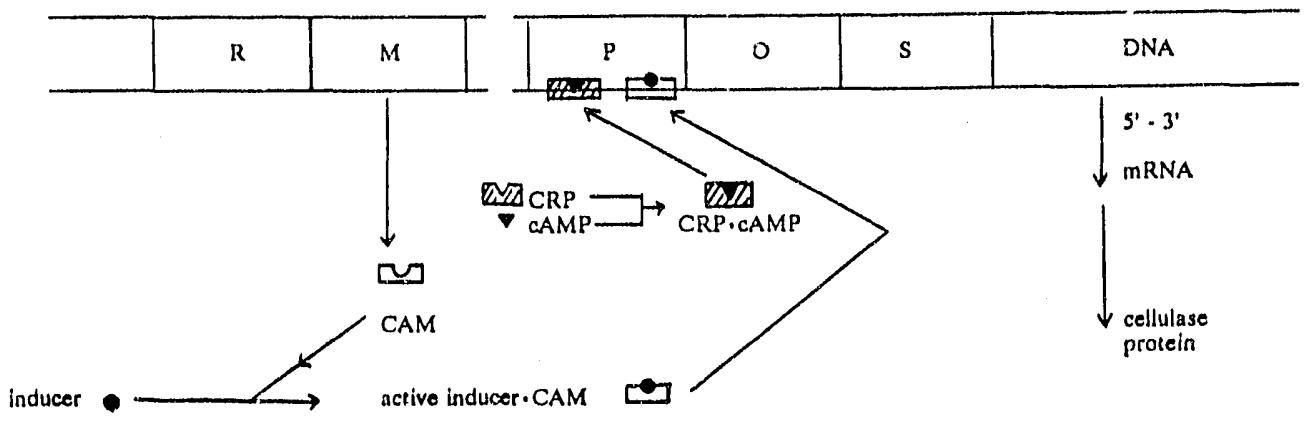

Figure 3. Proposed model for Induced synthesis of cellulase enzyme (a) In the presence of a repressor and (b) in the presence of an Inducer, CAMP and modulator

producing large amounts of CAMP. When neither CAM nor CRP is in their complexed states, cellulase expression occurs at a very low basal level (constitutive). Under the conditions of cellulose as a substrate, cAMP levels increase to create CRP.cAMP complexes that bind to the promoter region, increase the affinity of RNA polymerase at $\mathrm{P}$, and partially turn on the cellulase synthesis. In the presence of inducers, large amounts of CAM are produced analogous to the formation of protein $\mathrm{C}$ in the ara operon, both active inducer.CAM and CRP.cAMP complexes bind the promoter cooperatively. Their simultaneous presence allows maximal transcription for the expression of the cellulase enzymes. Sugars transported by a variety of mechanisms, including the PTS mechanisms for glucose and mannitol, proton symport mechanisms such as for lactose, and the facilitated diffusion of glycerol, can all inhibit cAMP production (Botsford 1981). However, in the system of $A$. cellulolyticus, glucose, sucrose, sorbose, and other compounds may still stimulate CAM production formed at different levels at various rates. Therefore, the time to initiate and to accomplish cellulase synthesis makes each substrate system for enzyme production unique.

\section{Acknowledgments}

This work was supported by the Biochemical Conversion Program of the U.S. Department of Energy Biofuels and Municipal Waste Technology Division through Contract XK-7-07031-2 from the Applied Biological Sciences Biotechnology Branch at the Solar Energy Research Institute in Golden, Colo., and from the Colorado State University Experiment Station under Series No. 353. The involvement of M.E. Himmel, A. Mohagheghi, M.P. Tucker, and K. Grohmann in associated work is acknowledged.

\section{References}

Alexander, J.K. 1968. J. Biol. Chem. 243:2899-2904. 
Ayers, W.A. 1958. J. Bacteriol. 76:515-517.

Bartley, T., Waldron, C., and Eveleigh, D. 1984. Appl. Biochem. Biotechnol. 9:337.

Berg, B. 1975. Can. J. Microbiol. 21:51-57.

Bernier, R., and Stutzenberger, F. 1987. Appl. Environ. Microbiol. 53:1743-1747.

Botsford, J.L. 1981. Microbiol. Reviews, 45:620-642.

Breuil, C., and Kushner, D.J. 1976. Can. J. Microbiol. 22:1776-1781.

Carpenter, A.S., and Barnett, L.B. 1967. Arch. Biochem. Biophys. 122:1-7.

Cato, E.P., Moore, W.E.C., and Bryant, M.P. 1978. Int. J. Syst. Bacteriol. 28:491-495.

Chang, W.T.H., and Thayer, D.W. 1977. Can. J. Microbiol. 23:1285-1292.

Coughlan, M.P. 1985. Biotechnol. Gen. Engin. Rev. 3:39-109.

Coughlan, M.P., and Ljungdahl, L.G. 1988. Biochem. Gen. Cell. Degrad. 11-30.

Creese, E. 1983. "Cellulases from Sporotrichum thermophile grown on wheat straw." M.E.Sc. Thesis, University of Westem Ontario, London, Ontario, Canada.

Creuzet, N., Berenger, J.-F., and Frixon, C. 1983. FEMS Microbiol. Lett. 20:347-350.

Duong, T.-V.C., Johnson, E.A., and Demain, A.L. 1983. "Thermophilic anaerobic cellulolytic bacteria." In Topics in Enzyme and Fermentation Biotechnology, ed. A. Wiseman, Vol. 7, 156-195. Chichester: Ellis Horwood.

Eriksson, K.-E. 1969. Adv. Chem. Ser. 95:83-104.

Fennington, G., Neubauer, D., and Stutzenberger, F. 1984. Appl. Environ. Microbiol. 47:201-204.

Fennington, G., Neubauer, D., and Stutzenberger, F. 1983. Biotechnol. Bloeng. 25:2271-2276.

Fusee, M.C., and Leatherwood, J.M. 1971. Can. J. Microbiol. 18:347-353.

Giuliano, C., and Khan, A.W. 1984. Appl. Environ. Microbiol. 48:446-448.

Goksoyr, J., and Eriksen, J. "Cellulases." In Microbial Enzymes and Bioconversions, ed. A.H. Rose, Vol. 5, 283-330. London: Academic Press.

Gong, C.-S., and Tsao, G.T. 1979. "Cellulase biosynthesis and regulation." in Cellulase Biosynthesis and Regulation, 111-140. New York: Academic Press, Inc.

Gordon, J. 1981. "Cellulose hydrolysis by Clostridium thermocellum: extracellular and cell-associated events." Ph.D Thesis, Massachusetts Institute of Technology.

Groleau, D., and Forsberg, C.W. 1983. Can. J. Microbiol. 27:504-517. 
Groleau, D., and Forsberg, C.W. 1981. Can. J. Microbiol. 27:517-530.

Hagerdal, B.G.R., Ferchak, J.D., and Pye, E.K. 1978. Appl. Environ. Microbiol. 36:606-612.

Hagerdal, B.G.R., Harris, H., and Pye, E.K. 1979. Biotechnol. Bioeng. 21:345-355.

Johnson, E.A., Bouchot, F., and Demain, A.L. 1985. J. Gen. Microbiol. 131:2303-2308.

Kolankuya, N. 1980. Hacettepe Bull. Nat. Sci. Eng. 9:1-10.

Lamed, R., and Bayer, E.A. 1988. Biochem. Gen. Cell. Degrad. 101-106.

Lamed, R., Naimark, J., Morgenstern, E., and Bayer, E.A. 1987. J. Bacteriol. 169:3792-3800.

Lamed, R., Setter, E., and Kenig, R. 1983. Biotechnol. Bloeng. Symp. 13:163-181.

Langsford, M.L., Gilkes, N.R., Wakarchuk, W.W., Kilburn, D.G., Miller, Jr., R.C., and Warrea, R.A.J. 1984. J. Gen. Microbiol. 130:1367-1376.

Lee, B.H., and Bīackburn, T.H. 1975. Appl. Microbiol. 30:346-353.

Lin, E., and Wilson, D.B. 1987. Appl. Environ. Micrnbiol. 53:1352-1357.

Ljungdahl, L.G., and Eriksson, K.-E. 1985. Adv. Microbial. Ecol. 237-299.

MacKenzie, C.R., Bilous, D., and Johnson, K.G. 1984. Can. J. Microbiol. 30:1171-1178.

Meyer, H., and Humphrey, A.E. 1982. Biotechnol. Bioeng. 24:1901-1904 and Adv. Microbial. Ecol. 5:237-299.

Mohagheghi, A., Grohmann, K., Himmel, M.E., Leighton, L., and Updegraff, D.M. 1986. International J. System. Bacteriol. 36:435-443.

Moreira, A.R., Phillips, J.A., and Humphrey, A.E. 1981. Biotechnol. Bioeng. 23:1339-1347.

Nakamura, K., and Kitamura, K. 1983. J. Ferment. Technol. 61:379-382.

Oberkotter, L.V., and Rosenberg, F.A. 1978. Appl. Environ. Microbiol. 36:205-209.

Ohmiya, K., Kurachi, Y., and Shimizu, S. 1985. J. Bacteriol. 161:432-434.

Ohmiya, K., Shimizu, M., Taya, M., and Shimizu, S. 1982. J. Bacteriol. 150:407-409.

Park, W.S., and Ryu, D.D.Y. 1983. J. Ferment. Technol. 61:563-571.

Priest, F.G. 1977. Rev. 41:711-753.

Robson, L.M., and Chambliss, G.H. 1989. Enzyme Microb. Technol. 11:626.

Ryu, D.D.Y., and Mandels, M. 1980. Enzyme Microb. Technol. 2:91-102. 
Saddler, J.N., and Chun, M.K.H. 1982. Euro. J. Appl. Microbiol. Biotechnol. 16:99.

Saddler, J.N., and Khan, A.W. 1980. Can. J. Microbiol. 26:760-765.

Saddler, J.N., and Khan, A.W. 1979. Can. J. Microbiol. 25:1427-1432.

Saddler, J.N., Khan, A.W., and Martin, S.M. 1980. Microbios. 28:97-106.

Schafer, M.L., and King, K.W. 1965. J. Bacteriol. 89:113-116.

Schimz, K.-L., Broll, B., and John, B. 1983. Arch. Microbiol. 135:241-249.

Shiang, M., Linden, J.C., Mohagheghi, A., Grohmann, K., and Himmel, M.E. 1990. "Enhanced cellulase production by Acidothermus cellulolyticus." Submitted to Appl. Microbiol. Technol.

Shiang, M., Linden, J.C., Mohagheghi, A., Rivard, C.J., Grohmann, K., and Himmel, M.E. 1990. Appl. Biochem. Biotechnol. 24/25:223-235.

Shiang, M., Linden, J.C., Mohagheghi, A., Tucker, M.P., Grohmann, K., and Himmel, M.E. 1991. "Cellulase production by Acidothermus cellulolyticus: Growth on Solka Floc cellulose and single sugar mixtures." Submitted to Appl. Biochem. Biotechnol.

Shoemaker, S.P., Raymond, J.C., and Bruner, R. 1981. "Cellulases: diversity among improved Trichoderma strains." In Trends in the Biology of Fermentations for Fuels and Chemicals, eds. A. Hollaender, R. Rabson, P. Rogers, A. San Pietro, R. Valentine, and R. Wolfe. New York, NY: Plenum Press.

Skinner, W.A., and Tokuyama, F. 1978. "Cellulase by a thermophilic, Thielavia terrestris." U.S. Patent $4,081,328$.

Stewart, B.J., and Leatherwood, J.M. 1976. J. Bacteriol. 128:609-615.

Stoppok, W., Rapp, P., and Wagner, F. 1982. Appl. Environ. Microbiol. 44:44-53.

Stutzenberger, F. 1985. Annual Reports of Ferment. Proc. 8:111-154.

Stutzenberger, F.J. 1972. Appl. Microbiol. 24:77-82.

Suzuki, H. 1975. "Cellulase formation in Pseudomonas fluorescens var. cellulosa." In Symposium on Enzymatic Hydrolysis of Cellulose, eds. M. Bailey, T.M. Enari, M. Linko, 115-169. Helsinki: SITRA.

Vladut-Talor, M., Kauri, T., and Kushner, D.J. 1986. Arch. Microbiol. 144:191-195.

Yamane, K., Yoshikawa, T., Suzuki, H., and Nisizawa, K. 1971, J. Biochem. 69:771-780.

Wood, T.M. 1985. Biochem. Soc. Trans. 13:407-410.

Wood, W.E., Neubauer, D.G., and Stutzenberger, F.J. 1984. J. Bacteriol. 160:1047-1054. 
Xylose Fermentation Research 


\title{
Introduction to Xylose Fermentation
}

\author{
S.M. Lastick \\ Biotechnology Research Branch \\ Fuels and Chemicals \\ Research and Engineering Division \\ Solar Energy Research Institute \\ Golden, Colorado 80401
}

Fermentation of xylose, which is found in the hemicellulose fraction of agricultural and hardwood biomass, is a key to the economic production of ethanol from these feedstocks (Hinman et al. 1989). Xylose can account for over one-third of the total amount of fermentable sugars in these feedstocks. The sugar is easily obtained by dilute acid prehydrolysis of biomass. Although many yeasts can grow on xylose, they are very inefficient in fermenting the sugar anaerobically. In this introduction, the methods by which xylose can be fermented to ethanol are described and additional research in this area is suggested.

In yeast, xylose is initially converted to xylitol, and then to xylulose. The enzymes that catalyze these conversions, xylose reductase and xylitol dehydrogenase, require the coenzymes $\mathrm{NADPH}_{2}$ and NAD, respectively, for hydrogen transfer. It has been shown that the regeneration of NAD, from the $\mathrm{NADH}_{2}$ produced in the xylitol dehydrogenase reaction, requires the presence of oxygen (Bruinenberg et al. 1983). Thus, although many yeasts can grow on xylose, they ferment it poorly, if at all.

Some yeast strains have been found to ferment xylose in a microaerophilic or "oxygen-limited" environment (du Preez and van der Walt 1983; du Preez and Prior 1985; Chung et al. 1986; Slininger et al. 1985). The species used, Pachysolen tannophilus, Candida shehatae, and Pichla stipitis, require the addition of low levels of oxygen (du Preez et al. 1988, 1989). They also require low temperatures $\left(\leq 30^{\circ} \mathrm{C}\right)$ and low substrate concentrations ( $\leq 5 \%$ xylose). In addition, the low ethanol tolerance of these strains and slow rates of fermentation, along with catabolism of ethanol in the presence of oxygen during or at the end of the fermentation, limit commercial application of this approach.

It has been found that converting xylose to the more fermentable xylulose, using the bacterial enzyme xylose isomerase, allows for totally anaerobic fermentation by ethanol-tolerant yeast strains such as Saccharomyces cerevisiae, Schizosaccharomyces pombe, or Candida tropicalis (Wang et al. 1980a, 1980b; Gong et al. 1981; . sffries 1981; Schneider et al. 1981; Chaing 1981a, 1981b; Lastick et al. 1989; Lastick et al. 1990). Simultaneous fermentation and isomerization of xylose (SFIX) is preferred over isomerization prior to fermentation because the ratio of xylulose to xylose is low at equilibrium $(\approx 1: 5)$ 
(Tewari et al. 1985). The simultaneous process allows the total fermentation of xylose in a single step because the yeast remove xylulose as the isomerization proceeds. However, with this procedure xylitol is produced as a byproduct and, depending on the strain of yeast used and the concentration of the xylose, the production of xylitol can significantly reduce the final ethanol yield.

Xylose can also be fermented to ethanol by using genetically engineered strains of the bacterium Escherichia coli. Two genes important for xylose fermentation, pyruvate decarboxylase and alcohol dehydrogenase, have been transferred from the bacterium Zymomonas mobilis to E. coll strains using plasmid vectors (Alterthum and Ingram 1989). Although impressive ethanol yields have been reported with this recombinant strain, a significant amount of organic acids are also produced, which are costly to neutralize. Also, the high yields have only been reported when using rich medium, raising the possibility that the yields are partly due to the metabolism of medium components.

In addition to these methods, a number of yeasts, fungi, and bacteria have been described as being capable of fermenting xylose, although none of these have been shown to be appropriate for industrial production of ethanol (Jeffries 1990). These natural xylose fermenters have either unacceptably low fermentation rates or ethanol yields.

In summary, several methods have been developed to ferment xylose to ethanol, but significant improvements can be obtained by reducing byproduct formation. In addition to reducing ethanol yield, treatment processes for the removal of byproducts would be required to prevent environmental damage. Thus, in addition to research on reducing byproducts, the value of the byproducts and cost of their extraction should be examined.

\section{References}

Alterthum, F, and Ingram, L.O. 1989. Appl. Environ. Microbiol. 55:1943-1948.

Bruinenberg, P.M., de Bot, P.H.M., van Dijken, J.P., and Sheffers, W.A. 1983. Appl. Microbiol. Biotechnol. 18:287-292.

Chaing, L.C., Gong, C.S., Chen, L.F., and Tsao, G.T. 198?a. "Fermentation to Ethanol by Saccharomyces cerevisiae." Appl. Environ. Microbiol. 42:284-289.

Chaing, L.C., Hsiao, H.Y., Ueng, P.P., Chen, L.F., and Tsao, G.T. 1981b. Biotechnol. Bioeng, Symp. 2:263-274.

Chung, I.S., Lee, Y.Y., and Beck, M.J. 1986. Biotechnol. Bioeng. Symp. 17:391-400.

du Preez, J.C., and van der Walt, J.P. 1983. Biotechnol. Lett. 5:357-362.

du Preez, J.C., and Prior, B.A. 1985. Biotechnol. Lett. 7:241-246.

du Preez, J.C., van Driessel, B., and Prior, B.A. 1988. Biotechnol. Lett. 10:901-906.

du Preez, J.C., van Driessel, B., and Prior, B.A. 1989. Biotechnol. Lett. 5:901-906.

Gong, C.S., Chen, L.F., Flickinger, M.C., and Tsao, G.T. 1981. Appl. Environ. Microbiol. 41:430-436. 
Hinman, N.D., Wright, J.D., Hoagland, W., and Wyman, C.E. 1989. Appl. Blochem. Blotechnol. 20/21:391-401.

Jeffries, T.W. 1981. Biotechnol. Bioeng. Symp. 2:315-324.

Jeffries, T.W. 1990. "Fermentation of D-Xylose and Cellobiose." In Yeast: Biotechnology and Blocatalysis, eds. H. Verachtert and R. DeMot, 349-394. New York: Marcel Dekker, Inc.

Lastick, S.M., Tucker, M.Y., Beyette, J.R., Noll, G.R., and Grohmunn, K. 1989. Appl. Microbiol. Biotechnol. 30:574-579.

Lastick, S.M., Mohagheghi, A., Tucker, M.P. and Grohmann, K. 1990. Appl. Biochem. Biotechnol. 24/25:431-439.

Schneider, H., Wang, P.Y., and Johnson, B.F. 1981. "Pentose Fermentation by Yeasts." In Current Developments in Yeast Research, eds. G.G. Stewart and I. Russell, 81-85. Toronto: Pergamon Press.

Slininger, P.J., Bothast, R.J., Okos, M.R., and Lakisch, M.R. 1985. Biotechnol. Lett. 7:431-436.

Tewari, Y.B., Steckler, D.K., and Goldberg, R.N. 1985. Biophys. Chem. 22:181-185.

Wang, P.Y., Johnson, B.F., and Schneider, H. 1980a. Biotechnol. Lett. 2:273-278.

Wang, P.Y., Shopsis, C., and Schneider, H. 1980b. Biochem. Biophys. Res. Comm. 94:248-254. 


\title{
SImultaneous Fermentation and Isomerlzation of Xylose to Ethanol
}

\author{
S.M. Lastick, A. Mohagheghi, M.P. Tucker, and K. Grohmann \\ Biotechnology Research Branch \\ Fuels and Chemicals \\ Research and Engineering Division \\ Solar Energy Research Institute \\ Golden, Colorado 80401
}

\begin{abstract}
Enzyme-mediated fermentation of xylose to ethanol is achieved by using the bacterial enzyme xylose isomerase to convert xylose to the more fermentable sugar xylulose. The simultaneous fermentation and isomerization of xylose (SFIX) is preferred over isomerization prior to fermentation because the ratio of xylulose to xylose is low at equilibrium. This report describes the optimization of the SFIX fermentation process with respect to yeast strain, $\mathrm{pH}$, enzyme loading, substrate concentration, and temperature. Comparisons between this process and other methods of xylose fermentation are also presented.
\end{abstract}

\section{Introduction}

The cost of producing ethanol from biomass feedstocks is significantly reduced if the pentose sugar xylose, which constitutes a significant portion of these substrates, is utilized. Yeasts metabolize xylose by initially converting it to xylitol, and then converting it to xylulose. Two enzymes, xylose reductase and xylitol dehydrogenase, catalyze these conversions from the aldose form of the sugar to the alcohol form, and then to the ketose form. These enzymes require the co-enzymes $\mathrm{NADPH}_{2}$ and $\mathrm{NAD}$, respectively, for hydrogen transfer. It has been shown that the regeneration of NAD from the $\mathrm{NADH}_{2}$ produced in the xylitol dehydrogenase reaction requires the presence of oxygen (Bruinenberg et al. 1983). For this reason many yeasts can grow on xylose, but they are unable to ferment it anaerobically.

Yeast strains have been found to ferment xylose in an "oxygen-limited" environment (du Preez and van der Walt 1983; du Preez and Prior 1985; Chung et al. 1986; Slininger et al. 1985). The species used, Pachysolen tannophilus, Candida shehatae, and Pichia stipitts, require very low oxygen concentrations (du Preez et al. 1988,1989$)$, low temperatures $\left(\leq 30^{\circ} \mathrm{C}\right)$, and low substrate concentrations ( $\leq 5 \%$ xylose). In addition, the low ethanol tolerance of these strains and slow rates of fermentation, along with 
catabolism of ethanol in the presence of oxygen during or at the end of the fermentation (Ligthelm et al. 1988; du Preez et al. 1986, 1987), limit commercial application of this approach. Genetically engineered strains of the bacterium Escherichia coll also have been used to ferment xylose. This has been done by transferring two genes important for xylose fermentation. These genes, pyruvate decarboxylase and alcohol dehydrogenase, were isolated from the bacterium Zymomonas mobilis, and then introduced into $E$. coli strains using plasmid vectors (Alterthum and Ingram 1989). Although impressive ethanol yields have been reported with this recombinant strain, a significant amount of organic acids are also produced, which are difficuit to neutralize. In addition, high yields have only been reported using a rich medium, raising the possibility that the high yields are partly a result of the metabolism of medium components. However, bacteria contain an enzyme, xylose isomerase, that converts xylose directly to xylulose without the need for co-factors. Thus, these fermentations can be performed anaerobically.

Converting xylose to the more fermentable sugar xylulose, using the bacterial enzyme xylose isomerase, allows for totally anaerobic fermentation by ethanol-tolerant yeast strains, such as Saccharomyces cerevisiae, Schizosaccharomyces pombe, or Candida tropicalis (Wang et al. 1980a, 1980b; Gong et al. 1981; Jeffries 1981; Schneider et al. 1981; Chaing 1981a, 1981b; Lastick et al. 1989; Lastick et al. 1990). Simultaneous fermentation and isomerization of xylose (SFIX) is preferred over isomerization prior to fermentation because the ratio of xylulose to xylose is low at equilibrium ( $\approx 1: 5)$ (Tewari et al. 1985). The simultaneous process allows the total fermentation of xylose in a single step because the yeast removes xylulose as the isomerization proceeds.

\section{Materlals and Methods}

Yeast strains were obtained from the U.S. Department of Agriculture Northern Regional Research Laboratories (NRRL), Peoria, Ill., or from the American Type Culture Collection (ATCC), Rockville, Md. Commercial xylose isomerases were gifts from the producers. Fermentations were conducted in six New Brunswick Biogen F-1000 fermentation units with 1-L vessels (working volumes of $400-500 \mathrm{~mL}$ ). These units provide temperature control; pH control was achieved using $1 \mathrm{M} \mathrm{KOH}$ and Cole-Palmer J-7537 peristaltic pumps controlled with a computerized scanning/control unit (Fisher Scientific) that monitors and/or controls temperature and $\mathrm{pH}$ and automatically records $\mathrm{pH} /$ temperature data at preset intervals.

S. pombe cells wore grown to late stationary phase at $30^{\circ} \mathrm{C}\left(2.2\right.$ to $2.7 \mathrm{OD}_{600}, 1.1 \mathrm{mg} / \mathrm{mL}$ dry weight $=$ $1 \mathrm{OD}_{600}$ ) in yeast extract-peptone medium (Difco, YEP), with $2 \%$ glucose. They were then centrifuged $(8000 \times \mathrm{g}, 10 \mathrm{~min})$ and resuspended in YEP medium with either filter-sterilized xylose and commercial xylose isomerase, or filter-sterilized glucose, at the specified concentrations. To maintain anaerobiosis, the fermentations were sparged with nitrogen at the beginning, and a small amount of nitrogen was used when sampling to displace $5 \mathrm{~mL}$ of culture.

Immobilized xylose isomerases were obtained as gifts from NOVO Industries (Sweetzyme Q), Finnsugar Biochemics Inc. (Spezyme IGI), International Bio-synthetics (Maxazyme GI) and Miles Laboratories (Taka-Sweet). Xylulose was prepared by chemical isomerization as described by Gong et al. (1981). Unreacted xylose and byproducts were removed by preparative chromatography at $25^{\circ} \mathrm{C}$ using Dowex $50 \mathrm{~W}-\mathrm{X} 4$ resin $(200-400 \mathrm{mesh})$ with deionized $\mathrm{H}_{2} \mathrm{O}$ as eluent. Xylose isomerase was assayed at $35^{\circ} \mathrm{C}$ in buffer containing $10 \mathrm{mM} \mathrm{MgCl}$ and $1 \mathrm{mM} \mathrm{CoCl} 2$. Control over a wide $\mathrm{pH}$ range was obtained by using $25 \mathrm{mM}$ glutamic acid plus $25 \mathrm{mM}$ histidine to buffer the assay. Xylulose produced in the assay was measured using the "cysteine carbazole" procedure (Horecker 1974); $1 \mathrm{IU}=1 \mu \mathrm{mol}$ xylulose was produced per minute under the specified conditions.

Ethanol concentration was measured using a Hewlett Packard gas-liquid chromatograph equipped with a flame-ionization detector and peak area integrator (model \#5880A with a Porapak Q 80-100 column) 
operated at an oven temperature of $175^{\circ} \mathrm{C}$, injection port at $225^{\circ} \mathrm{C}$, and the detector at $250^{\circ} \mathrm{C}$, with isopropanol as an internal standard. Sugar concentrations (xylose, xylulose, xylitol, and glycerol) were measured by high-performance liquid chromatography with a Bio-Rad HPX-87C column at $60^{\circ} \mathrm{C}$, HewlettPackard 1037A high-sensitivity refractive index detector, and a Shimadzu C-R3A integrating recorder (Baker et al. 1988) using mannitol as an internal standard. Filtered $\mathrm{H}_{2} \mathrm{O}$ was used as eluant at $0.2 \mathrm{~mL} / \mathrm{min}$. Computer analysis of chromatographic data was performed using a Lotus $123^{\mathrm{tm}}$ spreadsheet. The spreadsheet was constructed to correct for calibration between sugar concentrations and peak area, internal standard control of injection volume, and dilution of the fermentation by base used for $\mathrm{pH}$ control.

\section{Results and Discussion}

\section{Activity of Commerclal Xylose lsomerases}

The immobilization of xylose (glucose) isomerase can alter the pH/activity profile of the enzyme (Kent and Emery 1974; Huitron and Limon-Lason 1978) by microenvironmental effects created by the charged polymers used for immobilization (Gianfreda et al. 1987). Because it is important to reduce the pH in the SFIX process to allow for efficient fermentation, the activities of four commercial immobilized xylose isomerase samples were determined at different $\mathrm{pH}$ levels (Table 1). Sweetzyme Q (NOVO), a preparation of immobilized Bacillus coagulans cells, was chosen for further SFIX runs because of its high activity at low pH. The activity of Sweetzyme $Q$ used in this study was determined to be $25 \mathrm{IU} / \mathrm{g}$ (Vmax) at pH 5.75 and $35^{\circ} \mathrm{C}$ (see Materials and Methods).

\section{Screening of Yeasts}

Five species of yeast (13 strains) that have previously been shown to ferment either xylulose or xylose were examined (Table 2). Fermentations of $6 \%$ xylose, using $10 \mathrm{~g} / \mathrm{L}$ NOVO Sweetzyme $Q$ xylose isomerase, were controlled at $\mathrm{pH} 5.75$ and $30^{\circ}$ or $35^{\circ} \mathrm{C}$. Table 2 shows the ethanol yield and the xylitol/ethanol ratio of each strain after 4 days of fermentation.

Table 1. Effect of pH on Commerclal Xylose Isomerases $\%$ Maximum Activity, SD, (n)

\begin{tabular}{|c|c|c|c|c|}
\hline $\mathrm{pH}$ & Sweetzyme Q & Spezyme |G| & Maxazyme & Taka-sweet \\
\hline 7.00 & $100 \pm 6.1(3)$ & $100 \pm 2.5(3)$ & $100 \pm 11(3)$ & $100 \pm 6.5(3)$ \\
\hline 6.00 & $77 \pm 4.9(4)$ & $54 \pm 1.6(4)$ & $73 \pm 4.6(4)$ & $74 \pm 4.2(4)$ \\
\hline 5.75 & $73 \pm 4.3(3)$ & $36 \pm 0.0(3)$ & $40 \pm 4.4(4)$ & $45 \pm 0.0(3)$ \\
\hline 5.50 & $57 \pm 5.5(4)$ & $17 \pm 1.2(4)$ & $33 \pm 9.0(4)$ & $37 \pm 1.9(3)$ \\
\hline 5.00 & $46 \pm 3.7(4)$ & $11 \pm 1.8(3)$ & $13 \pm 1.9(3)$ & $36 \pm 3.2(4)$ \\
\hline
\end{tabular}


The best of the strains tested, in terms of fermentation rate and ethanol yield at both temperatures, was $S$. pombe Y-164. This strain was selected for further study because of these results, and because it was found to be extremely flocculent, which could be advantageous for cell recycle procedures (see below under recycle of cells and enzymes).

\section{Xylose lsomerase Optlmum}

S. pombe Y-164 and Sweetzyme Q, at enzyme loadings of $1.25,2.5,5.0,7.5,10.0$, and $12.5 \mathrm{~g} / \mathrm{L}$, were used in SFIX fermentations of $6 \%$ xylose at $\mathrm{pH} 5.75$ and $35^{\circ} \mathrm{C}$. If the xylose isomerase performed in the fermentation at the maximum velocity (assayed at $25 \mathrm{IU} / \mathrm{g}$ at $35^{\circ} \mathrm{C}$ ), an enzyme loading of $5.5 \mathrm{~g} / \mathrm{L}$ would result in total isomerization of $6 \%$ xylose in 2 days. Table 3 shows that enzyme loadings higher than 5 $\mathrm{g} / \mathrm{L}$ do not significantly improve the rate of fermentation or final ethanol yield. Because SFIX fermentations of $6 \%$ xylose take about 2 days, it can be assumed that the enzyme was at or near the maximum velocity. Higher enzyme loadings produce xylulose in excess of the amount that can be utilized by the yeasts at the cell concentration used $(\approx 3 \mathrm{~g} / \mathrm{L})$. In this report, an enzyme loading of $10 \mathrm{~g} / \mathrm{L}$ was used to assure maximal rates under the various conditions and strains that were tested.

\section{Temperature OptImum}

SFIX fermentations of $6 \%$ xylose were performed using $10 \mathrm{~g} / \mathrm{L}$ Sweetzyme $\mathrm{Q}$ and $S$. pombe $\mathrm{Y}-164$, controlled at $\mathrm{pH} 5.75$, at temperatures from $30^{\circ}$ to $41^{\circ} \mathrm{C}$ (Table 4). The xylose was completely utilized at $35^{\circ}, 37^{\circ}$ or $39^{\circ} \mathrm{C}$ in 2 days, whereas the fermentation at $30^{\circ} \mathrm{C}$ required approximately 1 more day. At $41^{\circ} \mathrm{C}$ the cells lost viability and left residual xylose at the end of the fermentation. The three fermentations run at $30^{\circ}, 35^{\circ}$, and $37^{\circ} \mathrm{C}$ produced a final average ethanol concentration of $2.19 \%$ (SD = 0.02 ), which is $71 \%$ of the theoretical yield from $6 \%$ xylose.

\section{pH Optlmum}

To estimate the effect of performing fermentations at the higher $\mathrm{pH}$ levels necessary for $x y l o s e$ isomerase activity, fermentations with either $6 \%$ xylose and $10 \mathrm{~g} / \mathrm{L}$ Sweetzyme $\mathrm{Q}$, or just $6 \%$ glucose, were run at $35^{\circ} \mathrm{C}$ with $\mathrm{pH}$ controlled at levels from 4.50 to 6.50 . It was found that as the $\mathrm{pH}$ is increased, ethanol yields from glucose were only slightly reduced, but larger reductions in yield were found when xylose was used as the substrate (Table 5).

Loss in ethanol yield in the xylose SFIX fermentations can be mostly accounted for by loss caused by xylitol production. For example, the amount of xylitol formed in the pH 5.75 fermentation shown in Table $4(0.79 \%)$ could theoretically be converted to $0.40 \%$ ethanol. If this amount is added to the $2.06 \%$ ethanol actually produced, the total, $2.46 \%$, is nearly the same as the amount of ethanol produced from glucose at pH $5.75(2.45 \%)$, and only $0.16 \%$ less than the arnount produced from glucose under these conditions at $\mathrm{pH} 5.00 .1$

\section{Xylltol Production In Xylulose Fermentations}

S. pombe Y-164 cells were used to ferment $6 \%$ purified xylulose (see Materials and Methods) at pH 5.0, which is optimal for fermentation, and at $\mathrm{pH} 5.75$ and 6.00 , but with no xylose isomerase. Smaller fermentation vessels with working volumes of $25 \mathrm{~mL}$ were constructed to minimize the amount of 
Table 2. Screening of Yeast Stralns for SFIX

\begin{tabular}{|c|c|c|c|c|c|}
\hline & & \multicolumn{2}{|c|}{$30^{\circ} \mathrm{C}$} & \multicolumn{2}{|c|}{$35^{\circ} \mathrm{C}$} \\
\hline \multicolumn{2}{|c|}{ STRAIN } & $\begin{array}{c}E T \\
\% w / v\end{array}$ & $X T / E T$ & $\begin{array}{c}E T \\
\% w / v\end{array}$ & XT/ET \\
\hline C. tropicalis & ATCC-9968 & 0.57 & 2.41 & 0.35 & 4.35 \\
\hline C. tropicalis & $Y-11860$ & 0.79 & 1.39 & 0.60 & 1.56 \\
\hline C. tropicalis & $Y-1552$ & 0.53 & 3.50 & 0.48 & 2.88 \\
\hline C. shehatae & $\begin{array}{l}Y-12878 \\
\text { (CSIR Y-492) }\end{array}$ & 0.11 & 2.00 & 0.35 & 2.20 \\
\hline C. shehatae & ATTCC-22984 & 1.02 & 0.34 & 0.20 & 0.81 \\
\hline P. stipitis & $Y-7124$ & 1.16 & 0.32 & 0.64 & 0.67 \\
\hline P. stipitis & ATCC- 58784 & 1.06 & 0.36 & 1.01 & 0.67 \\
\hline P. stipitis & $\begin{array}{l}Y-17104 \\
\text { (CSIR Y-633) }\end{array}$ & 1.27 & 0.27 & 1.01 & 0.57 \\
\hline S. cerevisiae & ATCC-24860 & 0.75 & 1.80 & 0.92 & 0.54 \\
\hline S. cerevisiae & Red Star-D5A & 0.56 & 0.48 & 0.35 & 0.52 \\
\hline S. pombe & ATCC-23192 & 1.37 & 0.60 & 1.60 & 0.61 \\
\hline S. pombe & $Y-164$ & 1.93 & 0.40 & 1.99 & 0.39 \\
\hline S. uvarum & ATCC-26602 & 1.25 & 0.52 & 1.56 & 0.70 \\
\hline
\end{tabular}

xylulose used. A fermentation with $6 \%$ xylose, also without xylose isomerase, was also run. It was found that xylitol is produced from both xylulose and xylose under the conditions used for SFIX. Incubation with xylose yielded $0.35 \%$ xylitol, but because the yeast is not capable of fermenting the sugar, it produced no ethanol. When pure xylulose is fermented, the amount of xylitol produced is approximately twice the amount found in SFIX fermentations. These results suggest that when pure xylulose is rapidly taken up into $S$. pombe cells, the enzymes in the pentose phosphate pathway (e.g. xylulokinase) that are required for downstream metabolism toward ethanol production, may become saturated with substrate, leading to higher byproduct formation. It has been found that mutants of $P$. tannophilus that produce higher ethanol yields all had xylulokinase levels of from 6 to 10 times that in the parent strain (Lachke and Jeffries 1986). 
Table 3. Loading of Xylose lsomerase

\begin{tabular}{lccccc}
\hline$g / L$ & $I U / L$ & $V_{p}^{a}$ & $\begin{array}{c}E T^{a} \\
\% w / v\end{array}$ & $E T_{f}$ & $\begin{array}{c}E T^{b} \\
\% w / v\end{array}$ \\
\hline 1.25 & 31.3 & 0.22 & 0.61 & 1.78 & 0.39 \\
2.50 & 62.5 & 0.30 & 0.84 & 1.97 & 0.78 \\
5.00 & 125.0 & 0.38 & 1.07 & 1.99 & 1.55 \\
7.50 & 187.5 & 0.33 & 0.93 & 1.94 & 2.35 \\
10.0 & 250.0 & 0.37 & 1.03 & 1.92 & 3.88 \\
12.5 & 312.5 & 0.41 & 1.13 & 2.01 & 3.88 \\
\hline
\end{tabular}

${ }^{\text {A At }} 27 \mathrm{~h}$ of fermentation

${ }^{b}$ Theoretical yield of ethanol calculated from xylose isomerization at $V \max (25$ IU/G) for $27 \mathrm{~h}$

Table 4. Effect of Temperature on Ethanol Yleld

\begin{tabular}{lllll}
\hline${ }^{\circ} \mathrm{C}$ & $E T$ & $Y_{s}$ & $V_{p} m$ & $X T$ \\
\hline 30 & 2.18 & 0.36 & 0.50 & 0.72 \\
35 & 2.18 & 0.36 & 0.60 & 0.75 \\
37 & 2.21 & 0.37 & 0.64 & 0.76 \\
39 & 2.06 & 0.34 & 0.58 & 0.65 \\
$41^{\mathrm{a}}$ & 1.33 & 0.30 & 0.40 & 0.38 \\
\hline
\end{tabular}

${ }^{a}$ Residual xylose after 3 days 
Table 5. Effect of pH on Ethanol Yleld

\begin{tabular}{|c|c|c|c|c|c|c|c|}
\hline \multirow[b]{2}{*}{$\mathrm{pH}$} & \multicolumn{2}{|c|}{ ET } & \multicolumn{2}{|c|}{$Y s^{a}$} & \multicolumn{2}{|c|}{$v_{p} m^{b}$} & \multirow{2}{*}{$\frac{X T}{X y l}$} \\
\hline & Glu & $x y l$ & Glu & $x y l$ & Glu & $x y l$ & \\
\hline 4.50 & 2.47 & $0.95^{\circ}$ & 0.41 & $0.34^{c}$ & 4.83 & $0.21^{\circ}$ & $0.44^{d}$ \\
\hline 5.00 & 2.62 & 2.02 & 0.44 & 0.34 & 5.04 & 0.52 & 0.73 \\
\hline 5.50 & 2.54 & 1.91 & 0.42 & 0.32 & 4.73 & 0.56 & 0.78 \\
\hline 5.75 & 2.45 & $2.09^{d}$ & 0.41 & $0.35^{d}$ & 4.65 & $0.58^{d}$ & $0.77^{d}$ \\
\hline 6.00 & 2.39 & 1.88 & 0.40 & 0.31 & 4.36 & 0.51 & 0.85 \\
\hline 6.50 & 2.10 & $1.25^{\mathrm{C}}$ & 0.36 & $0.27^{c}$ & 2.73 & $0.23^{c}$ & 0.94 \\
\hline
\end{tabular}

${ }_{b}^{a} g$ sthanol $g^{-1}$ xylose

bg ethanol $L^{-1} h^{-1}$, maximum

Average of 3 independent runs at pH 5.75

${ }^{d}$ Residual sugar remained after 3 days

\section{Substrate Concentration In SFIX}

The major obstacle in the production of ethanol from xylose at high yields has proven to be the byproduct formation of xylitol. Selection of mutant strains that have lower xylitol dehydrogenase and xylose reductase activities, as well as strains that contain higher levels of downstream enzymes, like xylulokinase, could produce a more efficient SFIX fermentation (Lachke and Jeffries 1986).

It can be stated in general that fermentation of xylose and xylulose to ethanol by yeast strains is slower and less efficient than glucose fermentation. Xylose must be converted by at least six additional enzymes in the pentose phosphate pathway to intermediates of the glycolytic pathway. The levels of these enzymes, their requirements for induction and availability of required co-factors are thought to be maior factors that cause the inefficiency of xylose fermentation (Ligthelm et al. 1988b; Alexander et al. 1988). When xylose levels exceed $4 \%$ to $6 \%$, microaerophilic xylose fermentations are inhibited (du Preez et al. 1986), either because of the factors mentioned above or ethanol toxicity.

Glucose fermentation by $S$. pombe at $35^{\circ} \mathrm{C}$ and $\mathrm{pH} 5.75$, the temperature and pH used in SFIX fermentations, is rapid and efficient at all levels tested (2\% to 16\%). An ethanol concentration of $6.5 \% \mathrm{w} / \mathrm{v}$ was obtained from $16 \%$ glucose within $30 \mathrm{~h}$; fermentations of glucose from $2 \%$ to $12 \%$ were all completed within $16 \mathrm{~h}$. The average initial rate, determined by linear regression over the first $12 \mathrm{~h}$ of these fermentations, was $55 \mathrm{~g} / \mathrm{L} /$ day $(2.3 \mathrm{~g} / \mathrm{L} / \mathrm{h}$ ) (Figure 1).

In contrast to these results, SFIX conversion of xylose to ethanol by $S$. pombe is slower and less efficient. The average initial rate of xylose fermentation, $12 \mathrm{~g} / \mathrm{L} / \mathrm{day}(0.5 \mathrm{~g} / \mathrm{L} / \mathrm{h})$, is approximately 4.5 times slower than the initial rate of glucose fermentation. The times required to complete the xylose fermentations increase as the initial xylose concentration increases to over 7 days for fermentation of $16 \%$ xylose (Figure 2). Linear regression of the initial rates of SFIX fermentation indicate that at xylose levels of less than $6 \%$ the fermentations are apparently limited by insufficient levels of xylulose, whereas at levels over $10 \%$ the rate of fermentation is reduced by other factors (Figure 3). These effects on fermentation rate can be seen in the reduced rate of xylose utilization (Figure 4) and xylulose uptake (Figure 5). The increase in initial xylose concentration also caused increased byproduct (xylitol)/ethanol ratios (Figure 6), 
which indicates that the higher xylose or ethanol concentrations either inhibit or overload the ethanol production pathway.

Despite the difference in rate of fermentation between glucose and SFIX xylose fermentation, final yields of ethanol in SFIX were impressive when compared to those resulting from the microaerophilic fermentation by less ethanol-tolerant yeasts. Fermentation of $16 \%$ xylose resulted in a final ethanol concentration of $5.3 \% \mathrm{w} / \mathrm{v}$, a yield of $65 \%$ of the theoretical limit. At lower xylose concentrations (less than $8 \%$ ), which can be more easily produced from pretreated biomass, yields of $70 \%$ of the theoretical production are obtained. At these concentrations the fermentations require 2 to 3 days for completion.

\section{Comparlson between SFIX and Oxygen-LImlted Fermentatlons}

Considering their low ethanol tolerance and fermentation rates, it is not surprising that the yeast strains that perform best in oxygen-limited fermentations (e.g., C. shehatae and $P$. stipitis) are inferior in SFIX fermentations. Also, the yeast enzymes that convert xylose to xylulose, xylose reductase and xylitol dehydrogenase, are important for the oxygen-limited process whereas they are a detriment in anaerobic SFIX fermentation because they promote the byproduct formation of xylitol. Fermentation data on SFIX fermentation and oxygen-limited xylose fermentations found in recent reports are summarized in Table 6. Although the initial rates of xylose fermentation and ethanol yields are similar, the rates at which the overall fermentations occur show large differences. This can be seen by comparing either the volumetric or specific rates of ethanol production $\left(V_{p} f\right.$ and $\left.Q_{p} f\right)$. The rate of ethinol production $\left(Q_{p} m\right)$ from glucose is also significantly higher with $S$. pombe than with the other strains.

\section{Xylose Fermentation with Genetlcally EngIneered E. coll}

The transformed E. coli strain ATCC \#11310/pLOI297 (Alterthum and Ingram 1989) has been used to ferment xylose at different $\mathrm{pH}$ levels and different substrate concentrations, to optimize ethanol yield. Maintaining the $\mathrm{pH}$ of these fermentations at the higher levels required for $E$. coli viability (ca $\mathrm{pH} 6$ to 7) by the usual methods (i.e., additions of $1 \mathrm{M} \mathrm{KOH}$ ) became impossible because of the large amounts of base required.

Problems in the control of $\mathrm{pH}$ in these fermentations were found to be due, at least partially, to the production of organic acids during the fermentations. By using more concentrated base $(5 \mathrm{M} \mathrm{KOH}) \mathrm{pH}$ could be maintained, but the significant amount of concentrated base that was required diluted the fermentations, making estimates on ethanol yield and ethanol tolerance difficult. Table 7 summarizes these results. The table lists both the actual ethanol concentrations as measured by gas chromatography and a dilution corrected value. All concentrations are expressed as $\% \mathrm{w} / \mathrm{v}$.

The addition of potassium phosphate buffer at a high concentration $(0.2 \mathrm{M})$ to the fermentation medium was also used to control the $\mathrm{pH}$ in batch fermentations of the recombinant cells. In this case, in the absence of addition of any additional base for control, the $\mathrm{pH}$ was seen to continuously drop from a starting point of $\mathrm{pH} 7.0$ to a final level of pH. 5.9 (Table 8). With this method, fermentation of $8 \%$ xylose by the transformed cells produced $3.5 \%$ ethanol in 3 days, a yield of $85.6 \%$ of the theoretical maximum amount. Using this procedure, the effects of substrate concentration were measured. It was found that when xylose concentrations higher than $8 \%$ were used, residual substrate remained unfermented, but ethanol concentrations of up to $4.4 \%$ were achieved.

Because control of $\mathrm{pH}$ is difficult to achicve with these fermentations, the effect of $\mathrm{pH}$ on the fermentation was studied. It was found that, using $5 \mathrm{M}$ base, optimal fermentation conditions ranged from $\mathrm{pH} 6$ to 7 with an optimum at $\mathrm{pH} 6.5$, but in all cases it was found that organic acids (especially succinic acid) were produced at high levels. The ethanol yicld (ethanol produced/sugar fermented) at $\mathrm{pH} 6.5$ was calculated to be over $95 \%$ of the theoretical maximum, after correction for dilution of the fermentation by the addition of base to control $\mathrm{pH}$. 


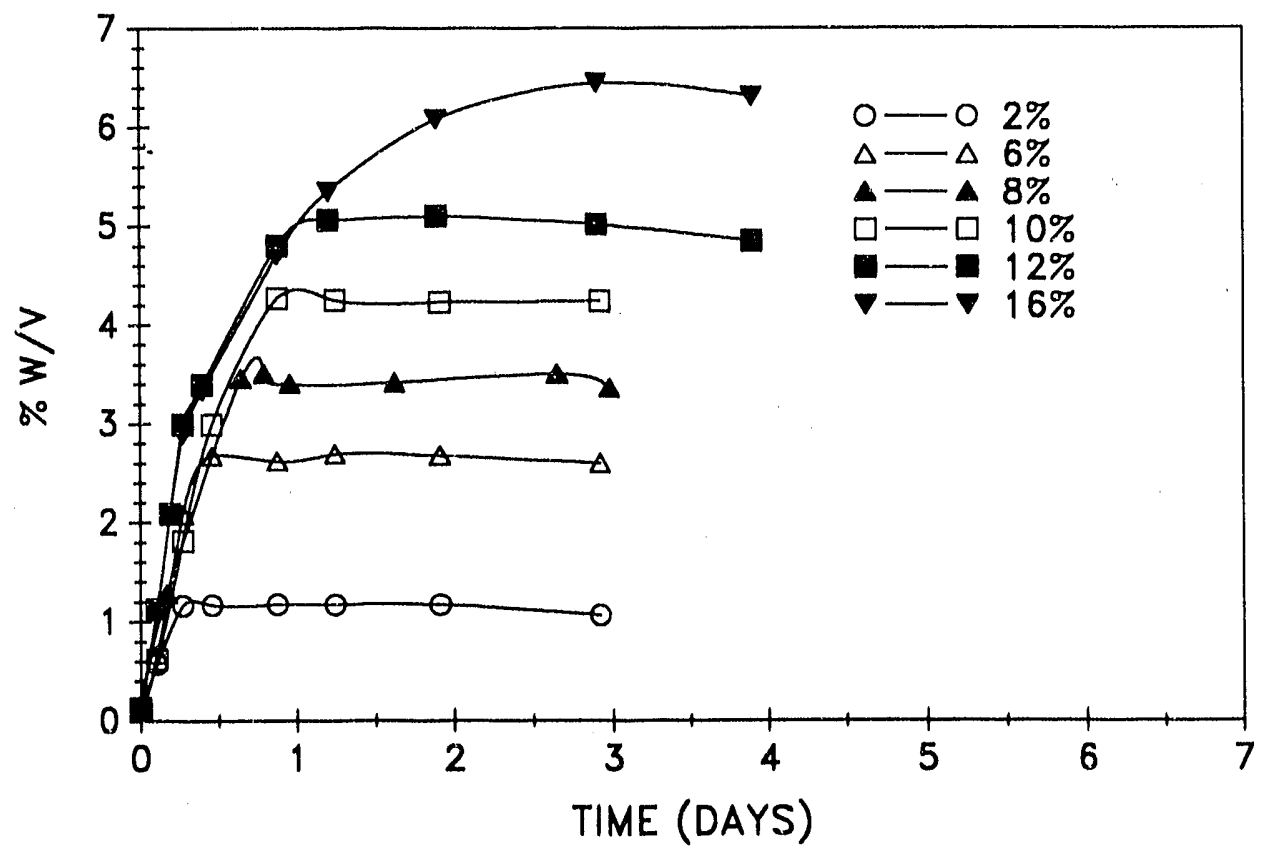

Figure 1. Ethanol production in batch glucose fermentations performed at $35^{\circ} \mathrm{C}, \mathrm{pH} 5.75$, and Inltial substrate concentrations of $2 \%, 6 \%, 8 \%, 10 \%, 12 \%$, and $16 \%$

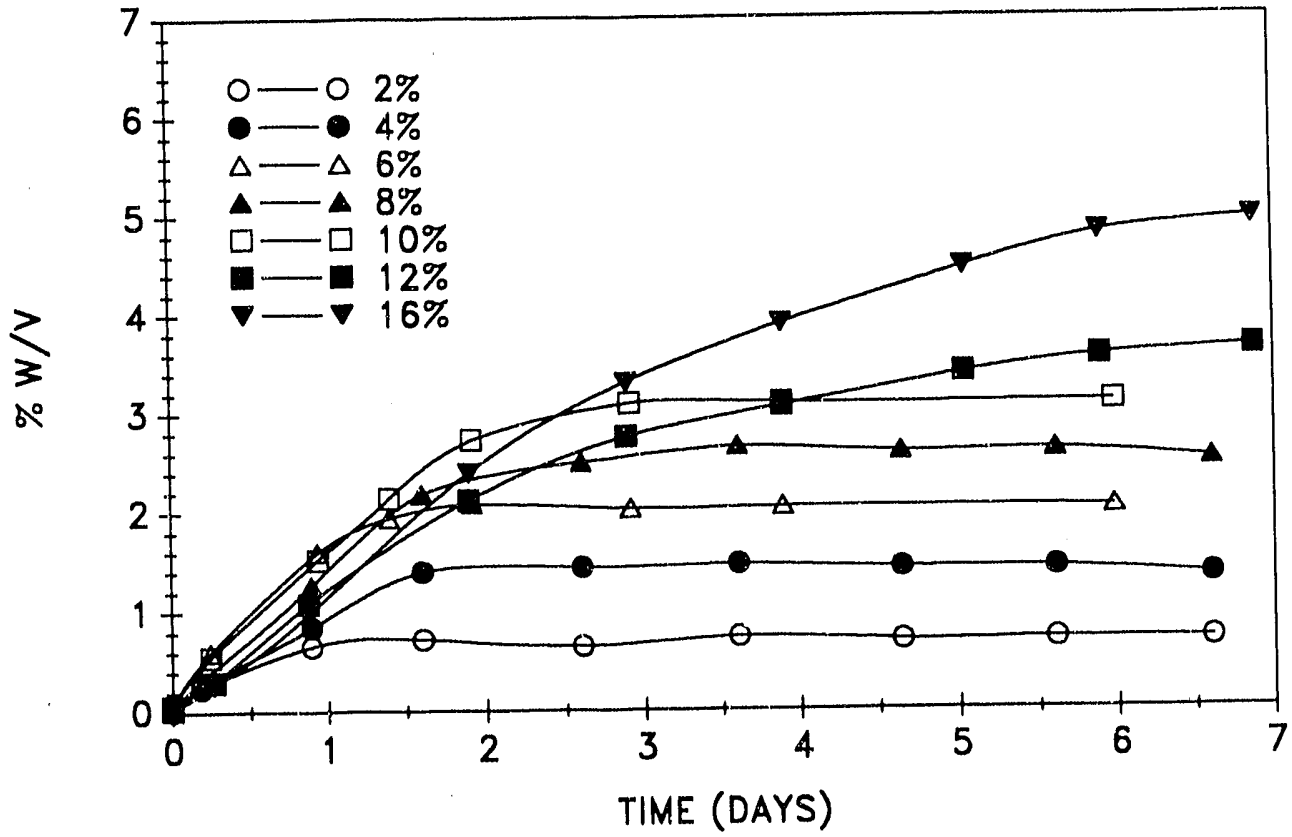

Figure 2. Ethanol production In SFIX xylose formentations performed at $35^{\circ} \mathrm{C}, \mathrm{pH} 5.75$, and Initlal substrate concentrations of $2 \%, 4 \%, 6 \%, 8 \%, 10 \%, 12 \%$, and $16 \%$ 


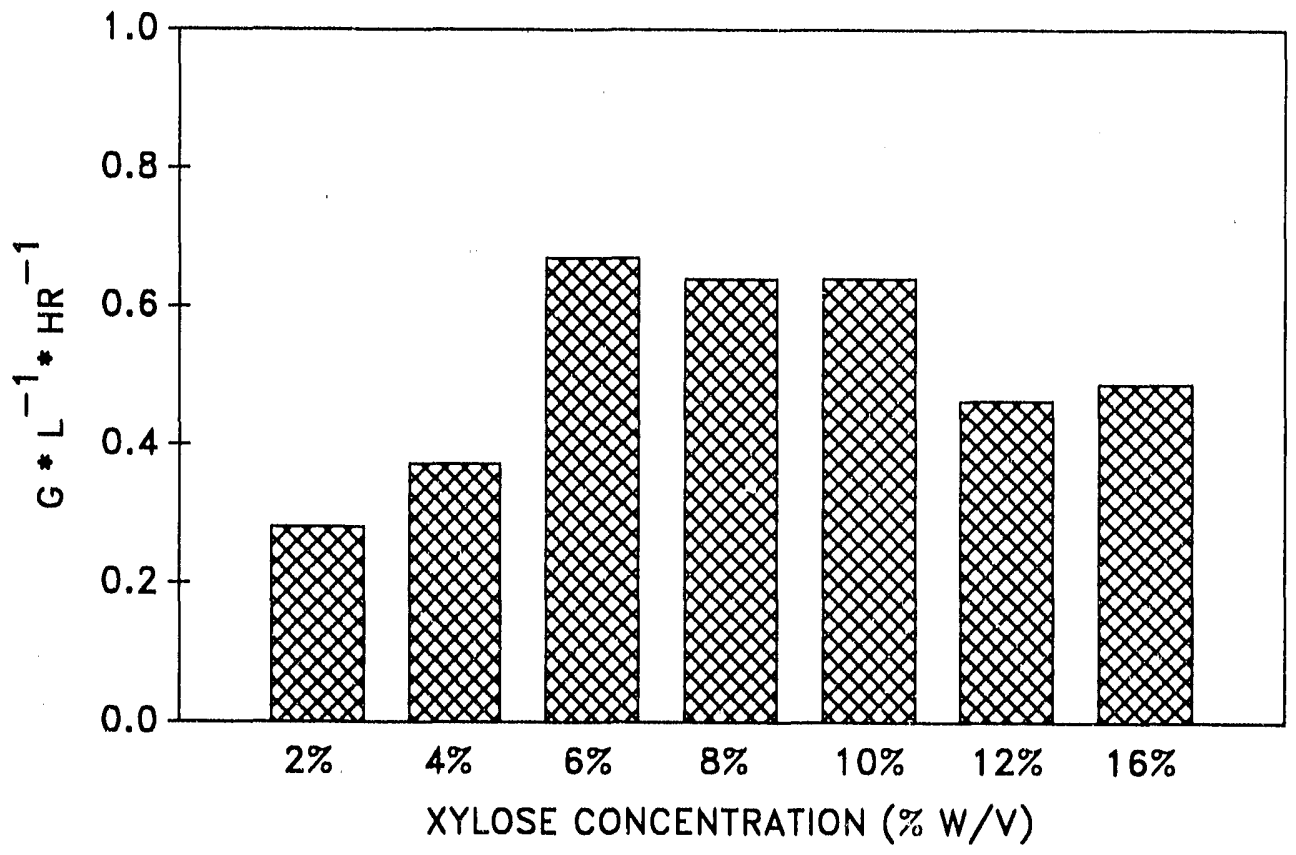

Figure 3. Initlal ethanol production rates In SFIX xylose fermentatlons

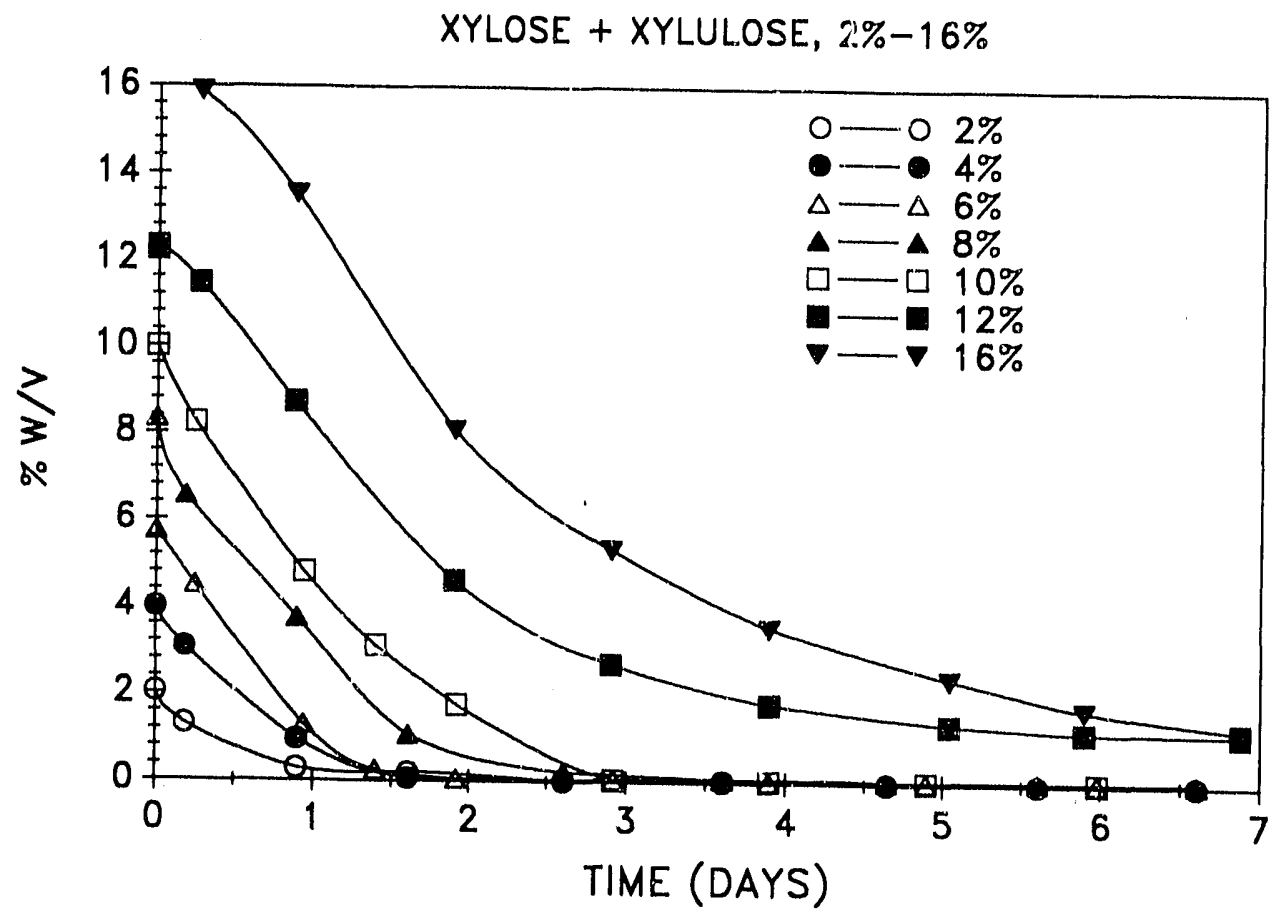

Figure 4. Substrate utllization In SFIX fermentation of xylose 


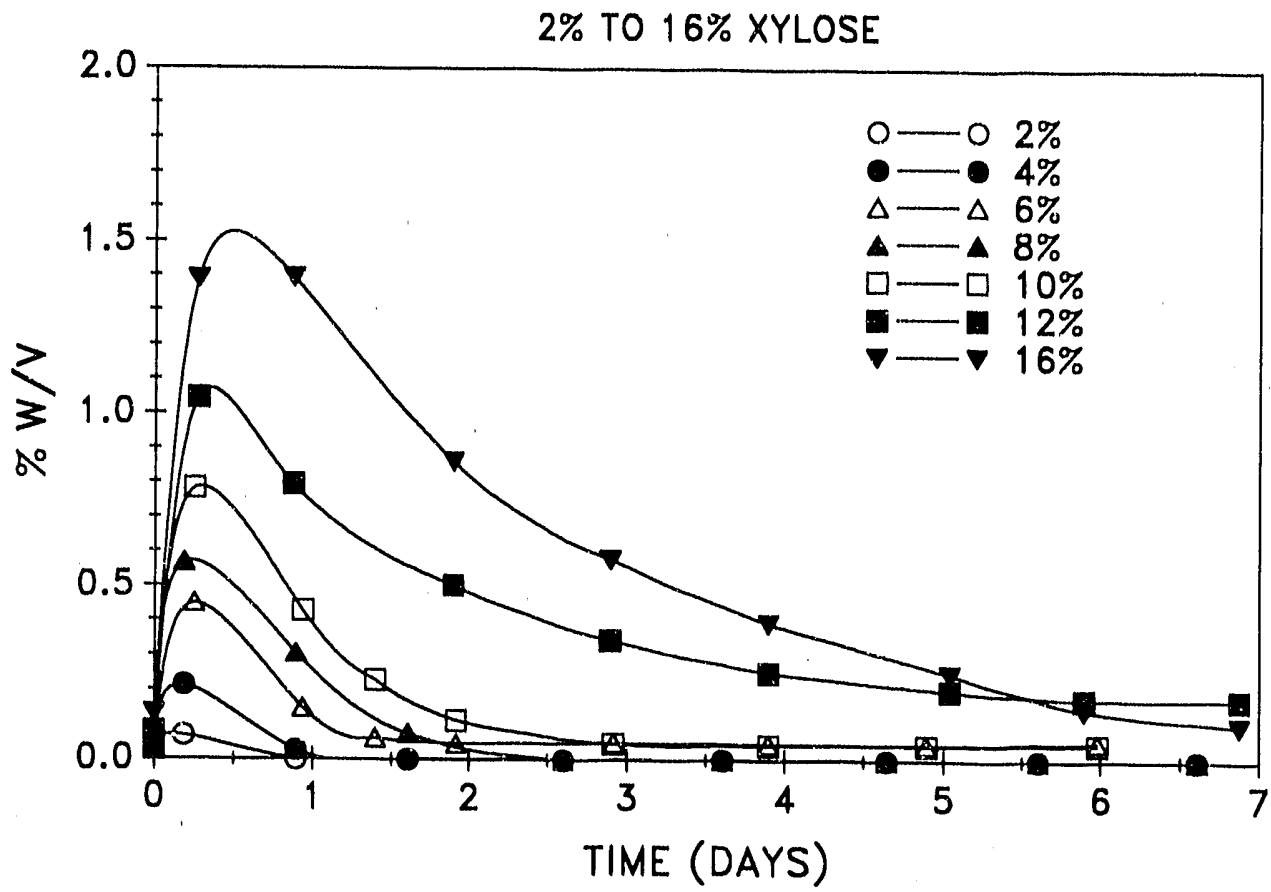

Figure 5. Changes in xylulose concentration during SFIX fermentations

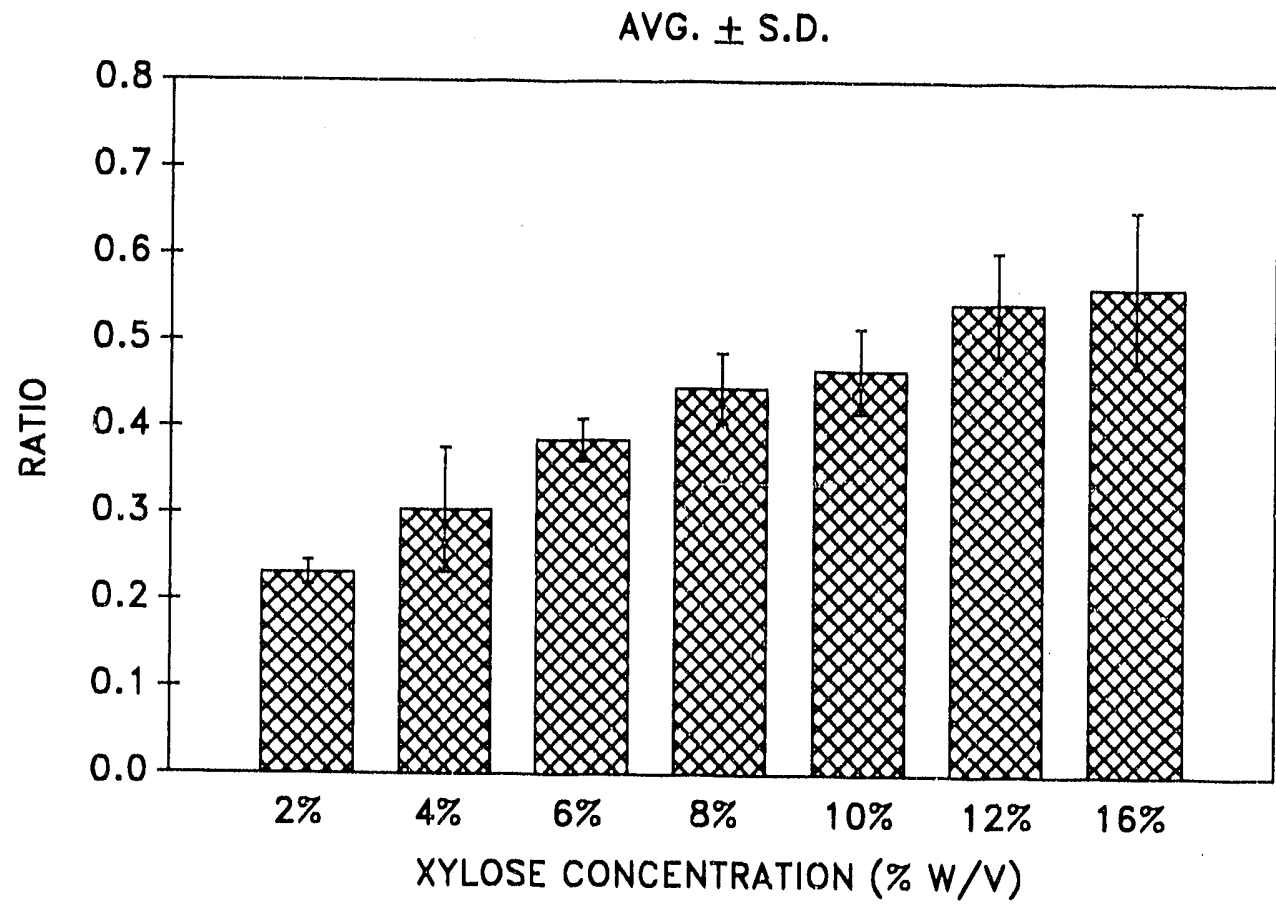

Figure 6. Changes In xylltol/ethanol ratio with Increasing Initlal xylose concentration In SFiX fermentations 
Table 6. Comparlson of Fermentation Parameters

\begin{tabular}{|c|c|c|c|c|c|c|}
\hline & $V_{p} m$ & $Q_{p} m$ & $V_{p} f$ & $Q_{p} f$ & $Y_{s} m$ & $Y_{s} f$ \\
\hline \multicolumn{7}{|l|}{ P. stipitis } \\
\hline Glucose20 g/L & $0.70^{a}$ & $0.39^{a}$ & $0.47^{a^{n}}$ & $0.26^{\mathrm{a}^{\mathrm{a}}}$ & $\cdots$ & $0.40^{\mathrm{a}}$ \\
\hline Xylose40 g/L & $0.18^{b^{\prime \prime}}$ & $0.20^{b}$ & $0.08^{b^{*}}$ & $0.04^{b^{n}}$ & $0.47^{b^{n}}$ & $0.38^{b^{n}}$ \\
\hline \multicolumn{7}{|l|}{ C. shehatae } \\
\hline Glucose $40 \mathrm{~g} / \mathrm{L}$ & $\cdots$ & $0.51^{b}$ & $\ldots$ & -- & $0.42^{b}$ & $\ldots$ \\
\hline $60 \mathrm{~g} / \mathrm{L}$ & $1.10^{\circ}$ & $0.27^{\circ}$ & $-\cdots$ & $0.23^{\circ}$ & $0.38^{\circ}$ & $0.33^{\circ}$ \\
\hline \multirow{3}{*}{$\begin{array}{r}\text { Xylose } 40 \mathrm{~g} / \mathrm{L} \\
60 \mathrm{~g} / \mathrm{L}\end{array}$} & $0.18^{b^{*}}$ & $0.32^{b}$ & $0.09^{b^{*}}$ & $0.09^{b^{n}}$ & $0.37^{b} 0$ & $0.31^{b}$ \\
\hline & $0.70^{c}$ & $0.21^{\circ}$ & $\ldots$ & $\cdots$ & $0.32^{\circ}$ & $0.27^{\circ}$ \\
\hline & \multicolumn{6}{|c|}{ P. tannophilus } \\
\hline Glucose60 g/L & $0.95^{d}$ & $0.22^{d}$ & $0.62^{d}$ & $0.62^{d}$ & --- & $0.27^{d}$ \\
\hline Xylose $40 \mathrm{~g} / \mathrm{L}$ & $0.10^{b^{*}}$ & $0.10^{b}$ & $0.05^{b^{*}}$ & $0.05^{b^{*}}$ & $0.28^{b}$ & $0.24^{b^{*}}$ \\
\hline \multicolumn{7}{|l|}{ S. pomb $\theta^{\theta}$} \\
\hline Glucose60 g/L & 4.70 & 1.57 & 4.17 & 1.39 & 0.40 & 0.40 \\
\hline Xylose $60 \mathrm{~g} / \mathrm{L}$ & $\begin{array}{l}0.58+0 \\
.03\end{array}$ & $\begin{array}{l}0.22+0 \\
.02\end{array}$ & $\begin{array}{l}0.44+0 \\
.03\end{array}$ & $\begin{array}{l}0.16+0 \\
.03\end{array}$ & $\begin{array}{l}0.35+0 \\
.01\end{array}$ & $\begin{array}{l}0.35+0 \\
.01\end{array}$ \\
\hline
\end{tabular}

"Data cialculated from graphs or tables

$a_{\text {du Preez et al. 1986. Yeast strains as in }}{ }^{b}: \mathrm{O}_{2}$-limited, $20 \mathrm{~g} / \mathrm{L}$ glucose

bLigthelm et al. 1988. P. stipitis, CSIR Y-633 $=Y-17104$,

C. shehatae, CSIR Y-492 $=$ Y12878, P. tannophilus Y-2460:

$\mathrm{O}_{2}$-limited, $40 \mathrm{~g} / \mathrm{L}$ substrate

'Jeffrles and Sreenath 1988. C. shehatae ATCC-22984:

$\mathrm{O}_{2}$-limited, $60 \mathrm{~g} / \mathrm{L}$ substrate

dJeffries et al. 1985. Strain as in ${ }^{b}: O_{2}$-limited, extrapolated from graph at $60 \mathrm{~g} / \mathrm{L}$ substrate

${ }^{\theta}$ This work, S. pombe Y-164: anaerobic, $60 \mathrm{~g} / \mathrm{L}$ substrate

'Average of 3 runs $\pm \mathrm{SD}: \mathrm{pH}=5.75,35^{\circ} \mathrm{C}, 60 \mathrm{~g} / \mathrm{L}$. xylose, $10 \mathrm{~g} / \mathrm{L}$ Sweetzyme $Q$ xylose isomerase 
Table 7. Xylose Fermentation Using Recomblnant E. coll at pH 5.5 to 7.0

\begin{tabular}{lcccc}
\hline $\mathrm{pH}^{\mathrm{a}}$ & $\begin{array}{c}\text { Xylose } \\
\% \mathrm{w} / \mathrm{v}\end{array}$ & $\begin{array}{c}\text { Etoh, Act. } \\
\% \mathrm{w} / \mathrm{v}\end{array}$ & $\begin{array}{c}\text { Etoh D/l. } \\
\text { Corr \% w/v }\end{array}$ & $\begin{array}{c}\text { Xylose, } \\
\text { Residual } \\
\% \mathrm{w} / \mathrm{v}\end{array}$ \\
\hline 5.5 & 8 & 1.9 & 2.3 & 2.3 \\
6.0 & 8 & 3.5 & 3.6 & 0 \\
6.5 & 8 & 3.5 & 3.9 & 0 \\
7.0 & 8 & 3.3 & 3.7 & 0 \\
\hline
\end{tabular}

${ }^{\mathrm{a}} \mathrm{pH}$ was controlled with $5 \mathrm{M} \mathrm{KOH}$, luria broth (LB) was used for medlum

However, these fermentations contained luria broth (LB), a rich growth medium that $E$, coll can grow well on in the absence of any additional carbon source. These nutrients may contribute to the production of ethannl and thereby increase yield estimates.

\section{SFIX with S. pombe Y-164}

Three independent fermentations have been performed using $10 \mathrm{~g} / \mathrm{L}$. Sweetzyme $\mathrm{Q}$ at $\mathrm{pH} 5.75$ and $35^{\circ} \mathrm{C}$, although the data indicate that slightly higher temperatures and lower $\mathrm{pH}$ levels would not be less efficient. The results of these SFIX runs are combined in Figure 7 and in Table 7. It can be concluded from these data that the SFIX process is a viable method for the fermentation of xylose derived from biomass wastes. Because the fermentations are totally anaerobic, there is no metabolism of ethanol. Thus, the ethanol levels remain stable for days after the fermentations have ended and all fermentable sugars have been consumed.

The temperature at which the SFIX process can be conducted is significantly higher than in fermentations using $P$. stipitis or $C$. shehatae. This allows for more rapid fermentation, reduced costs for cooling, and compatibility with other fermentation processes. The S. pombe strain Y-164 has proved to be superior to other strains tested for the SFIX process. It is ethanol- and temperature-tolerant and has the additional advantage of being extremely flocculent.

\section{Recycle of Cells and Enzyme In SFIX}

A preliminary SFIX fermentation with the recycle of the enzyme and yeast cells, using two consecutive runs each at $6 \%$ xylose, was shown to allow for more cost-effective utillzation of the biocatalysts (Figure 8). Because this strain of $S$. pombe cells tend to flocculate, no centrifugation was required. A total of $41 \mathrm{~g}$ of ethanol was produced from $120 \mathrm{~g}$ of xylose in this experiment, whereas $37 \mathrm{~g}$ was found when $12 \%$ xylose was fermented in a single batch. This experiment, and the results presented in Figure 5 , also show that low xylose fermentation rates are not the result of loss of xylose isomerase activity.

The major difference between fermentation of xylulose in SFIX fermentation and glucose fermentation is the uptake and conversion of xylulose to glycolytic intermediates by enzymes in the pentose phosphate pathway. Thus, it is likely that one or more of these conversion steps are inefficient, either because of low enzyme levels; inhibition of the enzymes; or enzyme synthesis, by xylose, xylulose, or ethanol, Detailed biochemical studies are needed to elucidate critical enzymatic steps that decrease the rate and yield of xylulose fermentation in $S$. pombe. 
Table 8. Xylose Fermentation UsIng RecombInant E. coll w/th 0.2 M Phosphate Buffer

\begin{tabular}{ccccc}
\hline $\mathrm{pH}^{*}$ & $\begin{array}{c}\text { Xylose } \\
\% \mathrm{w} / \mathrm{v}\end{array}$ & $\begin{array}{c}\text { Etoh, Act. } \\
\% \mathrm{w} / \mathrm{v}\end{array}$ & $\begin{array}{c}\text { Etoh Dil. } \\
\text { Corr \% w/v }\end{array}$ & $\begin{array}{c}\text { Xylose, } \\
\text { Residual } \\
\% \mathrm{w} / \mathrm{v}\end{array}$ \\
\hline $7 \rightarrow 6$ & 8 & 3.5 & 3.5 & 0 \\
$7 \rightarrow 6$ & 12 & 4.4 & 4.4 & 1.5 \\
$7 \rightarrow 06$ & 16 & 4.1 & 4.1 & 4.7 \\
\hline
\end{tabular}

\section{Nomenclature}

$\mathrm{V}_{\mathrm{p}} \quad$ volumetric production $\left(g\right.$ ethanol $\left.\mathrm{L}^{-1} \mathrm{~h}^{-1}\right)$

$\mathrm{Q}_{\mathrm{p}} \quad$ specific rate ( $\mathrm{g}$ ethanol $\mathrm{g}^{-1}$ cells $\mathrm{h}^{-1}$ )

$\mathrm{Y}_{\mathrm{s}}$ yield from substrate consumed (g ethanol $\mathrm{g}^{-1}$ xylose)

ET ethanol concentration $(\% \mathrm{w} / \mathrm{v})$

$\mathrm{XT}$ xylitol concentration (\%w/v)

Glu glucose

Xyl xylose

-m maximum

-f final

SD standard deviation

\section{Acknowledgments}

The authors wish to thank M. Himmel for his help in the preparation of xylulose by large-scale chromatography and NOVO Industries, Finnsugar Biochemics Inc., GB Fermentation Industries, and Miles Laboratories for their gifts of immobilized isomerases. We also thank L. Ingram for the gift of the E. coli strain ATCC \#11310/pLOI297. This work was funded by the Biochemical Conversion Program of the DOE Biofuels and Municipal Waste Technology Division. 


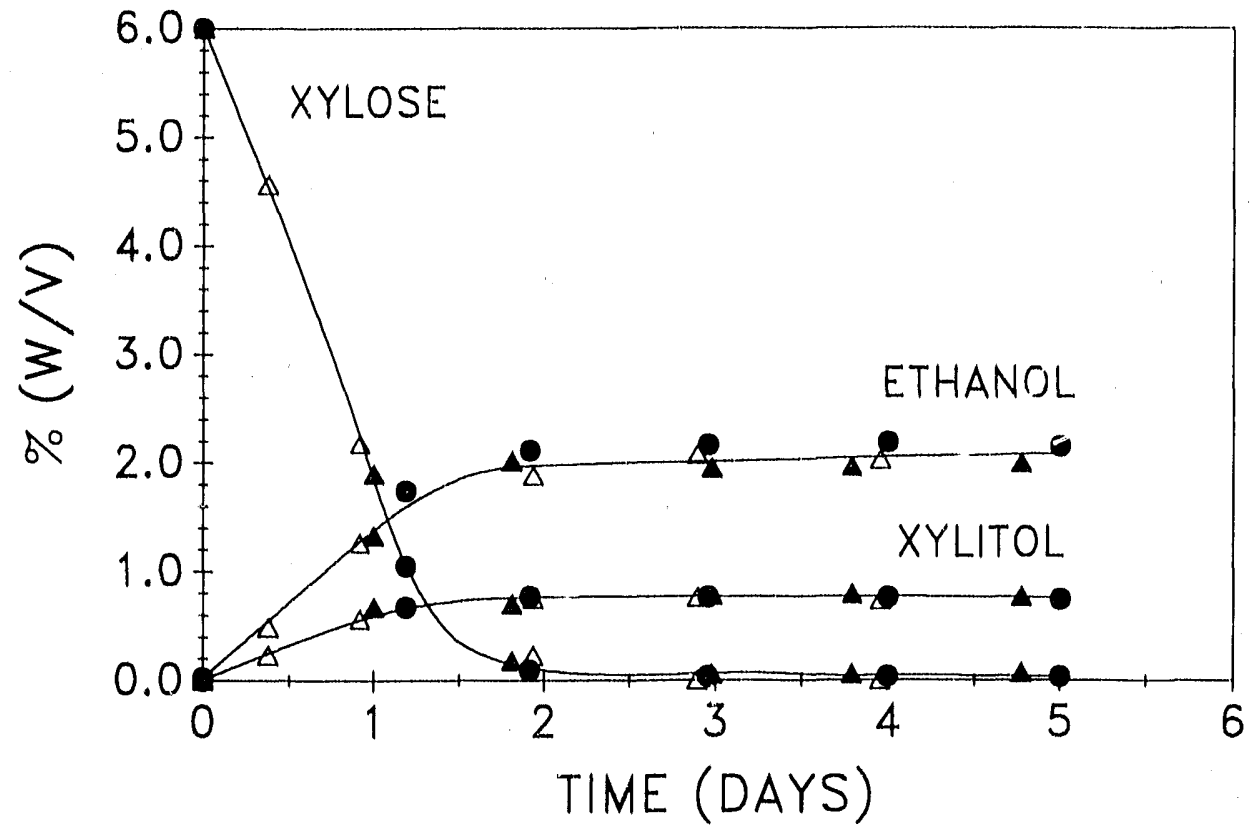

Flgure 7. SFIX fermentation of $6 \%$ xylose at $35^{\circ} \mathrm{C}$ and $\mathrm{pH} 5.75$. Symbols indicate results of three Independent fermentations using Sweetzyme Q (10 g/L) and S. pombe Y-164. A, Ethanol; $B$, Xylitol; C, Xylose

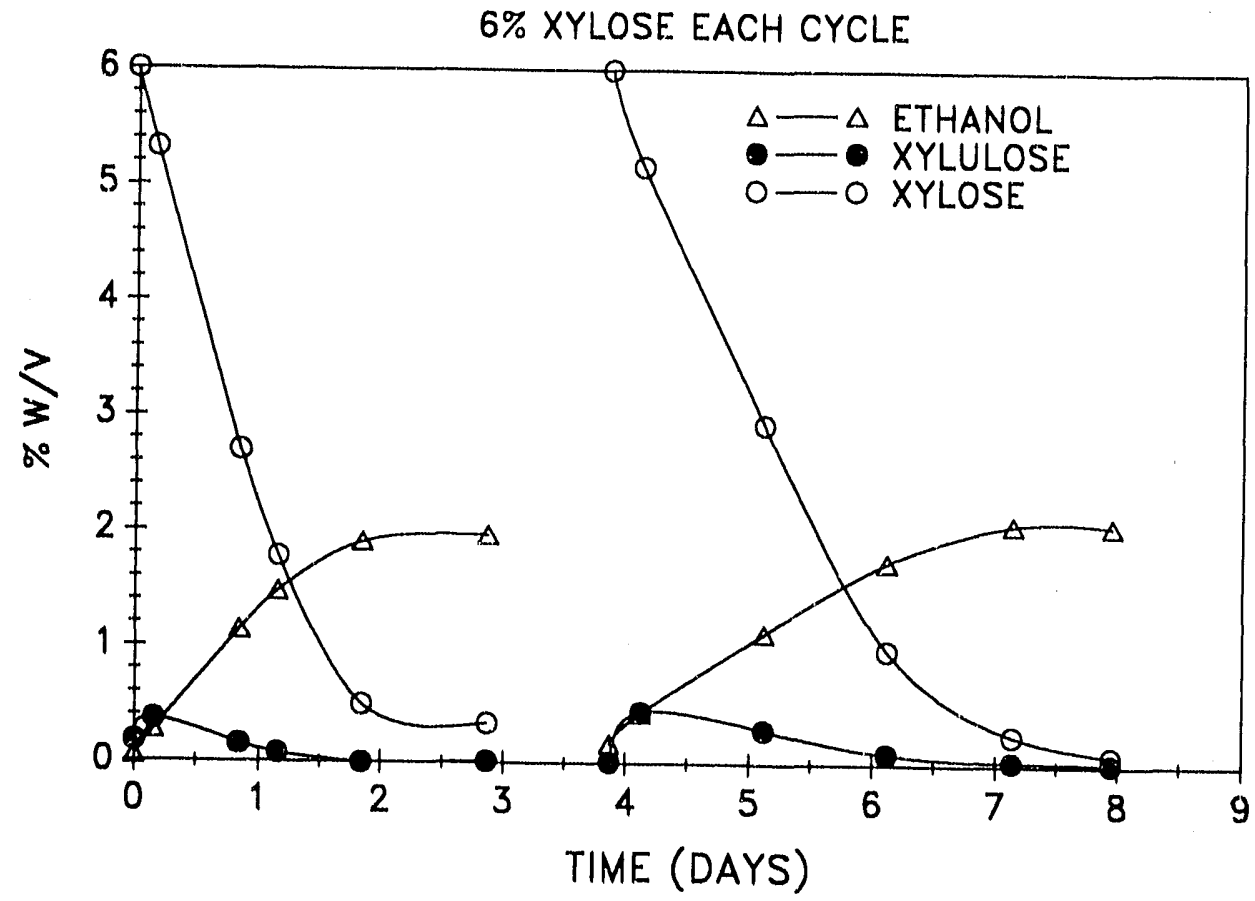

Figure 8. Recycle of cells and enzyme In SFIX fermentation 


\section{References}

Alexander, M.A., Yang, V.W., and Jeffries, T.W. 1988. Appl. Microbiol. Biotechnol. 29:282-288.

Alterthum, F., and Ingram, L.O. 1989. Appl. Environ. Microbiol. 55:1943-1948.

Baker, J.O., Tucker, M.Y., Lastick, S.M., and Himmel, M.E. 1988. J. Chromatogr. 437:387-397.

Bruinenberg, P.M., de Bot, P.H.M., van Dijken, J.P. and Sheffers, W.A. 1983. Appl. Microbiol. Biotechnol. 18:287-292.

Chaing, L.-C., Gong, C.-S., Chen, L.-F., and Tsao, G.T. 1981a. Appl. Environ. Microbiol. 42:284-289.

Chaing, L.-C., Hsiao, H.-Y., Ueng, P.P., Chen, L.-F., and Tsao, G.T. 1981b. Biotechnol. Bioeng. Symp. 2:263-274.

Chung, I.S., Lee, Y.Y., and Beck, M.J. 1986. Biotechnol. Bioeng. Symp. 17:391-400.

du Preez, J.C., Bosch, M., and Prior, B.A. 1986. Enzyme Microb. Technol. 8:360-364.

du Preez, J.C., Bosch, M., and Prior, B.A. 1987. Appl. Microb. Biotechnol. 25:521-525.

du Preez, J.C., van Driessel, B., and Prior, B.A. 1988. Biotechnol. Lett. 10:901-906.

du Preez, J.C., van Driessel, B., and Prior, B.A. 1989. Biotechnol. Lett. 5:901-906.

du Preez, J.C., and Prior, B.A. 1985. Biotechnol. Lett. 7:241-246.

du Preez, J.C., and van der Walt, J.P. 1983. Blotechnol. Lett. 5:357-362.

Glanfreda, L., Guido, G. Jr., and Marrucci, G. 1987. Annl. N.Y. Acad. Sci. 501:108-112.

Gong, C.-S., Chen, L.-F., Flickinger, M.C., and Tsao, G.T. 1981. Appl. Environ. Microbiol. 41:430-436.

Horecker, B.L. 1974. "D-Xylose and D-Xylulose: Determination with Xylose Isomerase." In Methods in Enzymatic Analysis, Second Edition, Vol. 3, eds. H.U. Bergmeyer and K. Gawehn, 1371-1376. New York: Academic Press.

Huitron, C. and Limon-Lason, J. 1978. Biotechnol. Bioeng. 22:1377-1391.

Jeffries, T.W. 1981. Biotechnol. Bioeng. Symp. 2:315-324.

Jeffries, T.W., and Sreenath, H.K. 1988. Biotechnol. Bioeng. 31:502-506.

Jeffries, T.W., Fady J.H., and Lightfoot, E.N. 1985. Biotechnol. Bioeng. 27:171-176.

Kent, C.A., and Emery, A.N. 1974. J. Appl. Chem. Biotechnol. 24:663-676.

Lachke, A.H., and Jeffries, T.W. 1986. Enzyme. Microb. Technol. 8:353-359. 
Lastick, S.M., Tucker, M.Y., Beyette, J.R., Noll, G.R., and Grohmann, K. 1989. Appl. Microbiol. Biotechnol. 30:574-579.

Lastick, S.M., Mohagheghi, A., Tucker, M.P., and Grohmann, K. 1990. Appl. Biochem. Biotech. 24/25:431-439.

Ligthelm, M.E., Prior, B.A., and du Preez, J.C. 1988a. Appl. Microbiol. Biotechnul. 28:63-68.

Ligthelm, M.E., Prior, B.A., and du Preez, J.C. 1988b. Blotechnol. Lett. 10:207-212.

Schneider, H., Wang, P.Y., and Johnson, B.F. 1981. "Pentose Fermentation by Yeasts." In Current Developments in Yeast Research, eds. G.G. Stewart and I. Russell, 81-85. Toronto: Pergamon Press.

Slininger, P.J., Bothası, R.J., Okos, M.R., and Lakisch, M.R. 1985. Biotechnol. Lett. 7:431-436.

Tewari, Y.B., Steckler, D.K., and Goldberg, R.N. 1985. Biophys. Chem. 22:181-185.

Wang, P.Y., Johnson, B.F., and Schneider, H. 1980a. Biotechnol. Lett. 2:273-278.

Wang, P.Y., Shopsis, C., and Schneider, H. 1980b. Biochem. Biophys. Res. Comm. 94:248-254. 


\title{
Xylose Isomerase Productlon and Plasmid In Recombinant E. coll
}

\author{
T. Spencer and M. Potts \\ Department of Biochemistry \\ Virginia Polytechnic Institute \\ Blacksburg, Virginia
}

\section{Introduction}

The simultaneous fermentation and isomerization of xylose (SFIX) requires the bacterial enzyme D-xylose sumerase (EC 5.3.1.5) (David and Wiesmeyer 1970). This enzyme acts in the SFIX process to overcome the inability of normal fermenting yeasts to convert xylose to ethanol (Lastick et al. 1989). The process makes practical use of the considerable xylose fraction present in plant biomass feedstocks but creates a need for a cheap source of the xylose isomerase enzyme. The goal of the research described in this review is to develop methods to efficiently produce large quantities of xylose isomerase from a recombinant $E$. coli system for use in the SFIX process. The methods described can further be applied to the production of other enzymes and may be used to compare this overproduction system to other enzymeproducing systems.

A classical method for bacterial enzyme production is to cultivate large amounts of the organism with the desired protein and isolate the enzyme from cell lysates. In the case of xylose isomerase, genetic engineering techniques have been employed to increase the amount of enzyme the host can produce (Lastick et al. 1986). The xylose isomerase gene has been isolated from $E$. coli and inserted into a plasmid vector (pTXI-1). The plasmid has allowed the gene to be reintroduced into the $E$. coli under the control of the bacteriophage lambda $P_{L}$ promoter. A second plasmid, $p R K 248$, encodes a temperaturesensitive repressor from the lambda $\mathrm{C}_{\mathrm{I} 857}$ gene that prevents transcription of the xylose isomerase gene at $32^{\circ} \mathrm{C}$, but allows for massive enzyme production at $42^{\circ} \mathrm{C}$. This dual plasmid system has been shown to produce the enzyme at approximately 12 times that of constituent levels. The overproduction effectively kills the cells, leaving memhrane-bound "bags" of xylose isomerase that can be easily harvested and used as a catalyst for the SFIX fermentations.

The molecular biological details of this overproduction system have been investigated, but studies involving its applied uses at the fermentation level are not well documented (Rosenburg et al. 1983). If this process is to be more efficient than conventional xylose isomerase production, the viability of the recombinant organism under the stress of aerobic fermentation must be studied. Although the plasmid system has increased the ability of the cells to make enzyme, the total activity produced is relative to the cell densities achieved by the growing recombinant organism. Therefore, the fermentation conditions for optimal cell yields are necessary to ensure efficient enzyme production. However, the fact that the cells are healthy and grow well does not necessarily mean activity levels are high. Mutational events occur 
normally during cell replication. These events may prevent the expression of the enzyme or the loss of the recombinant system. Problems concerning the stability of the plasmids during the growth cycle must be understood and measures to enhance the stability should be considered. The purpose of the work described in this report is to evaluate and improve the $E$. coli pRK248/pTXI-1 xylose isomerase overproducing system, from the level of cell production and plasmid stability. One of the primary results of this research has been the development of methods to evaluate the performance of the system under different fermentation conditions. These methods may be further applied to the overproduction of other enzymes using this same recombinant design.

\section{Materials and Methods}

Experiments were conducted to optimize cell growth. The $E$. coll cells used in these experiments were obtained from stock cultures frozen at $-70^{\circ} \mathrm{C}$. These cells were streaked out onto luria broth (LB) plates containing $100 \mu \mathrm{g} / \mathrm{mL}$ ampicillin and $15 \mu \mathrm{g} / \mathrm{mL}$ tetracycline. Single colonies were used to inoculate $3 \mathrm{~mL}$ of $\mathrm{LB}$ broth containing $100 \mu \mathrm{g} / \mathrm{mL}$ ampicillin. These cultures were shaken at $32^{\circ} \mathrm{C}$ until stationary phase and $2 \mathrm{~mL}$ were used to inoculate $25-\mathrm{mL}$ seed cultures of varying media composition. These seed cultures were used as inoculum for fermentations conducted in a 0.6-L air-lift fermenter (Kontes Biotechnology, Vineland, N.J.). In these experiments, the parameters of $\mathrm{pH}$, temperature, dissolved oxygen, and media composition were optimized. Nutrient-feeding techniques were also tested. Cell growth was measured by optical density at $600 \mathrm{~nm}$ and was used, in terms of final cell density, to rate the different experimental conditions.

The effects of various culture conditions on the levels of xylose isomerase activity were characterized. For Figure 1, samples of $1.5 \mathrm{~mL}$ were taken at time points over the growth curve and enzyme production was induced at $42^{\circ} \mathrm{C}$. After $3 \mathrm{~h}$ of incubation, the samples were spun down and lyophilized. The dry cells were weighed and the activity was determined by a modified Cysteine-Carbazole assay (Dische and Borenfreund 1951). Enzyme levels were expressed in specific activity units (IU/mg cells).

An assay was developed to detect reversion of the temperature-sensitive $\mathrm{C}_{1857}$ repressor mutant. Figure 2 illustrates the results of what has been termed the temperature-dependent lysis (TDL) assay. In this experiment, strains of LE392 pRK248/pTXI-1 with the temperature-sensitive repressor, the temperatureinsensitive mutant, and lacking the plasmid system were grown in the presence of the bacteriophage lambda at $37^{\circ} \mathrm{C}$. These three cultures are labeled, respectively, temperature-sensitive repressor, revertant repressor, and no repressor. Assay conditions were optimized for distinguishing between these cell types. The TDL assay was applied in the experiment shown in Figure 3. The LE392 pRK248/pTXI-1 strain containing the temperature-sensitive repressor was grown in two ways. Cells from fresh plates were used to inoculate a $10-\mathrm{mL}$ culture of the defined media containing $0.2 \%$ glucose. This culture was grown to late exponential phase and was then used to inoculate $0.5 \mathrm{~L}$ of the same media in a New Brunswick fermentation system. The cells were grown at $32^{\circ} \mathrm{C}$ in a glucose-limited chemostat at a dilution rate of $0.6 \mathrm{~h}^{-1}$ using the defined media with $0.2 \%$ glucose as a feed. The second method of growth used cells from plates stored for 2 days at $4^{\circ} \mathrm{C}$ to inoculate a $25-\mathrm{mL}$ culture of $\mathrm{LB}$ media containing $2 \%$ glucose in $125-\mathrm{mL}$ Erlenmeyer flasks. This culture was incubated at $32^{\circ} \mathrm{C}$ for a $24-\mathrm{h}$ period. These cells were then used to inoculate culture grown under identical conditions. This cycle was repeated a total of seven times or approximately 21 generations.

Samples from these two different culturing methods were taken at intervals of three generations, diluted appropriately, and plated on LB agar plates containing ampicillin and tetracycline. Twenty colonies from 
Activity and growth curve

for JC1553-XI In low-density batch culture

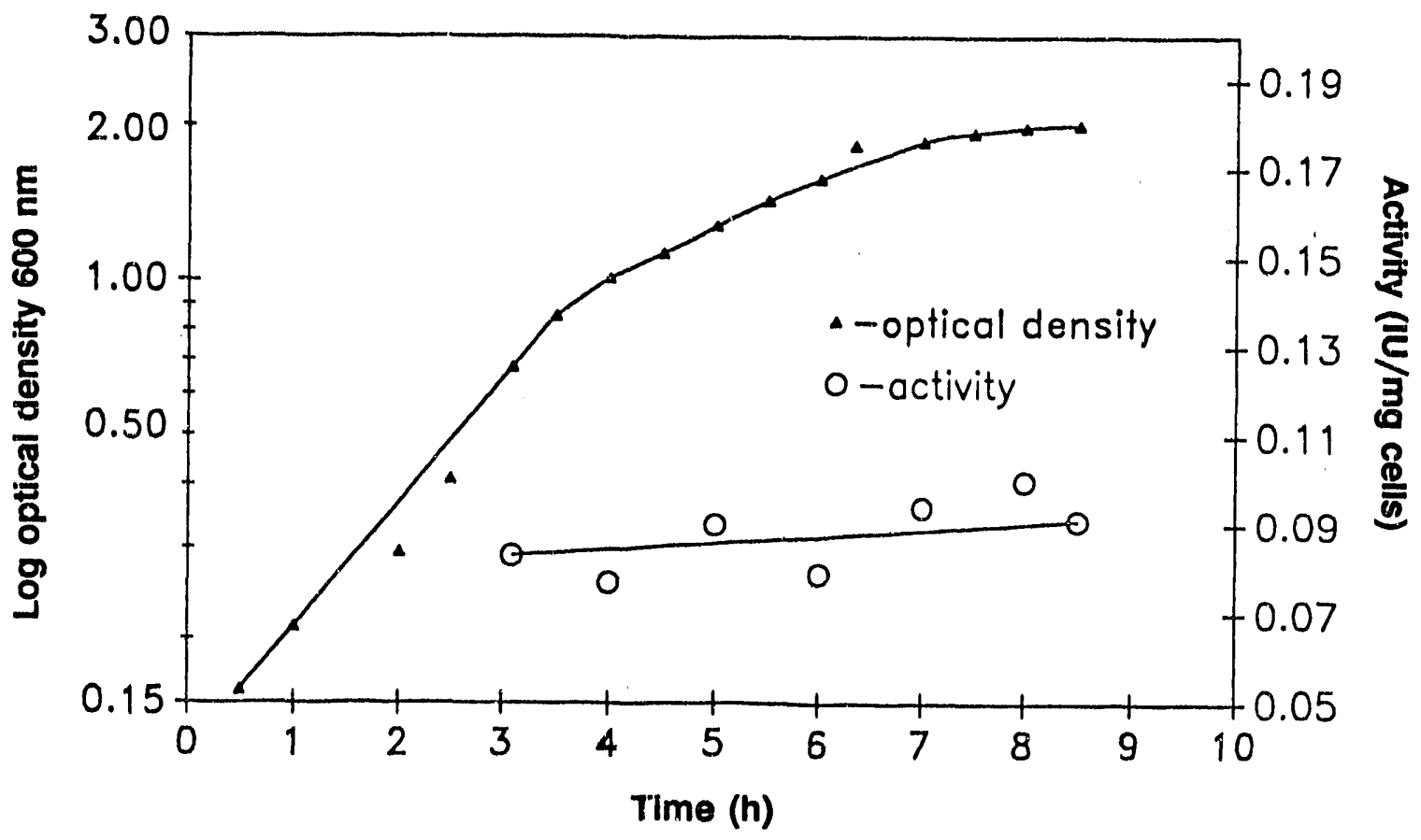

Activity and growth curve for JC1553-XI in fed-batch culture

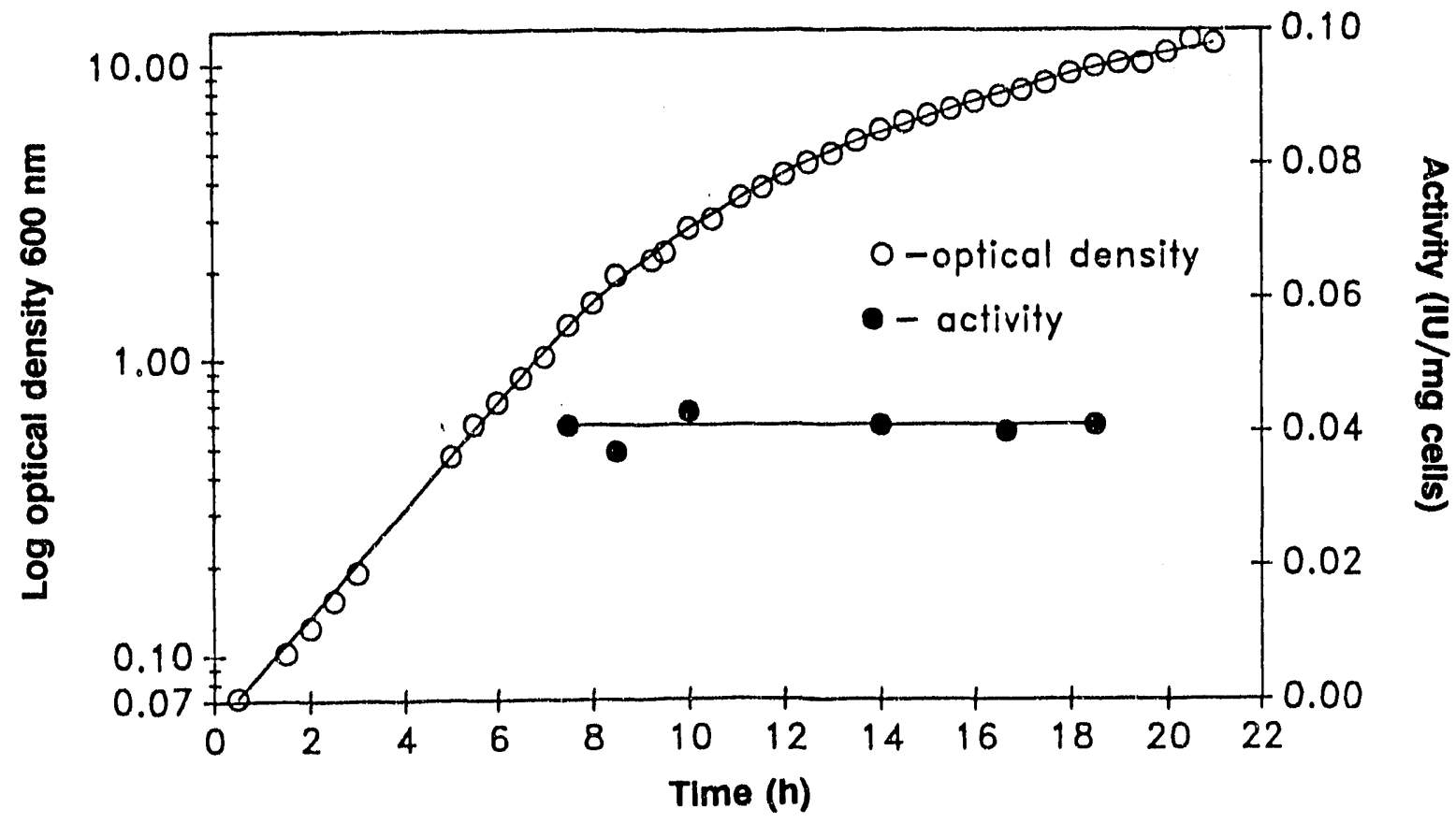

Flgure 1. HIgh cel! denelty grouth of straln LE392 

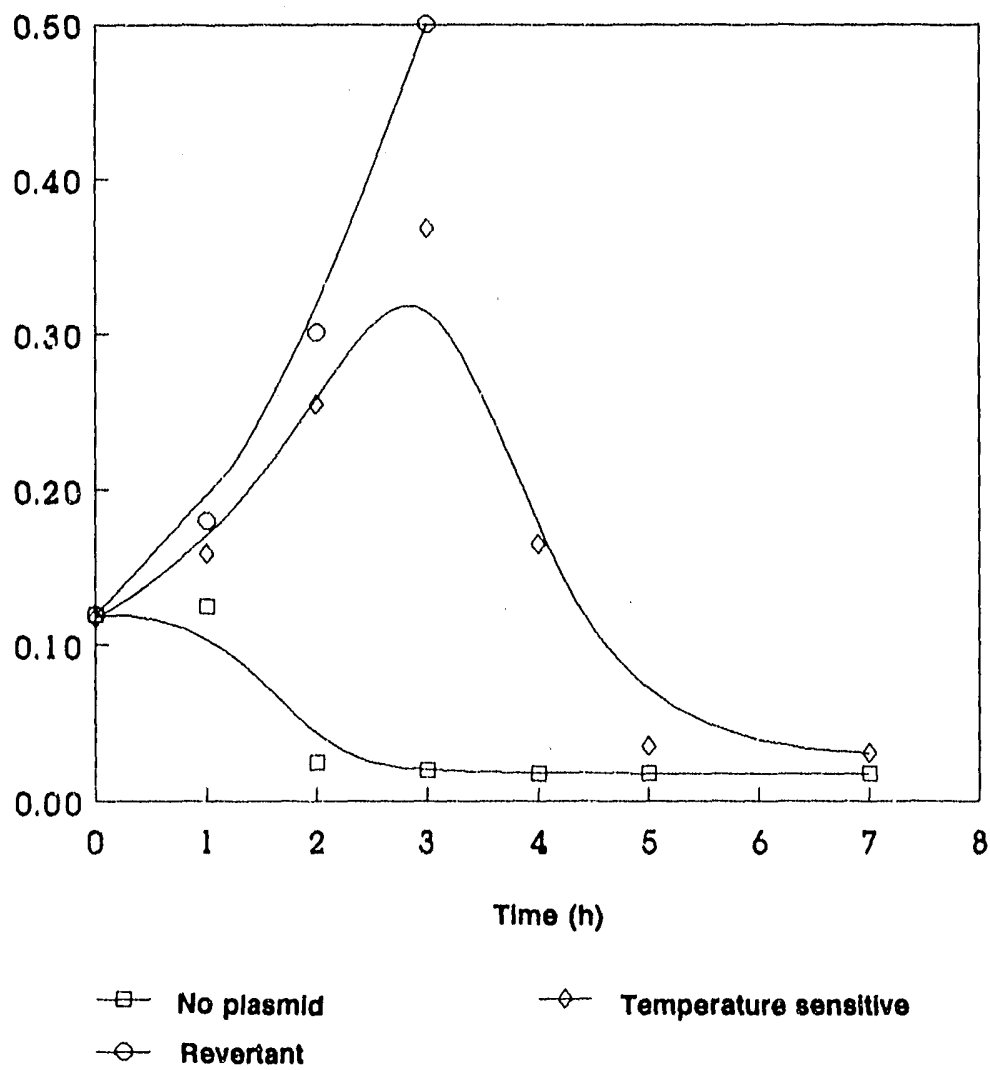

Figure 2. Comparison of high cell density growth of different stralns

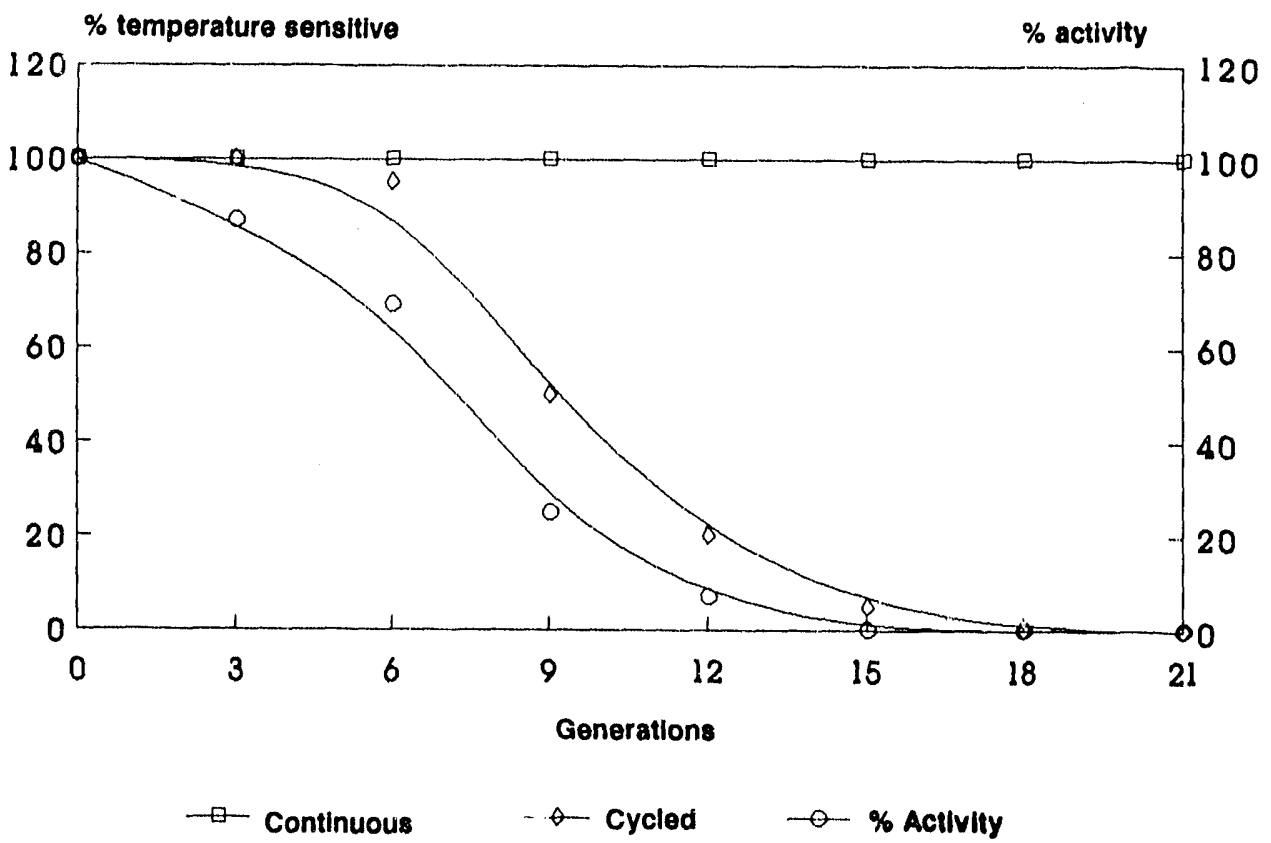

Figure 3. Effect of feed method on activity 
each plate were picked and used to inoculate LB media containing lambda phage. These cultures were incubated at $37^{\circ} \mathrm{C}$ and after 3 to $4 \mathrm{~h}$ the optical densities were measured. Cultures that showed cell growth were determined to be revertant and those that lysed were considered temperature sensitive. Enzyme activity was also measured, as described previously, for the cells grown in the cycled fashion.

\section{Results and Discussion}

Growth to high cell densities was achieved, in part, because of the controlled environment of the fermentation system. Maintenance of $\mathrm{pH}$, temperature, dissolved oxygen, and nutrient concentration effected the levels of cell mass production to a varying extent. The $E$. coli typically produce large quantities of organic acids, especially acetate, which limit their growth. The pH drop caused by these acids is so rapid that if left uncontrolled the cells will enter stationary phase at densities of $1 \mathrm{~g} / \mathrm{L}$. The

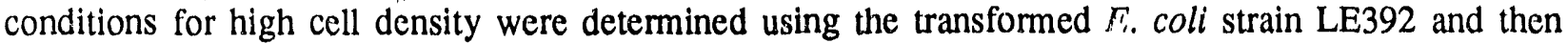
applied to other transformed strains. Cells were grown in a phosphate buffered media derived from Mizutani et al. (1986) with amino acid supplementation. The specific amino acids and their required concentrations were determined for each strain of $E$. coli in shaker flask experiments. Although temperature optimum for $E$. coll growth is about $37^{\circ} \mathrm{C}$, the reactor in the growth experiments was maintained at $32^{\circ} \mathrm{C}$ to prevent loss of gene repression. A Horizon controller kept the $\mathrm{pH}$ at 6.8 by addiug $\mathrm{NH}_{4} \mathrm{OH}$. The concentration of glucose varied between experiments. Incremental additions of glucose during the fermentation, in a fed-batch fashion, restored the concentration to initial levels. Urea as a nitrogen source was fed along with the glucose at a ratio of 2 to 15. Dissolved oxygen concentrations were maintained at $20 \%$ saturation using a New Brunswick D. O. controller by increased addition of pure oxygen to the inlet gas during the fermentations. By the end of the cultivations, pure oxygen alone was being sparged through the reactor.

In Figure 4, the methods for optimal growth were applied to LE392 pRK248/pTXI-1 cells. In this fermentation, a density of $32 \mathrm{~g} / \mathrm{L}$ was attained. This experiment illustrates the effects of two parameters that have a profound effect on final cell density: glucose feed and dissolved oxygen concentrati $\lrcorner n$. At the beginning of the fermentation, the concentration of glucose is high in comparison to amount of cell mass. In this situation, the ceils produce acetate at a considerable rate. The acetate production gradually levels off as the cell mass increases. The importance of feeding technique is illustrated by this phase. If the initial concentrations of glucose are high, as seen in batch fermentations, inefficient metabolism of the carbon source leads to lower cell mass yields and the organic acids produced may prematurely halt growth. The latter effect was seen in a 10-fold improvement in final cell densities in experiments where fed-batch techniques were used in comparison to batch.

Fourteen hours into the batch fermentation, the glucose no longer is in excess and the cells make more efficient use of their carbon source. This fact is accentuated by the drop in acelate concentrations as the cells now metabolize the available organic acids. The beginning of a phase of optimal growth is occurring in which the ratio of cell mass to glucose used remains constant at around $0.5 \mathrm{~g} / \mathrm{g}$. The optimal growth continues until the late stages of the fermentation in which the ratio begins to drop, and the cell mass production levels off and finally enters stationary phase. The acetate production gradually increases in parallel with these events along with a drop in dissolved oxygen levels. These two parameters suggest that as the cells reach high densities, the lack of available oxygen causes them to enter fermentative catabolism and produce large quantities of organic acids. Further optimization experiments will target increasing the efficiency of oxygen transfer along with improved methods of glucose feeding as ways to lengthen the duration of that intermittent phase of optimal growth. 


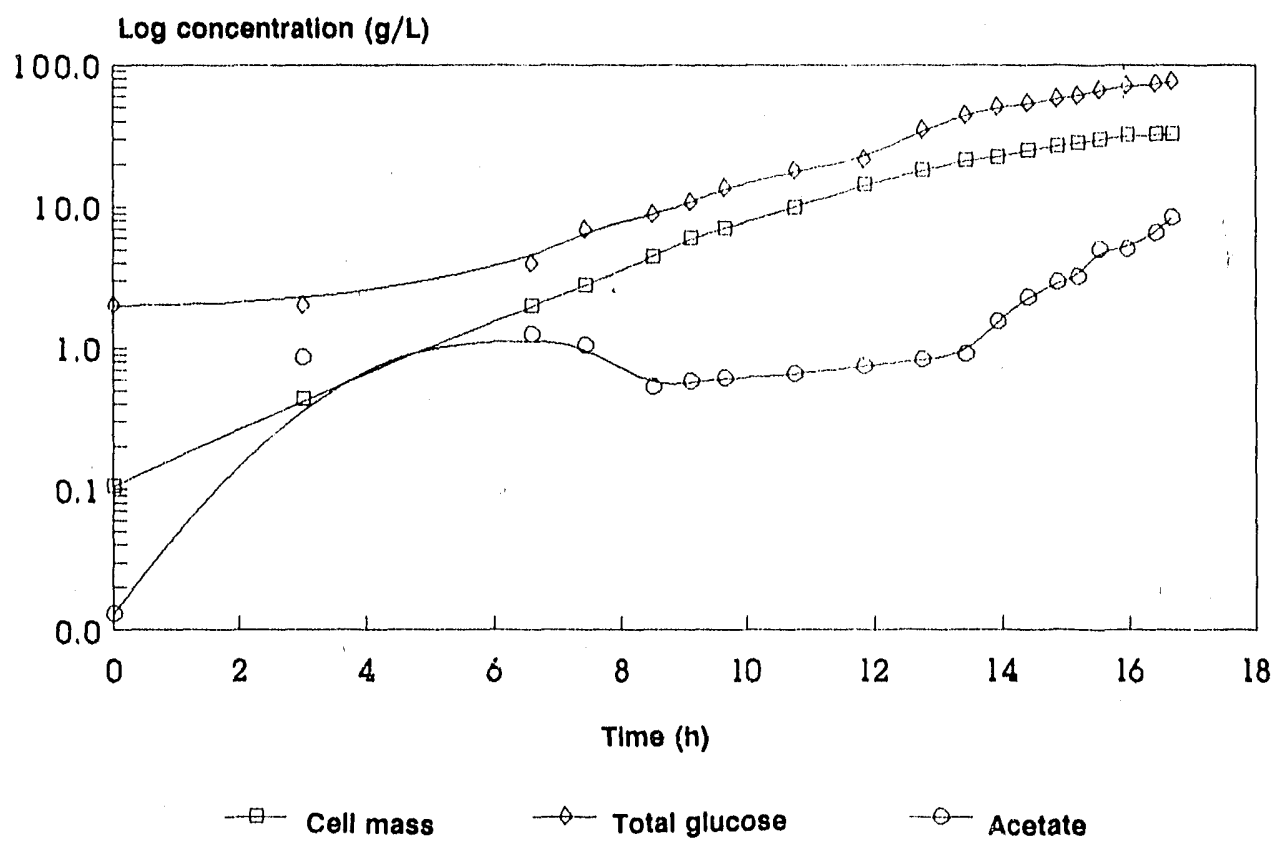

Figure 4. Temperature-dependent lysis

Figure 5 shows a comparison of high cell density growth by three different strains of the transformed E. coli. A large disparity in final cell densities is displayed, with strains LE392, JC1553, and JMB9 growing to levels of 33,14 , and $12 \mathrm{~g} / \mathrm{L}$ respectively. Activity experiments of cells grown at low densities also showed considerable differences between strains in their ability to produce enzyme. In these experiments, specific activities of $0.95,0.09$, and $0.12 \mathrm{IU} / \mathrm{mg}$ cells were produced by the respective $E$. coli. Strain selection was also found to play a role in plasmid stability, as will be discussed later. The reason for variable results between different strains is somewhat unclear, but some explanation may relate to the way each was derived. E. coli strains differ because of mutations of the genome that alter the phenotypic expression of the bacteria. The mutations are brought about by treating the bacteria with a series of mutagenic agents that randomly mutagenize the genome until a strain with the desired characteristics is attained. Over the years, scientists have developed hundreds of strains, from a few wildtype $E$. coli, with altered gene expression. These alterations have a variety of effects on the metabolism of the $E$. coli strains. Mutations may cause the cells to metabolize the substrate more or less efficiently and produce different amounts of inhibitory metabolites. The different degrees of mutaition may also account for the differences in enzyme production. For these and other reasons, strain selection will be studied further in an attempt to increase enzyme production and to identify some genetic factors crucial to that goal.

The levels of enzyme production during the growth of cells in batch and fed-batch fashion is described by Figure 1. In both cultures, the specific activity is stable over the growth curve. However, the level of activity differs between the two culturing methods. Levels of approximately $0.04 \mathrm{IU} / \mathrm{mg}$ cells were produced by the fed-batch culture, whereas the batch culture produced $0.09 \mathrm{IU} / \mathrm{mg}$ cells. An explanation of this might be that the batch grown cells contain greater quantities of metabolic intermediates from which the xylose isomerase is made. The fed-batch technique starves the cells to a certain degree so that they use their carbon source more efficiently but may infringe on their ability to overproduce the enzyme. Research is now under way to determine an intermediate between the batch and fed-batch conditions that will allow for both good cell mass production and good enzyme activity. This may be considered the search for a so-called "happy medium." 
O.D. @ 600 nm

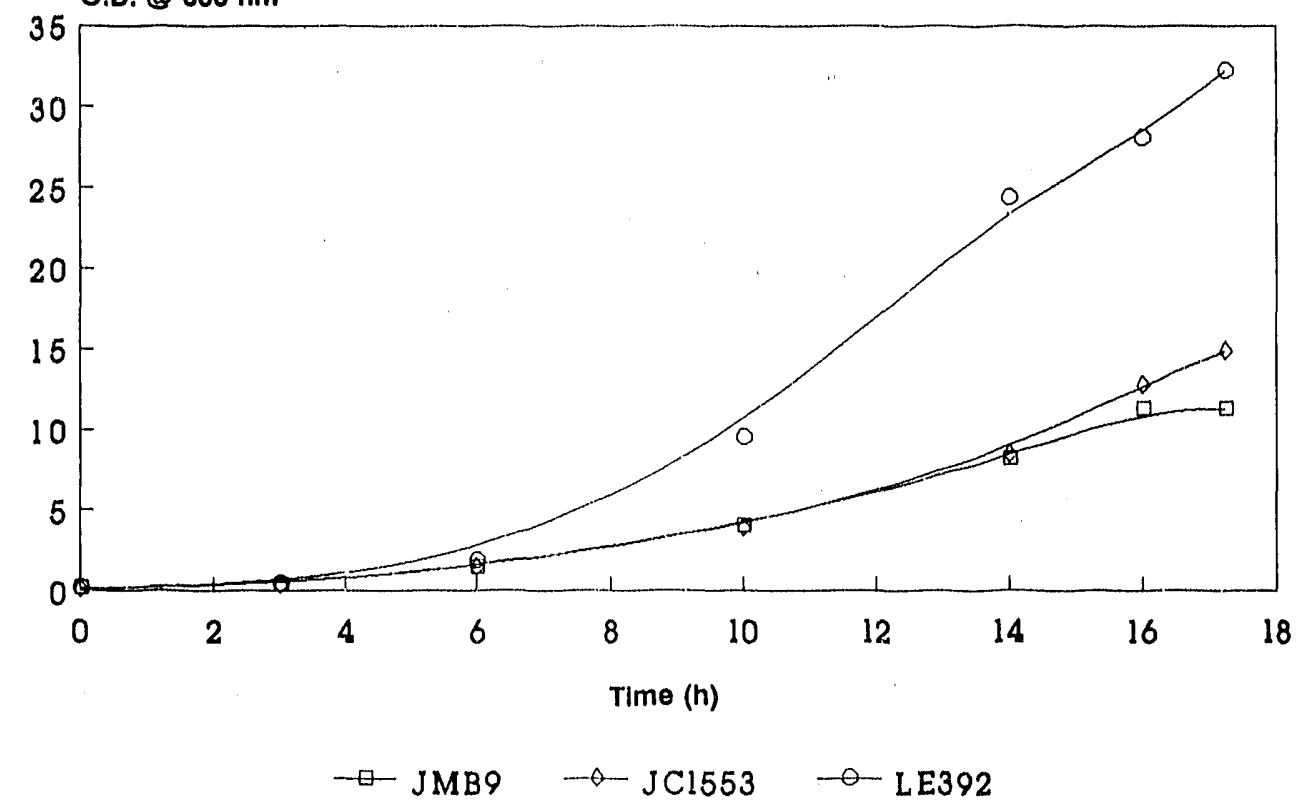

Figure 5. Reversion of LE392

Another area of concern with the recombinant system is plasmid stability. Activity experiments equivalent to those in Figure 1 demonstrated that all the fermentations of LE392 to high cell density were incapable of producing enzyme. The cells maintained resistance to the antibiotics encoded by the two plasmids and gel electrophoresis of cell lysates showed the presence of two bands corresponding to the plasmids. For these reasons, it was deduced that in these fermentations the temperature-sensitive $\mathrm{C}_{1857}$ gene on the pRK248 plasmid had reverted to its wild-type temperature-insensitive form. In this condition, the cells have lost their ability to induce the enzyme overproduction. Unfortunately, the occurrence of this phenomenon was seen mainly in LE392, the strain that produced the most cell mass and potential enzyme activity. This reversion may be promoted by the RecA (recombinant plus) phenotype of this strain, as opposed to RecA minus status of the other strains. To detect and characterize the appearance of these revertant cells, the TDL assay was developed.

The TDL assay makes use of the repressor-born immunity to lambda phage. $E$. coli cells containing active $\mathrm{C}_{\mathrm{I}}$ repressor are resistant to the normal infection and lysis activity of the bacteriophage (Gussin et al. 1983). It was discovered, however, that the $E$. coli containing the temperature-sensitive repressor lost their immunity, and lysed at ternperatures above $32^{\circ} \mathrm{C}$. The conditions for this temperature-dependent lysis were optimized so as to use it to distinguish between different cell populations. Figure 2 details the results of the assay as applied to cells containing the revertant and temperature-sensitive repressors, as well as cells containing no plasmids. At $37^{\circ} \mathrm{C}$ in the presence of lambda phage, the ternperature-sensitive cells grow for several hours. After this period, the repressor is denatured to an extent that it can no longer inhibit infection of the phage. At this point, the cells are lysed by the phage, seen as a drop in optical density. Under these same conditions, cells containing the revertant repressor maintain immunity and continue to grow in a normal fashion. Cells containing no plasmid, and therefore no repressor, lyse immediately without any period of growth. This response represents cells that have lost their plasmid. Thus, the assay can then be used to determine both if a cell population has suffered plasmid instability 
and to distinguish between structural instability, in the form of repressor reversion, and segregational instability, in the form of plasmid loss.

An initial use of the TDL assay is shown in Figure 3. In this experiment, reversion was tested for during extended growth of the transformed LE392 cells under favorable conditions, in the continuous culture, and under the stress of cycled culturing. As the results illustrate, the cycled cells lose the temperaturesensitive repressor in comparison to the unstressed cells, which show no reversion. These results are interesting because of the similarity the cycled cells have with the multiple sub-culturings necessary for growing $E$. coli at industrial levels. The degree of reversion is exaggerated in this experiment by the suboptimal conditions of the cycled cultures, especially with respect to the long periods of time when the cells were exposed to the stationary phase. However, the experiment does demonstrate the degree of care needed during pre-culture and scale-up. Further uses of the TDL assay will be aimed at characterizing reversion under the conditions for high cell density and investigating the role of RecA and other phenotypes on the loss of temperature sensitivity. The potential value of this assay in modeling the molecular events occurring with induction will also be studied.

\section{References}

David, J. D. and Wiesmeyer, H. 1970. Biochim. Blophys. Acta. 201: 497-499.

Dische, Z., and Borenfreund, E. 1951. J. Biol. Chem. 192: 583-587.

Gussin, G.N., Johnson, A.D., Pabo, C.O., and Sauer, R.T. 1983. "Represssor and Cro Protein: Structure, Function, and Role in Lysogenization." In Lambda II, eds. R.W. Hendrix, J. W. Roberts, F. W. Stahl, and R. A. Weisberg, Cold Spring Harbor, NY: Cold Spring Harbor Laboratory.

Lastick, S.M, Tucker, M.Y., Beyette, J.R., Noll, G.R., and Grohmann, K. 1989. Appl. Microbiol. Biotechnol. 30: 574-579.

Lastick, S., Tucker, M.Y., Mackedonski, V., and Grohmann, K. 1986. Biotech. Lett. 8:1-6.

Mizutani, S., Mori, H., Shimizu, S., Sakaguchi, K., and Kobayashi, T. 1986. Biotech. Bioeng. 28: 204 209.

Rosenburg, M., Ho, Y., and Shatzman, A. 1983. Meth. Enzymol. 101: 123-138. 


\title{
Cloning of Xylulokinase Gene for Improved Xylose and Xylulose Fermentation
}

\author{
N. W. Y. Ho \\ Molecular Genetics Group \\ Laboratory of Renewable Resources Engineering \\ Purdue University \\ West Lafayette, Indiana 47907
}

\begin{abstract}
D-glucose and D-xylose are the two major components of renewable plant biomass. Many yeasts, particularly Saccharomyces cerevisiae, can effectively ferment glucose to ethanol but cannot ferment xylose to ethanol. However, xylose can be converted to xylulose by the enzyme xylose isomerase and most super glucose fermenting yeasts can ferment xylulose to ethanol. Nevertheless, the effectiveness of these yeasts in fermenting xylulose varies considerably. For example, Schizosaccharomyces pombe can ferment xylulose quite effectively; $S$. cerevisiae, on the other hand, can only ferment xylulose very poorly.

We found that one key factor affecting yeast xylose and xylulose fermentation is its xylulokinase activity. By cloning the xylulokinase gene on a high copy-number plasmid, we have demonstrated that yeast (S. cerevisiae) can be genetically engineered to overproduce exceedingly high levels of its xylulokinase activity (more than 200 times greater than that of the ordinary yeast not harboring the cloned gene), and such genetically engineered yeasts can ferment xylulose more than $100 \%$ faster than the ordinary yeast.

Recombinant manipulation of yeast leading to the overproduction of xylulokinase makes yeast able to ferment xylulose much more effectively. It may also serve as a strong driving force to channel the xylose metabolism in yeast towards the production of ethanol, rather than the production of undesired byproducts such as xylitol. The new theory is that yeast has sufficient xylitol dehydrogenase activity and, in the presence of strong xylulokinase activity, may be made to directly ferment xylose by simply cloning one additional gene, the xylose reductase gene. We have already succeeded in the cloning of the Pichia stipitis xylose reductase gene on an Escherichia coli nlasmid. Hence, we are possibly only a few short steps away from making $S$. cerevisiae directly ferment xylose.
\end{abstract}

\section{Introduction}

D-glucose and D-xylose are two major components of renewable plant biomass. They are the most abundant renewable resources on earth. Glucose from plant biomass can be effectively converted to alcohol fuel via yeast fermentation. However, many yeasts, particularly Saccharomyces cerevisiae, which can effectiveily ferment glucose to ethanol, were found unabie to ferment xylose (Barnett i970). 
Nevertheless, it was found that xylose can be converted enzymatically in vitro to xylulose by xylose (glucose) isomerase, and most yeasts that can effectively ferment glucose can ferment xylulose to cthanol. This two-step process became particularly attractive when it was found that $E$. coli could be genetically engineered to produce xylose isomerase activity 20 to 50 times greater than the ordinary $E$. coli. This was first demonstrated by Stevis and Ho (1985) and later by other laboratories (Ho 1989; Lastick et al. 1986; Tucker et al. 1988).

Nevertheless, the effectiveness of these yeasts in fermenting xylulose varies considerably. For example, $S$. cerevisiae, which is traditionally the best yeast for fermenting glucose into ethanol, ferments xylulose very poorly. Early work by others implied that one key factor affecting yeast xylose and xylulose fermentation is its xylulokinase activity (Lachke and Jeffries 1986). This had prompted us to study whether it is possible to increase the level of xylulokinase activity in yeasts via gene cloning, and to study the effects of a high level of xylulokinase activity on yeast xylose or xylulose fermentation (if a yeast can be genetically engineered to produce high levels of such enzyme activity).

This project was initiated about 3 years ago. It was aimed at studying the possible cloning and overexpression of the yeast xylulokinase gene in S. cerevisiae and Schizosaccharomyces pombe, and the effect of overproduction of such an enzyme on their xylose and xylulose fermentation.

S. cerevialae was chosen for this study because it is a species superior for fermenting glucose to ethanol, but it ferments xylulose very poorly. Cloning and overexpression of the xylulokinase gene in S. cerevisiae have an excellent chance to improve the efficiency of this yeast for fermenting xylose and xylulose.

Sch. pombe is chosen because it can ferment xylulose better than most other yeasts, and it also contains a high level of xylulokinase activity. We believe it is desirable to know whether the efficiency of fermenting xylulose by such a yeast can be further improved by cloning an effective xylulokinase gene.

Batt et al. (1986), have demonstrated that $S$. cerevisiae contains sufficient xylitol dehydrogenase but very low levels of xylose reductase activity, if any at all. We have been able to confirm their results, and it is now believed that there are at least two reasons causing $S$. cerevisiae and related yeasts to be unable to ferment xylose directly. One is that they do not contain sufficient xylose reductase activity. The other is that the xylitol dehydrogenase present in yeasts catalyzes the reversible reactions between xylitol and xylulose, but favors the formation of xylitol rather than xylulose as illustrated below:

$$
\begin{gathered}
\text { xylitol } \\
\text { dehydrogenase }
\end{gathered}
$$

Thus, most of the product from fermentation of xylose or xylulose by these yeasts will be xylitol, not xylulose or ethanol (Figure 1), unless the presence of a strong enzyme activity catalyzing one of the alcohol fermentation reactions downstream to the reaction catalyzed by the xylitol dehydrogenase can channel the reactions towards xylulose or ethanol formation. We believe that the overproduced xylulokinase activity through the cloning and overexpression of the xylulokinase gene in $S$. cerevisiae possibly serves as a driving force to channel the xylitol dehydrogenase reaction towards xylulose or ethanol formation, and prevents the formation of xylitol. If the new theory is correct, in the presence of the strong xylulokinase activity, yeasts such as $S$. cerevisiae probably require the presence of only one additional enzyme, xylose reductase, to directly ferment xylose. Hence, our studies now also include the cloning of a yeast xylose reductase gene in $S$. cerevisiae and other yeasts. We are exploring the possible direct fermentation of xylose by those yeasts that contain both the cloned xylose reductase and xylulokinase genes and that produce strong activities for both xylose reductase and xylulokinase. 


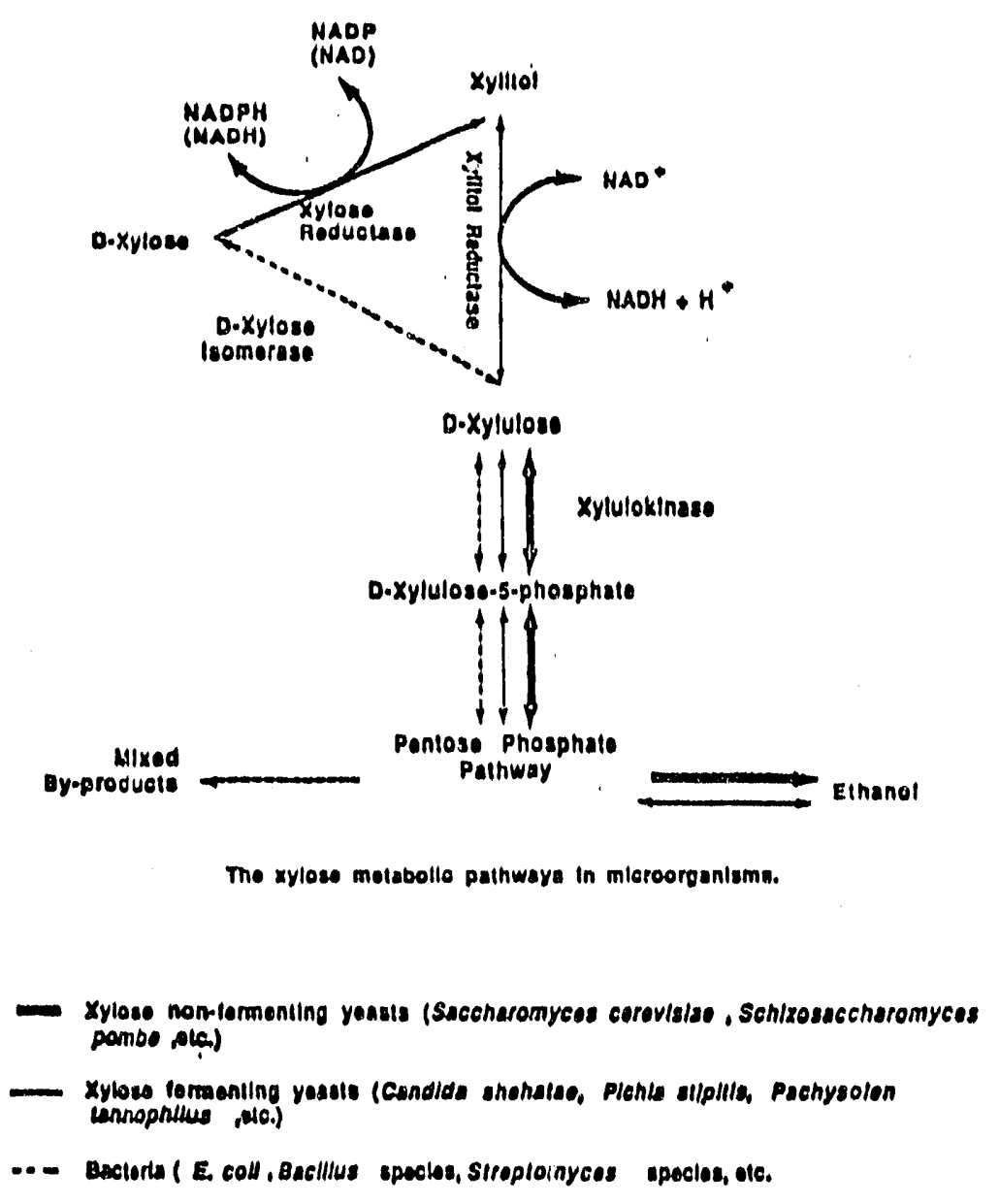

Figure 1. The xylose metabollc pathways in microorganlems

\section{Materials and Methods}

\section{Stralns}

S. cerevisiae AH22 was used for most S. cerevisiae studies that include preparing the xylulokinase mutant LSK1 by gene disruption. Sch. pombe Y-164 was used for Sch. pombe transformation as well as other studies. E. coll SR14, a xvlulokinase mutant (Rosenfeld et al. 1984) was used as the host for the construction of various plasmids containing the $E$. coll or yeast xylulokinase gene.

\section{Transformation}

E. coll transformation was carried out according to the $\mathrm{CaCl}_{2}$ procedure described in Norgard et al. (1978). Yeast transformation was by the spheroplast method (Hinnen et al. 1978). Sch. pombe transformation was carried out as described by Beach and Nurse (1981).

\section{DNA Isolation and Manlpulation}

Plasmid DNA from E. coli was isolated according to the clear lysate method of Godson and Vapnek (1973) and Guerry et al. (1979). Rapid plasmid preparations were carried out according to the method 
of Holmes and Quigley (1981). Conditions for DNA digestion and ligation were according to the specifications of the suppliers. Yeast xylulokinase (EC 2.7.1.17) activity was assayed by measuring the disappearance of xylulose, as described by Shamanan and Sanderson (1979).

\section{DNA Sequencing}

Double-stranded min-prep plasinid DNA was used as a template for DNA sequencing. The protocols provided by Kraft et al. (1988), and by United States Biochemical (Cleveland, Ohio) were used for sequencing. The enzymes and chemicals for DNA sequencing were from United States Blochemical.

\section{DNA Ampllfication by Polymerase Chaln Reaction}

Polymerase chain reaction (PCR) was carried out according to the protocol provided by Saiki (1990). The reactions were carried out with an automated system made by Ericomp, Inc. (San Diego, Calif.).

\section{Chemlcals and Medla}

Pure xyluiose was purchased from Sigma Chemical Co. (St. Louis, Mo.). Crude xylulose was prepared according to Gong et al. (1981), and consisted of a mixture of xylulose and xylose, usually around 2:1, respectively. YEPD consists of $1 \%$ yeast extract, $2 \%$ bacto peptone, and $2 \%$ dextrose. YEPGE is YEPD with $3 \%$ glycerol and $2 \%$ ethanol instead of dextrose.

\section{Results}

The highlights of our most important results of the past 3 years are presented below.

\section{Comparlson of Yeast Xylulokinase Activlty with the Efflclency of Varlous Yeasts in FermentIng Xylose or Xylulose to Ethanol}

Early work by Lachke and Jeffries (1986) had implied that xylulokinase in yeasts plays a pivotal role in yeast xylose and xylulose fermentation. In order to further define the importance of this enzyme to yeast xylose or xylulose fermentation, the xylulokinase activity of five important yeasts were measured (as $\Delta$ OD540, the larger the number, the higher the specific activity of the enzyme) and compared to their efficiency in converting xylose or xylulose to ethanol. Our results showed that yeast species that can ferment xylose or xylulose more effectively always contain higher levels of xylulokinase activity, and those yeasts that ferment xylose or xylulose very poorly always contain lower levels of xylulokinase activity. These results further prove that xylulokinase is a key enzyme for yeast xylose or xylulose fermentation. The data presented here have been incorporated into one of our recent publications (Deng and Ho 1990).

\section{Development of a Yeast Xylulokinase Mutant by the Gene Disruption Technique}

Prior to the initiation of this project, we were able to clone a plecc of yeast DNA fragment (designated $\mathrm{XYK}-\mathrm{Sc}$ ) that can complement the $E$. coli xylulokinase mutation (Chang and Ho 1988). However; yeagt transformants containing the cloned $X Y K$-Sc did not produce higher xylulokinase activity. This could 
imply that the cloned $X Y K$-Sc was not an intact gene and did not contain the intact genetic elements for the expression of the gene in yeast ( $S$. cerevisiae). For a number of reasons, including having a suitable yeast strain for proper characterization of the cloned $X Y K-S c$, we believed that it was highly desirable to isolate or construct a yeast xylulokinase mutant. It requires the use of pure xylulose as the carbon source to isolate yeast xylulokinase mutants by chemical mutagenesis. Pure xylulose is too expensive to be used for such a purpose, so the recently developed gene disruption technique (Rothstein 1983) was used to construct such a mutant. The key plasmid vector pLSK4::Leu2, which was used to disrupt the xylulokinase gene on yeast chromosome, is shown in Figure 2. The resulting yeast xylulokinase mutant, designated LSK1, cannot grow on medium containing xylulose as the sole carbon source as shown in Figure 3. A preliminary account of this work has been published (Stevis and Ho 1989).

\section{Complementation of Yeast Xyluloklnase Mutant LSK1 by the Cloned XYK-Sc}

After the mutant was constructed, plasmid pLSK10 (Figure 4), containing the cloned $X Y K$-Sc, was developed for transforming the mutant LSK1. Although LSK1 was not able to grow on medium containing xylulose as the sole carbon source as indicated in II, LSK1 transformants containing pLSK10, which harbors $X Y K$-Sc, were able to grow on xylulose medium as shown in Figure 3 . This result unequivocally proved that the cloned $X Y K$-Sc is the intact yeast xylulokinase gene. It contained its intact structural gene and also contained its genetic elements for the expression of the gene in S. cerevisiae. After we proved that the cloned $X Y K$-Sc is an intact gene from $S$. cerevisiae, the structure of the gene was further characterized in detail. This work was also published (Ho and Chang 1989).

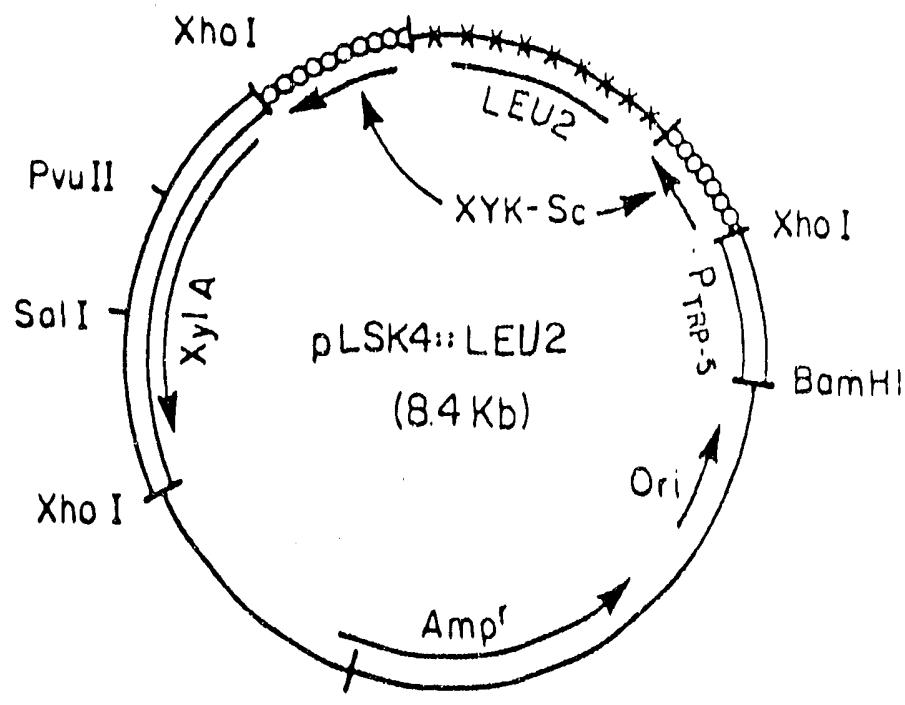

Figure 2. Xylulokinase gene disrupter plasmld 

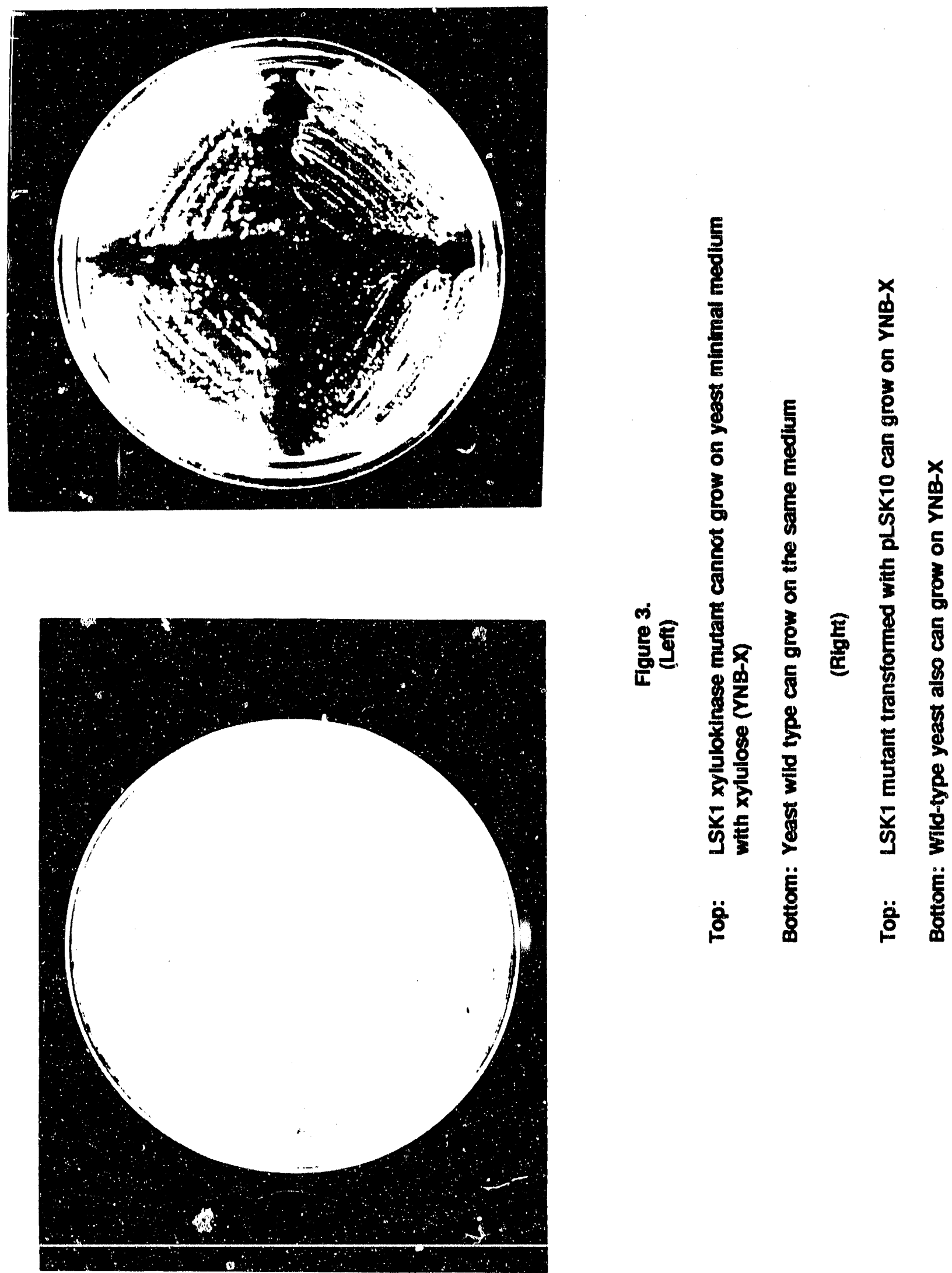


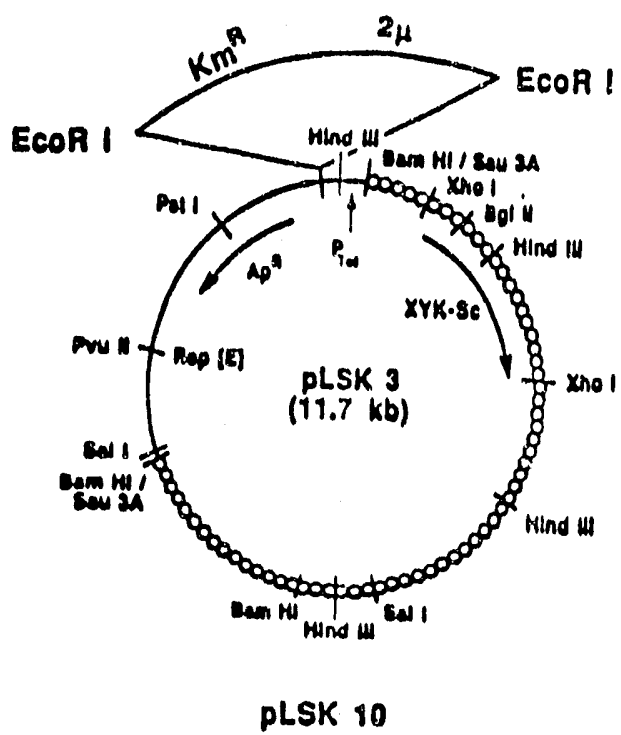

FIgure 4. PLSK10

\section{Fuslon of the Cloned XylulokInase Gene XYK-Sc with Another Yeast Promoter to Improve its Expression In S. cerevislas}

After we had demonstrated that the cloned $X Y K$-Sc contained the intact yeast xylulokinase gene, the xylulokinase activity of LSK1 harboring pLSK10 was analyzed with an improved procedure. Efficiency in converting xylulose to ethanol by the transformant was also analyzed. We found that the transformant was able to produce two times more of its xylulokinase activity than the wild-type yeast (strain AH22), but it was not able to convert xylulose more effectively to ethanol.

In order to study whether it was possible to further overproduce xylulokinase in $S$. cerevisiae, the promoter of the cloned xylulokin se gene $X Y K$-Sc was removed and the promoterless xylulokinase gene was fused to the yeast TRP5 promoter. The resulting gene was then cloned on a plasmid with a copy number identical to that of pLSK10. The new plasmid containing the TRP5-XYK-Sc fusion was designated as pLSK15 (Figure 5).

Analysis of the xylulokinase activity of yeast transformant containing pLSK15 indicated the new transformants could overprod'ce 100 times more xylulokinase activity than the wild-type $S$. cerevisiae AH22.

\section{Cloning the XylulokInase Gene on a High Copy-Number Plasmid to Further Improve Its Expression}

Both pLSK 10 and pLSK15 are low copy-number plasmids. Each plasmid has a copy-number of 10 in yeast cells. This means that, after successfully introducing these plasmids into yeast cells, each yeast cell wiii contain approximateiy ió copies of the same plasmid, or a yeast transformant will contain 10 extra 


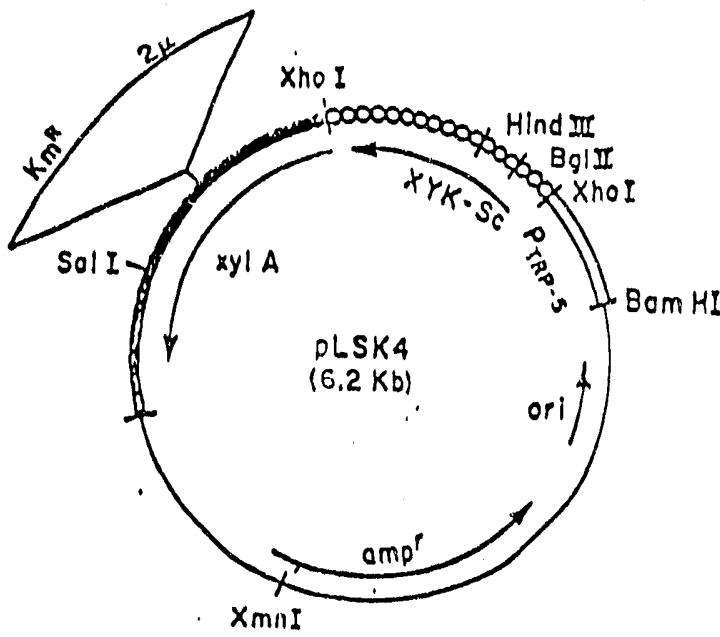

pLSK16

Flgure 5. pLSK15

copies of the xylulokinase genes. After successful overexpression of $X Y K$-Sc in yeast by fusion of the gene to another yeast promoter, we studied whether it was possible to further improve the expression of $X Y K$-Sc by cloning the original $X Y K-S c$ and the TRP5-XYK-Sc fusion on a high copy-number plasmid such as pUCKm8 (Figure 6) (which is a high copy-number yeast $E$. coll shuttle plasmid that we recently constructed). pLSK20, pLSK25, and pLSK30 are three such high copy-number plasmids containing $X Y K$ Sc gene fused to different promoters: one with $E$. coli lac promoter (pLSK20), one with its original promoter (pLSK25), and one with tha TRP-5 promoter (pLSK30) (Figure 7). Yeast containing each of these plasmids can produce high levels of xylulokinase activity as shown in Table 1.

\section{The Effect of Overproduction of XylulokInase In Yeast on Yeast Growth and Xylulose Fermentation}

After we demonstrated that yeast transformants containing the cloned xylulokinase gene could overproduce high levels of xylulokinase activity ( 2 to 260 times more than the parent yeast), we studied the effect on growth and xylulose fermentation of overproduction of xylulokinase in $S$. cerevisiae. These results are shown in Tables 2 and 3 . Our results demonstrated that increasing xylulokinase activity (2- to 260-fold) in $S$. cerevisiae could make the recombinant yeasts $35 \%-50 \%$ faster and ferment xylulose up to 2.5 times faster than the original untransformed parent yeast.

We have shown that genetically engineered yeasts containing the cloned xylulokinase gene can ferment faster than the parent yeast in rich medium (Table 1), and they can also ferment xylulose much better in minimal medium (Table 2). Since most industrial processes use minimal medium for culturing yeast, it is very important that the genctically engineered yeast can also gow and ferment better in such media. 


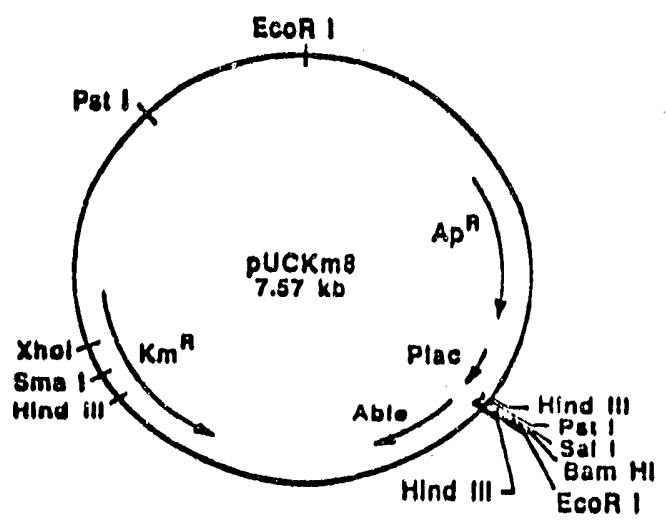

Flgure 6. pUCKm8

\section{Determination of the Stablilty of the Clone XylulokInase Gene DurIng Yeast Xylulose Fermentation}

We have examined the stability of the genetically engineered yeasts containing various constructs of the cloned xylulokinase gene under selective and nonselective conditions.

We found that low copy-number plasmid such as pLSK10 could not be stably maintained in the host LSK1. The general consensus is that high copy-number plasmids will have a better chance to be maintained in a nonselective medium.

LSK1 transformants containing high copy-number plasmid pLSK20 and pLSK25 [LSK1(pLSK20) and LSK1(pLSK25)] were chosen to carry out the stability studies. LSK1(pLSK20) and LSK1(pLSK25) were grown in 5-mL YEPD without G418 and YEPD with $50 \mu \mathrm{g} / \mathrm{mL} \mathrm{G418}$ for $24 \mathrm{~h}$. Cells from each sample $(100 \mathrm{~mL})$ were either plated on YEPD or YEPD with G418 or reinoculated into fresh 5-mL media and cultured overnight at $30^{\circ} \mathrm{C}$. One hundred microliters of the latter was then plated on either YEPD plates or YEPD with $\mathrm{G} 418$ plates.

Approximately 20 colonies from each YEPD or YEPD with G418 were selected and replicated on identical plates. The colonies on each plate were replicated on the indicator plates for the penicillinase assay (Chevallier and Aigle 1979). The procedure is outlined in Figure 8 and the results for LSK1(pLSK20) and LSK1(pLSK25) are shown in Figures 9 and 10, respectively. The results demonstrate that, in the absence of selection pressure, more than 50\%-70\% of the plasmids are lost for both LSK1(pLSK20) and LSK1(pLSK25). 


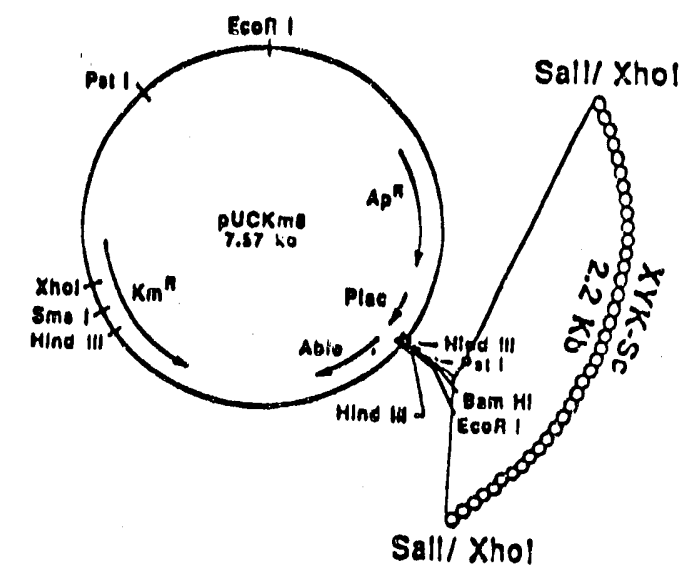

PLSK 20

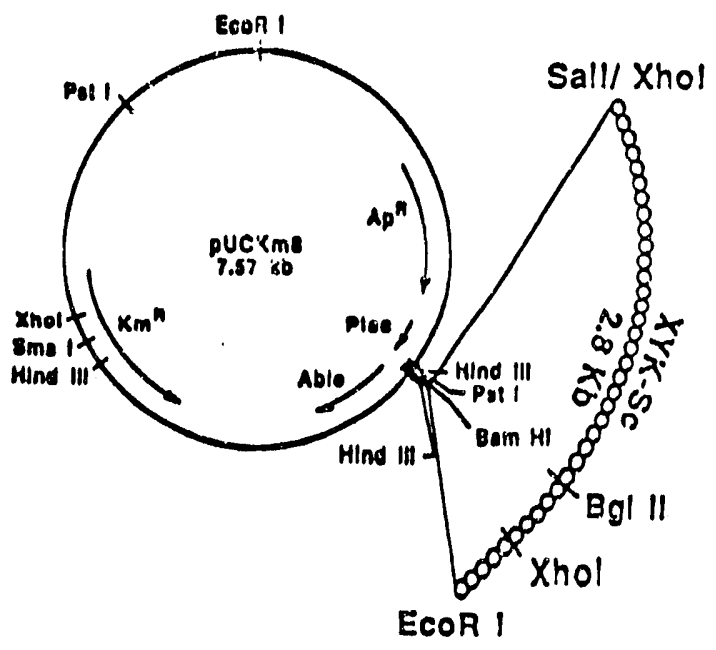

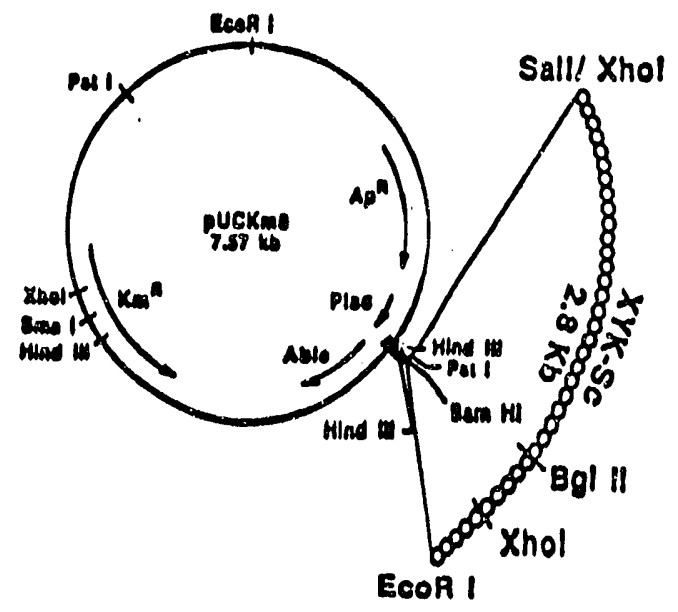

PLSK 25

PLSK 30

Flgure 7. pLSK 20, pLSK 25, pLSK 30 


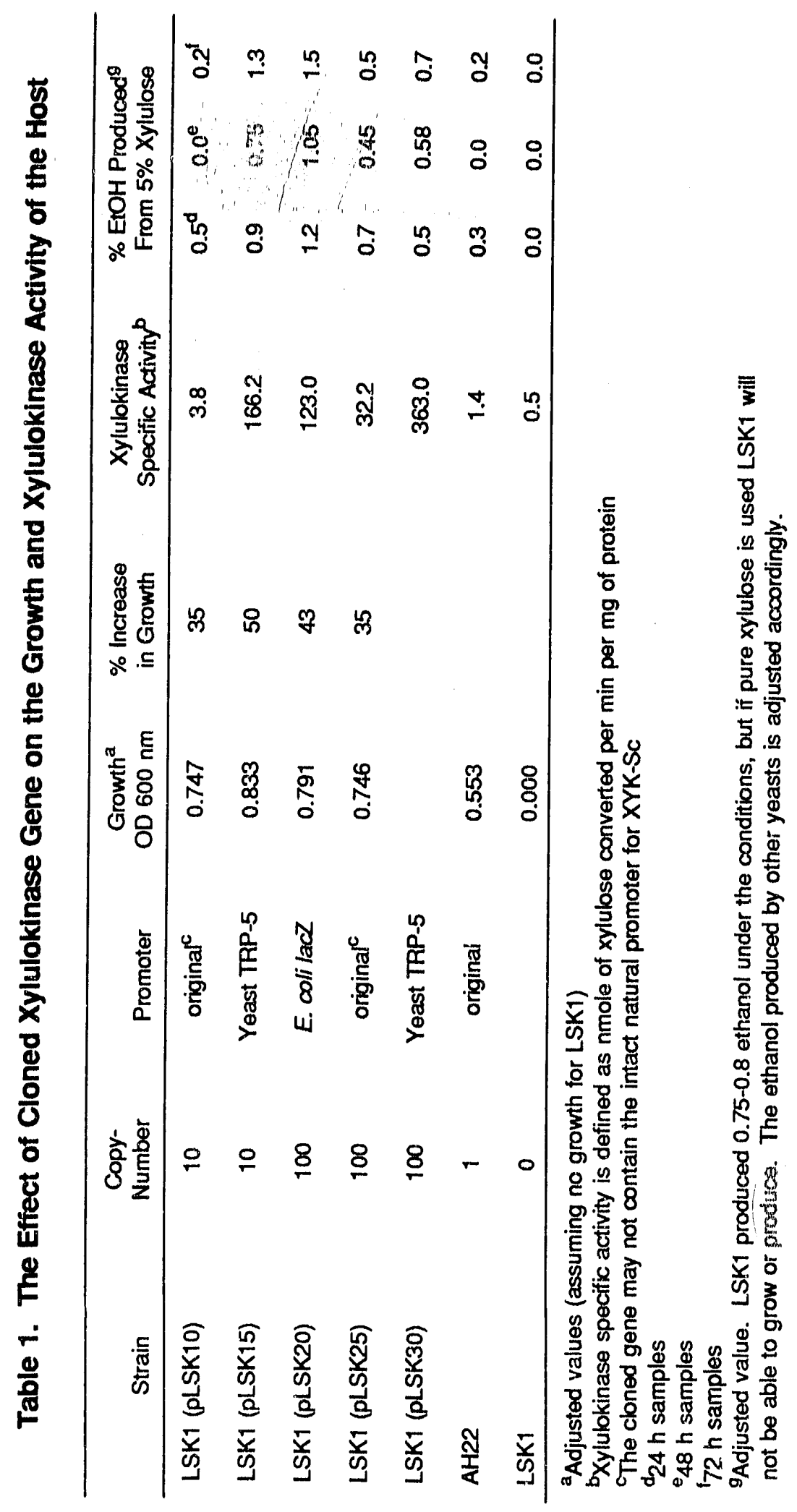




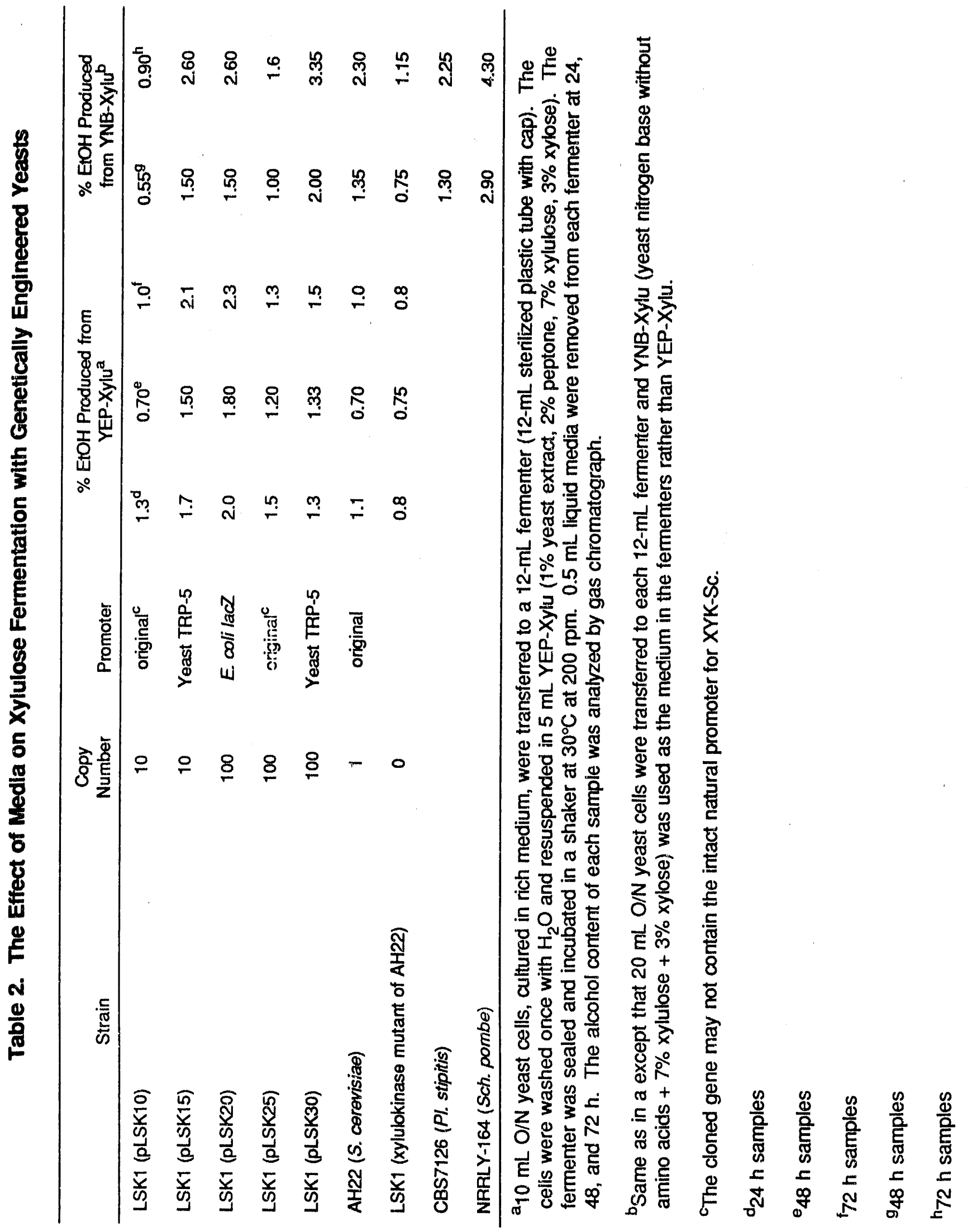


Table 3. Comparison of XylulokInase Actlvlty and Ethanol Production of Varlous Yeasts

\begin{tabular}{lcc}
\hline \multicolumn{1}{c}{ Stain } & $\begin{array}{c}\text { Xylulokinase } \\
\text { Actlvity }\end{array}$ & EtOH \% \\
A OD $540 \mathrm{~nm}$ & $\begin{array}{c}\mathrm{a} \\
\text { Produced }\end{array}$ \\
\hline Candida shehatae & 0.871 & $1.02^{\mathrm{b}}$ \\
Pachysolen tannophilus & 0.084 & $0.42^{\mathrm{c}}$ \\
Schizosaccharomyces pombe & 0.914 & $1.93^{\mathrm{b}}$ \\
Saccharomyces cerevisiae & 0.170 & $0.75^{\mathrm{b}}$ \\
Plchia stipitis & 0.849 & $1.27^{\mathrm{b}}$ \\
\hline
\end{tabular}

aFor xylulokinase assays, cells were grown in YEPD $(5 \mathrm{~mL})$ for 2 days, then washed with water and transferred to YEPGE with xylose (1\% yeast extract, $2 \%$ peptone, $3 \%$ glycerol, $2 \%$ ethanol, and $2 \%$ xylose).

bData obtained from S. Lastick et al.

${ }^{\circ} \mathrm{Calculated}$ from data reported by Tolvola et al.

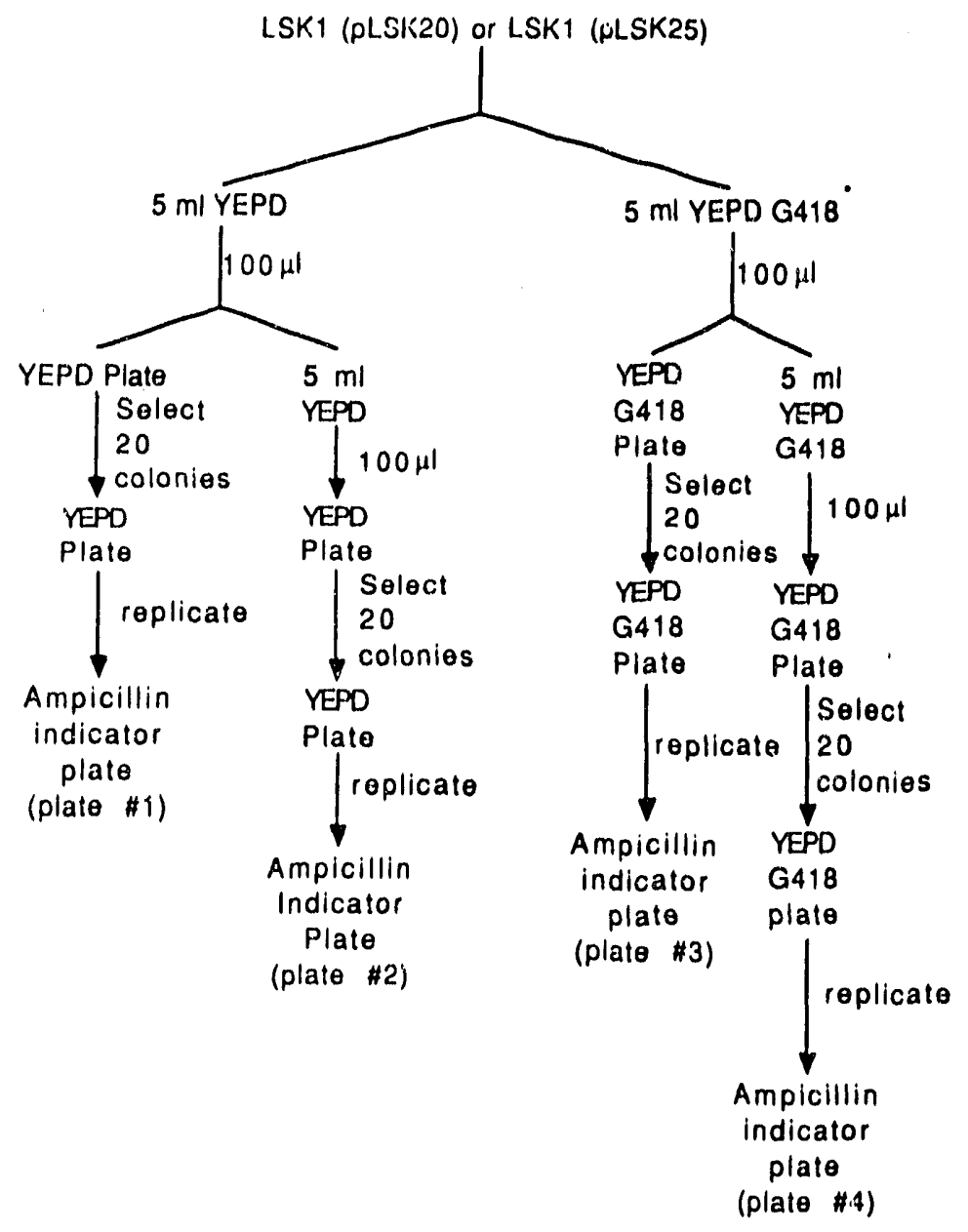

G418 connentratinn: 50 po/m! tor hnth solid and !quid modie.

Flgure 8. G418 concentration: $50 \mu \mathrm{g} / \mathrm{mL}$ for both solld and llquld medla 


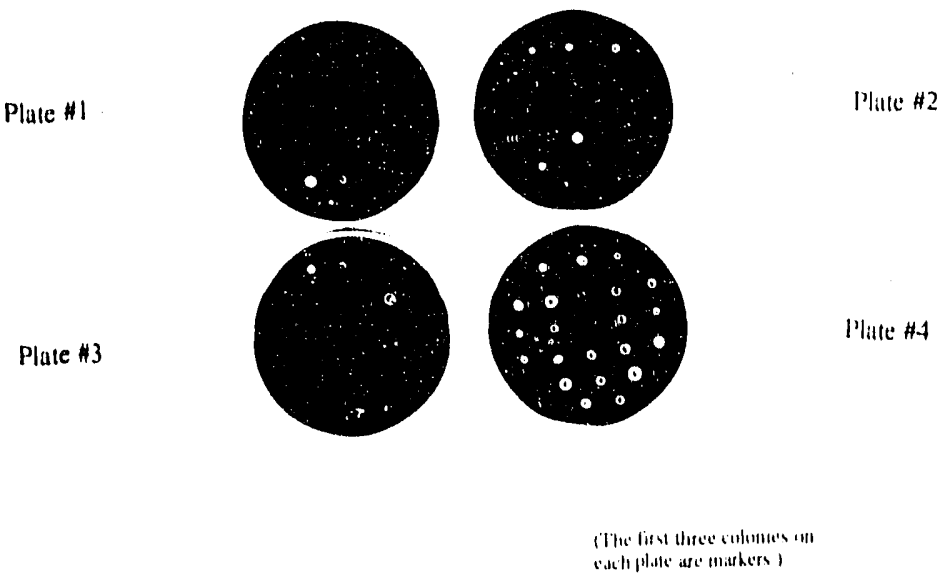

Figure 9. Results for LSK1(pLSK20)

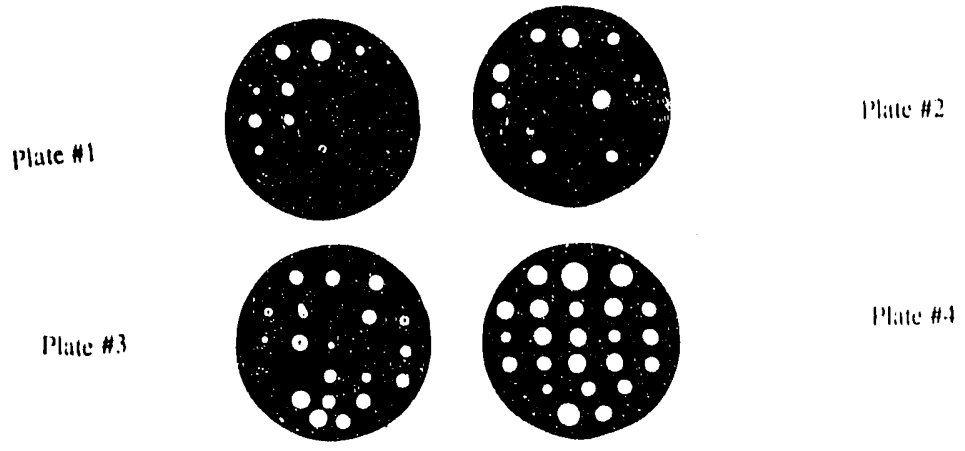

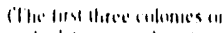

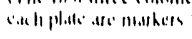

Figure 10. Results for LSK1(pLSK25)

Previousiy, we found that yeast requires the presence of a carbon source to grow even in rich medium (Figure 11). This may imply that xylose and xylulose may serve as a selection agent to maintain xylulokinase gene containing plasmid cloned in a xylulokinase mutant. W'e tested this theory by growing LSK1 (pLSK20) in YEPD + G418 medium and YEP + xylulose medium overnight, and the cells were then plated on the same respective medium. Colonies were replicated on the same medium and then plated on indicator plates and subjected to the penicillinase assay as shown in Figure 12. 'These results incicate that xylulose is as good, or even better, a selective agent for maintaining the plasmid pLSK20 in LSK1 mutant. Hence, as long as the xylulokinase mutant is used as the host to clone genes related to xylose metabolism, the plasmid will be stably maintained without the presence of additional selective agents. 

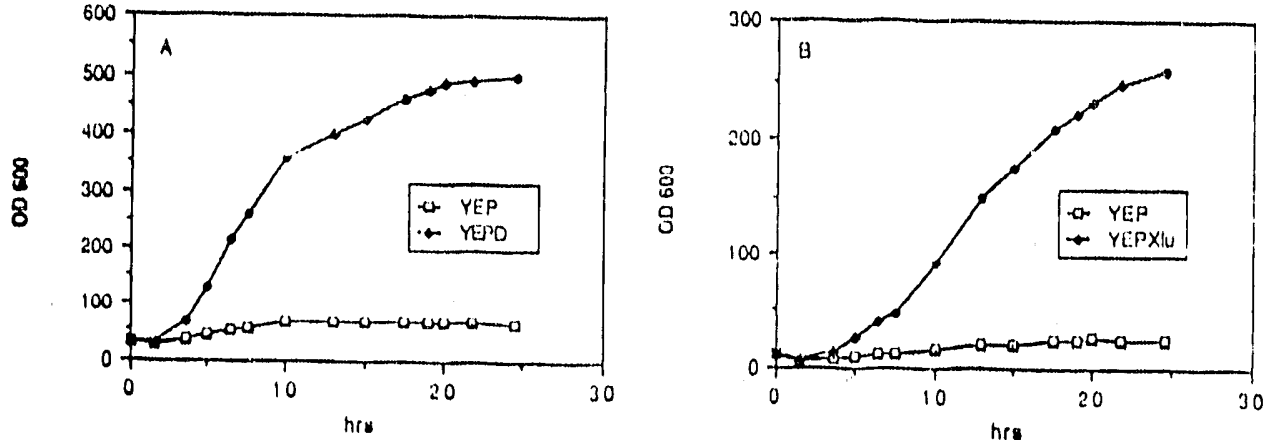

Figure 11. (A) Yeast (S. cerev/slae) AH22 cultured In YEPD (1\% yeast extracts, $2 \%$ peptone, $2 \%$ glucose) or YEP ( $1 \%$ yeast extracts, $2 \%$ peptone)

(B) Yeast AH22 cultured In YEPXIU (1\% yeast extracts, $2 \%$ peptone, $2 \%$ xylulose) or YEP

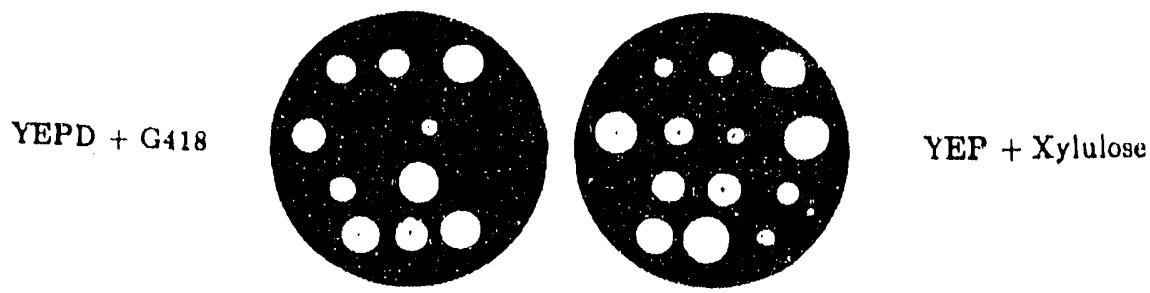

Figure 12. LSK1(pLSK20) 


\section{Sequence Analysls of the Cloned Yeast XylulokInase Gene}

The nucleotide sequences of the yeast xylulokinase gene, together with imore than 200 base pairs of its 5 ' and 3' flanking nucleotide sequences, were analyzed by the dioxy DNA-sequencing technique. In total, 3,440 nucleotides were analyzed (data not included).

\section{Cloning the Xylose Reductase Gene from P. stipltis}

The cloning of the xylose reductase gene from P. stipitis was accomplished by using proper primers and polymerase chain reaction (PCR) techniques to directly synthesize the gene from the Pichia chromosome, as shown in Figure 13. The gene has now been cloned on E. coli plasmid pUC18. The resulting plasmid pUC18-PSXR can be used to resynthesize the xylose reductase gene with PCR by using the same primers. This proves that the gene cloned on pUC18 is the correct xylose reductase gene. Currently, the gene is being subcloned into the high copy-number plasmid pUCKm8 and pUCKm30 for the transformation of S. cerevisiae and Sch. pombe.

In addition to those reported above, we have also developed an improved procedure for the analysis of xylulokinase activity in yeasts. This work has made it possible to accurately analyze the xylulokinase activity in various yeast transformants. We have also studied the expression of xylulokinase gene from $E$. coli and Pachysolen tannophilus in S. cerevisiae. We found that both genes can be expressed in $S$. cerevisiae. The genetic elements controlling the expression of the Pachysolen gene can also function in $S$. cerevisiae. We are also in the process of cloning the xylulokinase gene from Sch. pombe, which contains a strong xylose inducible promoter. Such a gene should be very useful for genetic manipulation of yeas: for improved xylose and xylulose fermentation.

Attempts have also been made to transform $S c h$. pombe with pLSK20 and pLSK30 by using $\mathrm{Km}^{\mathrm{R}}$ as the selective agent. G418 resistant transformants were obtained, but most of the plasmids recovered from the transformants were altered. This indicated that a different approach has to be used for genetic manipulation of Sch. pombe.
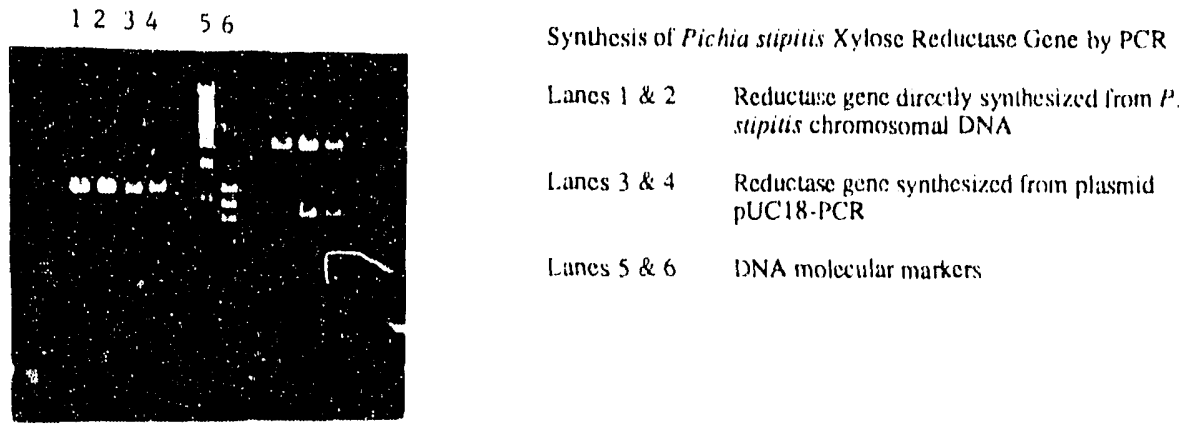

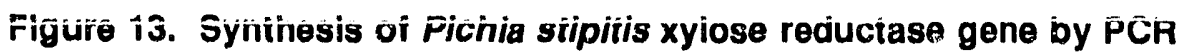




\section{Discussion}

We have demonstrated that yeast xylose and xylulose fermentation can be drastically improved by cloning and overexpression of its xylulokinase gene. Although we have not encountered any technique difficulties that we could not overcome, this work was not a simple cloning task; it was accomplished only after overcoming many difficulties. We decided to outline briefly our early work to explain why we had to undertake some of those tasks. The greatest difficulty for this project, however, was the low funding; we had to stretch our research dollars to make ends meet. Nevertheless, even under such conditions, we have made extraordinary progress and accomplished a great deal. I believe that these excellent results were obtained only because of our strong dedication to renewable energy research, our experience in recombinant DNA research, and our well-equipped and established laboratory for recombinant DNA research (which includes strains, cultures, and various plasmids we have contracted and collected. particularly in yeast research related to alcohol fermentation).

Although yeasts are not yet the ideal microorganisms for xylose fermentation, we have demonstrated that they can be greatly improved by using recombinant DNA techniques. We believe that they can be further improved for fermenting xylose, as we have described below. We hope that increased funding will allow this work to continue.

In this genetic engineering age, enormous research funds have been used for recombinant manipulation of species such as plant and animal cells (which are relatively difficult to manipulate by using recombinant DNA techniques). On the contrary, the techniques for recombinant manipulation has long been established for yeast ( $S$. cerevisiae), and it is a species most suitable for genetic manipulation by recombinant DNA techniques. Hence, it seems there is no excuse not to use this technique to improve yeast that has been so very useful for human society and, in the future, will be even more useful by helping to solve energy and environmental problems.

\section{Future Directions}

Because $S$. cerevisiae is still the microorganism used by industry for fermenting glucose to ethanol, we believe that we should concentrate on recombinant manipulation of this yeast for further improvement of xylose and xylulose fermentation. As we have shown, it is highly possible to make yeast to ferment xylose directly by cloning the xylose reductase gene. Our efforts should first be directed toward accomplishing this task.

It is known that all yeast xylose reductases require either NADPH or both NADPH and NADH as their cofactors, but a NADH-dependent xylose reductase will be much more effective for xylose fermentation. Efforts should also be made to change the coenzyme specificity of this enzyme. This can be accomplished by site-specific mutagenesis of the reductase gene. Since we have already cloned the gene and with the availability of new technology such as site-specific mutagenesis by PCR, this task is not a difficult to accomplish.

Although yeast does contain xylitol dehydrogenase activity, it is still desirable to clone the gene to study its effect on yeast xylose fermentation.

Eventually, the above-listed siudies should also be applied on Sch. pombe to determine which of these two species, Sch. cerevisiae or $S$. pombe, is most effective in fermenting xylose to ethanol. 


\section{Acknowlodgment}

This work was supported by a subcontract from the Solar Energy Research Institute.

\section{Roforences}

Barnett, J. A. 1976. Adv. Carbohydr. Chem. Blochem. 32:125.

Batt, C. A., Carballo, S., Easson, D. D., Jr., Akedo, M., and Sinskey, A. J. 1986. Biotechnol. Bioeng. 28:549-53.

Beach, D., and Nurse, P. 1981. Nature. 290:140-8.

Chevallier, M. R., and Aigle, M. 1979. FEBS Lett. 108(1):179-80.

Chang, S. F., and Ho, N. W. Y. 1988. Appl. Blochem. Blotechnol. 17:313-18.

Deng, X. X., and Ho, N. W. Y. 1990. Appl. Blochem. Blotechnol. 24/25:193-9.

Godson, G. N., and Vapnek, D. 1973. Biochem. Blophys. Acta. 299:516-20.

Gong, C. S., Chen, L. F., Flickinger, M. C., Chiang, L. C., and Tsao, G. T. 1981. Appl. Environ. Microblol. 41:430-6.

Guerry, P., LeBlane, D. J., and Falkow, S. 1979. J. Bacteriol. 116:1064-6.

Hinnen, A., Hicks, J. B., and Fink, G. R. 1978. Proc. Natl. Acad. Sci. USA 75:1929-33.

Ho, N. W. Y. 1989. "Cloning and Over-Expression of the $E$. coll D-Xylose Isomerase Gene in Various Microorganisms." In Bloproducis and Bloprocessses, 181-188. Berlin, Heidelberg: Springer-Verl

Ho, N. W. Y., and Chang, S-F. 1989. Enzyme. Microb. Technol. 11:417-21.

Holmes, D. S., and Quigley, M. 1981. Anal. Blochem. 114:193-7.

Kraft, D., Tardiff, J., Kracter, K. S., and Leinward, L. A., 1988, Biotechniques. 6:545.

Lachke, A. H., and Jeffries, T. W. 1986. Enzyme Microb. Technol. 8:353.

Lastick, S. M. et al. 1986. Biotechnol. Lett. 8(1):1-6.

Norgard, M. J., Keem, K., and Monahan, J. J. 1978. Gene 3:279-292.

Rosenfeld, S. A., Stevis, P. E., and Ho, N. W. Y. 1984. Mol. Gen. Genet. 194:410-15.

Rothstein, R. S. 1983. Methods Enzymol. 101:202-11.

Saiki, R. K. 1990. PCR Protocols. New York: Academic Press, Inc. 
Shamanan, D. R., and Sariderson, M. E. 1979. J. Bacteriol. 139:64-70.

Stevis, P. E., and Ho, N. W. Y. 1985. Enzym. Microbial Tech. pp. 592-6.

Stevis, P. E., and Ho, N. W. Y. 1989. Appl. Blochem. Blotechnol. 20/21:327-34.

Tucker, M. Y., et al. 1988. Biotechnol. Lett. 10:79. 


\title{
Studies in Ethanol Production from Xylose Using Recombinant Escherlchia coll Strains
}

\author{
M. J. Beck \\ Tennessee Valley Authority \\ Muscle Shoals, Alabama 35660
}

\begin{abstract}
Recombinant strains of Escherichia coli were evaluated for production of ethanol from xylose, mixes of sugars such as are recovered from acid hydrolysis of lignocellulosics, and first-stage hydrolyzate of hardwood. Comparisons were made of the $E$. coli strains to xylose-fermenting yeasts and to Saccharomyces cerevisiae for production of ethanol under specified conditions. The extent of microbial activity inhibition by substrate (xylose, sugar mixes, components of acid hydrolyzates) and prod.ct (ethanol) was determined. The extent of microbial activity inhibition by substrate (xylose, sugar mixes, components of acid hydrolyzates) and product (ethanol) was determined. The effects of inoculum concentration on growth, sugar uptake, and ethanol production were studied. A measure of effects of test parameters on microbial viability was incorporated into the experiments.
\end{abstract}

The recombinant strains were studied for effect of $\mathrm{pH}$ range and $\mathrm{pH}$ control on fermentation. Nutrient supply and source were also investigated for effects on fermentation. Cell recycle and exposure to acid hydrolyzates of hardwood were studied under specified conditions.

\section{Introduction}

A series of experiments was carried out in the study of ethanol production from xylose using recombinant Escherichia coli strains to determine effects of $\mathrm{pH}$, added ethanol concentration, sugar concentration, medium compnsition, and inoculum concentration on the production of ethanol from xylose. Recombinant strains were compared to a wild-type strain and to certain yeast strains for production of ethanol. The effects of dilute acid hydrolyzate of hardwood, containing xylose as the fermentable sugar, on ethanol production were observed.

\section{Materials and Methods}

The tests were carried out as batch fermentations in $100-\mathrm{mL}$ volumes in sterile, disposable Erlenmeyer flasks. Conditions of culture included incubation at $30^{\circ} \mathrm{C}$ and agitation at $100 \mathrm{rpm}$. Repeated batch fermentations were conducted in a $16-\mathrm{L}$ fermenter, that can be stciiized in place, at a working volume of $6 \mathrm{~L}$. Cell recycle was accomplished with an ultrafiltration urit. 


\section{Inoculum Preparation}

Yeast species of Saccraromyces cerevisiae (ATCC 24860) and Pachysolen tannophilus (NRRL Y-2640 and eth 2-1 X NO $3-\mathrm{NO}_{3-4}$, Clark et al. 1986), maintained on $\mathrm{YM}$ agar slants, were prepared in media containing $20 \mathrm{~g} / \mathrm{L}$ of the appropriate sugar, glucose or xylose, and $6.7 \mathrm{~g} / \mathrm{L}$, yeast nitrogen base at $\mathrm{pH} 4.5$. The $E$. coli strain S17-1 with pLOI 308-10 (Ingram and Conway 1988) was maintained on LB agar plus glucose. Inocula were prepared in luria broth supplemented with $20 \mathrm{~g} / \mathrm{L}$ glucose or xylose. Strains $D(297)$ (Alterthum and Ingram 1989) and ATCC 11303 vere received in a DMSO suspension from S. Lastick at SERI. They were stored at $-20^{\circ} \mathrm{C}$. A loopful of the culture medium was transferred to LB for inoculum preparation.

\section{Substrate Preparation}

Synthetic media contained xylose or a mixture of sugars as carbon source. Mixed sugars were used in a combination composed of $46 \%$ glucose, $44 \%$ xylose, $4 \%$ mannose, $4 \%$ arabinuse, and $2 \%$ galactose. Carbon source concentrations were varied from 20 to $200 \mathrm{~g} / \mathrm{L}$ sugars. Media were supplemented with one of the three formulations shown in the table. Ethanol was added to the medium in concentrations from 30 to $60 \mathrm{~g} / \mathrm{L}$ in certain tests.

Acid hydrolyzates of the hemicellulosic fraction of hardwood were produced as previously described (Beck and Strickland 1984). The hydrolyzates were overneutralized with calcium oxide to $\mathrm{pH} 9$ at $90^{\circ} \mathrm{C}$, filtered, adjusted to $\mathrm{pH} 7$ with sulfuric acid, and given an addition of $1 \mathrm{~g} / \mathrm{L}$ sodium sulfite. The hydrolyzate composition used in repeated-batch fermentations was $5 \mathrm{~g} / \mathrm{L}$ glucose, $15 \mathrm{~g} / \mathrm{L}$ xylose, $3 \mathrm{~g} / \mathrm{L}$ mannose, $1 \mathrm{~g} / \mathrm{L}$ arabinose, $1 \mathrm{~g} / \mathrm{L}$ galactose, and $8 \mathrm{~g} / \mathrm{L}$ acetic acid. The hydrolyzate was supplemented with the laboratory formulation (Table 1).

\section{Analytlcal}

Biomass production was estimated by gravimetric determinations of cell mass, monitoring of absorbance at $550 \mathrm{~nm}$, and determining viable populations by pour plate methods. Sugars and organic components were determined by high-pelformance liquid chromatographic (HPLC) methods.

\section{Results and Discussion}

\section{Comparlson of the Performance of a Recomblnant Strain to that of Other Microbes}

The performance of $E$. coli strain S17-1 with pLOI 308.10 was compared to that of other microbes in media containing xylose or mixed sugars as cartion source. The mix of sugars represented the composition of sugars recovered from hardwood by two-stage, dilute acid hydrolysis. The laboratory nutrient formulation was used to supplement the media. There was no $\mathrm{pH}$ control. Comparisons were made of batch fermentations and of coculture and sequential fermentation schemes. Inoculum levels were in the range of 0.1 to $0.2 \mathrm{~g} / \mathrm{L}$ cell mass.

Ethanol reached its highest concentration in 5 days with the $P$. tannophilus strains and then decreased ( $50 \mathrm{~g} / \mathrm{L}$ xylose). The $E$. coli strain lagged during the first 7 days, but at 10 days had reached about the same concentration of ethanol as the $P$. tannophilus strains. Therefore, in the fermentation of $50 \mathrm{~g} / \mathrm{L}$ xylose, the recombinant $E$. coli achieved an ethanol concentration and a yield coefficient comparable to those of the xylose-fermenting yeast strains. 
Table 1. Medla Formulatlons

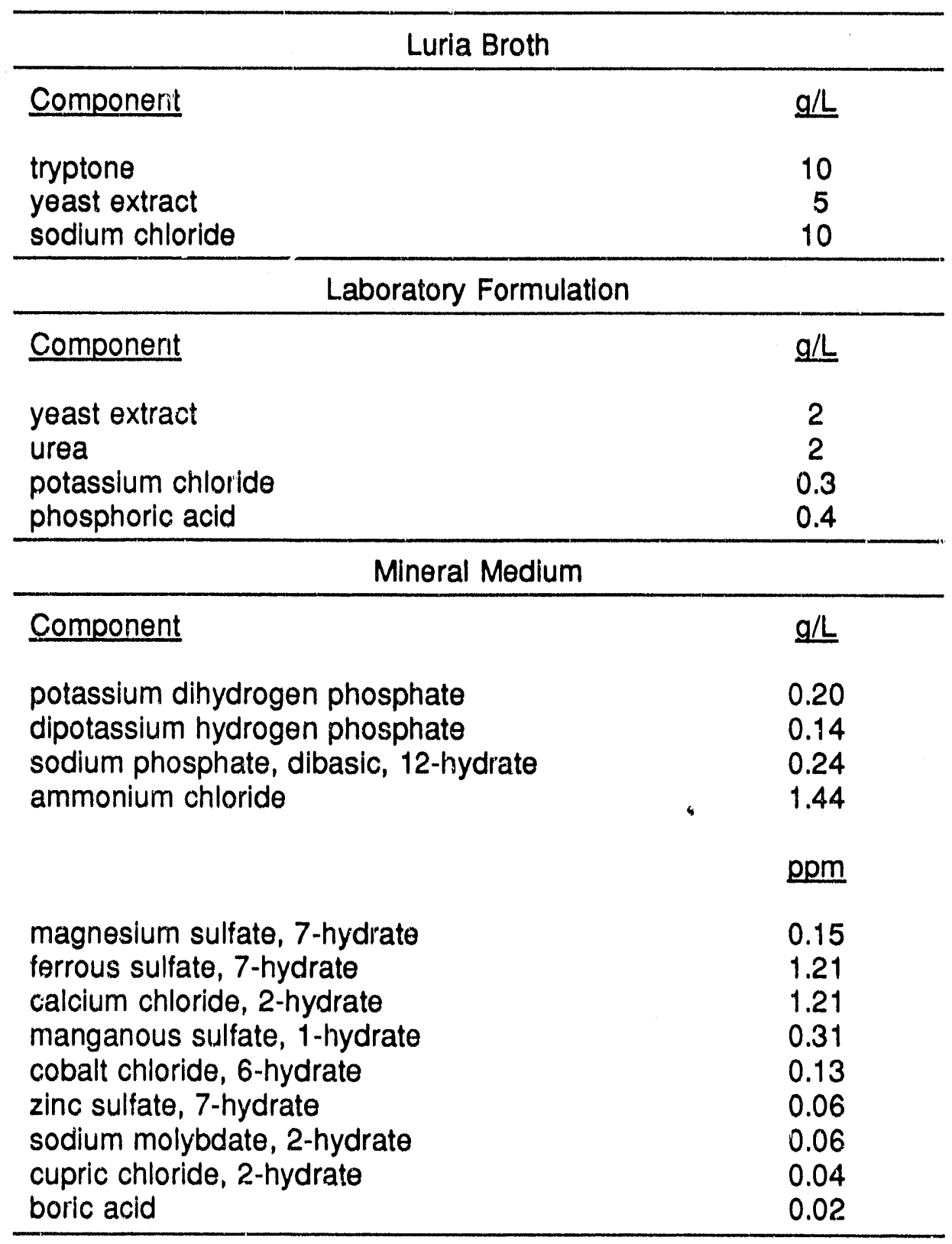

A lag observed with $E$. coli at $50 \mathrm{~g} / \mathrm{L}$ explains the lesser yields of ethanol by this strain at 125 and $200 \mathrm{~g} / \mathrm{L}$ xylose, in comparisnn to the $P$. tannophilus strains. If the fermentations had been held for an extended time, the $E$. coli yield could have equaled that of the other strains because the rate of production was similar among the strains, after $E$. coli recovered from the lag. The yield coefficient and ethanol produced per unit xylose consumed by the recombinant was similar to those of the xylose-fermenting strains.

The time course of the fermentation of $50 \mathrm{~g} / \mathrm{L}$ mixed sugars showed that $E$. coli lagged behind the $P$. tannophilus strains in glucos: as well as xylose use. Similar occurrences were seen at 125 and 200 xylose. How zver, E. coli reached a level of ethanol concentration silimar to that $P$. tannophilus 
at 10 days. The recombinant and the xylose fermenters were able to produce additional ethanol to that produced by $S$. cerevisiae. The calculation of ethanol per unit sugars fed is greater with the recombinant and the xylose fermenters in comparison to $S$. cerevisiae, confirming ethanol from xylose by the former.

Results of the coculture and sequential fermentation schemes were simlar to, but in most cases not as good as, those of batch fermentations of the mixed sugars. No advantage was achieved from combinations of the glucose fermenter, $S$. cerevisiae, and $E$. coli or either of the $P$. tannophilus strains for ethanol production.

The conditions of the fermentations in this series of tests were those that favored the xylose-fermenting yeasts. Yet $E$. coli performed in a remarkable fashion, recovering from initial lags in sugar usage and ethanol production, to provide yields of ethanol similar to those of the xylose-fermenting yeasts.

\section{pH Effects}

The effects of $\mathrm{pH}$ on $E$. coli strain S17-1 with pLOI 308-10 were determined in mixed sugars and dilute acid hydrolyzate. The laboratory formulation was used as the nutrient source. The $\mathrm{pH}$ was controlled in mixed sugar fermentations by frequent adjustment with sodium hydroxide. The $\mathrm{pH}$ was not controlled in the well-buffered hydrolyzate fermentations.

The effect of $\mathrm{p}:$ was dramatic with hydrolyzate as substrate. Ethanol yield was best at $\mathrm{pH} 7$. At $\mathrm{pH} 7$, $27 \%$ of the available xylose was consumed, and all the available glucose was consumed. The yield coefficient was $0.45 \mathrm{~g}$ ethanol per gram of xylose consumed. A coefficient of $0.24 \mathrm{~g}$ ethanol per gram of xylose fed was calculated. Sugar consumption was completely inhibited in the hydrolyzate at pH 5.5 and 6. Xylose-fermenting yeasts have typically been applied to such hydrolyzates at pH 5.5 to keep down contamination. This is the optimum $\mathrm{pH}$ for ethanol production using yeasts, although they perform in a satisfactory way at somewhat higher $\mathrm{pH}$ values.

With mixed sugars, increasing the $\mathrm{pH}$ from 5 to 7 caused an increase in the ethanol concentration. The consumption of xylose was improved with increased pHI over the range of 5,6 , and 7 . However, the yield coefficient actually decreased with increased $\mathrm{pH}$. It can be reasoned that with increased use of xylose, there is a less efficient conversion of the xylose to ethanol. At $200 \mathrm{~g} / \mathrm{L}$ sugars, in contrast to 50 and $125 \mathrm{~g} / \mathrm{L}$. sugars, all of the glucose was not consumed in 10 days. In the fermentation of $200 \mathrm{~g} / \mathrm{L}$ sugars, a slightly greater rate of nutrients was supplied than for the 50 and $125 \mathrm{~g} / \mathrm{L}$ sugars fermentations. In the $\mathrm{pH} 7$ fermentations of 50 and $125 \mathrm{~g} / \mathrm{L}$ sugars, glucose was used at a faster rate than xylose, in contrast to the fermentation of $200 \mathrm{~g} / \mathrm{L}$ sugar. In $200 \mathrm{~g} / \mathrm{L}$ sugars, there was simultaneous use of glucose and xylose. This phenomenon may have been the result of insufficient nutrient supplementation. This theory was not investigated fuither.

In summary, the results show that increasing $\mathrm{pH}$ in the range from 5 to 7 has a positive effect on xylose utilization and ethanol production. However, efficiency of conversion of sugars, xylose in particular, to ethanol suffers from the improvement.

\section{Effect of Nutrlent Formulation on Ethanol Production and Sugar Consumption}

Similar initial growth rates were achieved by the recombinant using luria brcth and the laboratory formulation as supplements. A similar initial growth rate was achieved by the wild type in the laboratory formulation. 
The recombinant strain showed a better overall growth response, as measured by viable cell counts, to all the nutrient formulations than did the wild type. Luria broth provided the best growth response for the recombinant. The laboratory formulation provided the best growth response for the wild type.

The yield of ethanol per unit of xylose consumed by $D(297)$ was best with luria broth as nutrient. The ratio of ethanol produced to sugars consumed was greatest with luria broth, the ethanol concentration was greatest with luria broth in comparison to the other two nutrient sources, and all $x y$ lose was used. With the laboratory formulation as nutrient, about $45 \%$ of the xylose was consumed by $D(297)$.

Analyses were made of acetic, lactic, and succinic acids. No lactic acid was produced using $D(297)$ with any nutrient formulation. The ratios of the quantities of products formed using the wild type, in both luria broth and the laboratory formulation, were similar. This was also the case with the recombinant. It can be concluded that there was no impact on the metabolic pathways resulting from the use of a particular nutrient supplementation.

The fate of the carbon from xylose was estimated. More carbon was accounied $f(r$ in fermentations using the recombinant than in those using the wild type. Ethanol was the predominant product with the recombinant and represents a substantial amount of the carbon accumulated in the products determined. Luria broth apparently increased the rate of fermentation, although it showed no benefit for diverting carbon to ethanol as product. No test was made to determine whether ethanol could be produced from any of the nutrient sources without added carbohydrate.

\section{Effect of Xylose Concentration on Growth and Ethanol Production}

Tests were made using $\mathrm{D}(297)$ with the laboratory formulation for the nutrient supply and varying xylose concentration from 20 to $100 \mathrm{~g} / \mathrm{L}$. Xylose concentrations in this range had no effect on the initial growth rate or on the initial specific ethanol productivity. The highest ethanol concentrations achieved were similar, over the 10-day incubation period, for each xylose concentration fermented. The initial xylose uptake rate increased with increase in xylose concentration from 20 up to $80 \mathrm{~g} / \mathrm{L}$. Ethanol was the only produci evaluated in the tests. It can be concluded from previous results that organic acids account for a portion of the carbon from xylose. No obvious effects of substrate or product accumulation on metabolism were noted in the range of xylose concentrations applied, 20 to $100 \mathrm{~g} / \mathrm{L}$.

\section{Effect of Added Ethanol on Growth and Ethanol Production}

Additions of ethanol of 21,43 , and $58 \mathrm{~g} / \mathrm{L}$ were made to fermentations using $\mathrm{D}(297)$ in $20 \mathrm{~g} / \mathrm{L}$ xylose and the laboratory formulation of nutrients. A similar rate of initial growth in $21 \mathrm{~g} / \mathrm{L}$ ethanol in comparison to the control with no added ethanol resulted. The ethanol production rate was similar for the control and the fermentation with $21 \mathrm{~g} / \mathrm{L}$ ethanol added. Cell death occurred during the first $8 \mathrm{~h}$ of incubation with the additions of 43 and $58 \mathrm{~g} / \mathrm{L}$ ethanol. The rate of death of the population increased slightly as the concentration of added ethanol increased from $43 \mathrm{~g} / \mathrm{L}$ to $58 \mathrm{~g} / \mathrm{L}$ added ethanol.

The data are insufficient for the determination of concentrations of added ethanol that are completely inhibitory to growth, xylose uptake, or ethanol production. However, the concentration that completely inhibits growth lies between 21 and $43 \mathrm{~g} / \mathrm{L}$ added ethanol. 


\section{Effects of Inoculum Level on Growth and Ethanol Production}

Tests were made using $\mathrm{D}(297)$ with the laboratory formulation for nutrient supply and either $20 \mathrm{~g} / \mathrm{L}$ xylose or a hemicellulosic hydrolyzate of hardwood as carbon source. The xylose concentration in the hydrolyzate was $28 \mathrm{~g} / \mathrm{L}$.

The initial growth and ethanol production rates and the xylose uptake rate were decreased as the inoculum level increased. These results support the general conclusion that smaller sized populations are more efficient at metabolism than larger populations because of a number of factors. However, as has been shown to be the case, larger populations can achieve greater ethanol concentrations than smaller ones. The yield of $7 \mathrm{~g} / \mathrm{L}$ ethanol reflects a yield coefficient of $0.50 \mathrm{~g}$ ethanol per gram of xylose consumed or $0.39 \mathrm{~g}$ ethanol per gram of xylose fed. The $10 \mathrm{x}$ inoculum is comparable to the inoculum levels used in other tests within this report, and the rate and yield data agree well with data of other tests.

The fermentation results from the hemicellulosic hydrolyzate using $D(297)$ were poor. In a previous section dealing with $\mathrm{pH}$ effects, it was shown that good results have been achieved with hydrolyzate using S17-1 with pLOI 308-10. These two recombinant strains have not been compared in the same testing regime. Therefore, this does not eliminate the possibility that the particular hydrolyzate used with $\mathrm{D}(297)$ was in some way more toxic than that used with S17-1 with pLOI 308-10. The differences between yields from $20 \mathrm{~g} / \mathrm{L}$ xylose and the $28 \mathrm{~g} / \mathrm{L}$ xylose contained in the hydrolyzate using $\mathrm{D}(297)$ point to the difficulties that can be encountered with harsh substrates.

\section{Repeated Batch Fermentations of Hemlcelluloslc Hydrolyzates}

The repeated baich fermentations were carried out over a total duration of 43 days. The laboratory formulation was used as the nutrient source. The first day of the process was used for inoculum preparation.

The fermentations were conducted in cycles. Twelve cycles of substrate addition, fermentation, and harvest were conducted. The first three cycles lasted 5 days each, the next three lasted 4 days, the next three lasted 3 days, and the last three lasted 2 days. The strain S17 with pLOI 308-10 was concentrated at the end of each cycle, and the bacteria were used as the inoculum for the subsequent cycle. The hydrolyzate feed concentration was $25 \mathrm{~g} / \mathrm{L}$ sugars, with about $60 \%$ of the sugars being xylose. The $\mathrm{pH}$ was controlled at 7. Samples were taken at regular intervals for analyses. Acetic and lactic acids were evaluated.

The ethanol concentration rose to as much as $6.2 \mathrm{~g} / \mathrm{L}$. The best conversion efficiency reached was $0.35 \mathrm{~g}$ ethanol per gram of sugars consumed. The ratio of ethanol produced to sugars fed reached as high as $0.27 \mathrm{~g} / \mathrm{g}$. As much as $11.3 \mathrm{~g} / \mathrm{L}$ acetic acid was meisurcd is well as $3.9 \mathrm{~g} / \mathrm{L}$ lactic acid during the 12 -cycle duration.

The product yields from each cycle was calculated and an efficiency of carbon recovery estimated. In the particular 3-day cycle with the best ethanol yield, $69 \%$ of the carbon was accounted for by the accumulation of ethanol, acetic acid, and lactic acid. In the 2-day cycle with the best ethanol yield, 79\% of the carbon was accounted for by the three products. During the fermentation course, $167 \mathrm{~g}$ of sodium hydroxide had been used in $\mathrm{pH}$ control for the fermentation producing $260 \mathrm{~g}$ ethanol, $66 \mathrm{~g}$ acetic acid, and $55 \mathrm{~g}$ lactic acid. 


\section{Conclusions}

The recombinant strains of $E$. coli in these tests showed several characteristics that make them more favorable for use in xylose fermentations than the xylose-fermenting yeasts. One favorable characteristic was tolerance to xylose. Concentrations, in the range of 20 to $100 \mathrm{~g} / \mathrm{L}$, had no adverse effects on growth or the production of ethanol by $\mathrm{D}(297)$. Yeasts exhibit a decreased yield and productivity of ethanol as the concentration of xylose is increased (Skoog and Hahn-Hagerdal 1988). The strain S17-1 with pLOI 308-10 was tolerant of a hemicellulosic hydrolyzate of hardwood. No problem was experienced with the acetic acid concentration encountered in the hydrolyzate. Many of the xylose-fermenting yeasts are sensitive to such acetic acid concentrations (Beck 1986).

On the other hand, the rates of growth and ethanol production that resulted from these tests were similar to those reported for other xylose-fermenting organisms (du Preez and van der Walt 1983; Delegenes et al. 1986; du Preez and Prior 1985). Strain D(297) was rather sensitive to added ethanol, suggesting that this would be a deterrent to obtaining relatively high ethanol concentrations.

Such a characteristic suggests the need for ethanol separation techniques, should the strain be considered for an ethanol-processing scheme. The apparent improvement in ethanol productivity and yield brought about by the use of the nutrient source, luria broth, in comparison to the laboratory formulation, suggests that similar sources of nutrients would need to be sought at a lower cost. The need for pH control could increase costs of applying the recombinant strains to production of ethanol from xylose.

In conclusion, the characteristics that have been demonstrated to belong to the recombinant $E$. coli strains are similar to those of the xylose-fermenting yeasts and do not represent a substantial improvement over the latter.

\section{References}

Alterthum, F., and Ingram, L. O. 1989. Appl. Environ. Microbiol. 55:1943-48.

Beck, M. J. 1986. Biotechnol. Bioeng. Symp. No. 17:617-27.

Beck, M. J., and Strickland, R. C. 1984. Biomass 6:101-10.

Clark, T., Wedlock, N., and James, A. P. 1986. Biotechnol. Lett. 6:801-6.

Delegenes, J. P., Moletta, R., and Navarro, J. M. 1986. Biotechnol. Lett. 8:897-900.

du Preez, J. C., and Prior, BA. 1985. Blotechnol. Lett. 7:241-46.

de Preez, J. C., and van der Walt, J. P. 1983. Biotechnol. Lett. 5:357-62.

Ingram, L. O., and Conway, T. 1988. Appl. Environ. Microbiol. 54:397-404.

Skoog, K., and Hahn-Hagerdal, B. 1988. Enzyme Microb. Technol. 10:66-80. 


\section{Llgnin Conversion Research}


TP-3996

\title{
Lignin Conversion - An Overvlew
}

\author{
D. K. Johnson and H. L. Chum \\ Chemical Conversion Research 3ranch \\ Fuels and Chemicals \\ Research and Engineering Division \\ Solar Energy Research Institute \\ Golden, Colorado 80401
}

\begin{abstract}
Lignins are complex amorphous polymers that contain $30 \%-40 \%$ of the heat content of woody feedstocks. Biomass pretreatment alters the chemical composition and properties of the isolated lignin. The aromatic complex nature of lignins suggests that they can be converted into low-molecular-weight compounds, which could be excellent precursors for fuels or chemicals. Various approaches could be used to effect this conversion, including hydrotreating or pyrolysis. Mild hydrodeoxygenation and dealkylation can give a mixture of substituted phenolic compounds and hydrocarbons as main products. The phenolics can be converted to methyl or ethyl aryl ethers (MAE or EAE). The mixture of alkyl aryl ethers and hydrocarbons would have a high value as a low-vapor-pressure octane enhancer that is fully compatible with gasoline. Because of the complexity of lignins, a strategy to produce mixtures of acceptable products has been adopted to minimize the separation costs that have plagued lignin utilization for single products.

An integral part of lignin conversion into liquid fuels is lignin characterization. Thiough this activity, key chemical structures present in lignin are identified. The goal of the characterization studies is to then identify the occurrence of these structures in feedstocks and to follow their modification during pretreatment and subsequent processing. Such studies will help to determine how lignin may most efficiently be converted into a liquid fuel within the overall process of converting biomass to ethanol.
\end{abstract}

\section{Introduction}

Lignins are complex amorphous phenolic polymers that cannot be fermented to ethanol. They are present in higher plants to provide a vascular system for mechanical reinforcement and conduction of solutes over extended distances. Lignins contribute to the storage of energy in plants and improve their resistance to changes in humidity, biodegradation, and atmospheric degradation, because they are very good antioxidizing agents. Lignins are present in amounts ranging from $18 \%$ to $33 \%$ by weight in various wood 
species. Lower lignin contents are associated with annual plants in which the need to provide long-term resistance to biodegradation is not as high (Adler 1977; Sarkanen and Ludwig 1971; Fengel and Wegener 1984; Sjöström 1981; Sarkanen 1975).

Lignin is the biomass component of highest specific heat content $(11,300 \mathrm{Btu} / \mathrm{lb}$ compared to $7,400 \mathrm{Btu} / \mathrm{b}$ for cellulose), accounting for about $30 \%-40 \%$ of the overall wood heat content. For herbaceous species, lignin accounts for 10\%-20\% of the total h sat content. In an integrated ethanol plant, lignin could be used as the source of process fuel, giving it a vilue of about $\$ 0.025 / \mathrm{lb}$ (Bergeron and Hinman 1989). This task studies the utilization of lignin for higher value applications that would contribute more positively to the overall economics of biomass conversion to liquid fuels.

Lignin is a high-molecular-weight natural product formed initially by the enzymatic dehydrogenation of p-hydroxycinnamyl alcohols, which yields resonance-stabilized phenoxy radicals. Polymeric lignin is formed by free-radical coupling of the various resonance hybrids in a statistical manner resulting in a polymer containing a variety of inter-unit linkages. The types of bonds that can result are mostly ether linkages between the phenolic $\mathrm{O}$ and one of the side-chain $\mathrm{Cs}(\alpha-\mathrm{O}-4$ or $\beta-0-4)$, or C-C linkages between aliphatic and aromatic Cs ( $\beta-5)$ or two aromatic Cs (5-5). Two main types of lignins are the guaiacyl lignins, in which alcohol precursors with one methoxy substituent predominate (characteristic of softwoods); and the guaiacyl-syringyl lignins, in which both monomethoxy- and dimethoxy-substituted alcohols are present. Hardwoods and grasses contain guaiacyl-syringyl lignins and also acids, such as phydroxy benzoic acid, esterified to the lignin macromolecular core (Sarkanen and Ludwig 1971).

The use of lignin as process fuel is the main utilization route for the conventional kraft industry. Of the 20 million tons of kraft lignins and 1.5 million tons of lignosulfonates (produced from sulfite pulping) roughly 35,000 tons of kraft lignins and 700,000 tons of lignosulfonates are consumed worldwide in a variety of products (1980 data from $\operatorname{Lin} 1983$ ). These products cover a wide range of applications such as animal feed binding, water treatment, oil well drilling, soil stabilization, concrete additives, dyestuff dispersant, asphalt emulsion, protein precipitation, gypsum bcard additives, metal refining aids, and others. The key to successful lignin utilization is a better understanding of the relationship between lignin's structure, properties, and performance. Inroads into understanding this relationship are a goal of this task. An estimation into the potential for lignin utilization by the year 2000 demonstrated that if fuel ethanol production was in the billions of gallons, lignin markets overall would not be saturated (Chum et al. 1985). The markets for low-molecular-weight phenols and liquid fuels have been estimated to be very large (Gaines and Karpuk 1987).

A recent report has indicated another large-scale use of lignins could be for enhanced oil recovery with a market of about 500,000 tons/yr (Whittington et al. 1990). Only kraft lignins and lignosulfonates have so far been tested, but biomass-to-ethanol lignins should also be effective. The lignins were hydrogenated to give a substantially deoxygenated and demethoxylated product, which after sulfonation gave a surfactant comparable to petroleum-derived surfactants. The lignin-derived surfactants should be much cheaper. If they can be produced for $40 \phi / 1 \mathrm{~b}$, they could be used to recover oil at about $\$ 25 / \mathrm{barrel}$, compared to the $\$ 35-\$ 40 /$ barrel necessary for petroleum-derived surfactants to be cost effective.

Lignins are chemically similar to the high-octane components already found in gasoline, but must be depolymerized to monomeric units and then be hydrodeoxygenated and dealkylated before they are compatible with petroleum-derived fuels. This conversion can be accomplished by several methods, such as hydrotreating or pyrolysis. Mild hydrotreating can be used to convert lignin into a mixture of phenolic compounds and hydrocarbons (Gendler et al. 1983). After conversion of the phenols to methyl or ethyl aryl ethers (MAE or EAE), this mixture could be used as a high-octane additive for gasoline or ethanol. MAE have already been fleet tested and are accepted as octane enhancers that are fully compatible with gasoline (Singerman 1980). The MAE or EAE are oxygenated ethers that are similar to MTBE, which 
is currently added to gasoline to increase octane and decrease CO emissions. MAE and EAE should have similar pollution-control properties. The proposed lignin-derived fuel additive has another advantage in that it would have a lower vapor pressure than methanol, ethanol, or the ether octane enhancers currently being used. Use of the lignin-derived additive would therefore allow refiners to add more of the volatile inexpensive butanes into gasoline. In addition, refineries could reduce cracking severity, consequently improving refinery energy utilization and gasoline yiclds from crude oil (Van Tassel 1985). In the near future, it is important that more fuel testing with a lignin-derived fuel additive be performed so that the benefits and problems of using these alkyl aryl ethers with gasoline and ethanol can be definitively established.

Hydrotreating lignin to a high-octane fuel additive has focused on the development of catalysts specifically designed for use with lignins-catalysts that give the maximum yields of phenols that can be converted to $\mathrm{MAE}$ or EAE. Initially, traditional hydrotreating catalysts developed for the petroleum industry were used. These are sulfided metals such as molybdenum, nickel, and cobalt dispersed on high surface area $\gamma$-alumina. The cracking activity of the support was later augmented by increasing its acidity, accomplished by addition of phosphate (Ratcliff et al. 1988), or silica. This was designed to result in lower molecular weight products by dealkylation. The metals impregnated on the supports have also been changed to unsulfided metals with higher hydrogenation activity, such as platinum, which quench the alkyl fragments formed in dealkylation, preventing the reversal of the dealkylation reaction and the formation of higher molecular weight dialkyl phenolics. These catalysts can be used with the lignins from biomassto-ethanol processes because these lignins contain almost no sulfur. Another advantage of using high hydrogenation activity catalysts is that much lower hydrogen pressures can be used which would result in significant savings in the operation of a lignin hydrotreating plant. Catalyst activity testing is initially performed using lignin model compounds in a packed bed reactor. The activity of selected cata ysts with lignin is then tested in a stirred autoclave reactor, set up, and operated to maximize the yield of lowmolecular-weight phenols and hydrocarbons.

Chemically, lignin is very reactive. It is easily oxidizable and can undergo a variety of acid- and basedcatalyzed hydrolysis reactions. Consequently, attempts to remove lignin from whole biomass induces substantial chemical changes. Understanding these chemical reactions and characterizing the resulting polymer is essential for the efficient utilization of lignin in liquid fuel and polymeric applications. This program attempts to correlate the chemical changes that oscur when using relevant biomass feedstocks and pretreatments that render the cellulosic residue amenable to enzymatic hydrolysis. The methods of biomass and lignin characterization available in the literature were primarily developed for the feedstocks and lignins involved in commercial processes, such as pulping (kraft or sulfite). A biomass-to-ethanol process cculd use much different feedstocks including short-rotation crops, herbaceous plants, and agricultural residues, as well as hardwoods and softwoods. The typically acidic biomass-to-ethanol pretreatment processes can produce much lower molecuiar weight polymers than the commercial pulping processes. Consequently, the methods of analyses needed for biomass-to-ethanol feedstocks and lignins are significantly different. This program has developed and applied chemical and spectroscopic techniques to the analysis of relevant feedstocks and lignins coming from pretreatments such as dilute acid hydrolysis, steam explosion, and organosolv, that could be used in a biomass-to-cthanol process (Chum 1989). Two worldwide round robins are being co-ordinated through SERI to firmly establish the techniques that will be used to analyze both the types of feedstocks and lignins likely to be involved in biomass-to-ethanol processes.

There is aiso a need to cievelop more rapid methods of analysis. By combining spectroscopic and data correlation techniques, such as partial least squares regression, it should be possible to simultaneously quantify, with quantitative or semi-quantitative results (depending on how broad a range of samples are included in the data set), several different functional groups in lignins. These techniques are being developed so that a minimum of sample preparation is needed resulting in considerable time savings over 
traditional techniques. This will provide essential guidance to the genetics and hybridization program for the design of the best feedstocks for the various conversion processes.

\section{References}

Adler, E. 1977. Wood Sci. Technol. 11:169-218.

Bergeron, P. W., and Hinman, N. D. 1989. "Technical and Economic Analysis of Lignin Conversion to Methyl Aryl Ethers," Proceedings of Ethanol from Biomass Annual Review Meeting, Golden, CO: Solar Energy Research Institute.

Chum, H. L., Johnson, D. K., Ratcliff, M., Black, S., Schroeder, H. A., and Wallace, K. 1985. Proceedings International Symposium on Wood and Pulping Chemistry, 223-225. Vancouver, Canada.

Chum, H. L. 1989. "Lignin Characterization." Proceedings of the Ethanol from Biomass Annual Review Meeting. Golden, CO: Solar Energy Research Institute.

Fengel, D., and Wegener, G. 1984. Wood - Chemistry, Ultrastructure, Reactions. New York: Walter de Gruyter.

Gaines, L. L., and Karpuk, M. E. 1987. "Fermentation of Lignocellulosic Feedstocks: Product Markets and Values." Energy from Biomass Wastes X, ed. D. L. Klass, 1395-1416. London: Elsevier Applied Publishers.

Gendler, J. L., Huibers, D. T. A., and Parkhurst, H. J. 1983. "Hydroxy Aromatics from Lignin Hydrogenolysis," Wood \& Agr. Residues ed. E. J. Soltes, 391-400.

Lin, S. Y., 1983. "Lignin Utilization: Potential and Challenge." In Progress in Biomass Conversion, eds. D. A. Tillman and E. C. Jahn, Vol. 4, 32-77, and references therein.

Ratcliff, M. A., Johnson, D. K., Posey, F. L., Maholland, M. K., Cowley, S. W., and Chum, H. L. 1988. "Hydrodeoxygenation of a Lignin Model Compound," Proceedings of the IEA International Conference on Research in Thermochemical Biomass Conversion, 941-55. Phoenix, AZ: Elsevier Applied Science.

Sarkanen, K. V., and Ludwig, C., eds. 1971. Lignins: Occurrence, Formation, Structure and Reactions. New York: Wiley.

Sarkanen, K. V. 1975. "Wood Lignins," In The Chemistry of Wood, ed. B. L. Browning. New York: Robert Krieger Publishing Co.

Singerman, G. M. 1980. Methyl Aryl Ethers from Coal Liquids as Gasoline Extenders and Octane Improvers. Prepared under contract No. DE-AC01-79C50022. Pittsburgh, PA: Gulf Research and Development Co.

Sjoström, E. 1981. Wood Chemistry - Fundamentals and Applications. New York: Academic Press. Van Tassel, B. 1985. Biochemical Conversion Contractor's Meeting, Denver, Colorado. 
Whittington, L. E., Naae, D. G., and Davis, C. A. 1990. "Conversion of Lignin intn Surfactants," presented at the 200th meeting of the American Chemical Society, Washington D.C., Augusi '26-31, CELL 13. 


\title{
Llgnin Characterization-Progress Report
}

\author{
F. A. Agblevor, D. K. Johnson, and H. L. Chum \\ Chemical Conversion Branch \\ Fuels and Chemicals \\ Research and Engineering Division \\ Solar Energy Research Institute \\ Golden, CO 80401
}

\begin{abstract}
The goal of this task is to develop rapid chemical and spectroscopic characterization methods for lignin feedstocks from biomass-to-fuels conversion processes and relate the composition to conversion of lignins into fuels and chemicals. 'Thus, this task bridges biomass production and conversion programs; it relates to the production of lignin feedstocks for further conversion and provides the understanding of suitable lignin properties in feedstocks that facilitate pretreatment and conversion of biomass into liquid fuels such as ethanol. Thus, the understanding of lignin structures as a function of the pretreatment to which the various feedstocks are subjected is a goal of this task, as well as to develop suitable analytical processes that allow lignin analyses to be carried out quickly and reliably. This report summarizes research in progress on various aspects of the task. The main areas addressed during this period include (1) partial least squares analyses of Fourier-transform infrared spectroscopic data for the determination of methoxyl content of isolated lignins and whole biomass; (2) International Energy Agency (IEA) two-dimensional round-robin on lignin analyses in cooperation with the IEA/Voluntary Standards Activities; (3) preliminary carbon-13 nuclear magnetic resonance (NMR) characterization of ball-milled lignins from short-rotation species grown by the biomass production program in collaboration with D. Robert (Grenoble); and (4) other on-going activities.

Since the last review, four papers have been published in the peer-reviewed literature, and six presentations were made in national and international meetings, including a special presentation illustrating lignin structural properties and the conditions of preparation and isolation of lignins. Five papers related to these areas are under preparation or submitted to publication.
\end{abstract}

\section{IEA Two-Dimensional Round-Robln on Lignin Analyses}

The International Energy Agency (IEA) through Biomass Conversion Annexes since 1986 has sponsored the Voluntary Standards Activity with SERI as the lead organization. Many countries are participating in this effort: Canada, Finland, the Netherlands, New Zealand, Norway, Sweden, and the United States. The IEA is conducting a series of analytical round-robin tests among many activities, including the round- 
robin on whole feedstock analysis described in the Biomass Characterization-Progress $R$, ort, and the lignin analytical round-robin described here.

A considerable fraction of the Presymposium on Modern Methods of Analysis of Wood, Annual Plants and Bleach Effluents co-organized by H. L. Chum, G. Gellerstedt, and D. Robert, (Myrtle Beach, S.C., May 1989), with nearly 250 participants, was dedicated to lignin analyses, methods, and new techniques. This symposium followed the pioneer one carried out in Grenoble in 1987 and organized by D. Robert. At the end of the Myrtle Beach symposium it became very clear that discussions on the comparative value of methods, principally degradative methods of analyses, was clouded by the lack of common substrates to which these powerfil analytical methods were being applied. It became apparent that the community needed to perform these analytical tests (or as many as possible) on common lignin substrates. After the meeting a questionnaire was circulated to the participants and there was an extremely positive response by researchers worldwide who would volunteer their time and effort in performing analyses on these materials. This effort has been called a Two-Dimensional Round-Robin on Lignin Analyses (2-D RoundRobin) (both the same methods and different methods will be used).

A call for participation in the 2-D Round-Robin for lignin aralyses was issued by H. L. Chum in July 1990 to about 700 researchers in various laboratories worldwide. Participation in the round-robins is on the basis of confidentiality as to which results belong to any specific laboratory. In order to preserve confidentiality, statistical analysis of the data will te performed by rapporteurs, who do not have the knowledge or access to the files at SERI that contain the identity of the coded laboratories. Results of this test will be discussed at the Pre-Symposium on Modern Methods of Analysis of Wood and Annual Plants in New Orleans, La., in 1991, organized by H. L. Chum and G. Gellerstedt. This symposium precedes the international conference, Cellulose ' 91 , which combines three international conferences of 1991, in New Orleans, La., December 2-6, 1991. As of September 1, 1990, 22 laboratories worldwide joined the 2-D Round-Robin on lignin as defined. Countries involved so far are: Australia, Brazil, Canada, France, Finland, Germany, Japan, New Zealand, Sweden, and United States. The presymposium results will be published, most likely as an American Chemical Society (ACS) symposium series.

Several samples have been prepared for this effort, some at SERI and some by laboratories and industries in the United States and Canada. Because the milled-wood lignin sample preparation is extremely time consuming, only one feedstock was selected. Though a softwood species could have been selected, it was felt that a well-characterized hardwood species, such as a Populus deltoides clone, could be a suitable feedstock for this round-robin.

\section{Preparatlon of Ball-MIIIed/Enzyme-Liberated Wood LIgnin for the IEA Two-DImenslonal Round-RobIn Analyses}

A.ir-dried 6- to 7-year-old $P$. deltoides clone \#42-7 wood samples were supplied by R. Hall of Iowa State University. These wood samples were debarked, chipped, and Wiley milled to pass $1 \mathrm{~mm}$ mesh size. The milled wood was extracted with ethylenediaminetetracetic acid (EDTA) solution to remove any metal pieces that might have contaminated the samples during the milling process. The EDTA extracted samples were vacuum filtered and air dried at room temperature. The air-dried samples were then Soxhletextracted successively with a toluene/ethanol mixture $(2: 1 \mathrm{v} / \mathrm{v}), 95 \%$ ethanol, and finally distilled water. Each solvent extraction lasted $8 \mathrm{~h}$, after which the solvent was removed by vacuum suction. After the water extraction, the extractives-free wood meal was thoroughly washed with water and vacuum filtered. The sample was initially air dried at room temperature and then finally dried over anhydrous calcium sulfate in a vacuum desiccator. About $100 \mathrm{~g}$ of the dry extractives-free wood was ball milled in toluene in a ceramic jar for 1 wcek. The ball-milled wood was recovered and extracted twice with aqueous dioxane mixture (9:1 v/v dioxane water ratio), each extraction lasting $24 \mathrm{~h}$. The aqueous dioxane extract 
was centrifuged, filtered, and vacuum evaporated on a rotovap to dryness. This crude lignin was then purified by the Bjorkman procedure.

The solid residue, after the second aqueous dioxane extraction, was thoroughly washed with distilled water and hydrolyzed with a Genencor prepared cellulase enzyme (Cytolase 123). The hydrolysis was carried out twice for $24 \mathrm{~h}$, each time at $50^{\circ} \mathrm{C}$, with continuous stirring of the hydrolysis medium. The hydrolysis solid residue was recovered and thornughly washed with water and extracted with aqueous dioxane and purified with a modified Bjorkman procedure. In this procedure, purification of the crude lignin was stopped after the dissolution of the crude lignin in $90 \%$ acetic acid and precipitation into water. All the purified lignins were then freeze dried. The yields of lignin from this process were rather low $(25 \%$ of the weight of lignin in the wood), compared to lignin yields of $65 \%$ prepared by a similar process using cellulase enzyme prepared by Novo Enzyme of Toronto, Canada, and different clones of $P$. deltoides and other species (Agblevor 1988). It appears that the Genencor enzyme contains different proportions of active enzymes than the Novo Enzymo preparations. Consequently less carbohydrate, was hydrolyzed from the lignin-carbohydrate complex for extraction with aqueous dioxane. Water washings are being used to remove soluble carbohydrates and produce as lc $\%$ sugar content m.lled-wood lignin samples as feasible for this round-robin. About $100 \mathrm{~g}$ of this enzyme hydrolyzed milled wood lignin has been prepared for the 2-D Rouna-Robin.

\section{Commerclal/PIlot Scale LignIn Preparations Contrlbuted to the IEA TwO-DImenslonal Round-RobIn on LIgnin Analyses}

Steam-Exploded LIgnin. One kilogram of steam-exploded lignin was donated by E. Chornet of the Universite de Sherbrooke, Québec, Canada. The steam explosion was performed on Populus deltoides (Clone D-38) wood at a severity of 3.8. The lignin was isolated by dissolution in alkali followed by' precipitation with acid. The yield of lignin was $13 \%$ based on the oven-dried weight of the wood.

Steam-Exploded LIgnIn. One kilogram of steam-exploded lignin was donated by W. Glasser from the Biobased Materials Center at Virginia Tech, Blacksburg, Va. The steam explosion was performed on yellow poplar at a severity of 4.2. Lignin isolation was performed similarly to that described previously.

Organosolv LIgnin. Two kilograms of ALCELL ${ }^{\text {TM }}$ lignin was donated by Repap Technologies, Inc. of Valley Forge, Pa., by J. Lora and K. Pye. This lignin (Sample No. AD1/L920) was produced at Repap's demonstration plant in Canada from mixed hardwoods (e.g. maple, birch, poplar). At SERI the sample was dried to eliminate residual solvent still present in the sample.

Kraft LIgnin. Indulin AT-Special lignin $(1.5 \mathrm{~kg})$ was donated by the Polychemicals Department of the Chemical Division of Westvaco in Charleston Heights, S.C., through B. Wright. This lignin was produced from mixed softwoods by the same process used to make Westvaco's commercial product Indulin $\mathrm{AT}^{\mathrm{TM}}$. For this special grade of lignin, inorganic salts were removed from the lignin by dissolving it in alkali and then reprecipitating it with acid to a low ash content of $0.6 \%$.

Acetylated Steam-Exploded LIgnin. At SERI, $100 \mathrm{~g}$ of the steam-exploded lignin from the Universite de Sherbrooke was quantitatively acetylated in five $20 \mathrm{~g}$ batches using a modified procedure proposed by Gierer and Lindeberg (1980). This involved stirring pyridine $(400 \mathrm{~mL})$ and acetic anhydride $(400 \mathrm{~mL})$ with lignin $(20 \mathrm{~g})$ at $60^{\circ} \mathrm{C}$ for $48-72 \mathrm{~h}$. The excess acetic anhydride and pyridine is then removed by azeotropic distillation with toluene. Residual traces of toluene are subsequent ly removed by azeotropic distillation with acetone and ethanol. Finally, the acetylated lignin is dried on a vacuum pump at $40^{\circ} \mathrm{C}$. The weight increase on acetylation was $25 \%$ of the starting weight of the lignin. 
Acetylated Steam-Exploded LIgnin. One kilogram of acetylated steam-exploded yellow poplar was donated by W. Glasser from the Biobased Materials Center at Virginia Tech, Blacksburg, Va. The steam explosion was performed on yellow poplar at a severity of 4.2 . The acetylation was also carried out at Blacksburg on a large scale.

\section{Partlal Least Squares Analyses of Fourier Transform Infrared Spectroscoplc Data for the Determination of Methoxyl Content of Lignins and Whole Blomass}

The application of factor analysis to Fourier transform infrared spectroscopy (FTIR) data for materials characte:ization has been widespread in the literature (see, for instance, Fredericks et al. 1985; Holmgren and Norden 1988; Donahue et al. 1988). Other physical property measurements and spectroscopic measurements, such as the NMR, and other methods of data analyses, such as partial least squares, have also been employed (Fuller et al. 1988; Wallbacks et al. 1989). Factor analyses of part (or all) of the FTIR spectra data set can be used. In factor analysis, a combination of mathematical and interpretative methods derives a set of axes that efficiently displays the data vectors and the variance contained in the original measurement data, while giving some insight into the fundamental influences in the system represented by the data vectors (samples). Thus, the method allows the determination of the minimum number of factors (an eigenvector or other axis in the measurement space, which can be interpreted according to the variables that contribute to it in a manner that identifies a source of influence in the data) and associated factor scores (the projection of the sample into the principal component plane) required to reproduce the spectra.

Such methods are fast compared to conventional techniques, and by suitable choice of the calibration set, can give semiquantitative results for a very wide range of samples, or quantitative results of accuracy comparable with conventional techniques for a calibration set and unknowns from a narrower range of samples. The method has been applied successfully to substrates, such as coal, peat, humic acid, bauxite, manganese dioxide ores, diesel fuel, wood pulp, detergents, and many others, to predict many different properties, such as energy content (of coal, peat, humic acids), ash content (coal, peat), and carbon, hydrogen, and oxygen contents (peat, coal, etc.), and fine chemical structure and kinetics (wood delignification). A relevant review of these multivariate techniques is given by Beebe and Kowalski (1987).

During FY 1989 and 1990, SERI researchers have been involved in the development of rapid techniques for functional group analysis of lignins. A method has been developed for the rapid determination of the methoxyl contents of a number of biomass-derived materials using a partial least squares (PLS) regression method and FTIR. The complex structure of lignin requires an infrared (IR) analysis method capable of interpreting spectra with composite peaks and extensive peak interactions (Sarkanen and Ludwig 1971). The PLS multivariate analysis method uses all of the spectral information that is considered to be statistically significant (Fuller et al. 1988). Complex interactions and peak overlap can be deconvoluted at this level. The method employed is much more accurate than multiple linear regression analysis described by Schultz and Glasser (1986) (see also Beebe and Kowalski 1987), which does not distinguish noise from real data correlations.

The PLS/FTIR method was calibrated using a set of well-characterized milled-wood lignins (MWL) and milled-wood enzyme lignins (MWEL) supplied by J. Obst of the Forest Products Laboratory (FPL) from a variety of hardwood species. Correlation between actual and predicted values, as shown in Table 1 (Obst and Landucci 1986), had a coefficieni of 0.99 or better. Analysis of additional MWL samples and a series of isolated organosolv lignins compared very well with methoxyl contents obtained using carbon13 NMR $\left({ }^{13} \mathrm{C}\right.$ NMR) (Figure 1) (see Chum et al. 1988 and previous reports of this subtask at previous contractors review meetings). 
Table 1. Methoxyl Contents for Lignins Used In the Calibration Set for the FTIRPLS Method. The lignins were donated by the Forest Products Laboratory, Madison, Wis.

\begin{tabular}{lllll}
\hline & \multicolumn{2}{c}{ MeO/Aryl } & \multicolumn{2}{c}{ MeO \% } \\
\hline Lignin & $\mathrm{C}^{13^{*}}$ & PLS & $\mathrm{C}^{13^{*}}$ & PLS \\
\hline American Elm Kraft Fiber MWL & 1.35 & 1.35 & 20.0 & 20.0 \\
American Elm Kraft Krill MWL & 1.39 & 1.41 & 20.4 & 20.6 \\
Birch Kraft Crill MWL & 1.41 & 1.42 & 20.7 & 20.8 \\
Birchwood MWL & 1.44 & 1.43 & 21.0 & 20.9 \\
Aspen Wood MWL & 1.47 & 1.46 & 21.4 & 21.3 \\
Birch Ráy Cell MWL & 1.52 & 1.52 & 21.7 & 21.7 \\
Beechwood MWL & 1.52 & 1.55 & 21.9 & 22.2 \\
Birch Kraft Fiber MWL & 1.58 & 1.54 & 22.6 & 22.2 \\
Sweetgum Woods MWEL & 1.65 & 1.65 & 23.4 & 23.4 \\
\hline
\end{tabular}

"Data published in Obst et al. 1986

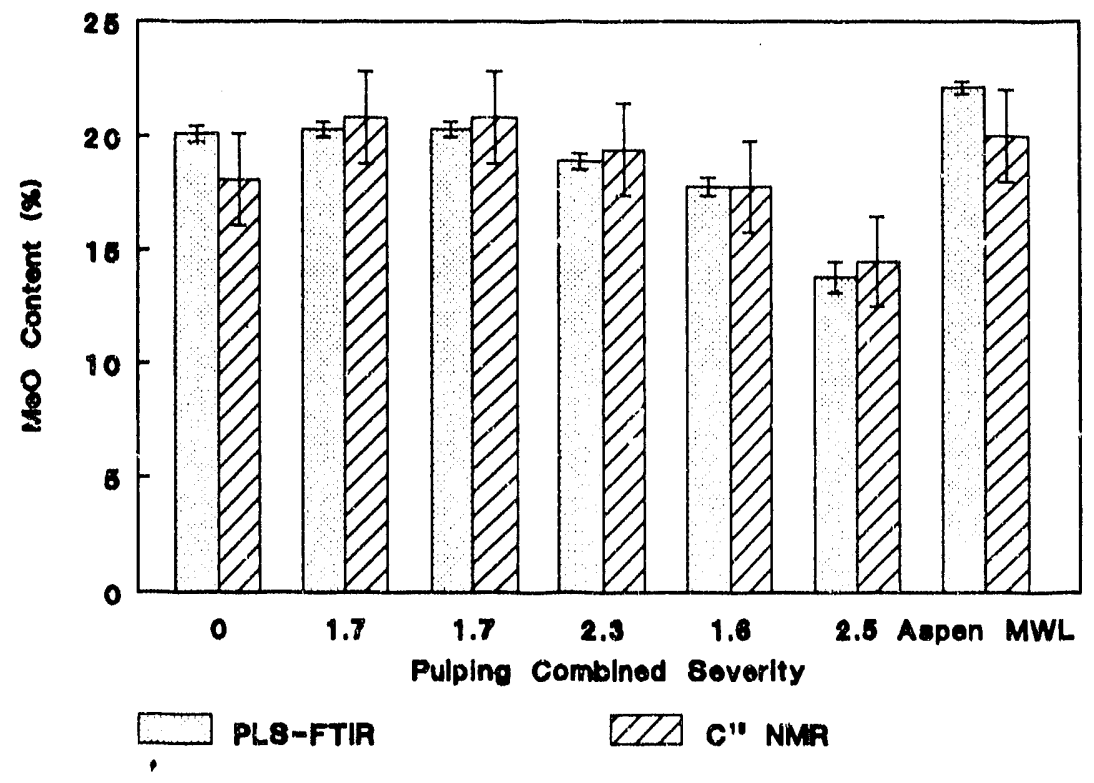

Figure 1. Aromatic MeO $\%$ for organosolv Ilgnins ${ }^{13} \mathrm{C}$ NMR versus PLS using MWL callbration 


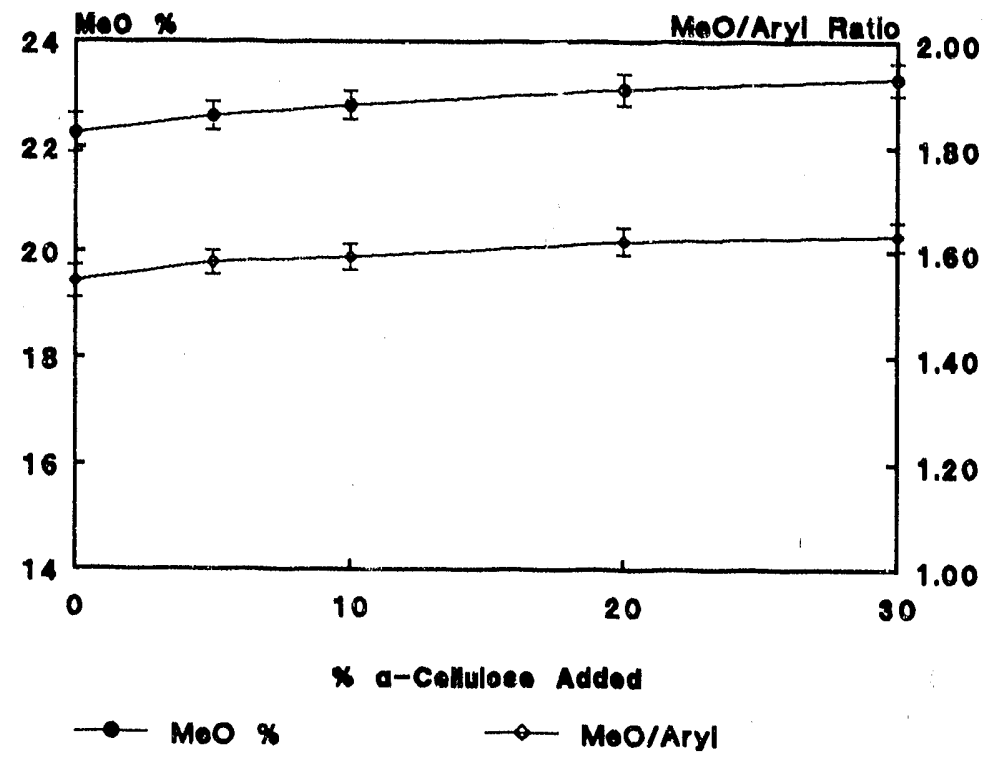

Figure 2. Effect on MeO content of adding a-cellulose to aspen MWL

${ }^{13} \mathrm{C}$ NMR analysis of lignins requires extensive purification of the sample to eliminate interference from carbohydrates. However, combination of lignin samples, with up to $30 \%$ carbohydrates, did not significantly affect the methoxyl determination by PLS/FTIR (Figure 2). Analysis of biomass samples before and after removal of extractives showed no significant interference for samples with extractives contents of up to $14 \%$ (Figure 3). The lack of interference by carbohydrates and extractives suggested the application of this method to a wide variety of biomass samples. The technique was then applied to whole woods, grasses, and legumes, showing slightly different values in some cases from those predicted for MWL and MWEL. As complete sample series (whole wood, extractives-free wood, MWL, and MWEL) become available, they are being analyzed to determine the ability of the PLS/FTIR method to monitor fractionation patterns in the isolation of lignin from wood (Figure 4 and Table 2). Currently, the calibration set is being expanded to include softwoods, other legumes, and grasses. Detailed explanations of the procedures of preparation of the MWL and enzymatically hydrolyzed lignins is given in the section on preparation of ball-milled/enzyme-liberated wood lignin.

The PLS/FTIR technique requires minimal sample preparation. Purified MWL, are required for calibration only. Other advantages include reduced sample size and short analysis time. The method also shows excellent reproducibility: $\pm 0.5 \%$ for methoxyl wt $\%$ and \pm 0.04 for methoxyl per aromatic unit (using four faciors).

By applying data reduction techniques, such as partial jeast squares regression to infrared spectroscopy, it should be possible to simultancously quantify several different functional groups in the lignin structure, with considerable time savings over traditional techniques. Such a technique would provide essential guidance to the genetics and hybridization program for the design of the best feedstocks for the various conversion processes. The technique will be expanded to include phenolic hydroxyl, total hydroxyl, and other important group contents of the available lignin sets and additional samples provided by researchers throughout the world. 


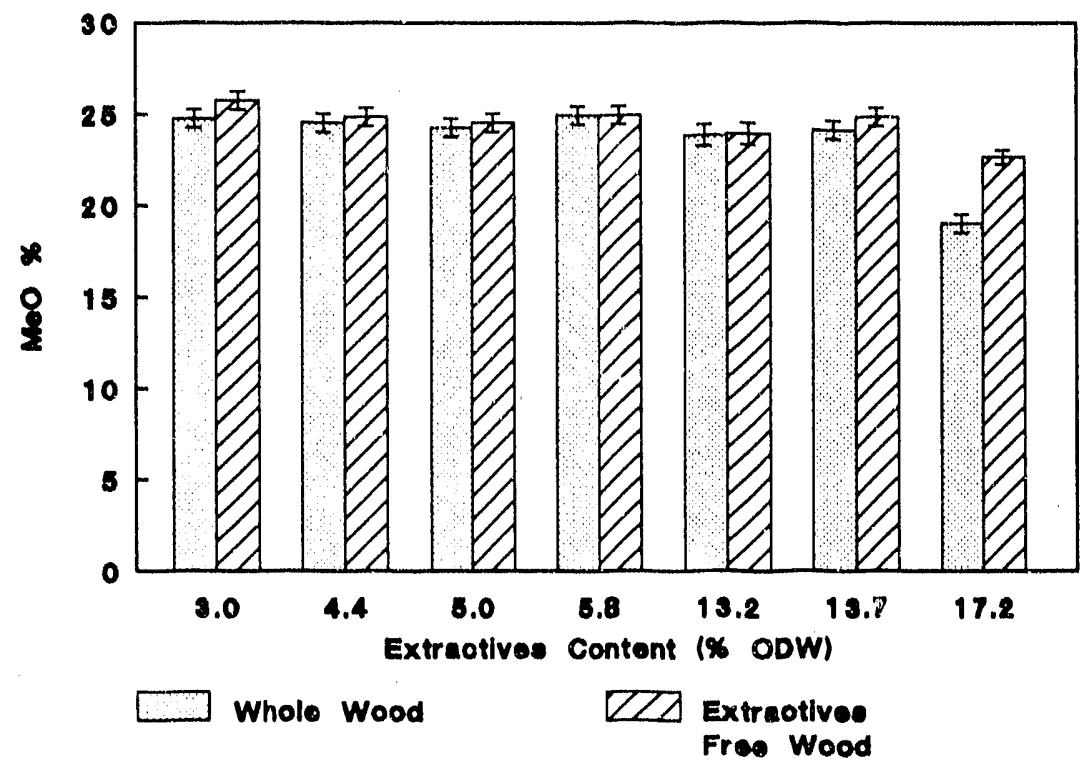

Figure 3. Effect of removing extractlves on PLS prediction of IIgnin MeO content (\%)

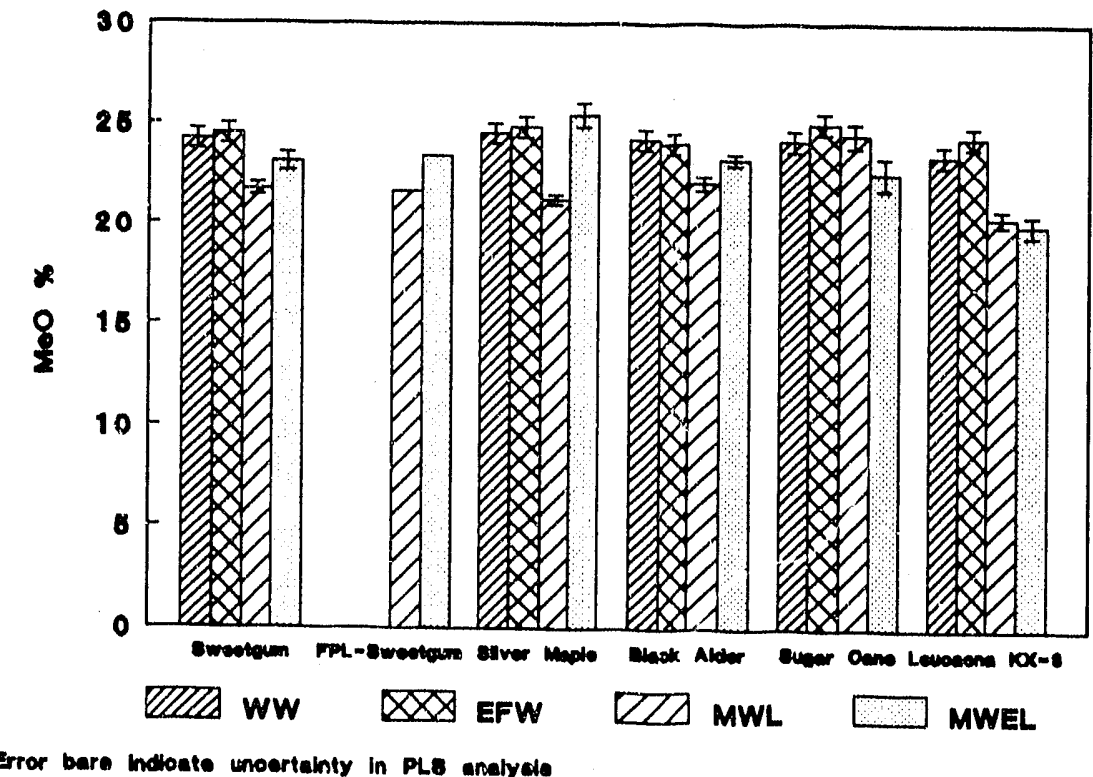

Figure 4. Comparison of whole woods, extractives-free woods, and Isolated lignins 
Table 2. Methoxyl Content Per Aromatic Unit and Percent Content of Lignins in Whole Woods by FTIR and PLS Correlation

\begin{tabular}{lcc}
\hline & MeO/Aryl & $\%$ MөO \\
\hline Eucalyptus Grandis & 1.81 & 25.1 \\
Eucalyptus Saligna & 1.79 & 24.9 \\
Silver Maple & 1.75 & 24.5 \\
Sweetgum & 1.73 & 24.3 \\
Leucaena K-156 (Clone) & 1.73 & 24.1 \\
Black Alder & 1.72 & 24.2 \\
Sugar Cane & 1.72 & 24.1 \\
Gliricidia & 1.69 & 23.7 \\
Leucaena KX-3 (Clone) & 1.64 & 23.4 \\
Black Locust & 1.76 & 24.7 \\
Forage Brassica & 1.47 & 20.9 \\
Eucalyptus Tereticornis & 1.28 & 19.0 \\
Serlcea Lespedeza & 0.83 & 13.8 \\
\hline
\end{tabular}

\section{Prellminary ${ }^{13} \mathrm{C}$ NMR Spectroscoplc Characterlzation of Ball-Milled LIgnins from Short- Rotation Specles Grown by the Blomass Production Program}

Four samples of ball-milled lignins prepared were subjected to quantitative ${ }^{13} \mathrm{C} N \mathrm{NM}$, including distortionless enhancement by polarization transfer (DEPT) analyses (see, for instance, Breitmeier and Voelter 1987). The samples were: Populus deltoides, sycamore, silver maple, and a leucaena KX-3 clone. Examples of selected spectra are shown in Figures 5a and 5b. All samples prepared contained small to large amounts of carbohydrate contamination, since the activity of the enzyme preparation employed was not as high as those described in the literature before (see Agblevor 1988).

The spectroscopic data are summarized in Table 3 for the key lignin peaks displayed by these samples and corresponding assignments. Table 4 lists the key carbohydrate-derived peaks present in these samples and their assignments.

Through the quantitative NMR, using the gated-decoupling sequence and DEPT (see Bardet et al. 1985), it is possible to estimate various structures present in these lignins. For instance, the methoxyl content per aromatic unit was calculated and compared with the results from the PLS/FTIR method described previously. These results are summarized in Table 5. One important consideration of the numbers in the table is that the methods ignore contributions of nonmethoxylated precursors to the lignin methoxyl content. There is a very good agreement among all samples within the experimental errors of the methods. Considering the method development stage of both techniques, these results are quite encouraging for the accuracy of the methoxyl content by the combined PLS/FTIR method. 


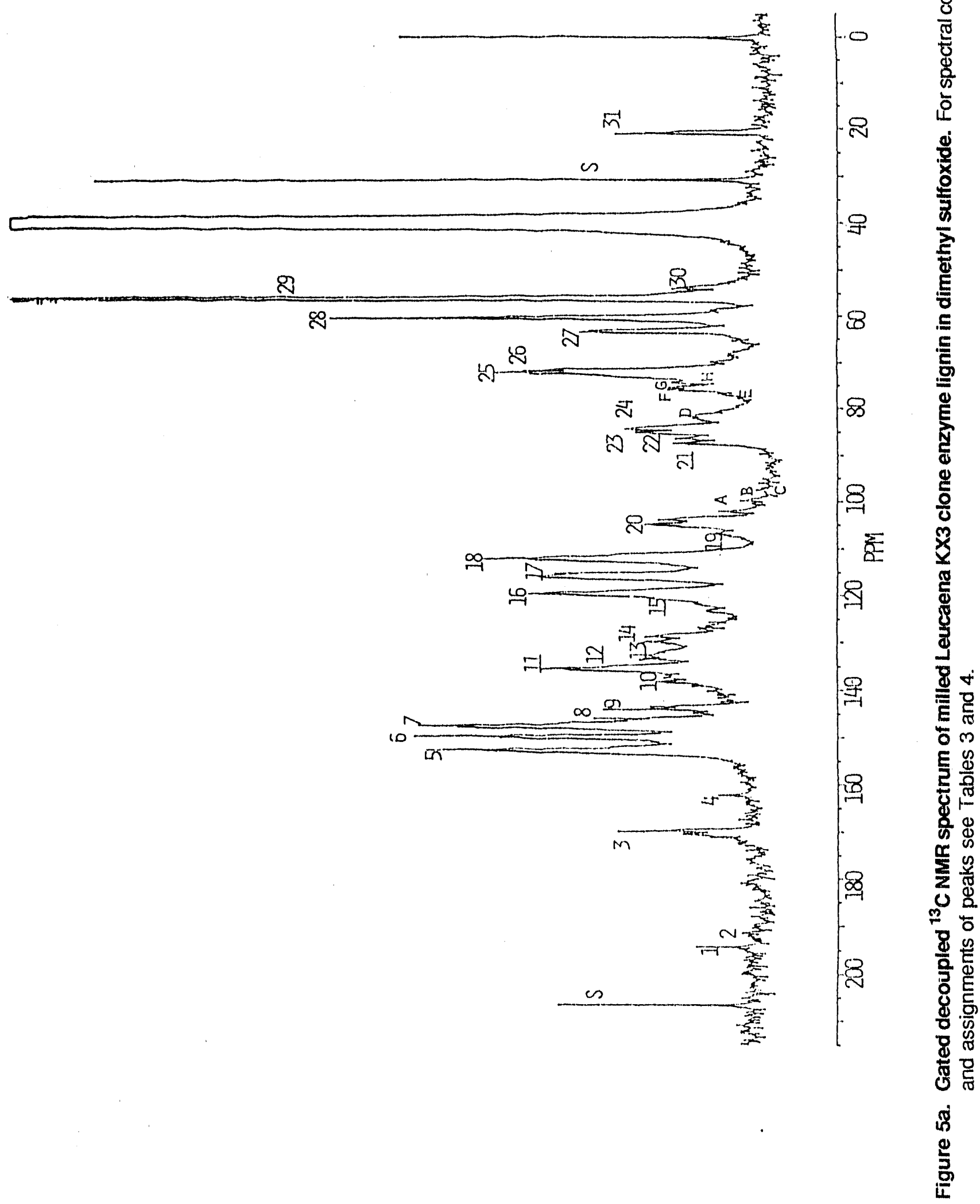




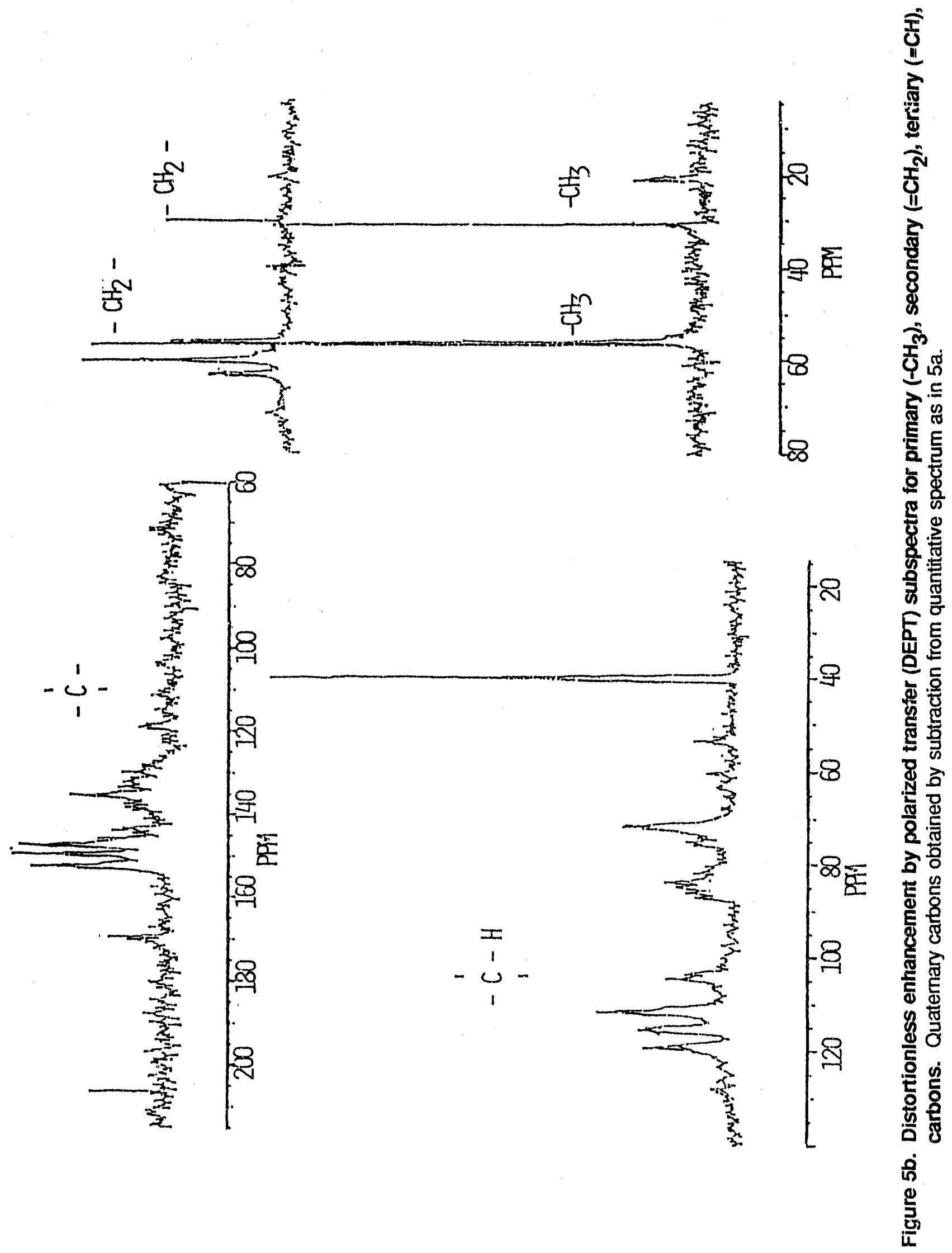




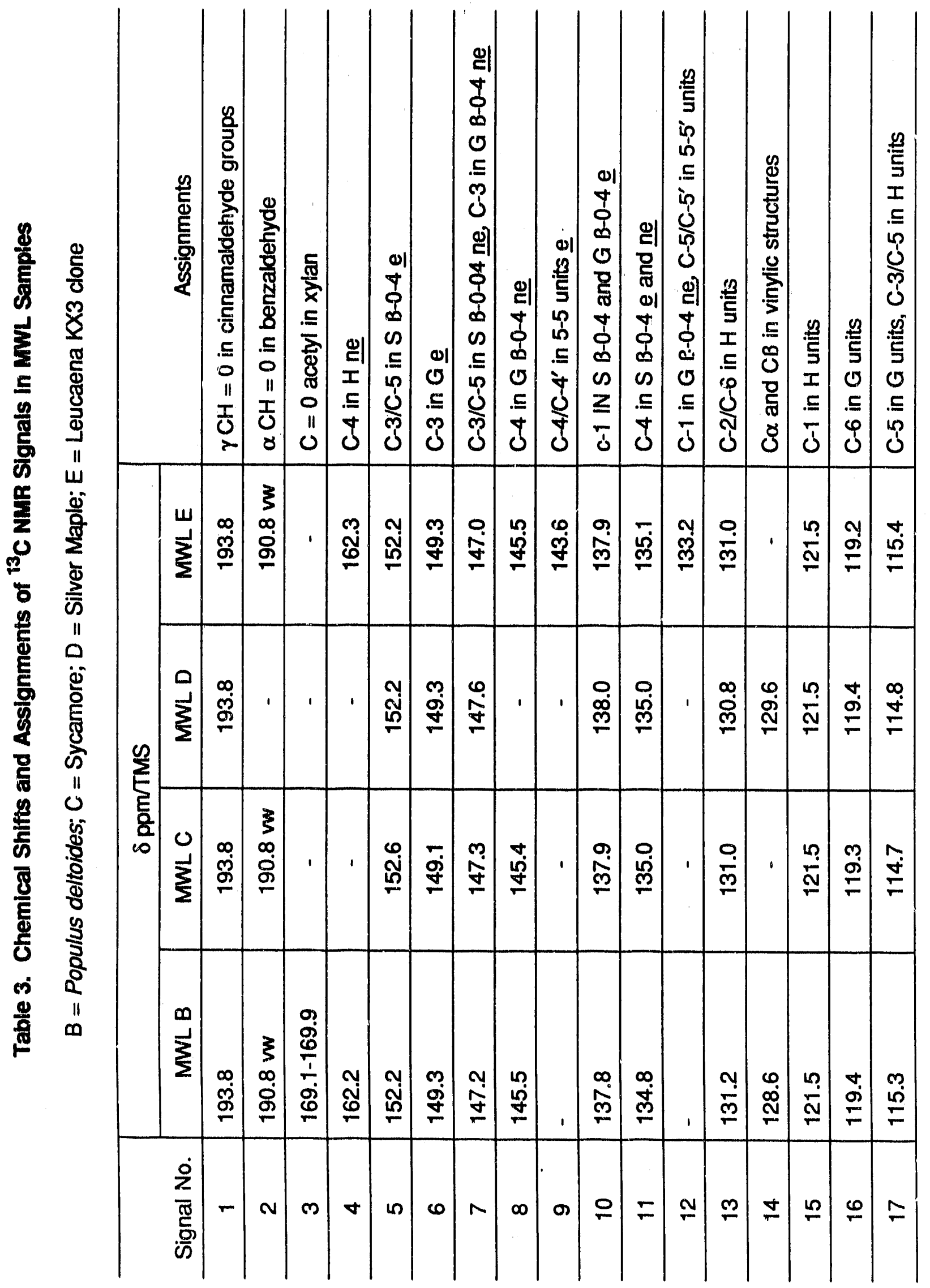




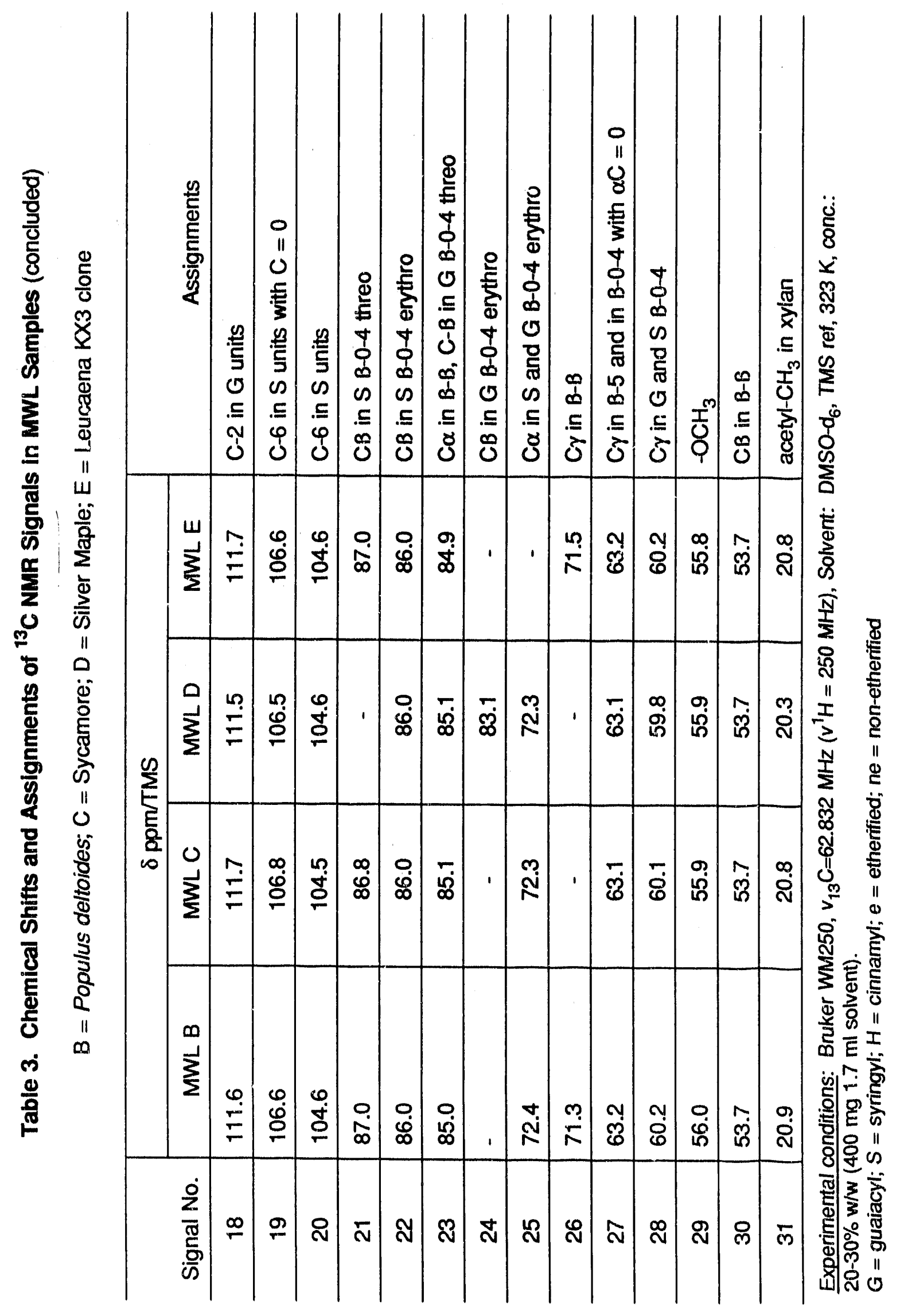

TP-3996 
Table 4. Chemicals and Assignments of ${ }^{13} \mathrm{C}$ NMR SIgnals In Hemlcelluloses and Xylans In Preparatlons of MWL Samples of: $\mathrm{B}=$ Populus deltoldes; $\mathrm{C}=$ Sycamore; $\mathrm{D}=$ Sllver Maple; E = Leucaena KX3 Clone

\begin{tabular}{c|c|c|c|c|l}
\hline \multirow{2}{*}{ Signal No. } & \multicolumn{3}{|c|}{$\delta$ ppm/TMS Lignins Samples } & \multicolumn{1}{c}{} \\
\cline { 2 - 6 } & MWL B & MWL C & MWL D & MWL E & \multicolumn{1}{|c}{ Assignments* } \\
\hline $\mathrm{a}$ & 101.6 & - & 101.7 & 101.7 & C-1 in xylose \\
\hline $\mathrm{b}$ & 99.6 & - & 99.5 & 99.6 & C-1 in acetylated xylose \\
\hline $\mathrm{c}$ & 97.7 & - & - & - & C-1 in 4-OMe Glucuronic acid \\
\hline $\mathrm{d}$ & 81.3 & 81.4 & 81.3 & 81.3 & C-4 in 4-OMe Glucuronic acid \\
\hline $\mathrm{e}$ & 76.6 & - & 76.5 & - & C-2 in xylose units inked to C-1 \\
\hline $\mathrm{f}$ & 75.7 & 75.6 & 75.7 & 75.6 & C-4 in xylose units \\
\hline $\mathrm{g}$ & 75.0 & 75.0 & 75.0 & 75.0 & - not identified \\
\hline $\mathrm{h}$ & 73.6 & - & - & - & - not identifled \\
\hline $\mathrm{l}$ & 69.9 & - & - & - & C-5 in 4-OMe Glucuronic acid \\
\hline $\mathrm{f}$ & 63.2 & - & - & - & C-5 in xylose \\
\hline
\end{tabular}

"These assignments have been made according to Utille 1979 (Ph.D. thesis, Grenoble) and Kovacs et al. 1982 (Cell. Chem. Technol. 16, 261-269.) See Table 3 for experimental conditions.

Table 5. Comparlson of Methoxyl Content per Aromatlc Unit of Selected Samples Determlned through Quantlative ${ }^{13} \mathrm{C}$ NMR and through Quantltative PLS/FTIR

\begin{tabular}{lcc}
\hline \multicolumn{1}{c}{ Sample } & \multicolumn{2}{c}{ Methoxyl Content/Aromatic Unit } \\
\hline NMR $( \pm 0.1)$ & $\begin{array}{c}\text { PLS/FTIR } \\
( \pm 0.05)\end{array}$ \\
\hline Populus deltoides & $1.55(40 \% \mathrm{G} ; 60 \% \mathrm{~S})^{*}$ & 1.55 \\
Sycamore & $1.7(30 \% \mathrm{G} ; 70 \% \mathrm{~S})$ & 1.7 \\
Silver maple & $1.6(40 \% \mathrm{G} ; 60 \% \mathrm{~S})$ & 1.65 \\
Leucaena (KX3 clone) & $1.25(25 \% \mathrm{G} ; 75 \% \mathrm{~S})$ & 1.35 \\
\hline${ }^{*} \mathrm{G}=$ guaiacyl group; $\mathrm{S}=$ syringyl group &
\end{tabular}


The examination of the aromatic region through the DEPT spectra allows the estimation of quaternary and ternary carbons present in these samples. As expected by the similar methuxyl content, the two samples with 1.55 and 1.6 methoxyl content/aromatic unit exhibited 3.6 quaternary carbons/aromatic unit and 2.4 ternary carbons/aromatic unit ( $P$. deltoides and silver maple, respectively). The sycamore sample had a higher extent of quaternary carbons (3.7), whereas the leucaena sample had a much lower content of aromatic carbons (3.25), in agreement with their highest and lowest methoxyl content/aromatic unit content (see Table 5).

The ${ }^{13} \mathrm{C}$ NMR of the ball-milled leucaena KX3 clone lignin exhibits all structures that have been found in the literature for ${ }^{13} \mathrm{C}$ NMR of lignins so far, including $H, G, S$ units, pinoresinol, ethers, etc., as described in Table 3.

Additional details of the structures of these lignin preparations will be published elsewhere.

\section{Other Actlvitles}

Work continues in the characterization of lignins from acid hydrolysis, compared to other pretreatments that fractionate the lignocellulosic materials. These materials are being prepared for publication. Work also continues in the development of analytical techniques based on multivariate analyses coupling several spectroscopic techniques through canonical correlations. This material will be presented at the next review meeting. There is a considerable amount of work in this area in Sweden, followed by Germany. Our methods and approaches differ somewhat from those in the literature, and profit from the interaction that the branch has with W. Windig of Eastman Kodak (see discussion in the section entitled Biomass Characterization - Progress Report). Emphasis this year has been on method development such that fast characterization techniques can replace powerful but time-consuming and more costly srectroscopic techniques. Exploration of FTIR as a method for assessment of feedstock quality intensifies, because this is a technique inexpensive enough to be used in industry for process control. Other areas of activities include the development of a method to replace the TAPPI method for soluble lignin determination and the confirmation of the characterization of lignins from a variety of feedstocks considered in biomass-toethanol pretreatments. These activities are coordinated very closely with those in biomass characterization described earlier in this report.

Examples of publications of this period are:

Chum, H. L., Johnson, D. K., and Black, S. K. 1990. Ind. Eng. Chem. Res. 29: 156-162.

Chum, H. L., Black, S. K., Johnson, D. K., and Overend, R. P. 1990. Appl. Biochem. Biotechnol. 24/25: $1-14$.

Himmel, M. E., Tatsumoto, K., Grohmann, K., Johnson, D. K., and Chum, H. L. 1990. J. Chromatog. 498:93-104.

Johnson, D. K., Chum, H. L., and Hyatt, J. A. 1989. "Molecular Weight Distribution Studies," In Lignin Properties and Materials, eds. W. G. Glasser and S. Sarkanen, pp. 109-123. ACS Symposium Series, No. 397 , chapter 8.

Chum, H. L.., Johnson, D. K., and Black, S. K. 1989. "Organosolv Pretreatment," In Proc. 1989 Int'l Symposium on Wood and Pulping Chemistry, pp. 691-695. Raleigh, N.C.

Chum, H. L. 1990. Lignin Uilization. Syracuse, NY: New York Gas Group. 
Chum, H., Evans, R., Black, S., Hames, B., and Agblevor, F. 1989. "Multivariate Analysis in Wood Chemistry." 1989 International Chemical Congress of Pacific Basin Societies. Honolulu, Hawail, December.

Agblevor, F., Evans, R. J., Milne, T. A., and Antal, M. J. 1989. "Multivariate Dala Analysis of Biomass Feedstocks Using Pyrolysis-Mass Spectrometry." 1989 International Chemical Congress of Pacific Basin Societies. Honolulu, Hawaii, December.

Chum, H. L., Black, S. K., and Johnson, D. K. 1989. "Fractionation of Lignocellulosics - Catalyst Effects," CELL 13, presented at the 197th American Chemical Society Meeting, Dallas, Texas, April.

Agblevor, F., Black, S. K., Evans, R., Johnson, D. K., Hames, B., and Chum, H. L. 1990. Methoxyl Content per Aromatic Units of Lignins in Isolated Pulps and Wood by FTIR and Partial Least Squares, CELL 83, presented at the 199th American Chemical Society Meeting, Boston, Massachusetts.

\section{Acknowledgments}

Members of the lignin research community are acknowledged for their participation in the analytical efforts in the round robin. In particular, G. Gellerstedt, R. Overend, D. Robert, and K. Sarkanen have made substantial contributions to the round-robin efforts. The cost sharing by the IEA Voluntary Standards activity is also gratefully acknowledged, in addition to partial funding from the Biofuels Program of the U.S. Department of Energy and partial funding from SERI's Director's Development funds.

\section{References}

Agblevor, F. A. 1988. "Alkaline Hydrolysis and Rapid Hydrothermolysis of Hybrid Poplar Lignins." Ph.D. Thesis, Department of Chemical Engineering, University of Toronto.

Bardet, M., Foray, M.-F., and Robert, D. 1985. Makromol. Chem. 186:1495-1504.

Beebe, K. B., and Kowalski, B. R. 1987. Anal. Chem. 59:1007A-1017A.

Breitmeier, E., and Voelter, V. 1987. Carbon-13 NMR Spectroscopy, pp. 30-80. New York, NY: VCH. Chum, H. L., Johnson, D. K., Black, S., Baker, J., Grohmann, K., Sarkanen, K. V., Wallace, K., and Schroeder, H. A. 1988. Biotechnol. Bioeng. 31:643-649.

Donahue, S. M., Brown, C. W., and Obremski, R. 1988. Applied Spectroscopy 42:353-359.

Fredericks, P. M., Lee, J. B., Osborn, P. R., and Swinkels, D. J. 1985. Applied Spectroscopy 39:303310.

Fredericks, P. M., Lee, J. B., Osborn, P. R., and Swinkels, D. J. 1985. Applied Spectroscopy 39:311316.

Fuller, M. P., Ritter, G. L., and Draper, C. S. 1988. Applied Spectroscopy 42(2):217-227.

Gierer, J., and Lindcberg, O. 1980. Acta Chem. Scand. B34:161-167. 
Holmgren, A., and Norden, B. 1988. Applied Spectroscopy 42:255-262.

Obst, J. R., and Landucci, L. L. 1986. Holzforschung 40:87-92.

Sarkanen, K. V., and Ludwig, C. H. 1971. Llgnins - Occurrence, Formation, Structure and Reactions. New York, NY: John Wiley and Sons.

Schultz, T., and W. G. Glasser, 1986. Holzforschung 40(suppl):37-44.

Wallbacks, L., Edlund, U., and Norden, B. 1989. J. Wood Chemistry and Technology 9:235-249. 


\title{
Liquid Fuels From Lignins
}

\author{
D. K. Johnson, Y. W. Rhee, F. L. Posey-Eddy, and H. L. Chum \\ Chemical Conversion Research Branch \\ Fuels and Chemicals \\ Research and Engineering Division \\ Solar Energy Research Institute \\ Golden, Colorado 80401
}

\begin{abstract}
The objective of this task is to develop a process for converting lignins from biomass-to-ethanol processes to a high-octane oxygenated fuel additive. For the past 4 years, catalytic hydrotreating has been studied as a method of converting lignin to a mixture of phenols and hydrocarbons. After conversion of the phenols to methyl or ethyl aryl ethers, this mixture would be fully compatible with gasoline, or possibly ethanol, for use as a transportation fuel. Catalyst development conducted under subcontract at the Colorado School of Mines has been aimed at the formation of a product mixture with a boiling range similar to gasoline. At SERI, the activity of these catalysts with lignins has been studied on a bench scale.

Model compound studies have shown that the catalysts with increased support acidity are much more effective than commercial catalysts for performing hydrodeoxygenation and hydrodealkylation reactions. The best catalysts have been tested on a larger scale with lignins in a stirred autoclave. Because lignin is a solid, a solvent or liquid vehicle must be used to permit its transport into a hot pressurized reactor. The solvent or vehicle also allows the impeller to provide intimate mixing of catalyst, gas, and lignin. $\mathrm{m}$-Cresol, which dissolves lignin, was used because it permits simple pumping of the feed into the reactor. Tetradecane was used, although this requires handling the lignin as a slurry, because the products of lignin hydrotreating are clearly discernible from those originating from tetradecane. A lignin-derived pasting oil has also been used, as this more closely approximates the operating conditions of a commercial process. This progress report describes the effect of hydrotreating lignin in thesc three systems.
\end{abstract}

\section{Introduction}

Lignin is a nonfermentable oxygenated aromatic polymer comprising $15 \%-25 \%$ of the dry weight of hardwoods (Sarkanen and Ludwig 1971). As part of the overall goal of converting biomass into ethanol for use as a liquid fuel, the utilization of lignin as a liquid fuel has been investigated. In an integrated ethanol plant, lignin could be used as the source of process fuel, giving it a value of about $\$ 0.025 / \mathrm{lb}$ (Bergeron and Hinman 1989). This task studies the conversion of lignin into an oxygenated high-octane 
blending agent for gasoline or ethanol that would contribute more positively to the overall economics of biomass conversion to liquid fuels.

During the 1960s and also in 1980, Hydrocarbon Research Inc. (HRI) operated a pilot plant for the conversion of kraft lignin and lignosulfonates into phenol and benzene for use as commodity chemicals (Gendler et al. 1983). This was a two-step process involving hydrotreating of lignin to a mixture of phenols and hydrocarbons which was further thermally hydrodealkylated to increase the yields of phenol and benzene. The economics of this process did not permit commercialization, primarily because of the cost of separating the final products from a rather complex mixture, the cost of the hydrodealkylation step, and the low cost of phenol at that time. The aim of this research is to convert lignins from biomass-toalcohol processes to a mixture of phenols and hydrocarbons by catalytic hydrotreating similar to the process used by HRI. Methylation of the phenols in a second step would give a high octane mixture of methyl or ethyl aryl ethers (MAE or EAE) and hydrocarbons suitable for blending with gasoline (as shown by Singerman 1980) or possibly with ethanol. A stirred autoclave has been set up to study the hydrotreating of biomass-to-ethanol process lignins and to test catalysts developed by S. Cowley under subcontract at the Colorado School of Mines (CSM). These catalysts perform better than commercial catalysts used in the petroleum industry. Some of the early research into hydrotreating of lignin in the stirred autoclave was also performed under subcontract at CSM with R. Baldwin.

Initially, thermal depolymerization of lignin must occur to produce molecules small enough to enter catalyst pores before hydrotreating can begin. Products of the correct boiling range $\left(<200^{\circ} \mathrm{C}\right)$ can then be formed by mild catalytic hydrodeoxygenation with some hydrocracking to give hydrocarbons and phenols with only small a"yl side chains. In addition, direct hydrogenation should be minimized to prevent formation of relai / sly low-octane cyclohexanes and excessive consumption of hydrogen. A comparison of boiling poir:s and octane numbers of relevant compounds is shown in Table 1. Catalysts that meet these goals have been developed at CSM under the subcontract entitled Catalyst Development for Liquid Fuels from Lignins. Catalysts with increased support acidity, made by coprecipitating alumina with phosphate, have been shown (Erickson 1980; Maholland 1987; Ratcliff et al. 1988) to have increased cracking or hydrodealkylation activity. Catalysts prepared with these phosphated alumina supports show increased activity for the removal of alkyl side chains from 4-propyl substituted phenolic lignin model compounds. These supports were originally impregnated with metals, normally used for upgrading in the petrolcum industry and in coal processing, that are used in their sulfided form and are, therefore, not poisoned by the sulfur compounds present in these feeds. Most often the metal used is molybdenum (Mo), which is further activated by the presence of another metal, such as nickel or cobalt. With lignin model compounds Mo and nickel-molybdenum (Ni/Mo), impregnated catalysts showed good hydrodeoxygenation activity with minimal formation of cyclohexanes; however, the dealkylation reactivity gave some undesirable products. When the propyl side chain is cracked off it can either be hydrogenated and leave the system as propane, tile desired reaction pathway, or it can react with a molecule of the model compound to give a dialkylated product, such as dipropyl phenol, whose methyl ether would have a boiling point substantially above the normal gasoline boiling range. Similarly, methyls coming from methoxyl substituents may also be either hydrogenated to methane or produce dialkylated products. Some of these higher boiling point phenolic ethers may indeed be compatible with ethanol as a major fuel and lower the Reid vapor pressure of the resulting fuel. These fuel properties need to be assessed. With Moand $\mathrm{Ni} / \mathrm{Mo}$-impregnated catalysts, significant amounts of dialkylated products were observed at the expense of methane, propane, and other hydrocarbon gases (Ratcliff et al. 1988). Consequently, catalysts impregnated with a more hydrogenating metal were produced. Because of lignin's low sulfur content, it was possible to consider using a metal not normally used for hydrotreating petroleum and coal feedstocks because it would be poisoned by the sulfur present in these materials. Using platinum-impregnated (Pt) 
Table 1. Bolling Polnts, Research (RON) and Motor (MON) Octane Numbers, and Blending Research (BRON) and Motor (BMON) Octane Numbers for Posslble Components of a Fuel Additlve Derlved from Lignin Hydrotreating

\begin{tabular}{|c|c|c|c|c|c|c|c|}
\hline \multirow{2}{*}{ Compound } & \multirow{2}{*}{ B. Pt. } & \multirow{2}{*}{ RON } & \multirow{2}{*}{ MON } & \multicolumn{2}{|c|}{ BRON } & \multicolumn{2}{|c|}{ BMON } \\
\hline & & & & a & $b$ & $\mathbf{a}$ & $b$ \\
\hline \multicolumn{8}{|l|}{ Aromatic Hydrocarbons } \\
\hline Benzene $\theta^{\circ}$ & 80 & $>100$ & $>100$ & 99 & 110 & 91 & 89 \\
\hline Toluene & 111 & $>\$ 00$ & $>100$ & 124 & 117 & 112 & 95 \\
\hline $\mathrm{p}$-Xylene & 138 & $>100$ & $>100$ & 146 & 117 & 127 & 96 \\
\hline \multicolumn{8}{|l|}{ Cyclohexanes } \\
\hline Cyclohexane & 81 & 83 & 79 & 110 & & 97 & \\
\hline Methyl Cyclohexane & 101 & 75 & 73 & 104 & & 84 & \\
\hline $\begin{array}{l}\text { 1,4 Dimethyl } \\
\text { Cyclohexane }\end{array}$ & 122 & 81 & 79 & 68 & & 66 & \\
\hline \multicolumn{8}{|l|}{ Methyl Aryl Ethers } \\
\hline Anisole & 155 & & & & 112 & & 108 \\
\hline 4-Methyl Anisole & 177 & & & & & & \\
\hline 4-Ethyl Anisole & 196 & & & & & & \\
\hline 4-Propyl Anisole & 210 & & & & & & \\
\hline
\end{tabular}

${ }^{a}$ Blending octane numbers based on addition of each component to 60 octane unleaded gasoline at a $20 \%$ level (Lovell 1948)

bilending octane numbers based on addition of each component to unleaded premlum (octane 90-94) gasoline (Unzelman 1971)

${ }^{\mathrm{C}} \mathrm{Can}$ be minimized by conversion into other aromatic compounds

catalysts, it was possible to substantially decrease the formation of dialkylated products and direct the cracking activity of the catalyst to the pathway that produces alkanes. In addition, higher yields of phenols were produced at lower pressures using the Pt catalyst than with the originai catalysts (Erickson 1990). This would result in a significant decrease in operating and capital costs if translated into a lignin hydrotreating plant. The research conducted at SERI has attempted to reproduce these indications of catalyst activities, observed using model compounds and a packed-bed trickle-flow reactor, with lignin in a stirred autoclave.

The economics of converting lignin to a high-octane blending agent containing methyl aryl ethers was assessed by the Engineering Research Section of the Biotechnology Research Branch using the Aspen Simulator software during 1988-89 (Bergeron 1989). 'The assessment was based on current technology and examined the influence on process economics of improvements in several areas of the overall process. It was determiried that increases in yields and other improvements in the hydrotreating process as 
developed by HRI should have the most effect on the economics of the process. More recently some refinements of thu original idea for the process were examined for their effect on process economics (Bergeron 1989b). Production of a nonoxygenated product, with no phenols, only hydrocarbons, results in lower mass yields of product per pound of lignin but substantially reduces the complexity of the plant, reducing the cost of the product by about $12 \phi / \mathrm{gal}$ of product. If ethyl aryl ethers are produced instead of methyl aryl ethers, a higher mass yield results, but the price of EAE is highly dependent on the price of ethanol ( $\$ 0.60$ to $\$ 1.05$ ), changing the cost from $-4 \phi$ to $+9 \notin /$ gal of product, respectively, relative to MAE. If the hydrocracker pressure were reduced from 1000 to 200 psi because of higher catalyst activity, equipment changes, especially in compression of the recycled hydrogen, could decrease the cost of MAE by as much as $12 \phi / \mathrm{gal}$.

\section{Experimental}

In virtually all the experiments reported here, a number of experimental conditions were held constant. The reactor used was an Autoclave Engineers Inc. (Erie, Pa.) $300-\mathrm{mL}$ stirred autoclave. The reactor temperature was chosen as $400^{\circ} \mathrm{C}$ based on previous work on lignin hydrotreating by other researchers (e.g., Gendler et al, 1983) and also based on the experience of hydrotreating lignin model compounds (e.g., Ratcliff et al. 1988). The feed was made up of the catalyst, lignin, and a solvent or vehicle present in the ratio of $1: 3: 10.8$ on a weight basis. The catalysts were presulfided, except in the case of the Ptimpregnated catalyst, and were loaded into the reactor prior to sealing the reactor. Catalyst presulfidation was accomplished at $400^{\circ} \mathrm{C}$ in a tubular reactor using a mixture of $10 \% \mathrm{H}_{2} \mathrm{~S}$ in $\mathrm{H}_{2}$, which was flowed through the catalyst fed. The catalysts were grourd to a fine powder $(-230$ to +170 mesh $)$ and dried in an oven prior to sulfidation. After sulfidation the catalysts were stored in a desiccator in a nitrogen atmosphere until used. A twofold excess of $\mathrm{H}_{2} \mathrm{~S}$ was passed over the catalysts, based on their molar metal content, to ensure their complete sulfidation. In addition, catalysts were sulfided a second time after being unpacked from the tubular reactor and then repacked, to ensure uniform sulfidation. Cataly'st sulfidation was maintained during the experiments by using a gas feed of $2 \% \mathrm{H}_{2} \mathrm{~S}$ in $\mathrm{H}_{2}$. To ensure that the platinum catalysts were fully reduced, they were treated with $\mathrm{H}_{2}$ at $1100 \mathrm{psi}$ for $2 \mathrm{~h}$ at $450^{\circ} \mathrm{C}$, and of course the gas feed used during the hydrotreating experiments was $\mathrm{H}_{2}$, free of any $\mathrm{H}_{2} \mathrm{~S}$. During experiments, gas was flowed into the reactor to maintain a high $\mathrm{H}_{2}$ partiai pressure. If this was not done, $\mathrm{H}_{2}$ consumptions greater than $90 \%$ could be observed. The feed gas was fed into the bottom of the reactor via the stirrer shaft, and product gas, including volatile products, was bled from the reactor into a pressurized condenser where the stream was cooled to separate the liquid products from the gases. This also served to decrease the residence time of reactive monophenolics and other products in the reactor, thus minimizing the possibility of their further reaction. A micrometering valve downstream of the reactor was used to control the flow rate of gas from the reactor. The setting of the valve was adjusted to maintain a relatively constant flow (about $750 \mathrm{sccm}$ ) of $\mathrm{H}_{2}$ into the reactor, as measured by the mass flow meter upstream of the reactor. The pressure in the reactor was controlled to $1000 \mathrm{psi}$ by a forward pressure regulator also upstream of the reactor. A PC computer was used to acquire data from the pressure transducers in the gas feed line and reactor, and from the mass flow detector. Integration of the mass flow over the period of an experiment pernitted calculation of the amount of $\mathrm{H}_{2}$ fed into the reactor.

Two lignins have been used in this study. Reotek Co., a small business company of Jacksonville, Fla., supplied an ikali-extracted steam-exploded aspen lignin (AESEAL). The lignin was washed with deionized water, centrifuged, and dried prior to use. Elemental analysis of this lignin found $61.1 \%$ carbon, $5.6 \%$ hydrogen, $32.2 \%$ oxygen, and $0.4 \%$ nitrogen. An organosolv lignin made from mixed hardwoods was supplied by Repap T :hnologies, Inc., of Valley Forge, Pa., produced by their ALLCELL ${ }^{\text {TM }}$ process. This lignin was soxhlet-extracted with deionized water for $24 \mathrm{~h}$ and then freeze dried before use. Analysis of this lignin found $92 \%$ klason lignin, $5 \%$ acid soluble lignin, and $0.5 \%$ ash. Elemental analysis of the lignin found $67.3 \%$ carbon, $6.0 \%$ hydrogen, $26.9 \%$ oxygen, $0.1 \%$ nitrogen, and $0.05 \%$ sulfur. The 
phenolic hydroxyl content was determined to be $5.3 \%$. The AESEAL was mostly used to prepare a relatively large batch of pasting oil, whereas the organosolv lignin was used in the catalyst comparison studies.

Researchers decided early that where possible the lignin feed should be introduced into the reactor after the reactor had been preheated to the reaction temperature. Loading the lignin feed into the autoclave at room temperature before it has been sealed is the simplest method of getting the feed into the reactor; however, this results in subjecting the lignin to a long heat-up perlod, which for the $300-\mathrm{mL}$ autoclave is about $45 \mathrm{~min}$. Lignins are very reactive and the possibility of cleaving relatively labile carbon-oxygen bonds at low temperatures with subsequent formation of more stable carbon-carbon bonds does exist. Other researchers experienced in the field of lignin hydrotreating have advised that results obtained under these conditions of slow heatup are not reproduced in reactor systems similar to those used in commercial operations that operate continuously. In most of the experiments reported here, the lignin feed was injected into the reactor preheated to slightly above the reaction temperature so that the reaction temperature was reached in the shortest possible time. A pneumatic pump was used to inject the lignin feed into the reactor, which was preheated and prepressurized with $\mathrm{H}_{2}$. By this means, delivery of the liquid and gas feeds into the reactor was decoupled. The lignin feed comprised the lignin and a solvent or vehicle in which the lignin was dissolved or suspended. Three groups of experiments were performed that are differentiated by the material used to r:ake up the lignin feed in addition to lignin. $\mathrm{m}$-Cresol was used because it dissolved lignin, and the resulting feed was easily pumped. The nonvolatile fraction of the product of hydrotreating lignin in $\mathrm{m}$-cresol, i.e. a lignin-derived pasting oil, was also used. The pasting oil partially dissolved and partially suspended the lignin and was much more viscous and therefore more difficuli to pump than the $m$-cresol solution. However, the pasting oil system is more representative of the situation expected in a commercial hydrotreating plant in which the lignin feed would be made up of fresh lignin and a recycle stream of partially converted liquefied lignin, as was used by HRI in its pilot plant. A third system has also been used in which tetradecane was used to make a lignin suspension. The pneumatic pump could not handle the suspension so, for these experiments, the feed was loaded into the reactor at room temperature. Consequently, the lignin was subjected to a long heat-up period. A new injector has recently been constructed that should be able to pump slurries, and this will be tested as soon as possible.

The main purpose of this work in the past year has been to study the effect of different catalysts on lignin hydrotreating, and to try to reproduce the catalyst activities observed with lignin model compounds with lignin itself. Four catalysts have been used, two of which were commercial $\gamma$-alumina-supported catalysts and two were supported on phosphated alumina $(\mathrm{P}: \mathrm{Al}$ mole ratio $=0.8)$ prepared at $\mathrm{CSM}$ according to the method described by D. A. Erickson (1990). The catalysts were impregnated with Mo, Ni/Mo, and Pt. The physical characteristics and metal loadings are shown in Table 2. Unfortunately, it was only after completing the first study, using the lignin in $\mathrm{m}$-cresol system, that it was discovered that there was a problem with the Pt-impregnated catalyst. It was found that the Pt catalyst was more sensitive to the conditions of preparation than had originally been anticipated. The $\mathrm{Pt}$ on the fresh batch of catainst prepared for this study was found to be inactive. This was confirmed by subsequent testing with model compounds. The preparation of a $\mathrm{Pt}$ catalyst with activity similar to that originally prepared and tested with model compounds has taken several months and has only recently been made. The new catalyst has yet to be tested with lignin in any of the feed systems.

At the end of experiments the product was immediately removed from the reactor via a dip tube into a high-pressure sample bottle, thus rapidly cooling the product. The heater was then lowered and the reactor 
Table 2. Catalyst Metal Loadings and Physlcal Characterlstics

\begin{tabular}{|c|c|c|c|c|}
\hline Catalyst & NI/Mo & Mo & Mo.P & Pt-P \\
\hline Support & $\gamma$-alumina & $\gamma$-alumina & $\begin{array}{l}\text { phosphated } \\
\text { alumina }\end{array}$ & $\begin{array}{l}\text { phosphateo } \\
\text { alumina }\end{array}$ \\
\hline P:Al Ratio & 0 & 0 & 0.8 & 0.8 \\
\hline Supplier & Harshaw & Strem & CSM & $\operatorname{CSM}$ \\
\hline Cat. No. & HT-500 & $42-1500$ & IC21 & $D E-01 A$ \\
\hline Speciflc Area $\left(\mathrm{m}^{2} / \mathrm{g}\right)$ & 200 & 64 & 134 & 134 \\
\hline Motal Loading & $\begin{array}{c}3.5 \% \mathrm{NiO} \\
15.5 \% \mathrm{MoO}_{3}\end{array}$ & $\begin{array}{l}10-12 \% \\
\mathrm{MoO}_{3}\end{array}$ & $18.4 \% \mathrm{MoO}_{3}$ & $0.3 \% \mathrm{Pt}$ \\
\hline
\end{tabular}

rapidly cooled with a high-pressure air hose, so that the small amount of product remaining in the reactor was also rapidly cooled. The reactor was then depressurized through the pressurized condenser so that no volatile products were lost. During depressurization the total volume of the product gas was measured and samples were taken so that gas compusition could be determined (by gas chromatograph [GC]). From this the yields of gas products and hydrogen consumption were calculated. Organic products from the reactor and the condenser were identified and quantiffed by capillary gas chromatograph/mass spectrometer detector (GC/MSD) analysis, and yields of volatile products were calculated. The water content in the products was also determined by GC. The reactor was washed with acetone to recover the catalyst and the acetone-insoluble product. The acetone-soluble product was vacuum distilled to recover the volatile products, and the distillation residue was saved for use as pasting oil for subsequent experiments. The fraction of nonvolatile product in the acetone soluble material, mostly partially hydrotreated lignin, was estimated by high-performance size exclusion chromatography (HPSEC). By summing the yields of these product fractions, the total mass closure for each experiment was calculated. Mass closures were good throughout this study, averaging $90 \pm 7 \%$. The reproducibility of replicate experiments was also good. For example, in three identical experiments using the Ni/Mo catalysit, total volatiles yields were $77 \pm 4 \%$, hydrocarbons yields were $11.4 \pm 0.3 \%$, nonvolatiles yields were $6.3 \pm 0.2 \%$, acetone-insoluble product yields were $1.2 \pm 0.1 \%$, and gas product yields were $3.4 \pm 0.35 \%$.

\section{Chromatographlc Analysls Conditions}

Molecular weight distributions of the pasting oils were determined by HPSEC. HPSEC was performed using a Hewlett-Packard HP 1090 high-performance liquid chromatograph with an ultraviolet diode-array detector (HP 1040) and a refractive index detector (HP 1037A). Chromatograms were obtained by monitoring the response at $260 \mathrm{~nm}$ (bandwidth $80 \mathrm{~nm}$ ). An HPSEC column (Polymer Labs. PL Gel, 300 $\times 7.5 \mathrm{~mm}$ ) containing polystyrene-divinyl benzene copolymer gel particles ( $5 \mathrm{j}$ m diameter) with a mean pore diameter of $50 \AA$ was used. Spectroscopic grade tetrahydrofuran was used for dissolving the samples and as an eluant at a flow rate of $1 \mathrm{~mL} / \mathrm{min}$. Injections $(5 \mu \mathrm{L})$ were made with an automatic sampler, and the column compartment was maintained at $28^{\circ} \mathrm{C}$. Elution time was converted to apparent molecular weight by calibration with polystyrene and IGEPAL ${ }^{\mathrm{TM}}$ standards of known molecular weight. Sample concentrations were accurately made up to be approximately $1 \mathrm{mg} / \mathrm{mL}$. All the samples were completely soluble in the solvent. 
Analysis of the volatic phenolics and hydrocarbons in the condensate and reactor products was accomplished using a Hewlett-Packard GC/MSD (IP 5970B) with an Ultra 2 capillary column (25 m length by $0.2 \mathrm{~mm}$ internal diameter). Chromatograplic conditions were a linear velocity of $28 \mathrm{~cm} / \mathrm{s}$, with the following temperature program: hold at $35^{\circ} \mathrm{C}$ for $3 \mathrm{~min}$ and then increase the temperature to $300^{\circ} \mathrm{C}$ at $5^{\circ} \mathrm{C} / \mathrm{min}$, holding for $3 \mathrm{~min}$ at $300^{\circ} \mathrm{C}$ for a total run time of $59 \mathrm{~min}$. This allowed maximum separation of the 200 to 300 components typically observed in thest samples. Peak assignments were made on the basis of comparison with the library of spectra supplied by the manufacturer and were verified where possible by injection of pure samples. In these analyses, 21 hydrocarbons and phenols were individually quantified using multilevel calibration standards. Standards at each level were run in triplicate to accurately establish calibration curves and check reproducibility. The samples were also run in triplicate and the results averaged. In addition, there was a very large number of peaks observed that were not identified. These were grouped as hydrocarbons, phenols with less than three carbons substituted on the ring $\left(<\mathrm{C}_{3}\right.$ phenols, e.g., dimethyl phenols), and phenols with three or more carbon substituents $\left(>\mathrm{C}_{3}\right.$ phenols, e.g., propyl phenols), by their retention times relative to phenol and 2-propyl phenol. These uncalibrated products were lumped together and average response factors were used to quantitate them. This complicated and very time-consuming analysis was necessary for quantitation of the products that would actually constitute any liquid fuel made from lignin. The yields of these volatile components were also used to try to judge differences in catalyst activity.

Gas samples were subjected to a refinery gas analysis on a Carle Analytical Gas Chromatograph $111 \mathrm{H}$ using a multicolumn multivalve automated analysis as described in application note No. 156-A of the Carle Series ". (Cat. No. 0156 AGC). This method is capable of determining up to 21. nydrocarbons and inert gases trom a single injection. Hydrogen, carbon monoxide, carbon dioxide, methane, ethane, propane, as d propene were commonly observed gaseous products.

\section{Results}

\section{Hydrotreating Lignin in m-Cresol to Produce a Lignin-Derlved Pasting Oll}

Catalytic hydrotreating of the Reotek lignin (usually $2.8 \mathrm{~g}$ ) in m-cresol (100 g) using the commercial $\mathrm{Ni} /$ Mo catalyst, normally consumed about $50 \%$ of the $3.5-4 \mathrm{~g}$ of hydrogen input. Under these conditions about $50 \%$ of the mass of the feed was collected in the condenser, and the remainder staying in the reactor was washed out with acetone. The material insoluble in acetone included the catalyst and the acetone insoluble product (yield $<2 \%$ of the feed). The yield of gas products, mostly methane and carbon dioxide, was about $3 \%$. The acetone solubles were vacuum distilled to recover the volatile products and $\mathrm{m}$-cresol. The material to be used as pasting oil was the distillation residue, which was recovered in about $12 \%$ yield based on the total feed. Taking into account the small amount of distillation residue (4\%-5\%) obtained from blank experiments using m-cresol alone, approximately $40 \%$ of the lignin was converted to pasting oil under these conditions. A substantial fraction of the lignin was converted to volatile products, however. This was necessary to obtain a residue of relatively low molecular weight and viscosity for use as a pasting oil. From many experiments about $200 \mathrm{~g}$ of pasting oil was produced, which was used in subsequent experiments to test the effect of the catalysts on hydrotreating lignin in pasting oil.

\section{Comparlson of Catalysts in the LIgnin/m-Cresol System}

To try to distinguish the effect of hydrotreating lignin from hydrotreating $\mathrm{m}$-cresol, an experiment using the solvent alone was conducted for each of the catalysts under the same conditions as employed when lignin was present. GC/MSD analysis of the volatile organic product from these experiments identified 21 hydrocarbons and phenols that were individually quantified. The largest products were methyl 
cyclohexane, toluene, and phenol, expected products of hydrotreating m-cresol (Odebunmi 1982; Odebunmi and Ollis 1983) or lignin (Gendler et al., 1983). Because the products from hydrotreating $\mathrm{m}$ cresol were the same as those produced when lignin was present, it was difficult to distinguish changes in yields caused by interaction of the various catalysts with the lig.in. However, m-cresol can be considered as a model for lignin, and the phenols yields may be interpre ed on the basis of the combined reactivity of $\mathrm{m}$-cresol and lignin with the catalysts.

As can be seen from Table 3, the highest hydrodeoxygenation activit' was found using the commercial Ni/Mo catalyst. Hydrogenation activity was also higher with relatively more cyclohexanes produced. With lignin in the feed, the yield of hydrocarbons decreased substantially; however, this was the highest yield of hydrocarbons from the combined feed using any of the catalysts. An unexpected trend observed for all the catalysts was a substantial decrease (mostly more than twofold) in the yield of hy drocarbons when lignin was present in the feed. As might be expected, the yields of gaseous, nonvolatile, and acetone insoluble products all increased when lignin was present in the feed. The Mo-P gave higher hydrocarbon yields than the commercial Mo catalyst, and very surprisingly, the Pt-P catalyst produced very little hydrocarbon product although a pressure of 1000 psi was used. The most desirable product, the $<\mathrm{C}_{3}$, was produced to the largest extent by the phosphated alumina-supported catalysts. This is in agreement with the model compound studies for the Mo-P catalyst; however, at a pressure of $1000 \mathrm{psi}$, the Pt-P catalyst should have been strongly hydrodeoxygenating and hydrogenating. Model compound experiments (Erickson 1990) have shown that the Pt-P is a very strong hydrodeoxygenating catalyst, converting more than $90 \%$ of 4-propyl phenol to hydrocarbons at high hydrogen pressure (>500 psi). The lack of hydrodeoxygenation activity for the Pt-P catalyst is also evidenced by the relatively low yield of water. Char formation as measured by acetone insolubility was also higher when using the Pt-P catalyst. This batch of catalyst was made specially for the lignin hydrotreating study and was from a different batch than that used with the model compounds. Subsequent testing of this batch with 4-propyl phenol found that the metal was almost completely inactive in this preparation, the catalyst behaving similarly to the support without any Pt on it. Since this work, the problem of reproducibly preparing the Pt-P catalyst has received a lot of attention at CSM and has only recently been solved. In the past, in preparing catalysts made with phosphated alumina supports impregnated with $\mathrm{Mo}$ and $\mathrm{Co}$ or $\mathrm{Ni}$, no problems of batch-to-batch reproducibility were found. Only with the Pt catalyst has this reproducibility problem arisen. In the future, all batches of catalysts will be tested with model compounds before being used with lignin to check their activity. The experiments with the Pt-P catalyst will be repeated with the new catalyst as soon as possible.

Comparison of the activities of the catalysts other than Pt-P is complicated, because the products of cresol hydrotreating and lignin hydrotreating are the same. The Ni/Mo catalyst appears to be more hydrodeoxygenating than the Mo-impregnated catalysts. It is also more hydrogenating with more cyclohexanes formed than aromatic hydrocarbons, as was expected. Comparing the two Mo-impregnated catalysts, the expected increased cracking activity of the Mo-P catalyst can be seen. More $<\mathrm{C}_{3}$ phenols and less $>\mathrm{C}_{3}$ phenols are produced using Mo-P, with more phenol and toluene. The Mo-P also appears to be less hydrogenating than Mo on the nonacidic support, as predicted by the model compound studies, with more aromatic hydrocarbons formed than cyclohexanes. Nonvolatile product, acetone-insoluble product, and gas product are also slightly decreased using the Mo-P catalyst. The addition of phosphate to the support does appear to shift the product spectrum in the desired direction. However, the interaction of the catalysts with the lignin cannot be separated from their interaction with the solvent $m$-cresol. There does appear to be a general decrease in activity for all the catalysts when lignin is present. This could be due to coking of the catalyst surface, although formation of char as measured by acetone insolubility is not high. Another factor that must be considered when comparing catalyst activities with lowmolecular-weight model compounds relative to a high-molecular-weight feed like lignin, is that the lignin must depolymerize to at least dimers or trimers before material from lignin can enter catalyst pores. Further experimentation will be necessary to determine the cause of decreased catalyst activity in the 
Table 3. Comparison of Product Ylelds from Hydrotreating Llgnin in m-Cresol with the Varlous Catalysts

\begin{tabular}{|c|c|c|c|c|c|c|c|c|}
\hline \multirow{2}{*}{$\begin{array}{c}\text { Yields } \\
\text { (wt\% based on } \\
\text { total feed) }\end{array}$} & \multicolumn{2}{|c|}{$\mathrm{Ni} / \mathrm{Mo}$} & \multicolumn{2}{|c|}{ Mo } & \multicolumn{2}{|c|}{ Mo-P } & \multicolumn{2}{|c|}{ Pt-P } \\
\hline & Cresol & $\begin{array}{l}\text { Cresol/ } \\
\text { Lignin }\end{array}$ & Cresol & $\begin{array}{l}\text { Cresol/ } \\
\text { Lignin }\end{array}$ & Cresol & $\begin{array}{l}\text { Cresol/ } \\
\text { Lignin }\end{array}$ & Cresol & $\begin{array}{l}\text { Cresol/ } \\
\text { Lignin }\end{array}$ \\
\hline $\begin{array}{l}\text { Total } \\
\text { Hydrocarbons }\end{array}$ & 32.5 & 11.4 & 16.7 & 1.9 & 25.3 & 5.4 & 0.6 & 0.5 \\
\hline $\begin{array}{l}\text { Total }<\mathrm{C}_{3} \\
\text { Phenols }\end{array}$ & 1.5 & 3.0 & 0.4 & 1.8 & 10.5 & 3.2 & 21.5 & 5.9 \\
\hline $\begin{array}{l}\text { Total }>C_{3} \\
\text { Phenols }\end{array}$ & 0.0 & 1.2 & 0.5 & 1.8 & 1.6 & 1.5 & 2.0 & 2.3 \\
\hline $\begin{array}{l}\% \text { m-Cresol } \\
\text { Recovered }\end{array}$ & 41.4 & 55.9 & 63.4 & 62.1 & 51.4 & 71.7 & 40.5 & 67.0 \\
\hline $\mathrm{H}_{2} \mathrm{O}$ & 7.3 & 6.1 & 7.9 & 6.1 & 9.7 & 5.4 & 2.2 & 3.5 \\
\hline Total Volatiles & 86.4 & 77.0 & 99.6 & 71.0 & 107.4 & 86.6 & 74.7 & 75.4 \\
\hline $\begin{array}{l}\text { Estimated } \\
\text { Nonvolatiles }\end{array}$ & 1.0 & 6.3 & 0.2 & 5.5 & 0.8 & 4.3 & 5.3 & 13.1 \\
\hline $\begin{array}{l}\text { Acetone } \\
\text { Insolubles }\end{array}$ & 0.3 & 1.2 & 0.2 & 0.9 & 0.1 & 0.7 & 0.2 & 2.4 \\
\hline Gas Product & 0.6 & 3.4 & 0.6 & 2.8 & 0.2 & 2.4 & 0.4 & 1.2 \\
\hline Mass Closure & 88.3 & 87.9 & 100.5 & 80.1 & 108.6 & 94.1 & 80.5 & 92.1 \\
\hline
\end{tabular}

presence of lignin. Catalyst deactivation by coking could be tested using physical measurements or by reexamination of catalyst activity with a model compound after a batch has been used with lignin.

\section{Comparison of Catalyst Activity In the Pasting OII/LIgnin System}

Lignin was also hydrotreated in lignin-derived pasting oil, because this is the feed system most likely to be used in a commercial operation. The pasting oil was produced in earlier experiments by hydrotreating lignin in $\mathrm{m}$-cresol using the $\mathrm{Ni} / \mathrm{Mo}$ catalyst. The aim of these experiments was to again attempt to observe the trends found in hydrotreating the model compounds with lignin. The effect of adding lignin was studied by hydrotreating pasting oil alone and with lignin added. The experiments using the Moimpregnated catalysts were performed as a series and are compared with an earlier experiment in which a pasting oil was hydrotreated with the Ni/Mo catalyst. In each case, the pasting oil used was analyzed for its volatile components by GC/MSD before it was used, so that the amounts of the products formed by hydrotreating could be carefully quantified. In addition, volatile products were isolated from the condenser trap and by vacuum distillation of the product collected from the reactor. The distillation residue was recycled and used as pasting oil for subsequent experiments. The results of these experiments are collected in Table 4. The data here represent the change in content of the various components in the product on a yield basis relative to the total feed. For some components that were not present in the feed, 
e.g., gas and acetone-insoluble products, this is a straightforward yield, whereas for others, such as mcresol, which was always present in the feed to a certain exterit, the yield is adjusted to account for the amount ortginally present in the feed.

Of these experiments, the one showing the largest yield of volatile products by GC/MSD analysis was the experiment using the Ni/Mo catalyst. The next highest yield of volatiles by GC/MSD occurred using the Mo-P catalyst with pasting oil alone, which was significantly higher than observed in the remaining experiments. Differences in the combined volatile product yields from the condenser and vacuum distillate were much smaller than the volatiles yields measured by GC/MSD. Differences between these two measures of volatile product yields occur because no adjustment was made of the isolated yield for the presence of volatiles in the feed. Variations in volatile content for the different pasting oils occurred because of difficulties in exactly controlling the vacuum distillation. Again the experiments giving the highest ylelds of volatiles used the Ni/Mo catalyst and the Mo-P catalyst with pasting oil containing no lignin.

The yields of acctone insolubles (char) were relatively low in all experiments while the gas yields appeared to increase when hydrotreating pasting oil containing lignin. The preferential formation of $\left\langle\mathrm{C}_{3}\right.$ phenols als's occurred in the two experiments producing the most volatiles, as did the largest decreases in the nonvolatile component measured either by size exclusion chromatography or the amount of pasting oil produced. Addition of lignin to the pasting oil resulted in the lowest yields of all volatile products, as was observed in the lignin in $\mathrm{m}$-cresol hydrotreating experiments. Again, catalyst deactivation by coking or rate limiting depolymerization of the lignin are possible reasons.

From these experiments, the influence of catalyst support acidity cannot be clearly differentiated. There was one important variable that could not be held constant throughout this study, namely the pasting oil. About 18 experiments were necessary to produce the initial batch of about $200 \mathrm{~g}$ of pasting oil. To maintain sufficient pasting oil to complete this series of experiments, the nonvolatile products from each of these experiments were also recycled. It appears possible that the history of the pasting oils was a significant factor in the total yield of volatiles from these experiments. The high yields of $\mathrm{m}$-cresol, much more than any other component, and the tendency for the yields of volatiles to decrease as the fraction of recycled pasting oil increased, suggest that the pasting oil composition was a significant factor in determining the products from these experiments. Although the early experiment using the Ni/Mo catalyst used a different batch of pasting oil that appeared to contain relatively higher molecular weight material compared to the pasting oils used in the later experiments, it gave the highest yield of volatiles. This could be a catalyst effect or could come from breakdown of relatively weak complexes or adducts of $\mathrm{m}$ cresol or other monophenolics with higher molecular weight material in the pasting oil. The other experiment that had a high volatiles yield also involved a pasting oil that contained no multiple recycled material. To perform meaningful catalyst comparison experiments using pasting oil, in the future, will require the use of a pasting oil from a single large batch so that pasting oil composition is not a factor. The pasting oil should also be recycled sufficiently so that volatile product formation from the oil is minimized. This will require the use of a much larger reactor than the $300-\mathrm{mL}$ autoclave currently used, for pasting oil production to occur in a timely manner. Some preliminary work to produce larger quantities of pasting oil more quickly has been performed using a Berty reactor on loan from CSM, which can also be run continuously.

\section{HydrotreatIng Llgnin In Tetradecane}

Most recently the Repap organosolv lignin has been hydrotreated in tetradecane $\left(\mathrm{C}_{14} \mathrm{H}_{30}\right)$, a large straight chain alkane solvent. Using the other solvents, $m$-cresol and pasting oil, it was difficult to distinguish 
Table 4. Comparlson of Product Ylelds from Hydrotreating Lignin In Pasting Oll with Different Catalysts

\begin{tabular}{|c|c|c|c|c|c|}
\hline \multirow{2}{*}{$\begin{array}{l}\text { Product Yields } \\
\text { (\% change based } \\
\text { on total feed) }\end{array}$} & $\mathrm{Ni} / \mathrm{Mo}$ & Mo & Mo & Mo-P & Mo-P \\
\hline & No Lignin & No Lignin & Lignin & No Llgnin & Lignin \\
\hline Total Hydrocarbons & 11.3 & 2.9 & 2.1 & 8.3 & 3.1 \\
\hline Total $<C_{3}$ Phenols ${ }^{a}$ & 13.6 & 2.4 & 1.1 & 10.6 & 0.5 \\
\hline Total $>C_{3}$ Phenols & 10.9 & 3.7 & 2.4 & 6.7 & 4.1 \\
\hline m-Cresol & 16.1 & 4.4 & -7.3 & 4.8 & 1.4 \\
\hline $\mathrm{H}_{2} \mathrm{O}$ & 2.5 & 0.6 & 1.8 & 3.3 & 2.2 \\
\hline Total Volatlles & 54.4 & 14.0 & 0.1 & 33.7 & 11.4 \\
\hline $\begin{array}{l}\text { Estimated } \\
\text { Nonvolatiles }\end{array}$ & -24.1 & -14.8 & -10.2 & -30.2 & -11.5 \\
\hline \multicolumn{6}{|l|}{ Isolated Products } \\
\hline Acetone Insolubles & 1.9 & 1.2 & 2.6 & 2.8 & 2.9 \\
\hline Gas Product & 1.8 & 0.9 & 4.7 & 0.8 & 2.9 \\
\hline Condensate & 11.5 & 4.9 & 10.9 & 18.5 & 9.2 \\
\hline Distillate & 23.9 & 5.6 & 17.1 & 13.9 & 5.8 \\
\hline Pasting Oll & 47.4 & 79.5 & 59.4 & 49.6 & 72.4 \\
\hline Mass Closure & 86.5 & 92.0 & 94.7 & 85.6 & 93.1 \\
\hline
\end{tabular}

${ }^{a}$ Excluding m-cresol

products formed from the solvents from products originating from the lignin. When tetradecane was subjected to hydrotreating conditions, other alkanes were the exclusive products. These are easily distinguishable in a GC/MSD analysis from the phenols, aromatic hydrocarbons, and cyclic paraffins formed from lignin. There is, however, a major operational difficulty in using tetradecane, in that lignin is insoluble in this solvent. This requires either a new injec: on system that can handle slurries, or the introduction of the feed into the reactor while it is still cold. If the feed is not injected into the preheated reactor it is subjected to a long heat-up period $(45-60 \mathrm{~min})$, which is thought to be deleterious to the formation of volatile products from lignin. In fact, the overall yields of volatile organics were disappointingly low, only 7\%-8\% of the lignin in the feed, from experiments where the lignin feed was subjected to the slow heatup. At the next opportunity, the new slurry injector will be used to test whether the slow heatup was the cause of these low yields.

These experiments using tetradecane as a solvent were performed with the Ni/Mo catalyst or the Mo-P catalyst. The char yields were very low from the catalyzed experiments, only about $2 \%$ based on the lignin charged (after subtraction of the small amount of char, about $1 \%$ yield, originating from the tetradecane measured in blank experiments without lignin). In an uncatalyzed experiment more than 50\% of the lignin was converted to char. The molecular weight distrioutions of the pasting oils from these 
experimer:s appeared to be relatively low and lower than those produced when $\mathrm{m}$-cresol was used as solvent.

The yields and types of products found by GC/MSD analysis clearly showed differences in activity between the two catalysts. The results from the model compound hydrotreating studies were for the most part observed in these experiments on hydrotreating lignin. The Ni/Mo catalyst showed higher hydrogenation and hydrodeoxygenation activity, and the Mo-P catalyst produced more phenols and had higher hydrocracking activity. The higher hydrogenating activity of the Ni/Mo catalyst resulted in twice the yield of saturated cyclic alkanes such as cyclohexane. One unexpected result of the lower hydrogenating activity of the Mo-P catalyst was the increase in yield of cyclohexene compared to cyclohexane. An increase in the yield of aromatic hydrocarbons was expected with the Mo-P catalyst. However, the largest increases in yield occurred for a number of substituted cyclohexenes, cyclopentanes, and cyclopentenes. The Mo-P catalyst was also less deoxygenating, as was predicted from the model compound studies, with a $50 \%$ higher production of phenols compared to the Ni/Mo catalyst. Both catalysts were, however, relatively strongly hydrodeoxygenating, as evidenced by the amounts of water produced. Based on the oxygen content of the lignin (25.8 wt\%), $78 \%$ and $63 \%$ of the maximum possible yield of water was produced from the Ni/Mo and Mo-P catalyzed experiments, respectively. The hydrocracking activity of the phosphated alumina supported Mo-P catalyst was also observed in a fourfold decrease in the yield of propyl substituted hydrocarbons and large increases in the relative yields of 0-2 carbon substituted products compared to propyl substituted products. Hydrotreating lignin under these conditions without a catalyst present resulted in much lower yields of volatile organic products, only 0.7 wt\% compared to the $7-8 \mathrm{wt} \%$ with the catalysts piesent. The yield of water was also much reduced from $18-23 \mathrm{wt} \%$ down to less than $7 \%$.

To be meaningful, these results need to be repeated under conditions in which much higher total yields of volatile organics are obtained, which will hopefully occur when the feed is injected into the preheated reactor. Future experiments will examine this, and if successful, the lignin/tetradecane feed will be a very effective system for studying the effects of catalyst, reaction time, and temperature, using an experimental design. A batch $(5 \mathrm{~kg})$ of steam-exploded lignin prepared at severity 3.8 was received recently from the University of Sherbrooke, which will also permit the study of lignin type. Additional lignins from steam explosion are now also available from the Biobased Materials Center at Virginia Tech., Blacksburg, Va. These samples and the organosolv lignins from Repap are examples of potential substrates for further conversion, in addition to the dilute acid hydrolysis lignins produced by the biofuels program.

The use of tetradecane as a vehicle for lignin promises to greatly simplify analysis of the GC/MSD data, as all the products of interest unequivocally originate from the lignin. In addition, analysis of the molecular weight distribution of the nonvolatile fraction of the product by size exclusion chromatography is also greatly simplified because of the lack of UV-absorbing tetradecane derived products. Only ligninderived products are observed by the UV detector of the chromatograph. The only problem with this system apparent at this time, is the delivery of the lignin/tetradecane slurry into the reactor.

\section{Summary}

Lignin has been hydrotreated using three different solvent/vehicle systems to deliver it into the reactor. Although it has been very difficult to get very clear data showing the influence of the different catalysts on the distribution of volatile organic products, some of the trends predicted by the lignin model compound studies have been observed. Using $\mathrm{m}$-cresol, the higher hydrogenating and hydrodeoxygenating activity of $\mathrm{Ni} / \mathrm{Mc}$ impregnation compared to Mo alone was seen. When comparing the two Moimpregnated catalysts, the increased hydrocracking activity of the acidic phosphated alumina support was also observed. Similar trends were observed in the few experiments performed with lignin and 
tetradecane. Experiments with the very promising Pt-impregnated catalyst must, however, be repeated with a catalyst prepared under better controlled conditions. No catalyst effects could be clearly ascribed to the data generated by hydrotreating lignin in pasting oil. In the future it will be important to observe catalyst effects in a lignin/pasting oil system, as this more closely represents the situation likely to exist in commercial lignin hydrotreating. It will be necessary to produce a large batch of multiple recycled pasting oil that can be used for a series of experiments.

Both the m-cresol and pasting oil experiments are difficult to interpret because the products from hydrotreating these materials are the same as those from hydrotreating lignin. This is not the case when tetradecane is used. All products of interest can only come from lignin; degradation products from tetradecane are clearly recognizable as such. From limited initial experimentation, tetradecane does not appear to form adducts with lignin and its products. In addition, tetradecane is not a hydrogen donor solvent and so appears to have minimal influence on lignin/catalyst interactions. Tetradecane seems to be an ideal solvent for studying catalyst effects on lignin hydrotreating, provided the problem of pumping lignin/tetradecane slurries can be solved, which hopefully the new injector will do.

\section{Acknowledigments}

We are most grateful to D. A. Erickson and X. H. Zhao at CSM for preparing the aluminophosphatesupported catalysts and S. Cowley for consultations on catalyst behavior. S. K. Black, J. Fennel, B. Hames, and P. Adams are thanked for their assistance in many ways, including analysis of samples and purification of lignins. J. Scahill. and J. Diebold are thanked for their support and helpful suggestions. We thank Reotek and Repap Technologies Inc. for the donation of considerable amounts of lignins for these studies. Without these substantial donations, this work would not have been possible. This work was sponsored by the Biofuels Systems Division of the DOE Office of Transportation Technologies through the Alcohol Fuels Biochemical Conversion Program, managed by R. Moorer (DOE) and B. Goodman (SERI).

\section{References}

Bergeron, P. W., and Hinman, N. D. 1989. "Technical and Economic Analysis of Lignin Conversion to Methyl Aryl Ethers," In Proceedings of Ethanol from Biomass Annual Review Meeting. Golden CO: Solar Energy Research Institute.

Bergeron, P. W. 1989. Personal communication.

Erickson, D. A. 1990. "Hydrodeoxygenation and Dealkylation of Model Lignin Compounds." Master's Thesis, Colorado School of Mines, Golden, Colorado.

Gendler, J. L., Huibers, D. T. A., and Parkłurst, H. J. 1983. "Hydroxy Aromatics from Lignin Hydrogenolysis," In Wood \& Agr. Residues, ed. E. J. Soltes, 391-400. Proc. ACS Conf. Kansas City, 1982.

Lovell, W. G. 1948. Ind. Eng. Chem. 40 (12):2388-2438.

Maholland, M. K. 1987. "Synthesis, Characterization, and Activity Evaluation of Phosphate-Modified Hydroprocessing Catalysts for Benzofuran Hydrodeoxygenation." Ph.D. diss., Colorado School of Mines, Golden, Colorado. 
Odebunmi, E. O. 1982. "Heterogeneous Catalytic Hydrodeoxygenation of Cresols (Methyl Phenols) on Sulfided CoO- $\mathrm{MoO}_{3} / \gamma-\mathrm{Al}_{2} \mathrm{O}_{3}$ Catalysts at High Temperatures and Pressures." Ph.D. diss., Princeton University.

Odebunmi, E. O. and Ollis, D. F. 1983. J. Catal. 80:56.

Ratcliff, M. A., Johnson, D. K., Posey, F. L., Maholland, M. K., Cowley, S. W., and Chum, H. L. 1988. "Hydrodeoxygenation of a Lignin Model Compound," In Proceedings of the IEA International Conference on Research in Thermochemical Biomass Conversion, 941-55. Phoenix, AZ. Elsevier Applied Science.

Sarkanen, K. V., and Ludwig, C. H., eds. 1971. Lignins, Occurrence, Formation, Structure and Reactions. New York, NY: Wiley-Interscience.

Singerman, G. M. 1980. Methyl Aryl Ethers from Coal Liquids as Gasoline Extenders and Octane Improvers. Prepared under contract No. DE-AC01-79C50022. Pittsburgh, PA: Gulf Research and Development Co.

Unzelman, G. H., Forster, E. J., and Burns, A. M. 1971. "Are There Substitutes for Lead Antiknocks," In Proceedings of the 36th Midyear Meeting of the American Petroleum Inst., Div. of Refining, 852-896. San Francisco, CA: American Petroleum Institute. 


\title{
The Conversion of Lignin Model Compounds Into Phenolic Products Using $\mathrm{MOS}_{2}$ and Pt on Acidic Supports
}

\author{
D.A. Erickson, X. Zhao, and S.W. Cowley \\ Department of Chemistry and Geochemistry \\ Colorado School of Mines \\ Golden, Colorado 80401
}

\begin{abstract}
The conversion of lignin into phenolic or hydrocarbon products has relied on conventional molybdenumbased hydrotreating catalysts used by the petroleum industry. A good hydrotreating catalyst for petroleum feedstocks must contain a hydrogenolysis function and an acceptable hydrogenation function, and must resist sulfur poisoning. Supported molybdenum sulfide catalysts meet these criteria.

In order to produce phenolic products from lignin the catalyst must have hydrogenolysis, hydregenation, and dealkylation functions. The dealkylation function is provided by using a support with strong Bronsted acidity. Since lignin feedstocks contain very little sulfur, materials other than molybdenum sulfide were considered as catalyst candidates.

Several $\mathrm{MoS}_{2}$ and $\mathrm{Pt}$ catalysts were prepared using silica-alumina and phospho-alumina supports. The model lignin compounds 4-propylphenol and 4-propylguaiacol were used to study the activity and selectivity of the catalysts. The platinum catalysts were found to be far superior to the $\mathrm{MoS}_{2}$ catalysts. Phenol was produced in $47 \%$ yield (mole \%) at $400^{\circ} \mathrm{C}$ and $200 \mathrm{psig}$. Hydrocarbons were produced in $100 \%$ yield at $350^{\circ} \mathrm{C}$ and 500 psig. These preliminary results indicate that the platinum catalysts may be excellent candidates for the hydrotreatment of real lignin feedstocks.
\end{abstract}

\section{Introduction}

Biomass has long been considered as a petroleum substitute from which a liquid fuel could be produced. Woody biomass contains three major fractions, which must be isolated, then processed separately. These fractions consist of crystalline cellulose, the hemicellulose, and lignin. The cellulose fractions can be processed for use in paper manufacture or hydrolyzed into sugar and converted to ethanol through a fermentation process. The remaining high-molecular-weight lignin material is very resistant to chemical breakdown and requires the use of high temperatures and catalysts in order to produce acceptable lower molecular weight compounds. 
The objective of this study is to develop a catalyst that will facilitate the conversion of lignin to a liquid fuel suitable for blending with gasoline. Ideally, the lignin will be converted in one step to a mixture containing primarily monomeric phenols. In order to yield a mixture of single-ring phenolic compounds, the lignin must first thermally depolymerize to smaller molecules. Second, the smaller molecules must diffuse into the pores of the catalyst support. The smaller molecules are catalytically hydrotreated to produce the desired phenolic products. The catalyst should possess a hydrogenolysis function for removal of excess oxygen, an acid function for dealkylation of alkylphenols, and a hydrogenation function to prevent the transalkylation reaction. In addition, the catalyst support should have sufficiently large pores to permit the entry of depolymerization products.

\section{Background}

An extensive research effort of catalytic hydrodeoxygenation (HDO) literature was conducted in 1983 by Furimsky (1983). He presented a compilation of reaction mechanisms for HDO furans and benzofurans, the model compounds most commonly used in deoxygenation studies. The catalysts used in these studies are conventional molybdenum-based hydrotreating catalysts. The HDO of phenols are also discussed, since phenolic products appear as intermediates in the HDO of benzofurans.

In 1984 Lee and Ollis studied the $\mathrm{HDO}$ of benzofuran over a $\mathrm{Co}-\mathrm{Mo} / \mathrm{Al}_{2} \mathrm{O}_{3}$ catalyst at temperatures ranging from $220^{\circ}-345^{\circ} \mathrm{C}$ and $1000 \mathrm{psig}$ of hydrogen (Lee and Ollis 1984). Under these conditions both the hydrogenation and hydrodeoxygenation reactions were nearly first order, and the rate-determining step was the dehydroxylation of 2-ethylphenol.

In a similar study on the HDO of benzofuran, Edelman and coworkers proposed a modification to the network presented by Lee and Ollis in order to account for the production of phenol, toluene, and benzene (1988). This investigation, which also provided kinetic data for the hydrogenation and HDO of benzofuran, used a commercial Ni-Co/ $\mathrm{Al}_{2} \mathrm{O}_{3}$ catalyst. Results from this study are in partial agreement with Lee and Ollis in that the hydrogenation of benzofuran was found to proceed by first-order kinetics. The hydrodeoxygenation kinetics, however, were found to be of -1 order.

Phenol and alkylated phenols are of interest in HDO because they comprise a major fraction of the oxygenated compounds in biomass-derived liquids. In addition, they are formed as intermediates in the HDO of benzofuran. The removal of oxygen from phenol has been reported to proceed through direct dehydroxylation (hydrogenolysis of the $\mathrm{C}-\mathrm{O}$ bond) as well as through the formation of cyclohexanol (Elliot 1983; Gavert et al. 1987). Oxygen removal from alkylated phenols depends largely on the position of alkyl substitution (Odebunmi and Ollis 1983; Weigold 1982). The relative order of cresol HDO is meta $>$ para $>$ ortho.

It is significant to note that in nearly all of the cases studied above, conventional Co-Mo or Ni-Mo catalysts on $\mathrm{Al}_{2} \mathrm{O}_{3}$ supports were used. Maholland studied the HDO of benzofuran over Mo and Ni-Mo using aluminum-aluminum phosphate supports (Maholland 1987). The catalysts and supports were tested and characterized in detail. The dealkylation activity and support acidity was found to increase with increasing phosphate content, resulting in an increased production of phenol. Alumina supports prepared without phosphate ( $0.0 \mathrm{P}: \mathrm{Al}$ atomic ratio) exhibited a broad pore size distribution with a median pore diameter of $48 \AA$, whereas the $1.0 \mathrm{P}: \mathrm{Al}$ support had a narrow pore size distribution and a median pore diameter of $253 \AA$. Hopkins and Meyers reported an increase in the thermal and steam stability of the catalyst with an increase in phosphate content (Hopkins and Meyers 1983).

The properties reported above make the aluminum-aluminum phosphate support an ideal candidate for the hydroprocessing of lignin materials. Ratcliff and coworkers tested Maholland's catalyst using 4- 
propylguaiacol as a model lignin depolymerization fragment (Ratcliff et al. 1988). The catalyst demonstrated a much higher selectivity for phenol production than did a commercial catalyst using alumina supports. Although the phenol yield was much higher with phosphated supports, the yield is not sufficient to be commercially viable. In addition, the high dealkylation activity promoted an increase in the undesirable transalkylation reaction. This is likely due to the low hydrogenation activity of the $\mathrm{MoS}_{2}$ based catalysts.

\section{Experimental Procedure}

\section{Catalyst Preparation}

All catalysts were synthesized in the Colorado School of Mines Catalyst and Surface Science Laboratory. Unless otherwise specified, the chemicals were used as received without further purification. The method used to incorporate phosphate into the catalyst support was primarily by the phospho-alumina coprecipitation method. Previous work by Maholland (1987) and Ratcliff et al. (1988) suggested that supports with a $\mathrm{P}: \mathrm{Al}$ atomic ratio in the 0.5 to 0.8 range gave the best results. In this study, two aluminum-aluminum phosphate supports, with a 0.5 and $0.8 \mathrm{P}: \mathrm{Al}$ ratio were prepared. For example, in order to prepare a support with a $\mathrm{P}: \mathrm{Al}$ atomic ratio of 0.5 , the following procedure was used. First, an acidic solution was prepared by adding $200 \mathrm{~g}$ of aluminum nitrate to $2 \mathrm{~L}$ of $18 \mathrm{M}$ ohm deionized water, followed by $31 \mathrm{~g}$ of an $85 \%$ (by weight) solution of orthophophoric acid. Second, a solution was prepared by diluting $250 \mathrm{~mL}$ of concentrated $(28 \mathrm{wt} \%)$ ammonium hydroxide with $250 \mathrm{~mL}$ of deionized water. The acidic and basic solutions were added simultaneously to a 4-L stirred reaction vessel, which contained $1 \mathrm{~L}$ of deionized water. The acidic solution was added at a rate of $100 \mathrm{~mL}$ per min, while the basic solution was added at a rate sufficient to maintain a $\mathrm{pH}$ of 9.0 in the reaction vessel. After the addition was complete, the reaction mixture was stirred for $30 \mathrm{~min}$. The resulting hydrogel was filtered, washed, dried at $120^{\circ} \mathrm{C}$ for $24 \mathrm{~h}$, calcined at $500^{\circ} \mathrm{C}$ for $16 \mathrm{~h}$, crushed and sieved to $20 / 40$ mesh particles, and stored in an airtight desiccator containing no desiccant.

The acidic support was then impregnated with the salt solutions of para ammonium molybdate or chloroplatinic acid using conventional impregnation techniques (Maholland 1987). The impregnated catalyst was dried at $120^{\circ} \mathrm{C}$ for $12 \mathrm{~h}$, calcined at $500^{\circ} \mathrm{C}$ for $16 \mathrm{~h}$, and stored in a desiccator.

\section{Catalyst Characterlzation}

The surface areas of all catalysts and supports were measured on a Micromeritics Accusorb 2100E surface area analyzer. Nitrogen was used as the adsorbate. Multipoint measurements were made and sample surface areas were replicated two to four times and the results averaged.

The x-ray diffraction patterns of selected catalysts and supports were obtained on a Rigaku powder diffractometer. A copper target was used with a current of $100 \mathrm{~mA}$ and an accelerating potential of $40 \mathrm{kV}$.

\section{Catalyst Testing}

The relative catalyst activities and selectivities were obtained using a continuous-flow, fixed-bed catalytic microreactor system. Liquid feed and hydrogen gas are metered separately and fed to a preheated mixing tee. The liquid is vaporized, mixed with hydrogen, and the mixture flows to the reactor through a heated 
line. The mixture enters the reactor, which is heated to reaction temperature by a tube furnace, and flows downward across the catalyst bed. The reactor effluent flows into a condenser where the liquid condensate is collected and analyzed by an off-line gas chromatograph. Noncondensible gases that exit the condenser are passed through a needle valve, which is used to control the total pressure and flow rate, and then through a heated line to a gas-sampling valve where it is analyzed by an on-line gas chromatograph.

The catalyst, $0.2 \mathrm{~g}$ is diluted in a 1:1 weight ratio with inert alpha alumina and placed on top of $1 \mathrm{~g}$ of alpha-alumina. Approximately $13 \mathrm{~g}$ of alpha-alumina is added to the top of the catalyst bed. A blank run using $4.2 \mathrm{~g}$ of alpha-alumina showed no significant activity. The molybdenum-based catalysts were presulfided using a methyl sulfide/heptane solution and hydrogen gas. This procedure is a modification of the sulfiding procedure described by Ede iman and coworkers (1988). The platinum-based catalysts were reduced in hydrogen at $450^{\circ} \mathrm{C}$ for $2 \mathrm{~h}$ before use.

The initial and final test conditions were the same in all experiments and are referred to as the standard test conditions. This permitted a comparison of the catalysts' relative activity on a weight basis and to measure the degree of deactivation during the test sequence. The standard test conditions were $350^{\circ} \mathrm{C}$, $500 \mathrm{psig}$, a hydrogen gas flow of $20 \mathrm{~mL} / \mathrm{m}$, and liquid flow of $3.5 \mathrm{~mL} / \mathrm{h}$. The feedstock consisted of $87 \mathrm{wt} \%$ heptane, $10 \mathrm{wt} \%$ model lignin compound, and $3 \mathrm{wi} \%$ dimethylsulfide for the molybdenum-based catalysts; and $90 \mathrm{wt} \%$ hexane and $10 \mathrm{wt} \%$ model lignin compound for the platinum-based catalysts.

\section{Results and Discussion}

\section{Catalyst Characterization}

The two aluminum-aluminum phosphate supports, with a 0.5 and $0.8 \mathrm{P}: \mathrm{Al}$ ratio, were characterized using Brunauer-Emmett-Teller (BET) surface area and x-ray diffraction techniques. The BET results were compared with those obtained previously by Maholland (1987) and are shown in Table 1. The total surface area decreases with an increase in the phosphorous content of the support. In this case, a decrease in total surface area corresponds to an increase in the average pore diameter. It is clear that the catalyst preparation and properties can be easily duplicated.

Table 1. Surface Areas of Phospho-aluminate Supports

\begin{tabular}{ccc}
\hline $\begin{array}{c}\text { Pt:Al } \\
\text { Atomic } \\
\text { Ratlo }\end{array}$ & $\begin{array}{c}\text { Previous } \\
\text { Results }(8) \\
(\mathrm{m} / \mathrm{g})\end{array}$ & $\begin{array}{c}\text { Current } \\
\text { Results } \\
(\mathrm{m} / \mathrm{g})\end{array}$ \\
\hline 0.5 & 166.8 & 164.7 \\
\hline 0.8 & 4.0 & 33.7 \\
\hline
\end{tabular}

The x-ray diffraction pattern for two supports ( $\mathrm{P}: \mathrm{Al}=0.0$ and 0.5 ), before and after incorporation of molybdenum oxide, is shown in Figure 1 . In the absence of phosphate $(\mathrm{P}: \mathrm{Al}=0.0)$, a gamma-alumina support with a low order of crystallinity is obtained, (see Figure 1[a]). Addition of phosphate changes this spectrum completely (see Figure $1[\mathrm{c}]$ ). The diffraction pattern for gamma-alumina has completely vanished and a new peak, emerging at 24 degrees $2 \Theta$, is characteristic of the tetrahedral structure of 
SUPPORT

CRYSTALLINITY
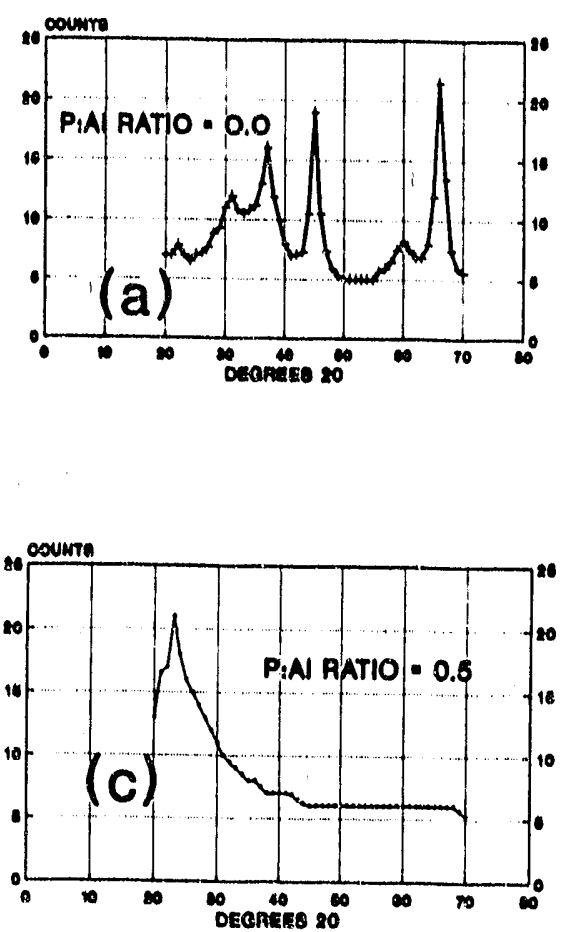

MOLYBDENUM DISPERSION
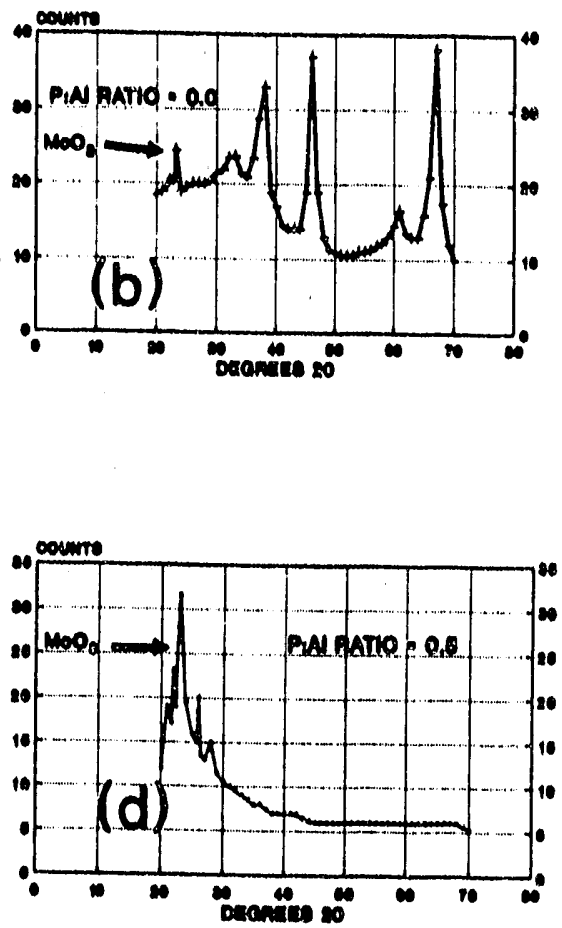

Figure 1. X-ray diffraction pattorns

$\mathrm{AlPO}_{4}$. This change in crystallinity indicates a new material, referred to as aluminum-aluminum phosphate, has been produced rather than a simple mixture of alumina and aluminum phosphate.

A diffraction pattern containing additional broad peaks of low intensity is superimposed on the patterns of the supports when molybdenum oxide is added (see Figures 1[b] and 1[d]). This is characteristic of molybdenum oxide, which is highly dispersed on the support. The intensity of the molybdenum oxide pattern is significantly greater for the support-containing phosphate, indicating a decrease in the molybdenum oxide dispersion.

\section{Catalytic Actlvity of the Blank Supports}

A blank support $(\mathrm{P}: \mathrm{Al}=0.8)$ was tested to obtain the activity and selectivity of the support alone. The results are shown in Table 2.

As was expected, dealkylation was the only reaction observed, as evidenced by the large amount (30.9 mole \%) of phenol produced. However, the transalkylation products, 2,6-dipropylphenol and the other dipropylphenol isomers, are produced in smaller quantities $(7.4$ mole $\%)$ than expected. For every mole of phenol, one would expect a mole of dialkylphenol to be produced, unless the surface propyl group desorbs as propene. Analysis of the non-condensible gas showed propene was present, and that the amount of propene produced increased with an increase in conversion. 
Table 2. Llquild Condensate Composition (Mole \%)

\begin{tabular}{|c|c|c|c|c|c|}
\hline \multirow[b]{2}{*}{$\begin{array}{l}\text { Reaction } \\
\text { Products (mole \%) }\end{array}$} & \multicolumn{5}{|c|}{ Catalyst Tested } \\
\hline & $\begin{array}{l}P: A l \\
(0.8)\end{array}$ & $\begin{array}{l}\text { SI:Al } \\
(0.2)\end{array}$ & $\begin{array}{c}\text { MoS/ } \\
\text { P:Al } \\
(0.5)\end{array}$ & $\begin{array}{l}\mathrm{Pt} \\
\mathrm{P}: \mathrm{Al} \\
(0.8)\end{array}$ & $\begin{array}{c}\mathrm{Pt} / \\
\text { Sl:Al } \\
(0.2)\end{array}$ \\
\hline $\begin{array}{l}\text { cyclohexane } \\
\text { methylcyclohexane } \\
\text { ethylcyclohexane } \\
\text { propylcyclohexane } \\
\text { benzenetoluene } \\
\text { ethylbenzene } \\
\text { prophylbenzene } \\
\text { dipropylbenzene } \\
\text { phenol } \\
\text { 2,6-dipropylphenol } \\
\text { 2-propyiphenol } \\
\text { 4-propylphenol } \\
\text { dipropylphenol } \\
\text { isomers }\end{array}$ & $\begin{array}{r}0 \\
0 \\
0 \\
0 \\
0 \\
0 \\
0 \\
0 \\
30.9 \\
2.1 \\
15.3 \\
34.2 \\
5.3\end{array}$ & $\begin{array}{l}0 \\
6.0 \\
0 \\
0 \\
0 \\
0 \\
0 \\
0 \\
16.8 \\
0 \\
4.7 \\
66.3 \\
6.1\end{array}$ & $\begin{array}{l}3.6 \\
0 \\
1.3 \\
9.4 \\
0 \\
2.2 \\
0 \\
10.0 \\
3.5 \\
18.0 \\
1.2 \\
6.9 \\
30.6 \\
13.3\end{array}$ & $\begin{array}{c}19.1 \\
1.4 \\
1.4 \\
42.3 \\
4.1 \\
0 \\
0 \\
24.9 \\
6.8 \\
0 \\
0 \\
0 \\
0 \\
0\end{array}$ & $\begin{array}{c}3.6 \\
4.8 \\
4.5 \\
39.7 \\
10.6 \\
0 \\
0 \\
10.8 \\
0 \\
0 \\
0 \\
6.1 \\
0\end{array}$ \\
\hline \multicolumn{6}{|c|}{$\begin{array}{l}\text { Operating Conditions: } \\
\text { Temperature }=350^{\circ} \mathrm{C} \\
\text { Pressure }=500 \mathrm{psig} \\
\text { Space Velocity }=1 \mathrm{~g} \text { reactant } / \mathrm{h} \text { g catalyst } \\
\text { Catalyst Weight }=0.2 \mathrm{~g} \\
\text { Feedstock }(\mathrm{MOS})=87 \% \text { heptane }+10 \% \text { reactant }+3 \% \text { DMS } \\
\text { Feedstock }(\mathrm{Pt})=90 \% \text { hexan }+10 \% \text { reactant }\end{array}$} \\
\hline
\end{tabular}

The support had tumed from white to black during the test, which is an indication of coking. Propene, a known coke precursor, can polymerize on the surface and eventually produce a non-volatile carbon deposit. As the temperature was raised from $350^{\circ}$ to $450^{\circ} \mathrm{C}$, the phenol production increased to 60 mole $\%$.

The blank silica-alumina support (see Table 2) is less active than the phospho-alumina support at $350^{\circ} \mathrm{C}$. At $450^{\circ} \mathrm{C}$ it produces nearly 60 mole $\%$ phenol with much less of the transalkylation products than the phospho-alumina support, but with severe coking as a consequence.

Although phenol is produced in good yield over the supports alone, a hydrogenation function is required to minimize the coking and transalkylation reactions. This is accomplished by the hydrogenation of propene to propane. Alkanes, such as propane or hexane (the solvent), are unreactive with the support.

\section{Actlvity of Molybdenum Sulflde Catalysts}

Two molybdenum sulfide catalysts were prepared and tested. The first catalyst was prepared using an alumina support $(\mathrm{P}: \mathrm{Al}=0.0)$ in which the major products were propylcyclohexane $(49.7$ mole $\%)$, toluene $(8.2$ mole \%), and propylbenzene $(9.0$ mole $\%)$. Although these catalysts have some inherent surface acidity, it is insufficient for the dealkylation reaction because very little phenol is produced. 
The second molybdenum sulfide catalyst tested had an phospho-alumina support ( $\mathrm{P}: \mathrm{Al}=0.5$ ), (see Table 2). The major product in this reaction was phenol (18.0 mole \%), a direct result of the increased acidity introduced by the presence of phosphate in the support. The large increase in phenol production is encouraging, but the large increase in transalkylated products $(18.0$ mole \%) is unacceptable. The product distribution indicates that dealkylated propyl groups attach, via the trunsalkylation reaction, to another aromatic ring.

\section{Actlvity of Supported Platinum Catalysts}

Several platinum catalysts were prepared and tested. The first catalyst was prepared using a barium oxidealumina support. The barium oxide neutralizes the acidity of the alumina support, leaving only the metal function available for reaction. Because the major product is propylcyclohexane $(45.6$ mole \%), the major function of the metal is hydrogenation.

Replacing the neutral support with an phospho-alumina ( $\mathrm{P}: \mathrm{Al}=0.08)$ or sillca-alumina support results in a much more active catalyst (see Table 2). Although the dealkylation activity is good, the production of phenol is low due to the high hydrogenation activity of the catalysts. The large production of propylcyclohexane verifies this conclusion. The rapid hydrogenation of the aromatic ring on the 4-propylphenol to 4-propylcyclohexanol assists the HDO reaction (C-O bond cleavage) but hinders the dealkylation reaction. It is necessary to select reaction conditions in which the dealkylation and propene hydrogenation reactions are optimized and aromatic ring hydrogenation is minimized.

\section{Effect of Temperature on Product Selectlvity}

The effect of temperature on the product distribution was siudied using a platinum catalyst on an phosphoalumina support $(\mathrm{P}: \mathrm{Al}=0.8)$. The results are shown in Figures 2 and 3 . The standard reaction temperature of $350^{\circ} \mathrm{C}$ and pressure of 500 psig were selected as the initial and final test conditions. During the test sequence the pressure was held constant while the temperature was increased. The total conversion was essentially $100 \%$ at the temperatures selected. As was expected, the production of

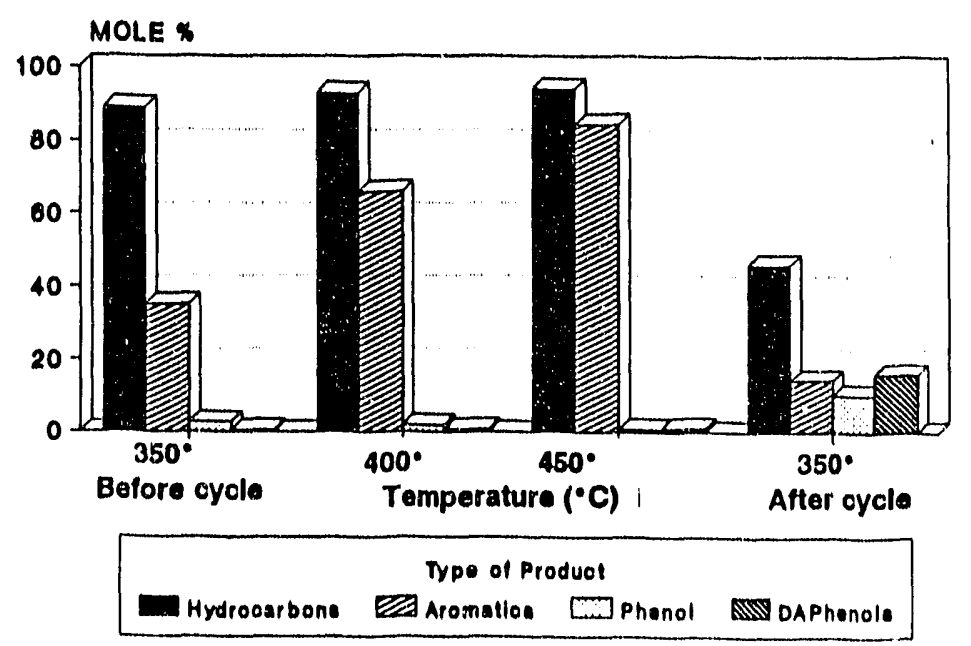

Flgure 2. Product distribution as a function of temperature $[\mathrm{Pt} / \mathrm{P}: \mathrm{Al}(0.8)]$ 


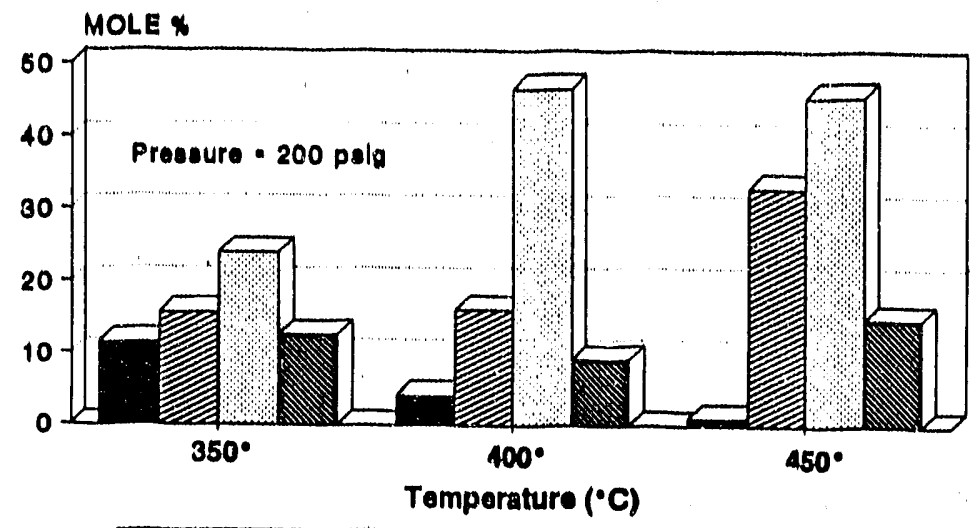

TP-3996

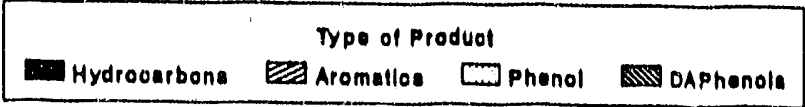

Figure 3. Product distrlbution as a function of temperature [Pt/P:Al(0.8)]

aromatics increased as the temperature increased. The dealkylation reaction also increased with an increase in temperature. However, the production of phenol was less than 2.0 mole $\%$, which suggests that the hydrogen pressure is too high. Upon returning to the original test conditions, the catalyst showed a loss in activity and selectivity. This is most likely due to coking of the catalyst during the hightemperature study.

It is of interest to note that this catalyst is very effective in the complete deoxygenation of the model lignin compound to hydrocarbons. This suggests that lignin can also be converted into a low-oxygencontaining product if the appropriate conditions are selected.

\section{Effect of Pressure on Product Selectivity}

The effect of hydrogen pressure on the product selectivity was studied using the same platinum catalysts as before. The conditions were identical except the temperature was kept constant at $350^{\circ} \mathrm{C}$ while the pressure was changed. The results are shown in Figures 4 and 5. The deoxygenation reaction decreased as the pressure decreased and the phenol production increased correspondingly. This would suggest that saturation of the aromatic ring is necessary before cleavage of the aromatic C-O bond in phenol is possible. The total conversion decreased as the pressure decreased but remained at an acceptable level. It is possible to produce additional phenol by increasing the temperature while keeping the pressure at a lower value, and thus promoling the dealkylation reaction.

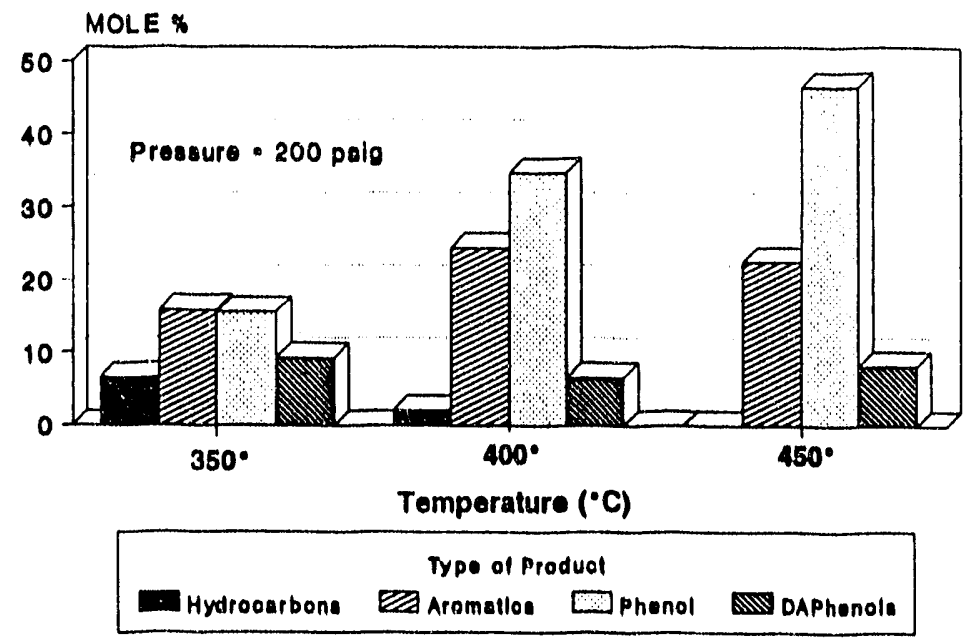

Figure 4. Product distribution as a function of temperature $[\mathrm{P} / \mathrm{Sl}: \mathrm{A} \mid(0.2)]$ 


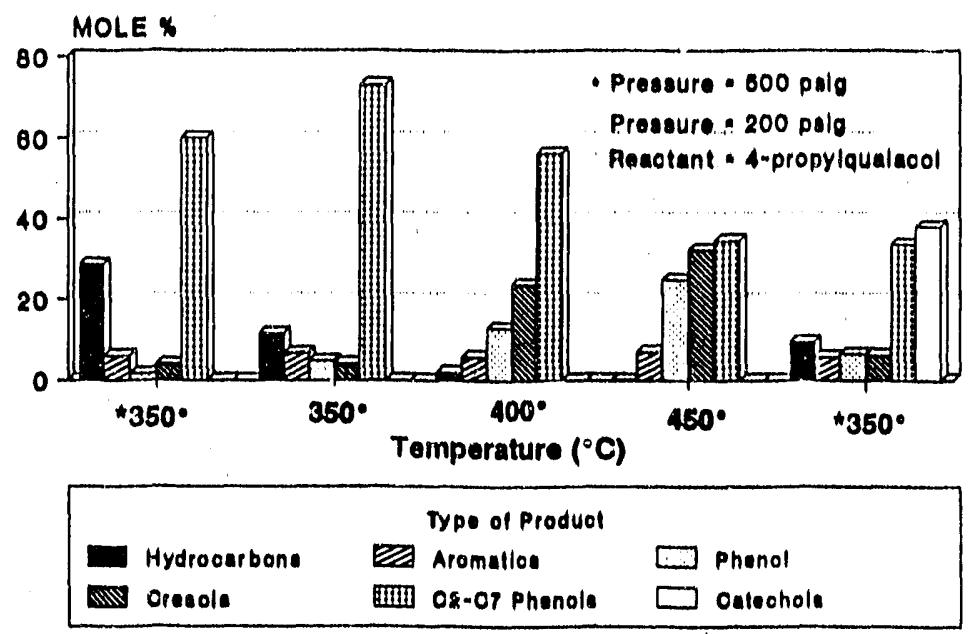

Figure 5. Product distribution as a function of temperature $\mathrm{Pt} / \mathrm{P}: \mathrm{Al}(0.8)]$

\section{The Effect of Temperature at Low Pressure}

In this experiment the reaction temperature was increased while the pressure was maintained at $200 \mathrm{psig}$. The catalyst and space velocity conditions are the same as before, and the results are shown in Figures 6 and 7. A dramatic increase in phenol production was observed as the temperature was increased from $350^{\circ}$ to $400^{\circ} \mathrm{C}$. The silica-alumina supported catalyst much less of the transalkylation products.

The platinum-based catalysts show great promise for the hydrotreatment of lignin feedstocks when using 4-propylphenol as a model lignin compound. However, real lignin feedstocks will contain substantially more oxygen than 4-propylphenol. In order to produce phenol, all but one oxygen must be removed. Therefore, a successful catalyst must be able to selectively deoxygenate lignin to a phenolic product. This requires a hydrogenolysis function for the cleavage of $\mathrm{C}-\mathrm{O}$ bonds, and platinum is known to possess this function. A good model compound for testing this reaction is 4-propylguatacol.

\section{Hydrotreatment of 4-Propylgualacol}

In this experiment the same conditions and catalyst were used as stated in the previous section, except 4-propylphenol was replaced by 4-propylguaiacol as the model lignin compound. This compound is more representative of lignin, since it contains two oxygen substituents per aromatic ring. The liquid samples collected during the test were collected and analyzed by gas chromatography and mass spectrometry. The results appear to follow the same trends observed previously when 4-propylphenol was used as the model lignin compound. The production of phenol, the desired product, increased as the temperature increased. The optimum conditions for phenol production were $450^{\circ} \mathrm{C}$ and $200 \mathrm{psig}$. The other predominant products under these conditions were the isomers of cresol. The methyl substituent on cresol most likely comes from the dealkylation of the methoxy group present in 4-propylguaiacol. These preliminary results suggest that the platinum-based catalyst may be an excellent candidate for hydrotreating lignin feedstocks. However, more work is required in order to determine the optimum reaction conditions and catalyst formulation. 


\section{Conclusions}

Model lignin compounds were successfully converted into phenolic products using a platinum-based catalyst. An acidic support is required for the necessary dealkylation reaction. "The platinum-based catalysts are much more active and selective than the molybdenum-based catalysts. In addition, the platinum-based catalysts do not require the addition of sulfur compounds to the feedstock in order to maintain their activity.

Additional work is needed in order to determine the optimum reaction conditions for this reaction. Eventually, this catalyst must be evaluated using a real lignin feedstock.

\section{Roferences}

Edelman, M. C., Maholland, M. K., Baldwin, R. M., and Cowley, S. W. 1988. J. Catal. 111:243.

Elliot, D. C. 1983. "Basic Research in Biomass Direct Liquefaction." In Proceedings of the 15th Biomass Thermochemical Conversion Contractors Meeting, 455.

Furimsky, E. 1983. Catal. Rev.-Sci. Eng. 25:421.

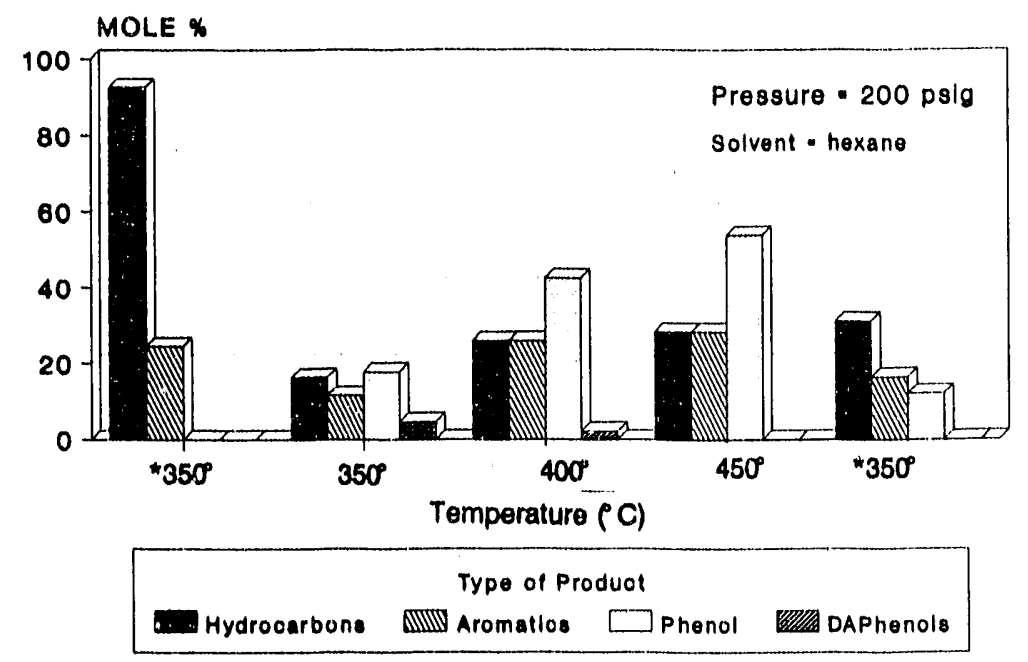

Fivure 6. 4-Propyiphenol results [Pt/SIA|(A):SI $=(0.2)]$ 


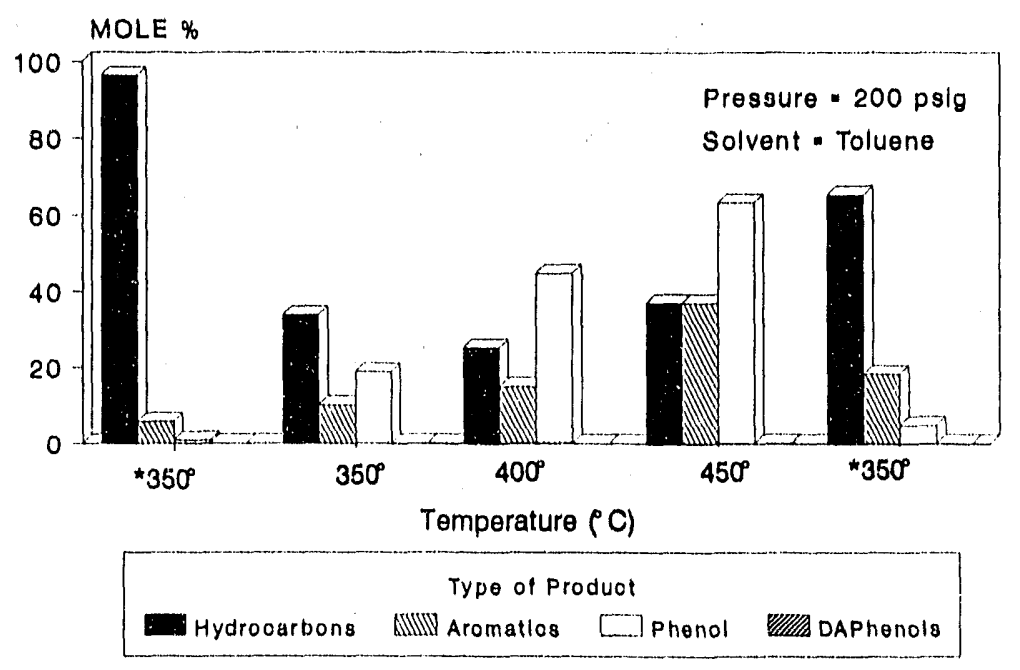

Flgure 7. 4-Propylphenol results [Pt/SI:Al(0.2)]

Gavert, B. S., Otterstedt, J. E., and Massoth, F. E. 1987. Appl. Catal. 119-131.

Hopkins, P. D. and Meyers, B. L. 1983. Ind. Eng. Chem. Prod. Res. Dev. 22:421.

Lee, C.-Li., and Ollis, D. F. 1984. J. Catal. 87:325.

Maholland, M. K. 1987. "Synthesis, Characterization, and Activity Evaluation of Phosphate-Modified Hydroprocessing Catalysts for Benzofuran Hydrodeoxygenation." Ph.D. diss., Colorado School of Mines, Golden, Colorado.

Odebunmi, E. O., and Ollis, D. F. 1982. J. Catal. 80:56.

Ratcliff, M. A., Johnson, D. K., Posey, F. L., Maholland, M. K., Cowley, S. W., and Chum, H. L. "Hydrodeoxygenation of Lignin Model Compounds," In Proceedings of the IEA Interational Conference on Research in Thermochemical Biomass Conversion. London: Elsevier Applied Sciences Publishers. 


\begin{tabular}{|c|c|c|c|c|}
\hline & $\begin{array}{l}\text { ocumont Control } \\
\text { Page }\end{array}$ & $\begin{array}{l}\text { 1. SERI Roport No. } \\
\text { TP-231-3996 }\end{array}$ & $\begin{array}{l}\text { 2. NTIS Accossion No. } \\
\text { DE91002125 }\end{array}$ & 3. Reclpient's Accession No. \\
\hline \multirow{2}{*}{\multicolumn{3}{|c|}{$\begin{array}{l}\text { 4. Title and Subtitlo } \\
\text { Ethanol Annual Report } \\
\text { FY } 1990\end{array}$}} & & $\begin{array}{l}\text { 6. Publication Date } \\
\text { January } 1991\end{array}$ \\
\hline & & & & 6. \\
\hline \multicolumn{4}{|c|}{$\begin{array}{l}\text { 7. Author(s) } \\
\text { R. H. Texeira and B. J. Goodman }\end{array}$} & $\begin{array}{l}\text { 8. Performing Organization Rept. } \\
\text { No. }\end{array}$ \\
\hline \multirow{2}{*}{\multicolumn{4}{|c|}{$\begin{array}{l}\text { 9. Porforming Organization Name and Address } \\
\text { Solar Energy Research Institute } \\
1617 \text { Cole Boulevard } \\
\text { Golden, CO } 80401\end{array}$}} & $\begin{array}{l}\text { 10. ProjectTask/Work Unit No. } \\
\text { BF921010 }\end{array}$ \\
\hline & & & & $\begin{array}{l}\text { 11. Contract (C) or Grant (G) No. } \\
\text { (C) } \\
\text { (G) }\end{array}$ \\
\hline \multirow{2}{*}{\multicolumn{4}{|c|}{ 12. Sponsoring Organization Name and Address }} & $\begin{array}{l}\text { 13. Type of Report \& Period } \\
\text { Covered } \\
\text { Technical report for FY } 1990\end{array}$ \\
\hline & & & & 14. \\
\hline \multicolumn{5}{|c|}{ 15. Supplementary Notes } \\
\hline \multicolumn{5}{|c|}{$\begin{array}{l}\text { 16. Abstrect (Limit: } 200 \text { words) } \\
\text { This report describes the research performed and the technical progress made by the Solar Energy Research } \\
\text { Institute and its subcontractors in the U. S. Department of Energy's Ethanol Program during fiscal year } 1990 . \\
\text { The report is divided into six sections: a program overview, technoeconomic analysis, pretreatment research, } \\
\text { cellulose conversion research, xylose fermentation research, and lignin conversion research. Each section } \\
\text { contains descriptions of the individual research projects in that area. }\end{array}$} \\
\hline \multirow{2}{*}{\multicolumn{5}{|c|}{$\begin{array}{l}\text { 17. Document Analysis } \\
\text { a. Descriptors } \\
\text { ethanol, biomass, feedstocks, conversion methods, alternative fuels } \\
\text { b. Idontlifiers/Open-Ended Term }\end{array}$}} \\
\hline & & & & \\
\hline \multirow[t]{2}{*}{18.} & \multirow{2}{*}{\multicolumn{3}{|c|}{$\begin{array}{l}\text { Availabllity Statement } \\
\text { National Technical Information Service } \\
\text { U.S. Department of Commerce } \\
\text { 5285 Port Royal Road } \\
\text { Springfield, VA } 22161\end{array}$}} & $\begin{array}{l}\text { 19. No. of Pages } \\
354\end{array}$ \\
\hline & & & & $\begin{array}{l}\text { 20. Price } \\
\text { A16 }\end{array}$ \\
\hline
\end{tabular}


